U. S. DEPARTMENT OF THE INTERIOR

U.S. GEOLOGICAL SURVEY

\title{
ANALYTICAL RESULTS, MINERALOGICAL DATA, AND \\ DISTRIBUTIONS OF ANOMALIES FOR ELEMENTS AND MINERALS IN THREE MOTHER LODE-TYPE GOLD DEPOSITS, HODSON MINING DISTRICT, CALAVERAS COUNTY, CALIFORNIA
}

by

\begin{abstract}
Maurice A. Chaffee* and Steven J. Sutley*
Open-File Report 94-640-A (Paper copy)

94-640-B (Diskette)
\end{abstract}

This report is preliminary and has not been reviewed for conformity with U. S. Geological Survey editorial standards and stratigraphic nomenclature. Any use of trade names is for descriptive purposes only and does not imply endorsement by the USGS.

"U. S. Geological Survey, Federal Center, Box 25046, MS 973, Denver, CO 80225 
REGIONAL GEOLOGIC SETTING

GEOLOGY OF THE HODSON DISTRICT

GEOLOGY AND ALTERATION IN THE VICINITIES OF THE CROSS SECTIONS

COLLECTION AND PREPARATION OF SAMPLES $\ldots \ldots \ldots \ldots \ldots \ldots \ldots$

ANALYSIS OF SAMPLES

DETERMINATION OF

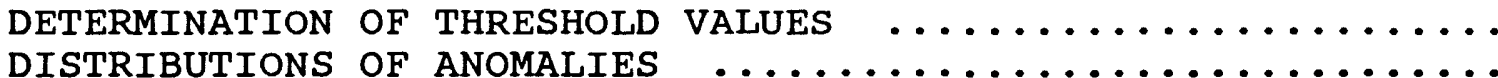

......

ACKNOWLEDGMENTS

REFERENCES CITED

DESCRIPTIONS OF APPENDICES 1 AND 2

\section{ILLUSTRATIONS}

Figure 1. Map showing location of study area .........

2. Generalized geologic map of the Hodson

district

3.

Geologic map for section $A-A$.

4. Geologic map for section $B-B^{\prime}$

$\ldots \ldots \ldots \ldots$

5 .

Geologic map for section $C-C^{\prime}$

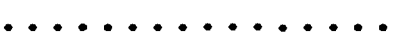

anomalous Ag.

$6 a-c$

Distributions of Sections $A-A^{\prime}$,

7a-c. Distributions of

$B-B^{\prime}, C-C^{\prime}$
anomalous $A l$

Sections $A-A^{\prime}$,

$B-B^{\prime}, C-C$

8a-c. Distributions of

Sections $A-A^{\prime}$,

anomalous As,

9a-c. Distributions of anomálous $A u$,

Sections $A-A^{\prime}$,

$B-B^{\prime}, C-C^{\prime}$

...

10a-C. Distributions of anomalous $\mathrm{Ba}$,

Sections $A-A^{\prime}, B-B^{\prime}, C-C^{\prime}$

$11 a-c$. Distributions of anomalous $B e$,

sections $A-A^{\prime}, B-B^{\prime}, C-C^{\prime}$

12a-c. Distributions of anomalous $\mathrm{Ca}$, Sections $A-A^{\prime}, B^{\prime}-B^{\prime}, C-C^{\prime}$

Sections $A-A^{\prime}$,
$13 a-c$. Distributions of anomalous $\mathrm{Cd}$, sections $A-A^{\prime}, B^{\prime}-B^{\prime}, C-C^{\prime}$

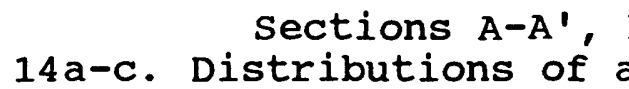
anomalous $\mathrm{Ce}$,

Sections $A-A^{\prime}, B^{\prime}-B^{\prime}, C-C^{\prime}$.
$15 a-c$. Distributions of anomalous Co,

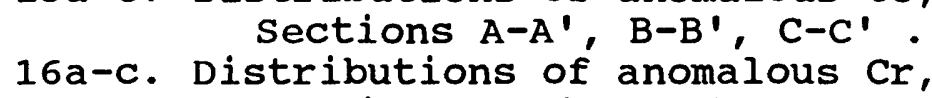
sections $A-A^{\prime}, B^{\prime}-B^{\prime}, C-C^{\prime}$.

17a-c. Distributions of anomalous $\mathrm{Cu}$, Sections $A-A^{\prime}, B^{\prime} B^{\prime}, C-C^{\prime} \ldots \ldots \ldots \ldots \ldots \ldots$

$18 \mathrm{a}-\mathrm{C}$. Distributions of anomalous $\mathrm{Fe}$, Sections $A-A^{\prime}, B^{\prime} B^{\prime}, C-C^{\prime} \ldots \ldots \ldots \ldots \ldots \ldots$

19a-c. Distributions of anomalous Ga, sections $A-A^{\prime}, B-B^{\prime}, C-C^{\prime} \ldots \ldots \ldots \ldots \ldots \ldots$

20a-c. Distributions of anomalous $\mathrm{Hg}$, sections $A-A^{\prime}, B^{\prime}-B^{\prime}, C-C^{\prime} \ldots \ldots \ldots \ldots \ldots \ldots$ 


\section{ILLUSTRATIONS (continued)}

Figure $21 \mathrm{a}-\mathrm{C}$. Distributions of anomalous $\mathrm{K}$, Sections $A-A^{\prime}, B-B^{\prime}, C-C^{\prime} \ldots \ldots \ldots \ldots . \ldots . . .70$

$22 \mathrm{a}-\mathrm{C}$. Distributions of anomalous $\mathrm{La}$, Sections $A-A^{\prime}, B-B^{\prime}, C-C^{\prime} \ldots . . \ldots . \ldots . . . .73$

23a-c. Distributions of anomalous $L i$, Sections $A-A^{\prime}, B-B^{\prime}, C-C^{\prime} \ldots \ldots \ldots . \ldots . \ldots 76$

$24 \mathrm{a}-\mathrm{C}$. Distributions of anomalous LOI, Sections $A-A^{\prime}, B-B^{\prime}, C-C^{\prime} \ldots . . . . . . . . .79$

25a-C. Distributions of anomalous $\mathrm{Mg}$, sections $A-A^{\prime}, B-B^{\prime}, C-C^{\prime}$

26a-c. Distributions of anomalous Mn, Sections $A-A^{\prime}, B-B^{\prime}, C-C^{\prime}$

$27 a-c$. Distributions of anomalous Mo, Sections $A-A^{\prime}, B-B^{\prime}, C-C^{\prime}$

28a-C. Distributions of anomalous $\mathrm{Na}$, Sections $A-A^{\prime}, B-B^{\prime}, C-C^{\prime}$

29a-C. Distributions of anomalous $\mathrm{Nb}$, Sections $A-A^{\prime}, B-B^{\prime}, C-C^{\prime}$

$30 \mathrm{a}-\mathrm{C}$. Distributions of anomalous $\mathrm{Nd}$, Sections $A-A^{\prime}, B-B^{\prime}, C-C^{\prime} \ldots \ldots \ldots \ldots \ldots \ldots$

31a-C. Distributions of anomalous $\mathrm{Ni}$, Sections $A-A^{\prime}, B-B^{\prime}, C-C^{\prime}$

$32 \mathrm{a}-\mathrm{c}$. Distributions of Sections $A-A^{\prime}$, anomalous $P$,

33a-c. Distributions of $B-B^{\prime}, C-C^{\prime}$

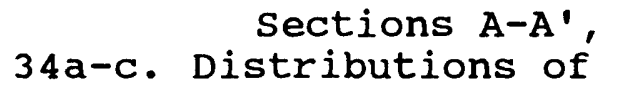
anomalous $\mathrm{Pb}$, $B-B^{\prime}, C-C^{\prime}$

Sections $A-A^{\prime}$,
$35 a-c$. Distributions of anomalous $S$, $B-B^{\prime}, C-C^{\prime}$

$36 \mathrm{a}-\mathrm{C}$. Distributions of anomalous $\mathrm{SC}$, Sections $A-A^{\prime}, B-B^{\prime}, C-C^{\prime}$

$37 \mathrm{a}-\mathrm{C}$. Distributions of anomalous $\mathrm{SiO}_{2}$, Sections $A-A^{\prime}, B-B^{\prime}, C-C^{\prime}$

$38 \mathrm{a}-\mathrm{C}$. Distributions of anomalous $\mathrm{Sr}$, Sections $A-A^{\prime}, B-B^{\prime}, C-C^{\prime}$

$39 a-c$. Distributions of anomalous $\mathrm{Te}$, sections $A-A^{\prime}$, $B-B^{\prime}, C-C^{\prime}$

40a-c. Distributions of anomalous $\mathrm{Th}$,

$41 \mathrm{a}-\mathrm{C}$. Distributions of anomalous $\mathrm{Ti}$. Sections $A-A^{\prime}, B-B^{\prime}, C-C^{\prime}$

Sections $A-A^{\prime}$,
$42 \mathrm{a}-\mathrm{c}$. Distributions of anomalous $\mathrm{Tl}$, sections $A-A^{\prime}, B-B^{\prime}, C-C^{\prime}$

$43 a-c$. Distributions of anomalous $V$,

Sections $A-A^{\prime}, B^{\prime}-B^{\prime}, C-C^{\prime}$
$44 a-c$. Distributions of anomalous $W$,

Sections $A-A^{\prime}, B^{\prime}-B^{\prime}, C-C^{\prime}$
$45 a-C$. Distributions of anomalous $Y$, sections $A-A^{\prime}, B-B^{\prime}, C-C^{\prime}$ 
Figure $46 \mathrm{a}-\mathrm{C}$. Distributions of anomalous $\mathrm{Yb}$,

Sections $A-A^{\prime}, B-B^{\prime}, C-C^{\prime} \ldots \ldots \ldots \ldots \ldots \ldots$

47a-C. Distributions of anomalous $\mathrm{Zn}$,

$48 \mathrm{a}-\mathrm{C}$. Distributions of anomalous mica,

49a-c. Distributions of anomalous kaolinite,

50a-c. Distributions of anomalous chlorite, Sections $A-A^{\prime}, B-B^{\prime}, C-C^{\prime} \ldots \ldots \ldots \ldots \ldots \ldots$

51a-C. Distributions of anomalous quartz, Sections $A-A^{\prime}, B-B^{\prime}, C-C^{\prime} \ldots \ldots \ldots \ldots \ldots \ldots \ldots$

52a-c. Distributions of anomalous orthoclase, Sections $A-A^{\prime}$, $B-$

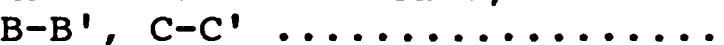

53a-c. Distributions of anomalous plagioclase, Sections $A-A^{\prime}, B-B^{\prime}, C-C^{\prime} \ldots \ldots \ldots \ldots \ldots . . .$.

$54 \mathrm{a}-\mathrm{C}$. Distributions of anomalous calcite, Sections $A-A^{\prime}, B-B^{\prime}, C-C^{\prime} \ldots . . . . . . . . .169$

55a-c. Distributions of anomalous ankerite, Sections $A-A^{\prime}, B-B^{\prime}, C-C^{\prime} \ldots \ldots \ldots$

$56 \mathrm{a}-\mathrm{C}$. Distributions of anomalous magnesite,

$57 \mathrm{a}-\mathrm{C}$. Distributions of anomalous pyrite, Sections $A-A^{\prime}, B-B^{\prime}, C-C^{\prime} \ldots \ldots \ldots \ldots \ldots \ldots$

\section{TABLES}

Table 1. Statistical summary for analyses in 136 samples of core and cuttings from the copper $\mathrm{Hill}$

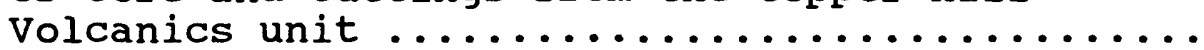

2. Statistical summary for analyses in 121 samples of core and cuttings from the salt spring

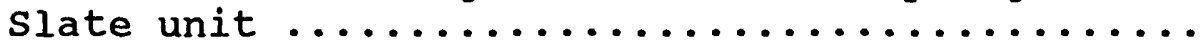

3. Statistical summary for analyses in 43 samples of core and cuttings from the tuff member of the salt spring slate unit ..............

4. d-spacings and diffraction peaks used for semiquantitative mineralogy ...............

5. Statistical summary for minerals in 172 samples of core and cuttings from 3 rock units ........

\section{APPENDICES}

Appendix 1. Chemical data for samples of drill core or cuttings ......................... 182

2. Mineralogical data for samples of drill core or cuttings ..................... 


\section{INTRODUCTION}

Although many geologic environments have been studied and explored for gold deposits in the last few decades, the classic Mother Lode environment in California was largely ignored until the $1980^{\prime} \mathrm{s}$. For a variety of reasons, including underground mining economics, metallurgical problems with ore treatment, lack of accessible land, and probably other factors, little attention was given to the gold resource potential of the Mother Lode region, and, consequently, modern scientific studies were not undertaken in this region. In recent years, however, the possibility of using surface mining methods, the adoption of newer techniques for recovering gold from the complex ores in the Mother Lode region, and other considerations have renewed interest in this environment.

Detailed descriptions that included information on the mineralogy and chemistry of various Mother Lode deposits were published many years ago when the underground mines of the region were still active and accessible (Knopf, 1929; Lindgren, 1896). The last of the underground mines was closed in 1942 and, except in the extreme northern part of the region, none has operated in recent years. As a result, little was written about the geological aspects of Mother Lode deposits between the 1940's and the 1980's, when exploration and mining in the region was renewed. Chemical and mineralogical data have been published for many gold deposits, some of which are probably Mother Lode analogues (see, for example, Boyle, 1979, and references therein). In spite of the renewed interest in the California deposits, however, only a few articles describing the abundances -and particularly the distributions-of suites of elements and minerals associated with Mother Lode-type deposits occurring in the United States have been published (see, for example, Chaffee and Hill, 1987; Chaffee and Kuhl, 1991; Coveney, 1981; Goldfarb, 1989; King, 1986; Kuhl and Garmoe, 1989; Landefeld and Silberman, 1987; Lechner and Kuhl, 1990; Nash, 1988; Silberman and Danielson, 1991).

To provide new information regarding the geochemistry of a typical Mother Lode-type deposit, we conducted a study in the Hodson mining district, which is in Calaveras County, California, in the westernmost foothills of the Sierra Nevada, several

kilometers northwest of the settlement of copperopolis and about $17 \mathrm{~km}$ west of the town of Angels Camp (Fig. 1). This district is in the West Gold Belt, which lies about 12 to $16 \mathrm{~km}$ west of, and generally parallel to, the better known Mother Lode Gold Belt in central California. The Hodson district produced more than $\$ 6$ million worth of gold between the 1880's and 1940's from underground mines (Clark, 1970). The two principal mines were the Royal, the largest and most productive mine in the West Belt, and the Mountain King ( $\mathrm{Clark}$ and Lydon, 1962). Mining from three open pits began in 1989 (Lechner and Kuhl, 1990) and continued until 1994 . 


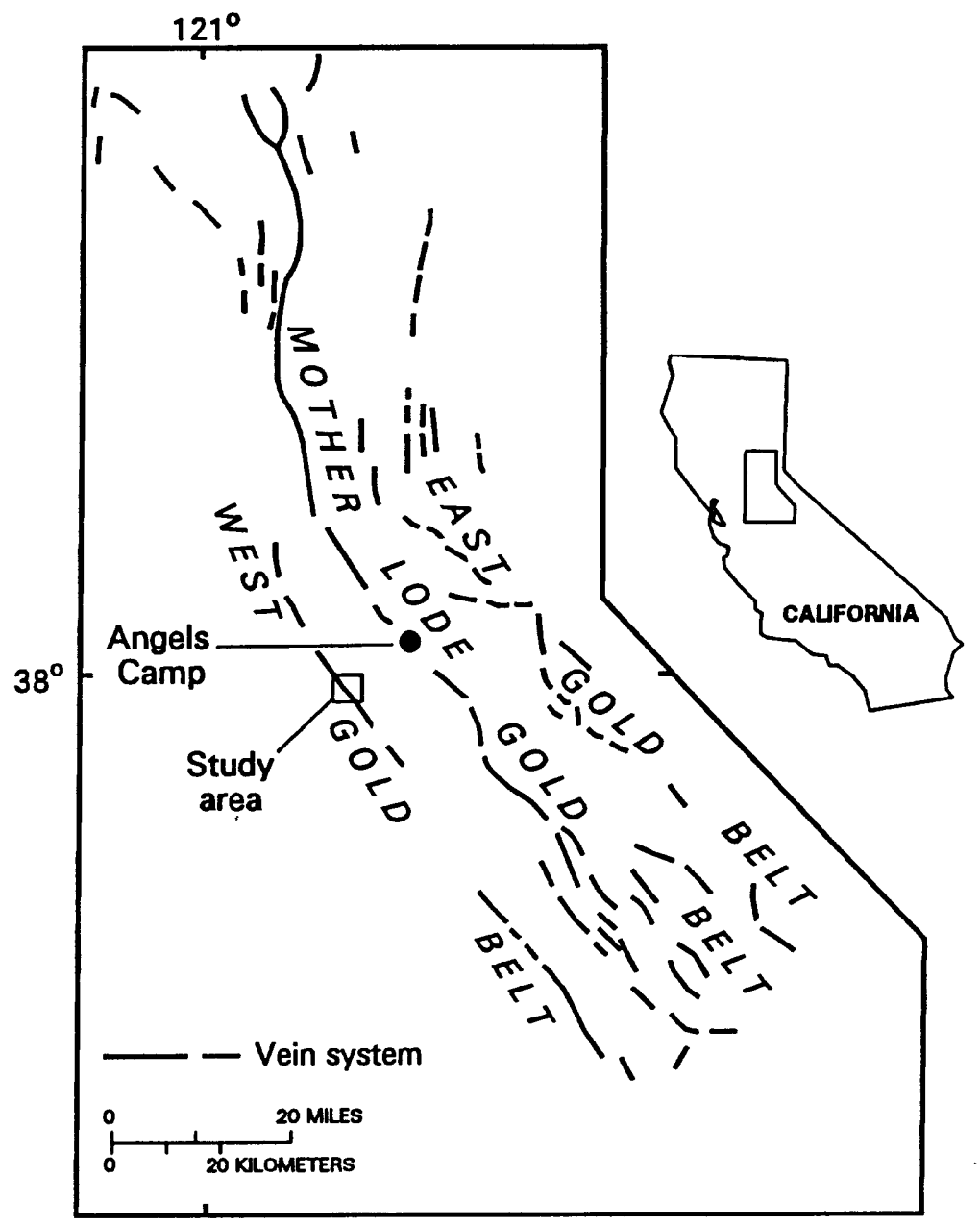

Figure 1.--Location of the study area 
This report briefly describes (1) the regional geologic setting and general geology of the Hodson mining district and the geology for three cross sections, each transecting a gold deposit in the district. In addition, the report provides details on the collection and analysis of 300 samples of drill core or cuttings, a tabulation of chemical and mineralogical data for 44 elements and 10 minerals, summary statistical data for these variables, and plots of anomalies for 42 chemical and 10 mineral variables on the three geologic cross sections.

This report consists of two parts. Part A is this printed report. Part $B$ is an electronic version on a diskette that includes this text in ASCII format as well as the data in Appendices 1 and 2 in a binary format.

\section{REGIONAL GEOLOGIC SETTING}

The Hodson district is located in the West Gold Belt, a part of the Foothills Metamorphic Belt that lies along the west side of the central Sierra Nevada in California (Fig. 1). This belt is thought to comprise a Mesozoic submarine volcanic arc and adjacent back arc basin that were accreted onto the western margin of North America (Landefeld, 1990). Rocks present in the areas of the main Mother Lode Gold Belt (Melones Fault zone) and the West Gold Belt include (1) mafic and ultramafic lava flows and breccias and (2) sedimentary sequences that were largely derived from these rocks and vary in grain size from conglomerates to argillites. All of these rocks were regionally metamorphosed to greenschist facies prior to the time of gold mineralization (Landefeld, 1990; Landefeld and Silberman, 1987). The only significant difference between the rocks in the Mother Lode Belt and the West Belt is in the composition of the metamorphosed volcaniclastic units. Those in the West Belt are more felsic to intermediate in composition, suggesting that these rocks were probably derived from the mature, calc-alkaline parts of the same volcanic arc that is the source of most of the rocks found in the rest of the Foothills Metamorphic Belt (Landefeld and Snow, 1990).

Major faulting in Nevadan time created the Melones and Bear Mountain Fault Zones. Splays from the latter, especially the Hodson fault, structurally control the gold mineralization in the Hodson district. The gold deposits, described below, exhibit the same gross characteristics as those of the Melones Fault Zone at this latitude.

\section{GEOLOGY OF THE HODSON DISTRICT}

Figure 2 shows the geology of the Hodson area as illustrated by Lechner and Kuhl (1990), as well as the locations of three cross sections along which samples of drill cuttings or core were collected for this study. Two major rock units are present. The first is the Salt spring Slate (Js on Fig. 2), which is of Late Jurassic age (Clark, 1964). In the study area this unit is predominantly a sequence of thin-bedded carbonaceous shales that have been metamorphosed to slates and phyllites. 


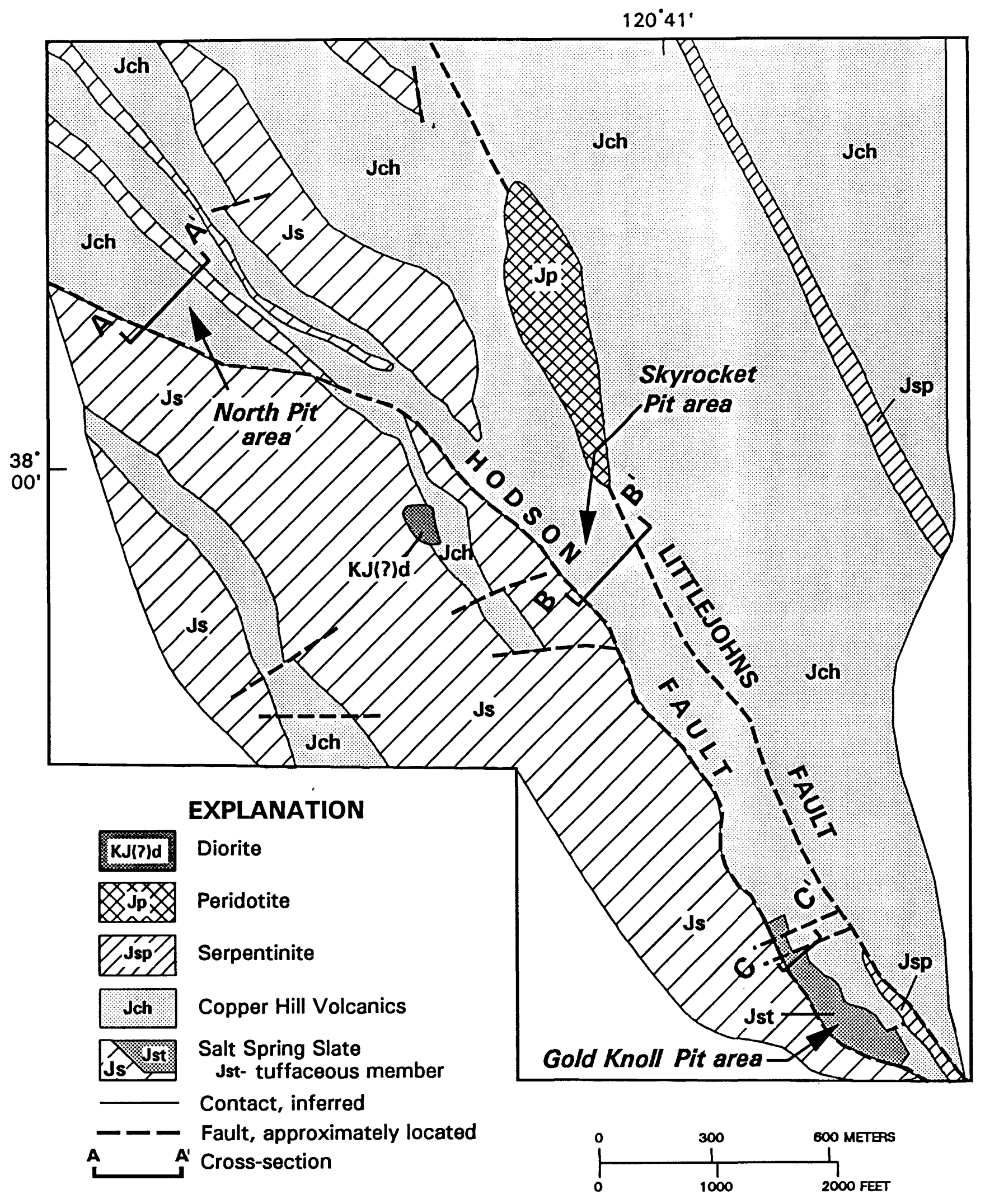

Figure 2.--Generalized geologic map of the Hodson district, Calaveras county, California. Modified from Lechner and Kuhl (1990) 
Beds of pebble conglomerate are found locally. In the southern part of the study area, a sequence of thinly interbedded

tuffaceous wackes and carbonaceous phyllites has been mapped locally as a part of this unit. This latter sequence has been informally named the tuffaceous member of the salt spring slate (Jst on Fig. 2) (Kuhl and Garmoe, 1989).

The other major unit in the study area is the copper Hill Volcanics (Jch on Fig. 2), which is also of Late Jurassic age (Clark, 1964). This unit consists of volcanic flows, flow breccias, and tuffs that range in composition from andesitic basalt to basalt and have been metamorphosed to produce massive to schistose sequences (Lechner and Kuhl, 1990). Regional metamorphism to greenschist facies has produced abundant chlorite that gives a green color (and thus the term "greenstone") to this unit.

Other small units crop out locally (Fig. 2). These consist of ultramafic rocks that include serpentinite (Jsp) and

peridotite (Jp) of probable Late Jurassic age (Clark, 1964) and a small body of diorite (KJd), which by inference with other similar bodies is of probable Late Jurassic to Middle Cretaceous age (Clark, 1964).

Major NNW- to NW-trending, northeast-dipping, low-angle faults trend parallel to the regional strike of the rock units. The Hodson fault and its splays (Fig. 2), a part of the major Bear Mountain Fault Zone (Clark, 1964), are the major structural controls of gold ore in the district.

Common hydrothermal alteration minerals include quartz, pyrite, sericite, ankerite, and calcite, which are widespread, and albite and mariposite, which occur locally (Kuhl and Garmoe, 1989; Lechner and Kuh1, 1990). Gold occurs locally in the free state but mainly as inclusions or microveinlets in pyrite. Minor amounts of other sulfide minerals (principally chalcopyrite, arsenopyrite, sphalerite, galena, and tetrahedrite) have been identified in the district (Kuhl and Garmoe, 1989; Lechner and Kuhl, 1990).

\section{GEOLOGY AND ALTERATION IN THE VICINITIES OF THE CROSS SECTIONS}

Three sections through the district-each crossing one of the three ore deposits at a roughly perpendicular orientation to the Hodson fault-were selected for study. These sections are located on Fig. 2. Each is viewed facing northwest. The locations of the drill holes that were sampled for each section are shown for reference (Figs. 3 to 5). All holes were collared within $20 \mathrm{~m}$ of the plane of the respective sections. The areas of significant weathering shown on each section were defined on the basis of the amount of visible secondary iron oxides in the samples collected for analysis. These areas are labelled as the "oxide zone" on each section. The geologic descriptions that follow are largely those of Kuhl and Garmoe (1989) and Lechner and Kuhl (1990), supplemented by our own observations.

The northernmost of the three deposits is in the North Pit and is shown on section $A-A^{\prime}$ (Fig. 3). The geology of the overall area of the pit is structurally complex (Lechner and 


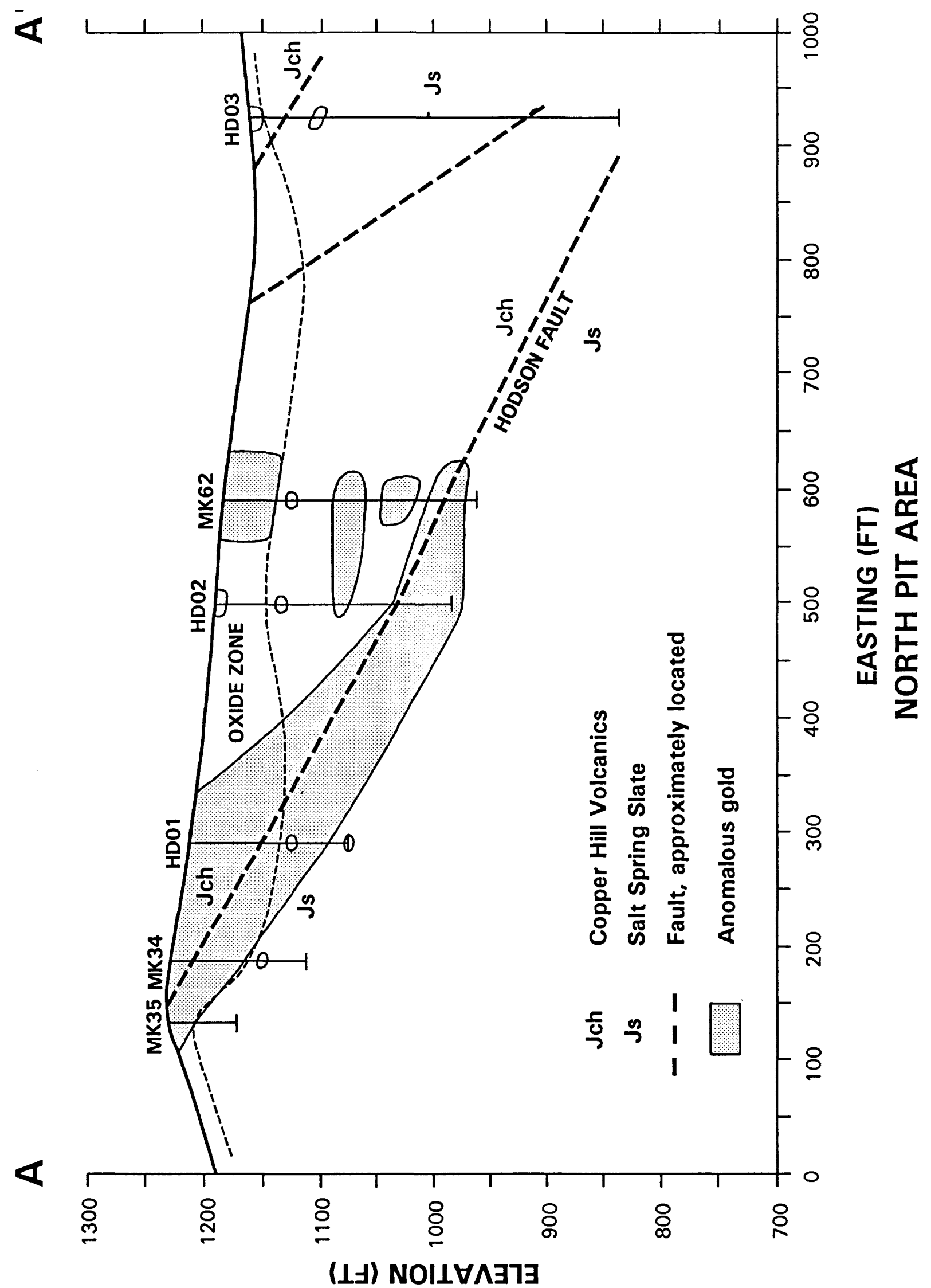

Figure 3.--Geologic map for section A-A' through the North Pit, Hodson district. Shaded areas show the distribution of anomalous gold. For location of $A-A^{\prime}$ see Figure 2 . 


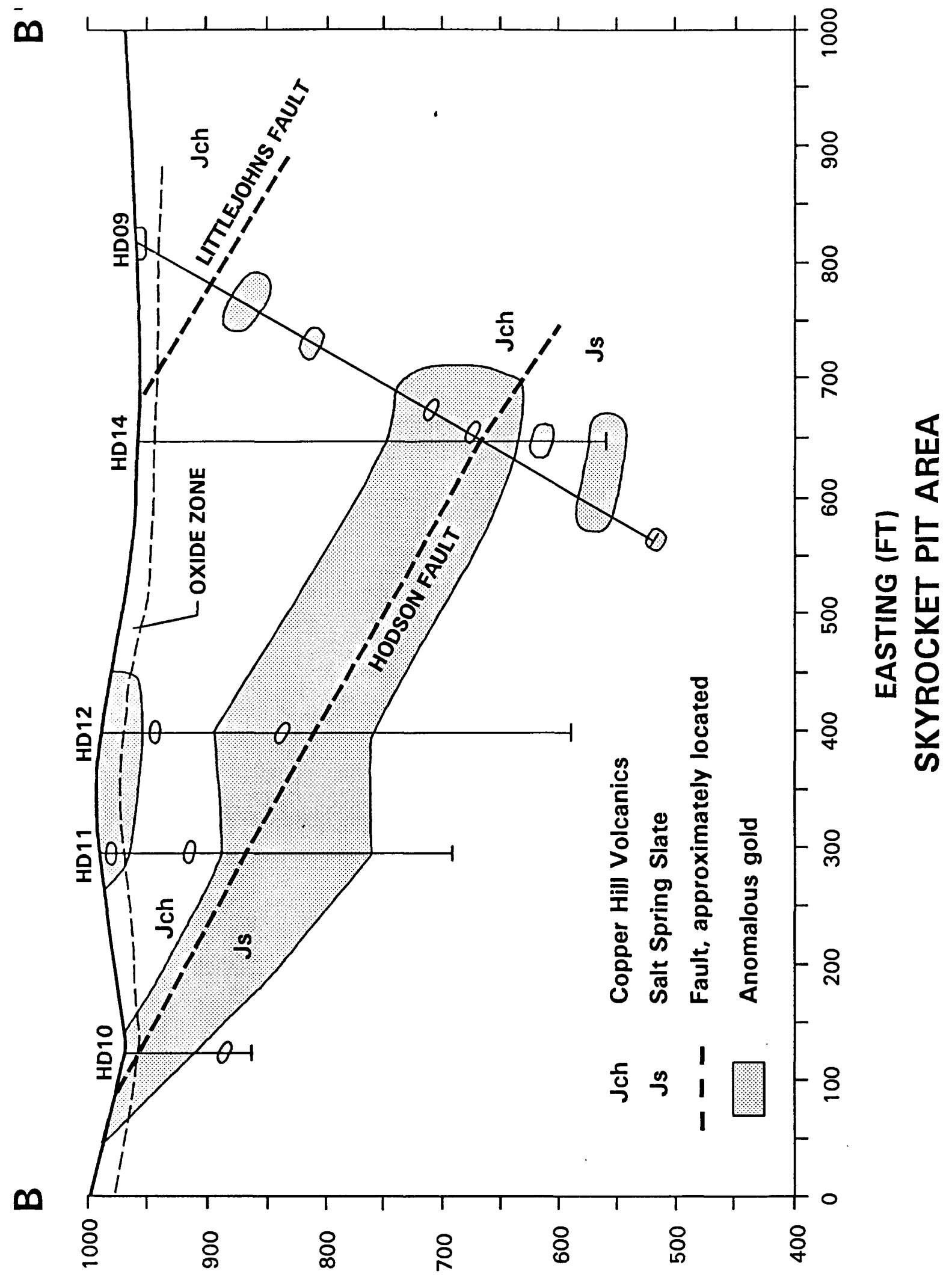

(ป」) NOIL

Figure 4.--Geologic map for section B-B' through the skyrocket Pit, Hodson district. Shaded areas show the distribution of anomalous gold. For location of $B-B^{\prime}$ see Figure 2 . 


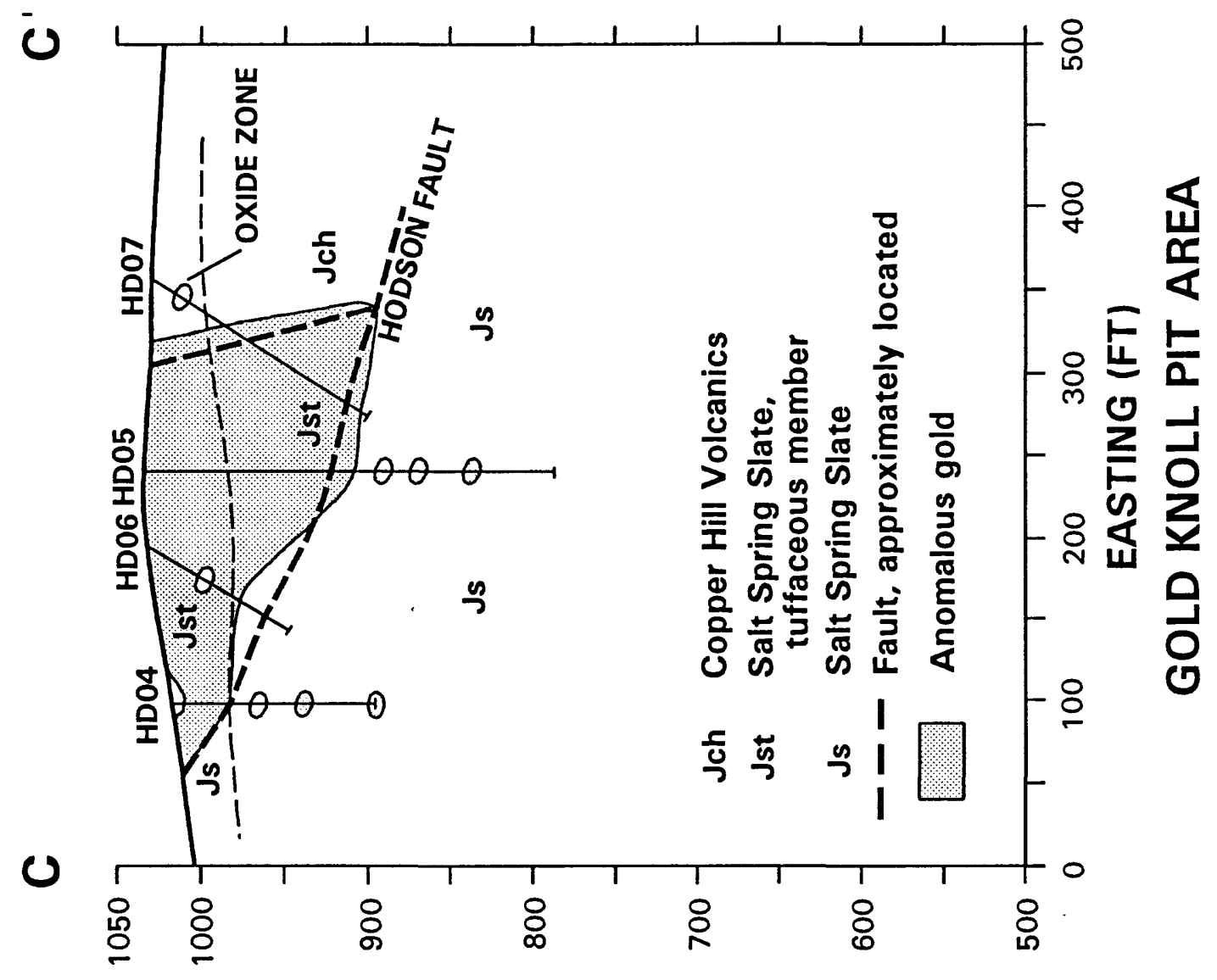

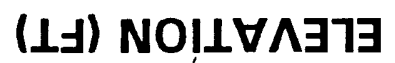

Figure 5.--Geologic map for section C-C' through the Gold Knoll Pit, Hodson district. Shaded areas show the distribution of anomalous gold. For location of $C^{-} C^{\prime}$ see Figure 2. 
Kuhl, 1990) and has been simplified for the cross section. In general, in the area of the section, the Hodson fault separates the Copper Hill Volcanics unit in the hanging wall from the salt Spring slate unit in the footwall. other faults farther east form contacts on either side of a block of salt spring slate. The Copper Hill Volcanics is the dominant ore host in this area. Hydrothermal alteration, which is more extensive here in the Copper Hill Volcanics, has visibly bleached this unit as a result of the destruction of chlorite and other mafic minerals and has also locally bleached the salt spring slate as a result of the leaching of carbon and the destruction of mafic minerals. oxidation related to weathering extends as deep as $24 \mathrm{~m}$ ( $80 \mathrm{ft}$ ) in the vicinity of the section (Fig. 3). Common alteration minerals identified either by visual inspection or $x$-ray diffraction analysis include quartz, white mica, plagioclase feldspar, kaolinite, pyrite, calcite, other mixed-element carbonates (all here called ankerite), magnesite, talc or pyrophyllite, smectites, and locally, mariposite (Cr-rich white mica).

The middle deposit is in the skyrocket Pit and is shown on Section B-B' (Fig. 4). In this area, the Hodson fault also separates the overlying Copper Hill Volcanics from the salt spring slate. However, here the salt spring slate is the dominant ore host. Alteration and ore minerals are similar to those described for these same two units in the North Pit area. oxidation related to weathering is relatively shallow here and occurs to depths of only about $8 \mathrm{~m}(27 \mathrm{ft})$ in the vicinity of the section (Fig. 4).

The southernmost deposit, in the Gold Knoll Pit, is shown on Section C-C' (Fig. 5). In the area of the section, the Hodson fault separates the hanging wall block containing the Copper Hill Volcanics (Jch) and the tuffaceous member of the salt spring Slate (Jst) from the footwall block containing the salt spring slate (Js). The dominant ore host-rocks in the Gold Knoll Pit area are the Copper Hill Volcanics and the tuffaceous member of the salt spring slate. Alteration assemblages in the copper Hill Volcanics and the salt spring slate are similar to those described for the other two areas. Alteration in the tuffaceous member is similar to that of the rest of the salt spring slate. The effects of weathering extend to depths of as much as $22 \mathrm{~m}$ (73 ft) in the vicinity of the section (Fig. 5).

\section{COLLECTION AND PREPARATION OF SAMPLES}

Three hundred samples of core or cuttings from 17 drill holes were collected and analyzed for this study. The samples were collected from approximately $1.5-$ to $3-\mathrm{m}$ (5- to $10-\mathrm{ft}$ ) runs along the length of each hole. Each sample was composited from material most closely representing typical rock lithology, alteration, and mineralization in a given run. In some cases no sample was collected for a desired interval because no suitable material was available.

The samples were crushed, if necessary, in a jaw crusher with steel plates. All samples were ground in a vertical pulverizer 
with ceramic plates to produce material passing a $0.15-\mathrm{mm}$ (100mesh) sieve. The samples were' submitted in random sequence to the USGS analytical laboratories in Denver.

\section{ANALYSIS OF SAMPLES}

The samples were analyzed for 44 variables. They were analyzed for 31 elements (Al, $\mathrm{As}, \mathrm{Ba}, \mathrm{Be}, \mathrm{Ca}, \mathrm{Ce}, \mathrm{Co}, \mathrm{Cr}, \mathrm{Cu}, \mathrm{Eu}$, $\mathrm{Fe}, \mathrm{Ga}, \mathrm{K}, \mathrm{La}, \mathrm{Li}, \mathrm{Mg}, \mathrm{Mn}, \mathrm{Na}, \mathrm{Nb}, \mathrm{Nd}, \mathrm{Ni}, \mathrm{P}, \mathrm{Pb}, \mathrm{Sc}, \mathrm{Sr}, \mathrm{Th}, \mathrm{Ti}$, $\mathrm{V}, \mathrm{Y}, \mathrm{Yb}$, and $\mathrm{Zn})$ by a total digestion, inductively coupled plasma-atomic emission specrometry (ICP-AES) method (Briggs, 1990), for 5 elements ( $\mathrm{Ag}, \mathrm{Bi}, \mathrm{Cd}, \mathrm{Mo}$, and $\mathrm{Sb}$ ) by a partialdigestion ICP method (Motooka, 1990), for $\mathrm{Au}, \mathrm{Te}$, and $\mathrm{Tl}$ by atomic-absorption spectrophotometry (O'Leary and Chao, 1990), for $\mathrm{Hg}$ and $\mathrm{W}$ by atomic-absorption spectrophotometry (O'Leary and others, 1990; O'Leary and Welsch, 1990), for total sulfur by a combustion technique (Curry, 1990), and for $\mathrm{SiO}_{2}$ by X-ray fluorescence (Taggart and others, 1990). In addition, the weight loss on ignition at $925^{\circ} \mathrm{C}$ (LOI) was determined by a gravimetric method (Taggart and others, 1990). This loss largely reflects the loss of $\mathrm{CO}_{2}$ resulting from the destruction of carbonate minerals and, to a much lesser extent, the loss of $\mathrm{H}_{2} \mathrm{O}$ and other relatively volatile species.

Unless otherwise stated for a given standard analytical procedure, the analysts included a set with one sample duplicate, one analysis method blank, and two reference samples in each job of 40 or less samples. The arithmetic mean and standard deviation of reference materials and duplicate samples were calculated in order to estimate accuracy and precision for each analytical method. A given analytical method was generally considered sufficiently accurate if the absolute value of the laboratory mean minus the best defined reported value was less than or equal to four times the estimated within-laboratory standard deviation. Generally, for the major elements (those commonly occurring in concentrations greater than 1 percent), a relative standard deviation (RSD) less than 1 to 2 percent was considered adequate for precision. For minor elements (those commonly occurring in concentrations of 0.1 to 1.0 percent) a RSD less than 5 percent was considered adequate, and for trace elements (concentrations generally less than 0.1 percent), a RSD of less than 15 percent was considered adequate. The quality assurance manual for the USGS Branch of Geochemistry (Arbogast, 1990) contains estimates of typical performance capabilities for different sample matrices and analyte concentrations, as well as specific data concerning the accuracy and precision of the techniques described above.

The analytical results are tabulated in appendix 1 . Data on these analyses are summarized by lithologies in tables 1 to 3 . Two elements ( $\mathrm{Bi}$ and $\mathrm{Eu}$ ) were not found in many samples in concentrations above their respective lower limits of determination ( $0.60 \mathrm{ppm}$ for $\mathrm{Bi}$ and $2 \mathrm{ppm}$ for $\mathrm{Eu})$, and thus these elements were not further studied. 
Table 1.--Statistical summary for 139 samples of core and cuttings from the Copper Hill Volcanics (Jch) unit, Hodson mining district, California

[All values shown in parts per million unless "\%" shown. $\mathrm{N}=$ not detected at lower limit of determination shown in parentheses. $\mathrm{L}=$ detected but in a concentration less than the lower limit of determination shown in parentheses. Leaders $(--)=$ value not significant]

\begin{tabular}{|c|c|c|c|c|c|c|c|c|c|}
\hline \multirow[b]{2}{*}{ Variable } & \multicolumn{2}{|c|}{ Range of values } & \multirow{2}{*}{$\begin{array}{l}\text { Percent } \\
\text { unqualified }\end{array}$} & \multirow{2}{*}{$\begin{array}{c}\text { Geometric } \\
\text { mean }\end{array}$} & \multicolumn{5}{|c|}{ Percentiles } \\
\hline & Minimum & Maximum & & & 2 & 5 & 10 & 15 & 20 \\
\hline Ag & $\mathrm{N}(0.045)$ & 9.2 & 72 & 0.26 & $N(0.045)$ & $N(0.045)$ & $N(0.045)$ & $\mathrm{N}(0.045)$ & $\mathrm{N}(0.045)$ \\
\hline $\mathrm{Al}(\%)$ & 0.13 & 9.82 & 100 & 5.34 & 0.22 & 1.48 & 2.64 & 3.89 & 4.65 \\
\hline As & $\mathrm{L}(10)$ & 530 & 64 & 62 & $L(10)$ & $\mathrm{L}(10)$ & $L(10)$ & $\mathrm{L}(10)$ & $L(10)$ \\
\hline $\mathrm{Au}$ & $\mathrm{N}(0.002)$ & 40 & 77 & 0.013 & $\mathrm{~N}(0.002)$ & $L(0.002)$ & $L(0.002)$ & $L(0.002)$ & $\mathrm{L}(0.002)$ \\
\hline $\mathrm{Ba}$ & 4 & 660 & 100 & 105 & 6 & 10 & 33 & 44 & 66 \\
\hline $\mathrm{Be}$ & $\mathrm{L}(1)$ & 3.0 & 41 & 1.3 & $\mathrm{~L}(1)$ & $\mathrm{L}(1)$ & $\mathrm{L}(1)$ & $\mathrm{L}(1)$ & $\mathrm{L}(1)$ \\
\hline $\mathrm{Bi}$ & $\mathrm{N}(0.60)$ & 0.64 & 3 & - & $N(0.60)$ & $N(0.60)$ & $N(0.60)$ & $\mathrm{N}(0.60)$ & $N(0.60)$ \\
\hline $\mathrm{Ca}(\%)$ & 0.03 & 13.5 & 100 & 3.53 & 0.08 & 0.31 & 0.47 & 0.75 & 2.04 \\
\hline $\mathrm{Cd}$ & $N(0.030)$ & 0.86 & 94 & 0.09 & $N(0.030)$ & $\mathrm{N}(0.030)$ & 0.038 & 0.047 & 0.054 \\
\hline $\mathrm{Ce}$ & $\mathrm{L}(4)$ & 55 & 49 & 26 & $\mathrm{~L}(4)$ & $\mathrm{L}(4)$ & $\mathrm{L}(4)$ & $\mathrm{L}(4)$ & $\mathrm{L}(4)$ \\
\hline Co & 3 & 115 & 100 & 34 & 6 & 12 & 18 & 22 & 24 \\
\hline $\mathrm{Cr}$ & 7 & 2380 & 100 & 220 & 18 & 24 & 39 & 52 & 58 \\
\hline $\mathrm{Cu}$ & 5 & 345 & 100 & 54 & 8 & 11 & 24 & 33 & 39 \\
\hline $\mathrm{Eu}$ & $\mathrm{L}(2)$ & 3.0 & 22 & -- & $L(2)$ & $\mathrm{L}(2)$ & $\mathrm{L}(2)$ & $\mathrm{L}(2)$ & $L(2)$ \\
\hline $\mathrm{Fe}(\%)$ & 1.05 & 8.12 & 100 & 5.51 & 1.48 & 3.31 & 4.15 & 4.64 & 4.86 \\
\hline $\mathrm{Ga}$ & $L(4)$ & 23 & 95 & 13 & $L(4)$ & 6 & 7 & 8 & 9 \\
\hline $\mathrm{Hg}$ & $\mathrm{N}(0.02)$ & 1.3 & 76 & 0.05 & $N(0.02)$ & $\mathrm{N}(0.02)$ & $\mathrm{N}(0.02)$ & $\mathrm{N}(0.02)$ & $\mathrm{N}(0.02)$ \\
\hline $\mathrm{K}(\%)$ & $L(0.05)$ & 3.29 & 91 & 0.80 & $\mathrm{~L}(0.05)$ & $L(0.05)$ & 0.06 & 0.14 & 0.22 \\
\hline $\mathrm{La}$ & $\mathrm{L}(2)$ & 31 & 88 & 7.2 & $L(2)$ & $\mathrm{L}(2)$ & $\mathrm{L}(2)$ & 2 & 2 \\
\hline $\mathrm{Li}$ & $L(2)$ & 100 & 99 & 20 & 3 & 3 & 4 & 5 & 8 \\
\hline LOI (\%) & 0.79 & 34.7 & 100 & 7.98 & 1.54 & 3.10 & 3.72 & 4.10 & 4.55 \\
\hline $\mathrm{Mg}(\%)$ & 0.06 & 21.1 & 100 & 3.13 & 0.11 & 0.33 & 1.12 & 1.27 & 1.42 \\
\hline Mn & 28 & 3030 & 100 & 898 & 117 & 404 & 533 & 684 & 742 \\
\hline Mo & $\mathrm{N}(0.09)$ & 2.0 & 88 & 0.27 & $\mathrm{~N}(0.09)$ & $\mathrm{N}(0.09)$ & $N(0.09)$ & 0.12 & 0.13 \\
\hline $\mathrm{Na}(\%)$ & 0.02 & 3.23 & 100 & 1.01 & 0.04 & 0.09 & 0.21 & 0.41 & 0.55 \\
\hline $\mathrm{Nb}$ & $L(4)$ & 22 & 26 & 11 & $\mathrm{~L}(4)$ & $\mathrm{L}(4)$ & $\mathrm{L}(4)$ & $L(4)$ & $L(4)$ \\
\hline Nd & L(4) & 39 & 88 & 11 & $L(4)$ & L(4) & L(4) & 4 & 5 \\
\hline $\mathrm{Ni}$ & 7 & 1430 & 100 & 93 & 13 & 16 & 22 & 24 & 27 \\
\hline$P(\%)$ & $L(0.005)$ & 0.24 & 86 & 0.05 & $L(0.005)$ & $\mathrm{L}(0.005)$ & $L(0.005)$ & 0.006 & 0.01 \\
\hline $\mathrm{Pb}$ & $\mathrm{L}(4)$ & 162 & 64 & 8.3 & $L(4)$ & $L(4)$ & $L(4)$ & $\mathrm{L}(4)$ & $L(4)$ \\
\hline$S(\%)$ & $\mathrm{L}(0.05)$ & 1.00 & 42 & 0.13 & $L(0.05)$ & $\mathrm{L}(0.05)$ & $\mathrm{L}(0.05)$ & $\mathrm{L}(0.05)$ & $L(0.05)$ \\
\hline $\mathrm{Sb}$ & $\mathrm{N}(0.60)$ & 16 & 51 & 1.9 & $N(0.60)$ & $\mathrm{N}(0.60)$ & $\mathrm{N}(0.60)$ & $N(0.60)$ & $N(0.60)$ \\
\hline Sc & 3 & 48 & 100 & 24 & 4 & 5 & 11 & 17 & 20 \\
\hline $\mathrm{SiO}_{2}(\%)$ & 21.8 & 92.3 & 100 & 48.7 & 28.2 & 35.2 & 37.4 & 39.5 & 41.4 \\
\hline $\mathrm{Sr}$ & 12 & 798 & 100 & 170 & 18 & 31 & 43 & 52 & 61 \\
\hline $\mathrm{Te}$ & $\mathrm{N}(0.005)$ & 0.85 & 60 & 0.016 & $N(0.005)$ & $L(0.005)$ & $L(0.005)$ & $L(0.005)$ & $L(0.005)$ \\
\hline Th & $\mathrm{L}(4)$ & 4 & 1 & -- & $L(4)$ & $\mathrm{L}(4)$ & $L(4)$ & $L(4)$ & $\mathrm{L}(4)$ \\
\hline $\mathrm{Ti}(\%)$ & $L(0.005)$ & 1.12 & 96 & 0.22 & $L(0.005)$ & 0.02 & 0.03 & 0.04 & 0.06 \\
\hline $\mathrm{Tl}$ & $N(0.05)$ & 0.40 & 64 & 0.14 & $\mathrm{~N}(0.05)$ & $N(0.05)$ & $\mathrm{N}(0.05)$ & $N(0.05)$ & $L(0.05)$ \\
\hline V & 8 & 398 & 100 & 177 & 22 & 40 & 100 & 121 & 138 \\
\hline W & $\mathrm{N}(0.5)$ & 36 & 96 & 2.3 & $L(0.5)$ & 0.5 & 1.0 & 1.0 & 1.0 \\
\hline $\mathbf{Y}$ & $\mathrm{L}(2)$ & 29 & 96 & 11 & $\mathrm{~L}(2)$ & 3 & 4 & 5 & 5 \\
\hline $\mathrm{Yb}$ & $L(1)$ & 3.0 & 67 & 1.6 & $L(1)$ & $\mathrm{L}(1)$ & $\mathrm{L}(1)$ & $L(1)$ & $L(1)$ \\
\hline $\mathrm{Zn}$ & 16 & 319 & 100 & 55 & 19 & 22 & 29 & 33 & 37 \\
\hline
\end{tabular}


Table 1.---Continued

[All values shown in parts per million unless "\%" shown. $\mathrm{N}=$ not detected at lower limit of determination shown in parentheses. $\mathrm{L}=$ detected but in a concentration less than the lower limit of determination shown in parentheses] .

\begin{tabular}{|c|c|c|c|c|c|c|c|c|c|c|}
\hline \multirow[b]{2}{*}{ Variable } & \multicolumn{10}{|c|}{ Percentiles } \\
\hline & 25 & 40 & 50 & 60 & 75 & 80 & 85 & 90 & 95 & 98 \\
\hline$\overline{\mathrm{Ag}}$ & $\overline{N(0.045)}$ & 0.061 & 0.13 & 0.20 & 0.42 & 0.53 & 0.74 & 1.0 & 1.4 & 2.5 \\
\hline $\mathrm{Al}(\%)$ & 5.00 & 5.99 & 6.76 & 7.37 & 8.04 & 8.29 & 8.66 & 8.92 & 9.05 & 9.45 \\
\hline As & $\mathrm{L}(10)$ & 10 & 20 & 40 & 100 & 130 & 170 & 245 & 325 & 465 \\
\hline $\mathrm{Au}$ & 0.002 & 0.002 & 0.004 & 0.006 & 0.019 & 0.05 & 0.10 & 0.23 & 3.70 & 1.93 \\
\hline $\mathrm{Ba}$ & 78 & 103 & 121 & 149 & 185 & 216 & 263 & 301 & 387 & 524 \\
\hline $\mathrm{Be}$ & $\mathrm{L}(1)$ & $\mathrm{L}(1)$ & $\mathrm{L}(1)$ & 1 & 1 & 1 & 1 & 2 & 2 & 2 \\
\hline $\mathrm{Bi}$ & $\mathrm{N}(0.60)$ & $N(0.60)$ & $\mathrm{N}(0.60)$ & $N(0.60)$ & $N(0.60)$ & $N(0.60)$ & $N(0.60)$ & $N(0.60)$ & $\mathrm{N}(0.60)$ & 0.61 \\
\hline $\mathrm{Ca}(\%)$ & 3.30 & 5.33 & 5.70 & 6.11 & 6.73 & 7.13 & 7.38 & 8.57 & 10.1 & 12.3 \\
\hline $\mathrm{Cd}$ & 0.062 & 0.072 & 0.077 & 0.086 & 0.13 & 0.13 & 0.15 & 0.16 & 0.27 & 0.40 \\
\hline $\mathrm{Ce}$ & $L(4)$ & $\mathrm{L}(4)$ & $\mathrm{L}(4)$ & 8 & 40 & 44 & 46 & 49 & 51 & 53 \\
\hline Co & 25 & 31 & 36 & 39 & 52 & 56 & 60 & 72 & 81 & 89 \\
\hline $\mathrm{Cr}$ & 63 & 122 & 346 & 430 & 662 & 745 & 833 & 1120 & 1490 & 1940 \\
\hline $\mathrm{Cu}$ & 44 & 53 & 59 & 68 & 85 & 90 & 96 & 102 & 117 & 139 \\
\hline $\mathrm{Eu}$ & $\mathrm{L}(2)$ & $L(2)$ & $\mathrm{L}(2)$ & $L(2)$ & $\mathrm{L}(2)$ & 2 & 2 & 2 & 2 & 2 \\
\hline $\mathrm{Fe}(\%)$ & 5.03 & 5.71 & 5.96 & 6.19 & 6.63 & 6.82 & 6.97 & 7.21 & 7.49 & 7.72 \\
\hline $\mathrm{Ga}$ & 10 & 12 & 13 & 15 & 19 & 19 & 20 & 21 & 21 & 22 \\
\hline $\mathrm{Hg}$ & 0.02 & 0.02 & 0.04 & 0.04 & 0.08 & 0.10 & 0.12 & 0.20 & 0.29 & 0.49 \\
\hline $\mathrm{K}(\%)$ & 0.36 & 0.74 & 0.93 & 1.22 & 1.46 & 1.62 & 1.86 & 2.24 & 2.65 & 3.12 \\
\hline $\mathrm{La}$ & 3 & 3 & 4 & 5 & 22 & 23 & 25 & 26 & 28 & 28 \\
\hline $\mathrm{Li}$ & 12 & 23 & 27 & 32 & 39 & 41 & 43 & 48 & 58 & 76 \\
\hline LOI (\%) & 5.03 & 6.42 & 7.31 & 8.71 & 14.1 & 16.8 & 17.7 & 21.1 & 24.8 & 30.5 \\
\hline $\operatorname{Mg}(\%)$ & 1.68 & 2.12 & 4.59 & 5.00 & 6.75 & 7.54 & 9.07 & 10.9 & 12.4 & 16.1 \\
\hline Mn & 799 & 997 & 1080 & 1130 & 1210 & 1230 & 1260 & 1290 & 1420 & 1600 \\
\hline Mo & 0.15 & 0.18 & 0.20 & 0.24 & 0.38 & 0.48 & 0.62 & 0.83 & 0.99 & 1.2 \\
\hline $\mathrm{Na}(\%)$ & 0.70 & 1.15 & 1.46 & 1.80 & 2.14 & 2.24 & 2.37 & 2.47 & 2.78 & 2.96 \\
\hline $\mathrm{Nb}$ & $\mathrm{L}(4)$ & $\mathrm{L}(4)$ & $L(4)$ & $\mathrm{L}(4)$ & 4 & 7 & 10 & 16 & 19 & 20 \\
\hline Nd & 5 & 7 & 7 & 9 & 27 & 29 & 30 & 32 & 33 & 34 \\
\hline $\mathrm{Ni}$ & 29 & 65 & 106 & 141 & 241 & 284 & 336 & 428 & 517 & 848 \\
\hline$P(\%)$ & 0.01 & 0.02 & 0.03 & 0.04 & 0.13 & 0.14 & 0.16 & 0.17 & 0.19 & 0.22 \\
\hline $\mathrm{Pb}$ & $L(4)$ & 4 & 5 & 6 & 7 & 9 & 11 & 14 & 27 & 80 \\
\hline$S(\%)$ & $\mathrm{L}(0.05)$ & $L(0.05)$ & $L(0.05)$ & 0.05 & 0.11 & 0.13 & 0.16 & 0.19 & 0.34 & 0.47 \\
\hline $\mathrm{Sb}$ & $N(0.60)$ & $N(0.60)$ & 0.67 & 0.91 & 1.8 & 2.3 & 2.8 & 4.3 & 6.1 & 8.1 \\
\hline Sc & 22 & 25 & 27 & 30 & 37 & 40 & 40 & 42 & 44 & 46 \\
\hline $\mathrm{SiO}_{2}(\%)$ & 43.2 & 46.4 & 48.1 & 50.2 & 53.0 & 54.8 & 59.6 & 67.3 & 79.3 & 90.1 \\
\hline $\mathrm{Sr}$ & 77 & 120 & 212 & 292 & 403 & 459 & 516 & 592 & 692 & 743 \\
\hline $\mathrm{Te}$ & $\mathrm{L}(0.005)$ & 0.005 & 0.005 & 0.010 & 0.015 & 0.020 & 0.030 & 0.048 & 0.080 & 0.11 \\
\hline Th & $L(4)$ & $\mathrm{L}(4)$ & $\mathrm{L}(4)$ & $\mathrm{L}(4)$ & $\mathrm{L}(4)$ & $\mathrm{L}(4)$ & $\mathrm{L}(4)$ & $\mathrm{L}(4)$ & $\mathrm{L}(4)$ & $\mathrm{L}(4)$ \\
\hline $\mathrm{Ti}(\%)$ & 0.07 & 0.21 & 0.28 & 0.31 & 0.53 & 0.80 & 0.89 & 0.97 & 1.02 & 1.05 \\
\hline $\mathrm{Tl}$ & $L(0.05)$ & 0.05 & 0.10 & 0.10 & 0.20 & 0.20 & 0.25 & 0.28 & 0.33 & 0.35 \\
\hline V & 146 & 195 & 210 & 242 & 256 & 264 & 286 & 296 & 324 & 352 \\
\hline W & 1.0 & 1.0 & 1.5 & 2.0 & 4.0 & 5.0 & 7.0 & 11 & 18 & 21 \\
\hline$Y$ & 5 & 10 & 11 & 13 & 18 & 20 & 22 & 22 & 24 & 26 \\
\hline $\mathrm{Yb}$ & $\mathrm{L}(1)$ & 1 & 1 & 2 & 2 & 2 & 2 & 2 & 3 & 3 \\
\hline $\mathrm{Zn}$ & 41 & 50 & 54 & 58 & 71 & 77 & 90 & 97 & 124 & 211 \\
\hline
\end{tabular}


Table 2.--Statistical summary for 118 samples of core and cuttings from the Salt Spring Slate (Js), Hodson mining district, California

[All values shown in parts per million unless "\%" shown. $\mathrm{N}=$ not detected at lower limit of determination shown in parentheses. $\mathrm{L}=$ detected but in a concentration less than the lower limit of determination shown in parentheses. ---=value not significant]

\begin{tabular}{|c|c|c|c|c|c|c|c|c|c|}
\hline \multirow[b]{2}{*}{ Variable } & \multicolumn{2}{|c|}{ Range of values } & \multirow{2}{*}{$\begin{array}{c}\text { Percent } \\
\text { unqualified }\end{array}$} & \multirow{2}{*}{$\begin{array}{c}\text { Geometric } \\
\text { mean }\end{array}$} & \multicolumn{5}{|c|}{ Percentiles } \\
\hline & Minimum & $\underline{\text { Maximum }}$ & & & 2 & 5 & 10 & 15 & 20 \\
\hline $\mathrm{Ag}$ & 0.046 & 9.2 & 100 & 0.58 & 0.096 & 0.11 & 0.13 & 0.16 & 0.17 \\
\hline $\mathrm{Al}(\%)$ & 0.55 & 9.92 & 100 & 6.05 & 2.62 & 3.74 & 4.58 & 4.88 & 5.05 \\
\hline As & $\mathrm{L}(10)$ & 800 & 98 & 74 & 15 & 20 & 20 & 20 & 30 \\
\hline $\mathrm{Au}$ & $\mathrm{N}(0.002)$ & 1.3 & 57 & 0.017 & $N(0.002)$ & $\mathrm{N}(0.002)$ & $\mathrm{N}(0.002)$ & $\mathrm{N}(0.002)$ & $\mathrm{N}(0.002)$ \\
\hline $\mathrm{Ba}$ & 31 & 1140 & 100 & 380 & 74 & 111 & 147 & 158 & 237 \\
\hline $\mathrm{Be}$ & $\mathrm{L}(1)$ & 3.0 & 86 & 1.4 & $\mathrm{~L}(1)$ & $\mathrm{L}(1)$ & $\mathrm{L}(1)$ & 1 & 1 \\
\hline $\mathrm{Bi}$ & $\mathrm{N}(0.60)$ & 0.78 & 1 & -- & $N(0.60)$ & $N(0.60)$ & $N(0.60)$ & $N(0.60)$ & $N(0.60)$ \\
\hline $\mathrm{Ca}(\%)$ & 0.03 & 9.40 & 100 & 2.05 & 0.26 & 0.36 & 0.95 & 1.37 & 1.58 \\
\hline $\mathrm{Cd}$ & $\mathrm{N}(0.030)$ & 0.98 & 99 & 0.27 & 0.14 & 0.14 & 0.16 & 0.18 & 0.19 \\
\hline $\mathrm{Ce}$ & $\mathrm{L}(4)$ & 55 & 98 & 19 & 6 & 7 & 12 & 13 & 14 \\
\hline Co & 2 & 41 & 100 & 16 & 8 & 11 & 11 & 12 & 13 \\
\hline $\mathrm{Cr}$ & 4 & 260 & 100 & 98 & 47 & 53 & 65 & 72 & 80 \\
\hline $\mathrm{Cu}$ & 6 & 130 & 100 & 49 & 20 & 26 & 30 & 31 & 33 \\
\hline $\mathrm{Eu}$ & $\mathrm{L}(2)$ & $\mathrm{L}(2)$ & 0 & --- & $\mathrm{L}(2)$ & $\mathrm{L}(2)$ & $\mathrm{L}(2)$ & $\mathrm{L}(2)$ & $\mathrm{L}(2)$ \\
\hline $\mathrm{Fe}(\%)$ & 0.65 & 6.46 & 100 & 4.21 & 2.47 & 2.84 & 3.24 & 3.36 & 3.55 \\
\hline $\mathrm{Ga}$ & $\mathrm{L}(4)$ & 24 & 99 & 14 & 7 & 9 & 10 & 11 & 11 \\
\hline $\mathrm{Hg}$ & 0.02 & 0.74 & 100 & 0.14 & 0.04 & 0.05 & 0.08 & 0.08 & 0.09 \\
\hline K (\%) & $\mathrm{L}(0.05)$ & 4.14 & 99 & 1.65 & 0.37 & 0.82 & 1.04 & 1.17 & 1.27 \\
\hline $\mathrm{La}$ & $\mathrm{L}(2)$ & 27 & 99 & 10 & 4 & 5 & 7 & 7 & 8 \\
\hline $\mathrm{Li}$ & $\mathrm{L}(2)$ & 75 & 99 & 14 & 3 & 3 & 3 & 3 & 4 \\
\hline LOI (\%) & 0.74 & 21.2 & 100 & $6.81^{*}$ & 3.62 & 4.02 & 4.44 & 4.97 & 5.22 \\
\hline $\operatorname{Mg}(\%)$ & 0.03 & 6.93 & 100 & 1.55 & 0.45 & 0.66 & 1.18 & 1.31 & 1.37 \\
\hline $\mathrm{Mn}$ & 14 & 1690 & 100 & 615 & 272 & 310 & 391 & 440 & 493 \\
\hline Mo & 0.13 & 5.3 & 100 & 0.91 & 0.21 & 0.33 & 0.48 & 0.57 & 0.65 \\
\hline $\mathrm{Na}(\%)$ & 0.13 & 3.74 & 100 & 1.01 & 0.27 & 0.32 & 0.43 & 0.55 & 0.65 \\
\hline $\mathrm{Nb}$ & $L(4)$ & 7 & 25 & -- & $\mathrm{L}(4)$ & $\mathrm{L}(4)$ & $\mathrm{L}(4)$ & $\mathrm{L}(4)$ & $\mathrm{L}(4)$ \\
\hline Nd & $\mathrm{L}(4)$ & 25 & 99 & 12 & 6 & 7 & 8 & 9 & 10 \\
\hline $\mathrm{Ni}$ & 6 & 180 & 100 & 53 & 24 & 29 & 35 & 38 & 41 \\
\hline$P(\%)$ & 0.01 & 0.21 & 100 & 0.08 & 0.03 & 0.03 & 0.04 & 0.05 & 0.06 \\
\hline $\mathrm{Pb}$ & 5 & 98 & 100 & 17 & 6 & 8 & 10 & 11 & 12 \\
\hline$S(\%)$ & $\mathrm{L}(0.05)$ & 5.58 & 89 & 0.61 & $\mathrm{~L}(0.05)$ & $\mathrm{L}(0.05)$ & $L(0.05)$ & 0.15 & 0.21 \\
\hline $\mathrm{Sb}$ & $\mathrm{N}(0.60)$ & 12 & 99 & 2.2 & 0.80 & 0.96 & 1.1 & 1.2 & 1.3 \\
\hline $\mathrm{Sc}$ & $\mathrm{L}(2)$ & 34 & 99 & 14 & 8 & 10 & 11 & 12 & 12 \\
\hline $\mathrm{SiO}_{2}(\%)$ & 38.8 & 95.5 & 100 & $61.2^{*}$ & 43.6 & 46.0 & 52.6 & 56.5 & 58.0 \\
\hline $\mathrm{Sr}$ & 9 & 1120 & 100 & 220 & 73 & 85 & 102 & 126 & 146 \\
\hline $\mathrm{Te}$ & $L(0.005)$ & 0.80 & 99 & 0.041 & 0.008 & 0.010 & 0.018 & 0.020 & 0.025 \\
\hline Th & $\mathrm{L}(4)$ & 10 & 52 & 5.7 & $\mathrm{~L}(4)$ & $\mathrm{L}(4)$ & $\mathrm{L}(4)$ & $\mathrm{L}(4)$ & $\mathrm{L}(4)$ \\
\hline $\mathrm{Ti}(\%)$ & 0.01 & 0.37 & 100 & 0.13 & 0.04 & 0.06 & 0.06 & 0.07 & 0.08 \\
\hline $\mathrm{Tl}$ & $\mathrm{N}(0.05)$ & 0.55 & 97 & 0.21 & $N(0.05)$ & 0.08 & 0.10 & 0.15 & 0.15 \\
\hline V & 11 & 237 & 100 & 118 & 58 & 76 & 81 & 88 & 93 \\
\hline W & $\mathrm{L}(0.5)$ & 17 & 99 & 3.1 & 1.0 & 1.0 & 1.0 & 1.5 & 1.5 \\
\hline 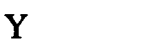 & $\mathrm{L}(2)$ & 24 & 99 & 10 & 6 & 7 & 8 & 8 & 9 \\
\hline $\mathrm{Yb}$ & $\mathrm{L}(1)$ & 3 & 78 & 1.4 & $\mathrm{~L}(1)$ & $\mathrm{L}(1)$ & $\mathrm{L}(1)$ & $\mathrm{L}(1)$ & $\mathrm{L}(1)$ \\
\hline $\mathrm{Zn}$ & 22 & 250 & 100 & 104 & 46 & 53 & 64 & 71 & 79 \\
\hline
\end{tabular}

* Mean value based on 117 samples 
Table 2.--Continued

[All values shown in parts per million unless "\%" shown. $\mathrm{N}=$ not detected at lower limit of determination shown in parentheses. $\mathrm{L}=$ detected but in a concentration less than the lower limit of determination shown in parentheses].

\begin{tabular}{|c|c|c|c|c|c|c|c|c|c|c|}
\hline \multirow[b]{2}{*}{ Variable } & \multicolumn{10}{|c|}{ Percentiles } \\
\hline & 25 & 40 & 50 & 60 & 75 & 80 & 85 & 90 & 95 & 98 \\
\hline $\mathrm{Ag}$ & 0.20 & 0.32 & 0.50 & 0.79 & 1.7 & 1.9 & 3.1 & 4.0 & 4.8 & 5.6 \\
\hline $\mathrm{Al}(\%)$ & 5.24 & 5.94 & 6.50 & 6.84 & 7.37 & 7.72 & 7.85 & 8.17 & 8.71 & 8.96 \\
\hline As & 30 & 40 & 60 & 80 & 160 & 230 & 265 & 345 & 460 & 530 \\
\hline $\mathrm{Au}$ & $N(0.002)$ & $\mathrm{L}(0.002)$ & 0.002 & 0.004 & 0.014 & 0.023 & 0.075 & 0.15 & 0.43 & 0.63 \\
\hline $\mathrm{Ba}$ & 310 & 388 & 469 & 531 & 611 & 627 & 682 & 717 & 765 & 788 \\
\hline $\mathrm{Be}$ & 1 & 1 & 1 & 1 & 2 & 2 & 2 & 2 & 3 & 3 \\
\hline $\mathrm{Bi}$ & $N(0.60)$ & $N(0.60)$ & $N(0.60)$ & $N(0.60)$ & $N(0.60)$ & $N(0.60)$ & $N(0.60)$ & $N(0.60)$ & $N(0.60)$ & $N(0.60)$ \\
\hline $\mathrm{Ca}(\%)$ & 1.67 & 2.22 & 2.36 & 2.61 & 3.14 & 3.33 & 3.52 & 3.74 & 5.50 & 6.19 \\
\hline $\mathrm{Cd}$ & 0.20 & 0.25 & 0.28 & 0.31 & 0.36 & 0.38 & 0.41 & 0.42 & 0.47 & 0.56 \\
\hline $\mathrm{Ce}$ & 15 & 18 & 20 & 21 & 24 & 25 & 28 & 32 & 41 & 43 \\
\hline Co & 14 & 15 & 16 & 17 & 20 & 21 & 24 & 27 & 31 & 34 \\
\hline $\mathrm{Cr}$ & 82 & 94 & 102 & 111 & 125 & 128 & 134 & 145 & 159 & 191 \\
\hline $\mathrm{Cu}$ & 36 & 51 & 54 & 57 & 64 & 66 & 70 & 79 & 91 & 111 \\
\hline $\mathrm{Eu}$ & $\mathrm{L}(2)$ & $\mathrm{L}(2)$ & $\mathrm{L}(2)$ & $\mathrm{L}(2)$ & $\mathrm{L}(2)$ & $\mathrm{L}(2)$ & $\mathrm{L}(2)$ & $\mathrm{L}(2)$ & $\mathrm{L}(2)$ & $\mathrm{L}(2)$ \\
\hline $\mathrm{Fe}(\%)$ & 3.79 & 4.33 & 4.50 & 4.69 & 4.87 & 4.95 & 5.07 & 5.30 & 5.59 & 5.72 \\
\hline $\mathrm{Ga}$ & 12 & 13 & 14 & 14 & 16 & 17 & 17 & 18 & 20 & 21 \\
\hline $\mathrm{Hg}$ & 0.10 & 0.12 & 0.14 & 0.17 & 0.21 & 0.23 & 0.24 & 0.28 & 0.42 & 0.48 \\
\hline $\mathrm{K}(\%)$ & 1.34 & 1.52 & 1.69 & 1.81 & 2.12 & 2.28 & 2.56 & 2.97 & 3.44 & 3.81 \\
\hline $\mathrm{La}$ & 8 & 9 & 10 & 11 & 12 & 13 & 15 & 17 & 21 & 23 \\
\hline $\mathrm{Li}$ & 4 & 8 & 14 & 27 & 43 & 47 & 52 & 55 & 59 & 66 \\
\hline LOI $(\%)$ & 5.55 & 6.24 & 6.85 & 7.74 & 8.62 & 8.93 & 9.48 & 10.3 & 11.4 & 13.3 \\
\hline $\mathrm{Mg}(\%)$ & 1.48 & 1.58 & 1.64 & 1.70 & 1.80 & 1.87 & 2.00 & 2.08 & 2.62 & 3.63 \\
\hline Mn & 534 & 595 & 652 & 714 & 773 & 797 & 870 & 957 & 1120 & 1380 \\
\hline Mo & 0.73 & 0.87 & 0.92 & 1.0 & 1.3 & 1.3 & 1.4 & 1.6 & 2.2 & 2.7 \\
\hline $\mathrm{Na}(\%)$ & 0.72 & 1.01 & 1.14 & 1.35 & 1.45 & 1.49 & 1.67 & 1.82 & 2.36 & 2.61 \\
\hline $\mathrm{Nb}$ & $L(4)$ & $\mathrm{L}(4)$ & $\mathrm{L}(4)$ & $\mathrm{L}(4)$ & $\mathrm{L}(4)$ & 4 & 5 & 5 & 6 & 6 \\
\hline Nd & 10 & 11 & 11 & 13 & 15 & 15 & 17 & 18 & 22 & 24 \\
\hline $\mathrm{Ni}$ & 43 & 52 & 55 & 60 & 67 & 71 & 73 & 79 & 88 & 106 \\
\hline$P(\%)$ & 0.06 & 0.08 & 0.09 & 0.09 & 0.10 & 0.11 & 0.11 & 0.12 & 0.14 & 0.14 \\
\hline $\mathrm{Pb}$ & 13 & 15 & 17 & 19 & 21 & 23 & 26 & 28 & 32 & 48 \\
\hline$S(\%)$ & 0.25 & 0.39 & 0.50 & 0.65 & 1.00 & 1.23 & 1.79 & 2.30 & 2.92 & 3.27 \\
\hline $\mathrm{Sb}$ & 1.4 & 1.7 & 1.9 & 2.2 & 3.3 & 3.9 & 4.3 & 5.1 & 6.3 & 7.6 \\
\hline Sc & 13 & 14 & 15 & 16 & 16 & 17 & 17 & 19 & 20 & 25 \\
\hline $\mathrm{SiO}_{2}(\%)$ & 58.7 & 61.3 & 62.4 & 63.6 & 65.2 & 65.9 & 66.4 & 68.7 & 72.3 & 76.3 \\
\hline $\mathrm{Sr}$ & 179 & 214 & 235 & 256 & 300 & 324 & 347 & 399 & 514 & 758 \\
\hline $\mathrm{Te}$ & 0.030 & 0.040 & 0.040 & 0.045 & 0.058 & 0.065 & 0.073 & 0.095 & 0.10 & 0.18 \\
\hline Th & $\mathrm{L}(4)$ & $\mathrm{L}(4)$ & 4 & 5 & 6 & 6 & 7 & 7 & 7 & 8 \\
\hline $\mathrm{Ti}(\%)$ & 0.09 & 0.12 & 0.14 & 0.16 & 0.19 & 0.20 & 0.21 & 0.23 & 0.27 & 0.29 \\
\hline $\mathrm{Tl}$ & 0.15 & 0.20 & 0.20 & 0.25 & 0.30 & 0.30 & 0.30 & 0.35 & 0.35 & 0.43 \\
\hline V & 95 & 114 & 124 & 126 & 150 & 157 & 162 & 172 & 193 & 212 \\
\hline W & 2.0 & 2.5 & 3.0 & 4.0 & 5.0 & 6.0 & 6.0 & 7.0 & 9.0 & 14 \\
\hline $\mathbf{Y}$ & 9 & 10 & 11 & 12 & 13 & 13 & 14 & 14 & 15 & 17 \\
\hline $\mathrm{Yb}$ & 1 & 1 & 1 & 1 & 2 & 2 & 2 & 2 & 2 & 2 \\
\hline $\mathrm{Zn}$ & 87 & 103 & 112 & 122 & 133 & 136 & 145 & 150 & 160 & 181 \\
\hline
\end{tabular}


Table 3.--Statistical summary for 43 samples of core and cuttings from the tuff member of the Salt Spring Slate (Jst), Hodson mining district, California

[All values shown in parts per million unless "\%" shown. $\mathrm{N}=$ not detected at lower limit of determination shown in parentheses. $\mathrm{L}=$ detected but in a concentration less than the lower limit of determination shown in parentheses. $---=$ =value not significant]

\begin{tabular}{|c|c|c|c|c|c|c|c|c|c|}
\hline \multirow[b]{2}{*}{ Variable } & \multicolumn{2}{|c|}{ Range of values } & \multirow{2}{*}{$\begin{array}{c}\text { Percent } \\
\text { unqualified }\end{array}$} & \multirow{2}{*}{$\begin{array}{l}\text { Geometric } \\
\text { mean }\end{array}$} & \multicolumn{5}{|c|}{ Percentiles } \\
\hline & Minimum & Maximum & & & 2 & 5 & 10 & 15 & 20 \\
\hline $\mathrm{Ag}$ & 0.096 & 16 & 100 & 1.2 & 0.12 & 0.15 & 0.16 & 0.22 & 0.32 \\
\hline $\mathrm{Al}(\%)$ & 1.81 & 8.06 & 100 & 5.27 & 1.85 & 2.47 & 3.34 & 3.74 & 4.09 \\
\hline As & 20 & 340 & 98 & 110 & 20 & 30 & 35 & 40 & 60 \\
\hline $\mathrm{Au}$ & $N(0.002)$ & 26 & 93 & 0.23 & $N(0.002)$ & 0.002 & 0.002 & 0.003 & 0.007 \\
\hline $\mathbf{B a}$ & 65 & 753 & 100 & 177 & 66 & 84 & 90 & 107 & 111 \\
\hline $\mathrm{Be}$ & $\mathrm{L}(1)$ & 2.0 & 40 & 1.1 & $\mathrm{~L}(1)$ & $\mathrm{L}(1)$ & $\mathrm{L}(1)$ & $\mathrm{L}(\mathbf{1})$ & $\mathrm{L}(1)$ \\
\hline $\mathbf{B i}$ & $N(0.60)$ & $\mathrm{N}(0.60)$ & 0 & -.- & $N(0.60)$ & $N(0.60)$ & $N(0.60)$ & $N(0.60)$ & $\mathrm{N}(0.60)$ \\
\hline $\mathrm{Ca}(\%)$ & 0.18 & 8.55 & 100 & 3.96 & 0.31 & 1.03 & 1.39 & 2.63 & $2.92^{\prime}$ \\
\hline $\mathrm{Cd}$ & 0.036 & 1.20 & 100 & 0.14 & 0.041 & 0.049 & 0.059 & 0.076 & 0.079 \\
\hline $\mathrm{Ce}$ & $\mathrm{L}(4)$ & 35 & 58 & 11 & $\mathrm{~L}(4)$ & $\mathbf{L}(4)$ & $\mathrm{L}(4)$ & $\mathrm{L}(4)$ & $L(4)$ \\
\hline Co & 10 & 46 & 100 & 22 & 11 & 11 & 12 & 4 & 14 \\
\hline $\mathrm{Cr}$ & 22 & 1240 & 100 & 170 & 30 & 49 & 79 & 90 & 112 \\
\hline $\mathrm{Cu}$ & 12 & 183 & 100 & 57 & 18 & 24 & 29 & 33 & 37 \\
\hline $\mathrm{Eu}$ & $\mathrm{L}(2)$ & $\mathbf{L}(2)$ & 0 & --- & $\mathbf{L}(2)$ & $\mathbf{L}(2)$ & $\mathrm{L}(2)$ & $\mathrm{L}(2)$ & $\mathrm{L}(2)$ \\
\hline $\mathrm{Fe}(\%)$ & 1.69 & 8.49 & 100 & 4.35 & 2.01 & 2.76 & 3.05 & 3.25 & 3.46 \\
\hline $\mathrm{Ga}$ & $L(4)$ & 17 & 98 & 11 & 5 & 6 & 8 & 9 & 10 \\
\hline $\mathrm{Hg}$ & $\mathrm{N}(0.02)$ & 2.9 & 91 & 0.08 & $N(0.02)$ & $N(0.02)$ & 0.02 & 0.02 & 0.02 \\
\hline K (\%) & 0.68 & 3.08 & 100 & 1.61 & 0.71 & 0.86 & 0.94 & 1.11 & 1.25 \\
\hline $\mathrm{La}$ & $\mathrm{L}(2)$ & 17 & 98 & 5 & 2 & 2 & 2 & 3 & 3 \\
\hline $\mathrm{Li}$ & $\mathrm{L}(2)$ & 91 & 72 & 7 & $\mathrm{~L}(2)$ & $L(2)$ & $\mathbf{L}(2)$ & $L(2)$ & $L(2)$ \\
\hline LOI (\%) & 4.19 & 21.4 & 100 & 10.7 & 4.27 & 5.51 & 6.38 & 6.97 & 7.72 \\
\hline $\operatorname{Mg}(\%)$ & 0.53 & 5.79 & 100 & 2.52 & 0.59 & 0.67 & 1.00 & 1.33 & 1.61 \\
\hline $\mathrm{Mn}$ & 315 & 1670 & 100 & 740 & 317 & 357 & 416 & 474 & 524 \\
\hline Mo & 0.92 & 3.6 & 100 & 0.33 & 0.09 & 0.10 & 0.10 & 0.12 & 0.13 \\
\hline $\mathrm{Na}(\%)$ & 0.07 & 3.61 & 100 & 0.66 & 0.09 & 0.11 & 0.14 & 0.23 & 0.29 \\
\hline $\mathrm{Nb}$ & $\mathrm{L}(4)$ & $\mathrm{L}(4)$ & 0 & -- & $L(4)$ & $L(4)$ & $\mathrm{L}(4)$ & $L(4)$ & $L(4)$ \\
\hline Nd & $\mathrm{L}(4)$ & 20 & 88 & 8.4 & L(4) & $\mathrm{L}(4)$ & 5 & 5 & 6 \\
\hline $\mathrm{Ni}$ & 24 & 476 & 100 & 72 & 25 & 29 & 36 & 38 & 44 \\
\hline P (\%) & $\mathrm{L}(0.005)$ & 0.12 & 88 & 0.03 & $\mathrm{~L}(0.005)$ & $\mathrm{L}(0.005)$ & 0.005 & 0.007 & 0.008 \\
\hline $\mathrm{Pb}$ & 4 & 289 & 98 & 13 & 4 & 5 & 5 & 6 & 6 \\
\hline$S(\%)$ & $\mathrm{L}(0.05)$ & 5.30 & 60 & 0.79 & $\mathrm{~L}(0.05)$ & $\mathrm{L}(0.05)$ & $\mathrm{L}(0.05)$ & $L(0.05)$ & $\mathrm{L}(0.05)$ \\
\hline $\mathrm{Sb}$ & $N(0.60)$ & 33 & 95 & 3.0 & $\mathrm{~N}(0.60)$ & 0.66 & 0.87 & 0.99 & 1.2 \\
\hline Sc & 9 & 42 & 100 & 22 & 9 & 10 & 11 & 13 & 16 \\
\hline $\mathrm{SiO}_{2}(\%)$ & 35.0 & 78.3 & 100 & 53.1 & 36.5 & 39.3 & 41.7 & 44.9 & 45.8 \\
\hline $\mathrm{Sr}$ & 59 & 885 & 100 & 272 & 60 & 63 & 79 & 115 & 182 \\
\hline $\mathrm{Te}$ & $\mathrm{L}(0.005)$ & 1.25 & 86 & 0.060 & $L(0.005)$ & $L(0.005)$ & $L(0.005)$ & 0.005 & 0.005 \\
\hline Th & $\mathrm{L}(4)$ & 7 & 14 & -- & $L(4)$ & $\mathrm{L}(4)$ & $\mathrm{L}(4)$ & $\mathrm{L}(4)$ & $\mathrm{L}(4)$ \\
\hline $\mathrm{Ti}(\%)$ & 0.02 & 0.16 & 100 & 0.06 & 0.02 & 0.03 & 0.03 & 0.04 & 0.04 \\
\hline $\mathrm{TI}$ & 0.05 & 0.55 & 100 & 0.23 & 0.08 & 0.10 & 0.15 & 0.15 & 0.15 \\
\hline V & 51 & 249 & 100 & 141 & 55 & 71 & 79 & 87 & 99 \\
\hline W & 1.0 & 10 & 100 & 4.0 & 1.5 & 2.0 & 2.5 & 2.5 & 2.5 \\
\hline$Y$ & 2 & 13 & 100 & 5 & 3 & 4 & 4 & 4 & 4 \\
\hline $\mathrm{Yb}$ & $L(1)$ & 2 & 14 & --- & $L(1)$ & $\mathrm{L}(1)$ & $\mathrm{L}(1)$ & $L(1)$ & $L(1)$ \\
\hline $\mathrm{Zn}$ & 9 & 393 & 100 & 55 & 11 & 20 & 27 & 32 & 35 \\
\hline
\end{tabular}


Table 3.--Continued

[All values shown in parts per million unless "\%" shown. $\mathrm{N}=$ not detected at lower limit of determination shown in parentheses. $\mathrm{L}=$ detected but in a concentration less than the lower limit of determination shown in parentheses].

\begin{tabular}{|c|c|c|c|c|c|c|c|c|c|c|}
\hline \multirow[b]{2}{*}{ Variable } & \multicolumn{10}{|c|}{ Percentiles } \\
\hline & 25 & 40 & 50 & 60 & 75 & 80 & 85 & 90 & 95 & 98 \\
\hline$\overline{A g}$ & 0.41 & 0.85 & 1.4 & 2.2 & 4.0 & 4.6 & 4.9 & 5.7 & 7.7 & 12 \\
\hline Al (\%) & 4.62 & 5.49 & 5.75 & 6.15 & 6.98 & 7.13 & 7.54 & 7.60 & 7.85 & 8.05 \\
\hline As & 75 & 100 & 120 & 150 & 175 & 195 & 210 & 230 & 280 & 330 \\
\hline $\mathrm{Au}$ & 0.012 & 0.13 & 0.30 & 0.48 & 1.05 & 2.05 & 3.75 & 6.45 & 13 & 22 \\
\hline $\mathbf{B a}$ & 119 & 149 & 166 & 184 & 240 & 284 & 295 & 358 & 475 & 669 \\
\hline $\mathrm{Be}$ & $\mathrm{L}(1)$ & $\mathrm{L}(1)$ & $\mathrm{L}(1)$ & 1 & 1 & 1 & 1 & 1 & 1.5 & 2 \\
\hline $\mathrm{Bi}$ & $N(0.60)$ & $N(0.60)$ & $N(0.60)$ & $N(0.60)$ & $N(0.60)$ & $N(0.60)$ & $\mathrm{N}(0.60)$ & $N(0.60)$ & $\mathrm{N}(0.60)$ & $\mathrm{N}(0.60)$ \\
\hline $\mathrm{Ca}(\%)$ & 3.27 & 4.06 & 5.45 & 5.75 & 6.70 & 7.27 & 7.55 & 7.81 & 7.94 & 8.41 \\
\hline $\mathrm{Cd}$ & 0.084 & 0.11 & 0.13 & 0.17 & 0.21 & 0.26 & 0.29 & 0.37 & 0.55 & 0.98 \\
\hline $\mathrm{Ce}$ & $L(4)$ & $\mathrm{L}(4)$ & 5 & 8 & 12 & 14 & 16 & 18 & 21 & 33 \\
\hline Co & 17 & 20 & 23 & 26 & 31 & 32 & 36 & 40 & 43 & 46 \\
\hline $\mathrm{Cr}$ & 118 & 141 & 167 & 191 & 263 & 286 & 316 & 413 & 561 & 965 \\
\hline $\mathrm{Cu}$ & 42 & 57 & 67 & 75 & 84 & 88 & 94 & 103 & 116 & 155 \\
\hline $\mathrm{Eu}$ & $\mathrm{L}(2)$ & $\mathrm{L}(2)$ & $\mathrm{L}(2)$ & $\mathrm{L}(2)$ & $\mathrm{L}(2)$ & $\mathrm{L}(2)$ & $\mathrm{L}(2)$ & $\mathrm{L}(2)$ & $\mathrm{L}(2)$ & $\mathrm{L}(2)$ \\
\hline $\mathrm{Fe}(\%)$ & 3.70 & 4.33 & 4.59 & 4.80 & 5.09 & 5.26 & 5.51 & 5.96 & 6.44 & 7.76 \\
\hline $\mathrm{Ga}$ & 10 & 11 & 11 & 12 & 14 & 14 & 15 & 15 & 16 & 17 \\
\hline $\mathrm{Hg}$ & 0.04 & 0.05 & 0.08 & 0.10 & 0.13 & 0.16 & 0.20 & 0.23 & 0.31 & 1.63 \\
\hline $\mathrm{K}(\%)$ & 1.29 & 1.53 & 1.66 & 1.84 & 2.08 & 2.15 & 2.17 & 2.64 & 2.71 & 2.98 \\
\hline $\mathrm{La}$ & 3 & 4 & 4 & 5 & 7 & 8 & 9 & 10 & 11 & 16 \\
\hline $\mathrm{Li}$ & $\mathrm{L}(2)$ & 3 & 3 & 4 & 8 & 11 & 14 & 25 & 44 & 80 \\
\hline LOI (\%) & 8.13 & 9.83 & 11.3 & 13.2 & 14.5 & 15.2 & 16.5 & 17.4 & 17.7 & 19.9 \\
\hline $\operatorname{Mg}(\%)$ & 1.68 & 2.52 & 2.73 & 3.53 & 4.25 & 4.47 & 4.64 & 4.92 & 5.18 & 5.61 \\
\hline Mn & 609 & 716 & 843 & 900 & 967 & 1010 & 1050 & 1090 & 1150 & 1420 \\
\hline Mo & 0.13 & 0.21 & 0.24 & 0.37 & 0.85 & 0.94 & 1.1 & 1.2 & 1.4 & 3.3 \\
\hline $\mathrm{Na}(\%)$ & 0.36 & 0.57 & 0.76 & 0.95 & 1.35 & 1.52 & 1.83 & 2.22 & 2.47 & 3.11 \\
\hline $\mathrm{Nb}$ & $\mathrm{L}(4)$ & $L(4)$ & $L(4)$ & $\mathrm{L}(4)$ & $L(4)$ & $\mathrm{L}(4)$ & $L(4)$ & $\mathrm{L}(4)$ & $L(4)$ & $\mathrm{L}(4)$ \\
\hline Nd & 6 & 8 & 8 & 9 & 10 & 10 & 10 & 11 & 14 & 19 \\
\hline $\mathrm{Ni}$ & 49 & 60 & 73 & 80 & 106 & 122 & 134 & 142 & 170 & 361 \\
\hline$P(\%)$ & 0.008 & 0.02 & 0.03 & 0.04 & 0.05 & 0.06 & 0.07 & 0.08 & 0.09 & 0.12 \\
\hline $\mathrm{Pb}$ & 6 & 8 & 9 & 12 & 19 & 25 & 29 & 41 & 53 & 200 \\
\hline$S(\%)$ & $\mathrm{L}(0.05)$ & 0.05 & 0.16 & 0.39 & 1.51 & 1.76 & 1.95 & 2.67 & 4.51 & 5.28 \\
\hline $\mathrm{Sb}$ & 1.2 & 2.0 & 2.9 & 3.5 & 4.4 & 5.5 & 7.1 & 11 & 17 & 29 \\
\hline Sc & 18 & 21 & 24 & 26 & 31 & 32 & 34 & 36 & 37 & 40 \\
\hline $\mathrm{SiO}_{2}(\%)$ & 46.3 & 48.9 & 53.3 & 56.4 & 59.2 & 62.6 & 64.5 & 67.6 & 73.4 & 77.4 \\
\hline $\mathrm{Sr}$ & 217 & 275 & 306 & 361 & 462 & 499 & 539 & 572 & 626 & 779 \\
\hline $\mathrm{Te}$ & 0.005 & 0.023 & 0.040 & 0.058 & 0.20 & 0.28 & 0.45 & 0.58 & 0.83 & 1.23 \\
\hline Th & $\mathrm{L}(4)$ & $\mathrm{L}(4)$ & $L(4)$ & $L(4)$ & $L(4)$ & $\mathrm{L}(4)$ & $L(4)$ & 4 & 6 & 7 \\
\hline $\mathrm{Ti}(\%)$ & 0.05 & 0.06 & 0.06 & 0.09 & 0.10 & 0.11 & 0.11 & 0.14 & 0.15 & 0.16 \\
\hline $\mathrm{Tl}$ & 0.18 & 0.20 & 0.25 & 0.25 & 0.35 & 0.35 & 0.40 & 0.45 & 0.50 & 0.53 \\
\hline V & 108 & 143 & 153 & 171 & 191 & 200 & 205 & 227 & 238 & 248 \\
\hline W & 3.0 & 4.0 & 4.0 & 4.5 & 5.5 & 6.0 & 7.0 & 8.0 & 8.0 & 9.5 \\
\hline Y & 4 & 5 & 5 & 6 & 7 & 7 & 8 & 9 & 9 & 12 \\
\hline $\mathrm{Yb}$ & $L(1)$ & $\mathrm{L}(1)$ & $\mathrm{L}(1)$ & $\mathrm{L}(1)$ & $L(1)$ & $\mathrm{L}(1)$ & $\mathrm{L}(1)$ & 1 & 1 & 2 \\
\hline $\mathrm{Zn}$ & 38 & 43 & 53 & 66 & 83 & 89 & 103 & 117 & 147 & 339 \\
\hline
\end{tabular}


of the 300 samples, 172 were prepared and analyzed for their gross mineralogy by $x$-ray diffraction. The samples were first ground in an agate mortar to about minus 200 mesh $(0.074 \mathrm{~mm})$. Approximately equal volumes of the resulting powders were mounted on glass slides and analyzed by $\mathrm{X}$-ray diffraction using a Philips XRG-3000 generator configured with a copper lamp and nickel filter and run at $40 \mathrm{Kv}$ and $26 \mathrm{Ma}$. The samples were scanned over a range of $4^{\circ}$ to $60^{\circ} 2 \theta$ at a speed of $2^{\circ} 2 \theta / \mathrm{min}$, and the responses were plotted on diffractograms. The relative abundances of 10 minerals in each sample were estimated on the resulting diffractograms using the d-spacing peak for the best line for which no interference from other mineral phases was present (Table 4) and measuring the height above background for that peak. The resulting data are tabulated in appendix 2 and summarized in table 5. For the configuration used, the lowest concentrations of a given mineral that could be detected was about 1 percent by volume.

\section{DETERMINATION OF THRESHOLD VALUES}

Chemical analyses for all 300 samples were used to determine threshold values; however, analyses for only 279 of the original 300 samples were used to construct the anomalies shown on the accompanying figures. The remaining 21 samples were from two drill holes that were well off the cross sections. As a consequence, the data for these two drill holes have not been plotted on the sections.

The rocks included in each of the three lithologic units vary in composition both laterally and vertically; consequently, the typical chemistry for each unit is not easily determined. Also, many of the samples collected for this study are rocks that have been chemically and mineralogically altered as a result of burial, regional metamorphism, hydrothermal alteration, and(or) weathering. Thus, a realistic background range for each element cannot be accurately determined. No sampling was done outside of the area of figure 2 because of the difficulty in finding outcrops that were geologically equivalent to those sampled in the drili holes.

Background ranges for the two main lithologies (Jch and Js) can be approximated from the data in tables 1 and 2 . For elements that were enriched as a result of mineralization (positive geochemical anomalies), the background range for equivalent unaltered rocks is best approximated by the values between the lowest concentration reported and the $25 \mathrm{th}$ percentile (tables 1 and 2). For elements that were depleted as a result of mineralization or weathering (negative anomalies), the values between the 75th percentile and the highest concentration reported most closely approximate the background ranges. Most of the tuff member of the salt spring slate (Jst) has been altered so that background ranges for elements in samples collected from this unit are not known. 
Table 4.--d-Spacings and diffraction peaks used for semiquantitative mineralogy

White mica

Kaolinite

Chlorite

Quartz

Orthoclase

Plagioclase

Calcite

Ankerite

Magnesite

Pyrite
d-Spacing $(\AA)$

9.95

7.15

4.73

4.25

3.24

3.19

3.03

2.89

2.74

1.63
Diffraction

peak (hkl)

002

001

003

100

002

040

104

104

104

311 
Table 5.--Statistical summary for minerals determined by X-ray diffraction in samples of core and cuttings from three major stratigraphic units, Hodson mining district, California

[All values shown are based on peak heights on $\mathrm{X}$-ray diffractograms. $\mathrm{N}=$ not detected at lower limit of determination shown in parentheses. Leaders $(---)=$ value not significant]

Copper Hill Volcanics (Jch) (83 samples)

\begin{tabular}{|c|c|c|c|c|c|c|c|c|c|}
\hline \multirow[b]{2}{*}{ Variable } & \multicolumn{2}{|c|}{ Range of values } & \multirow{2}{*}{$\begin{array}{l}\text { Percent } \\
\text { unqualified }\end{array}$} & \multirow{2}{*}{$\begin{array}{l}\text { Geometric } \\
\text { mean }\end{array}$} & \multicolumn{5}{|c|}{ Percentiles } \\
\hline & Minimum & Maximum & & & 10 & 20 & 40 & 50 & 60 \\
\hline White mica & $N(1)$ & 46 & 80 & 8.3 & $N(1)$ & 1 & 5 & 7 & 9 \\
\hline Kaolinite & $N(1)$ & 15 & 40 & 5.2 & $N(1)$ & $\mathrm{N}(1)$ & $N(1)$ & $N(1)$ & 1 \\
\hline Chlorite & $N(1)$ & 42 & 67 & 8.9 & $N(1)$ & $N(1)$ & 3 & 5 & 10 \\
\hline Quartz & 2 & 110 & 100 & 20 & 6 & 10 & 14 & 20 & 25 \\
\hline Orthoclase & $\mathrm{N}(1)$ & 36 & 63 & 7.4 & $N(1)$ & $N(1)$ & 3 & 5 & 7 \\
\hline Plagioclase & $N(1)$ & 100 & 94 & 33 & 8 & 18 & 33 & 37 & 45 \\
\hline Calcite & $N(1)$ & 100 & 66 & 16 & $N(1)$ & $N(1)$ & 2 & 4 & 13 \\
\hline Ankerite & $\mathrm{N}(1)$ & 130 & 78 & 26 & $\mathrm{~N}(1)$ & $\mathrm{N}(1)$ & 13 & 17 & 21 \\
\hline Magnesite & $N(1)$ & 160 & 19 & 88 & $N(1)$ & $\mathrm{N}(1)$ & $N(1)$ & $N(1)$ & $N(1)$ \\
\hline Pyrite & $N(1)$ & 13 & 28 & 3.5 & $N(1)$ & $N(1)$ & $N(1)$ & $N(1)$ & $\mathrm{N}(1)$ \\
\hline
\end{tabular}

Salt Spring Slate (Js) (64 samples)

\begin{tabular}{|c|c|c|c|c|c|c|c|c|c|}
\hline \multirow[b]{2}{*}{ Variable } & \multicolumn{2}{|c|}{ Range of values } & \multirow{2}{*}{$\begin{array}{c}\text { Percent } \\
\text { unqualified }\end{array}$} & \multirow{2}{*}{$\begin{array}{l}\text { Geometric } \\
\text { mean }\end{array}$} & \multicolumn{5}{|c|}{ Percentiles } \\
\hline & Minimum & Maximum & & & 10 & 20 & 40 & 50 & 60 \\
\hline White mica & 2 & 38 & 100 & 16 & 11 & 13 & 16 & 18 & 19 \\
\hline Kaolinite & $N(1)$ & 25 & 42 & 7.3 & $\mathrm{~N}(1)$ & $N(1)$ & $N(1)$ & $N(1)$ & 2 \\
\hline Chlorite & $\mathrm{N}(1)$ & 24 & 58 & 9.1 & $\mathrm{~N}(1)$ & $\mathrm{N}(1)$ & $\mathrm{N}(1)$ & 2 & 8 \\
\hline Quartz & 6 & 110 & 100 & 50 & 27 & 40 & 56 & 61 & 67 \\
\hline Orthoclase & $N(1)$ & 12 & 86 & 6.9 & $\mathrm{~N}(1)$ & 5 & 6 & 7 & 7 \\
\hline Plagioclase & 4 & 100 & 100 & 38 & 22 & 27 & 37 & 42 & 46 \\
\hline Calcite & $N(1)$ & 79 & 41 & 11 & $\mathrm{~N}(1)$ & $N(1)$ & $N(1)$ & $N(1)$ & 2 \\
\hline Ankerite & $\mathrm{N}(1)$ & 110 & 89 & 40 & $\mathrm{~N}(1)$ & 11 & 40 & 50 & 54 \\
\hline Magnesite & $\mathrm{N}(1)$ & 67 & 31 & 19 & $\mathrm{~N}(1)$ & $\mathrm{N}(1)$ & $N(1)$ & $N(1)$ & $N(1)$ \\
\hline Pyrite & $\mathrm{N}(1)$ & 19 & 66 & 5.0 & $\mathrm{~N}(1)$ & $\mathrm{N}(1)$ & 2 & 3 & 4 \\
\hline
\end{tabular}

Tuff member of Salt Spring Slate (Jst) (25 samples)

\begin{tabular}{|c|c|c|c|c|c|c|c|c|c|}
\hline \multirow[b]{2}{*}{ Variable } & \multicolumn{2}{|c|}{ Range of values } & \multirow{2}{*}{$\begin{array}{c}\text { Percent } \\
\text { unqualified }\end{array}$} & \multirow{2}{*}{$\begin{array}{l}\text { Geometric } \\
\text { mean }\end{array}$} & \multicolumn{5}{|c|}{ Percentiles } \\
\hline & Minimum & Maximum & & & 10 & 20 & 40 & 50 & 60 \\
\hline White mica & 6 & 46 & 100 & 19 & 11 & 15 & 19 & 20 & 21 \\
\hline Kaolinite & $N(1)$ & 5 & 8 & --- & $\mathrm{N}(1)$ & $N(1)$ & $N(1)$ & $\mathrm{N}(1)$ & $N(1)$ \\
\hline Chlorite & $\mathrm{N}(1)$ & 21 & 32 & 5.9 & $\mathrm{~N}(1)$ & $\mathrm{N}(1)$ & $\mathrm{N}(1)$ & $\mathrm{N}(1)$ & $\mathrm{N}(1)$ \\
\hline Quartz & 18 & 100 & 100 & 50 & 30 & 32 & 45 & 50 & 59 \\
\hline Orthoclase & $N(1)$ & 9 & 96 & 5.1 & 4 & 4 & 5 & 5 & 6 \\
\hline Plagioclase & 4 & 100 & 100 & 29 & 14 & 17 & 21 & 29 & 33 \\
\hline Calcite & $N(1)$ & 62 & 20 & 19 & $N(1)$ & $\mathrm{N}(1)$ & $N(1)$ & $N(1)$ & $\mathrm{N}(1)$ \\
\hline Ankerite & $N(1)$ & 125 & 84 & 78 & $\mathrm{~N}(1)$ & 15 & 78 & 100 & 100 \\
\hline Magnesite & $\mathrm{N}(1)$ & 47 & 28 & 9.7 & $\mathrm{~N}(1)$ & $\mathrm{N}(1)$ & $\mathrm{N}(1)$ & $\mathrm{N}(1)$ & $N(1)$ \\
\hline Pyrite & $N(1)$ & 14 & 36 & 5.0 & $N(1)$ & $\mathrm{N}(1)$ & $\mathrm{N}(1)$ & $\mathrm{N}(1)$ & $N(1)$ \\
\hline
\end{tabular}


Table 5.--Continued

[All values are based on peak heights on $\mathrm{X}$-ray diffractograms. $\mathrm{N}=$ not detected at lower limit of determination shown in parentheses]

\section{Copper Hill Volcanics (Jch)}

\begin{tabular}{|c|c|c|}
\hline \multirow[b]{2}{*}{ Variable } & \multicolumn{2}{|c|}{ Percentiles } \\
\hline & 80 & 90 \\
\hline White mica & 15 & 21 \\
\hline Kaolinite & 5 & 10 \\
\hline Chlorite & 15 & 21 \\
\hline Quartz & 35 & 88 \\
\hline Orthoclse & 10 & 12 \\
\hline Plagioclase & 56 & 69 \\
\hline Calcite & 47 & 71 \\
\hline Ankerite & 69 & 110 \\
\hline Magnesite & $N(1)$ & 91 \\
\hline Pyrite & 3 & 4 \\
\hline
\end{tabular}

Salt Spring Slate (Js)

Variable

White mica

\begin{tabular}{|c|c|}
\hline \multicolumn{2}{|c|}{ Percentiles } \\
\hline 80 & 90 \\
\hline 22 & 27 \\
\hline 10 & 10 \\
\hline 16 & 19 \\
\hline 73 & 80 \\
\hline 8 & 9 \\
\hline 55 & 65 \\
\hline 10 & 23 \\
\hline 74 & 88 \\
\hline 14 & 29 \\
\hline 7 & 10 \\
\hline
\end{tabular}

Tuff member of Salt Spring Slate (Jst)

\begin{tabular}{lrrr} 
& \multicolumn{2}{c}{ Percentiles } \\
\cline { 2 - 3 } Variable & 80 & & 90 \\
\cline { 2 - 3 } White mica & 27 & & 34 \\
Kaolinite & $\mathrm{N}(1)$ & $\mathrm{N}(1)$ \\
Chlorite & 4 & & 13 \\
Quartz & 84 & & 97 \\
Orthoclse & 7 & 7 \\
Plagioclase & 63 & 83 \\
Calcite & 5 & & 13 \\
Ankerite & 110 & 115 \\
Magnesite & 6 & & 12 \\
Pyrite & 4 & & 9
\end{tabular}


The threshold values for the chemical data were determined by first studying the dispersion patterns for gold and other closely associated elements, including silver, arsenic, sulfur, antimony, thallium, and tungsten. This initial examination revealed that approximately 50 percent of the samples in the major (JCh and Js) units and 80 percent of the samples in the tuff unit (Jst) were anomalous for these elements as a result of gold mineralization. Threshold values for all other elements represented by positive anomalies were therefore contoured using values for the 50th or 20 th percentiles, respectively (tables 1 to 3 ). Conversely, elements represented by negative anomalies were contoured using values for the 50th or 80 th percentiles, respectively. Where geologically warranted, or where the range of reported values for a given element was limited, minor adjustments were made for the threshold value for a few elements. Our evaluation of the plots revealed that slight variations in the threshold value do not materially affect the overall anomaly patterns. All values have been rounded to two or less significant digits for plotting.

The threshold values for the mineral anomalies plotted for this report were determined using these same criteria. In several cases, the thresholds were modified slightly because only a limited range of values. was present. The threshold values used for contouring each anomaly are shown on each cross section.

\section{DISTRIBUTIONS OF ANOMALIES}

The cross sections that follow (figs. 6-57) illustrate the distributions of anomalies for 42 chemical and $10 \mathrm{mineral}$ variables. There is no unique way to draw the contours for most of the variables. Emphasis has been given to showing the most significant areas of enrichment or depletion (or both) for each variable. Where considered geologically reasonable, the boundaries of anomalies have been extended to geologic contacts or faults. Note that in some cases the anomalies are shown to extend beyond the depths of drilling or into areas where analytical information is inadequate. In such cases a question mark is shown and the extent of these anomalies should be considered speculative.

\section{ACKNOWLEDGMENTS}

We thank P.H. Briggs, P.L. Hageman, R.H. Hill, J.M. Motooka, T.A. Roemer, B.H. Roushey, Will Sadler, D.F. Siems, and J.E. Taggart for the analytical determinations. We are indebted to FMC Gold Company (formerly Meridian Gold Company) for letting us collect samples of drill core and cuttings from the three deposits. T.0. Kuhl and Mike Lechner, formerly of that company, were particularly helpful in showing one of us (MAC) around the property and in sorting out some of the geological complexities of the deposits. 
Arbogast, B.F., 1990, Quality ássurance manual for the Branch of Geochemistry, U.S. Geological Survey: U.S. Geological Survey open-File Report 90-688, $183 \mathrm{p}$.

Boyle, R. W., 1979, The geochemistry of gold and its deposits (together with a chapter on geochemical prospecting for the element): Geological Survey of Canada Bulletin 280, $584 \mathrm{p}$.

Briggs, P.H., 1990, Elemental analysis of geologic materials by inductively coupled plasma-atomic emission spectrometry, in Arbogast, B.F., Quality assurance manual for the Branch of Geochemistry, U.S. Geological Survey: U.S. Geological survey Open-File Report 90-668, $184 \mathrm{p}$.

Chaffee, M.A., and Hill, R.H., 1989, Soil geochemistry of the Mother Lode-type gold deposits in the Hodson mining district, central California, U.S.A. (extended abst.): Journal of Geochemical Exploration, v. 32, nos. 1-3, p. 53-55.

Chaffee, M.A., and Kuhl, T.0., 1991, Primary and secondary dispersion patterns associated with Mother Lode-type gold mineralization, Hodson district, Calaveras county, California (abst.), in Abstracts with Program, 15th International Geochemical Exploration Symposium, Reno, April 1991: Association of Exploration Geochemists, p. 43.

Clark, L.D., 1964, stratigraphy and structure of part of the western Sierra Nevada metamorphic belt, California: U.S. Geological survey Professional Paper 410, $70 \mathrm{p}$.

Clark, W.B., 1970, Gold districts of California: California Division of Mines and Geology Bulletin 193, $186 \mathrm{p}$.

Clark, W.B., and Lydon, P.A., 1962, Mines and mineral resources of Calaveras County, California: California Division of Mines and Geology County Report 2, $217 \mathrm{p}$.

Coveney, R.M., Jr., 1981, Gold quartz veins and auriferous granite at the oriental mine, Alleghany district, California: Economic Geology, v. 76, no. 8, p. 2176-2199.

Curry, K.J., 1990, Determination of total sulfur in geologic materials by combustion, in Arbogast, B.F., Quality assurance manual for the Branch of Geochemistry, U.S. Geological survey: U.S. Geological Survey Open-File Report 90-668, $184 \mathrm{p}$.

Goldfarb, R.J., 1989, Genesis of lode gold deposits of the southern Alaskan Cordillera: Univ. Colorado, unpub. Ph.D. dissertation, $437 \mathrm{p}$.

King, D.A., 1986, Controls of gold mineralization in the southern portion of the Hodson mining district, west Mother Lode gold belt, California: Univ. Montana, unpub. M.Sc. thesis, $60 \mathrm{p}$.

Knopf, Adolph, 1929, The Mother Lode system of California: U.S. Geological Survey Professional Paper 157, 88 p.

Kuhl, T.O., and Garmoe, W.J., 1989, Geology of the Royal-Mountain King mine, Hodson district, Calaveras County, California: Preprint, Society for Mining, Metallurgy, and Exploration, 1989 Annual Meeting, Las Vegas, 11 p. 
Landefeld, L.A., 1990, The geology of the Mother Lode gold belt, Foothills Metamorphic Belt, 'Sierra Nevada, California, in

Landefeld, L.A. and Snow, G.G., eds., Yosemite and the Mother Lode Gold Belt: Geology, tectonics, and the evolution of hydrothermal fluids in the Sierra Nevada of California: Pacific Section, American Assoc. of Petroleum Geologists Guidebook 68, $200 \mathrm{p}$.

Landefeld, L.A., and Silberman, M.L., 1987, Geology and geochemistry of the Mother Lode Gold Belt, California, compared with Archaean lode gold deposits, in Johnson, J.L., ed., Guidebook for Field Trips, Bulk Mineable Precious Metal Deposits of the Western United States Symposium, Reno, April 6-8, 1987: Geological Society of Nevada, $418 \mathrm{p}$.

Landefeld, L.A., and Snow, G.G., 1990, Road logs and maps, in Landefeld, L.A. and Snow, G.G., eds., Yosemite and the Mother Lode Gold Belt: Geology, tectonics, and the evolution of hydrothermal fluids in the Sierra Nevada of California: Pacific Section, American Assoc. of Petroleum Geologists Guidebook $68,200 \mathrm{p}$.

Lechner, Mike, and Kuhl, Tim, 1990, Geology of the Royal Mountain King mine: Preprint, Northwest Mining Association annual convention, Spokane, December, 1990, $19 \mathrm{p}$.

Lindgren, Waldemar, 1896, The gold-quartz veins of Nevada City and Grass Valley, California, p. 1-262, in Seventeenth Annual Report of the United States Geological Survey to the Secretary of the Interior, 1895-96, Part II, $864 \mathrm{p}$.

Motooka, J.M., 1990, Organometallic halide extraction applied to the analysis of geologic materials for 10 elements by inductively coupled-atomic emission spectrometry, in Arbogast, B.F., Quality assurance manual for the Branch of Geochemistry, U.S. Geological Survey: U.S. Geological Survey Open-File Report 90-668, $184 \mathrm{p}$.

Nash, J.T., 1988, Geology and geochemistry of gold deposits of the Big Canyon area, El Dorado County, California: U.S. Geological Survey Professional Paper 1854, 40 p.

O'Leary, R.M., and Chao, T.T., 1990, Determination of gold, tellurium, and thallium in rock, stream-sediment, and soil samples by flame, and gold by graphite furnace, atomic absorption spectrophotometry following dissolution by $\mathrm{HF}$, aqua regia, and $\mathrm{HBr}-\mathrm{Br}_{2}$, in Arbogast, B.F., Quality assurance manual for the Branch of Geochemistry, U.S. Geological Survey: U.S. Geological Survey Open-File Report 90-668, 184 p.

O'Leary, R.M., and Welsch, E.P., 1990, Determination of tungsten in rock, soil, and stream-sediment samples by visible absorption spectrophotometry, in Arbogast, B.F., Quality assurance manual for the Branch of Geochemistry, U.S. Geological Survey: U.S. Geological Survey Open-File Report $90-668,184 \mathrm{p}$. 
O'Leary, R.M., Crock, J.G., and Kennedy, K.R., 1990, Determination of mercury in geologic materials by continuous flow-cold vapor-atomic absorption spectrophotometry, in Arbogast, B.F., Quality assurance manual for the Branch of Geochemistry, U.S. Geological Survey: U.S. Geological Survey Open-File Report 90-668, $184 \mathrm{p}$.

Silberman, M.L., and Danielson, Joanne, 1991, Geologic setting, characteristics, and geochemistry of gold-bearing quartz veins in the Klamath Mountains in the Redding 1 × 2 degree quadrangle, northern California: U.S. Geological Survey OpenFile Report 91-595, 27 p.

Taggart, J.E., Jr, Bartel, Ardith, and Siems, D.F., 1990, High precision major element analysis of rocks and minerals by wavelength dispersive $\mathrm{X}$-ray fluorescence spectroscopy, in Arbogast, B.F., Quality assurance manual for the Branch of Geochemistry, U.S. Geological Survey: U.S. Geological Survey Open-File Report 90-668, $184 \mathrm{p}$. 


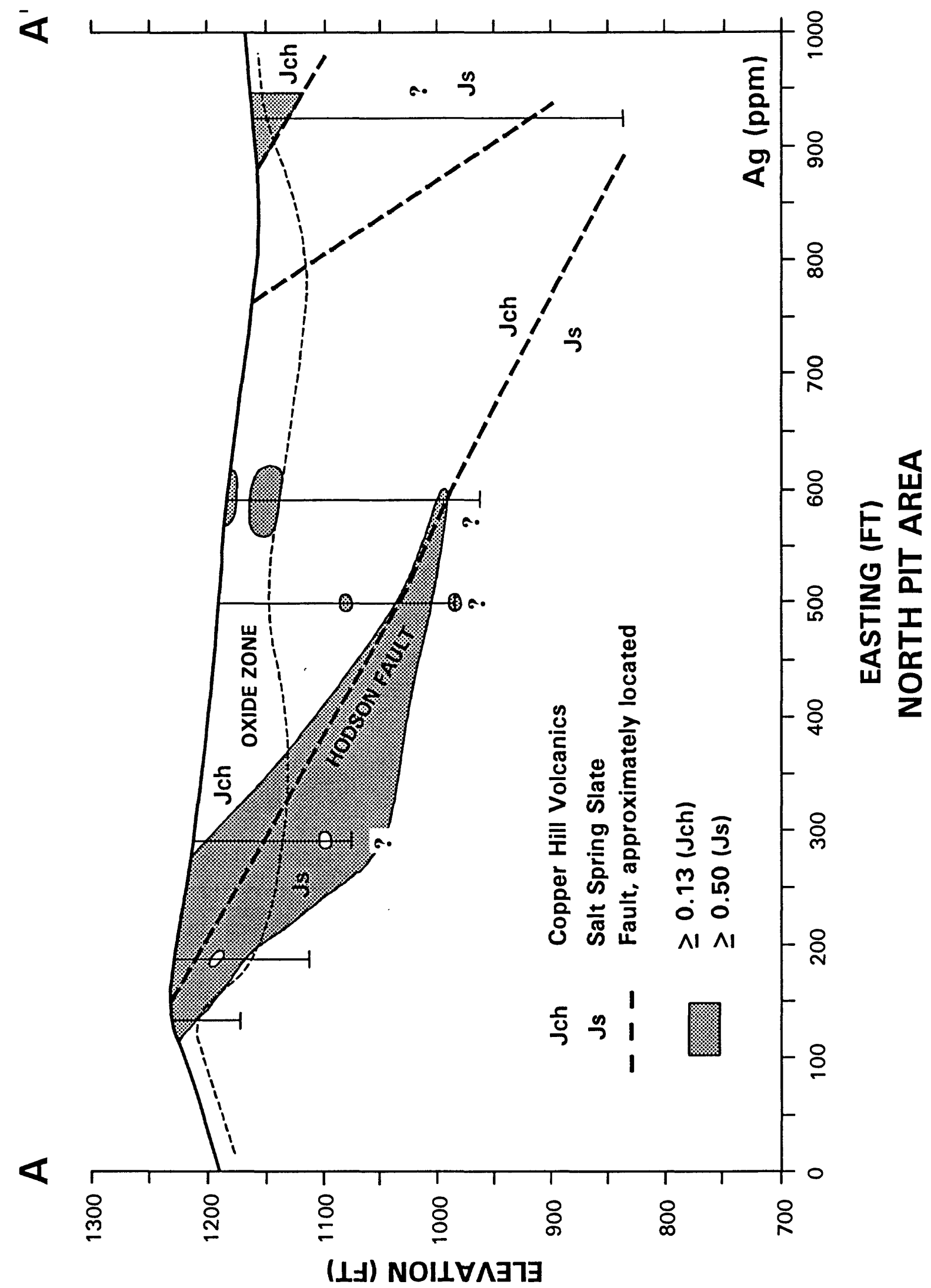




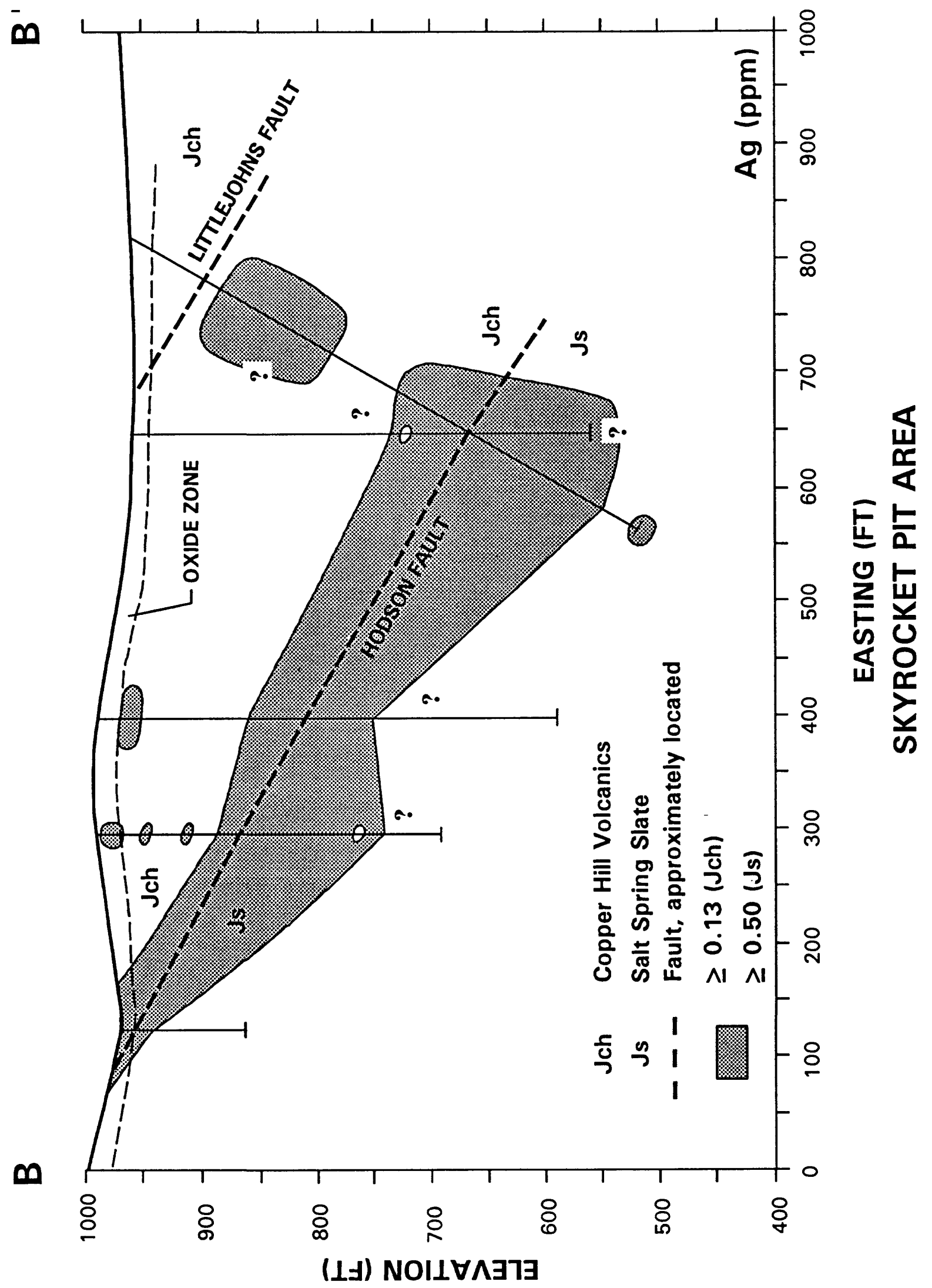




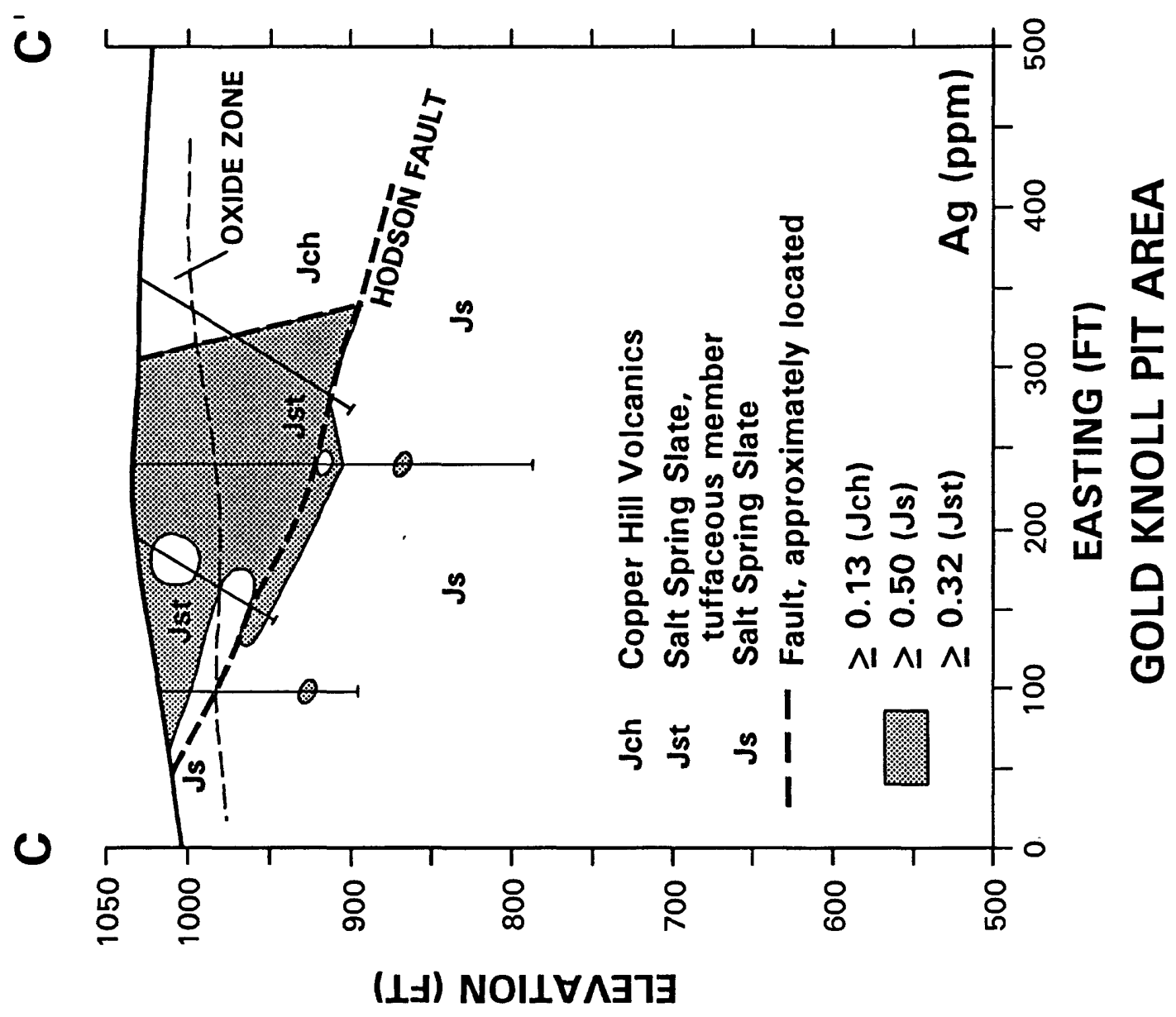




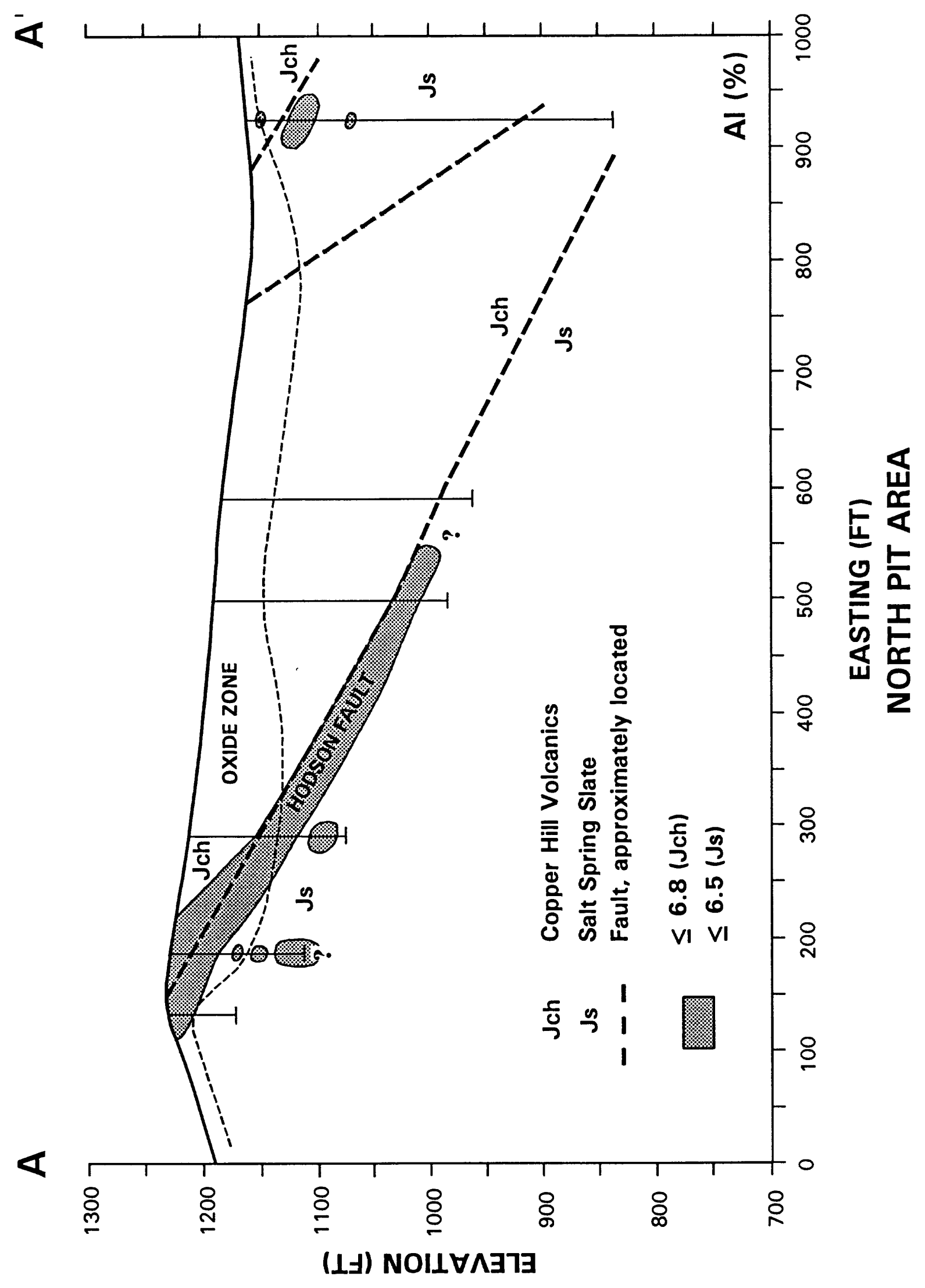




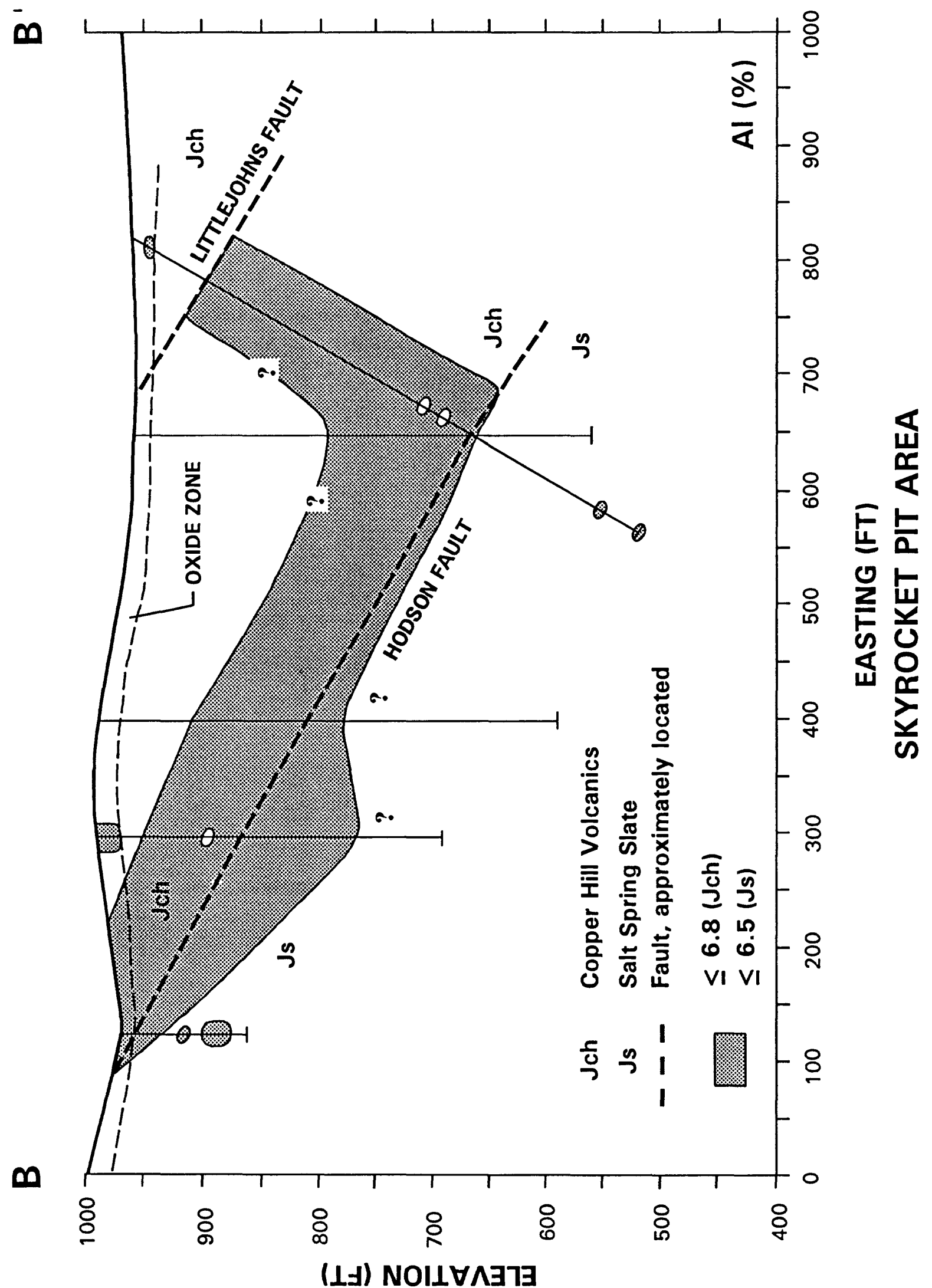




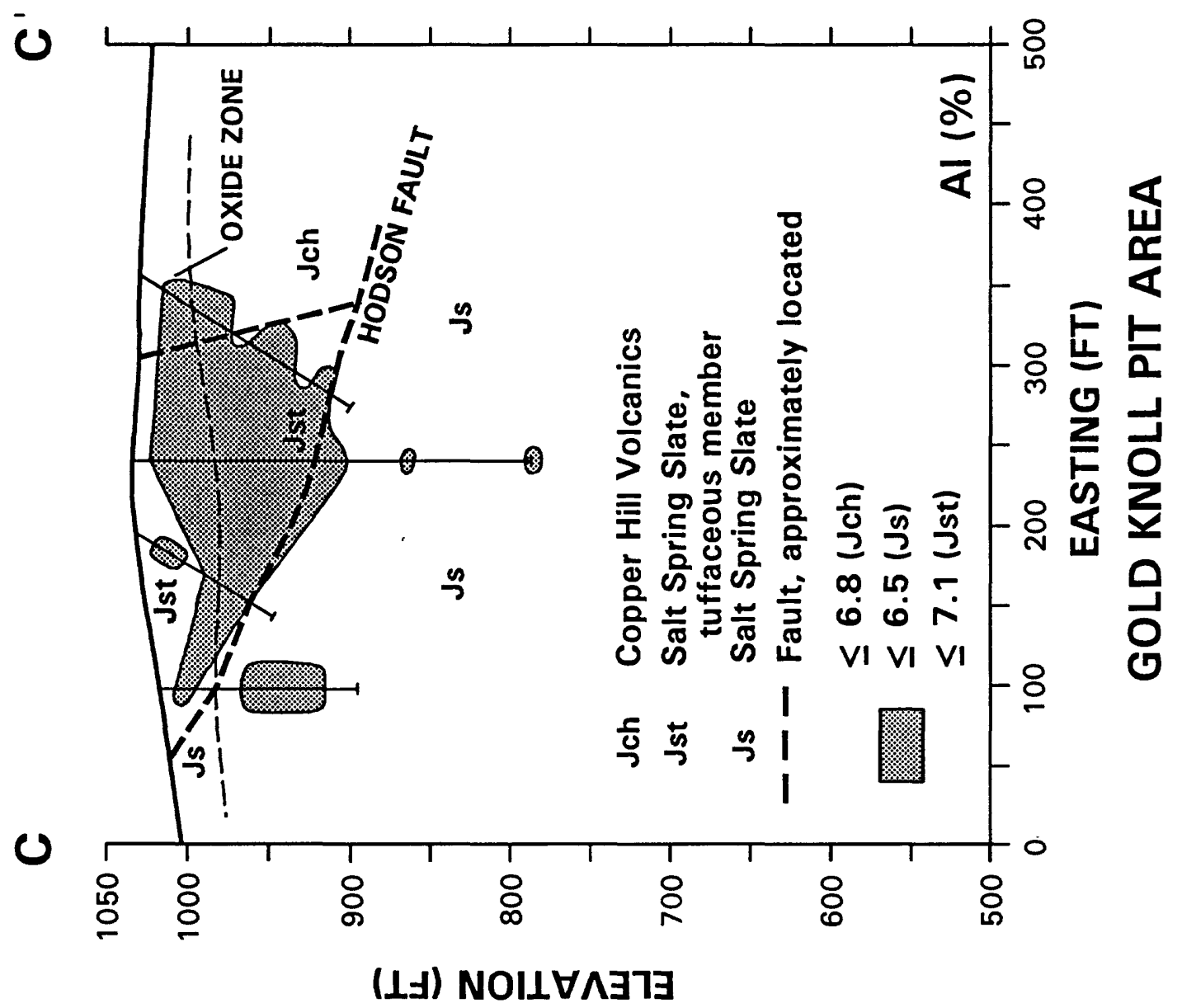




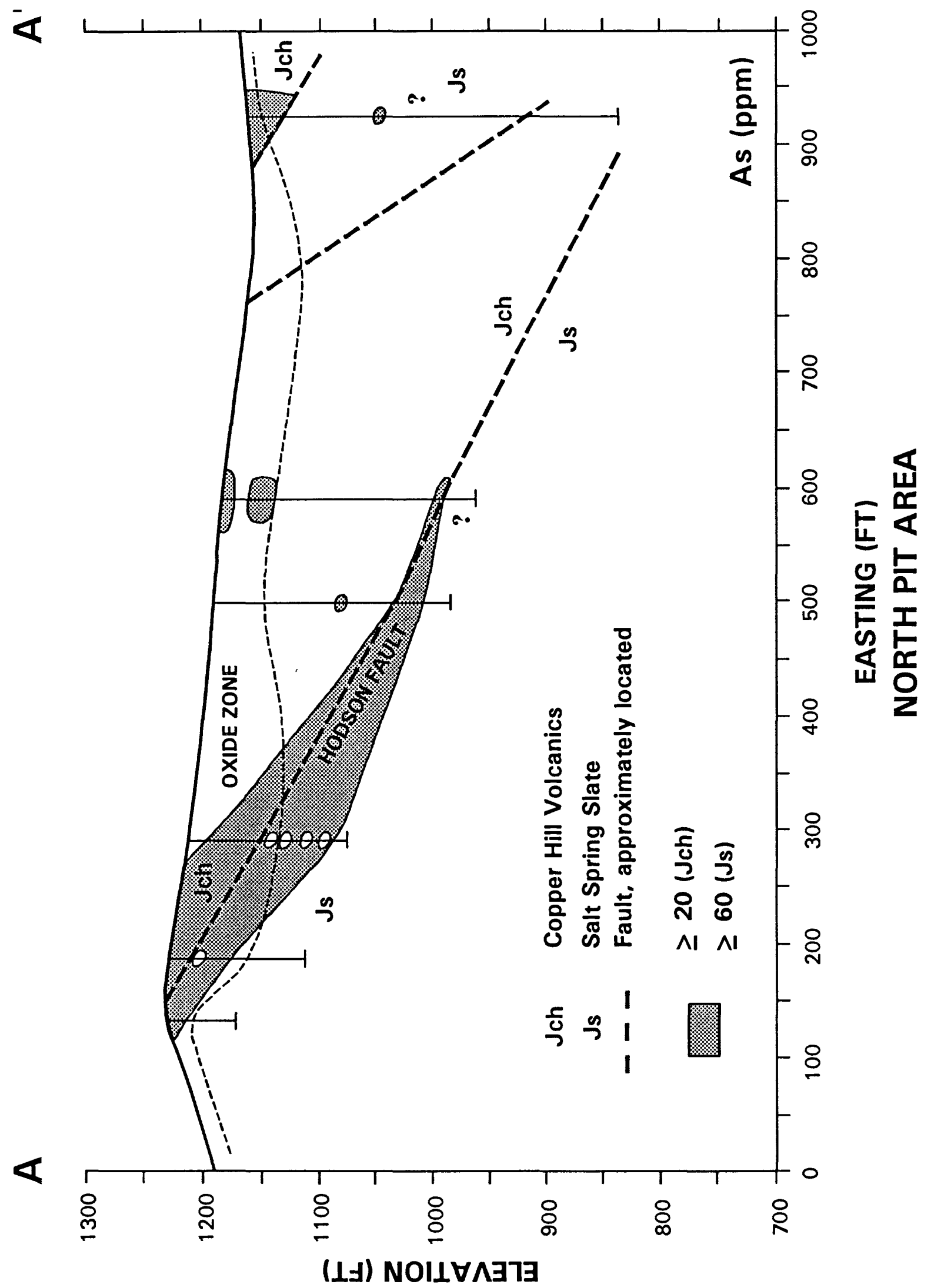




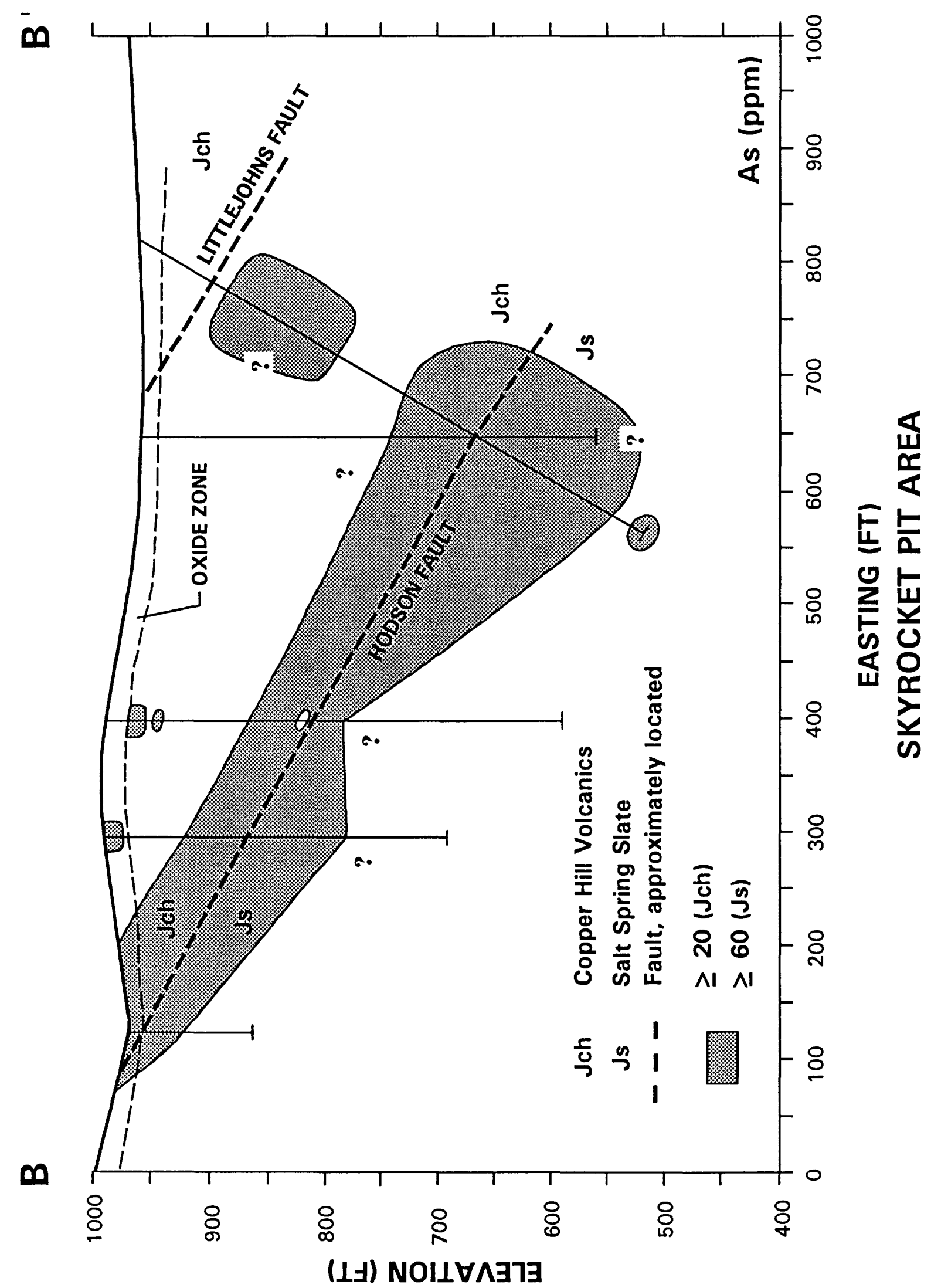




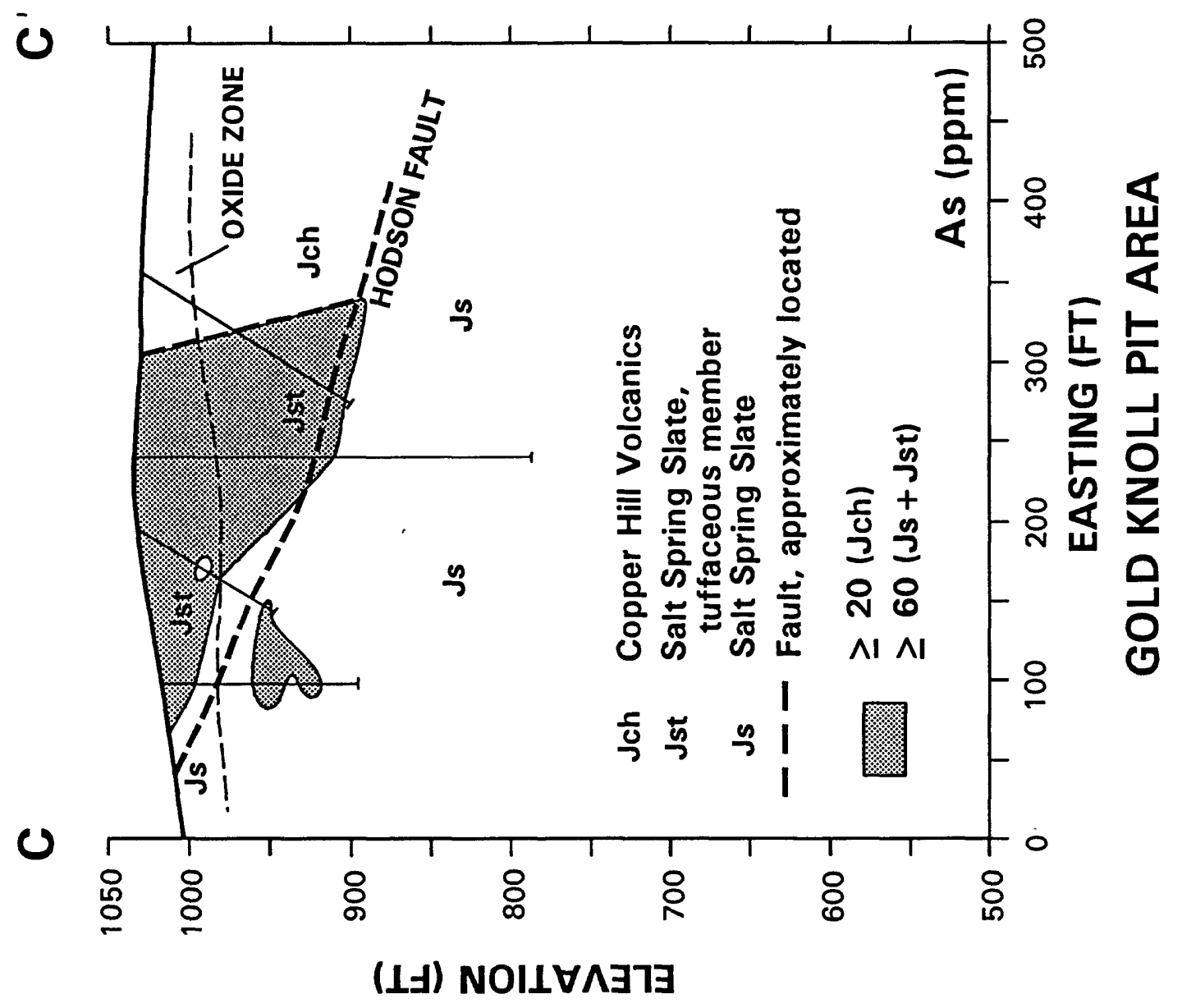




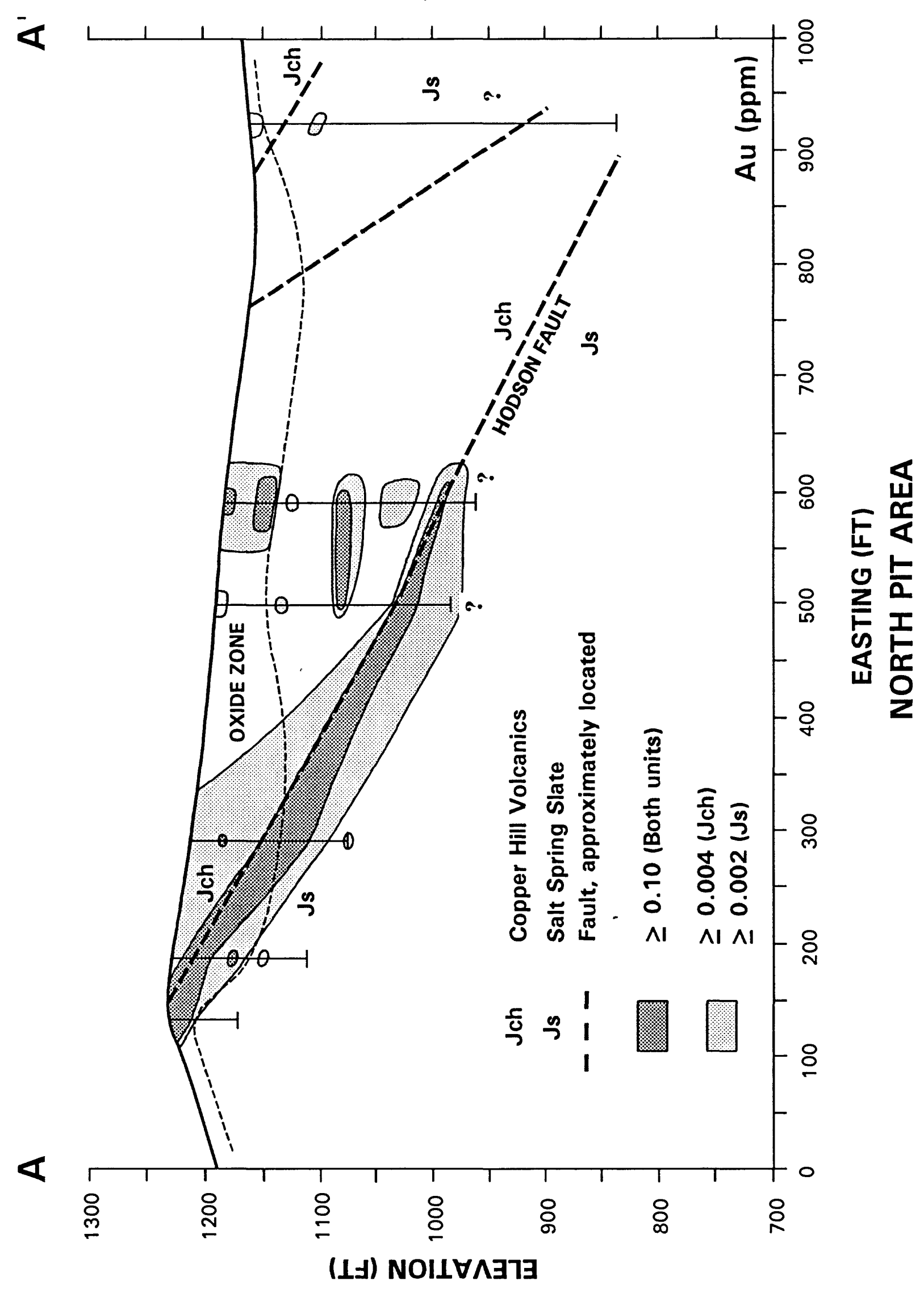




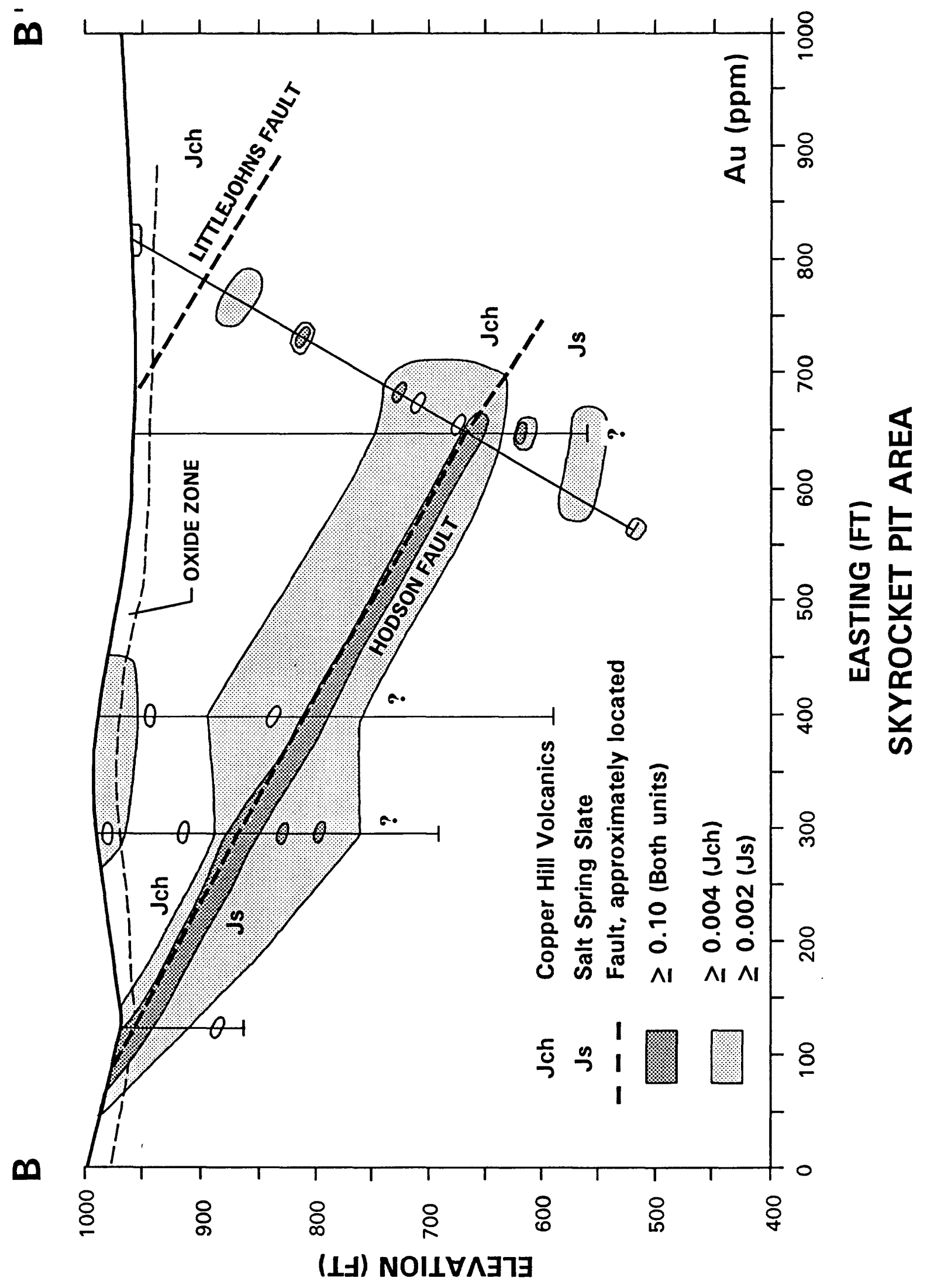




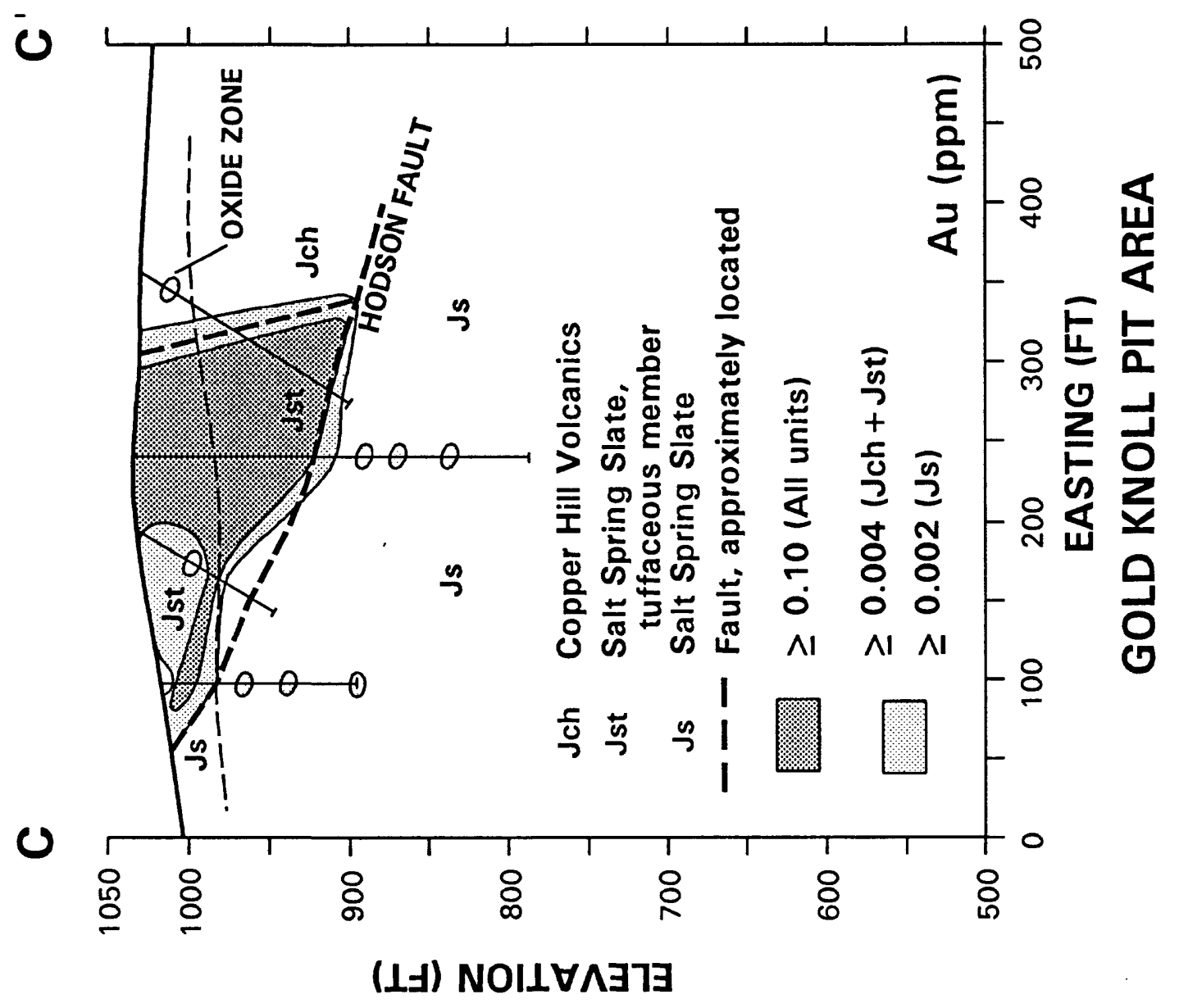




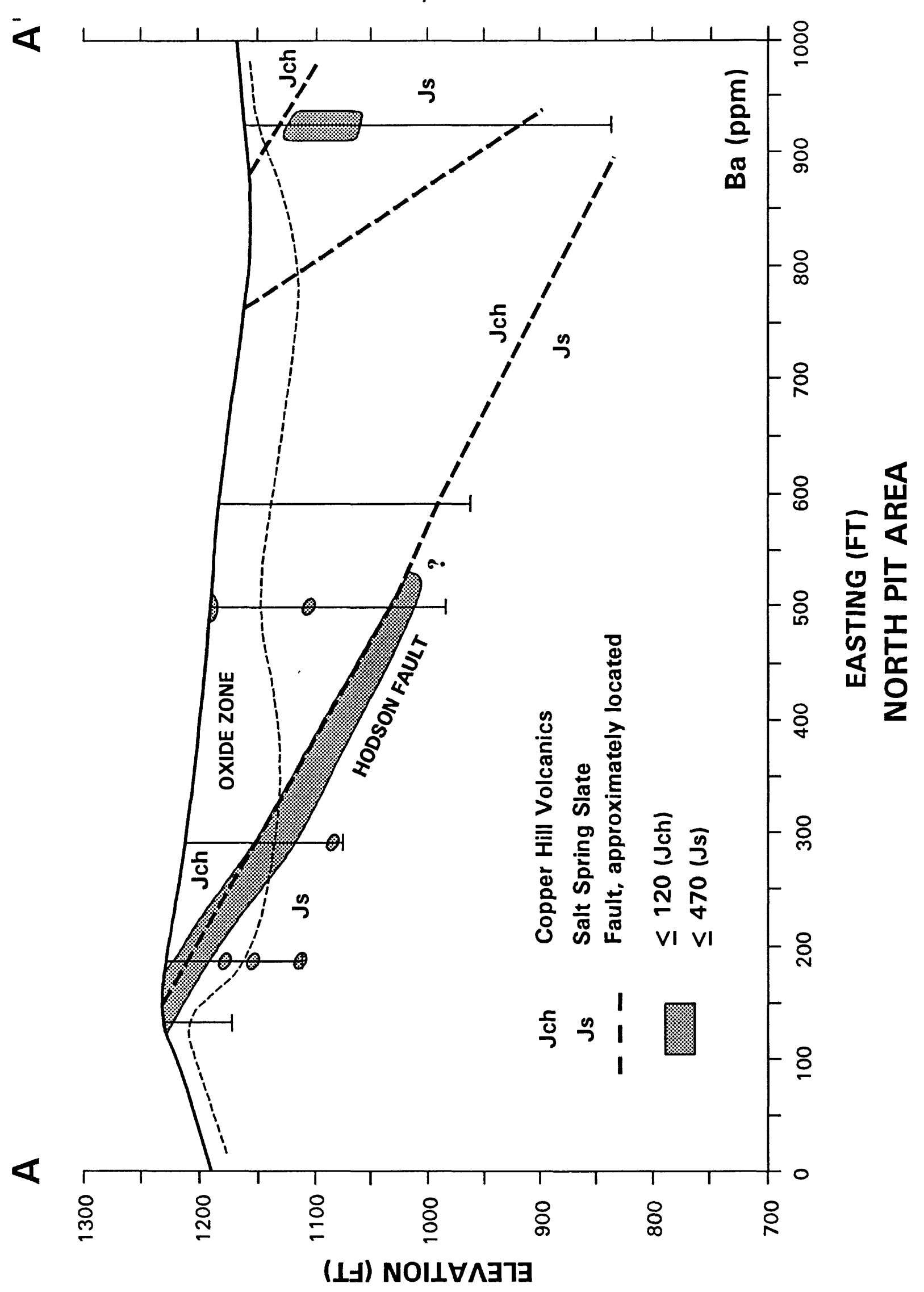




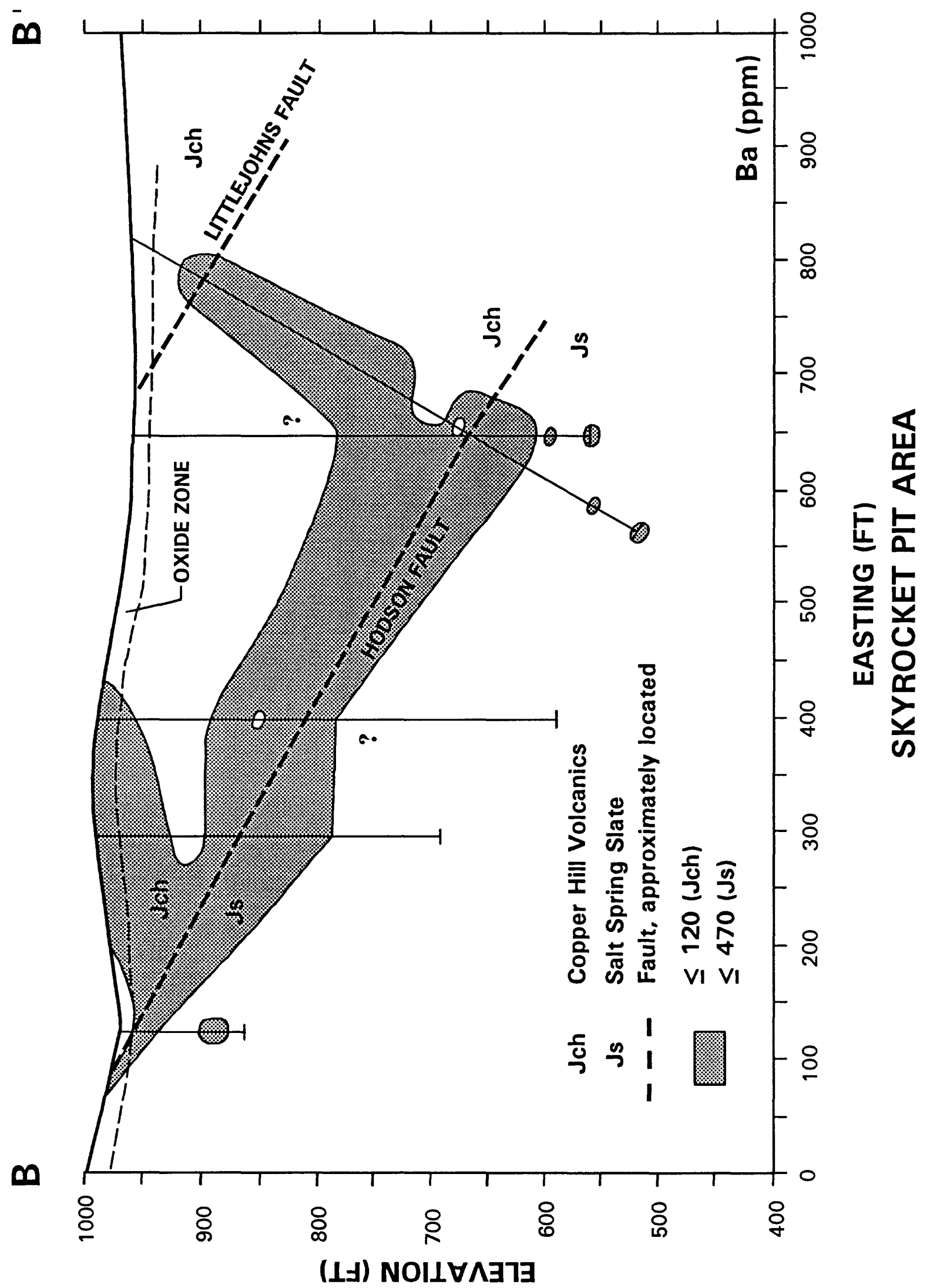




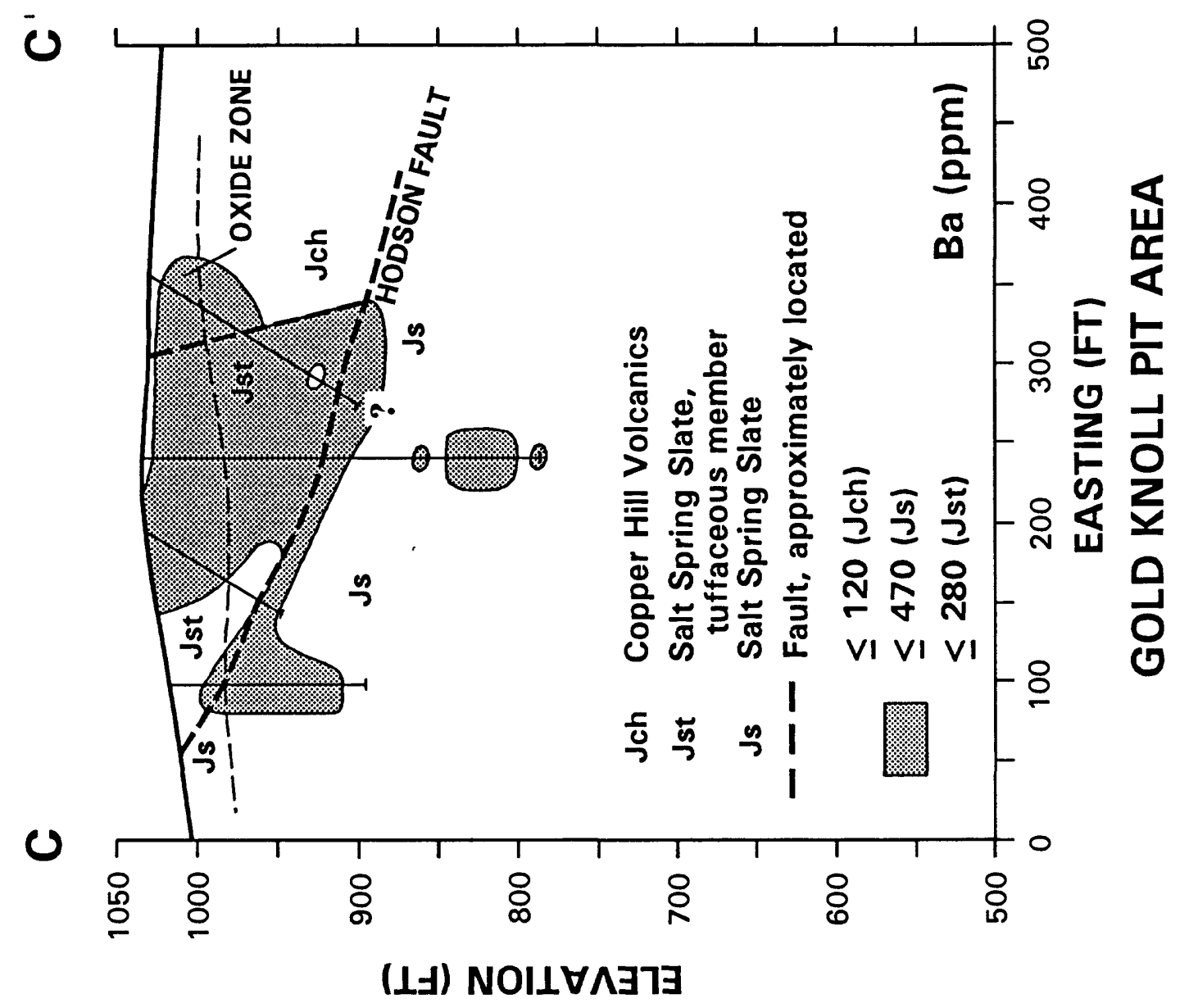




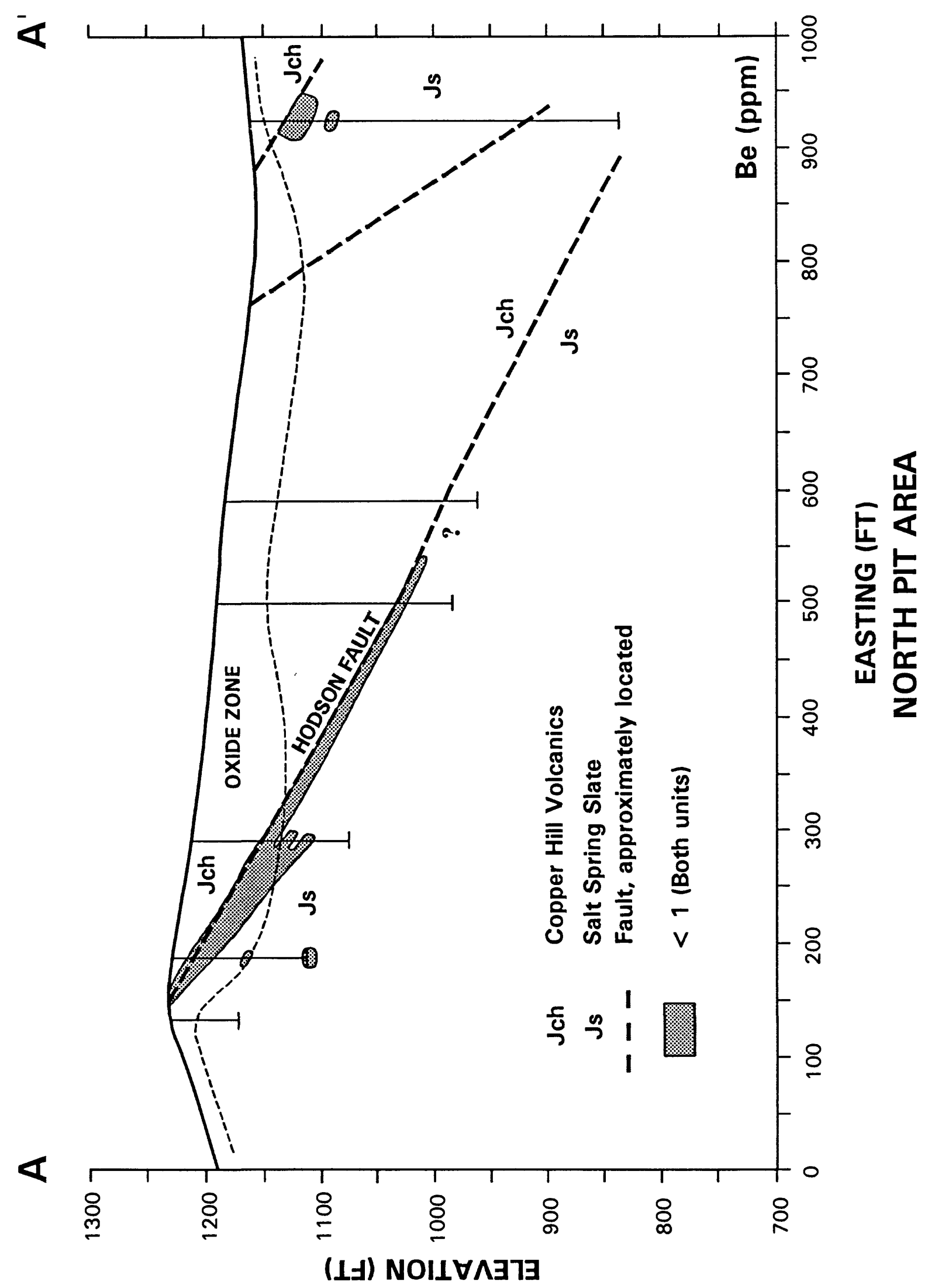




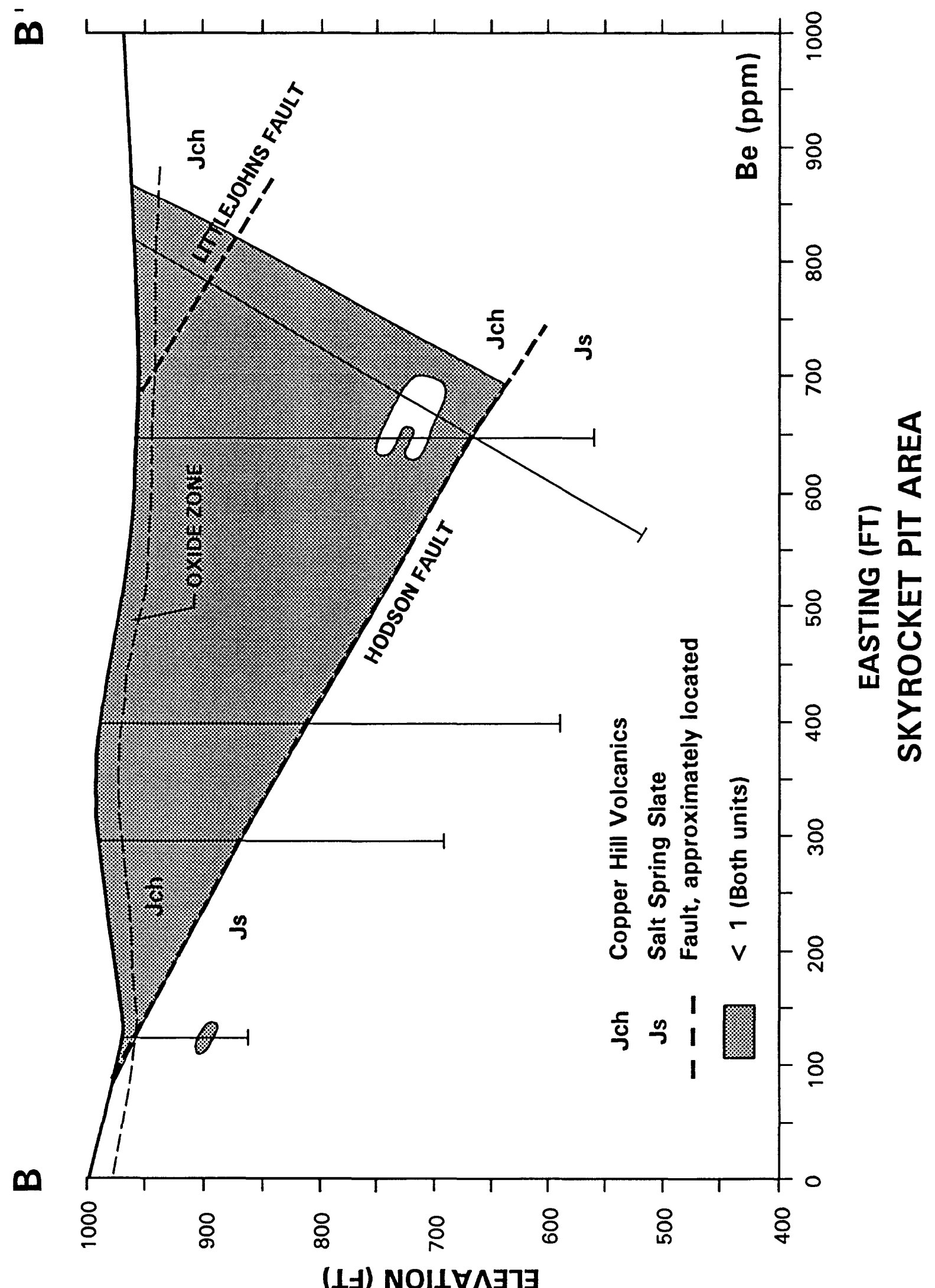




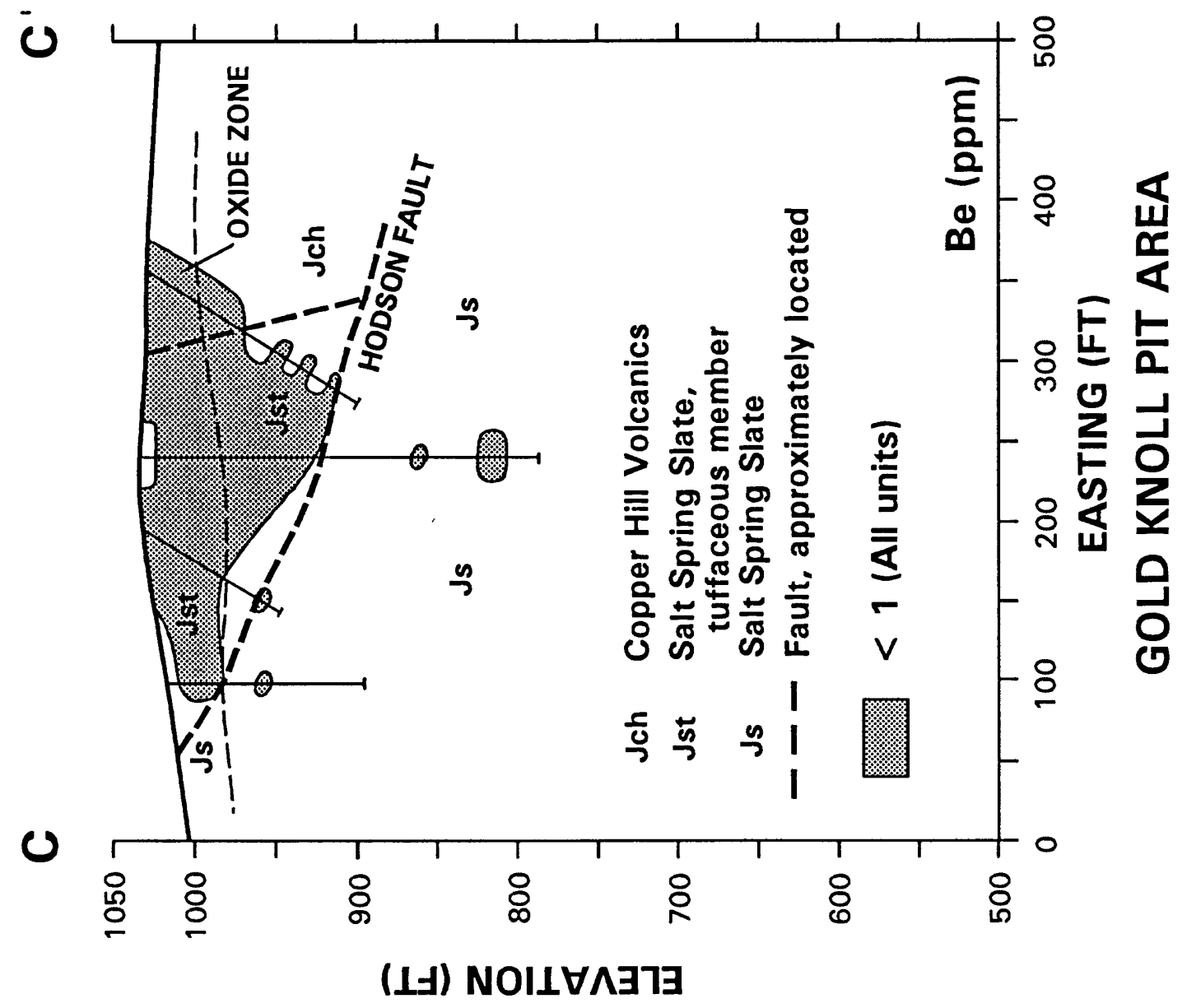




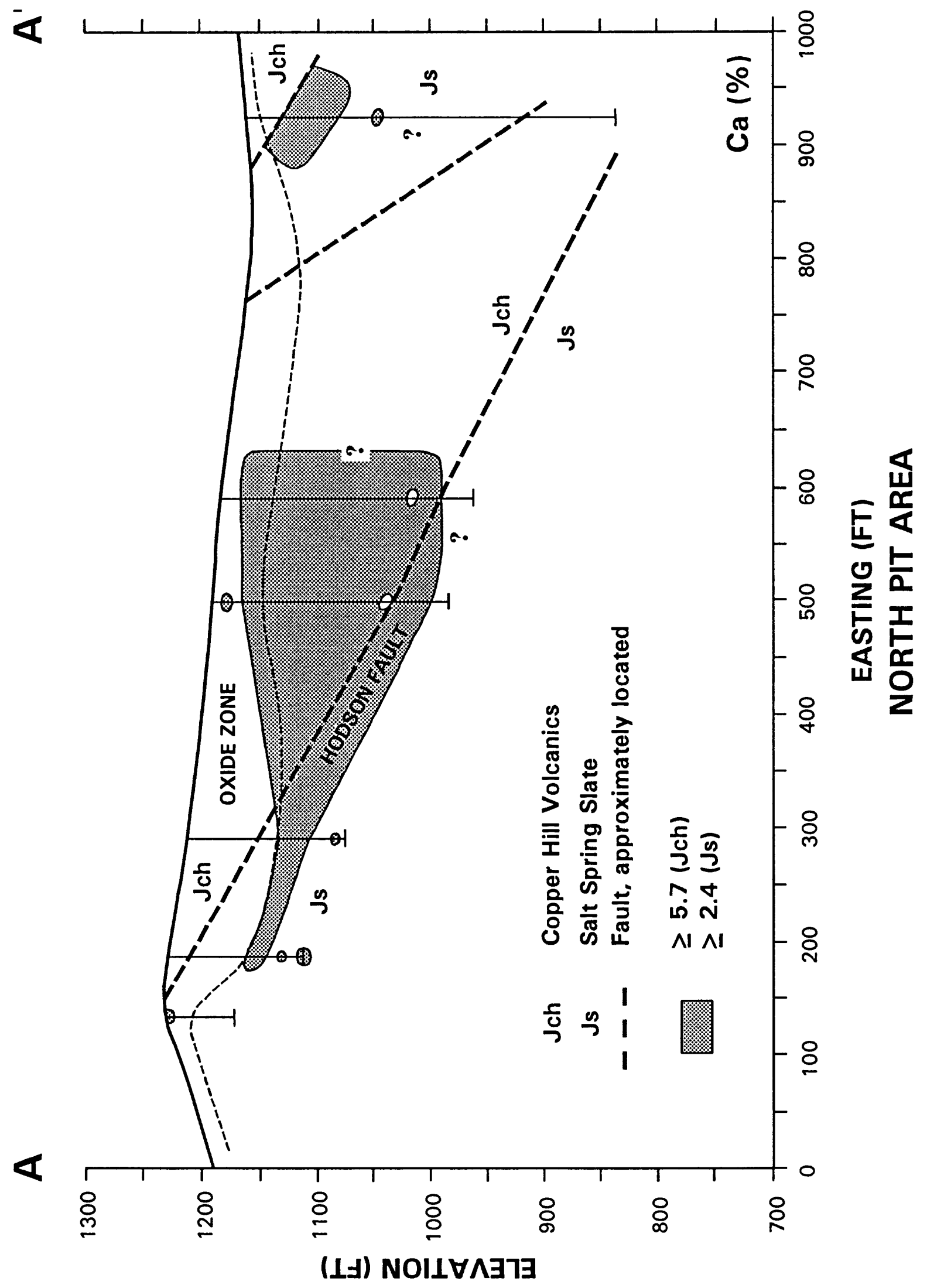




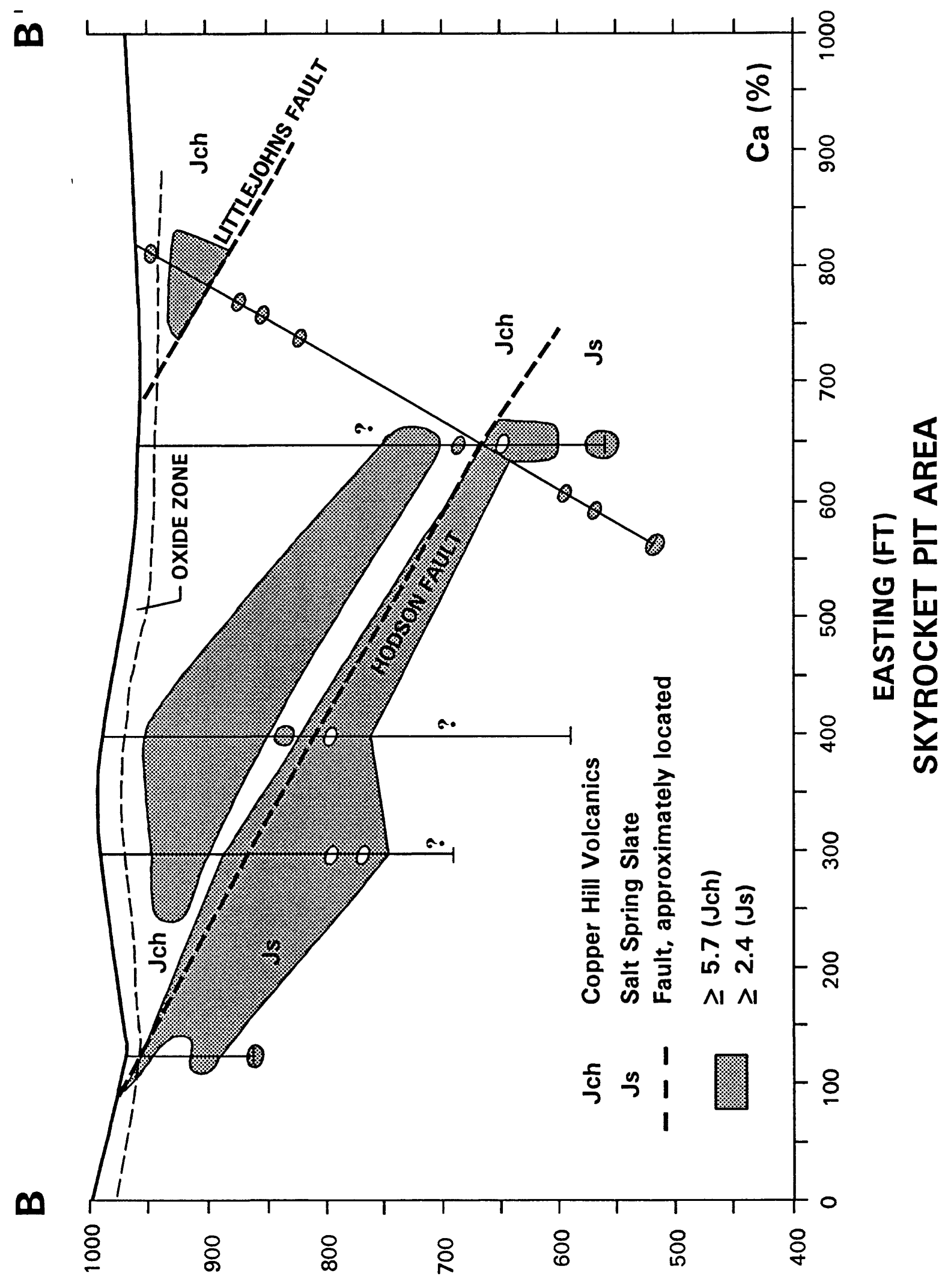

(L-1) NOII $\forall \wedge \exists 7 \exists$ 


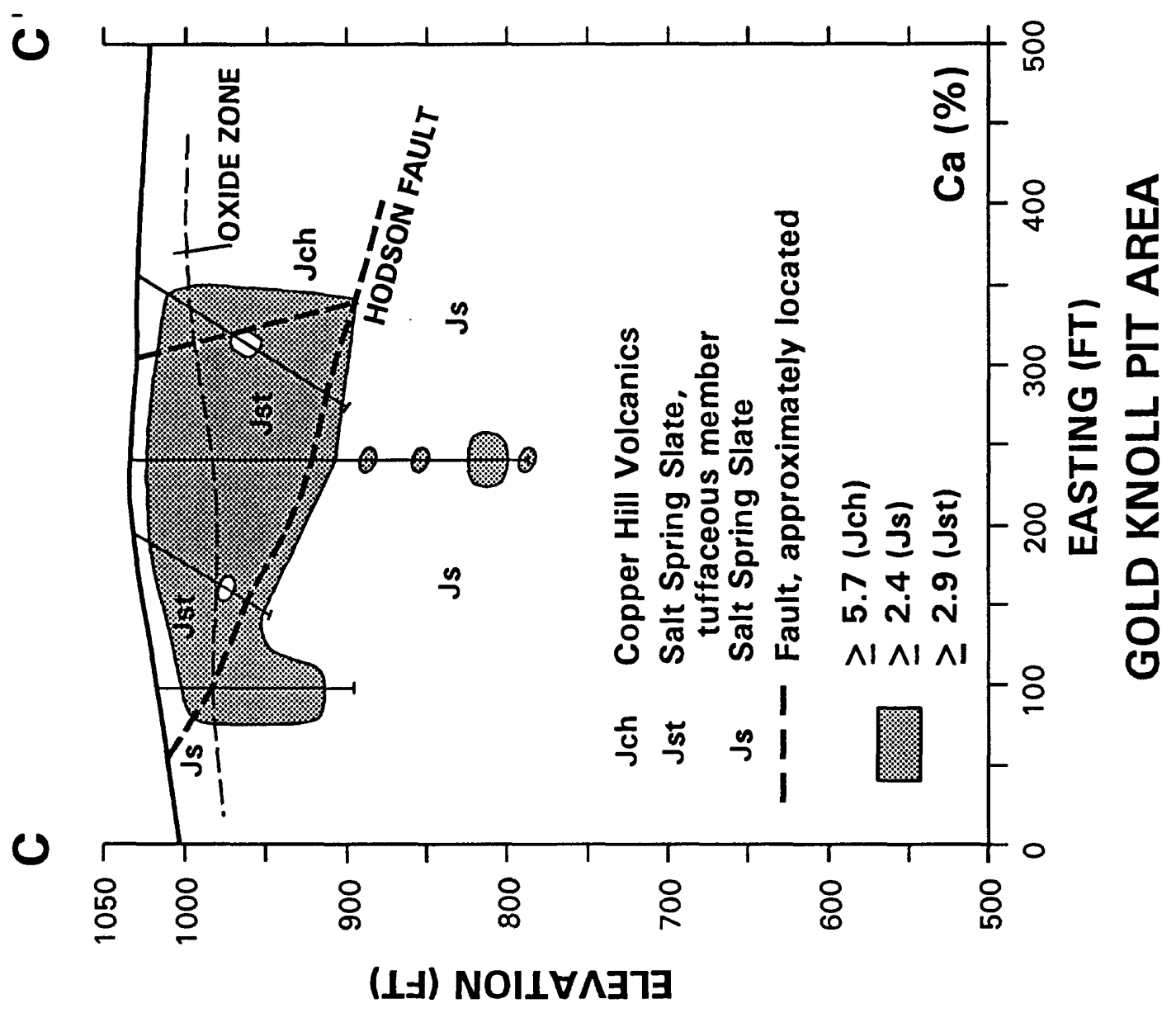




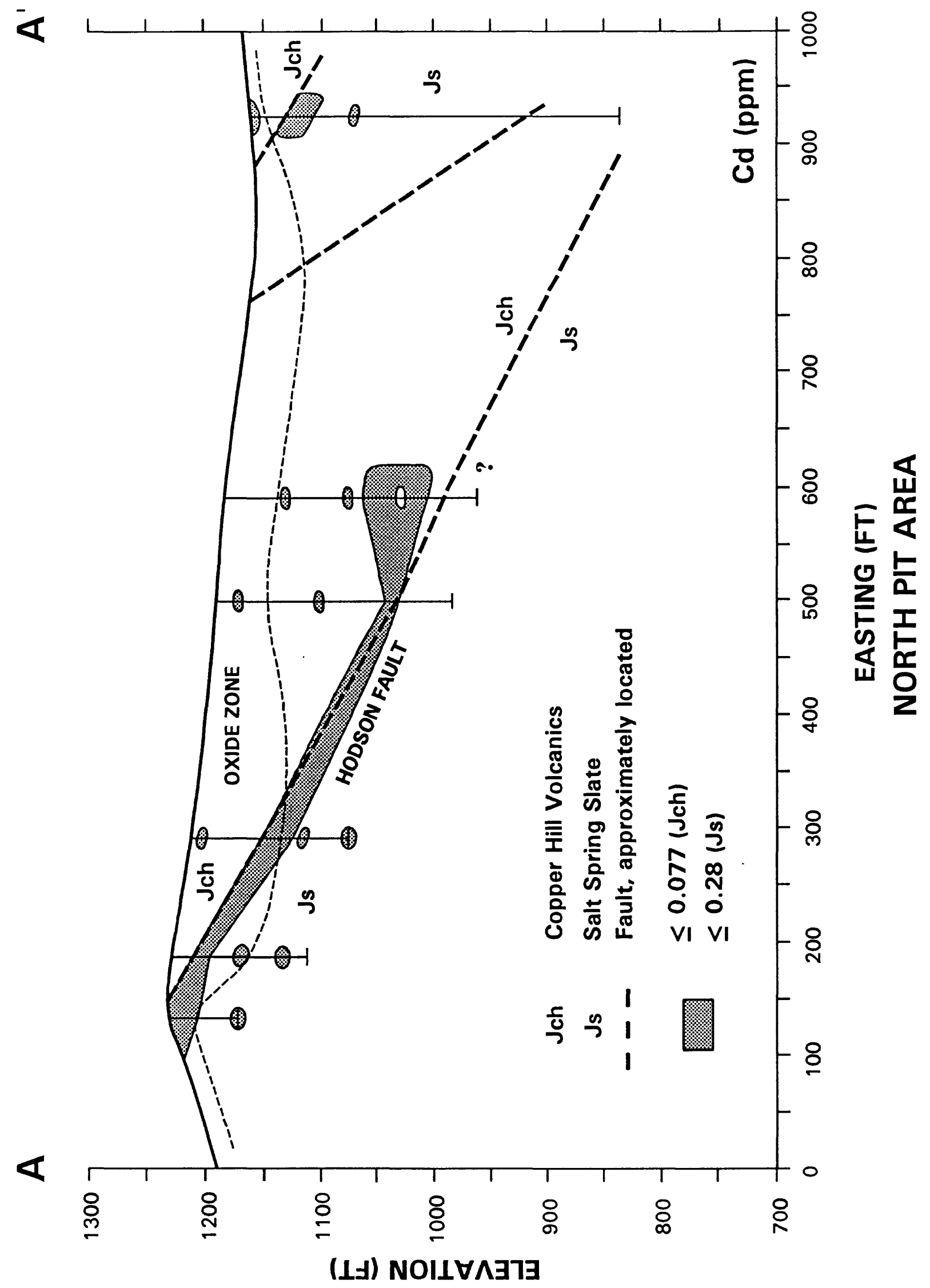




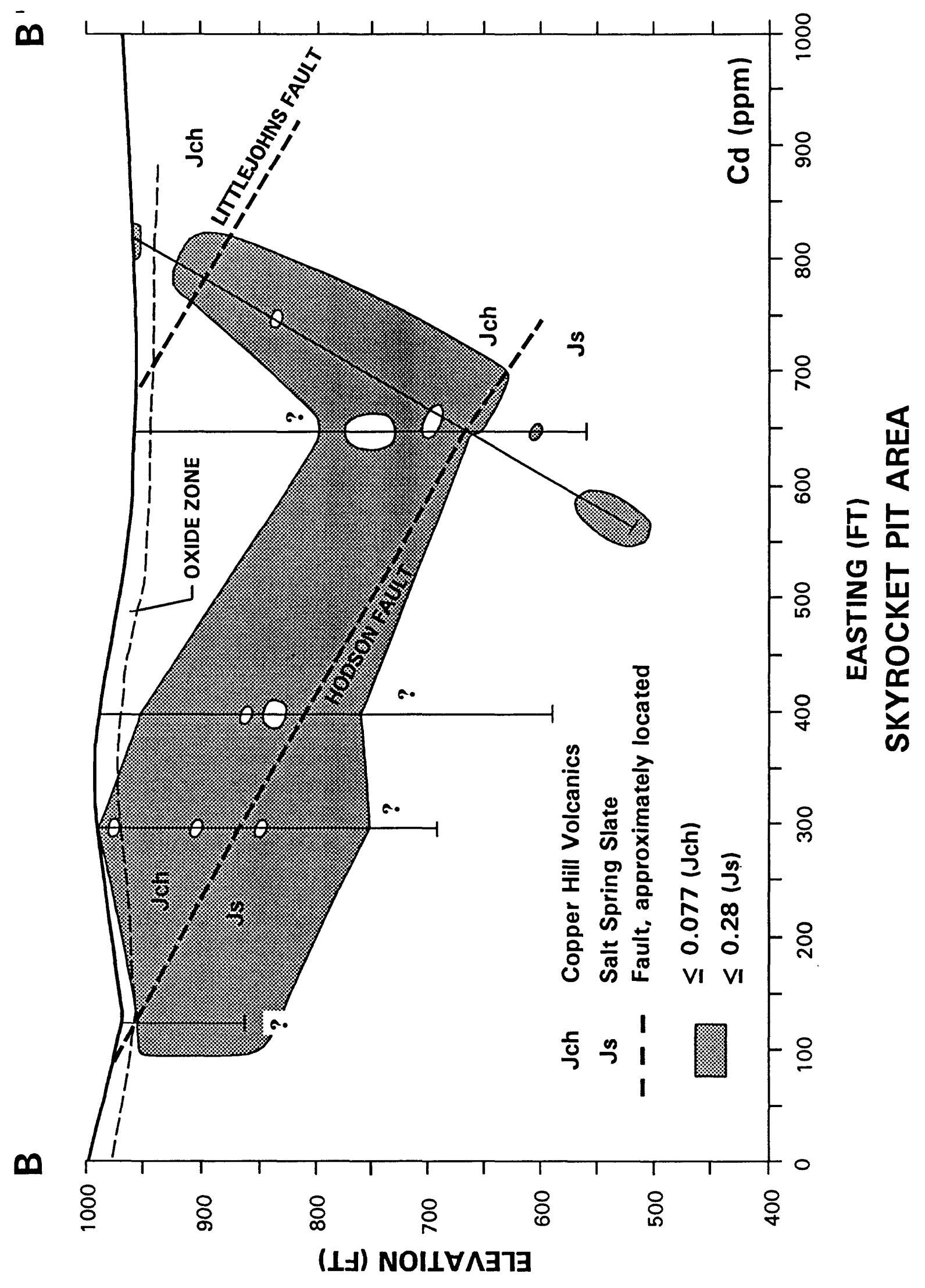




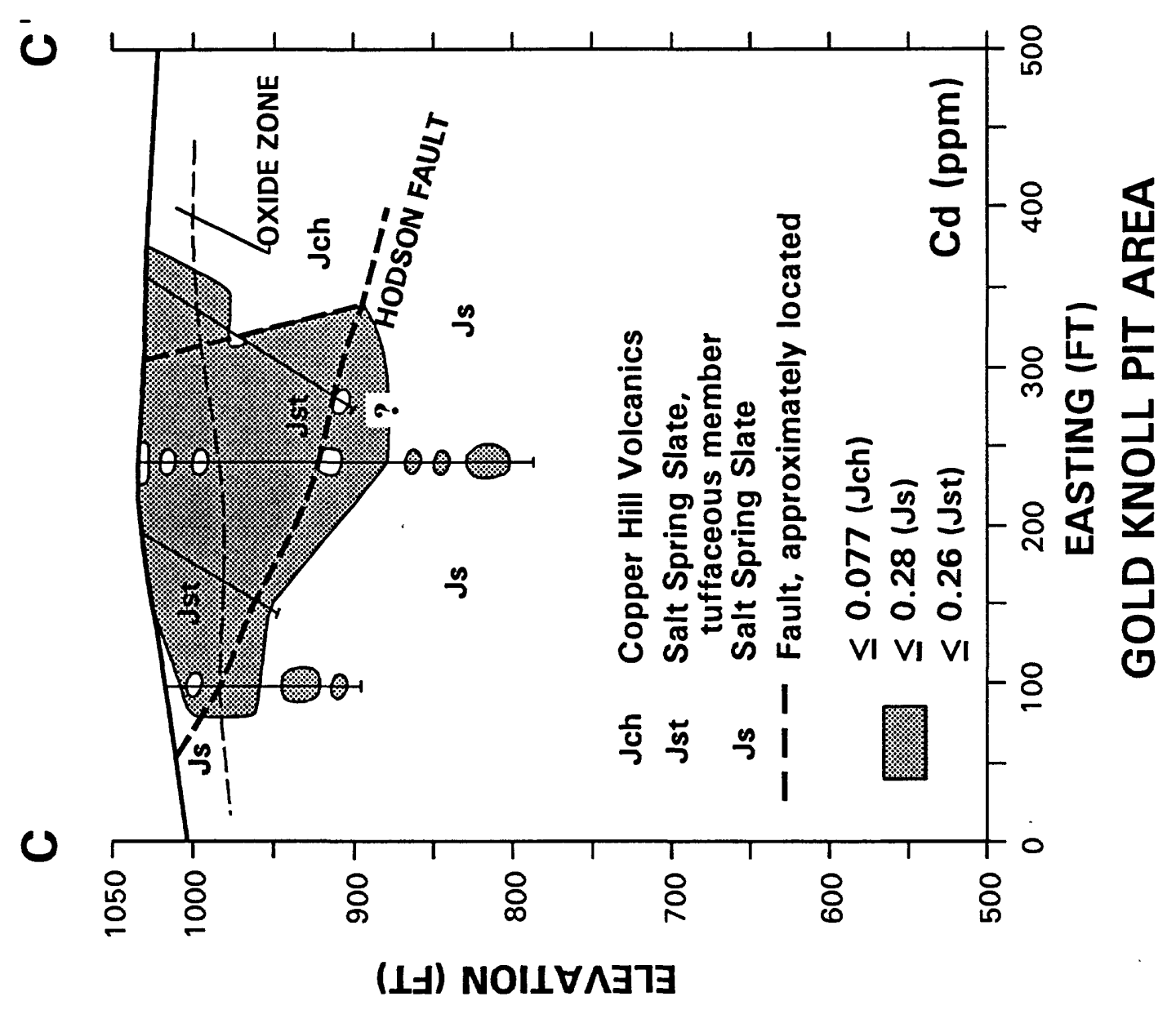




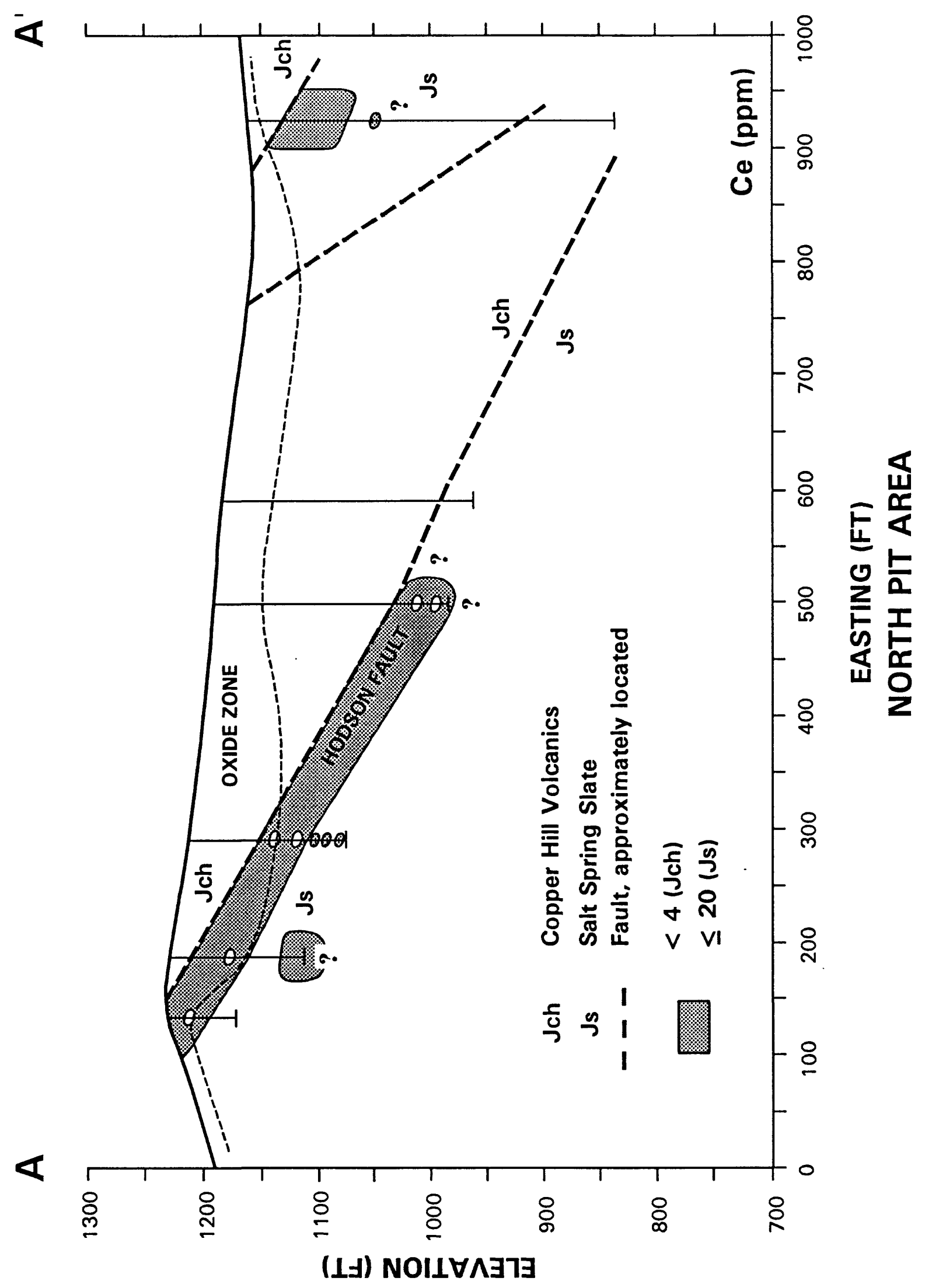




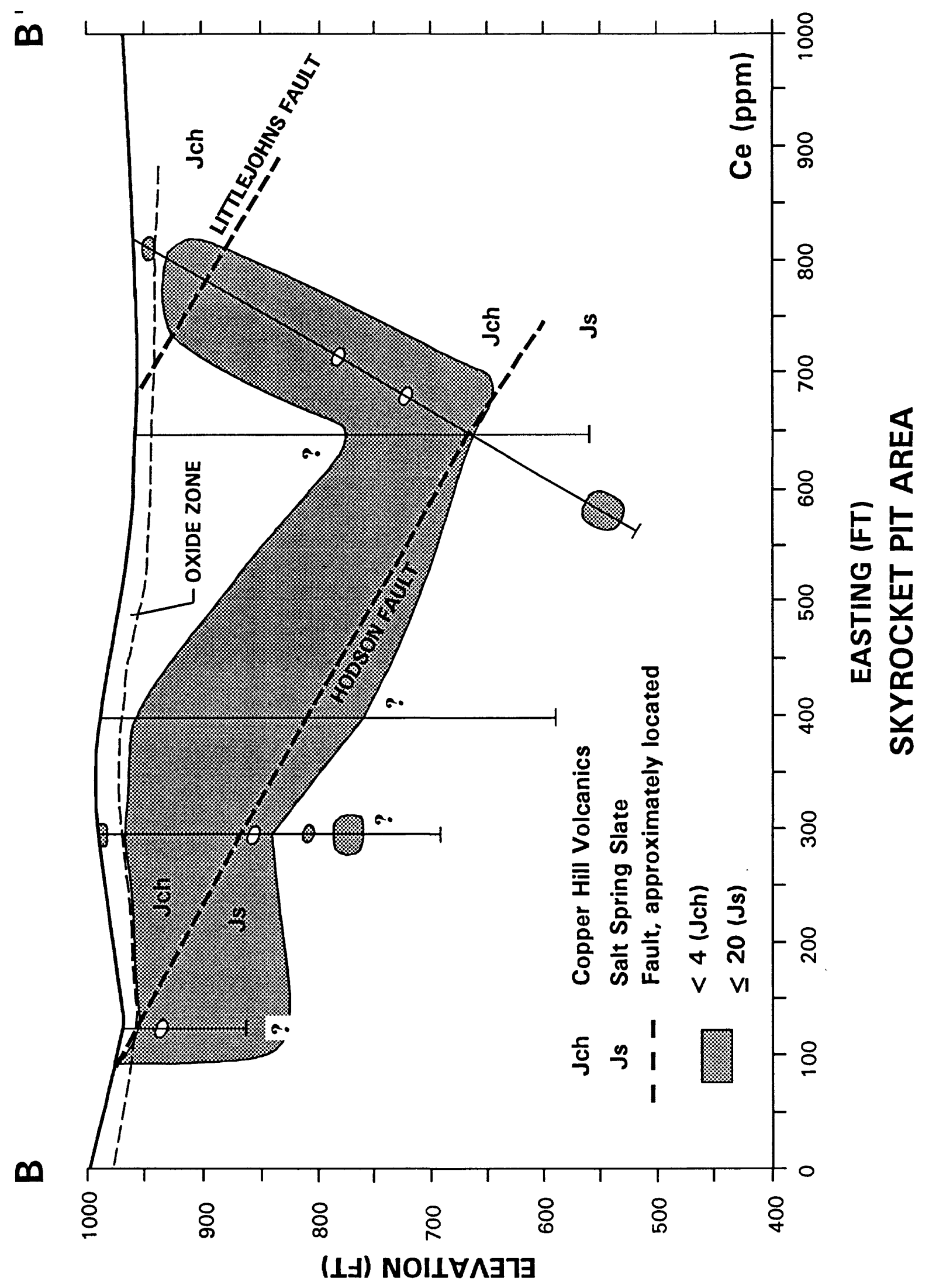




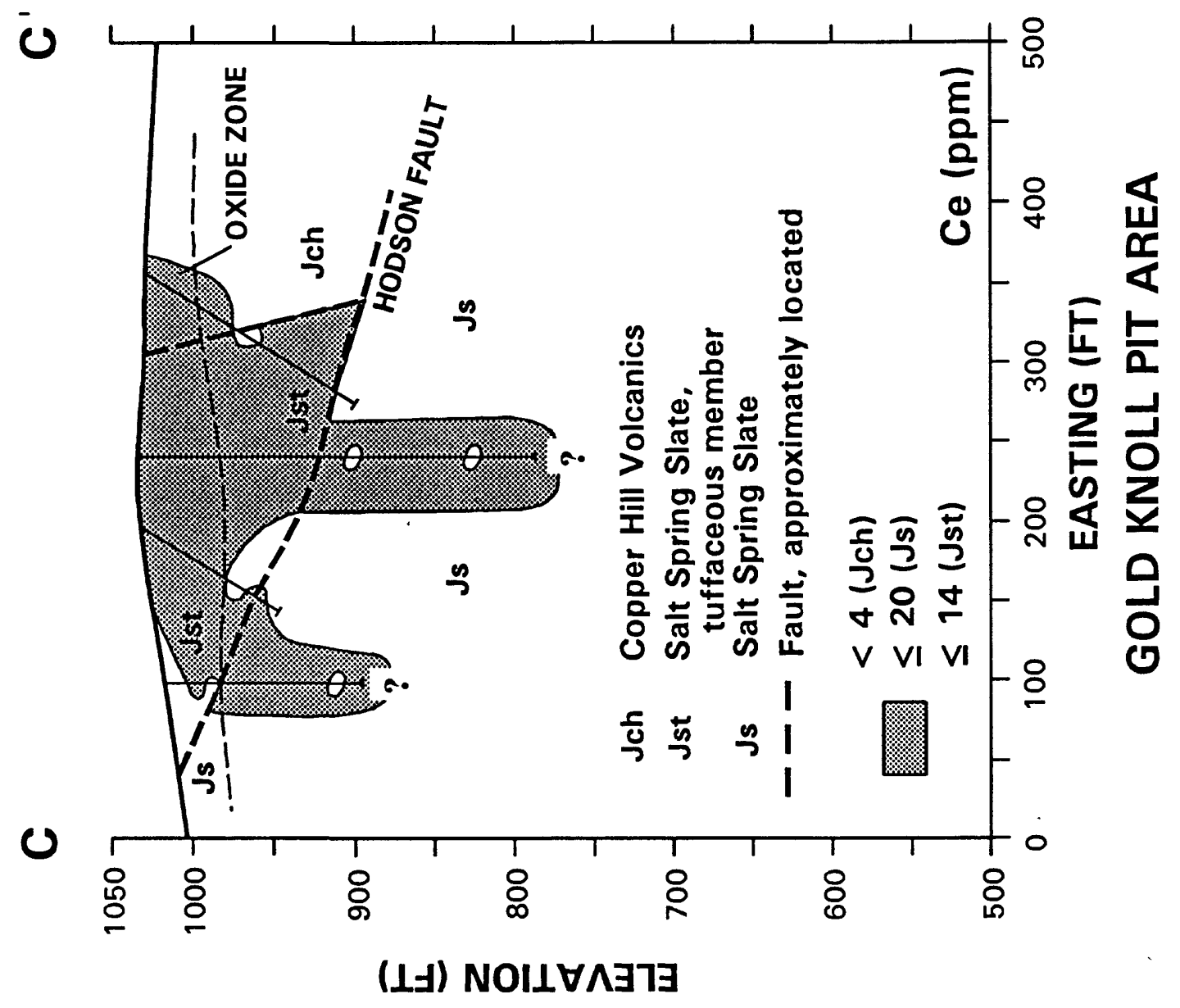




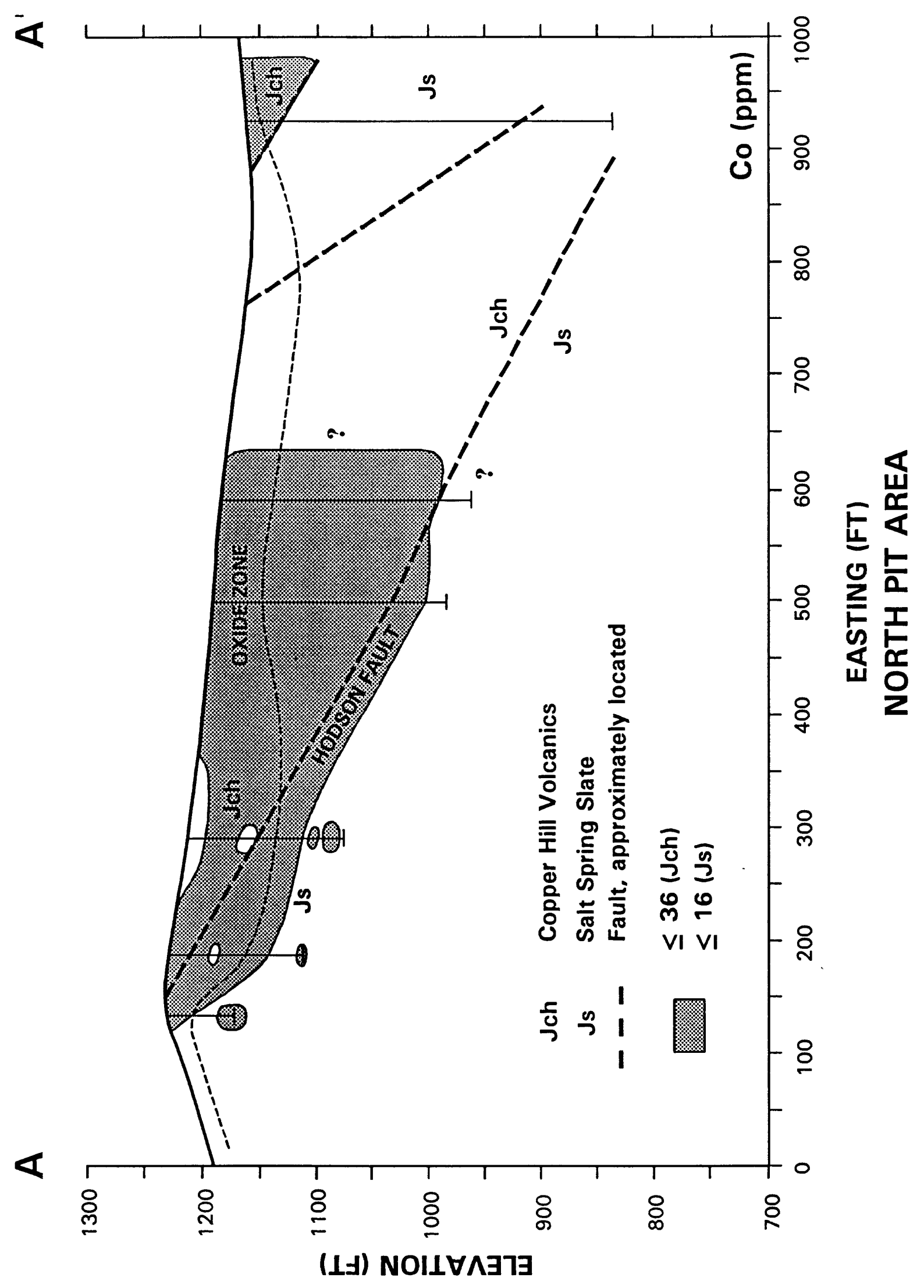




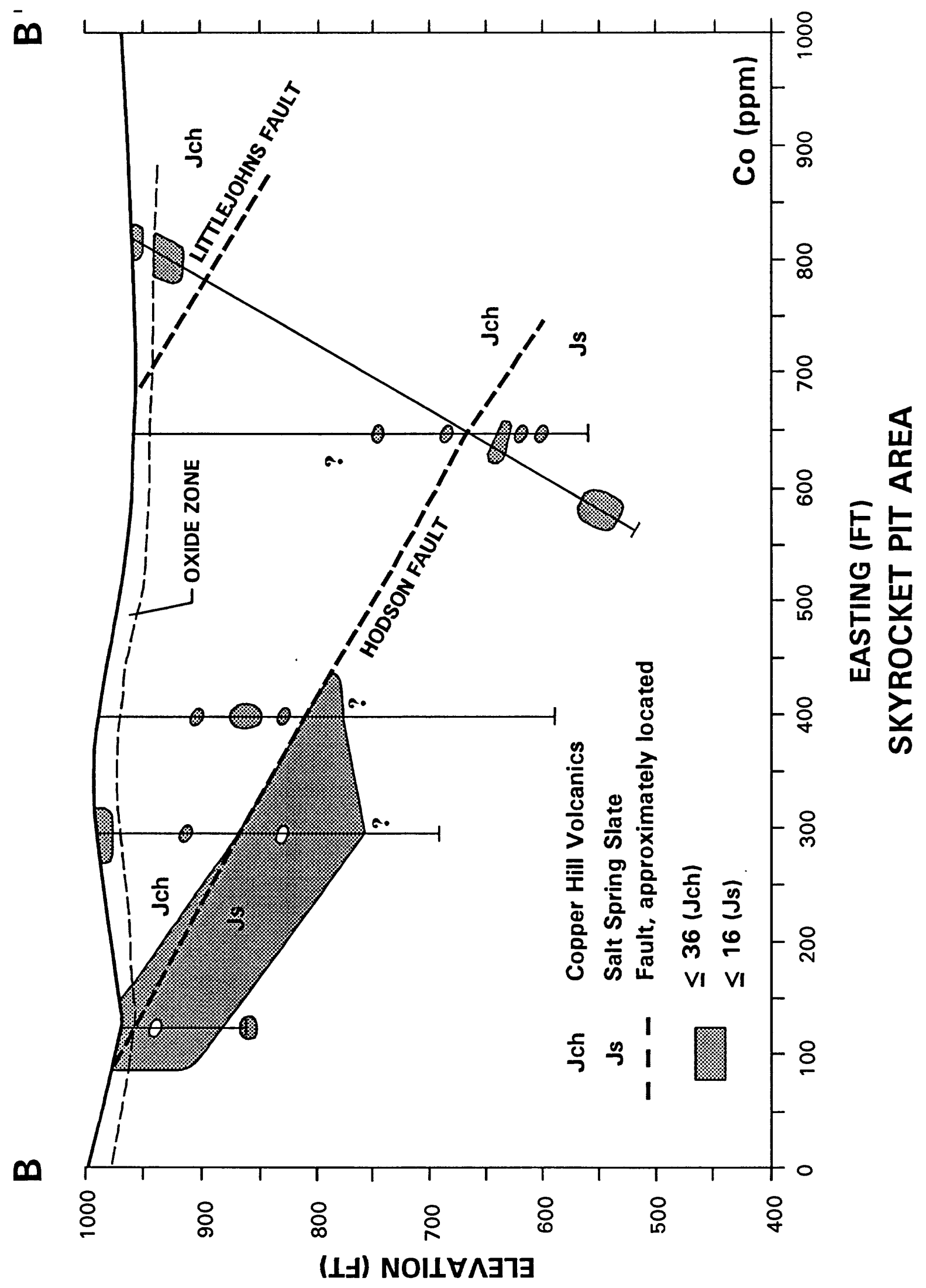




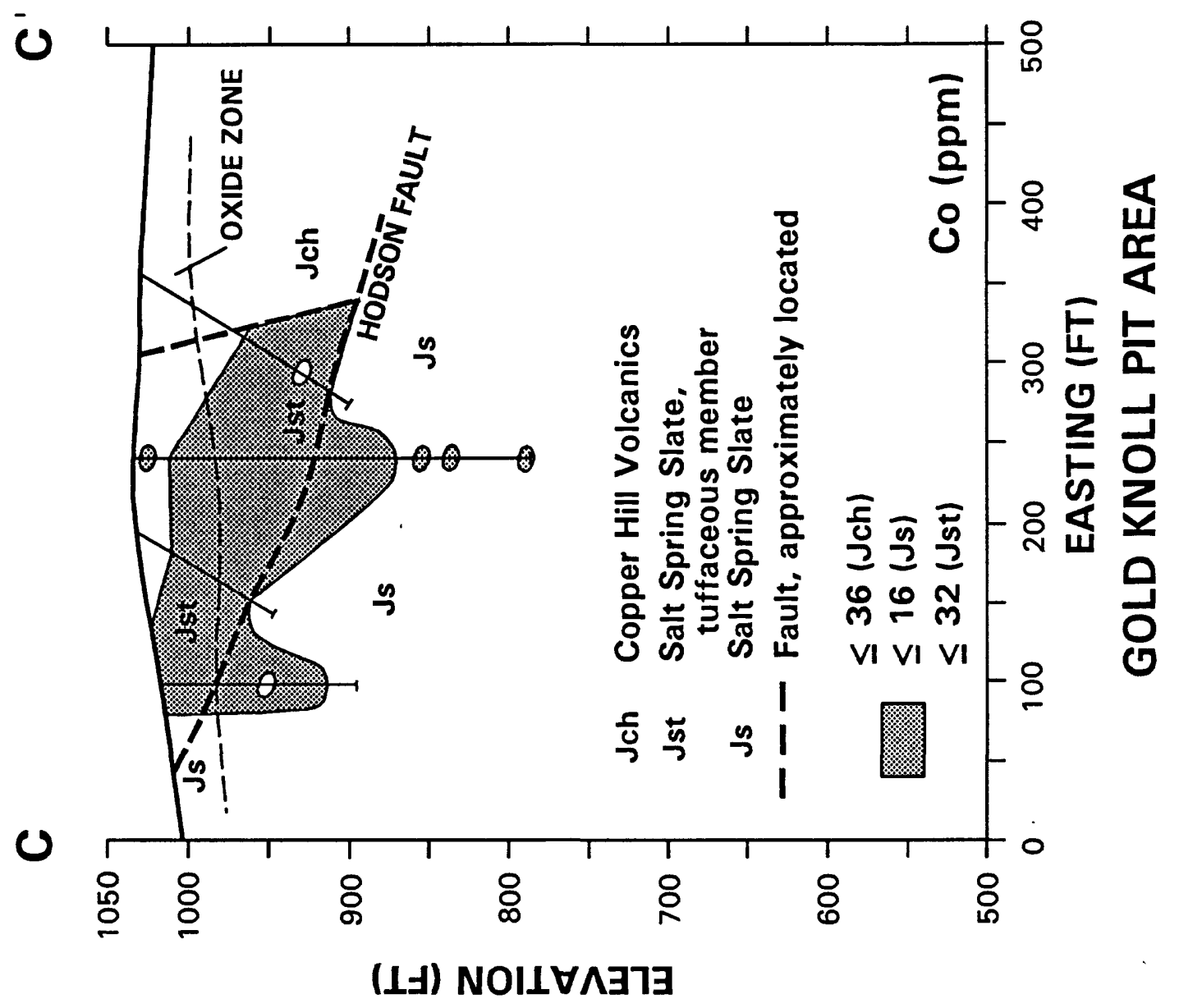




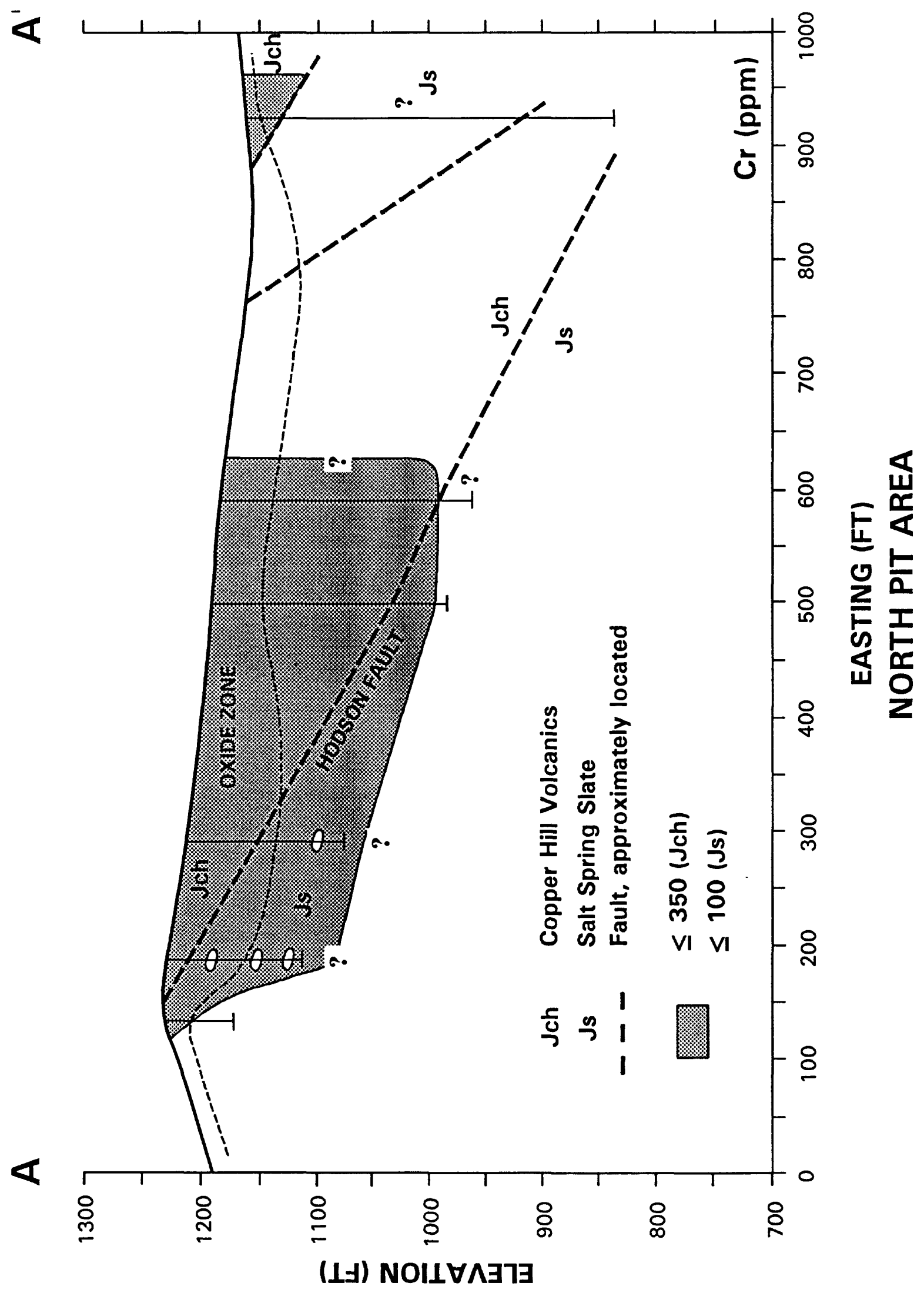




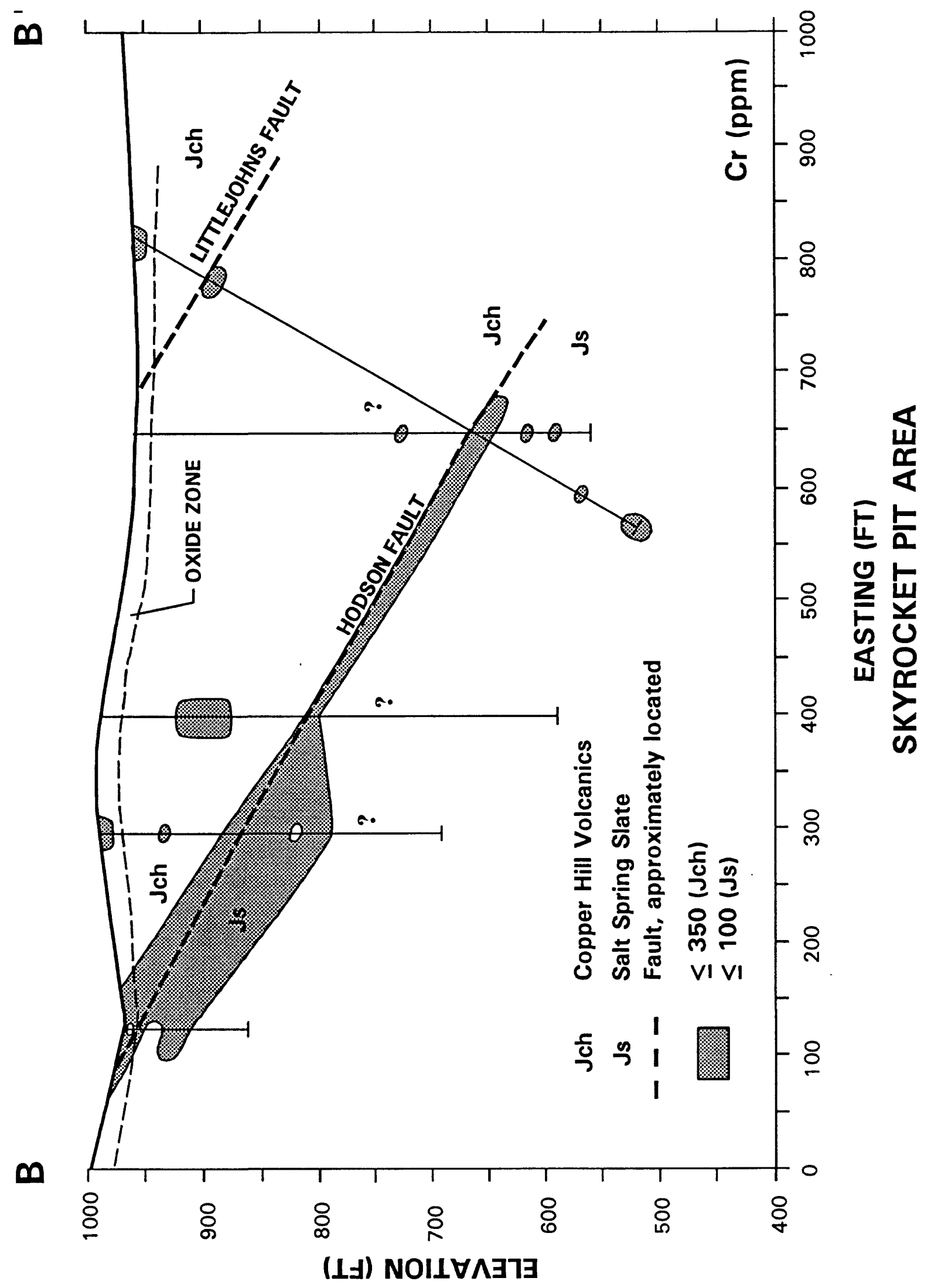




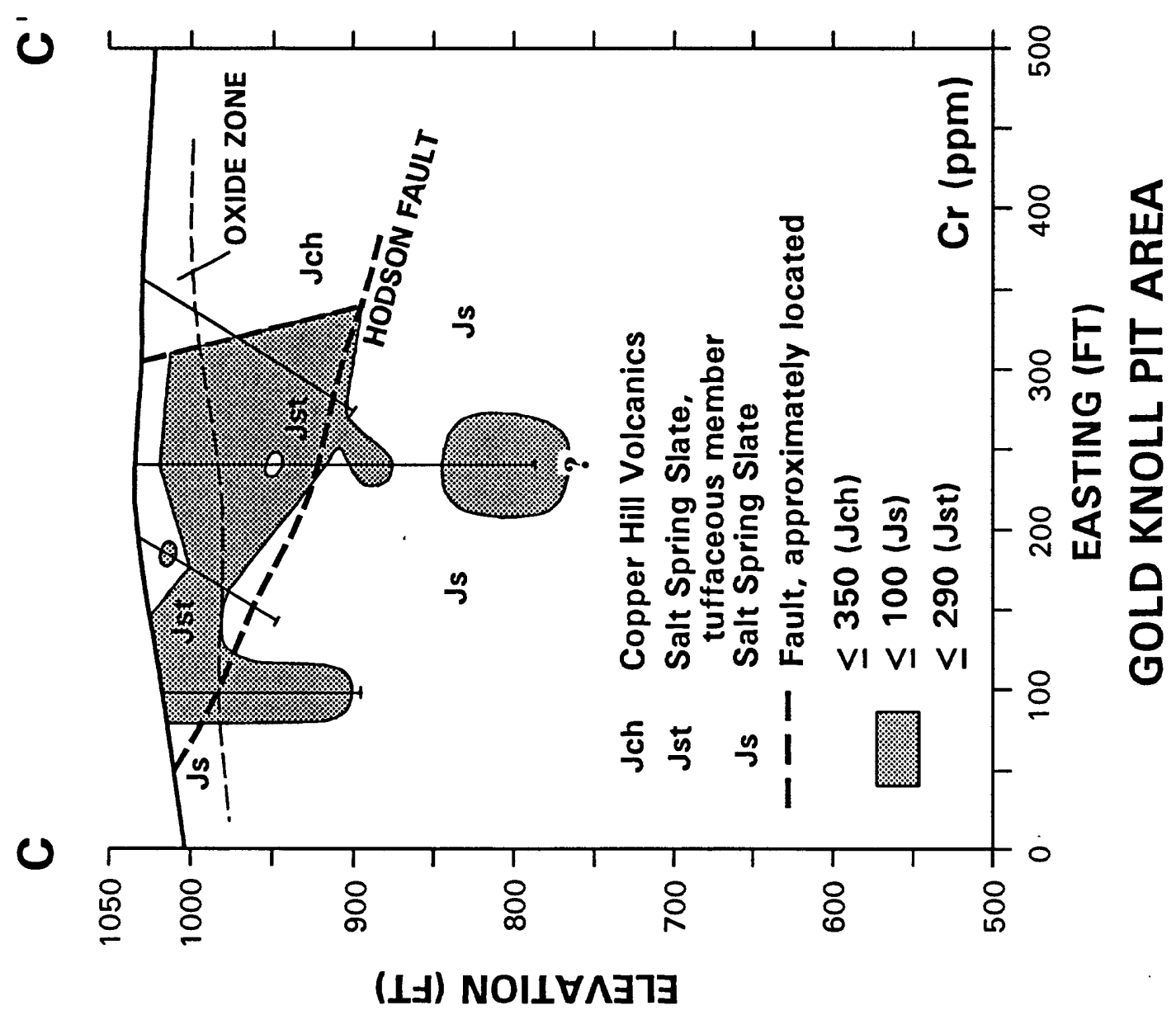




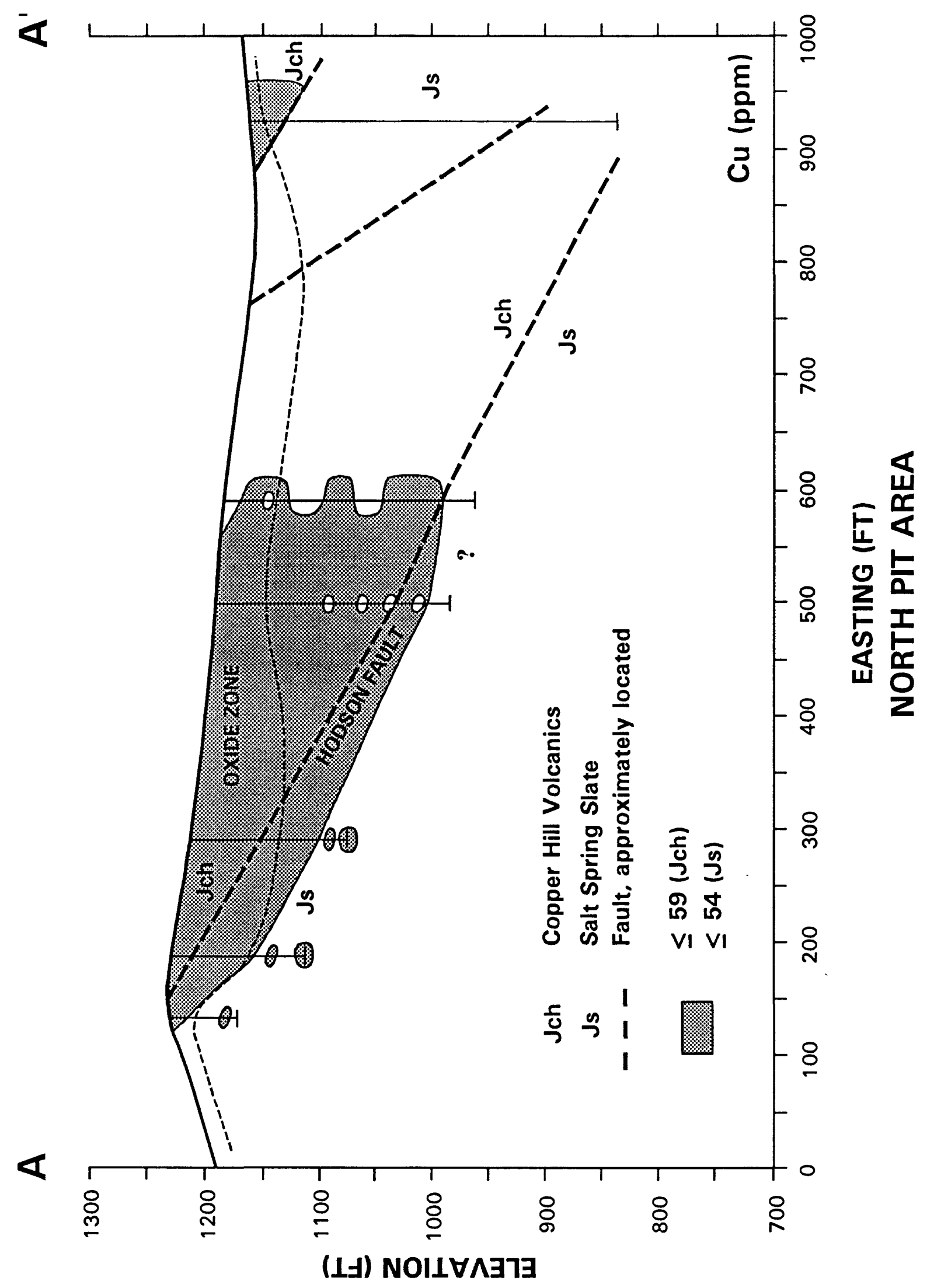




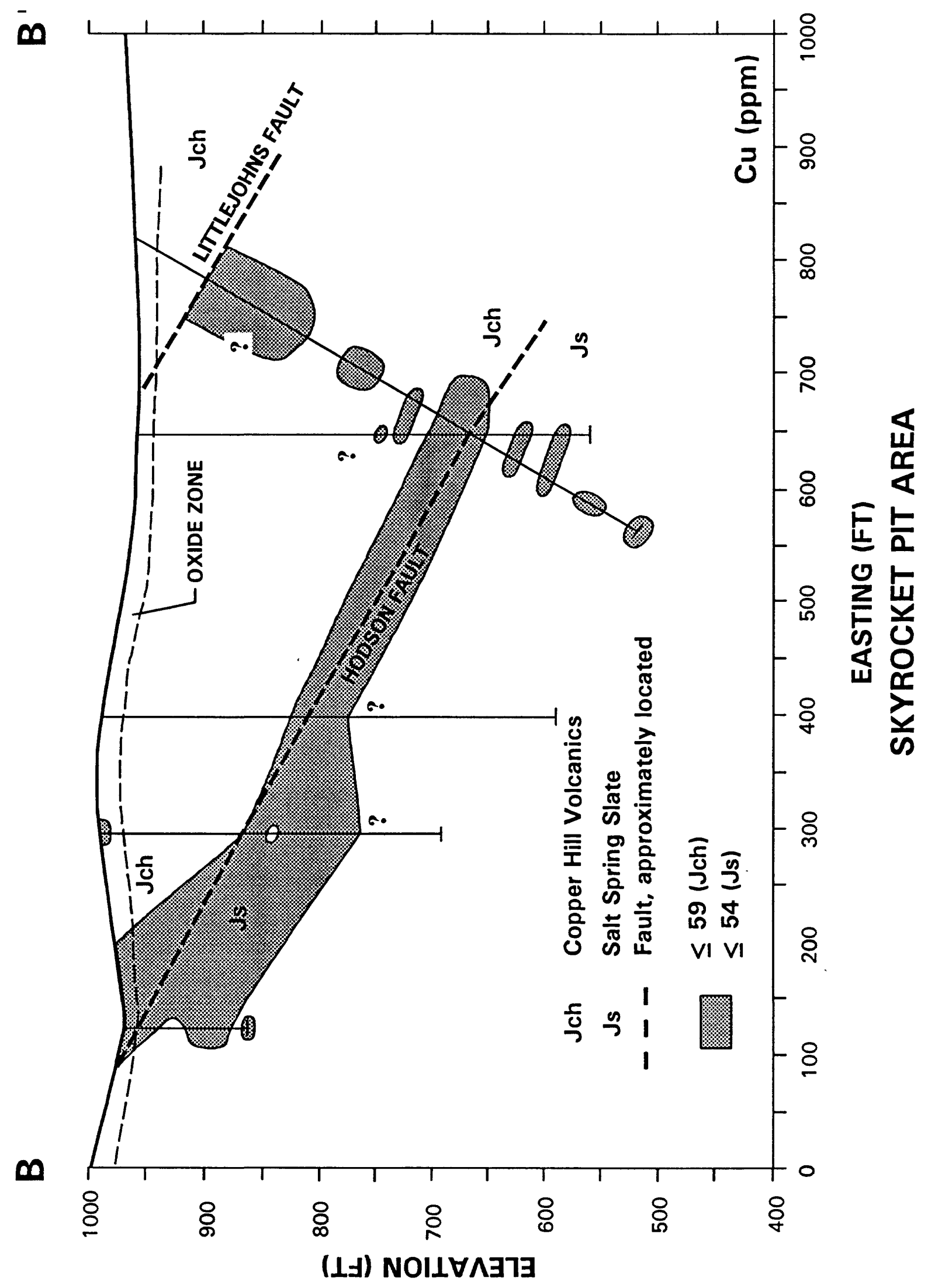




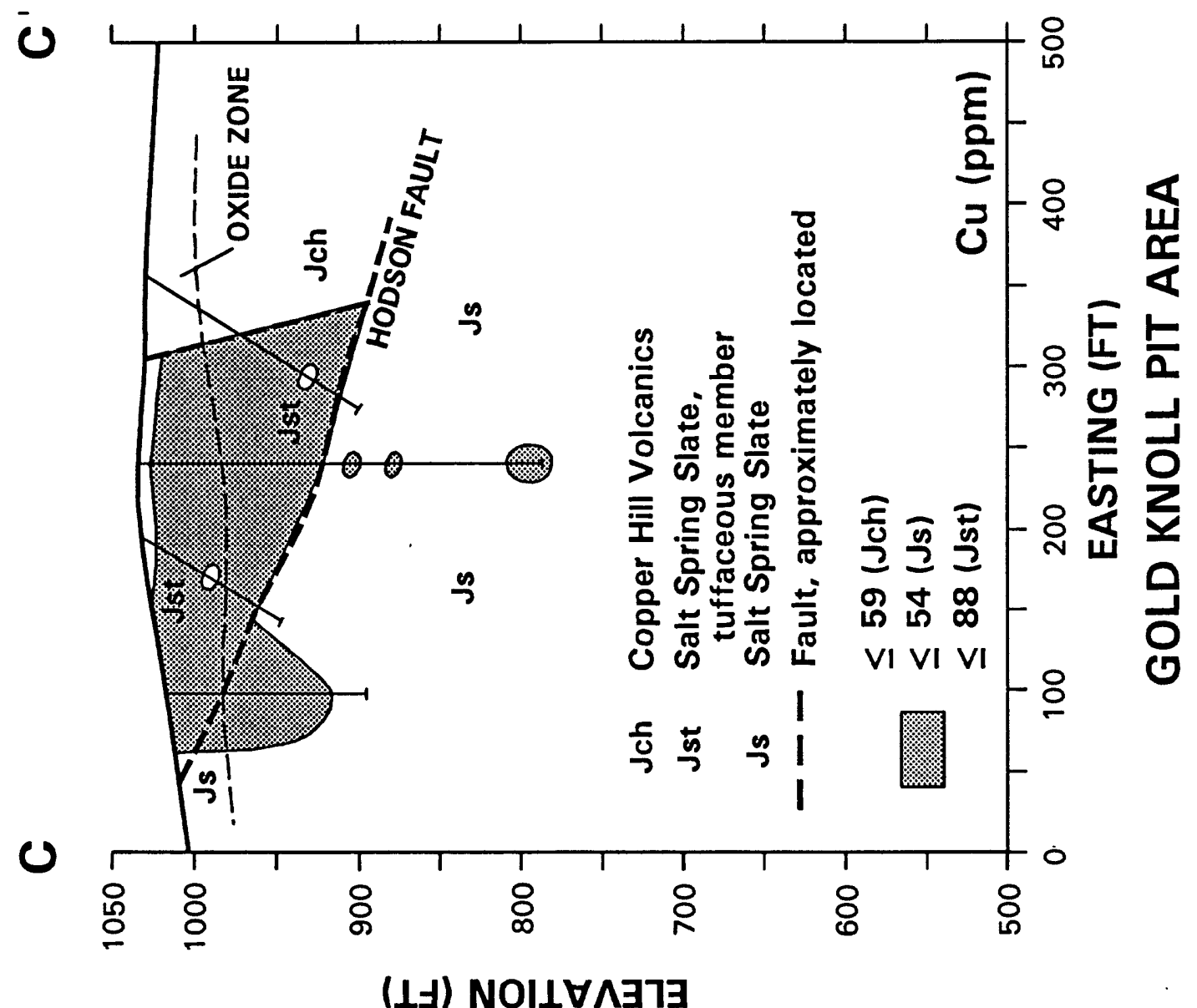




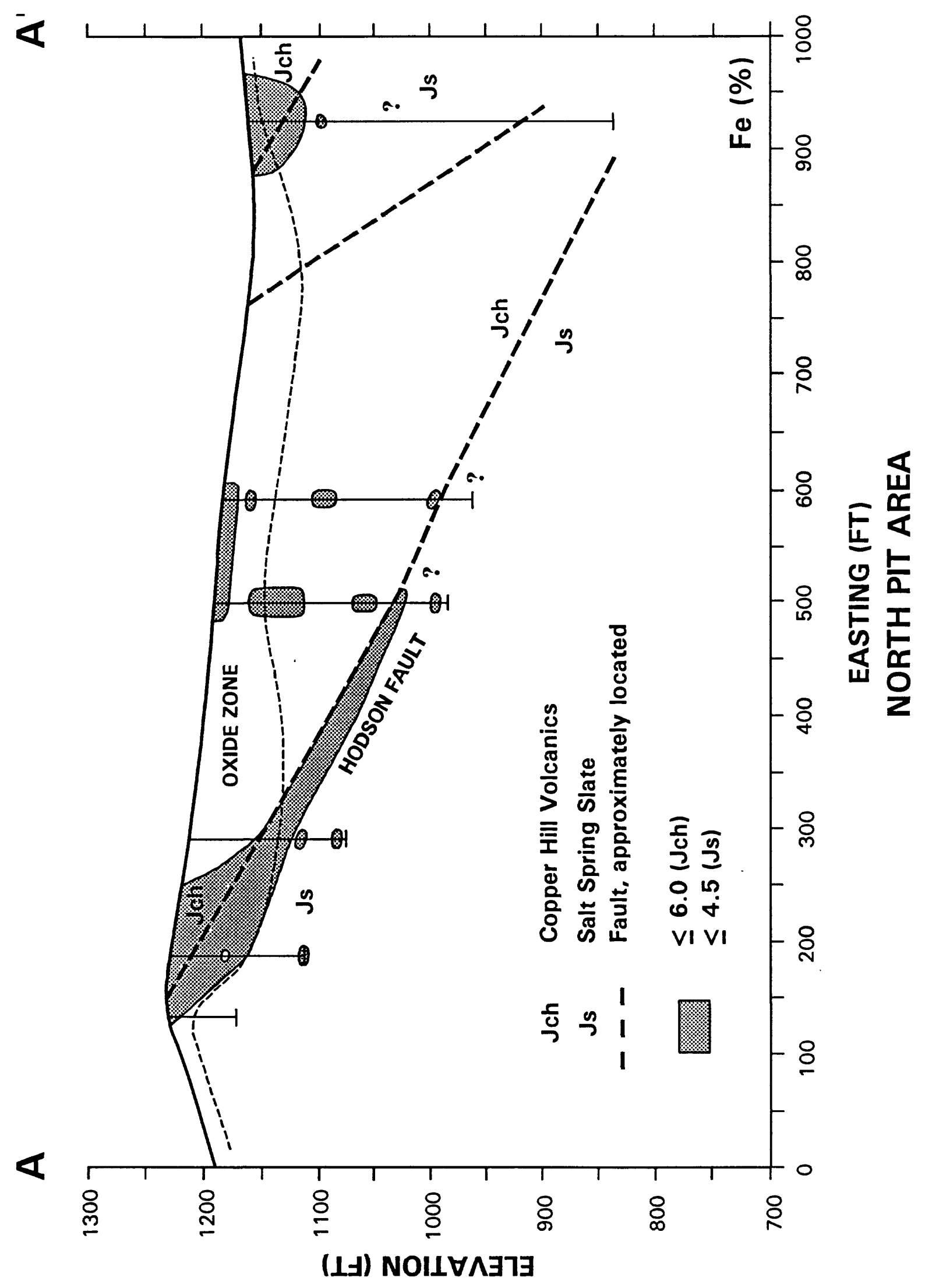




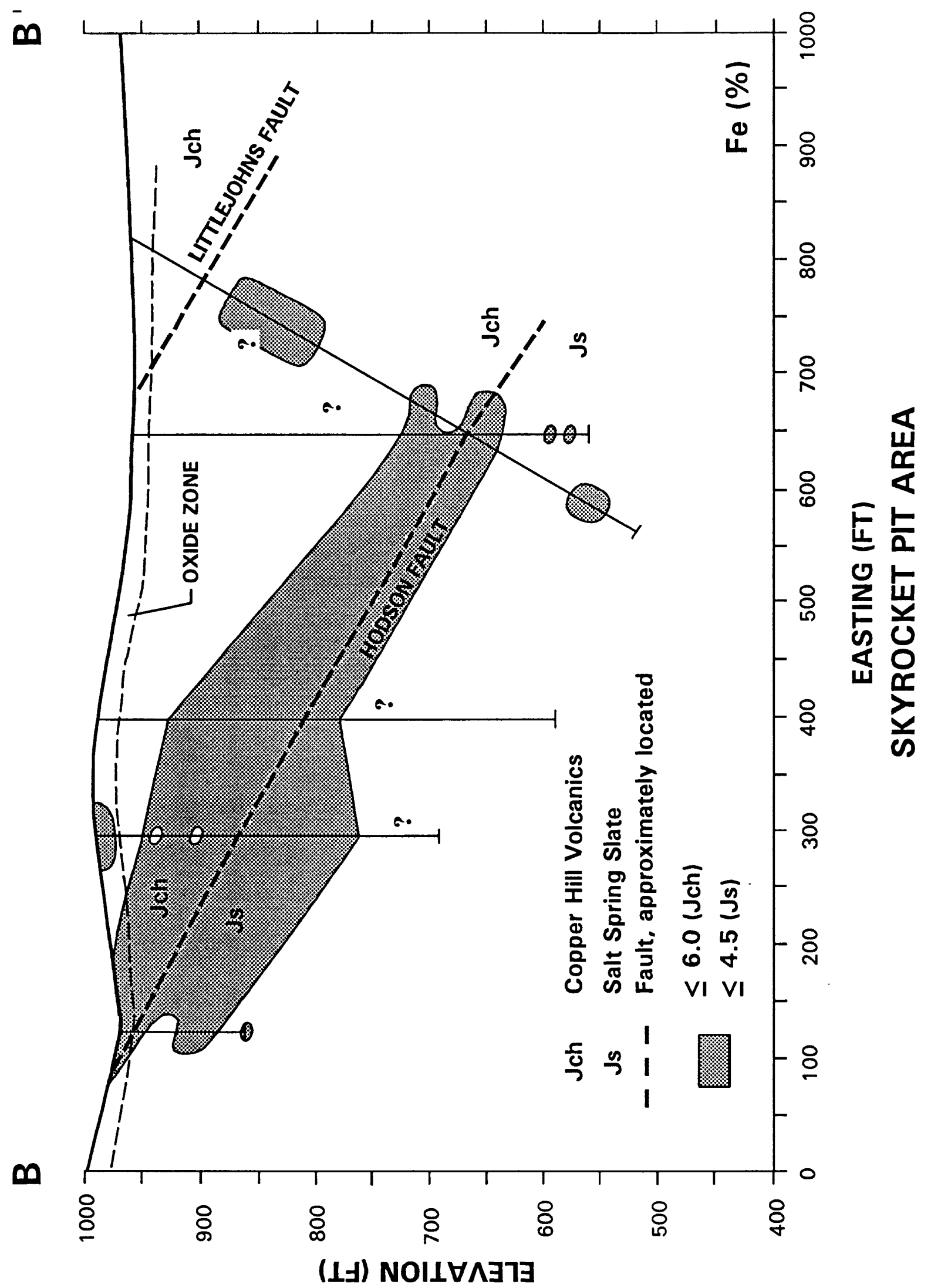




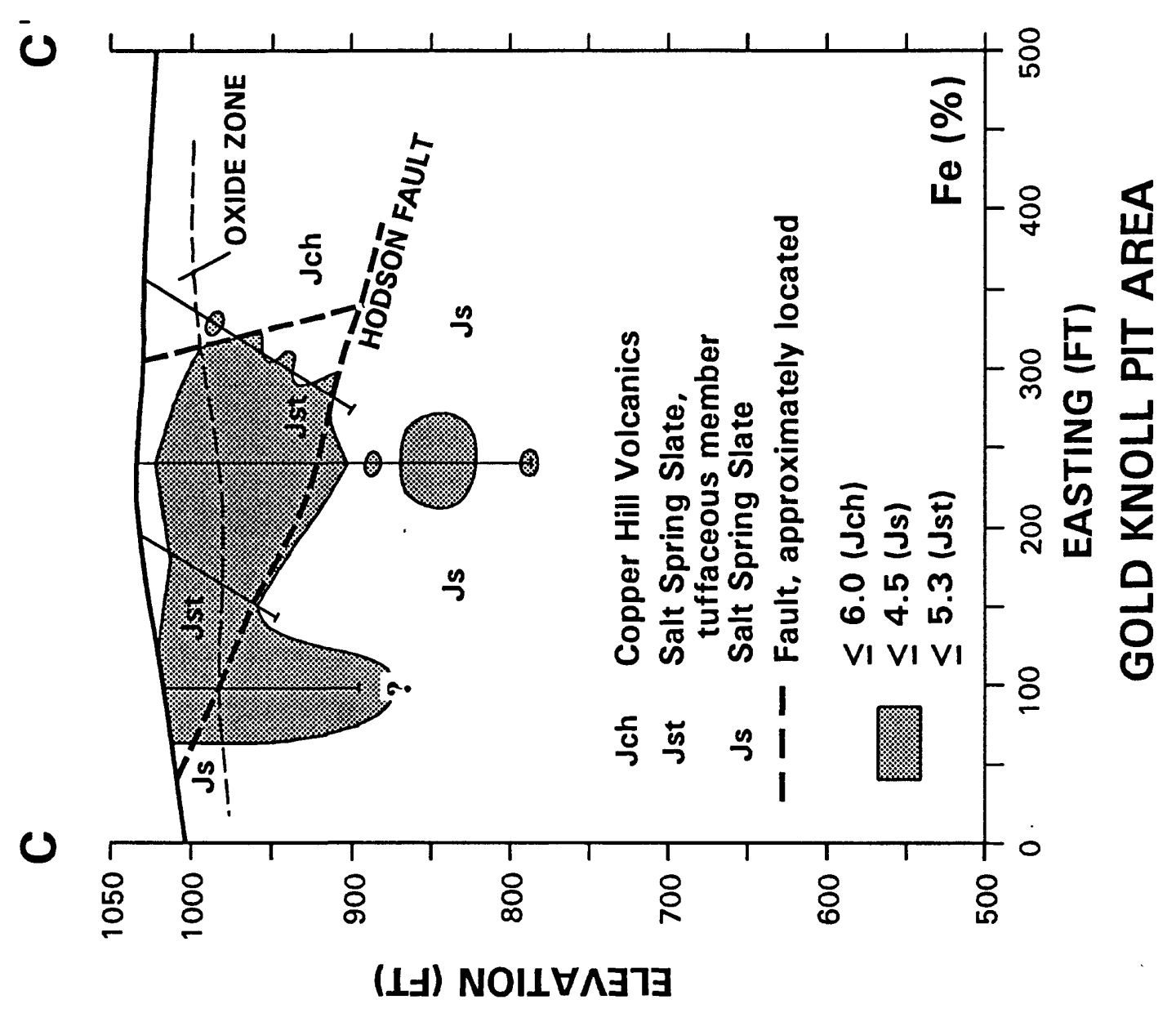




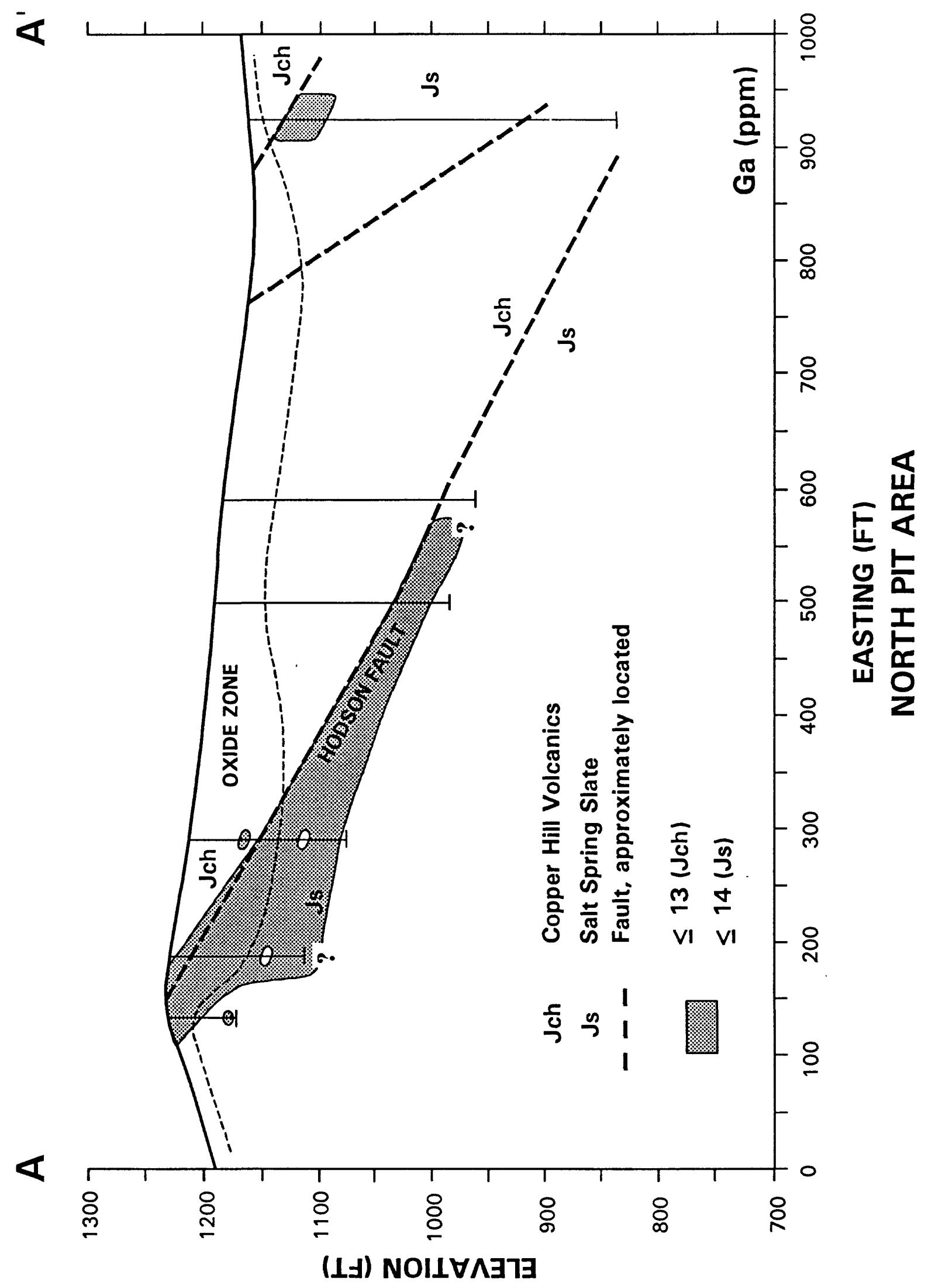




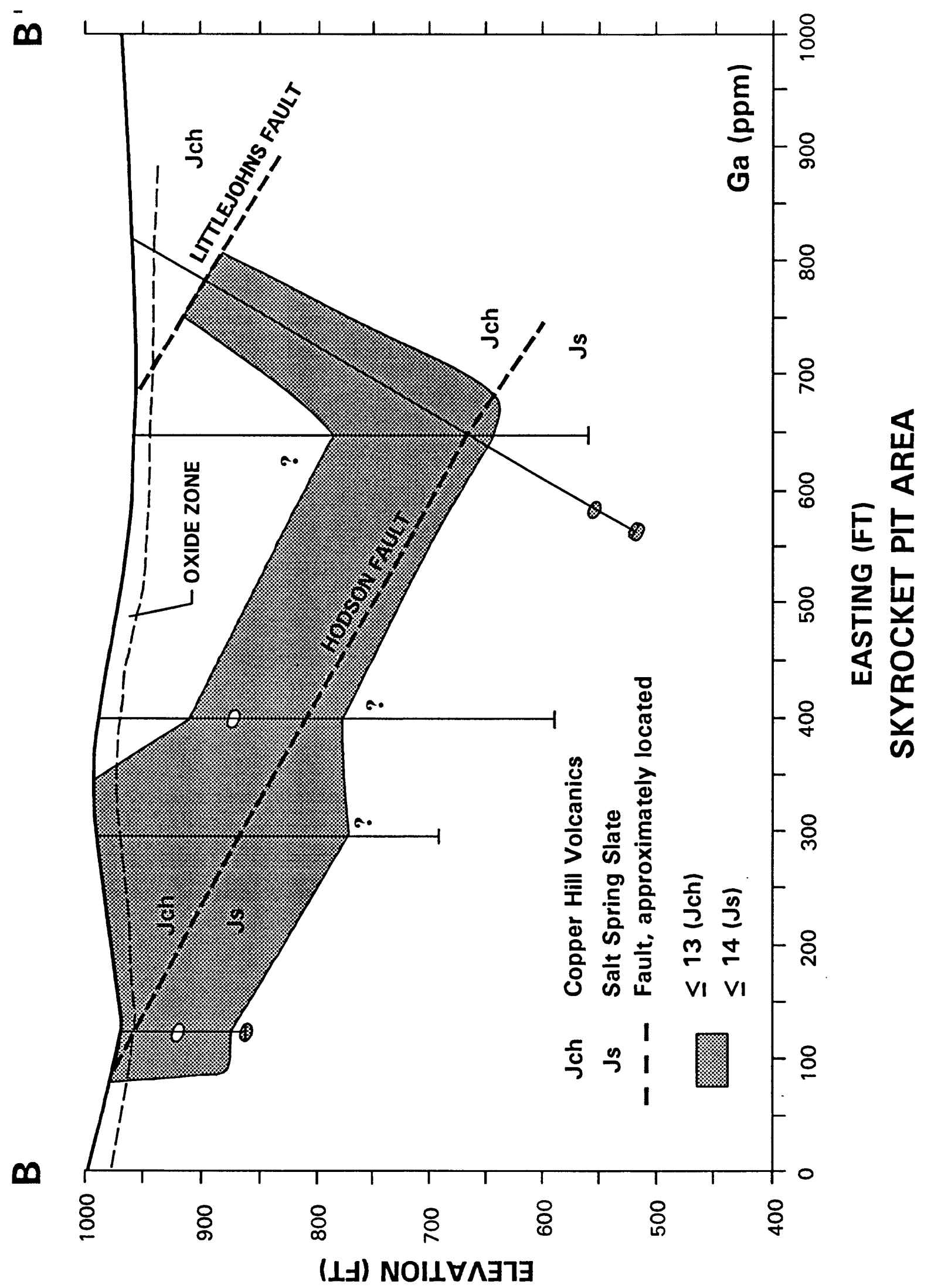




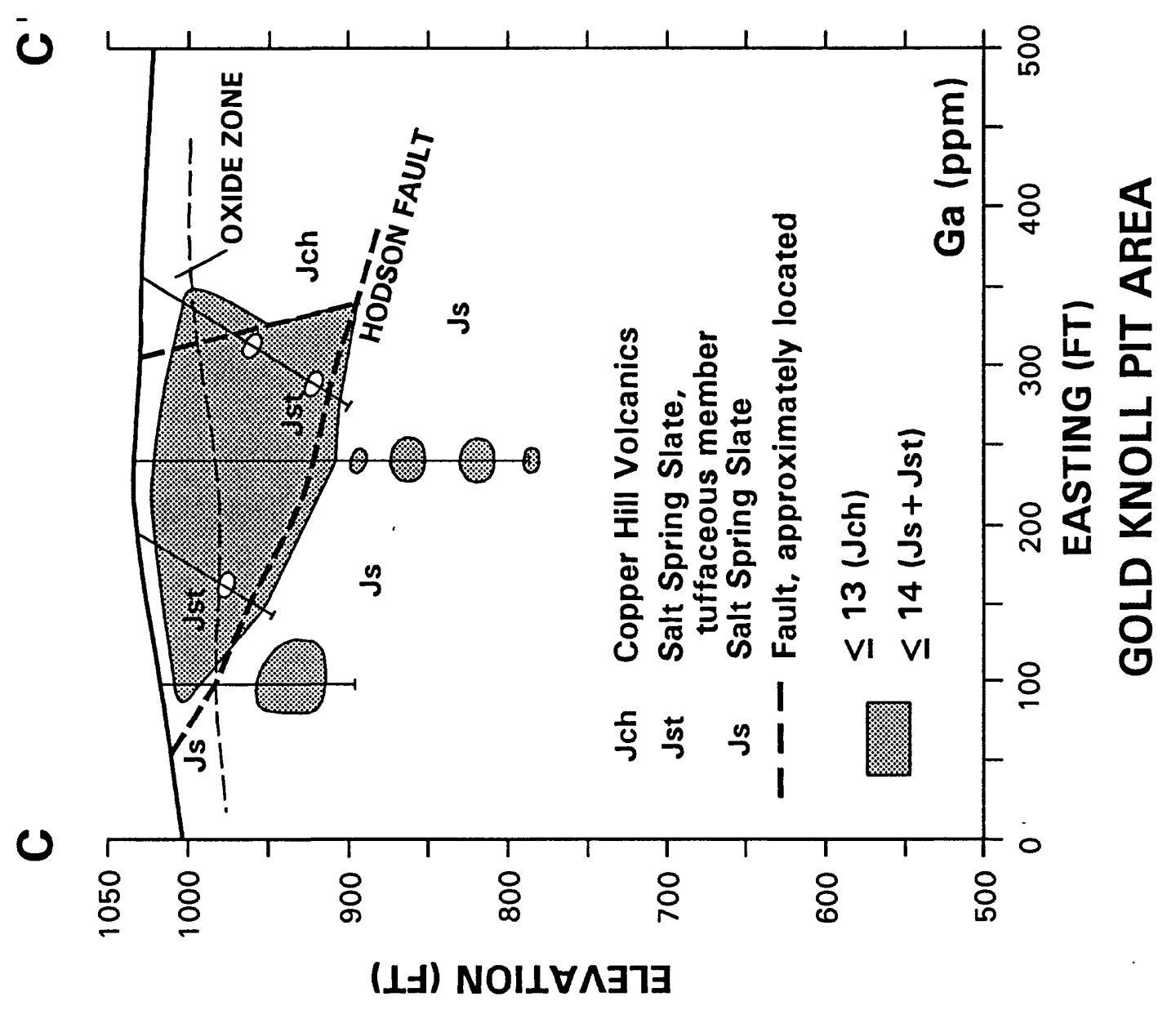




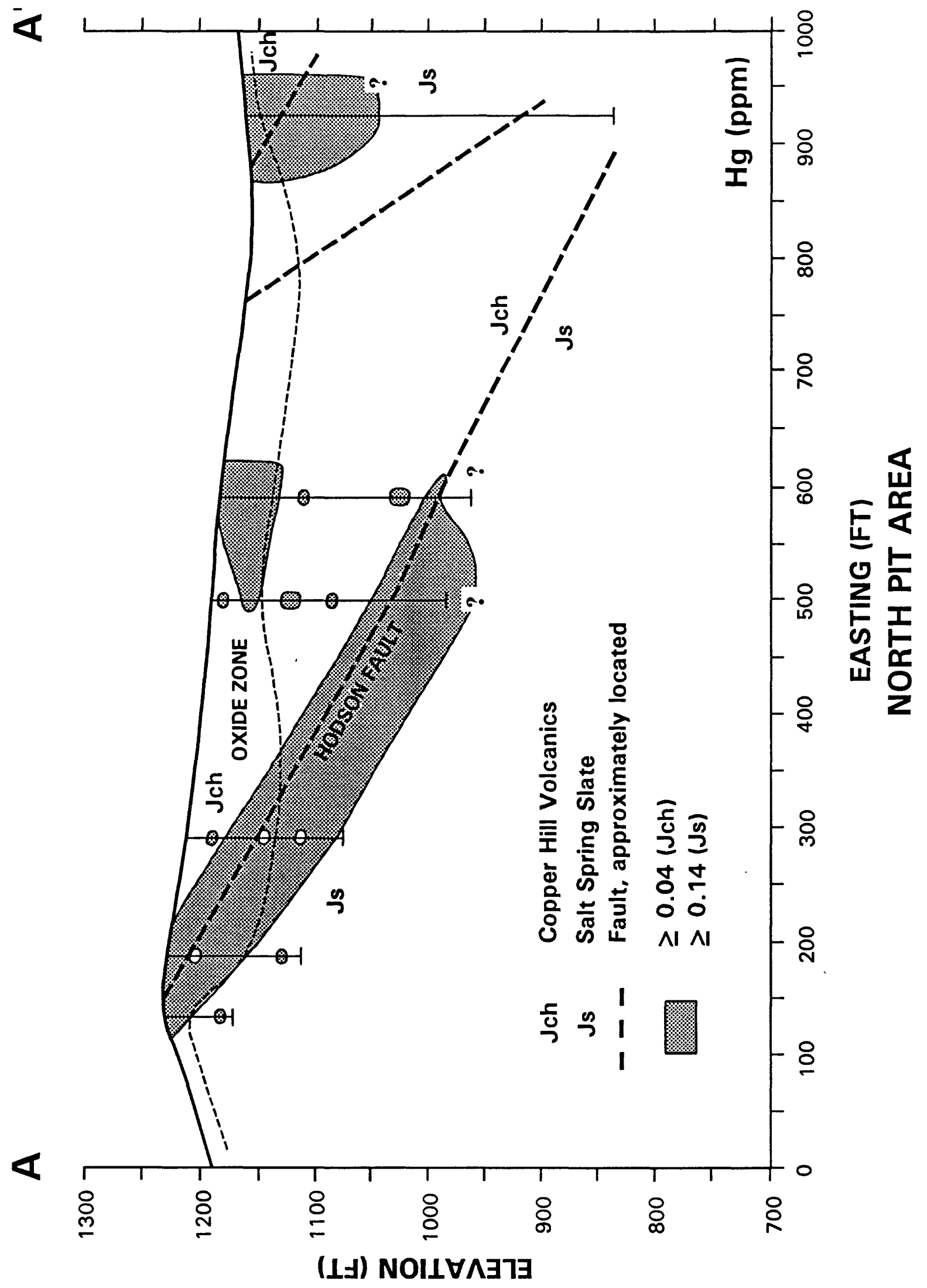




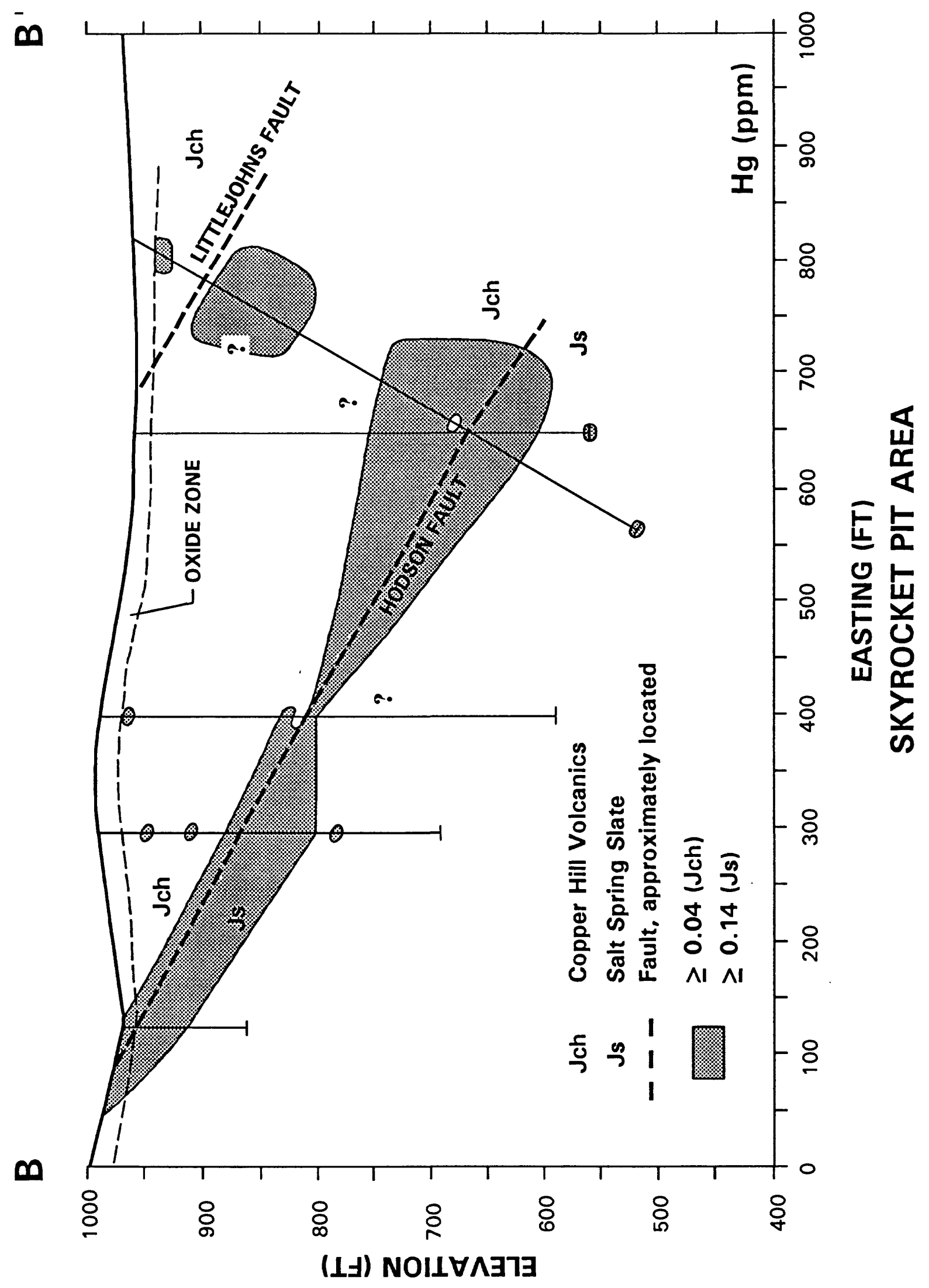




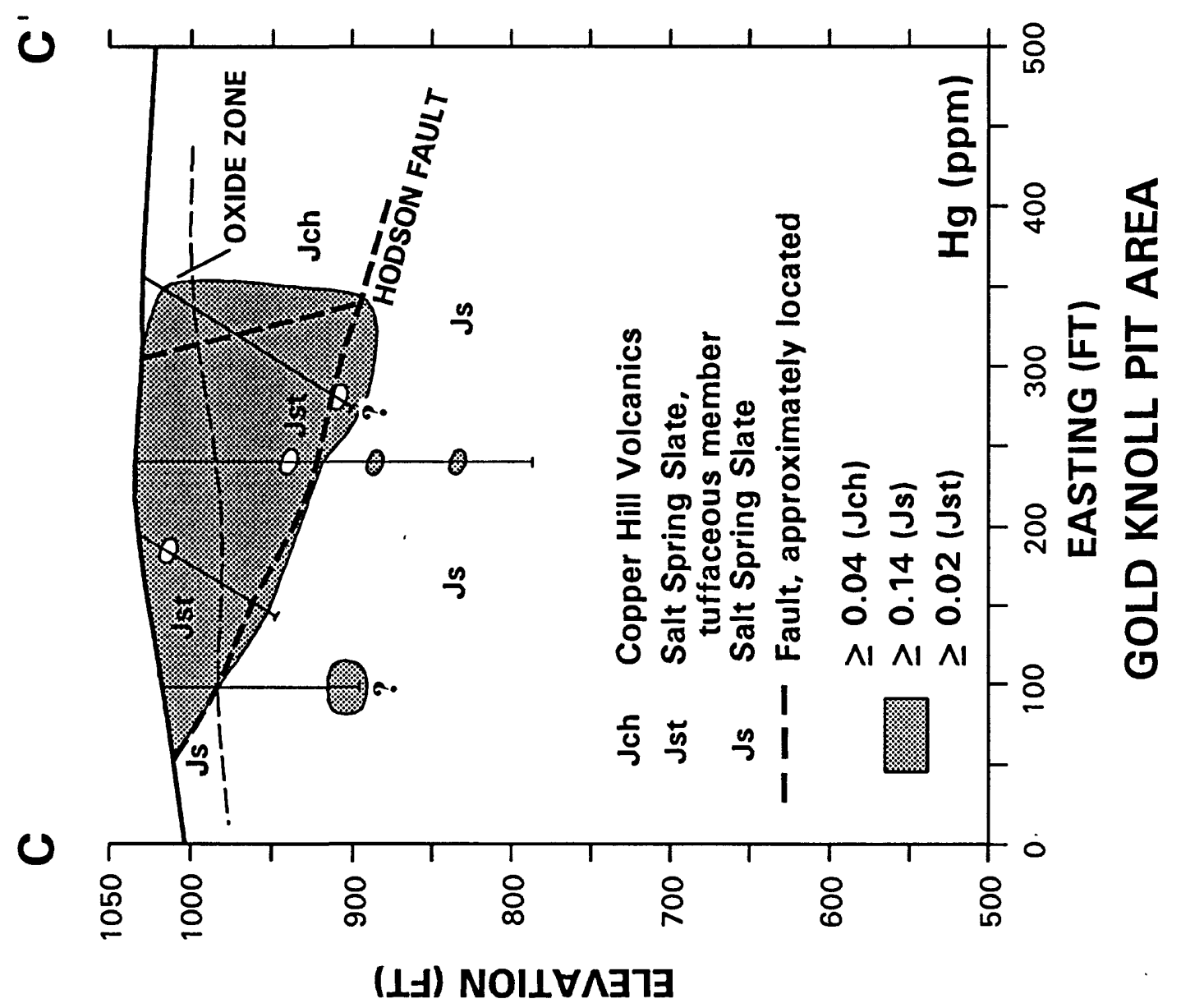




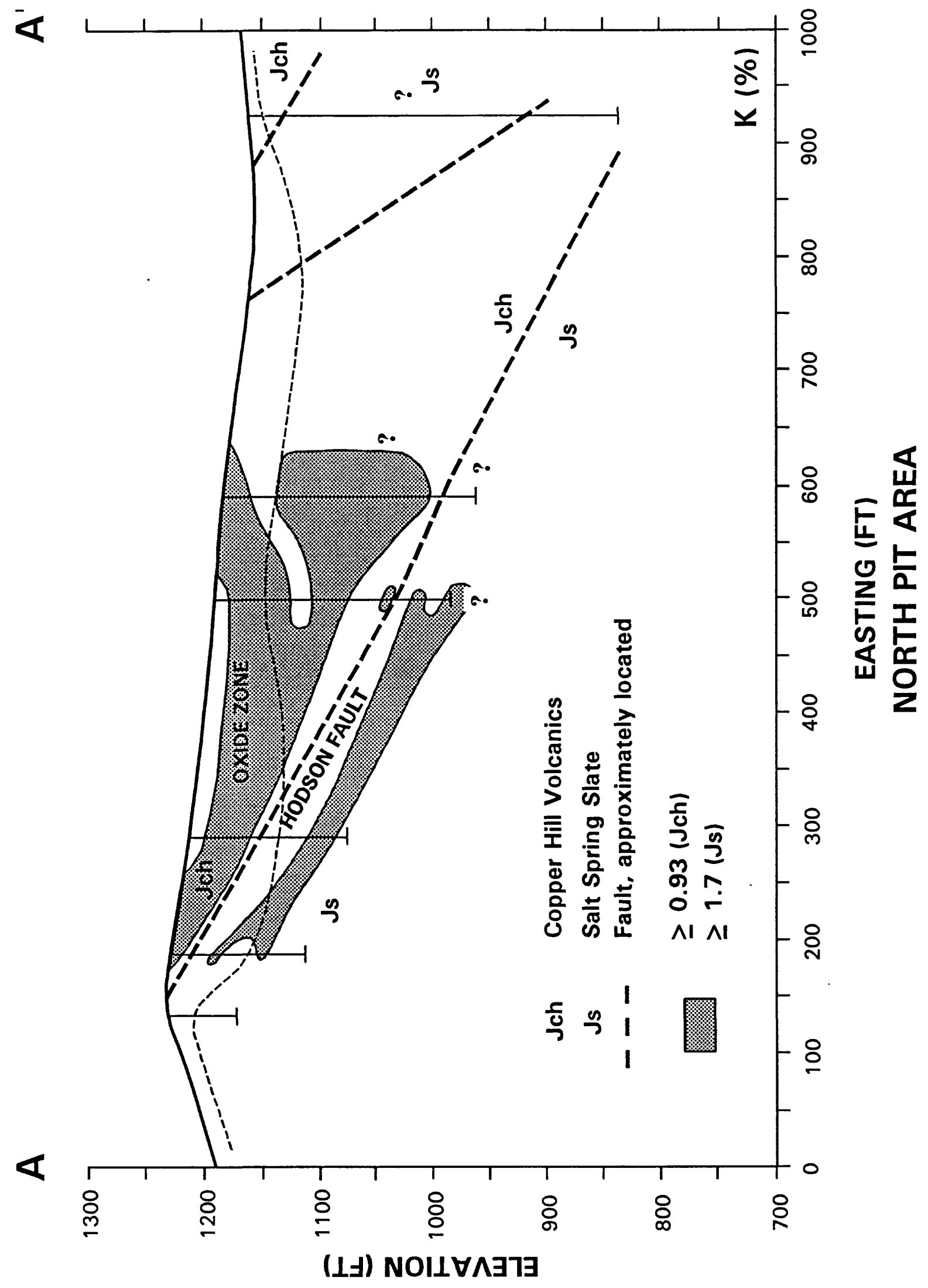




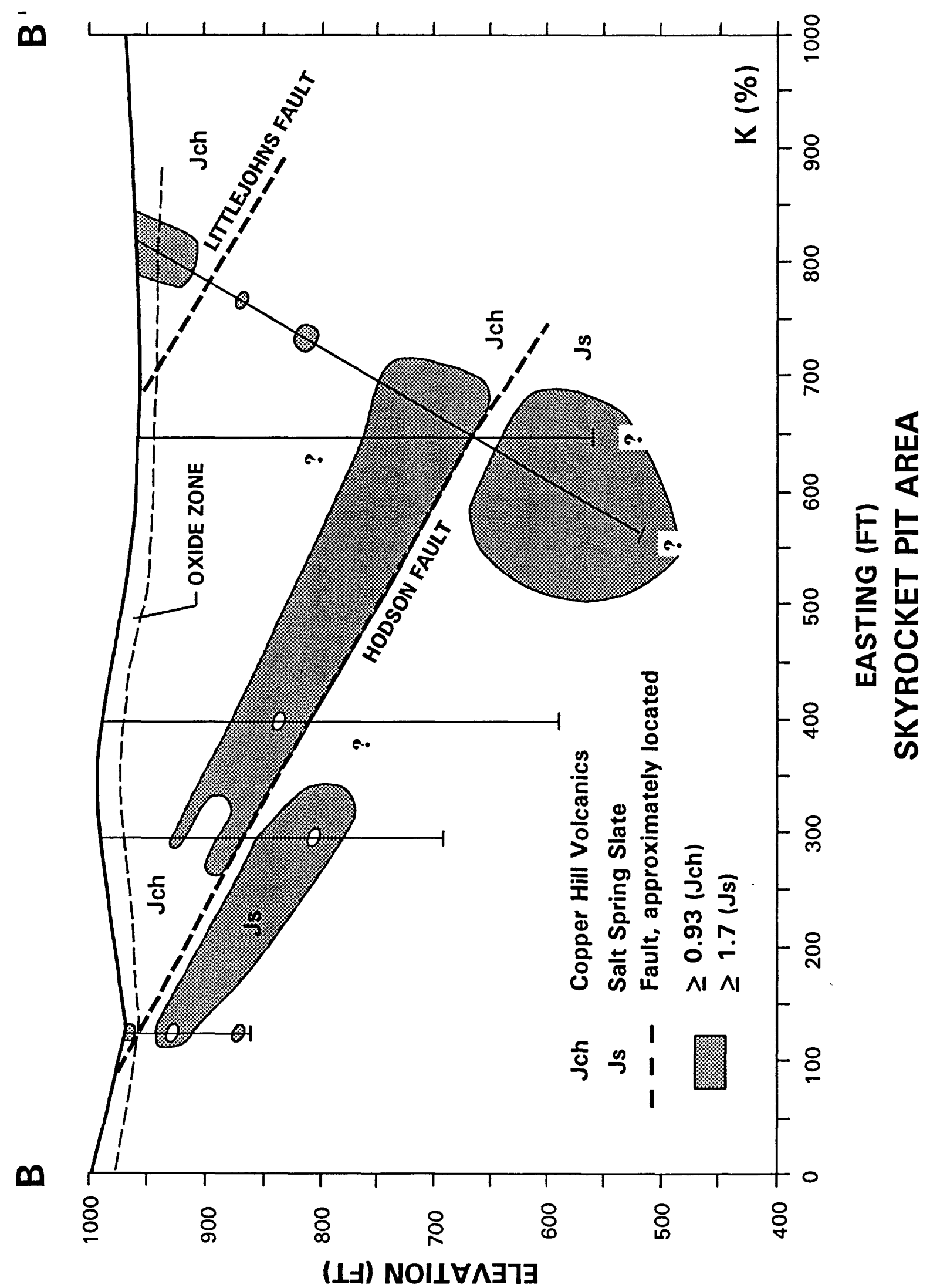




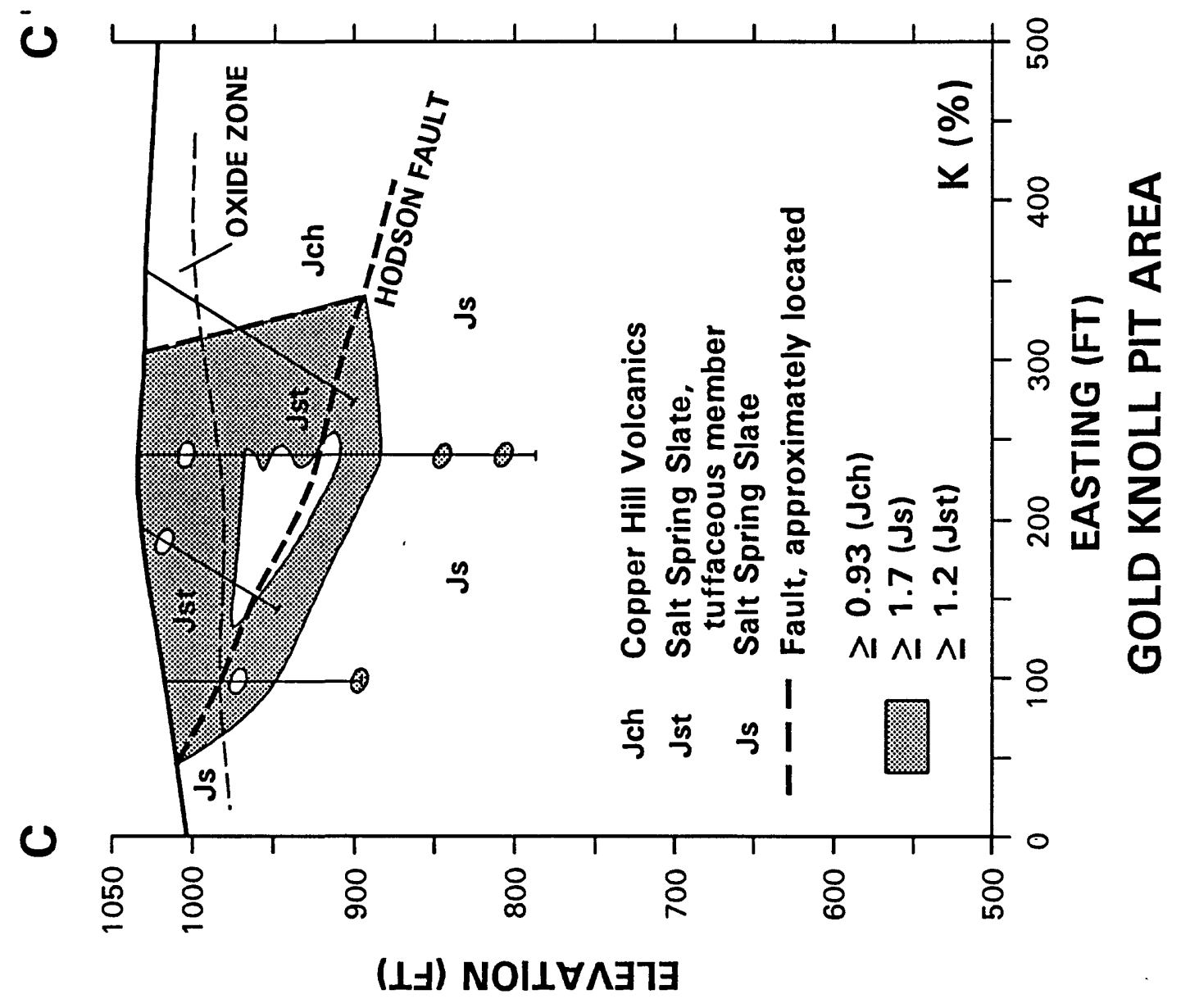




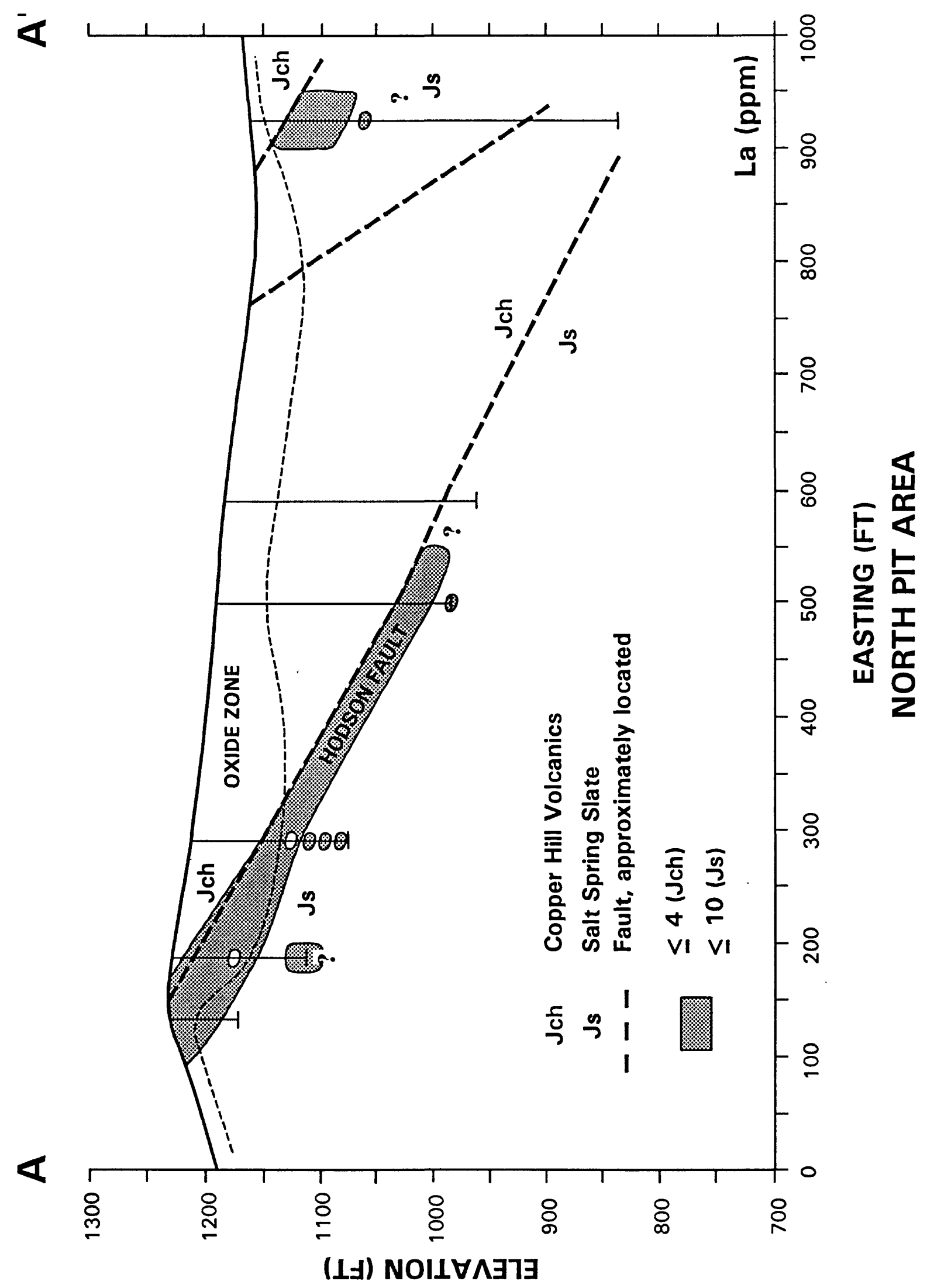




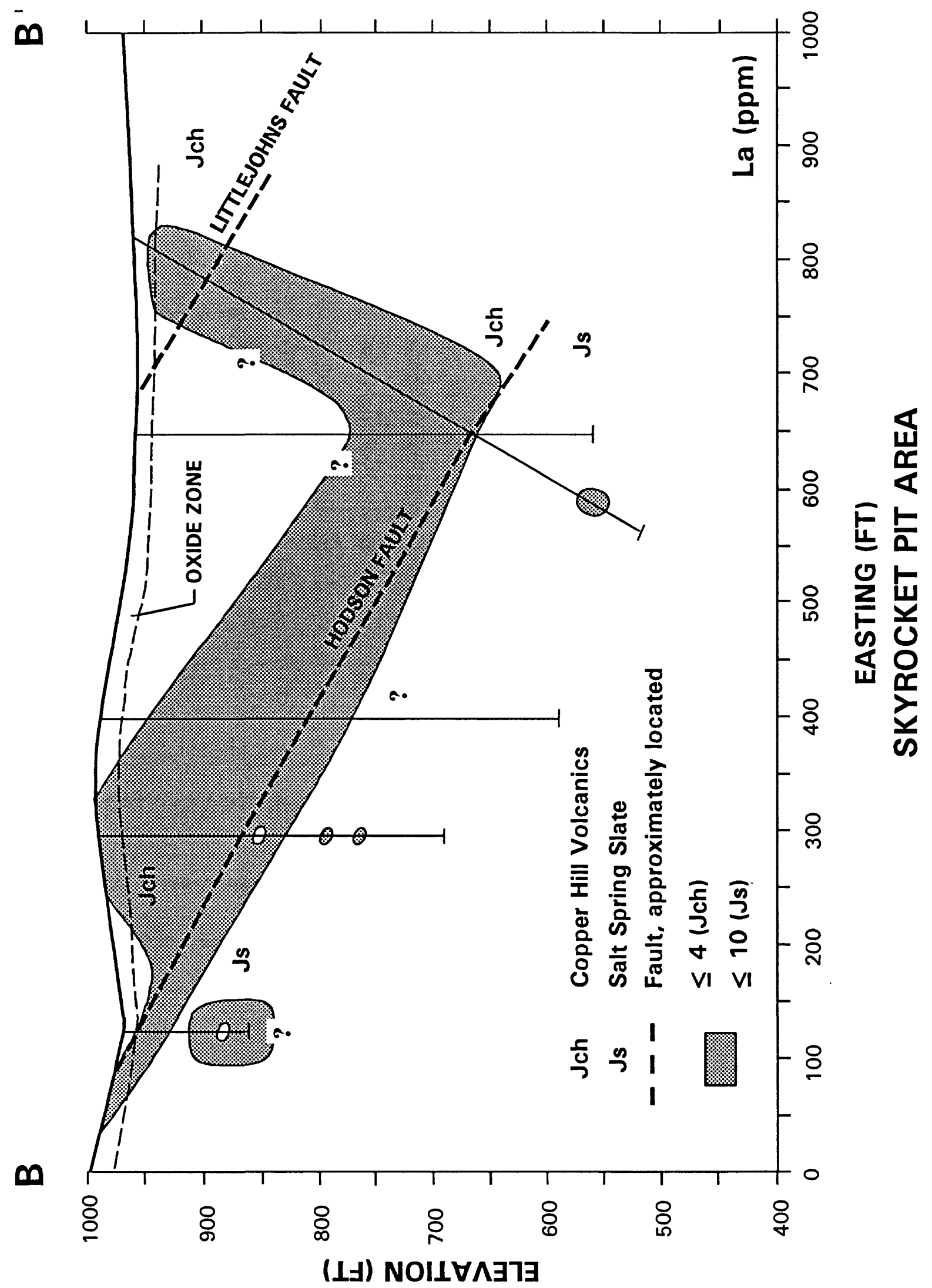




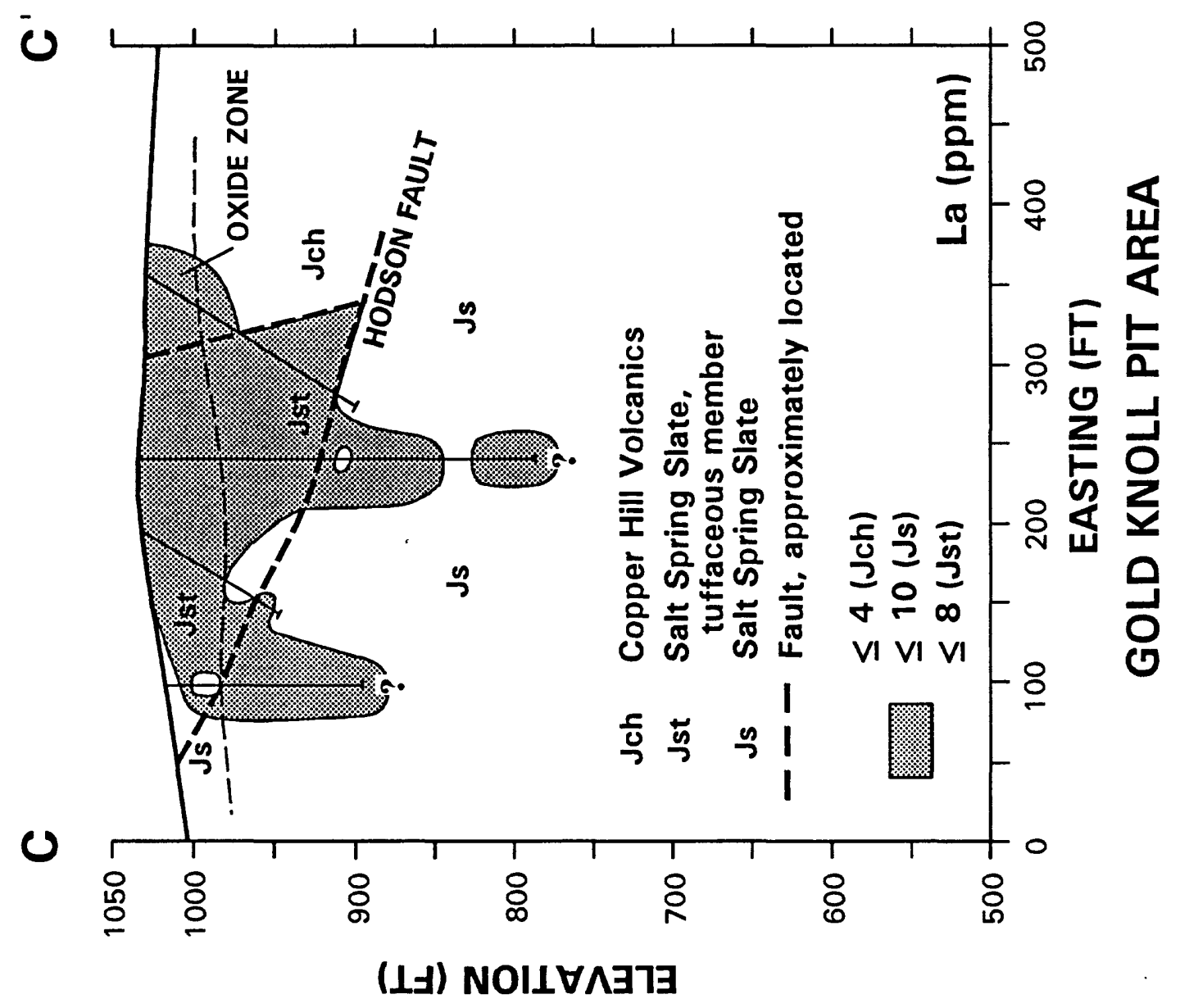




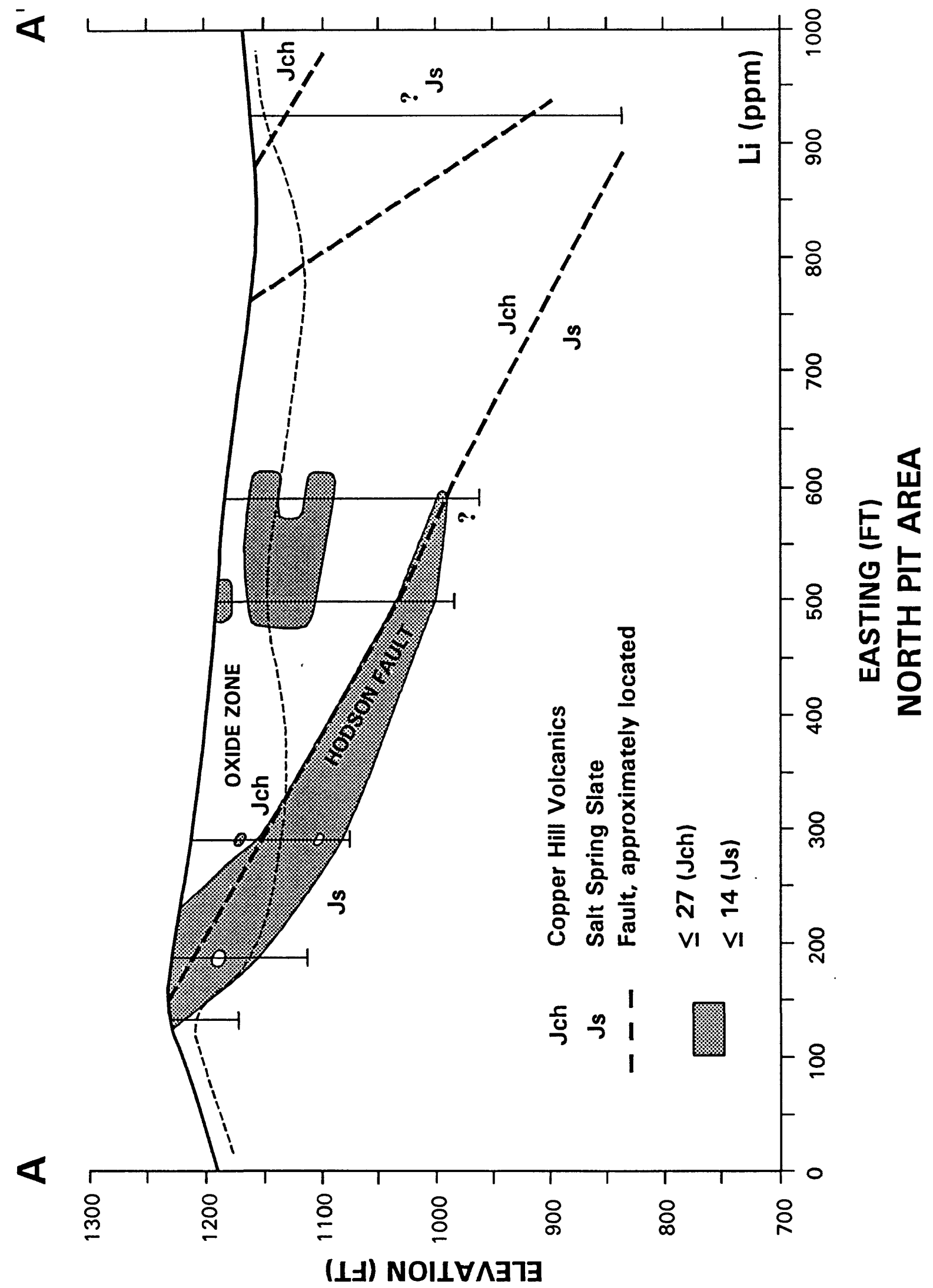




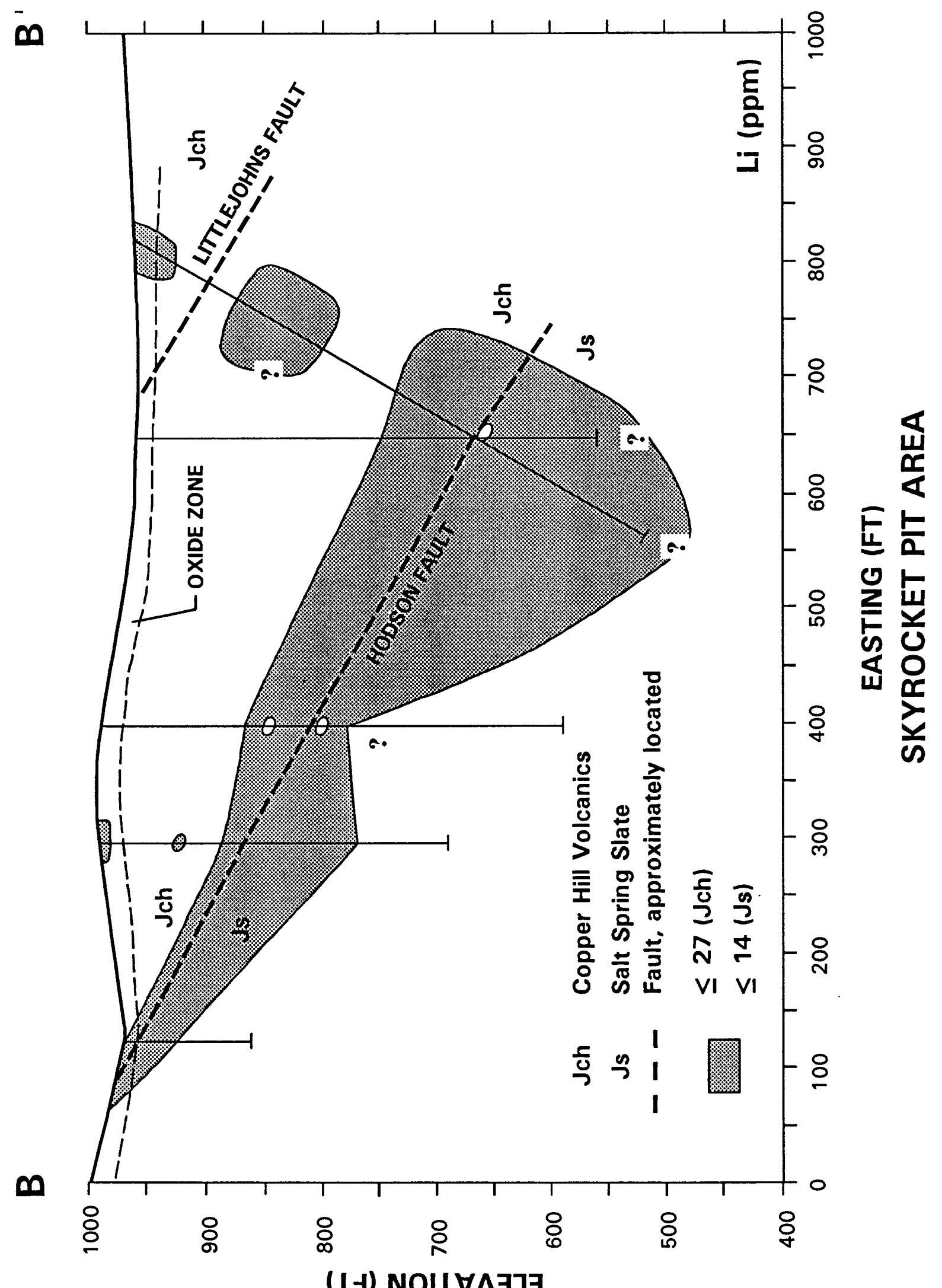




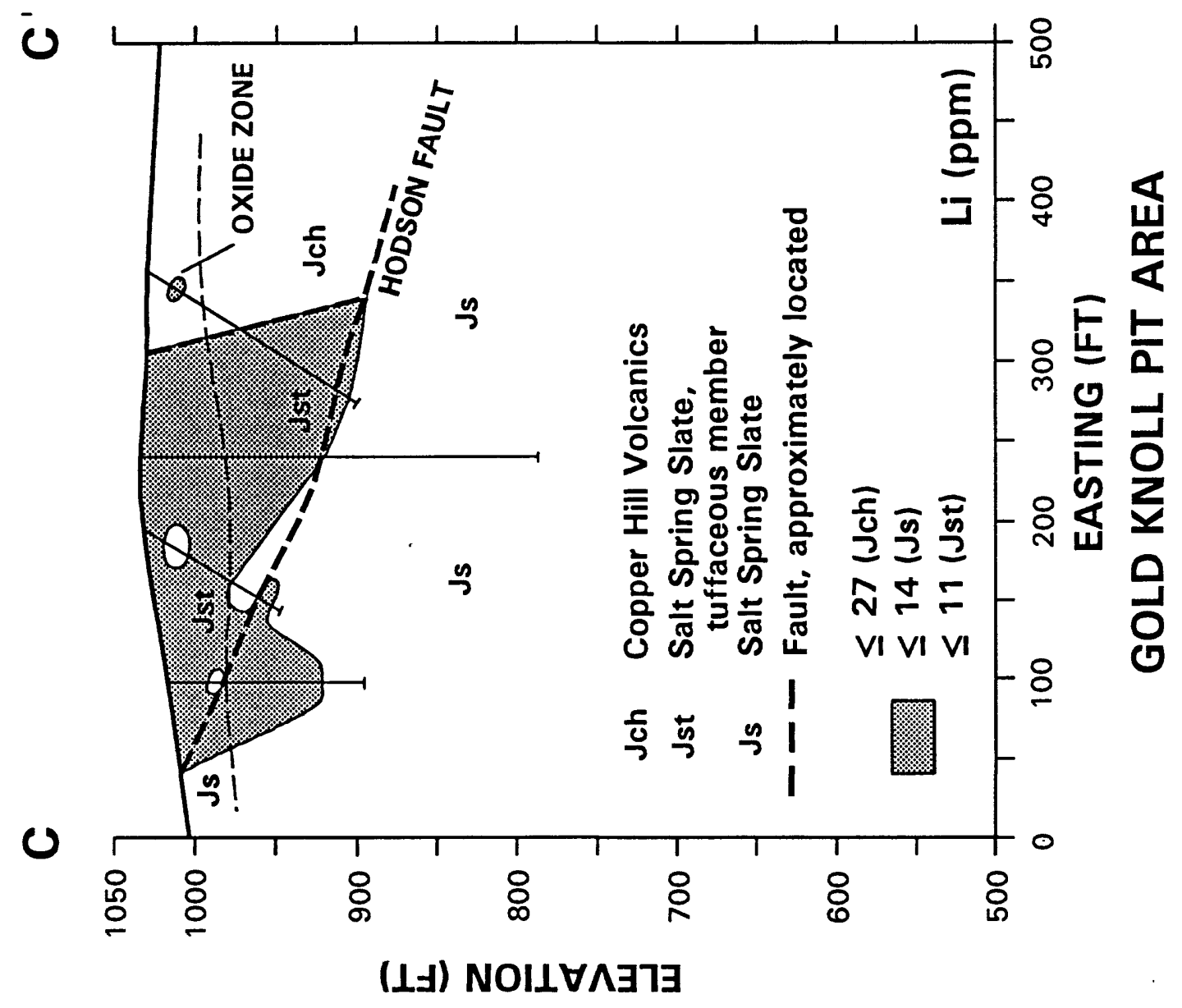




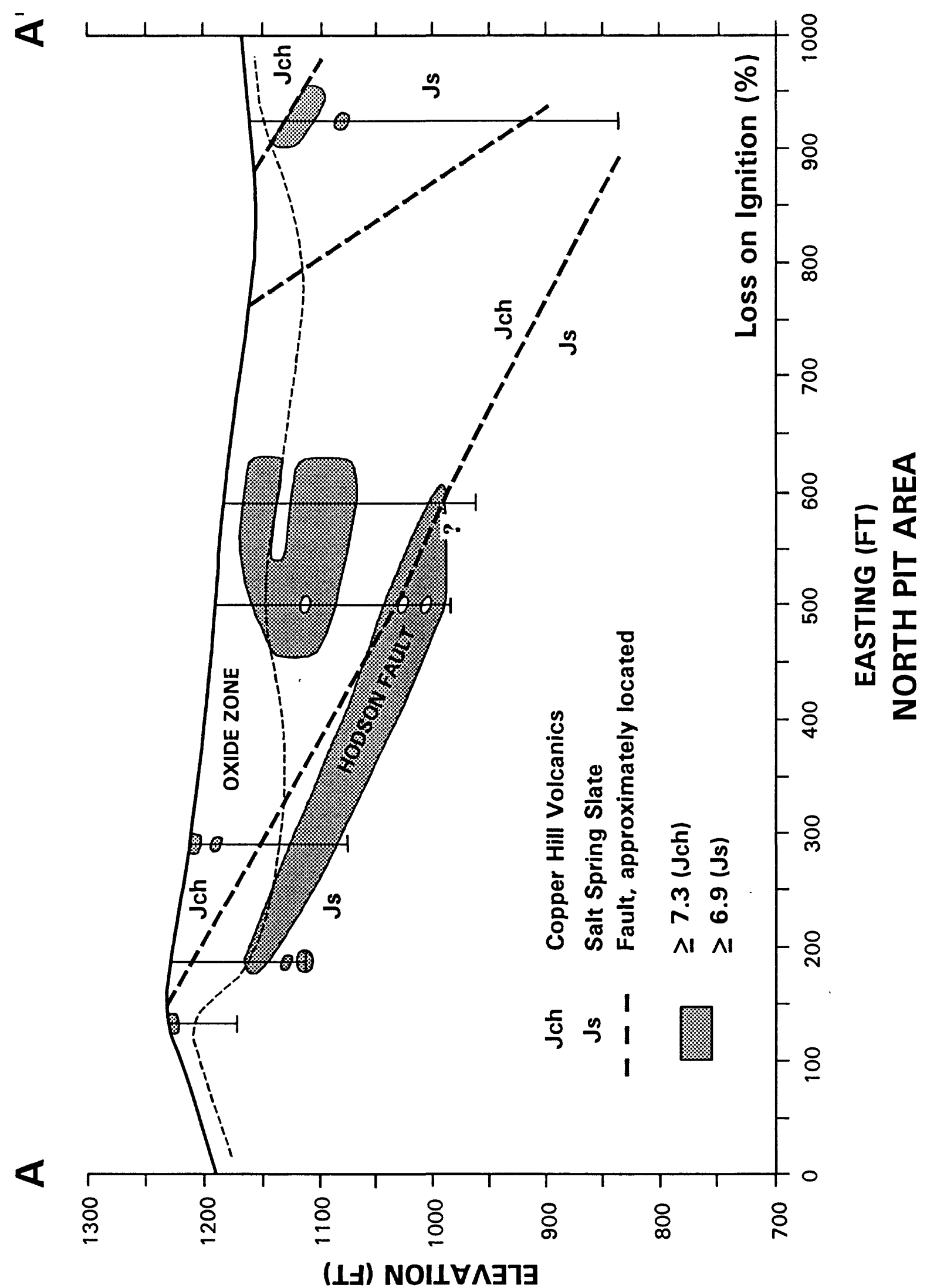




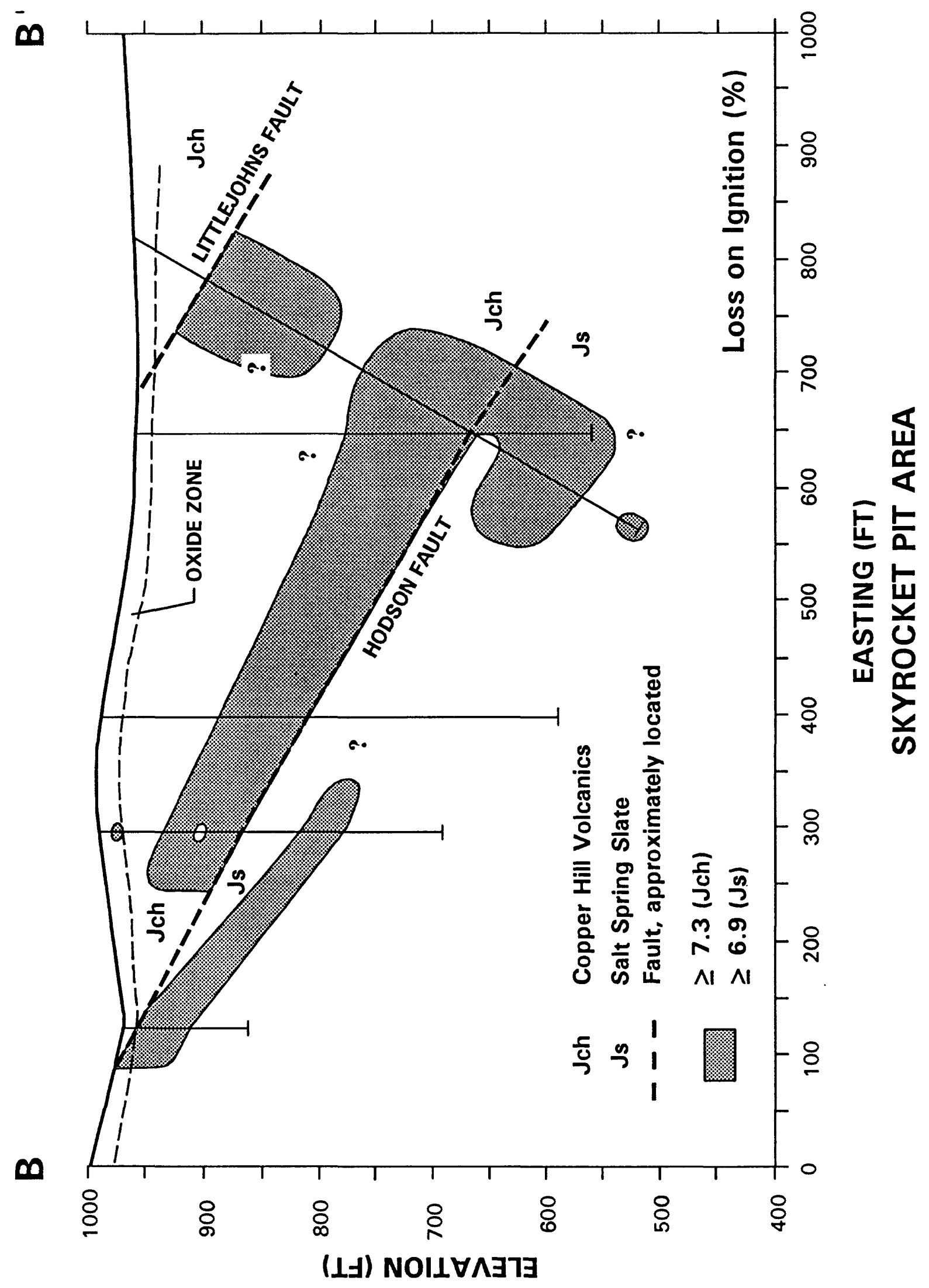




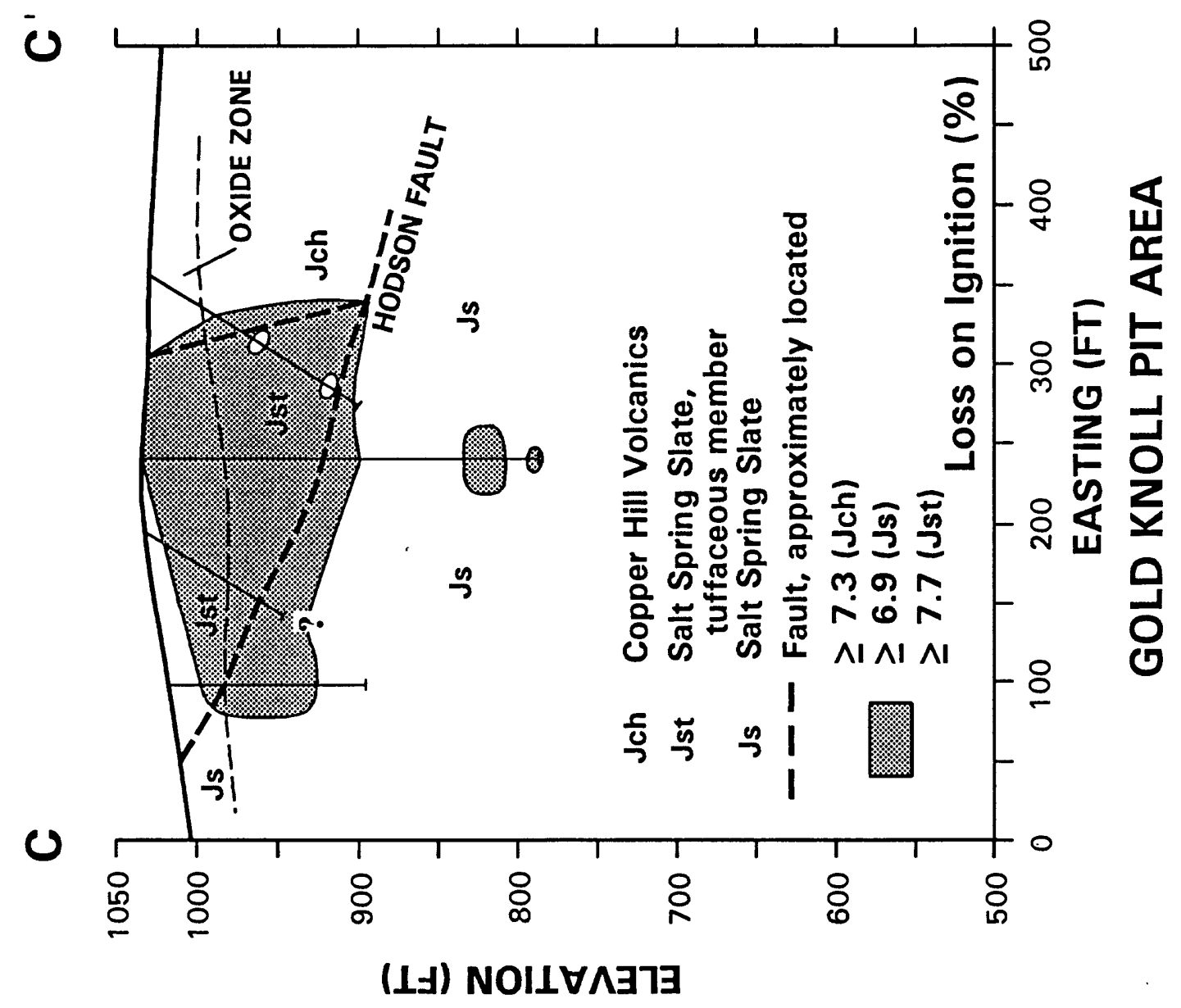




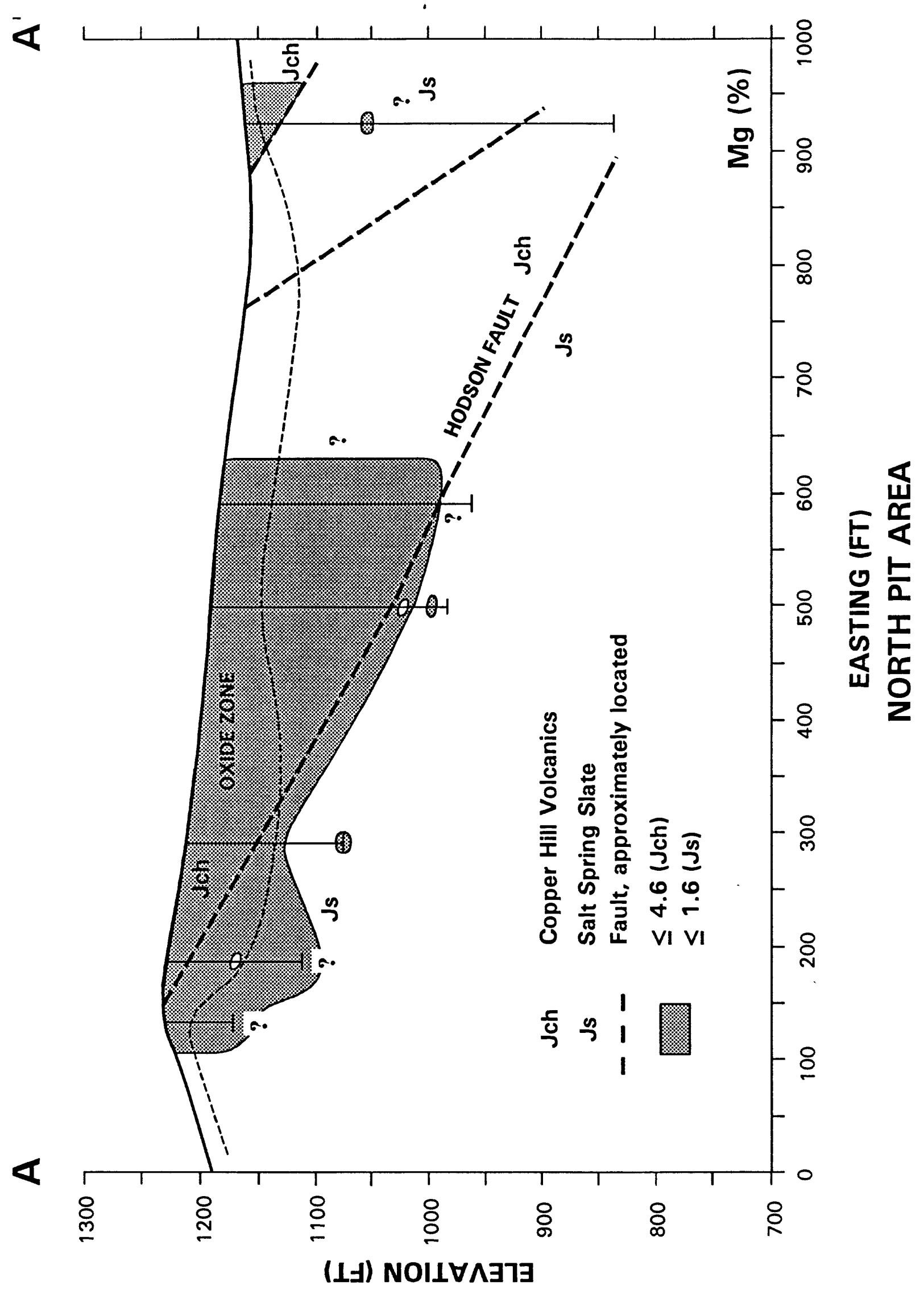




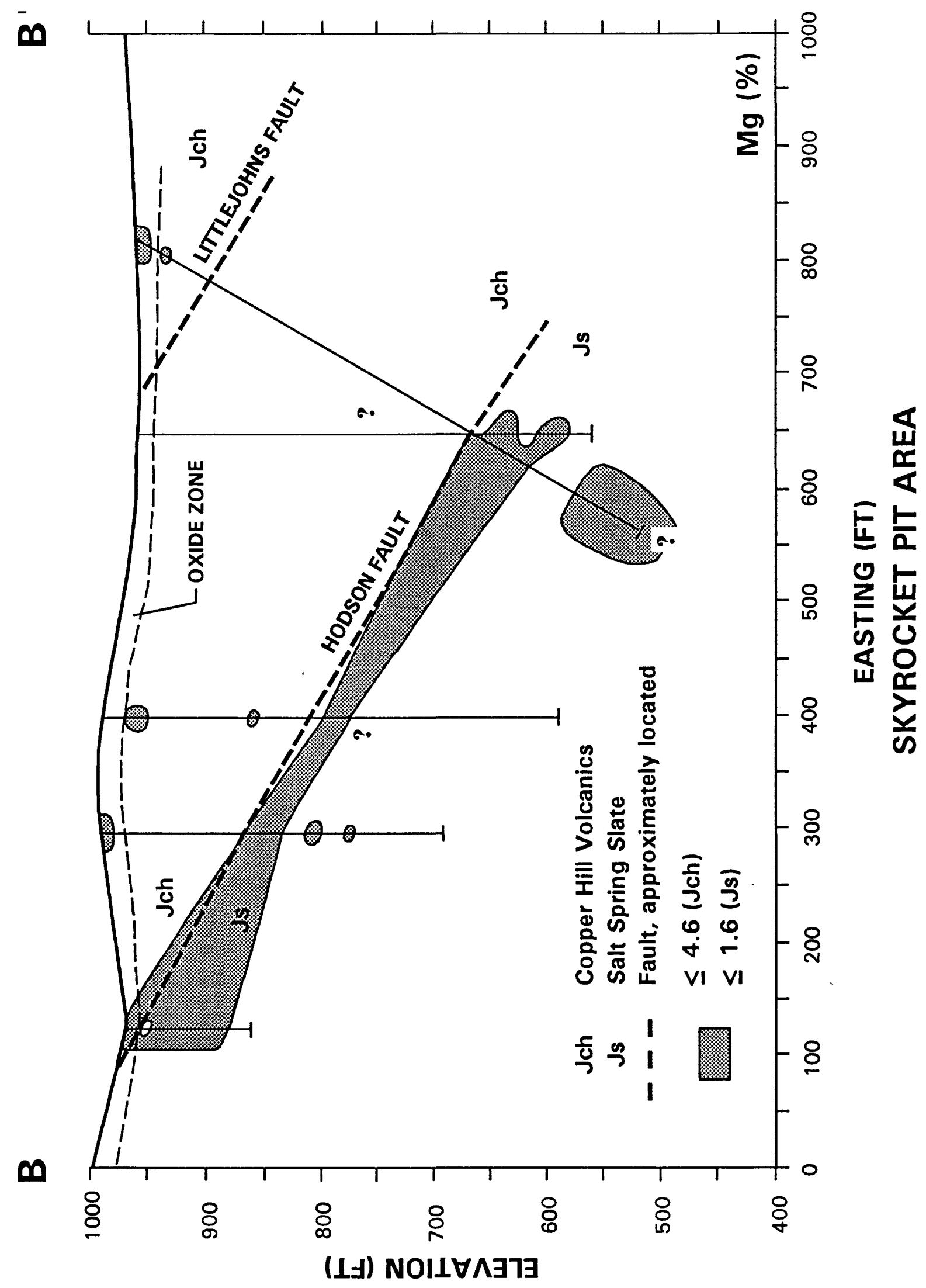




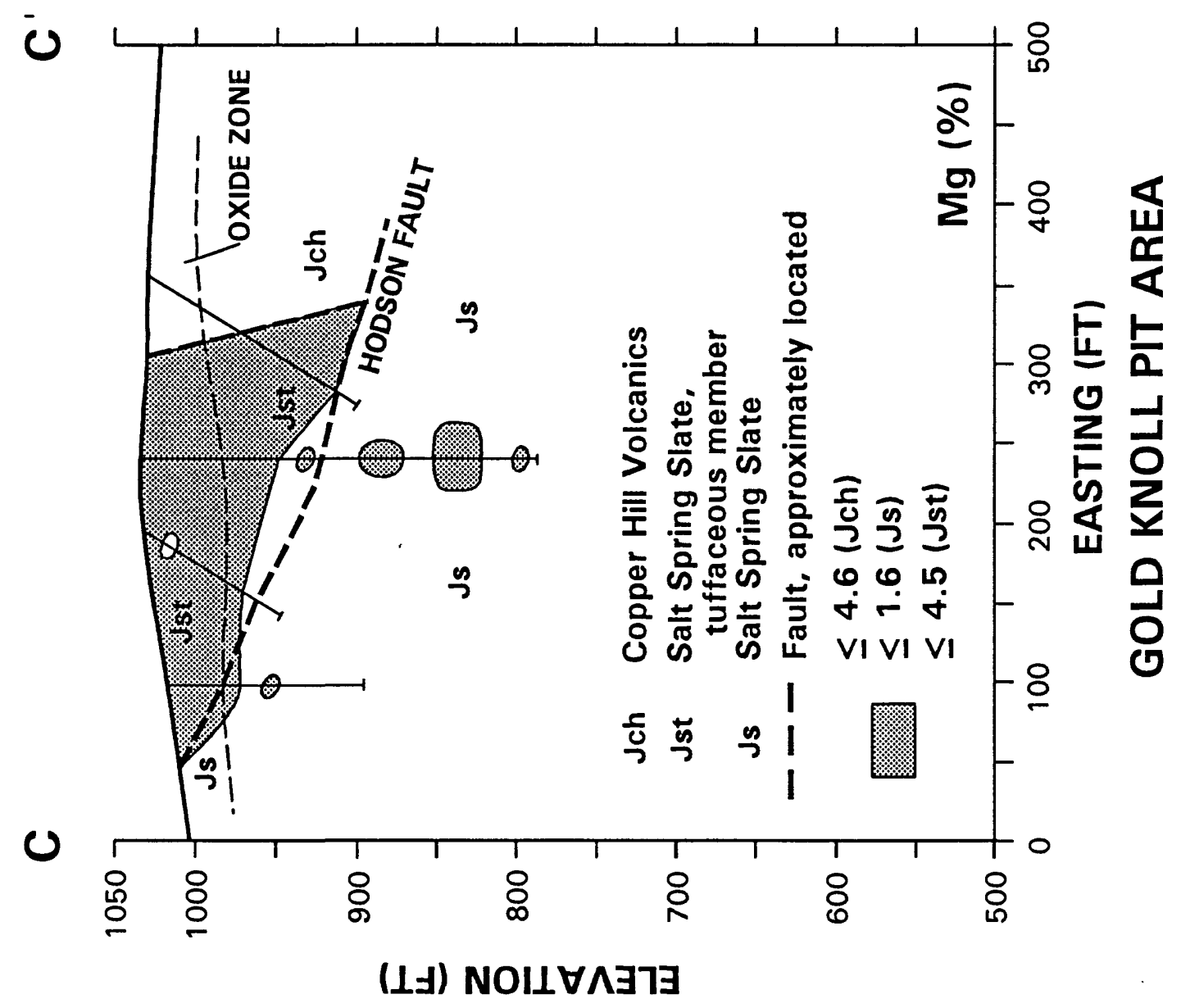




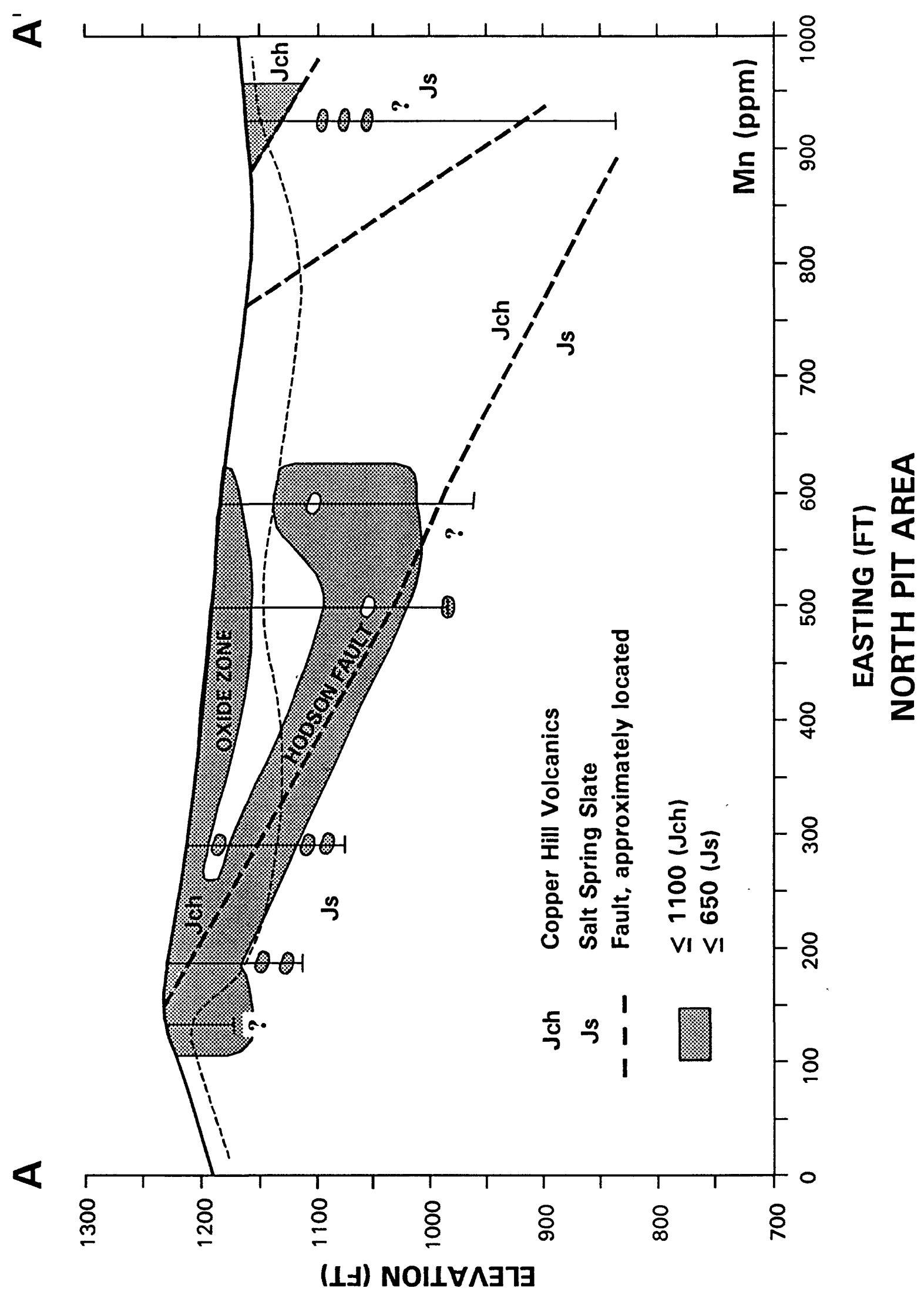




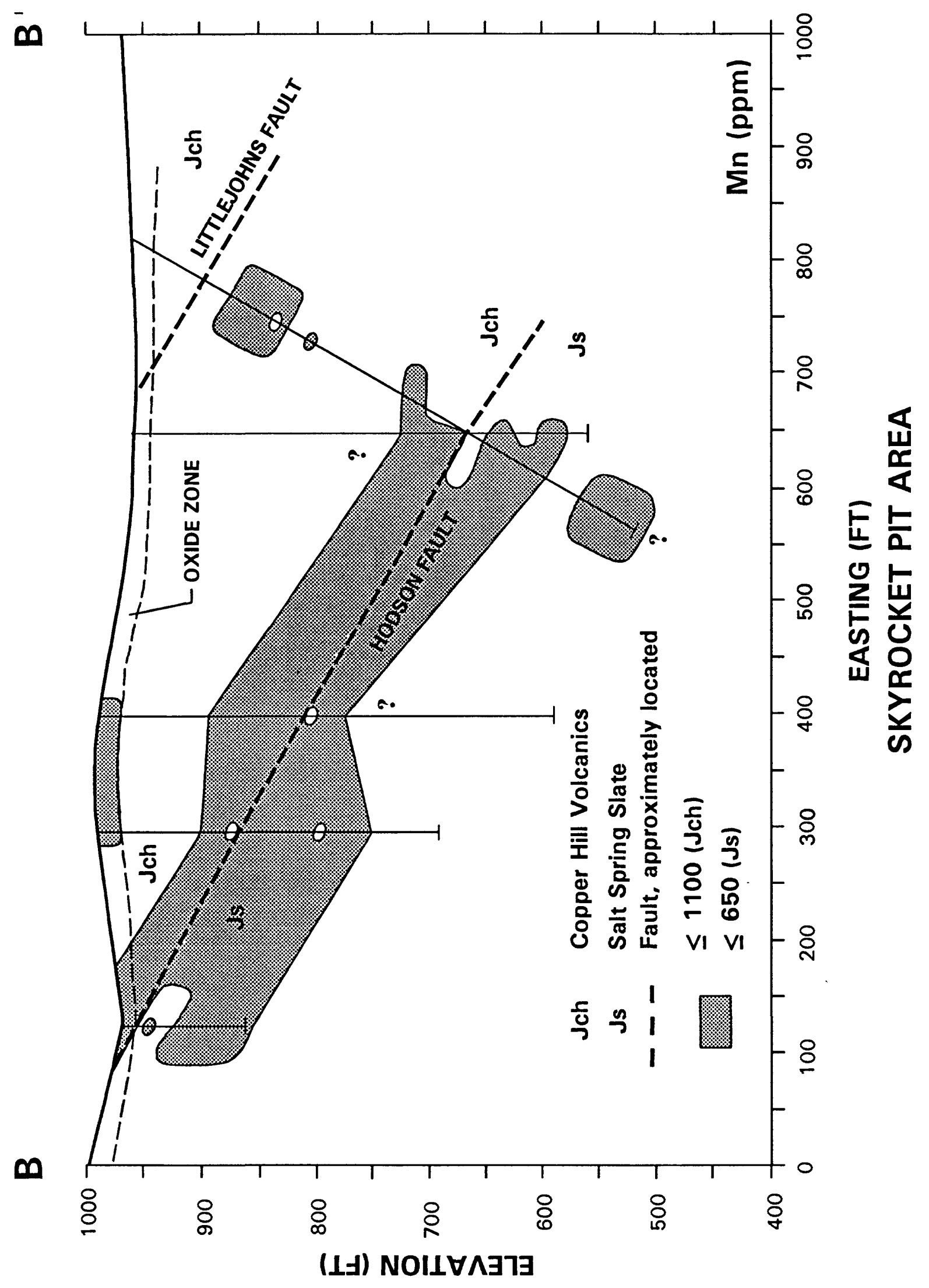




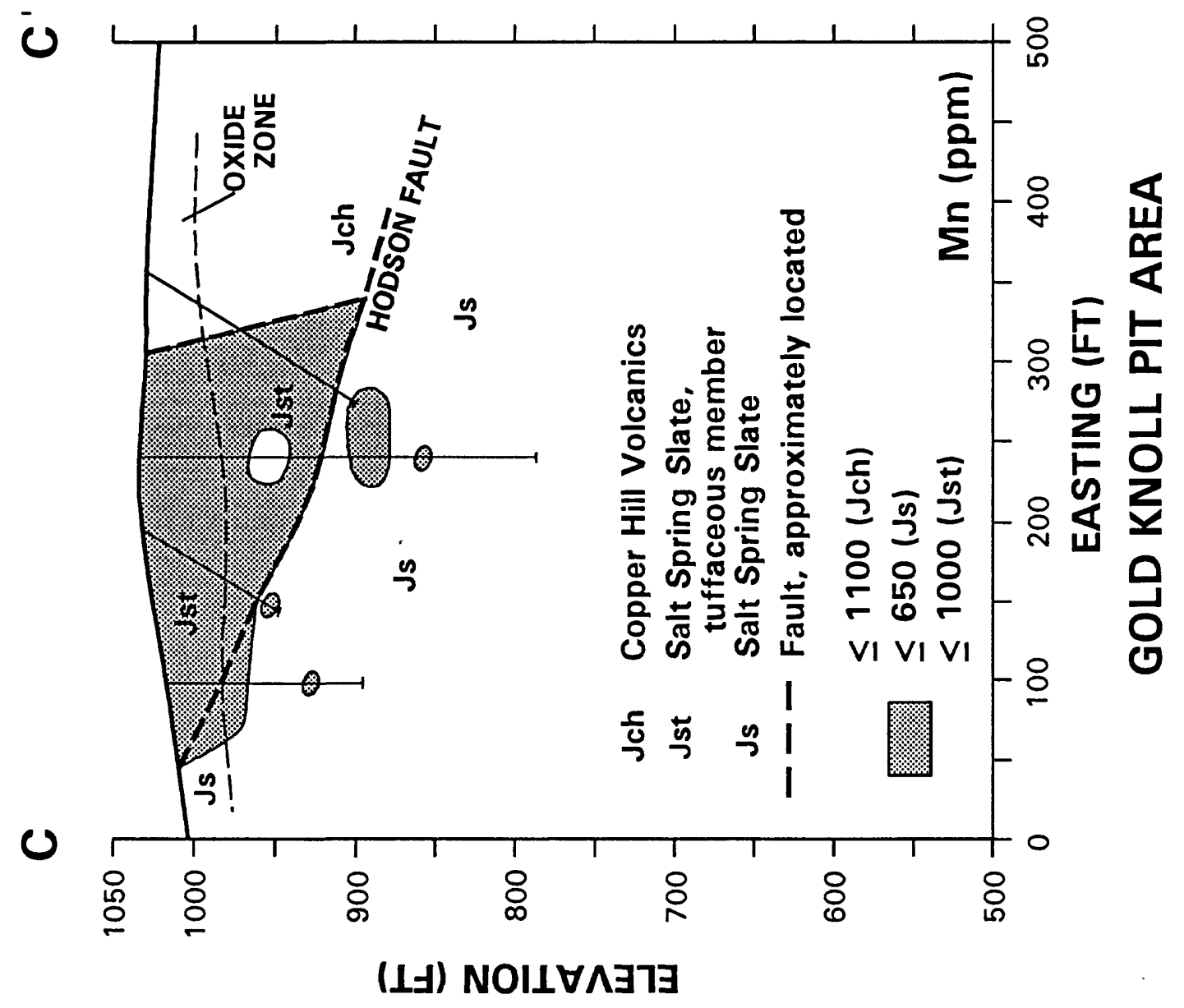




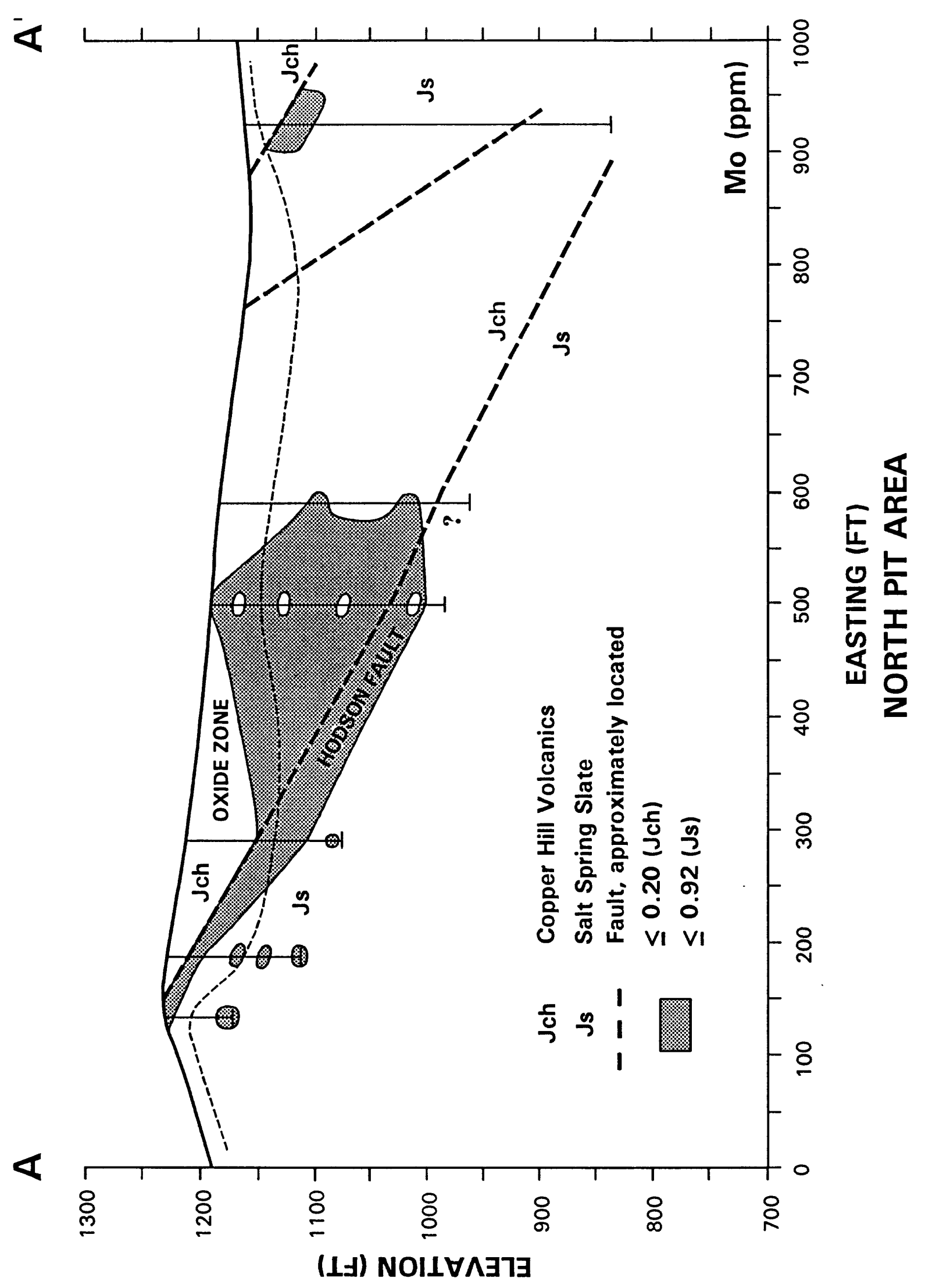




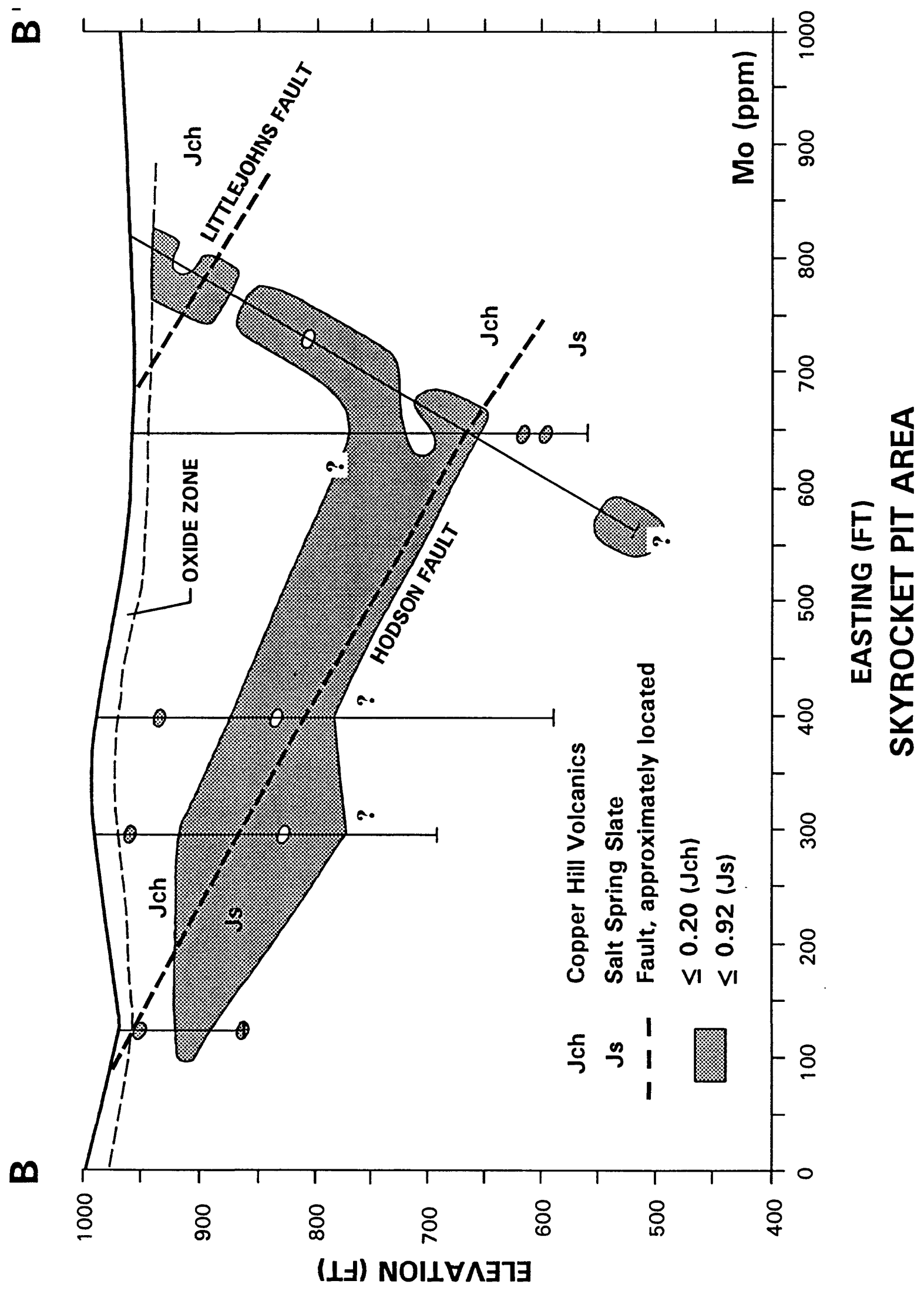




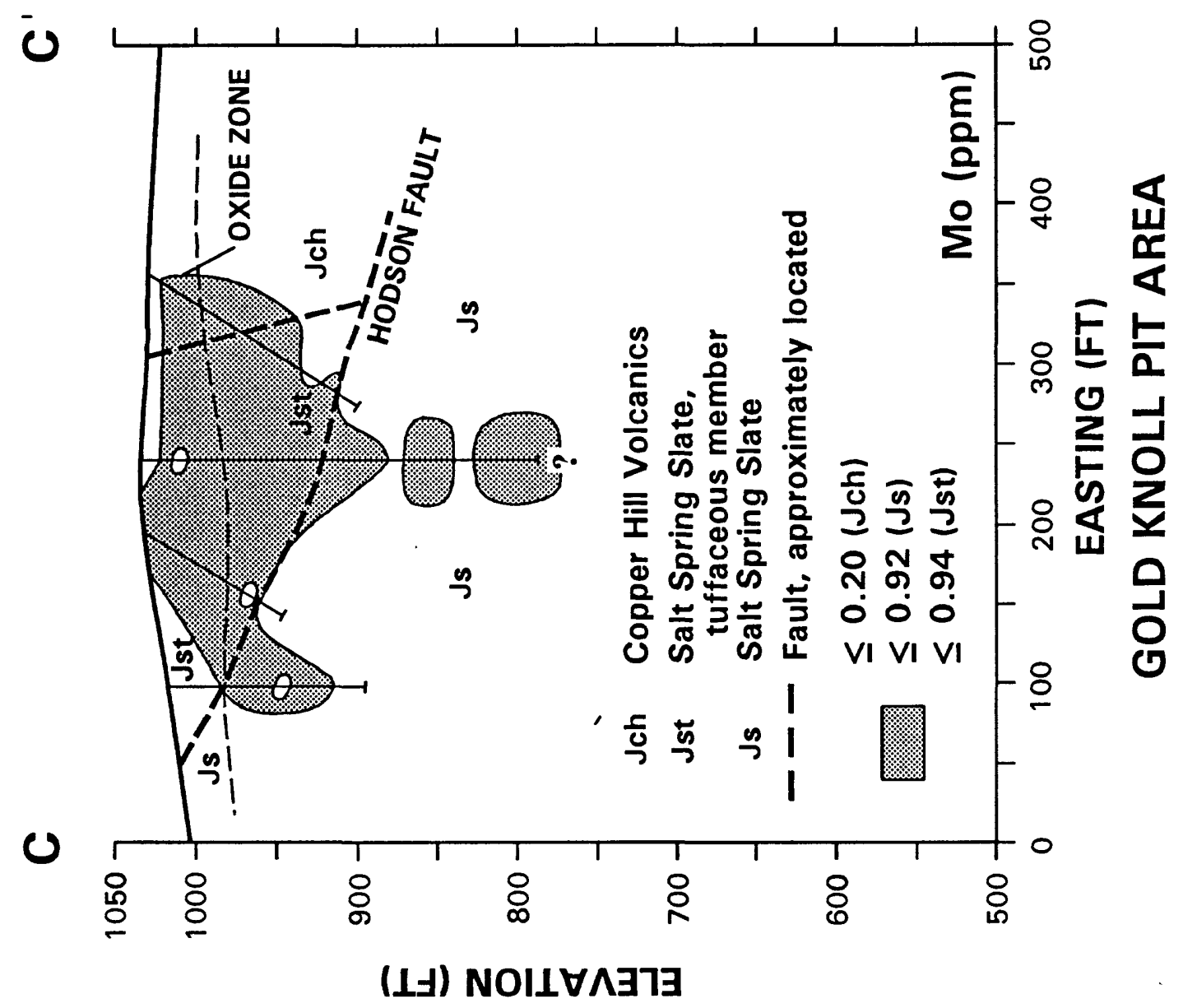




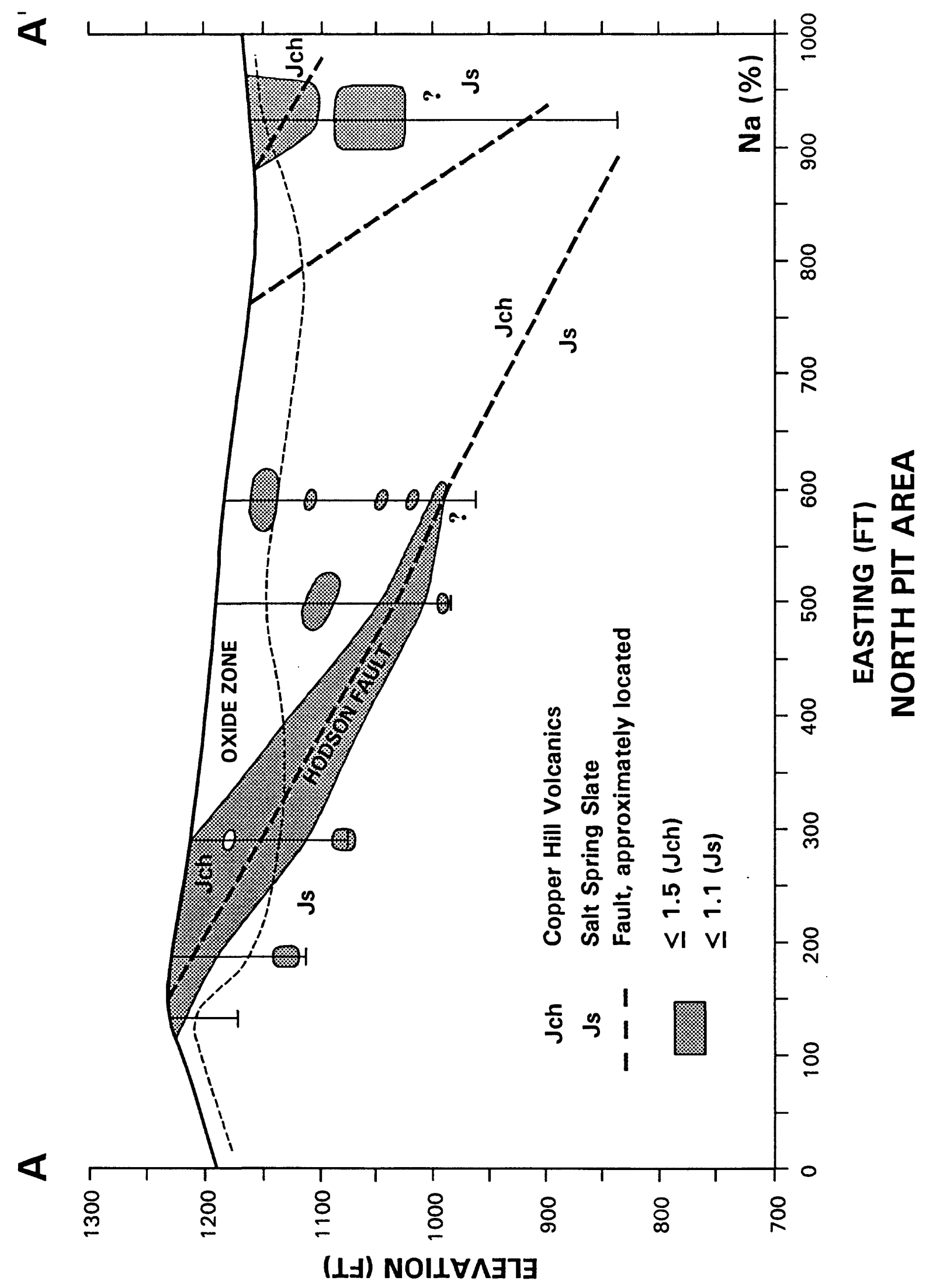




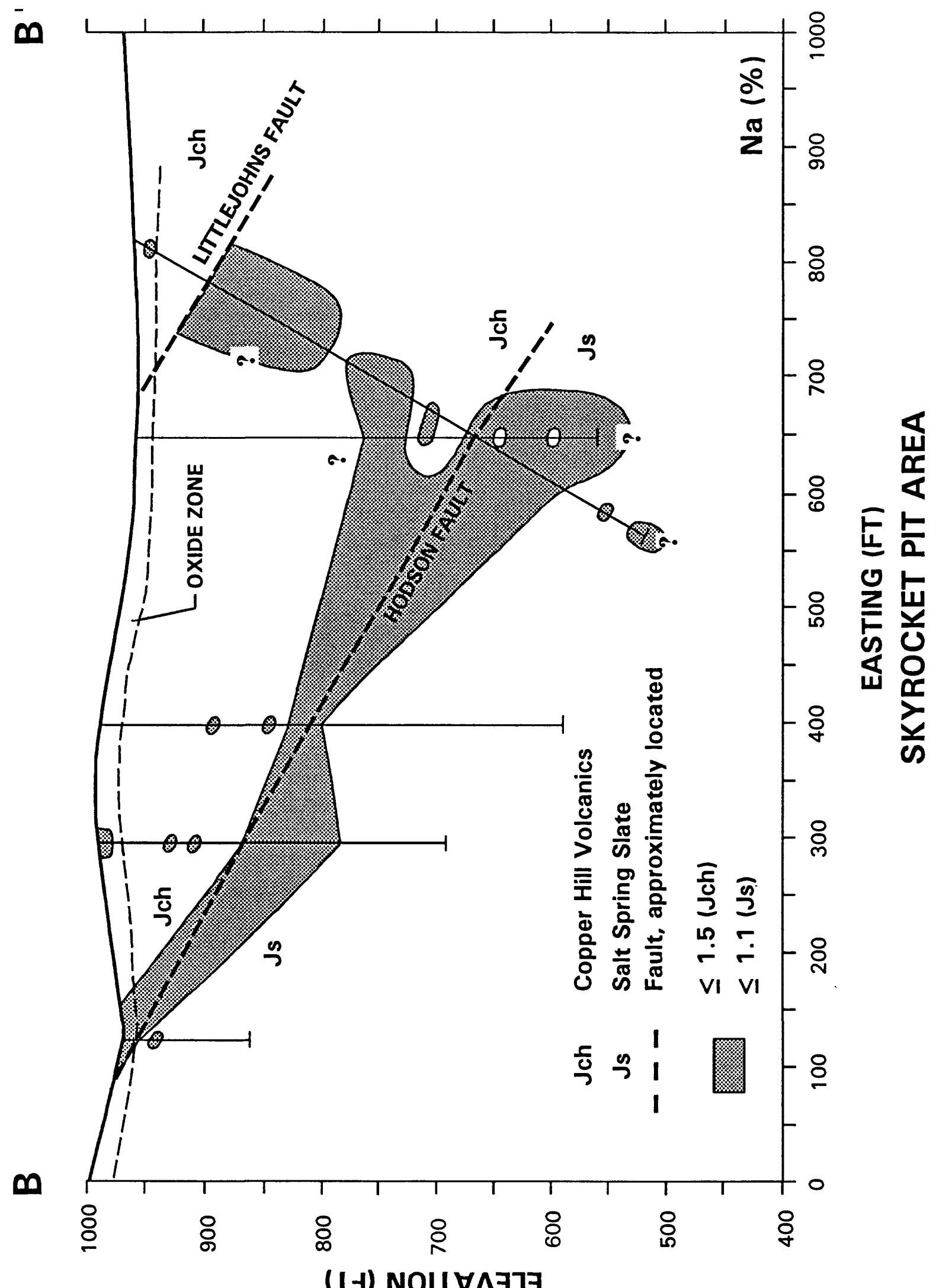




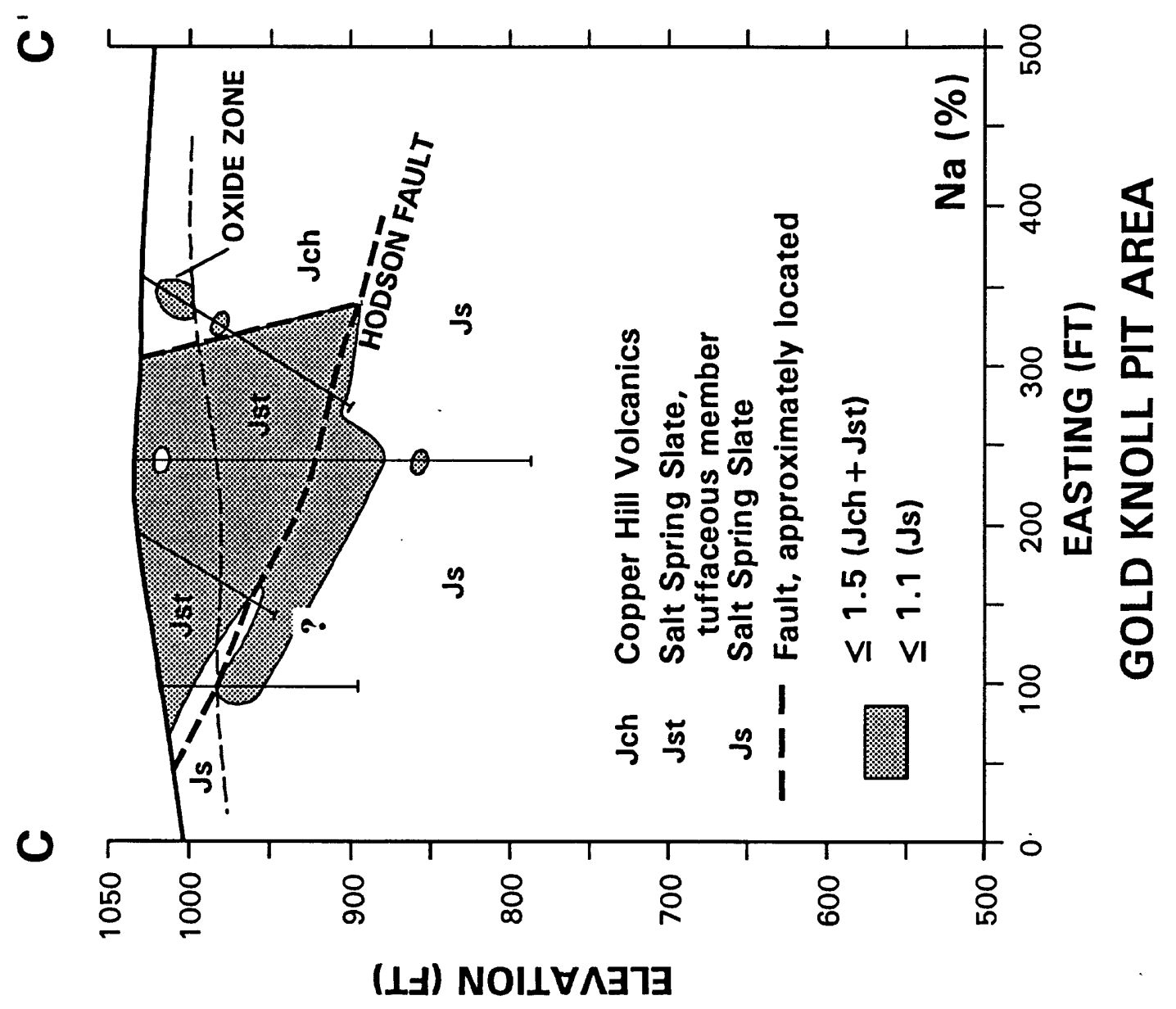




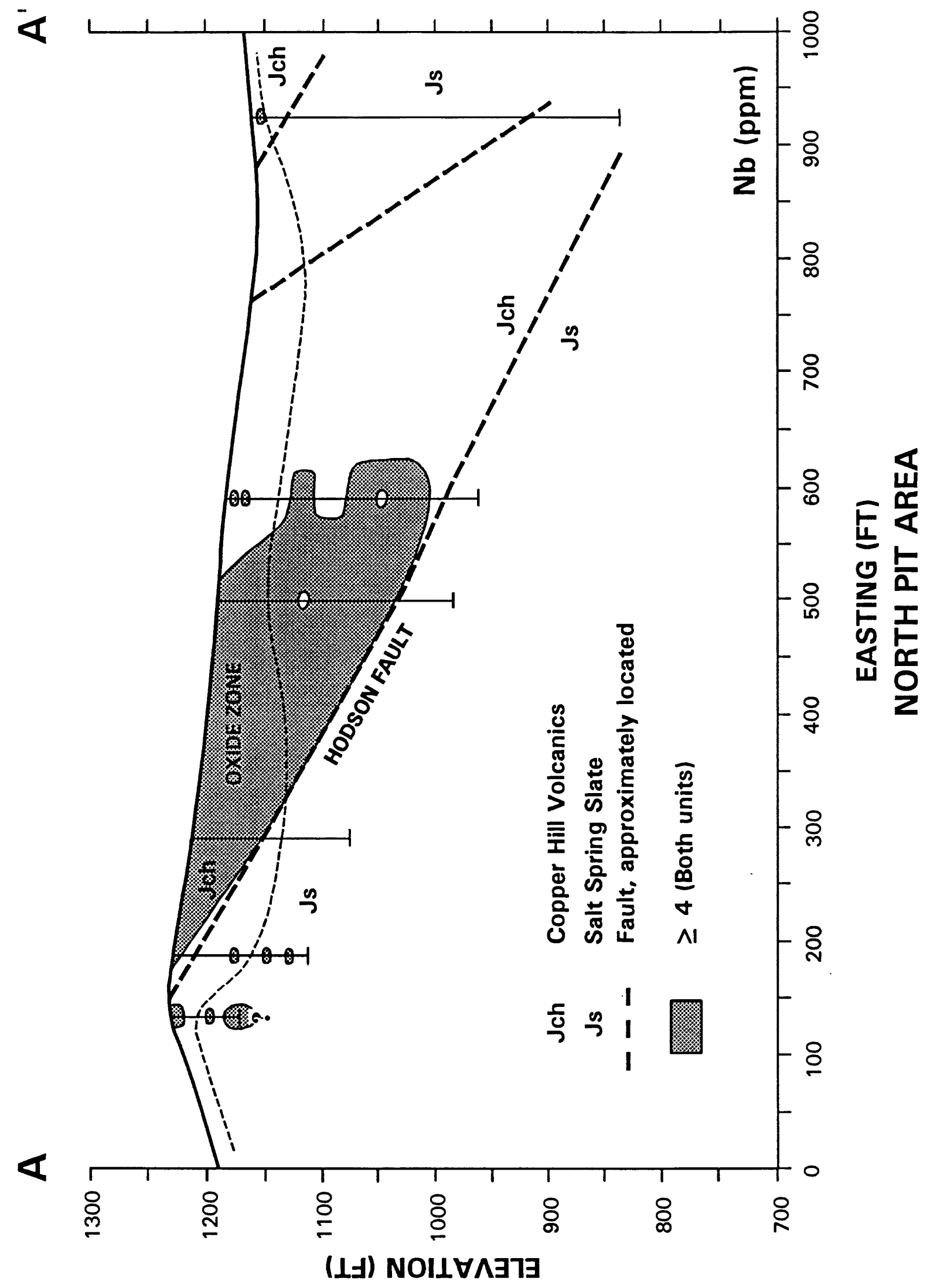




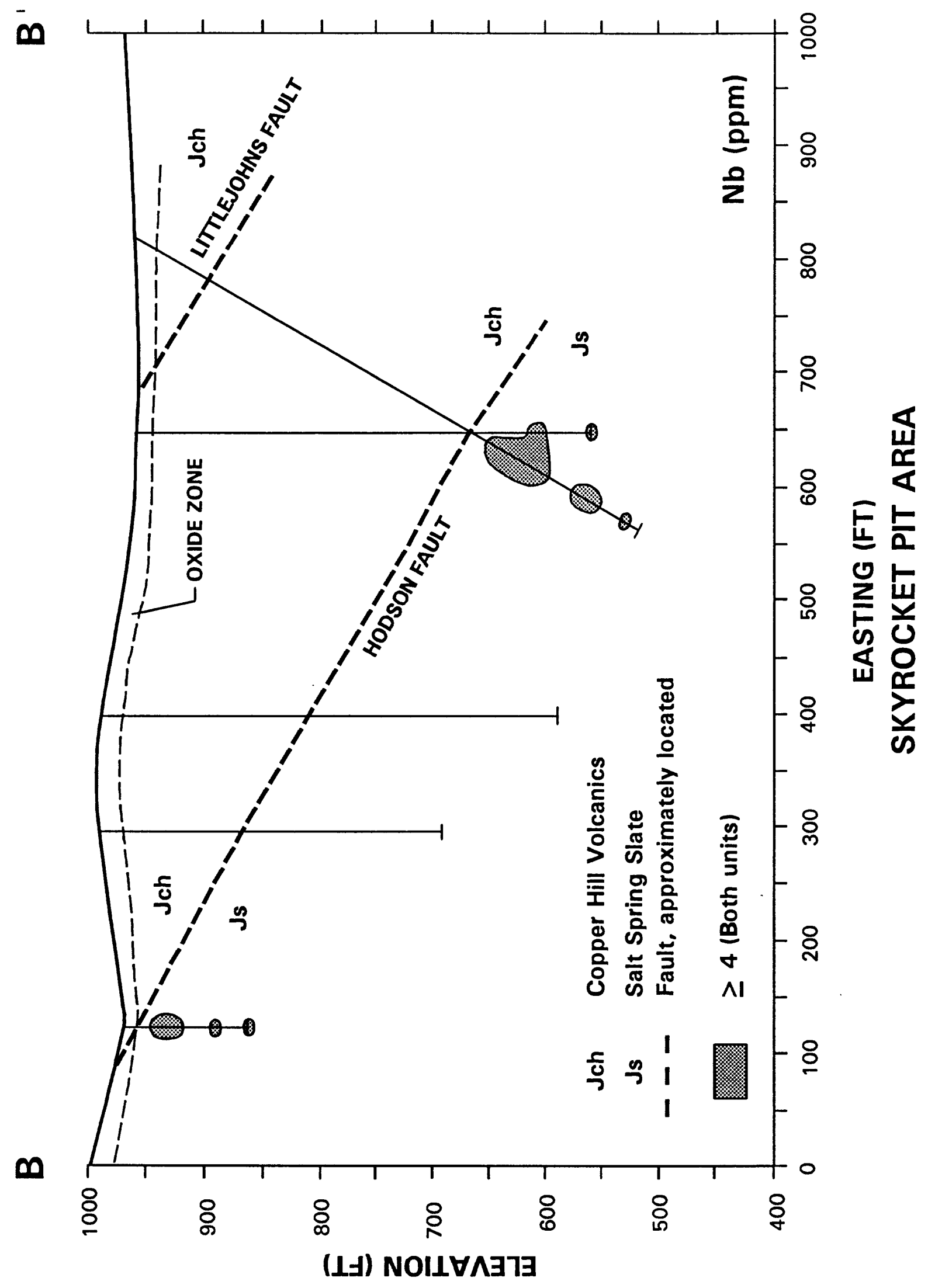




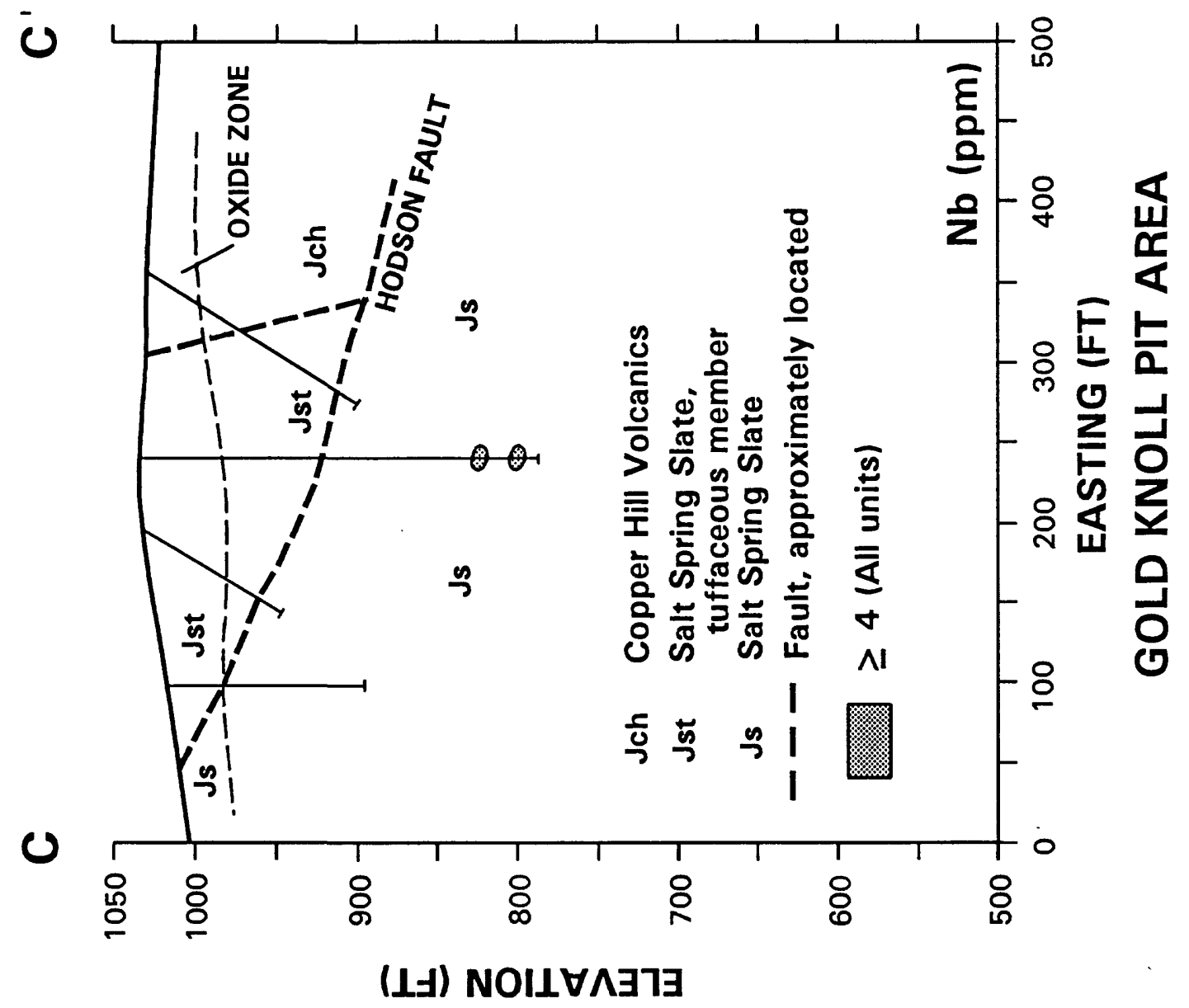




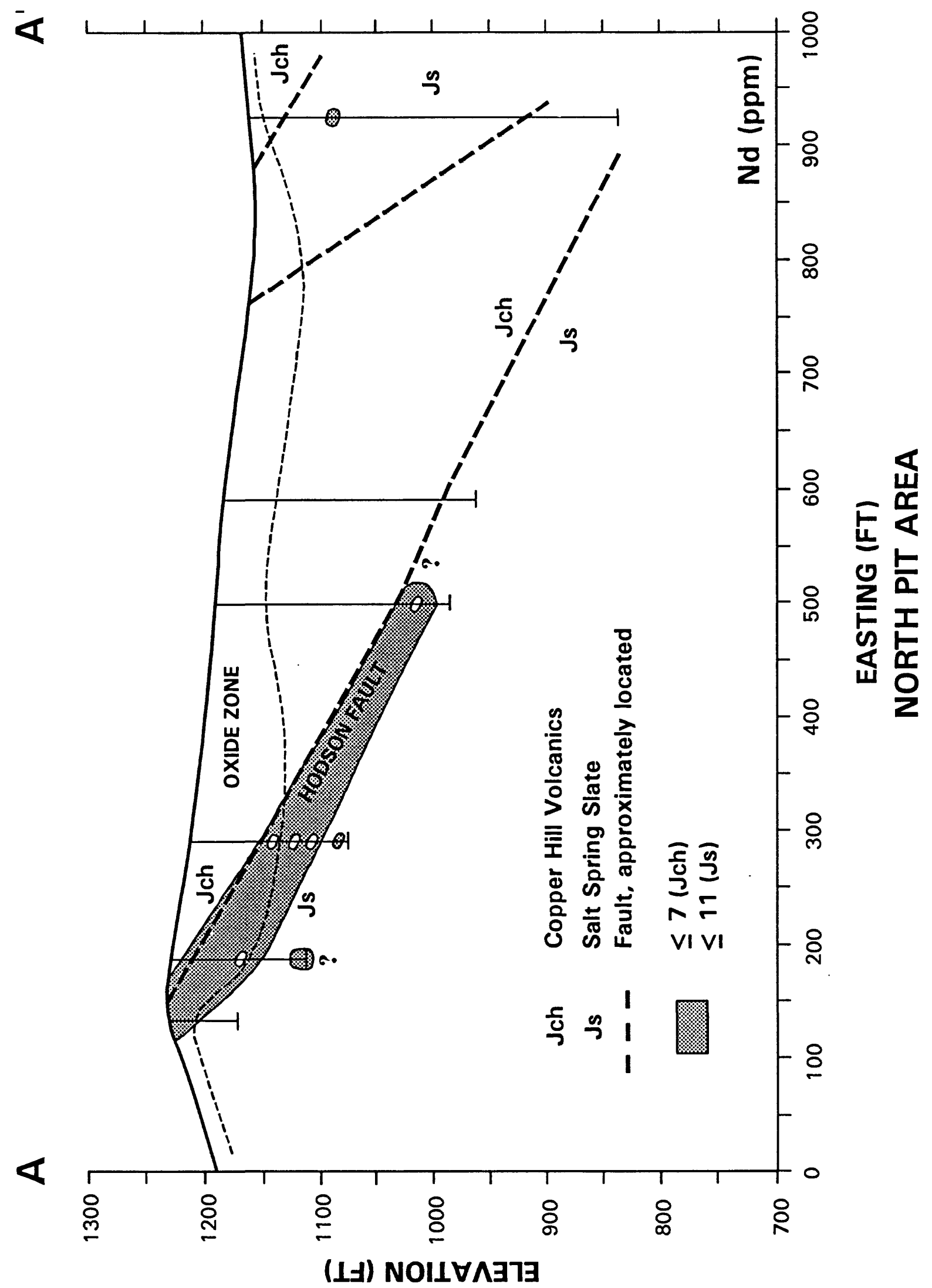




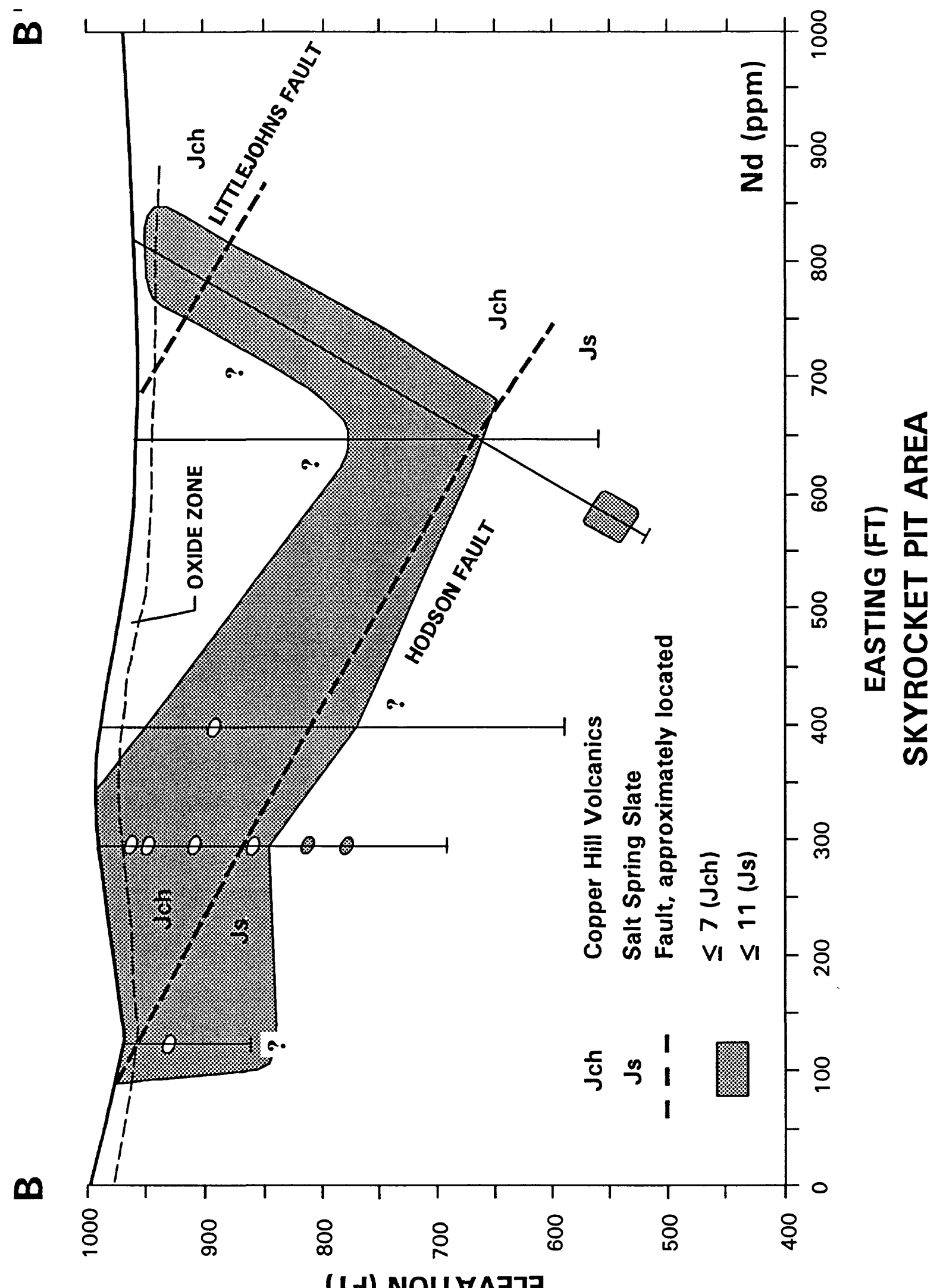




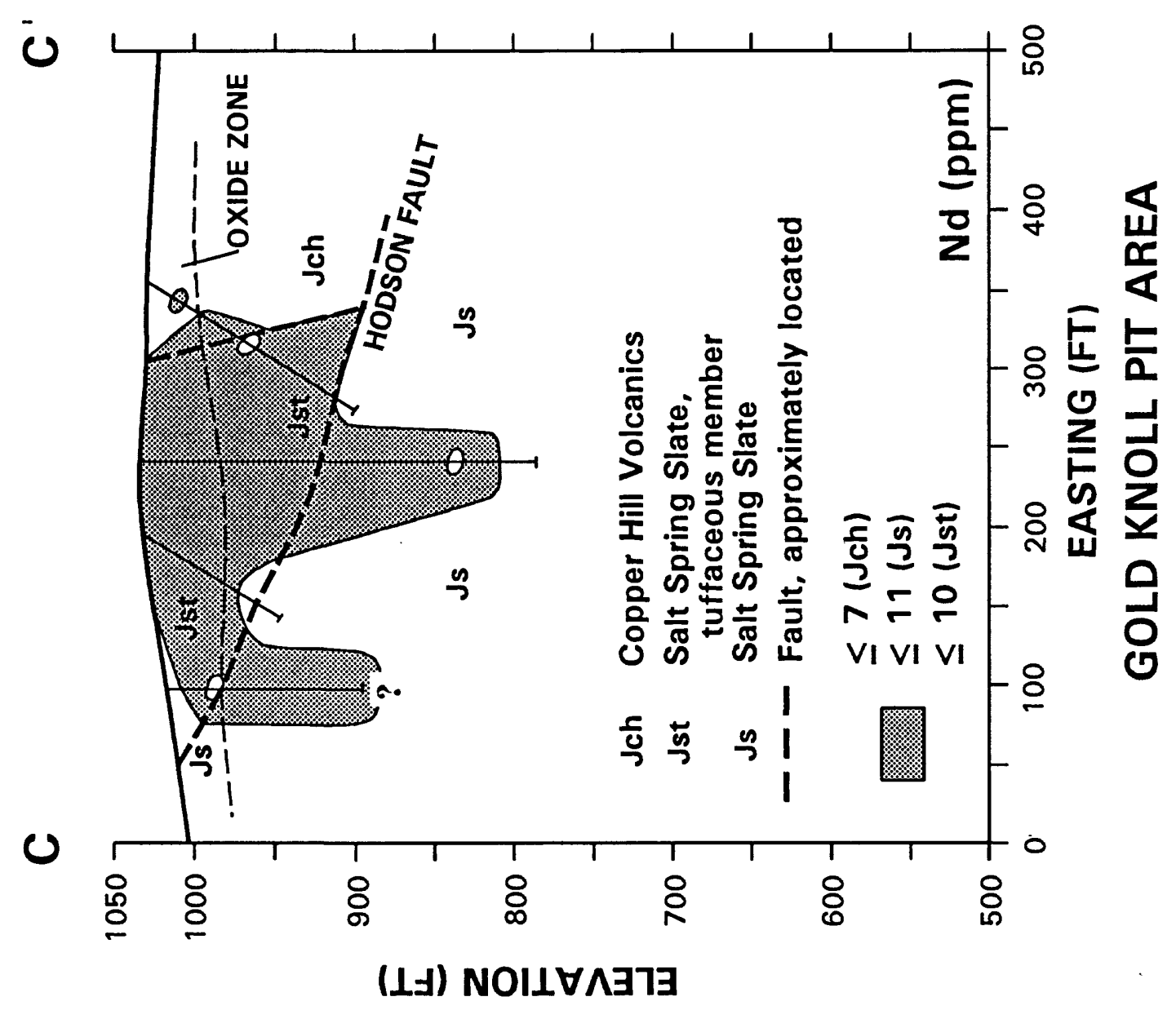




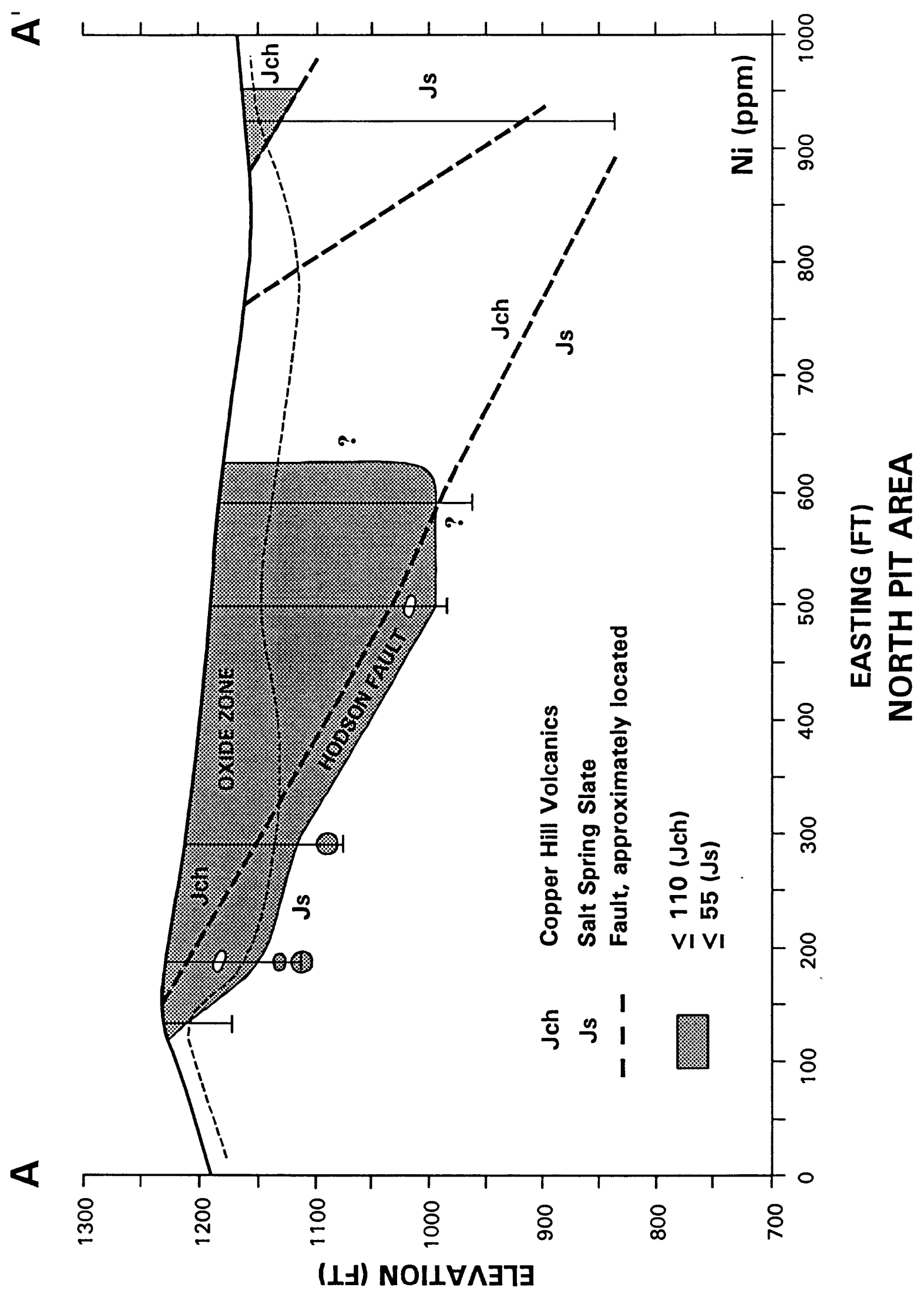




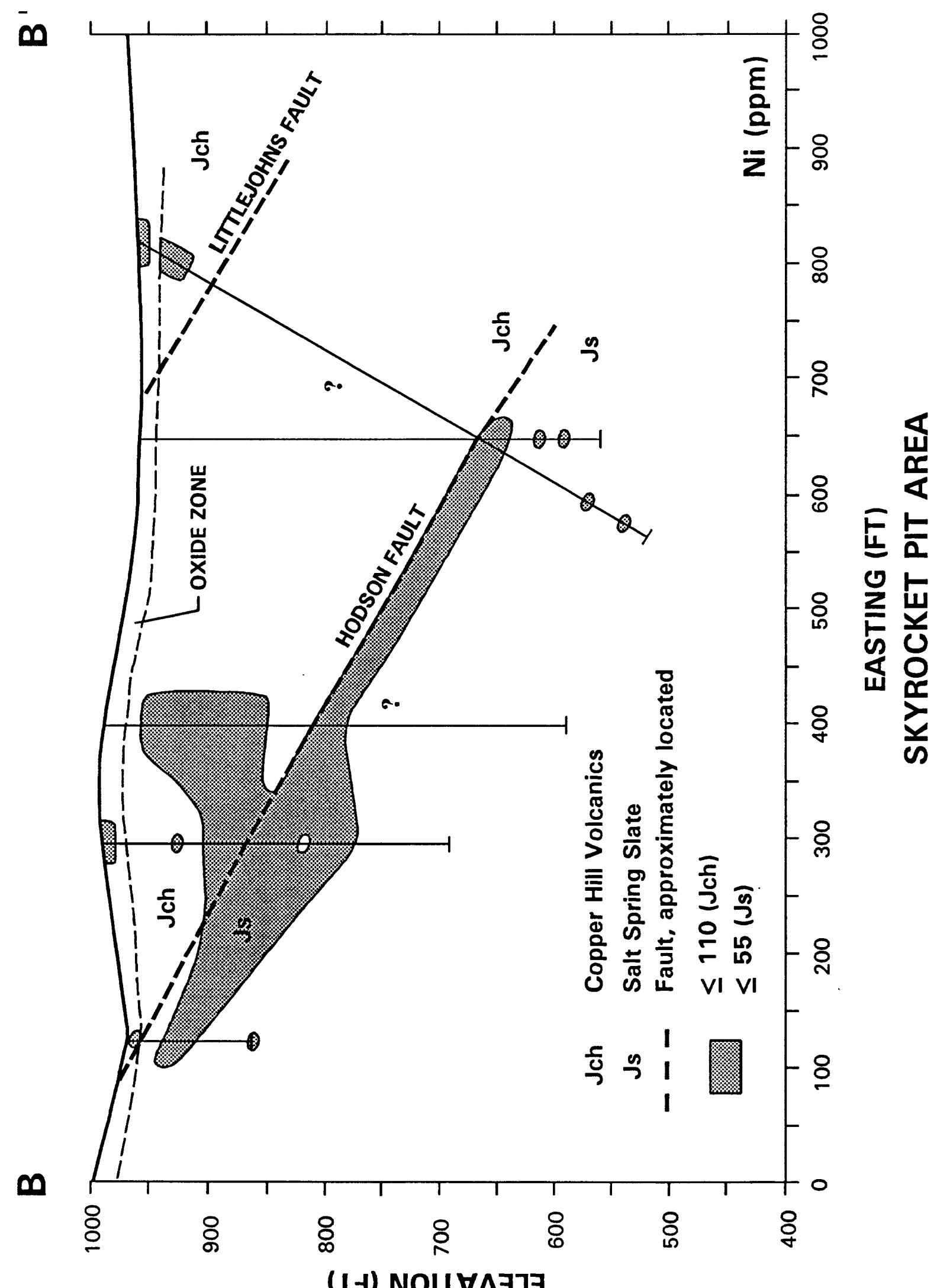




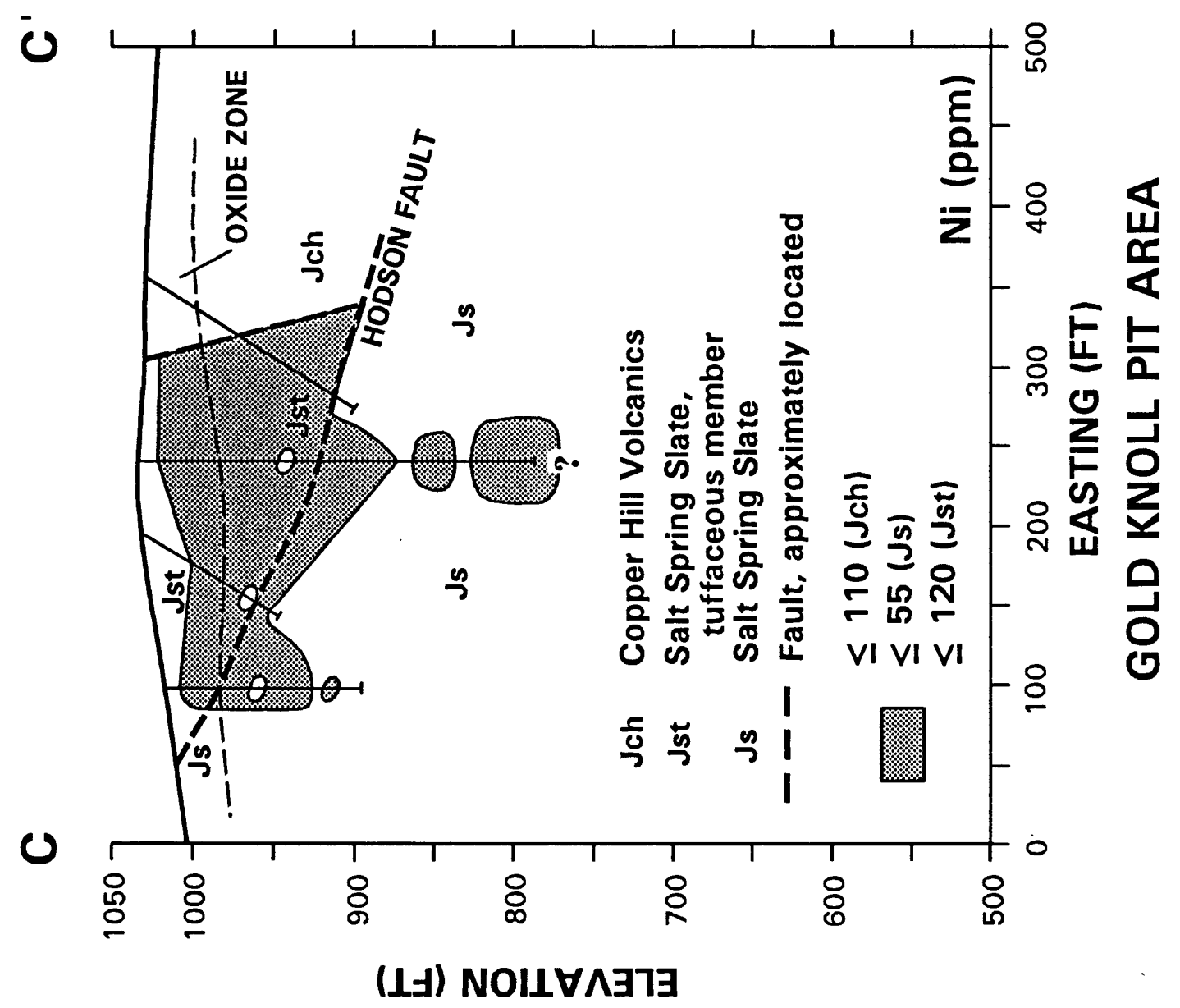




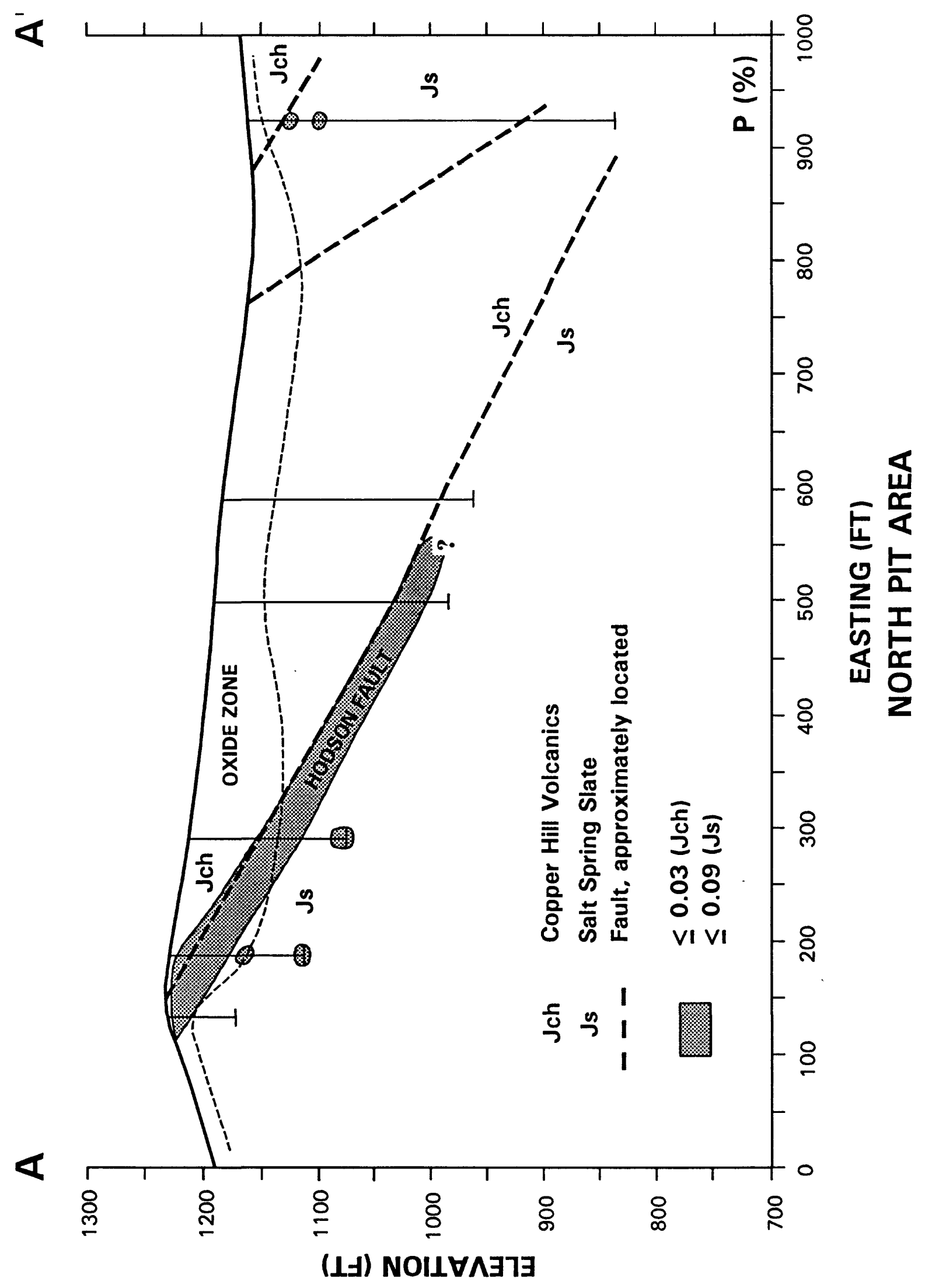




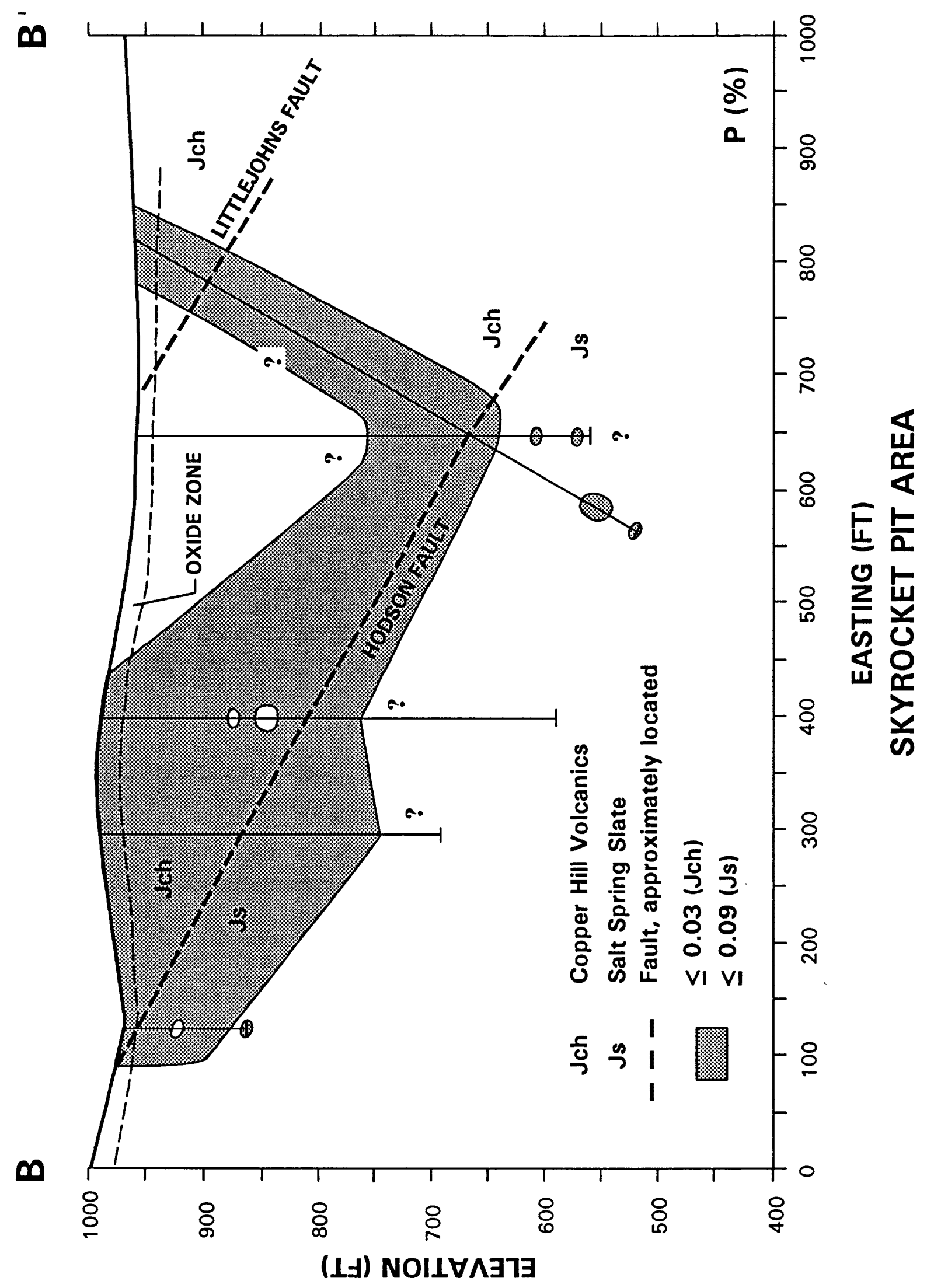




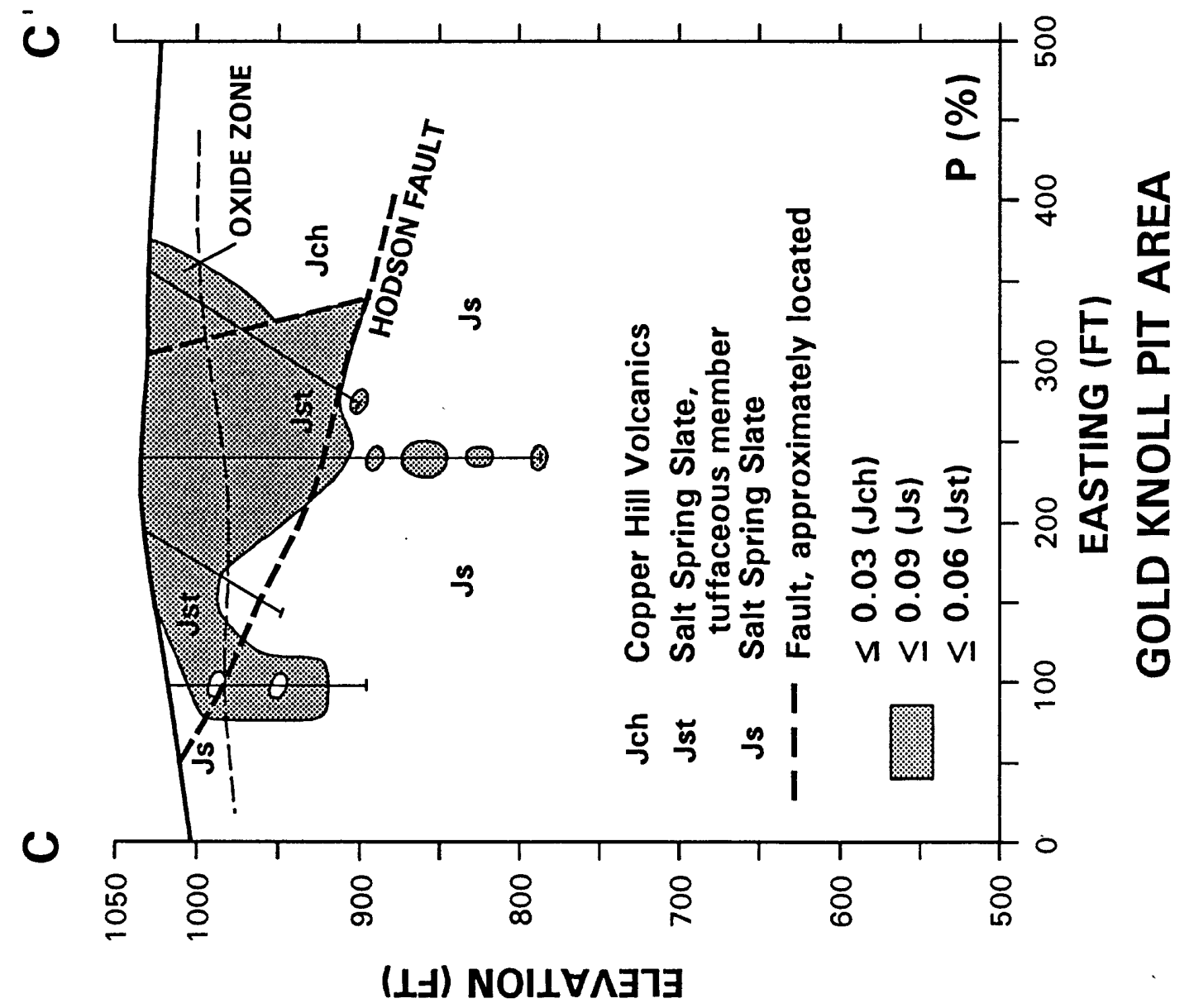




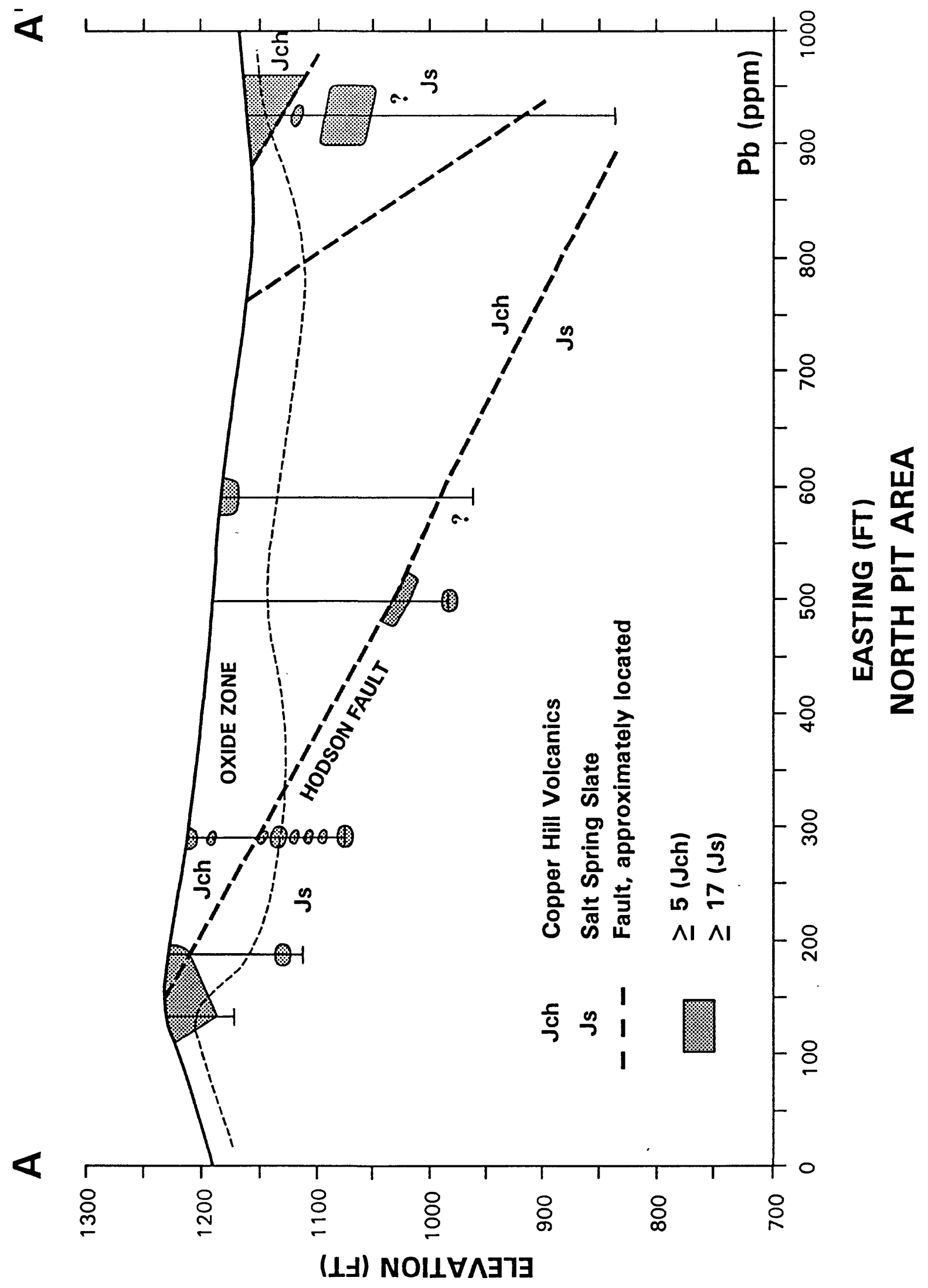




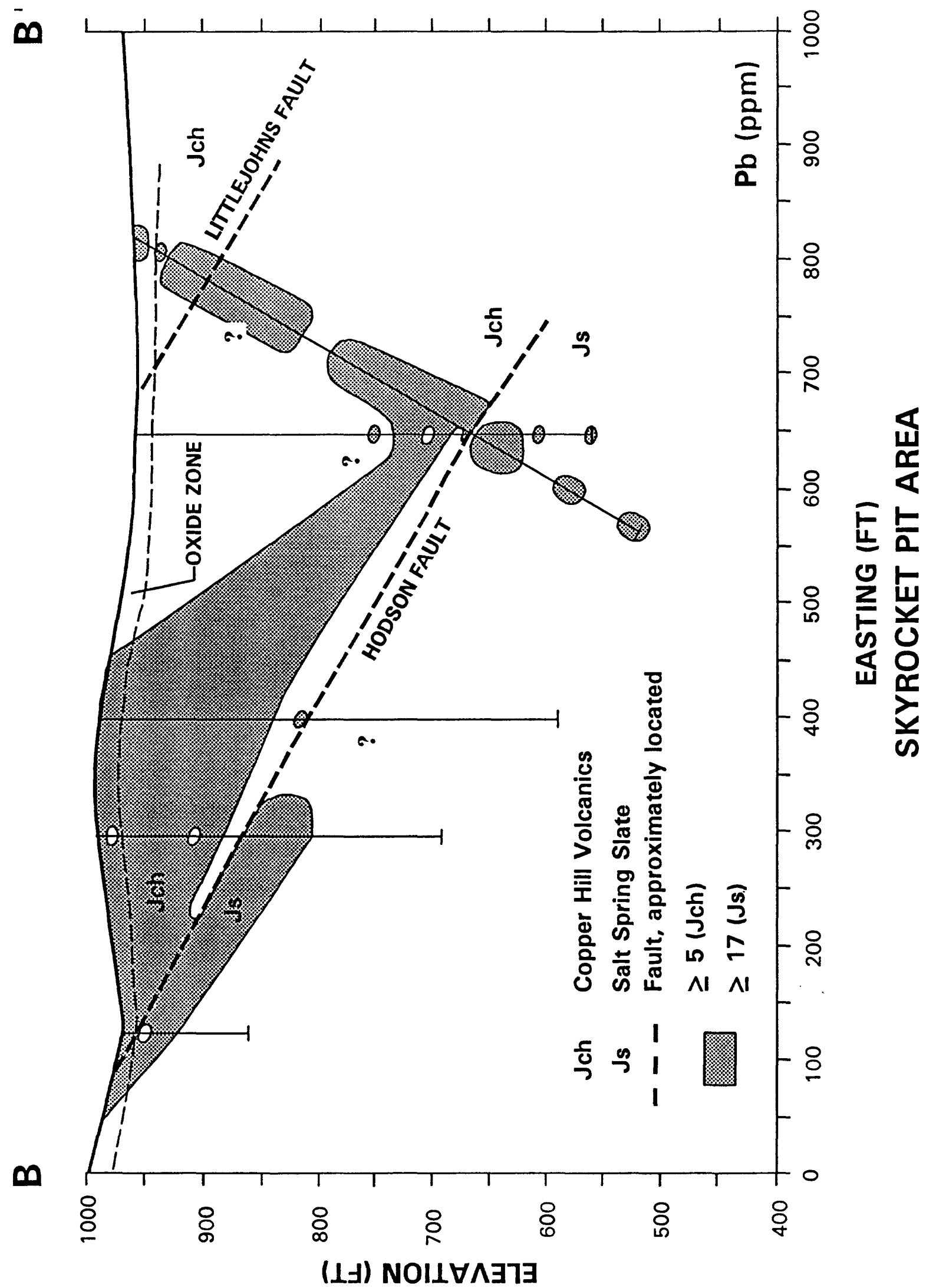




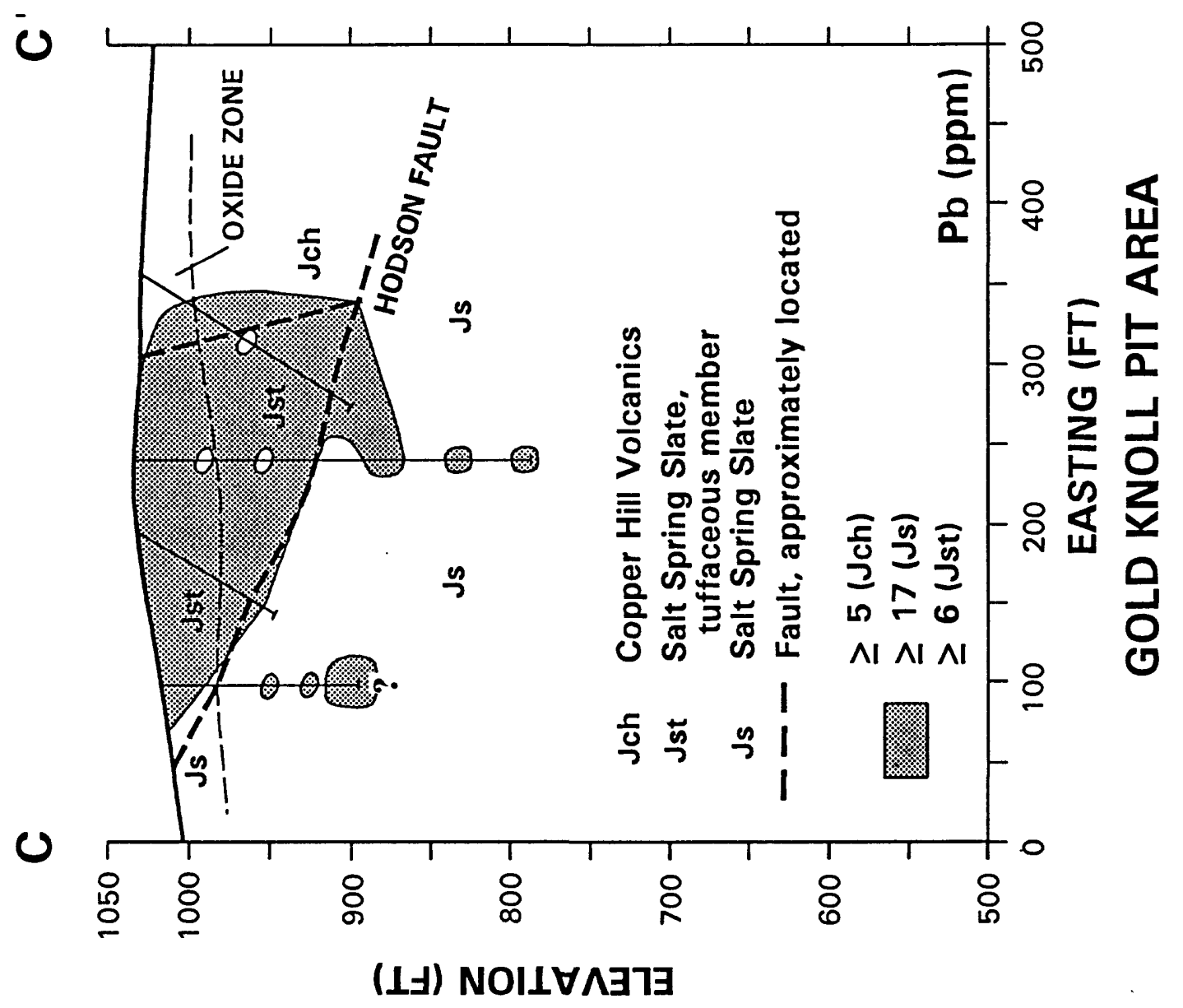




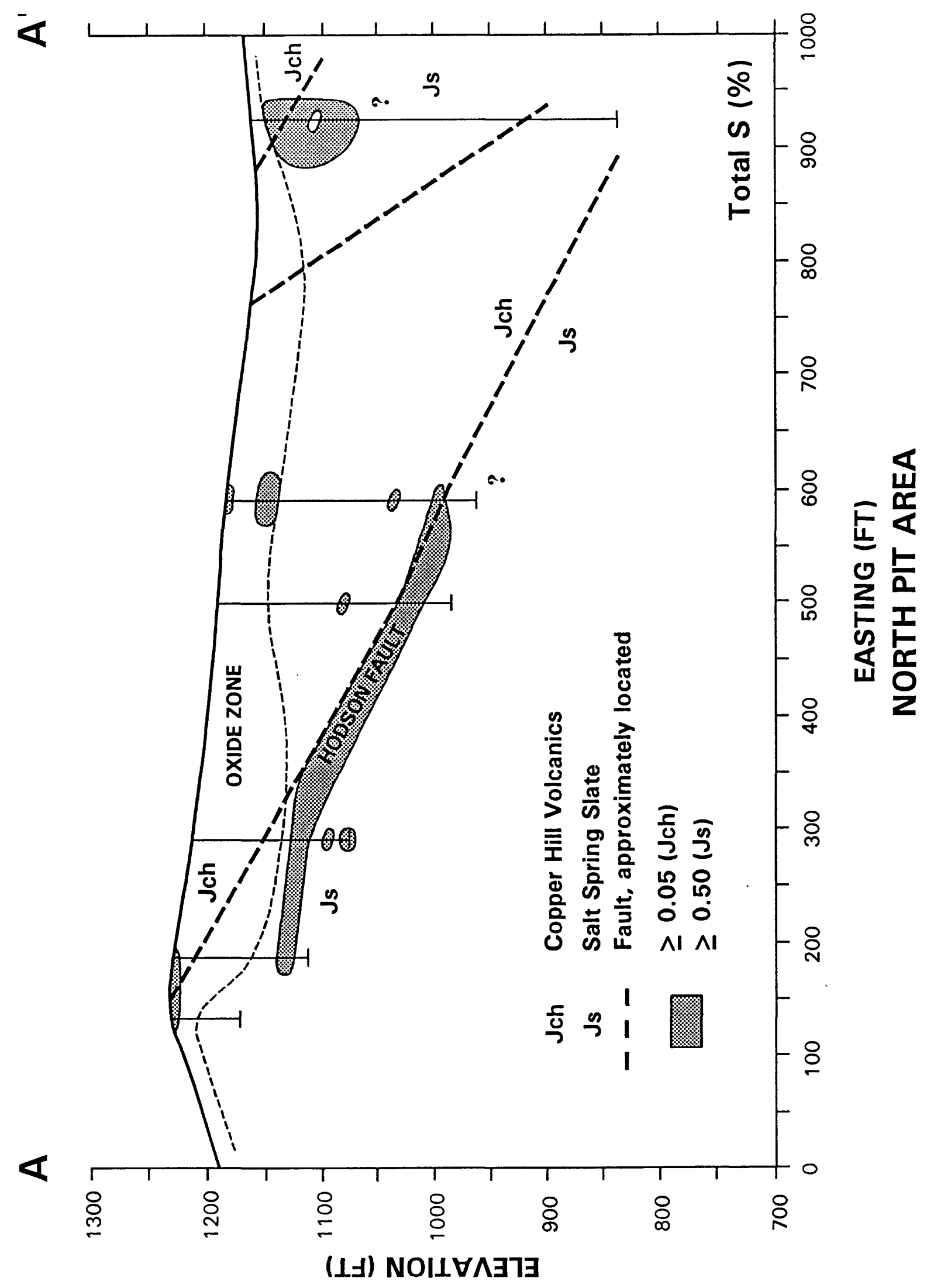




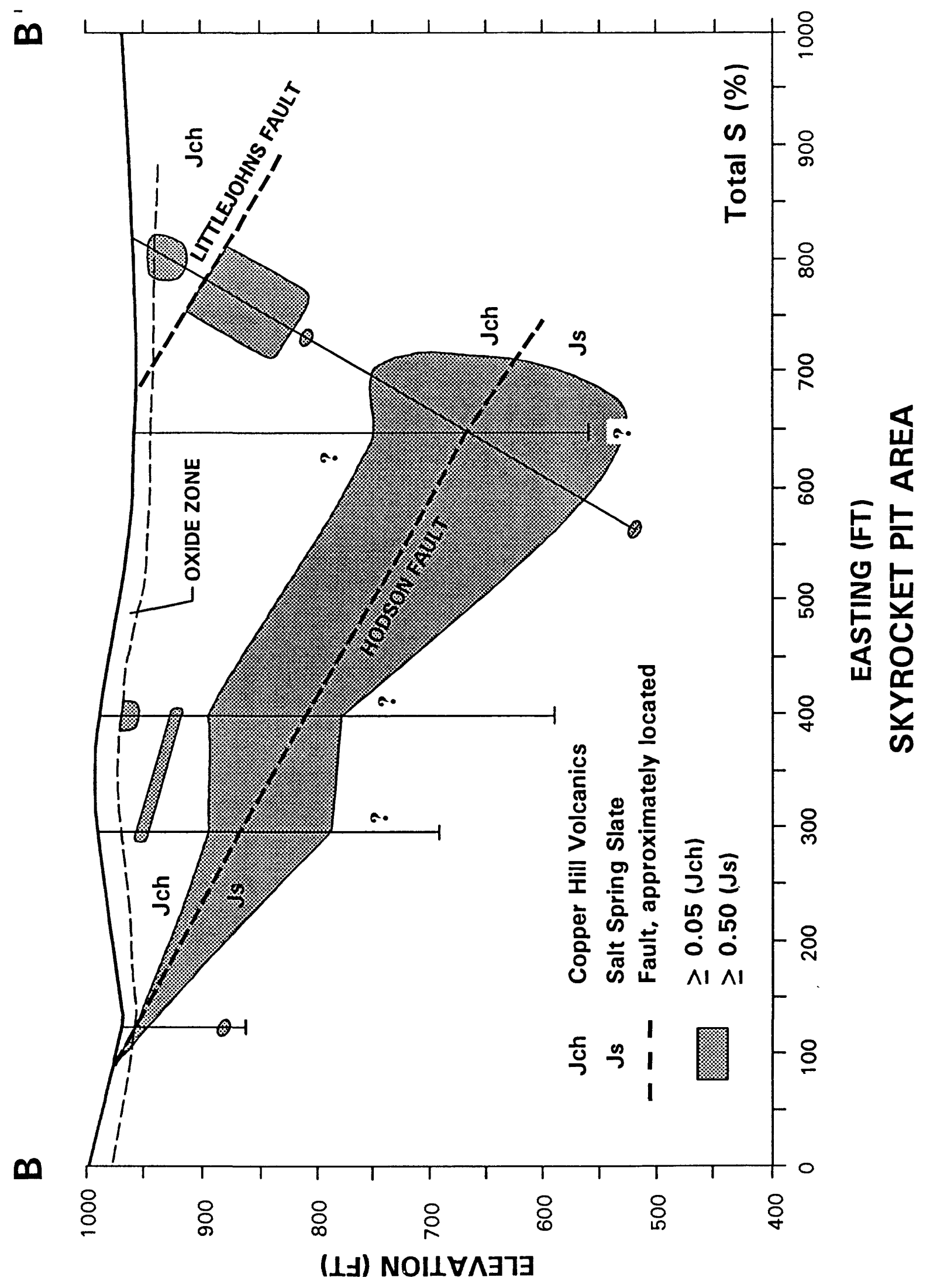




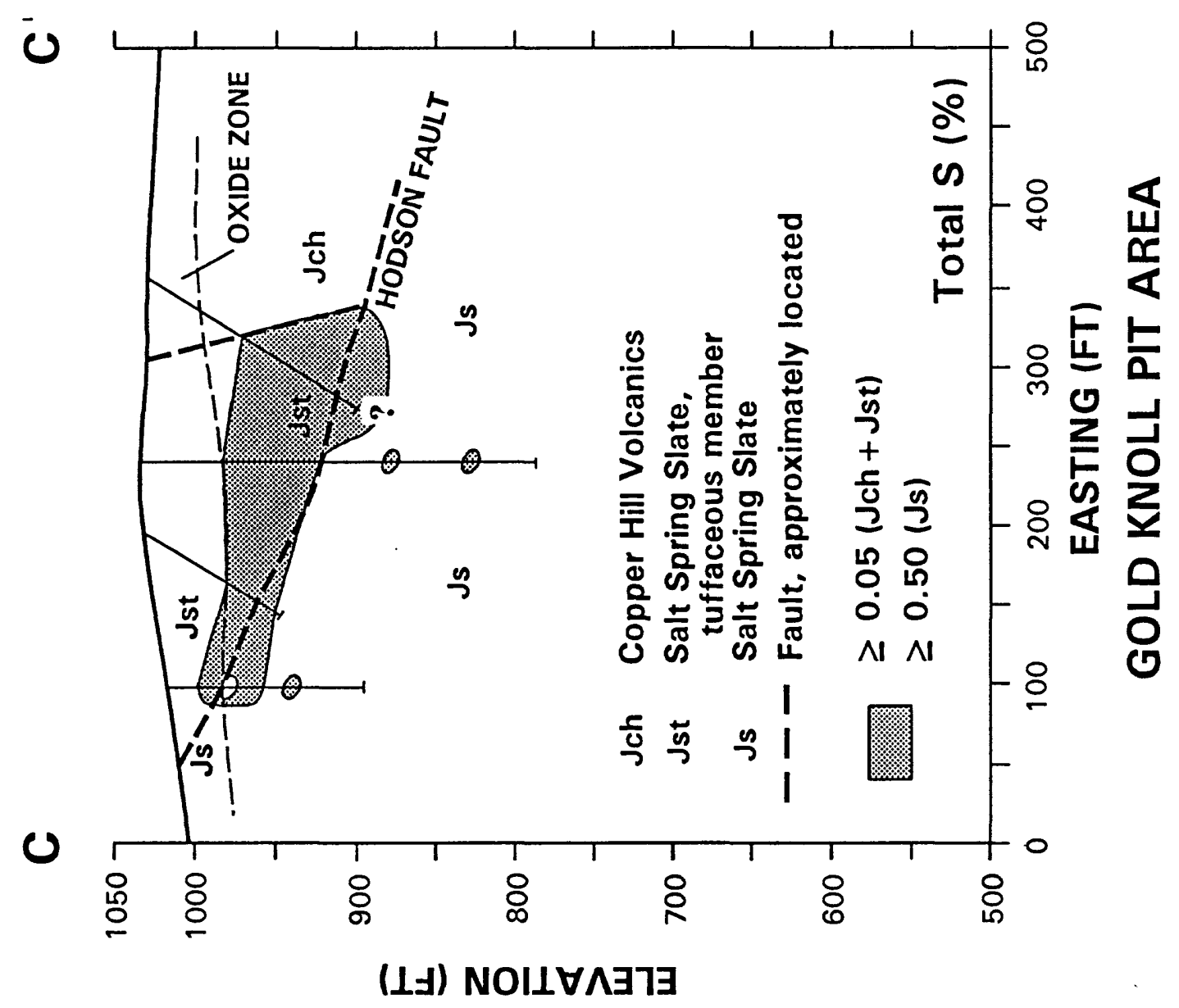




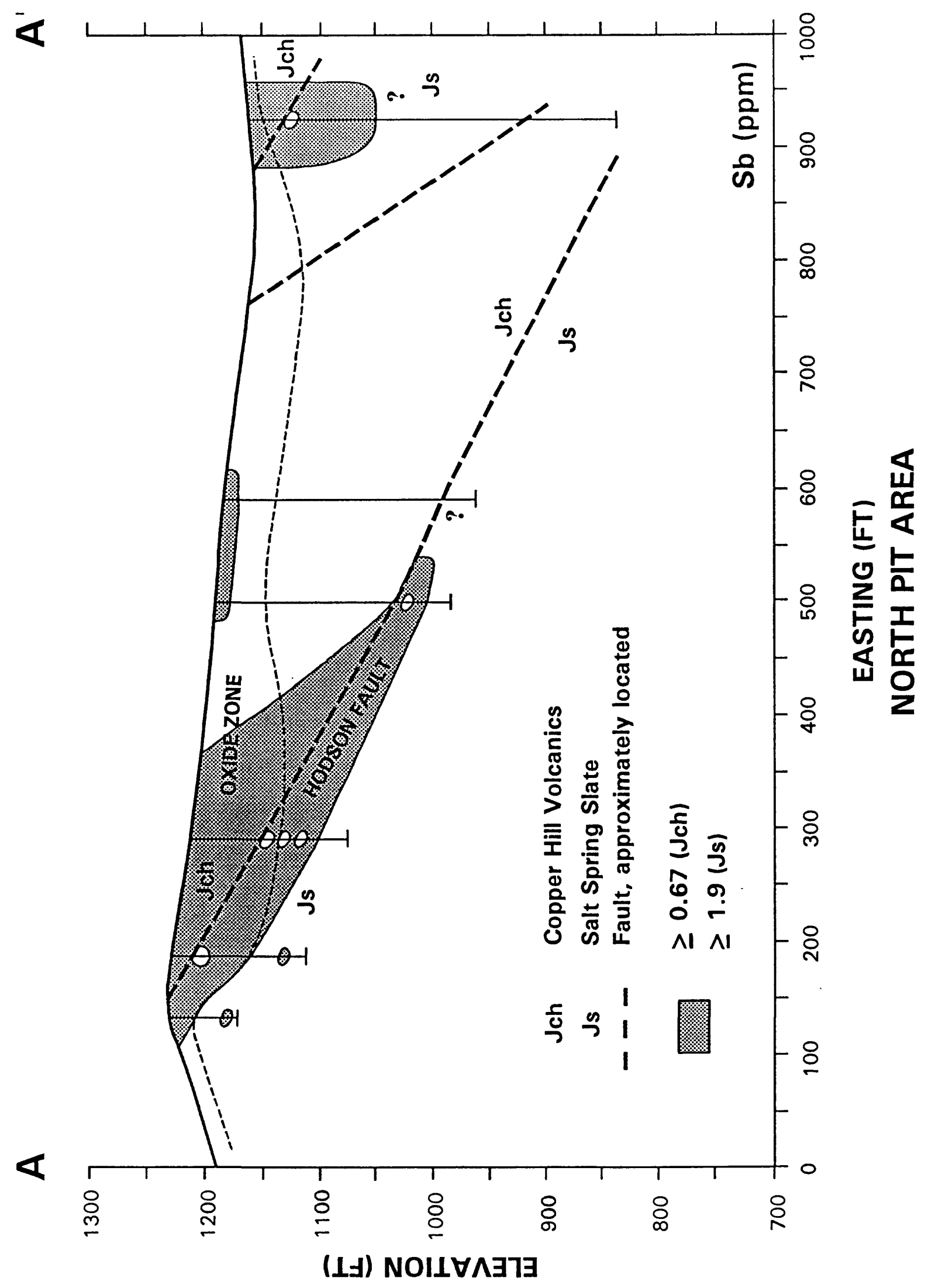




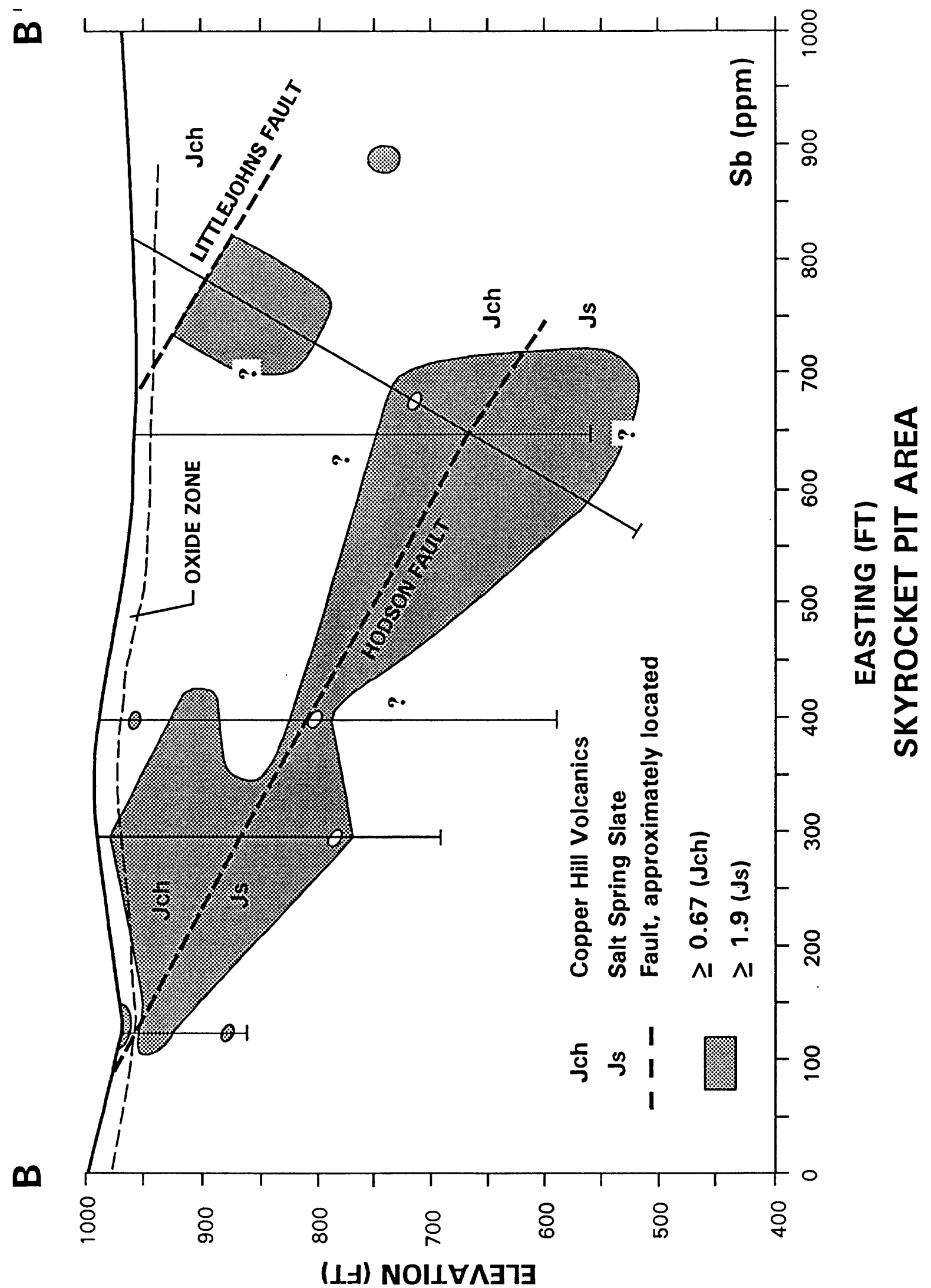




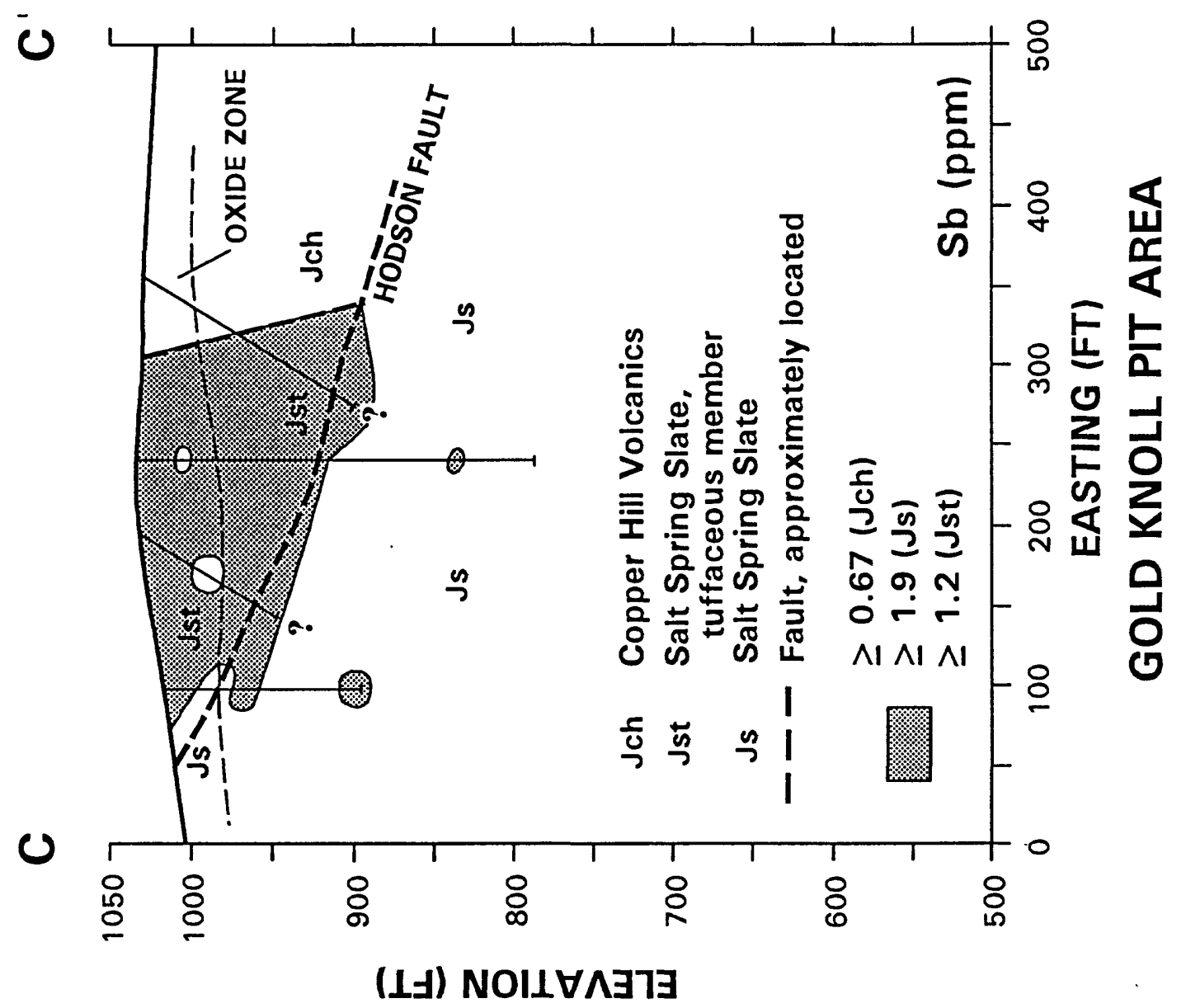




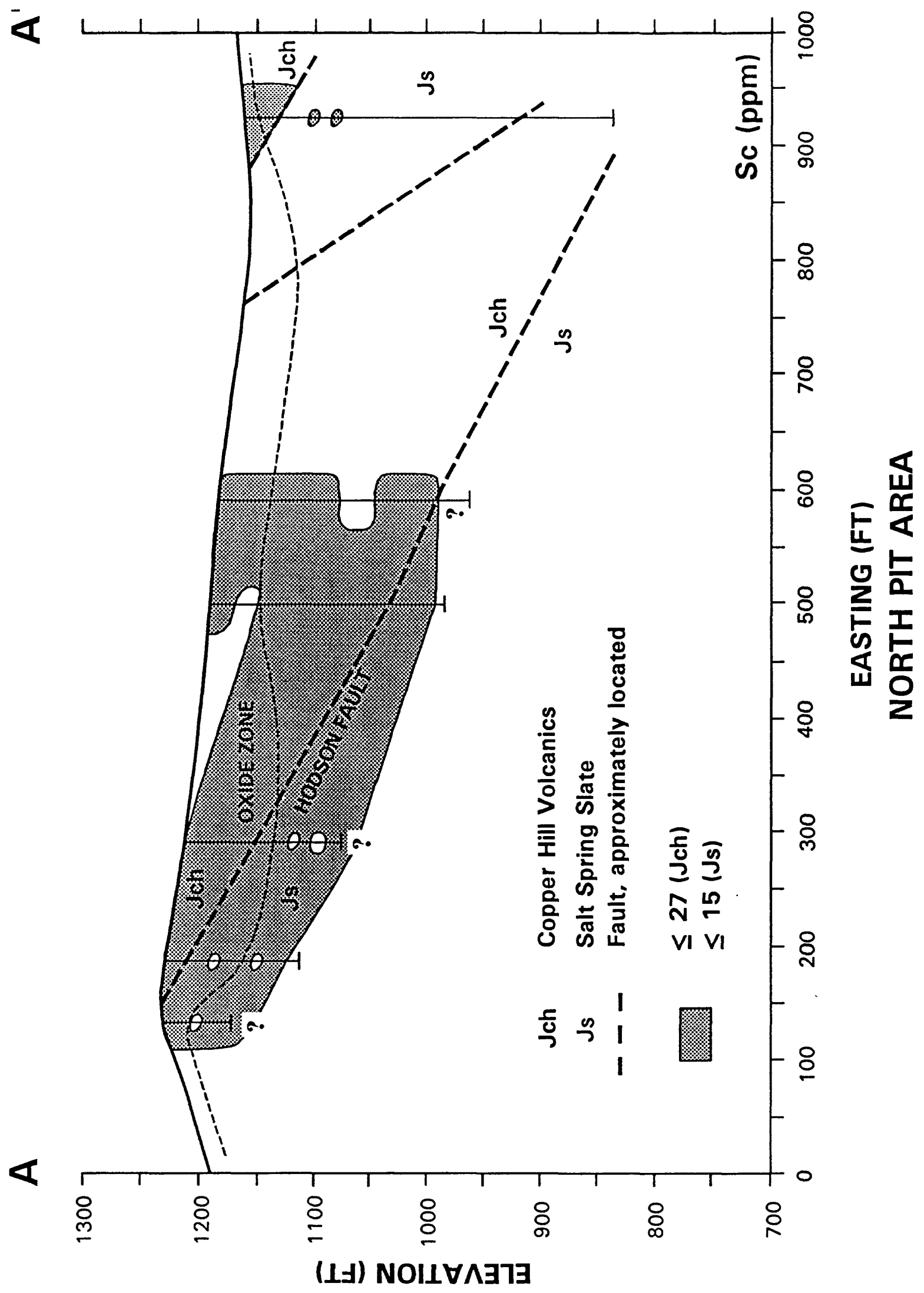




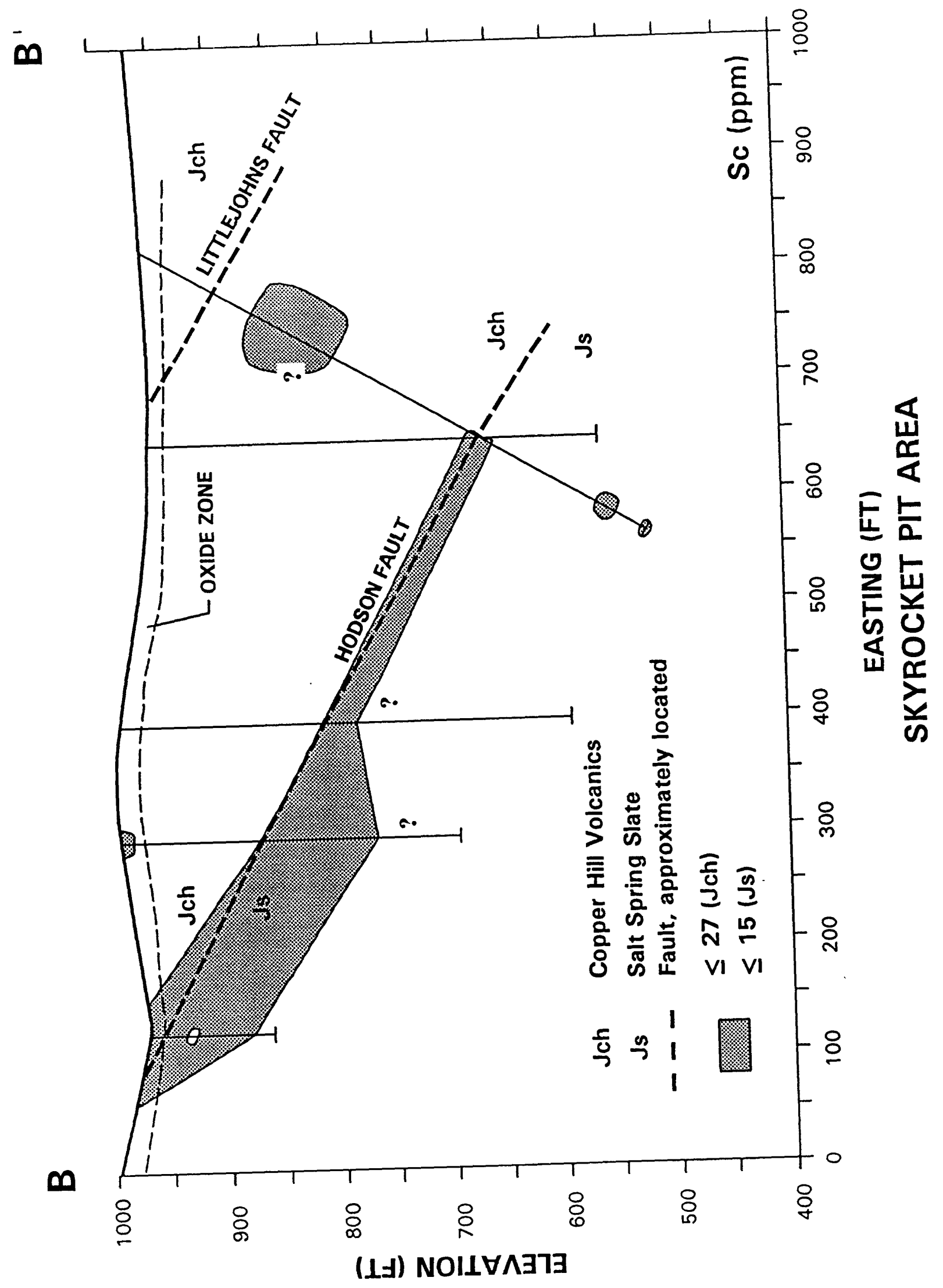




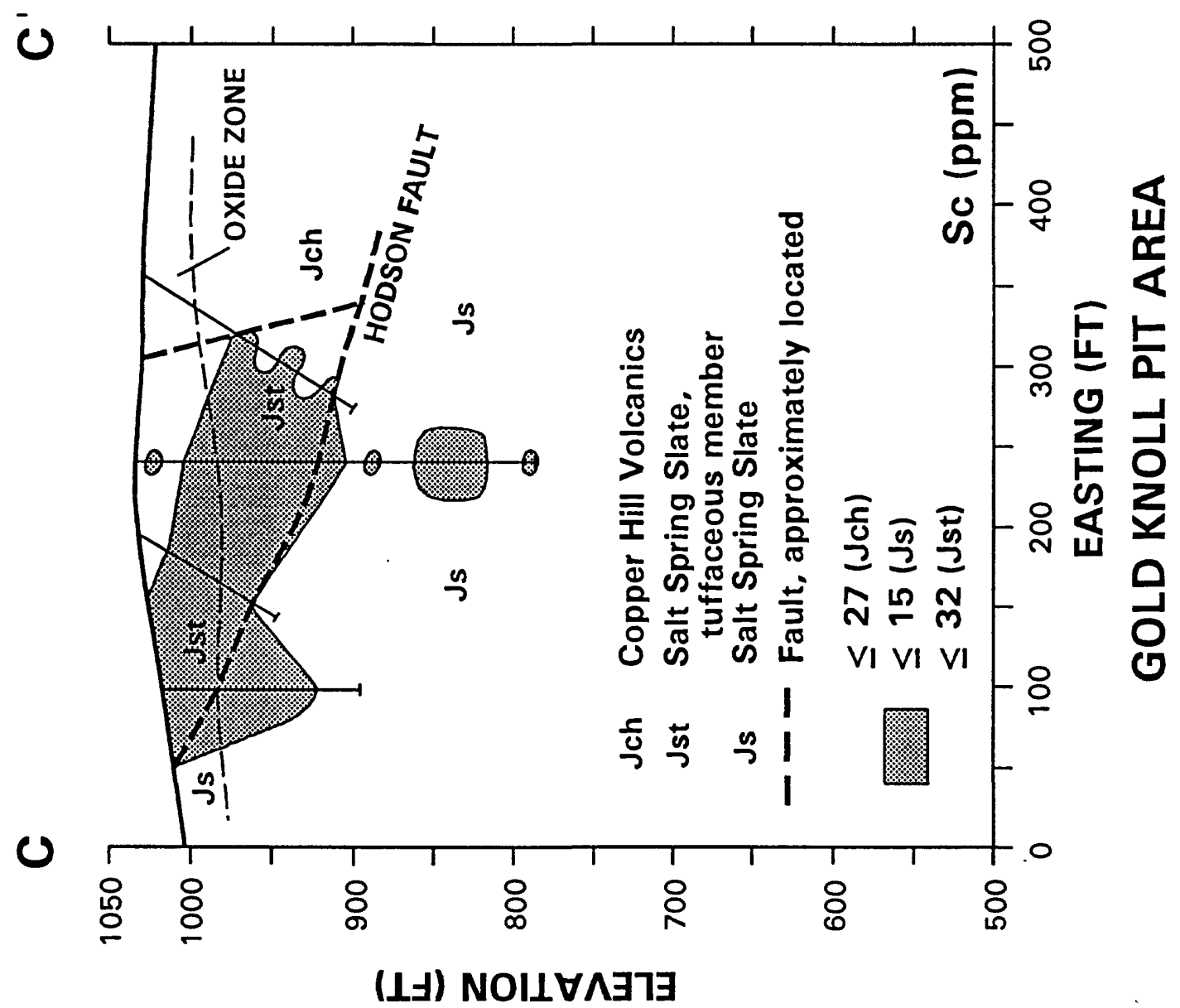




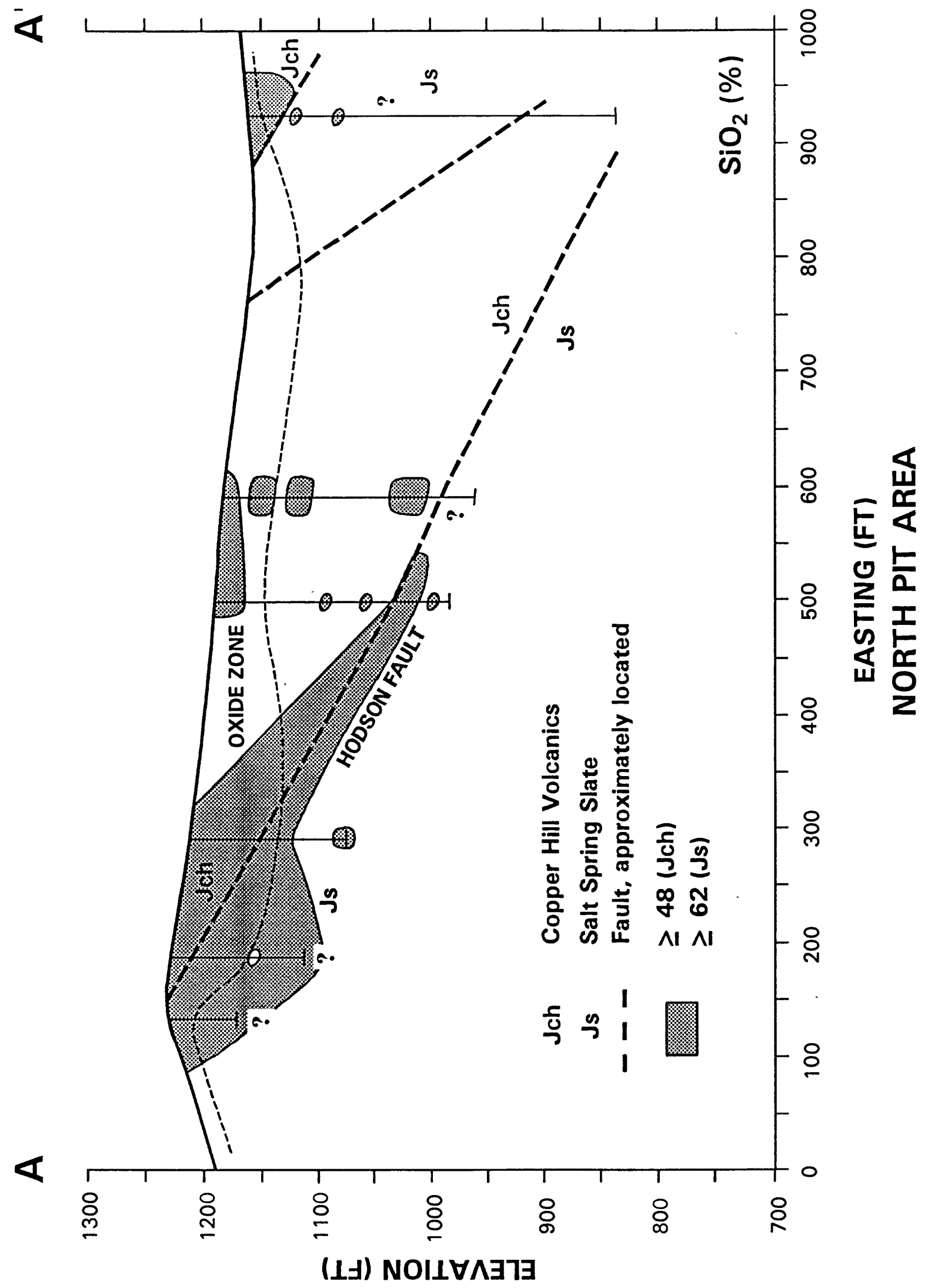




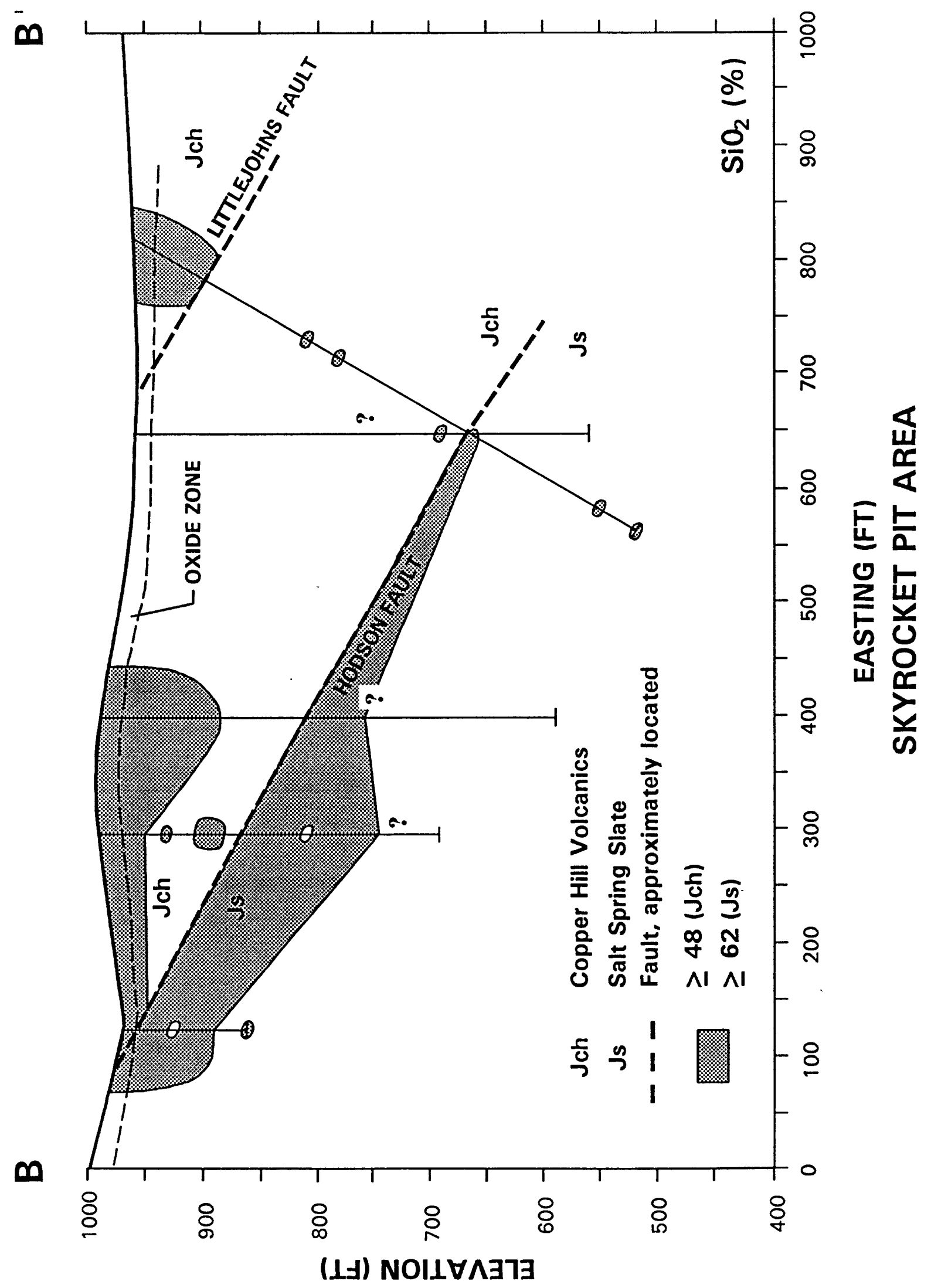




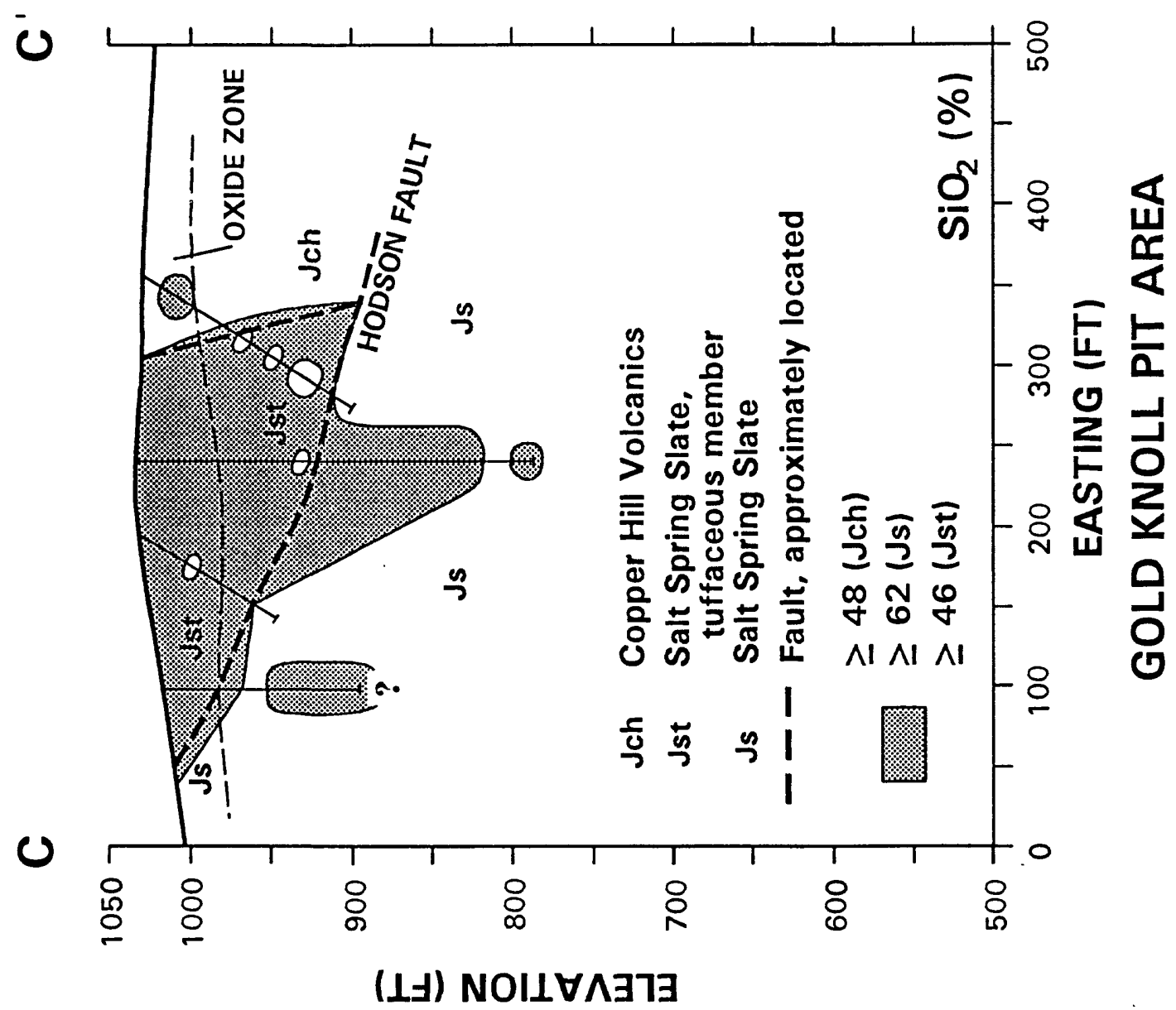




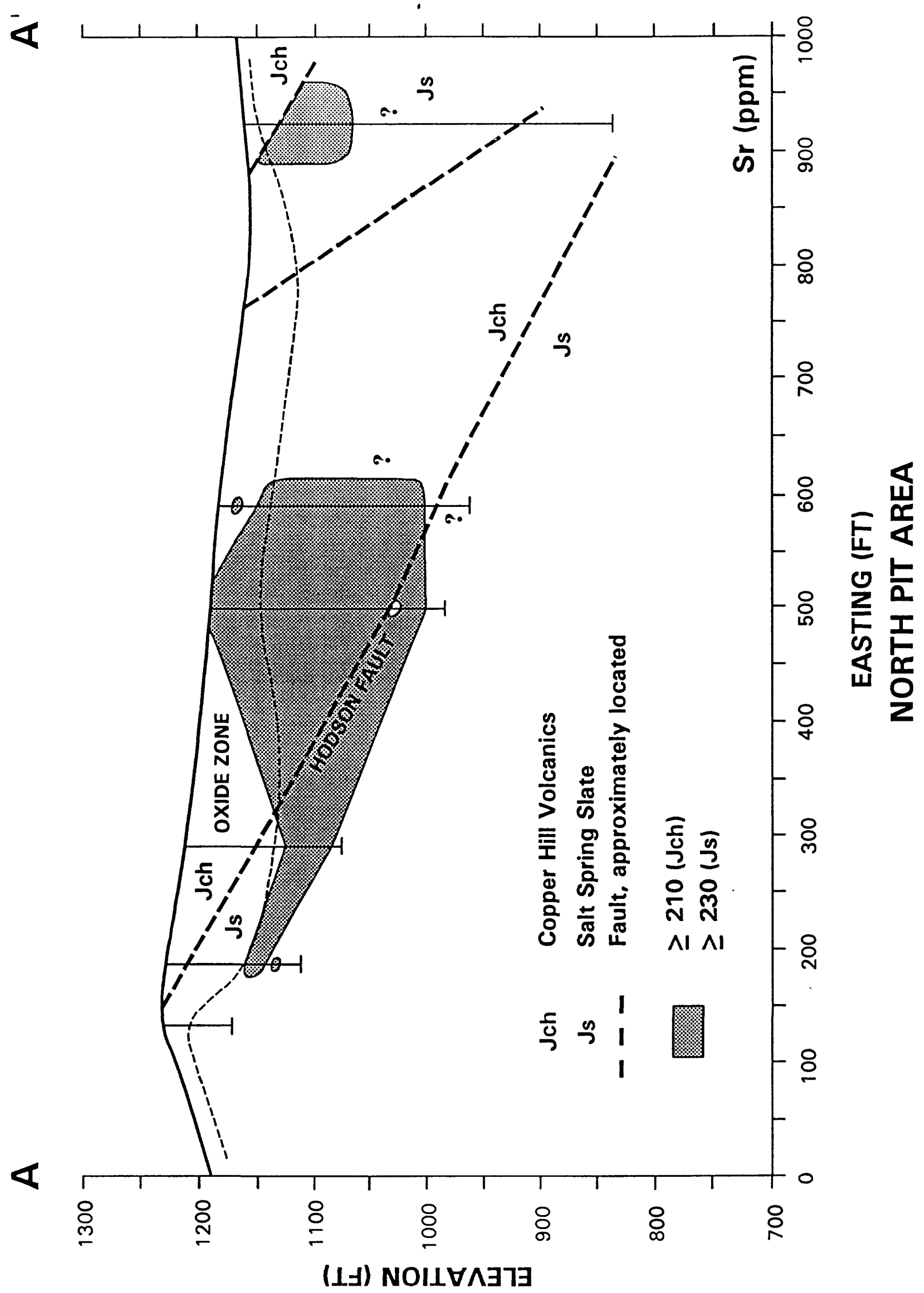




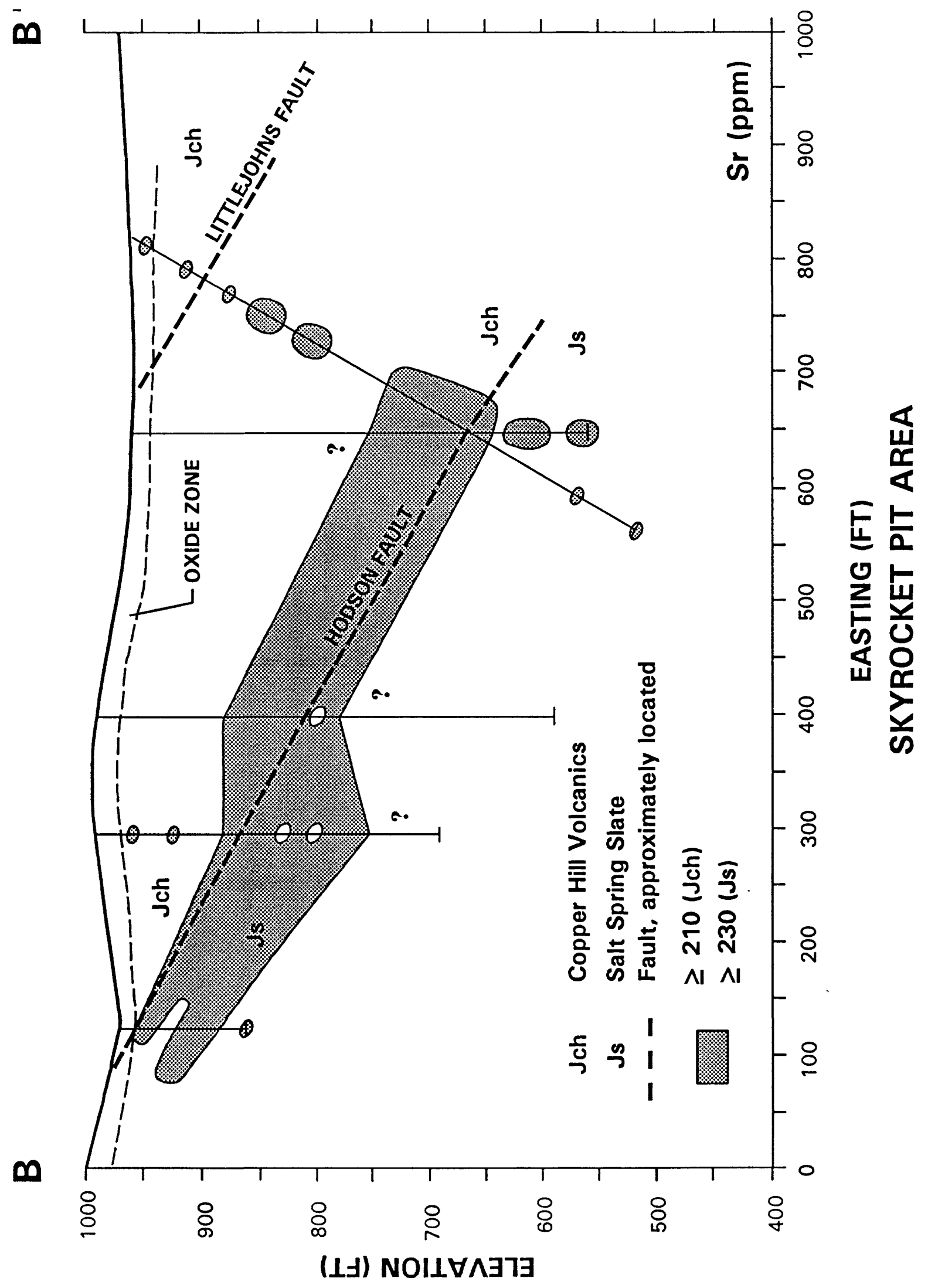




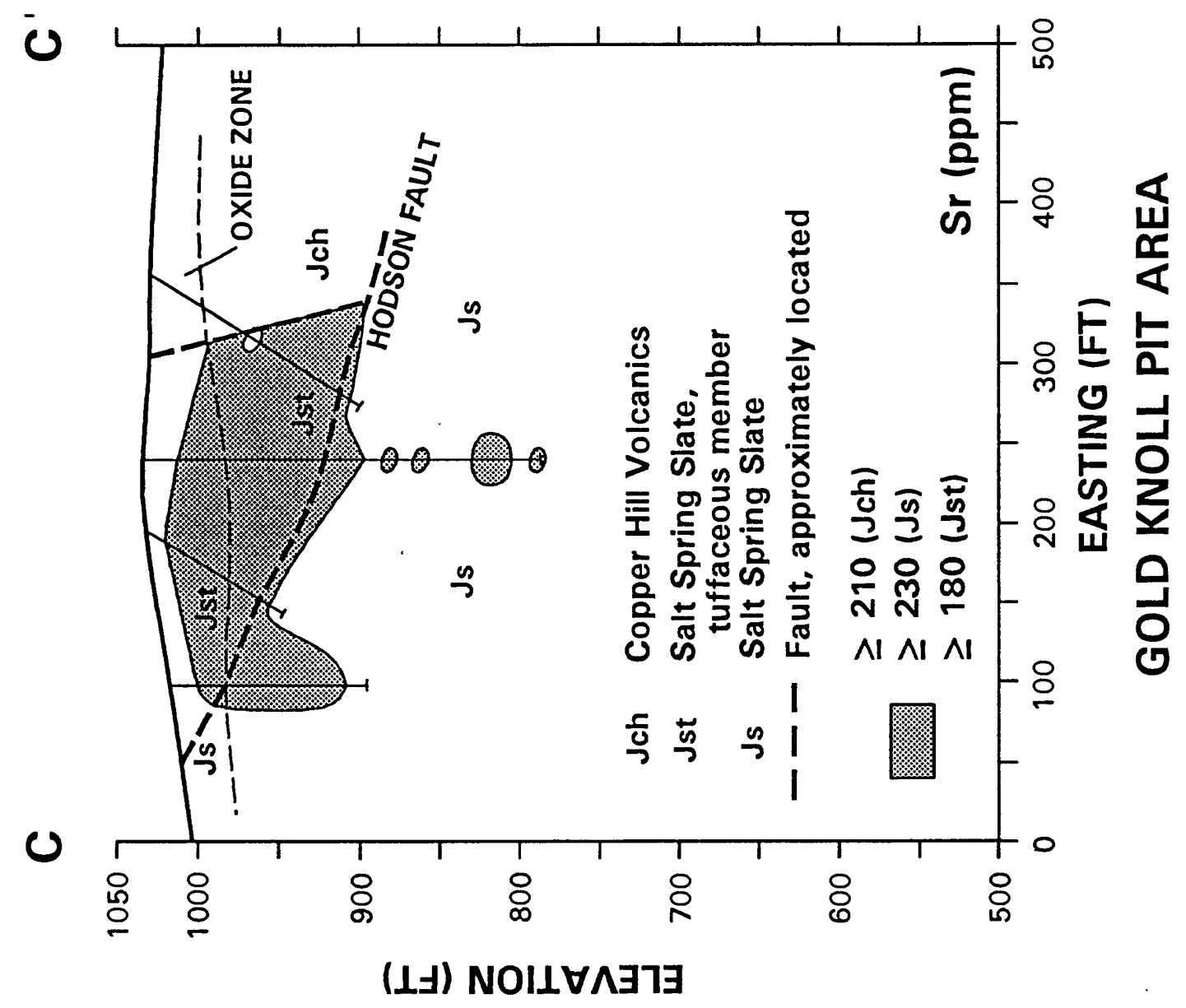




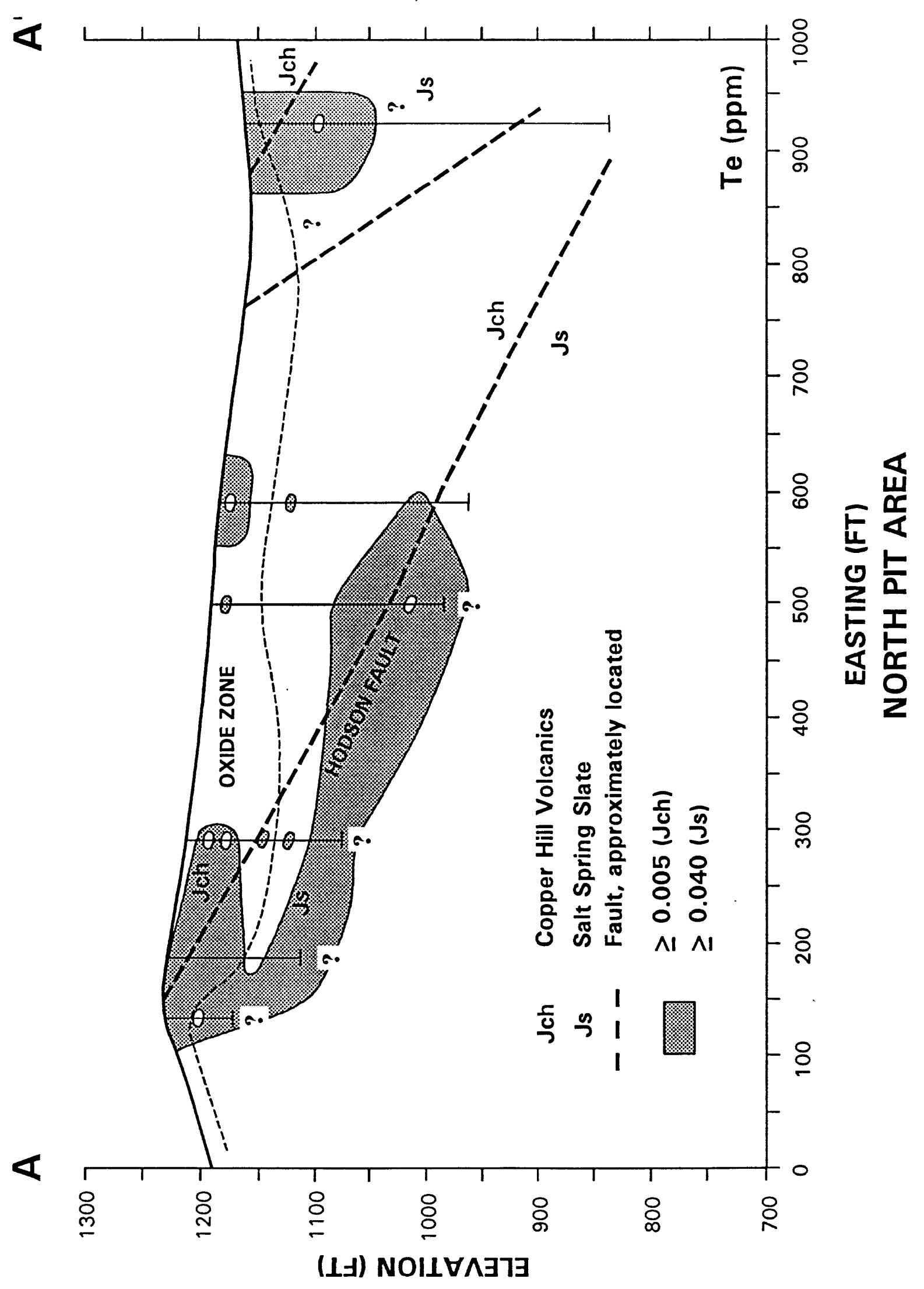




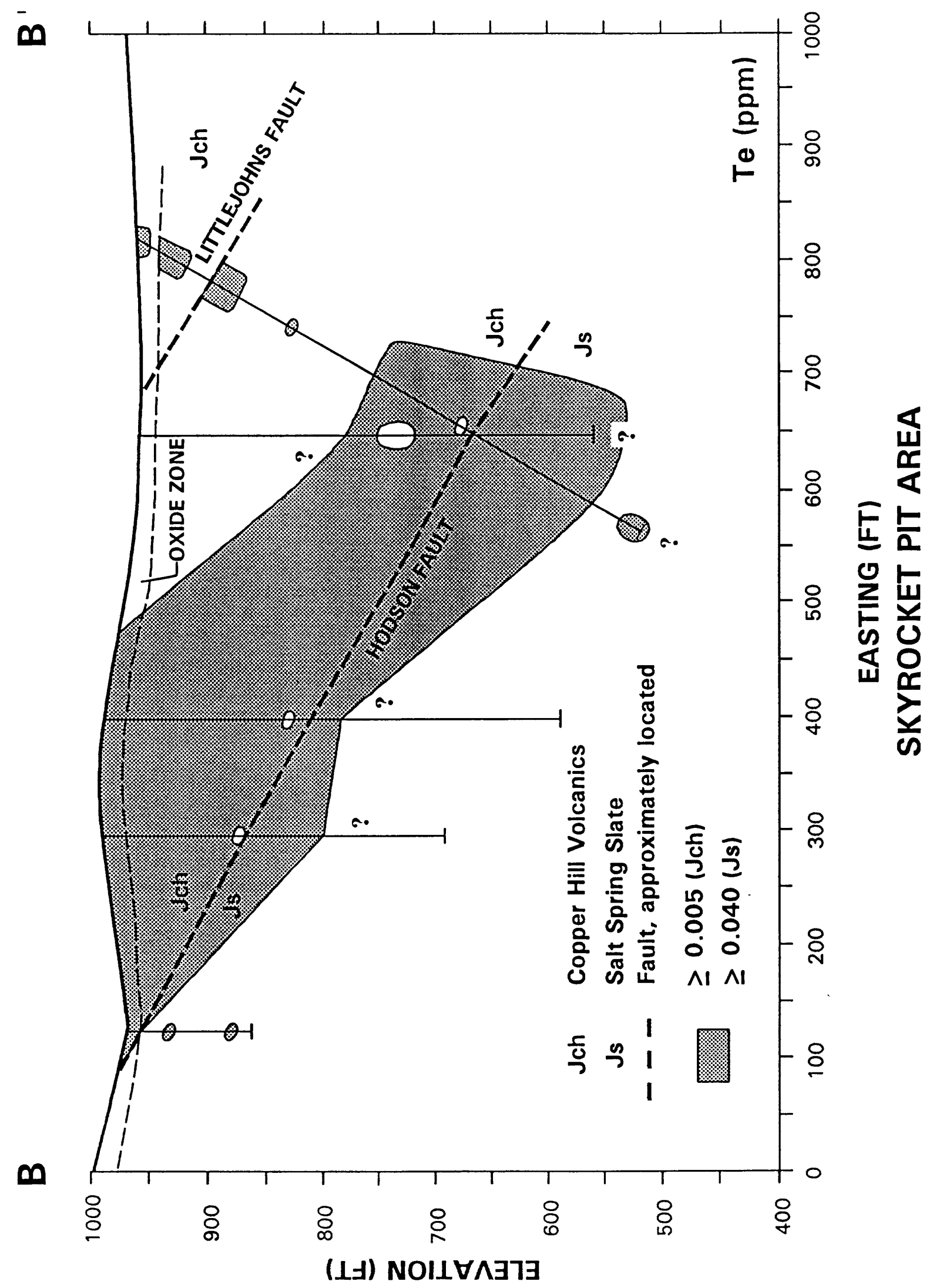




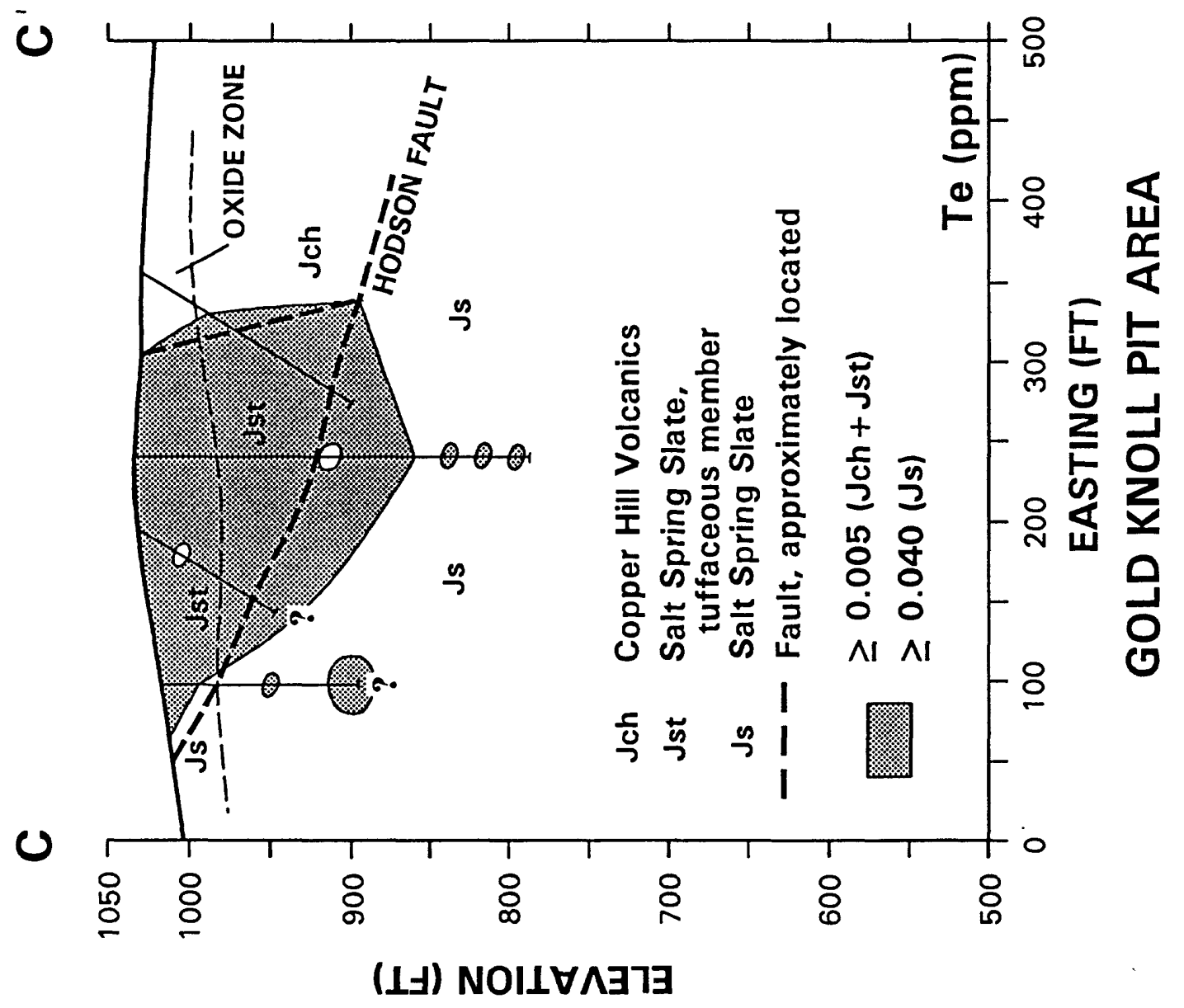




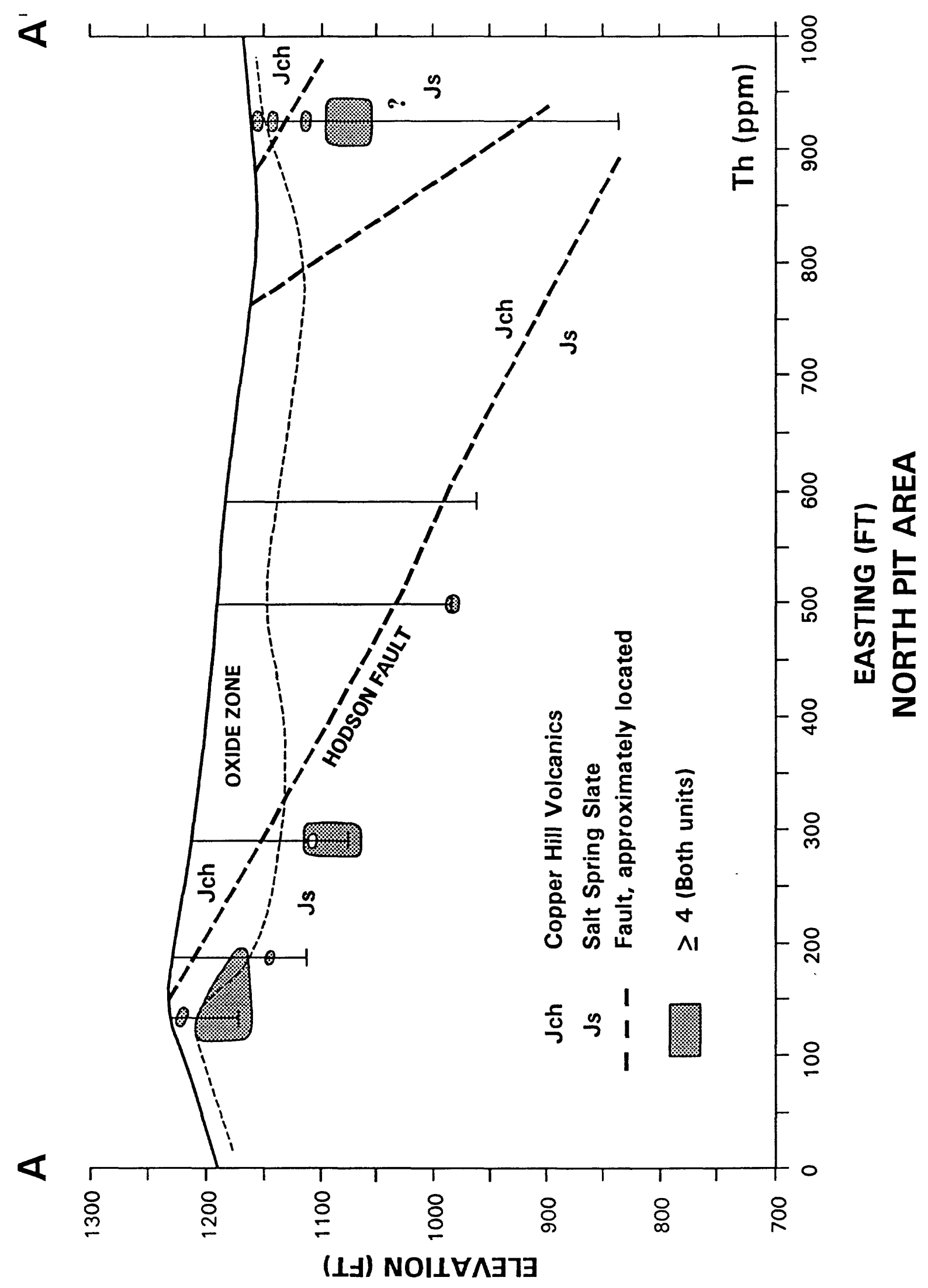




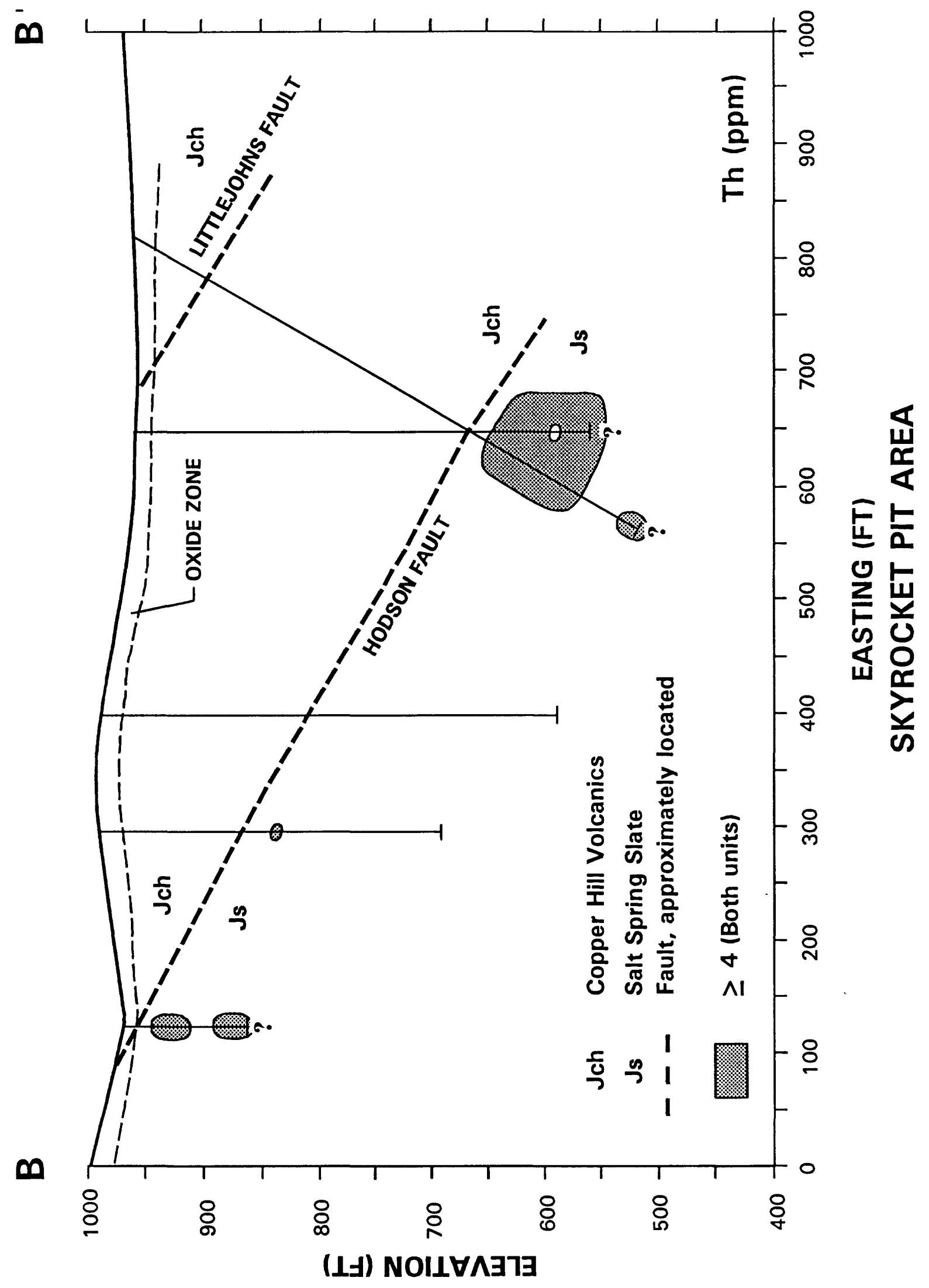




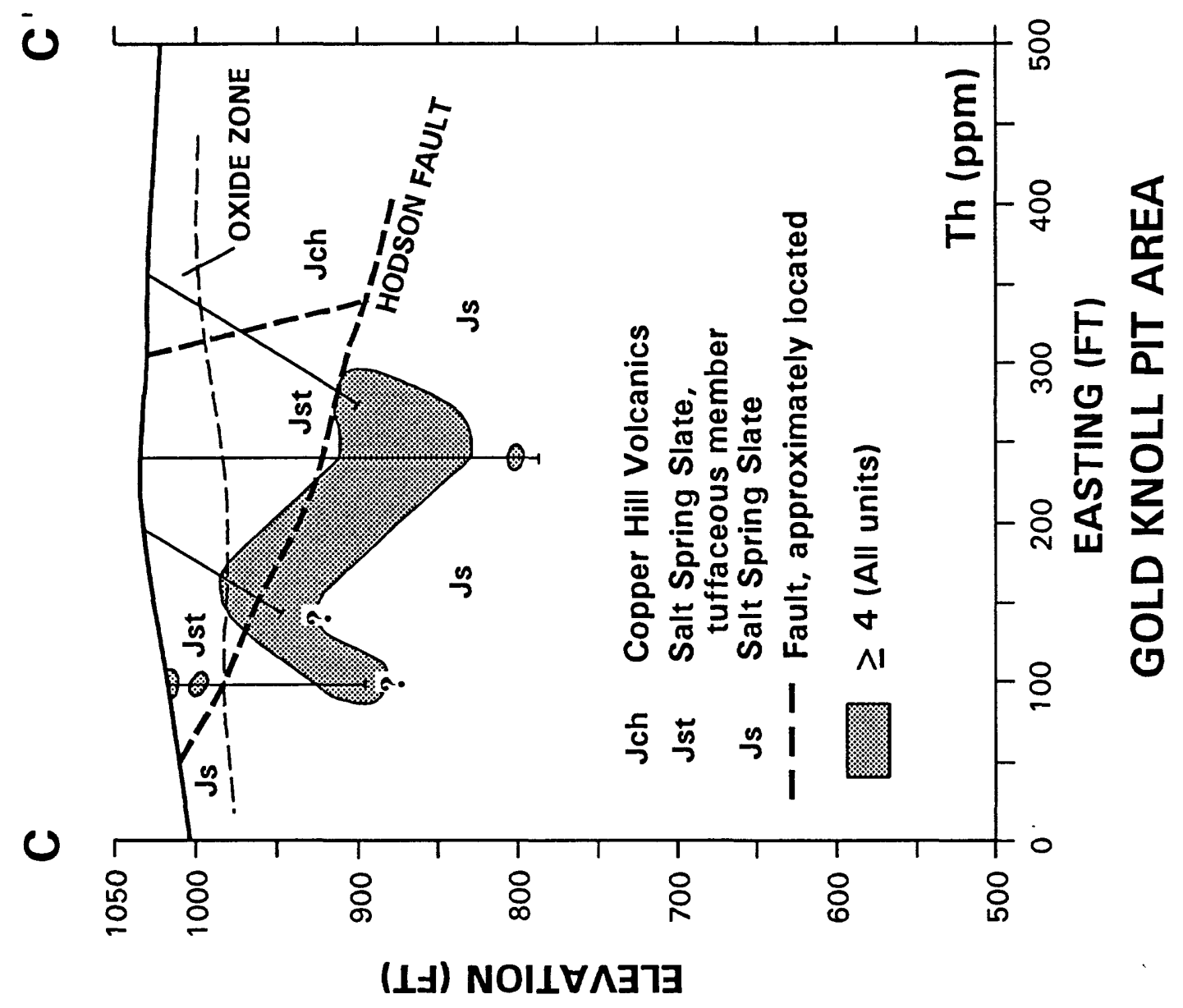




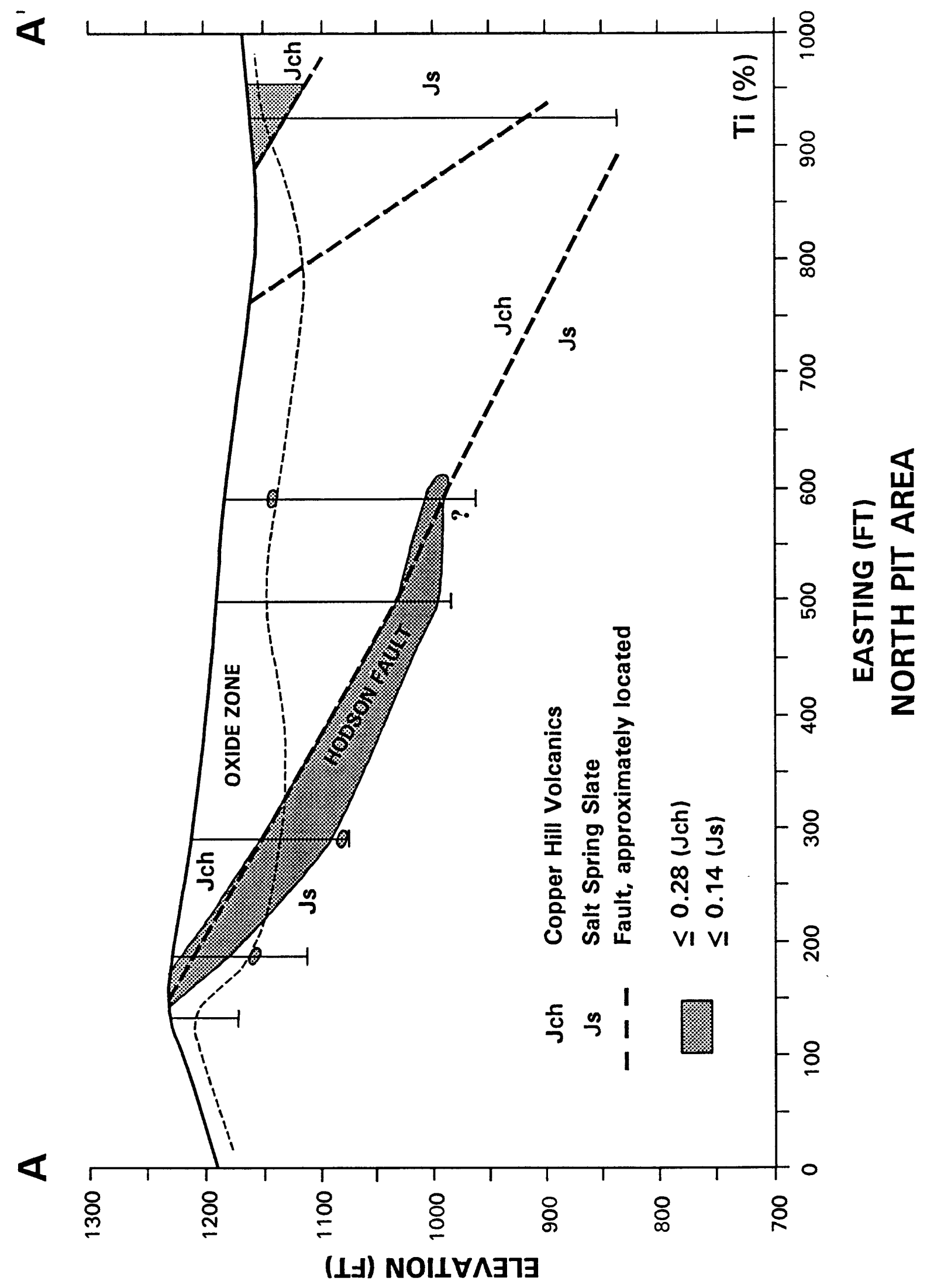




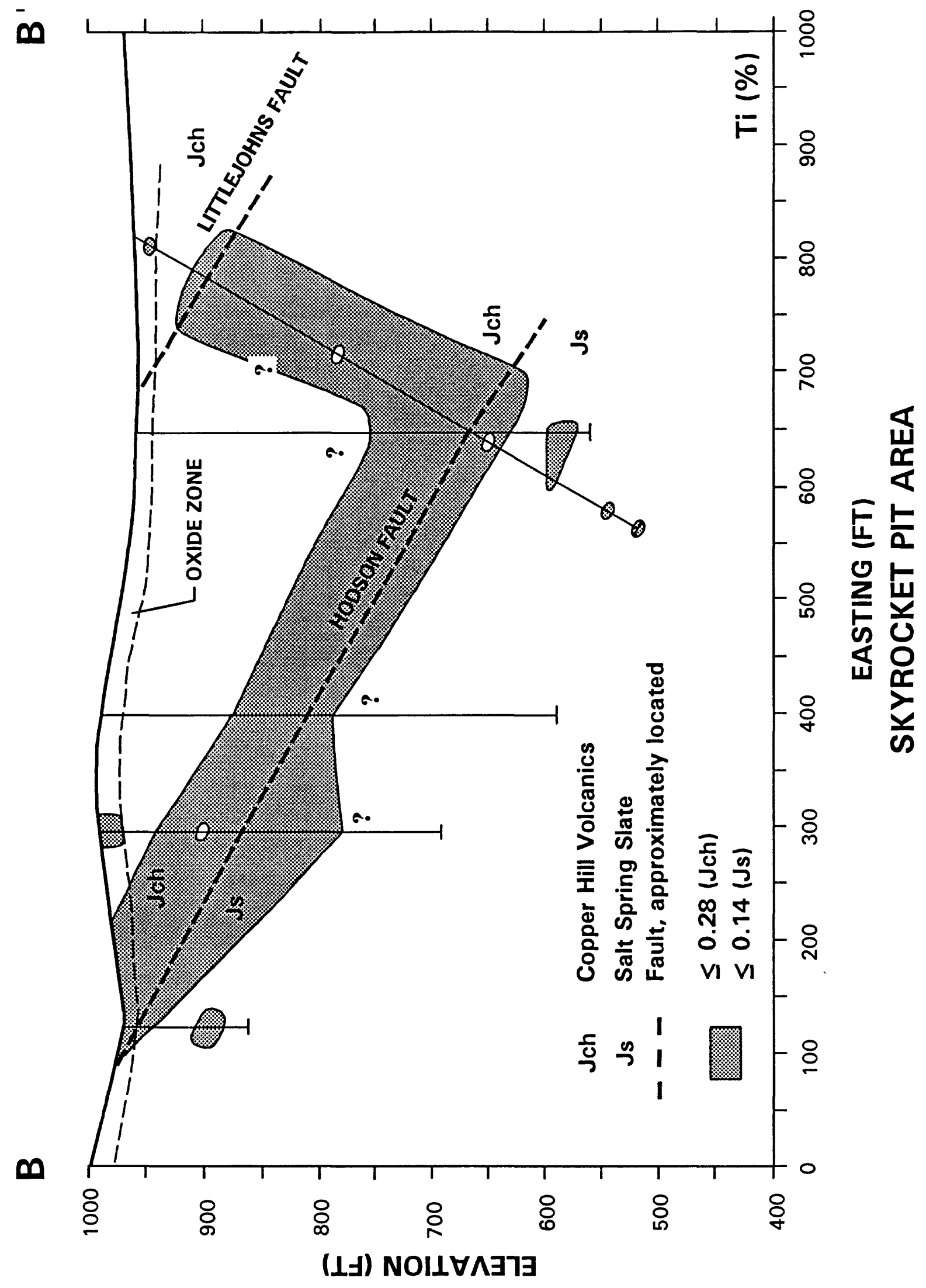




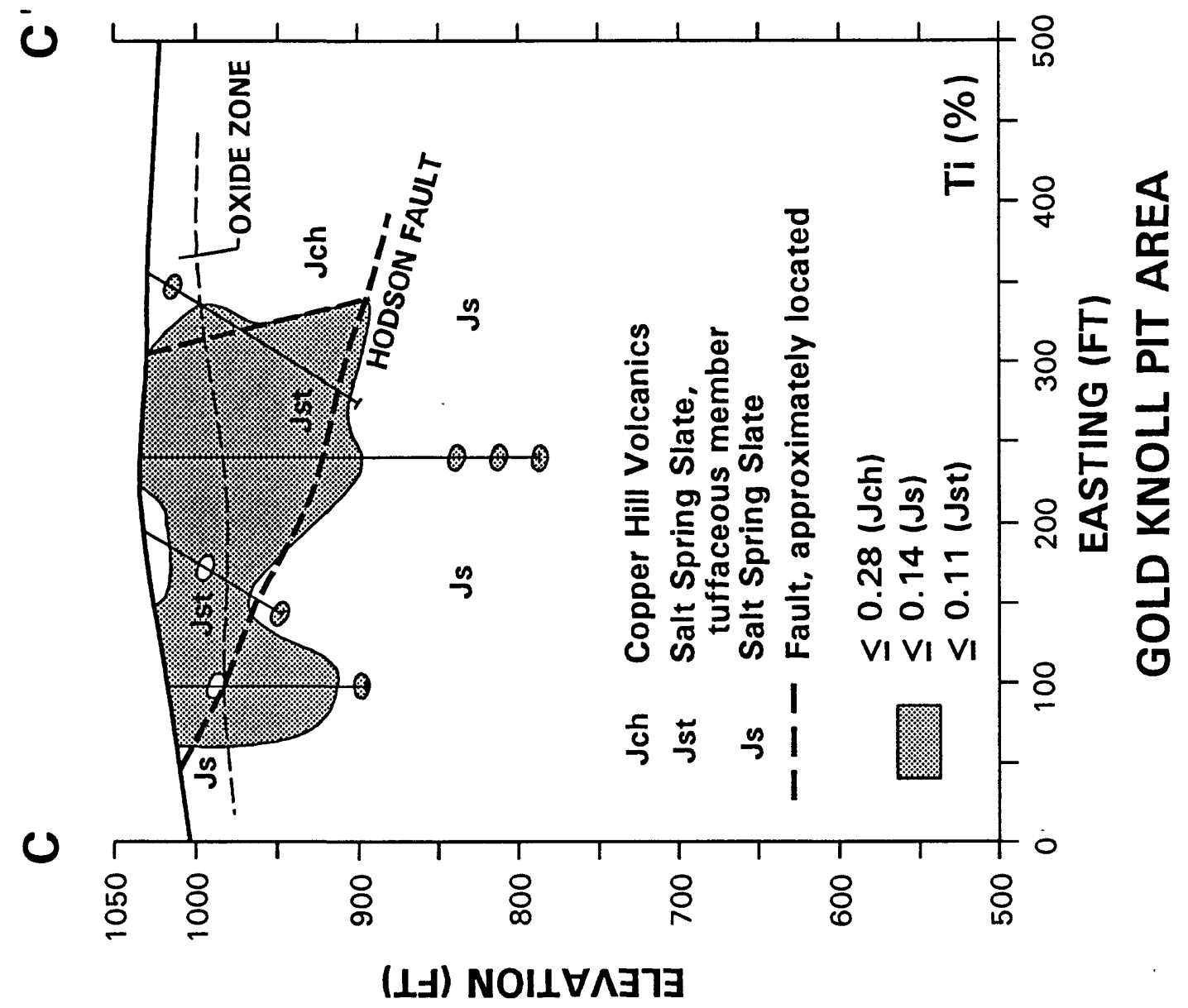




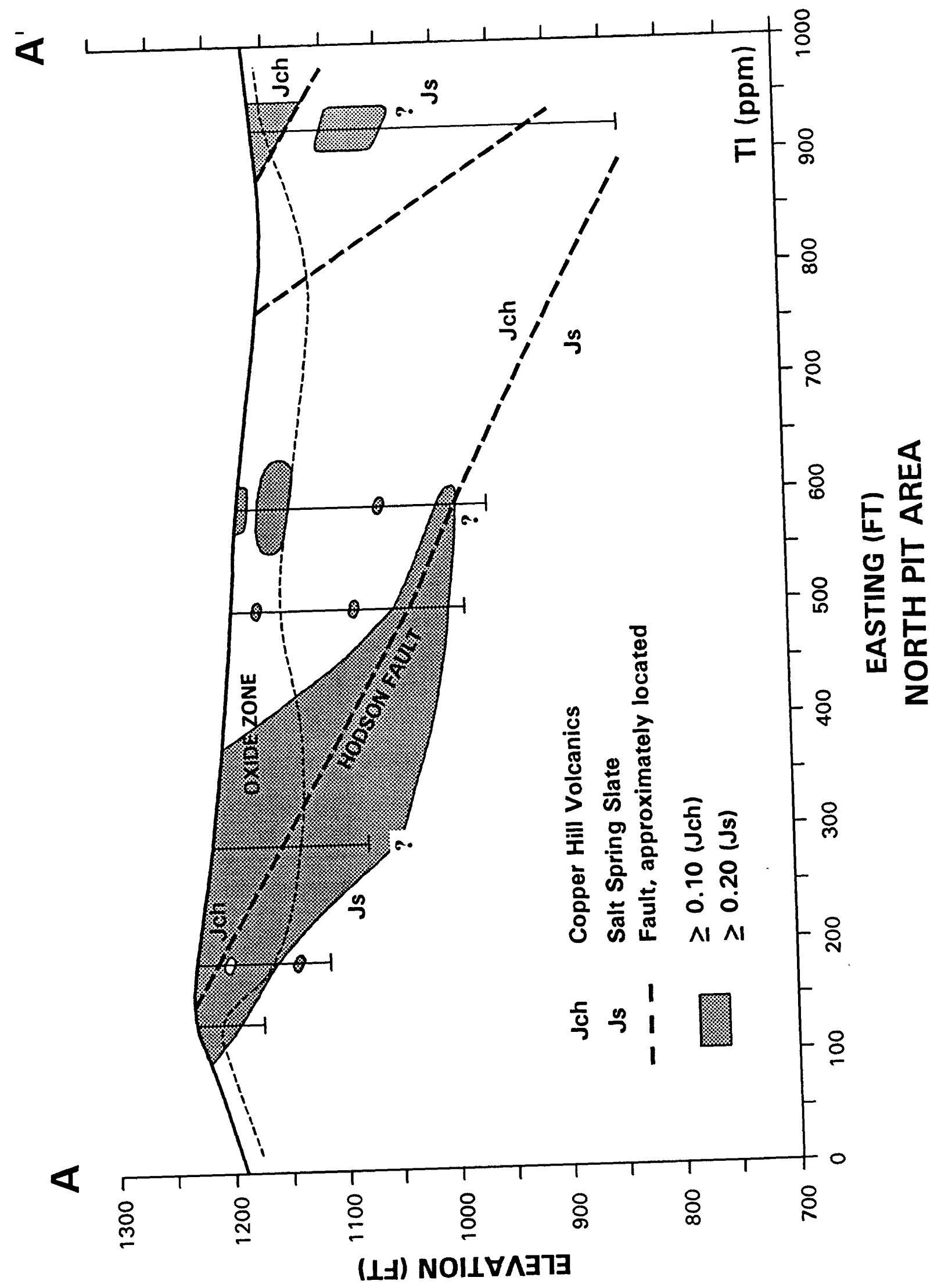




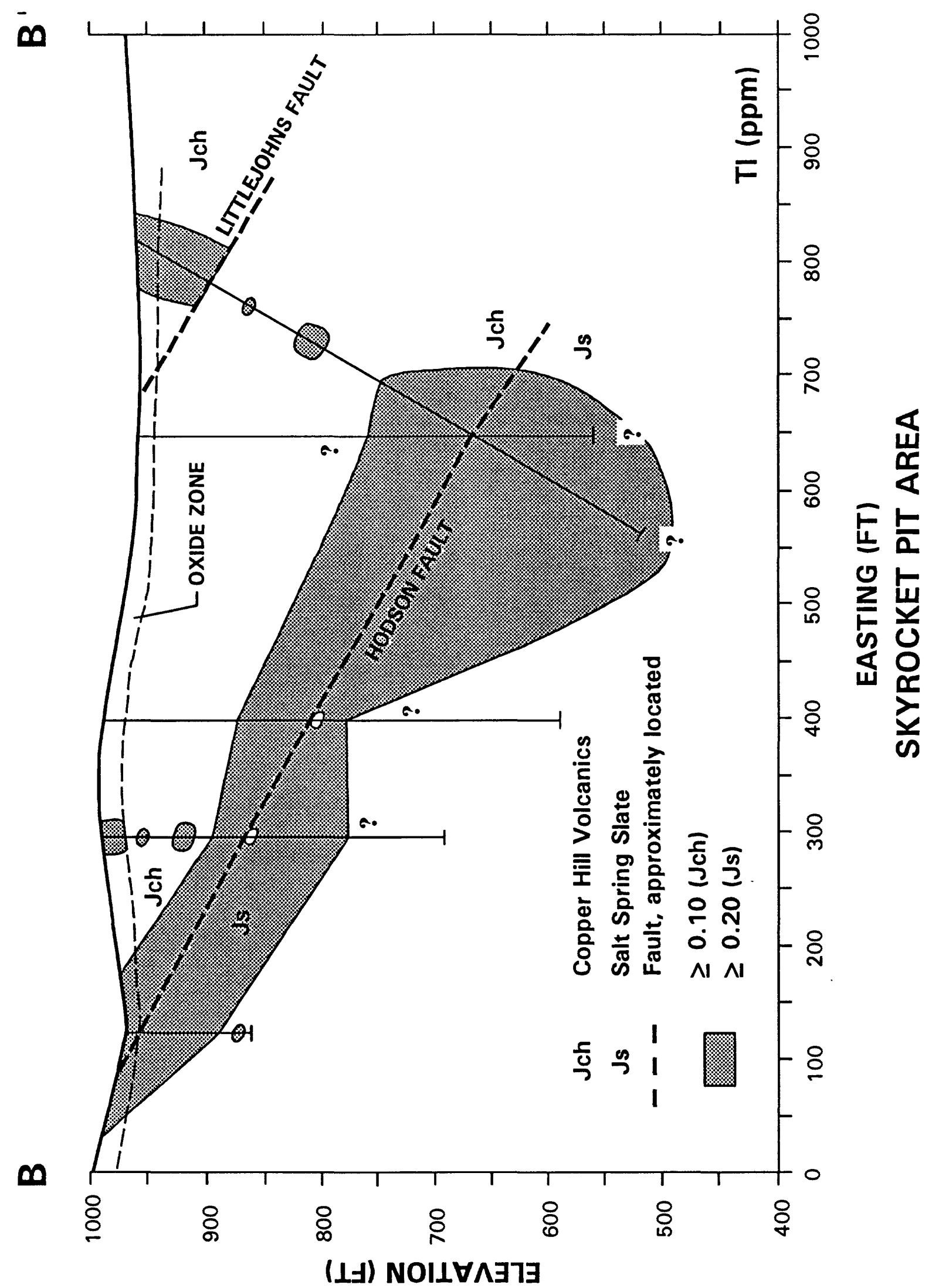




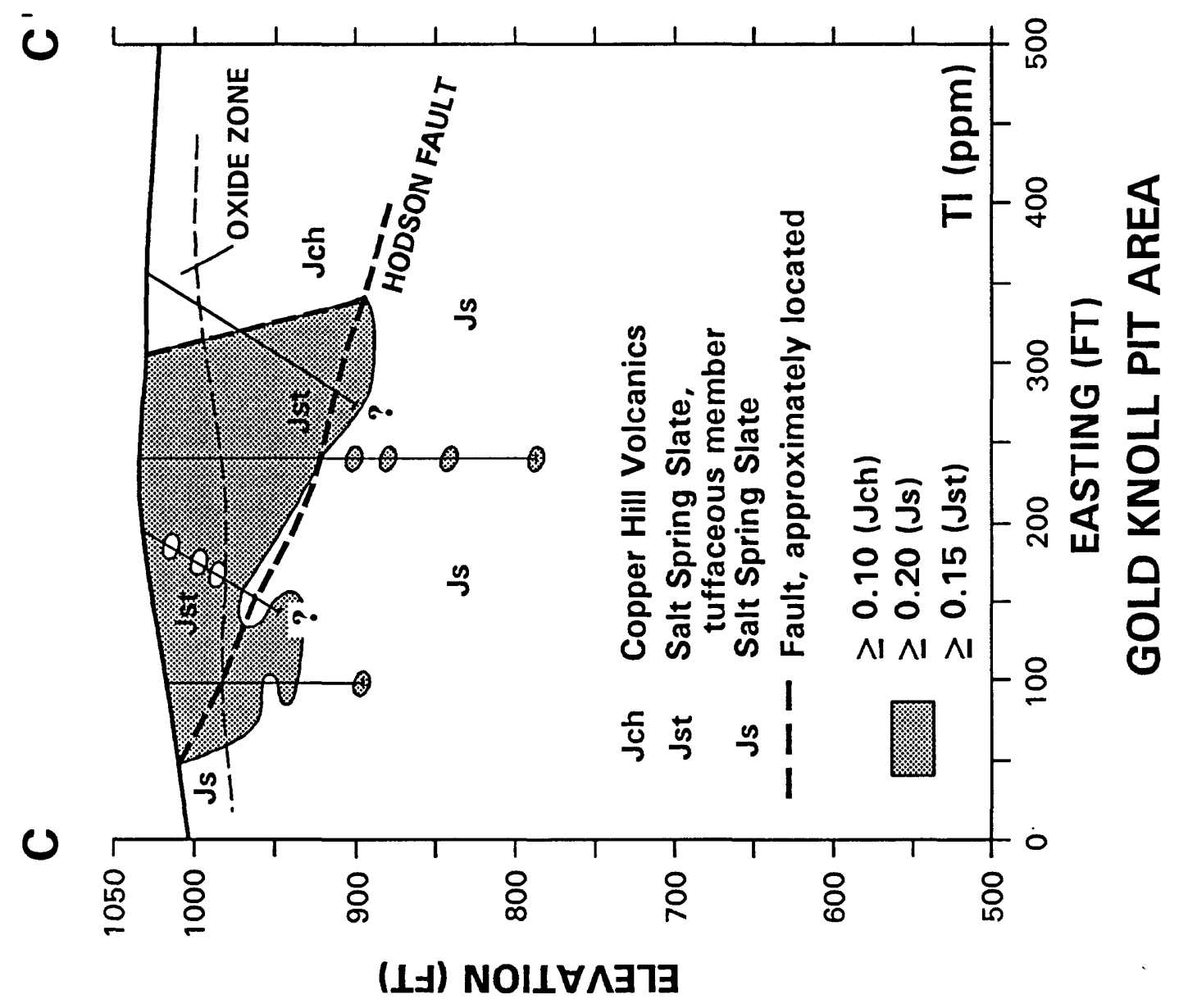




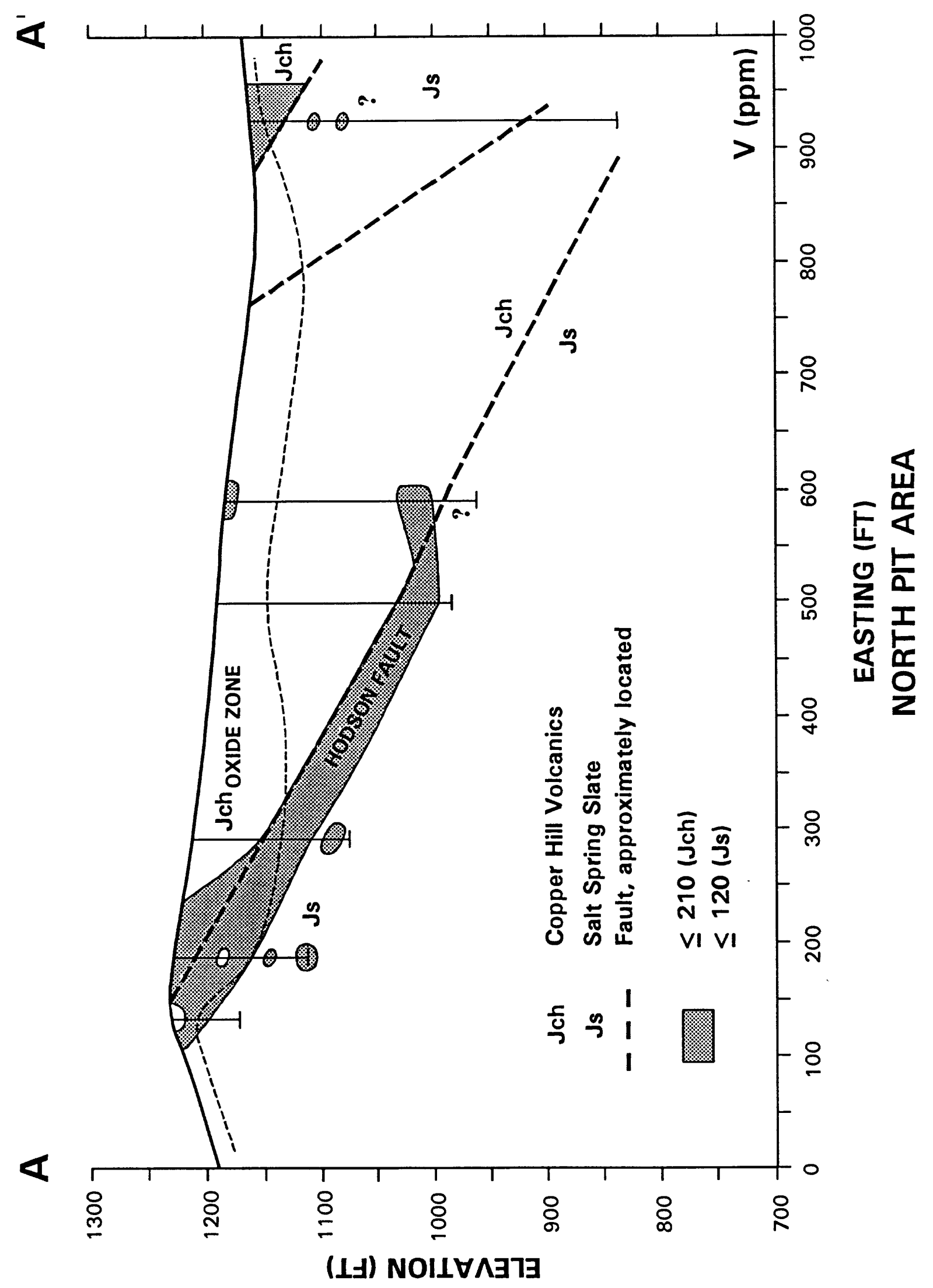




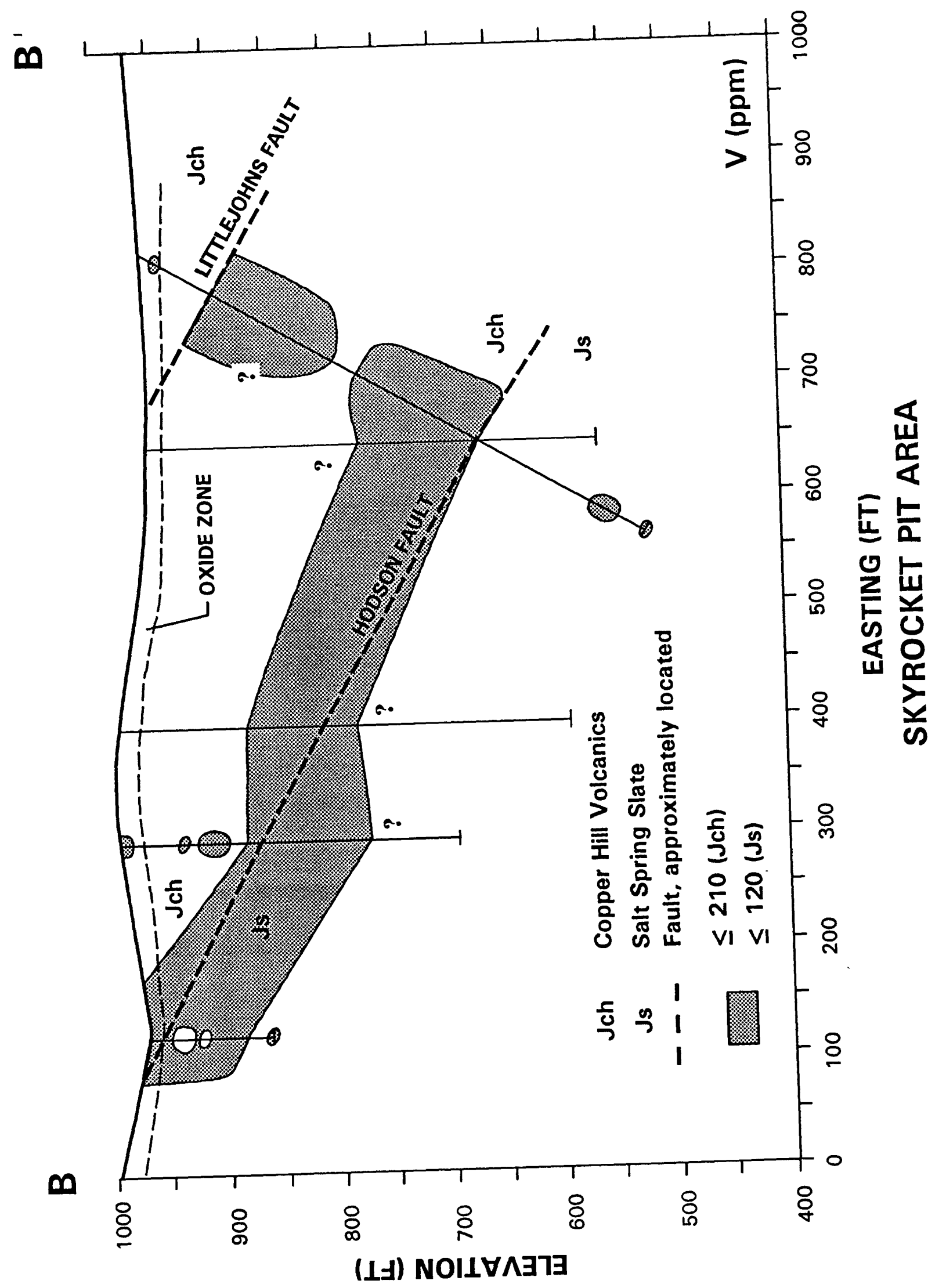




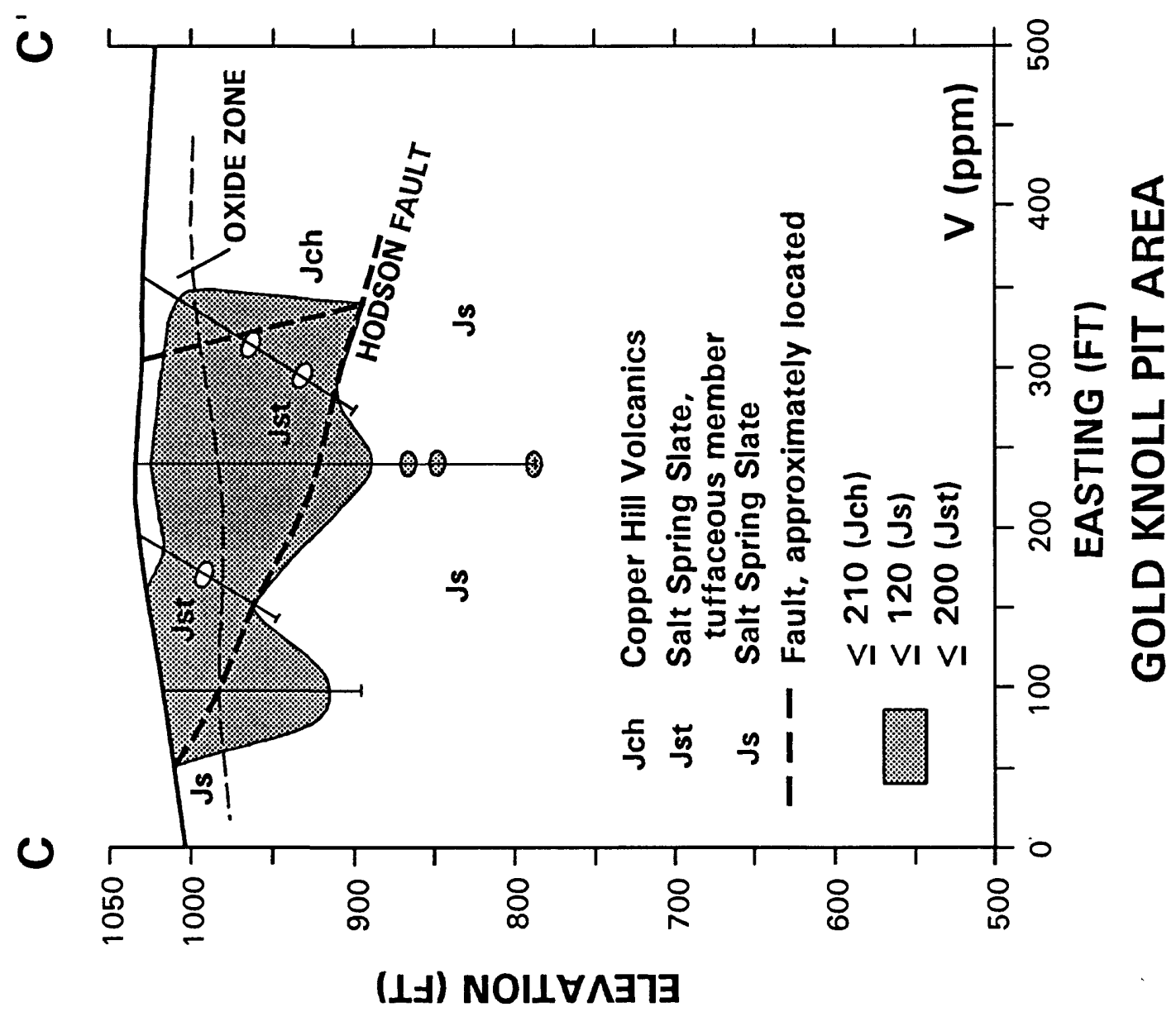




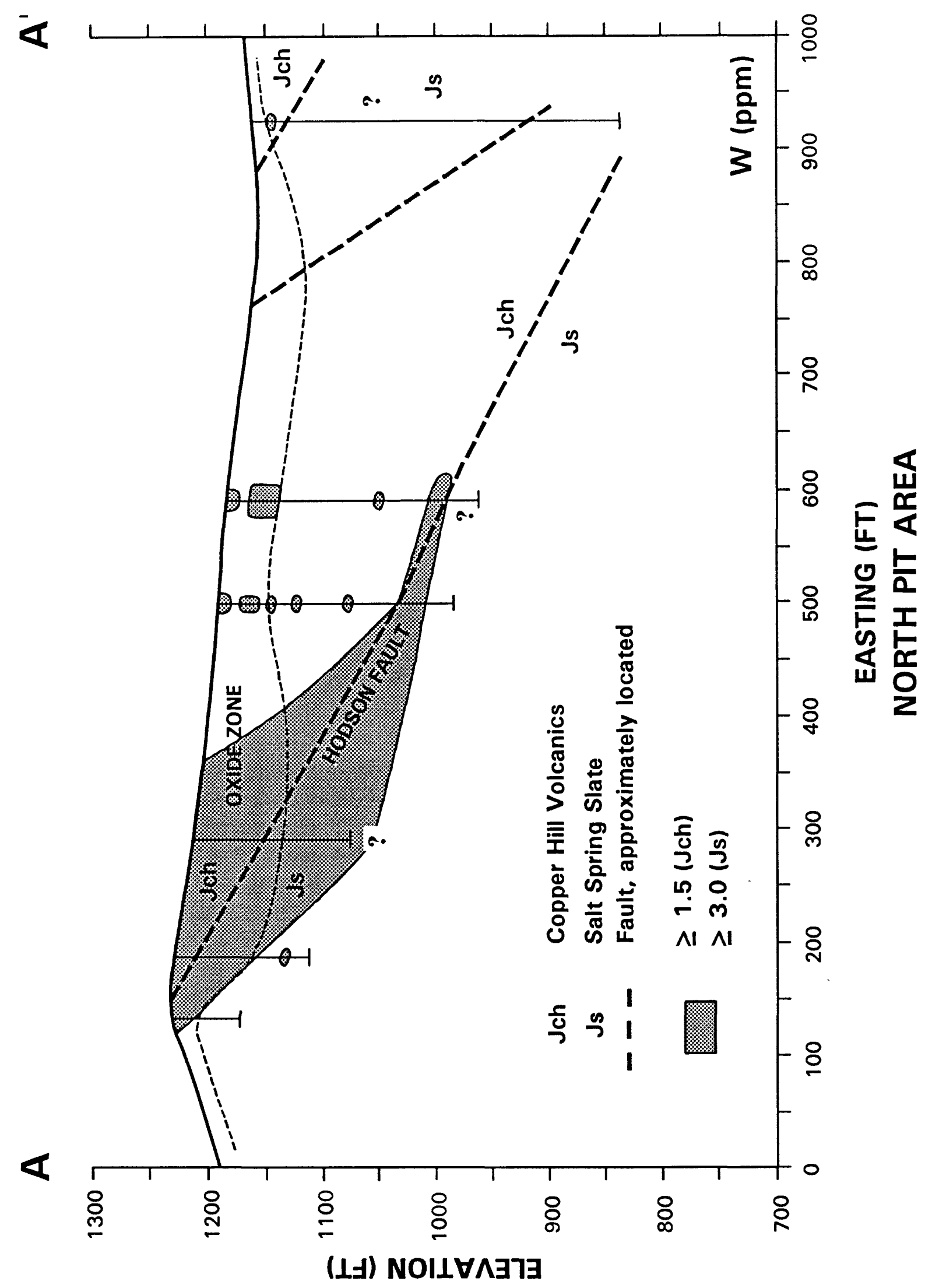




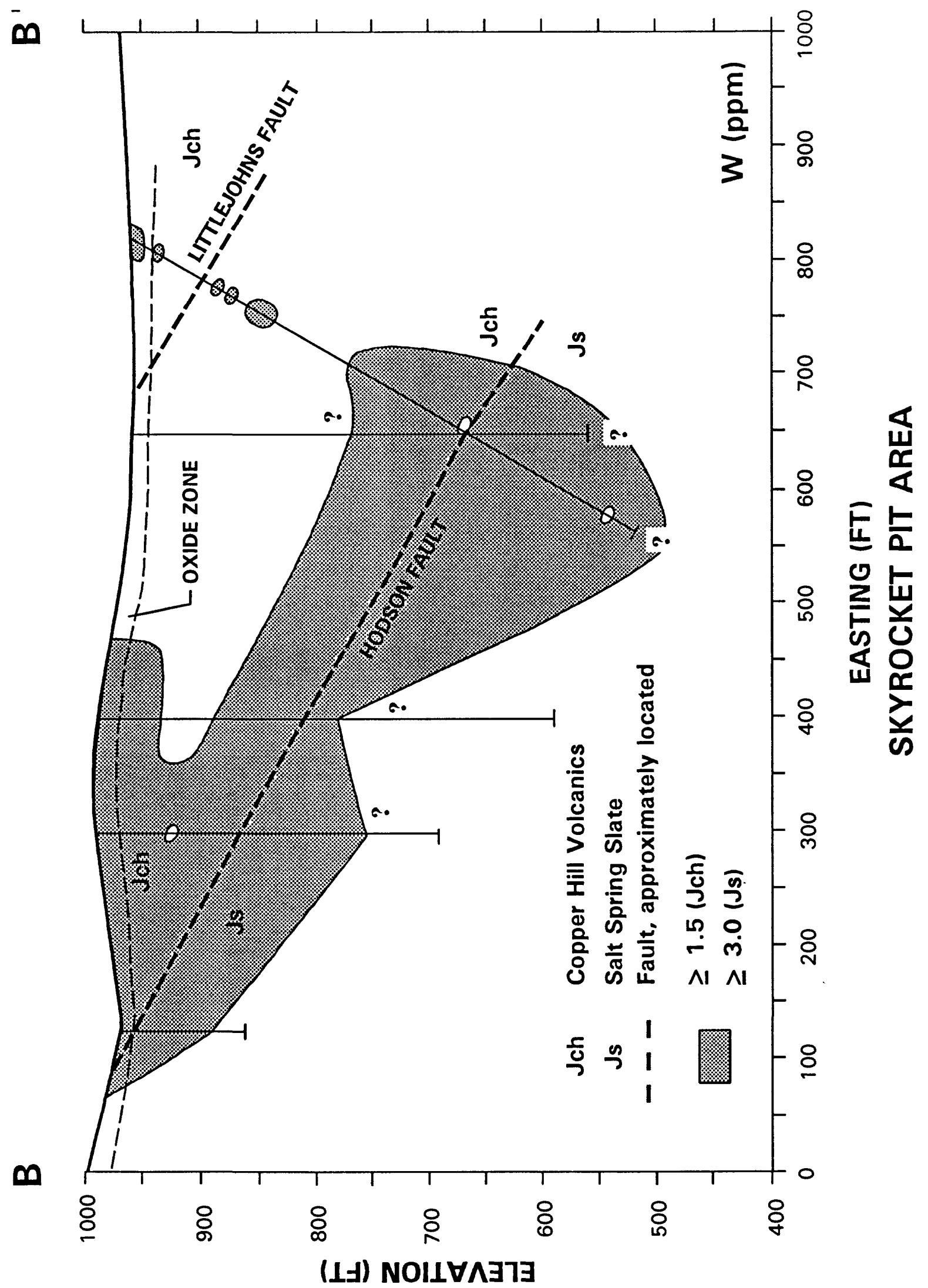




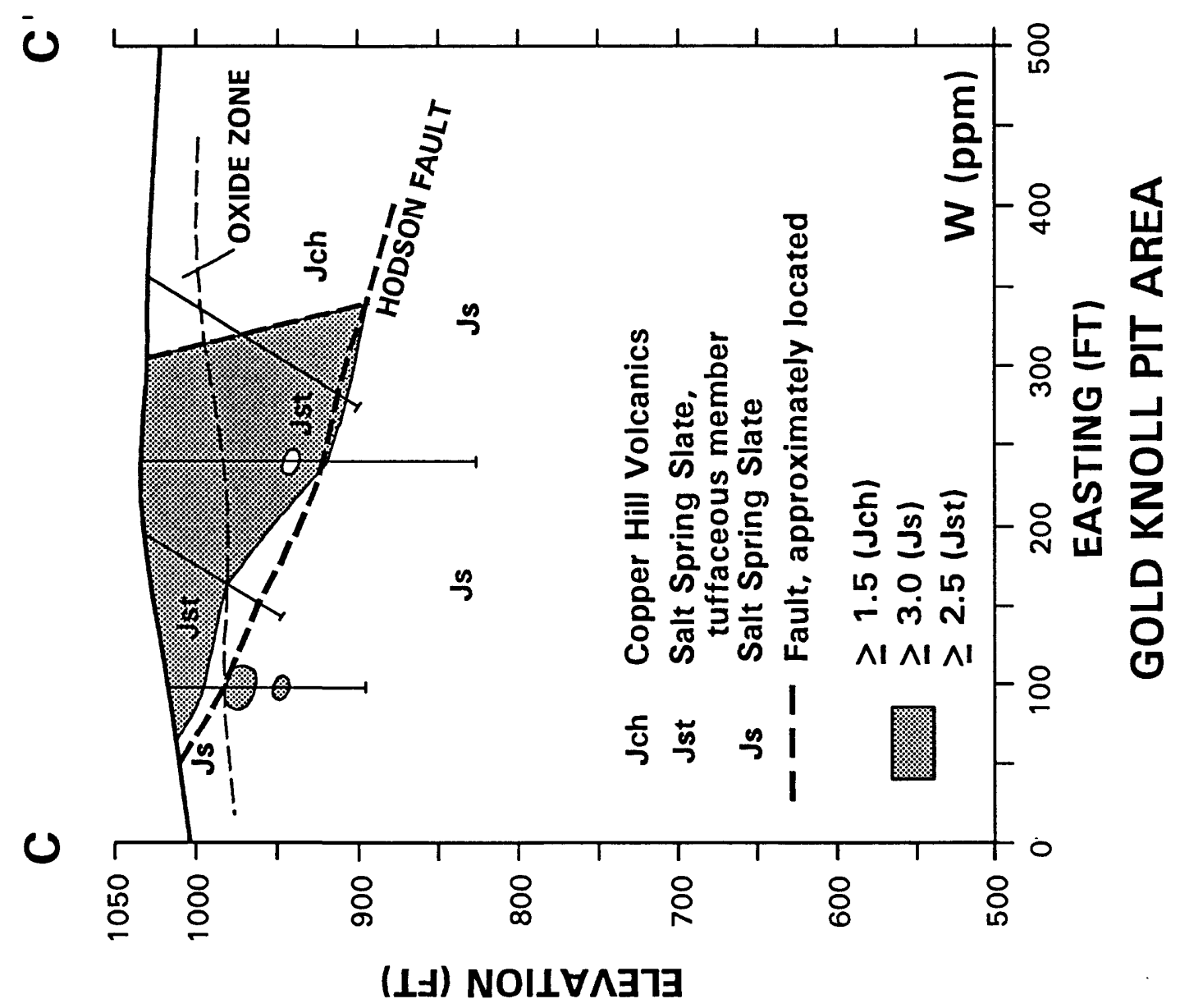




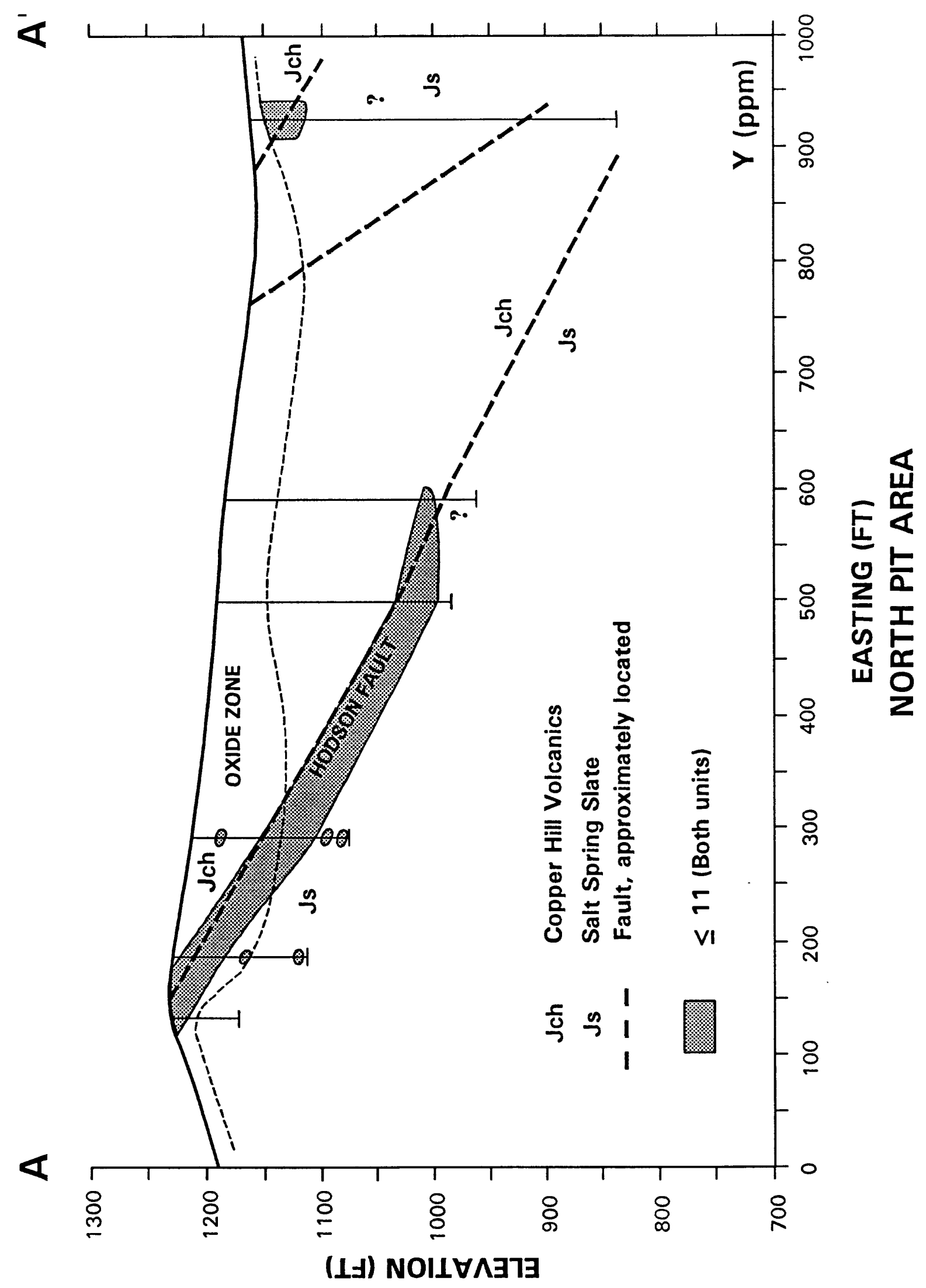




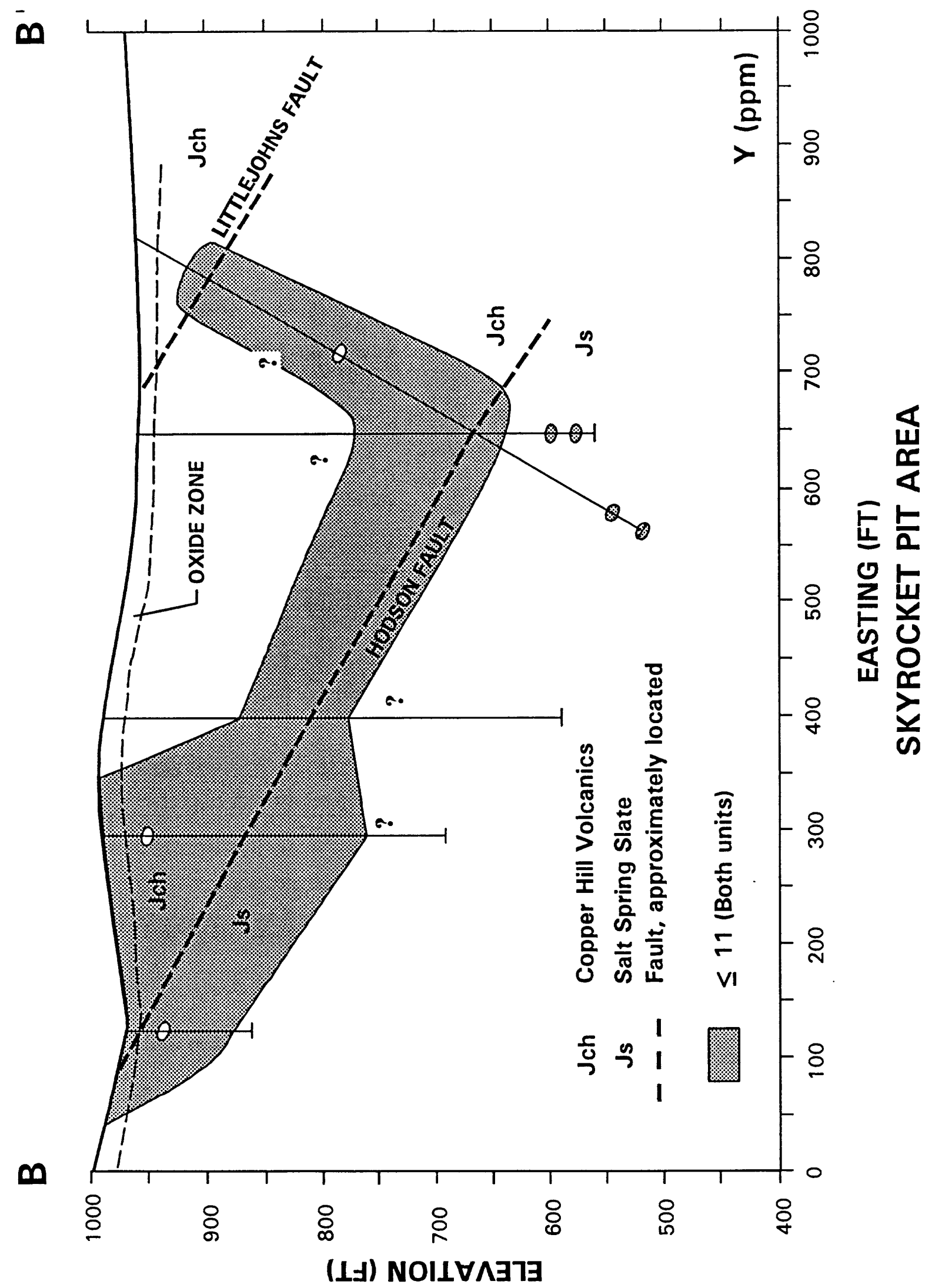




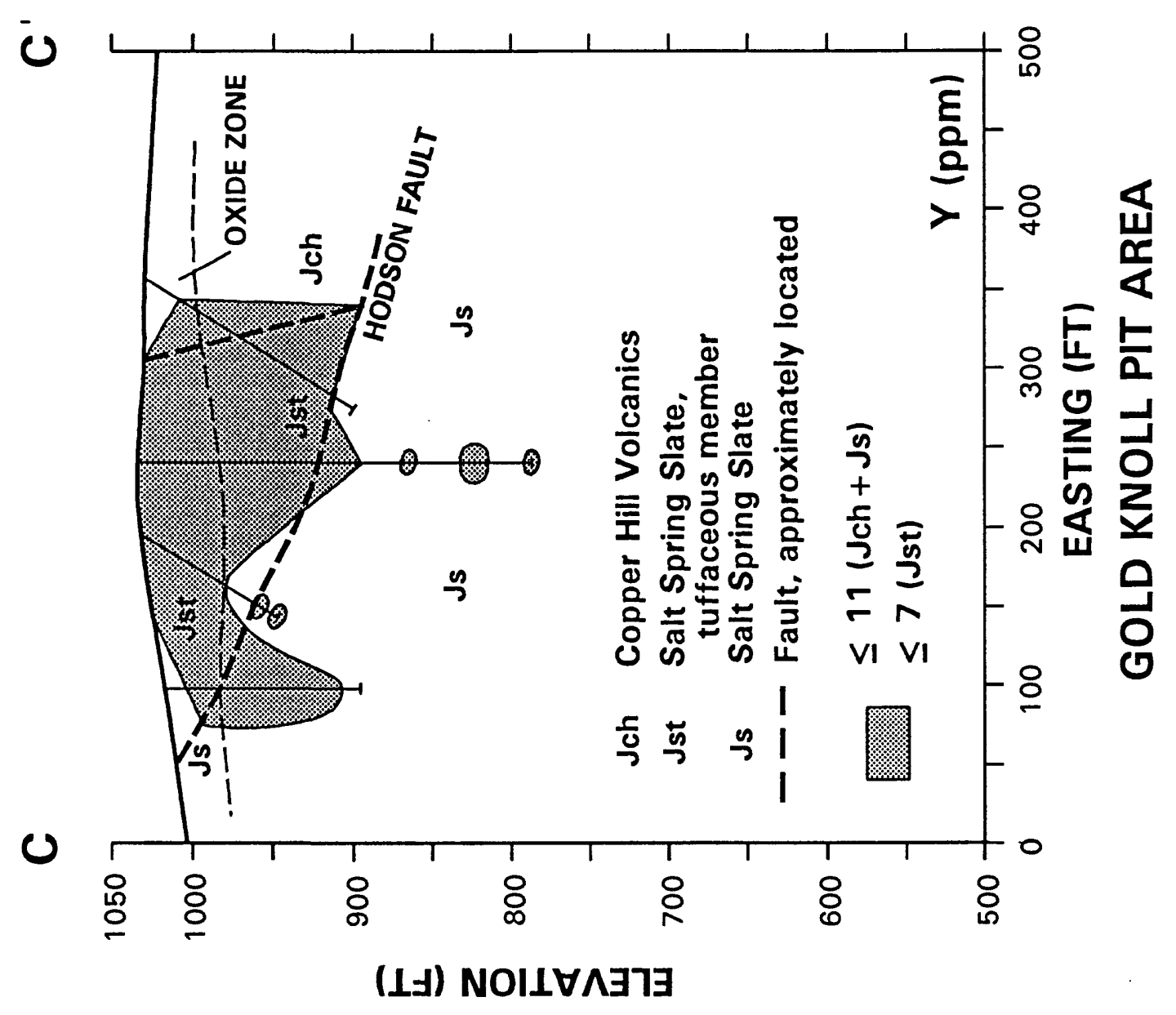




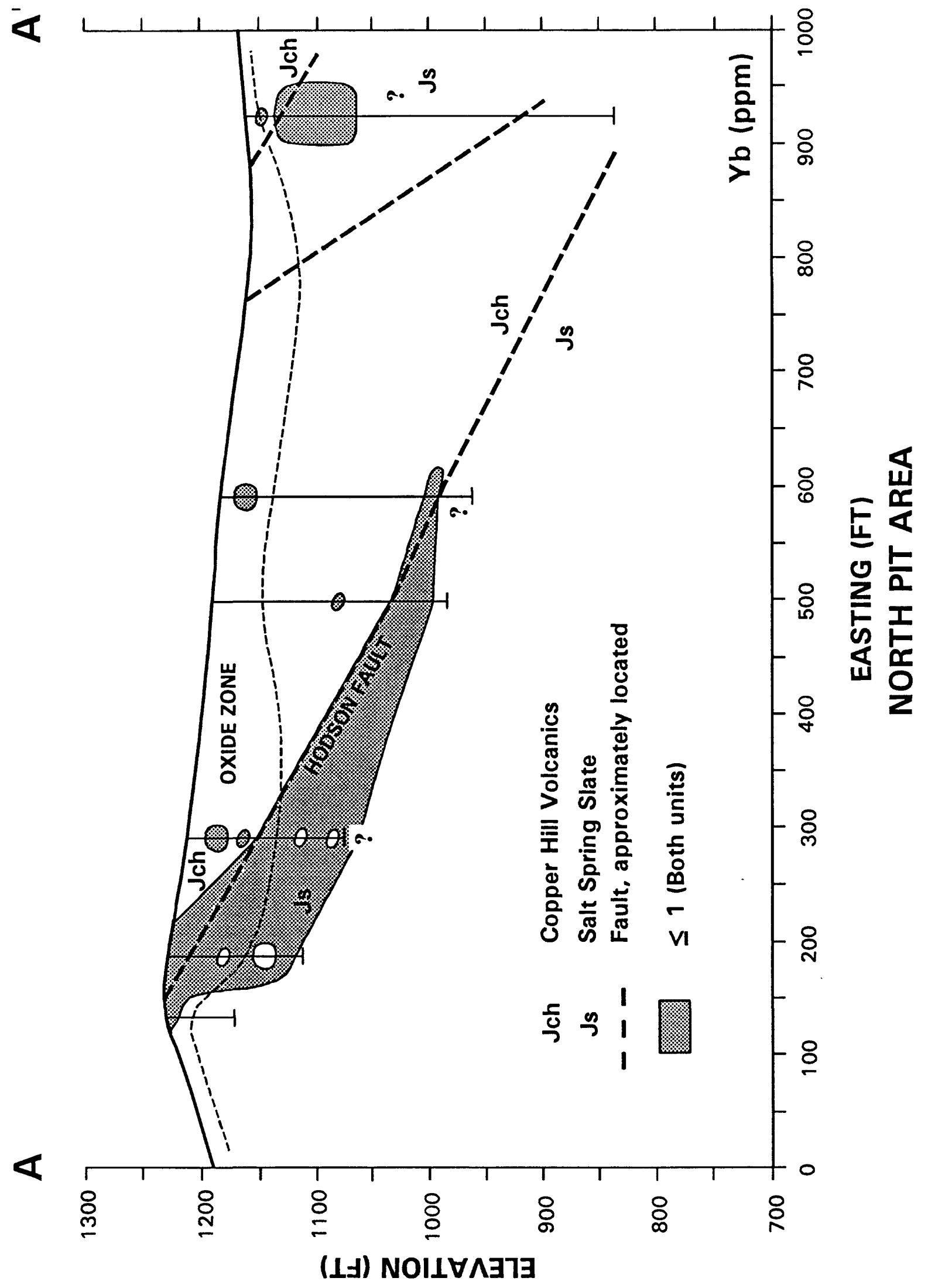




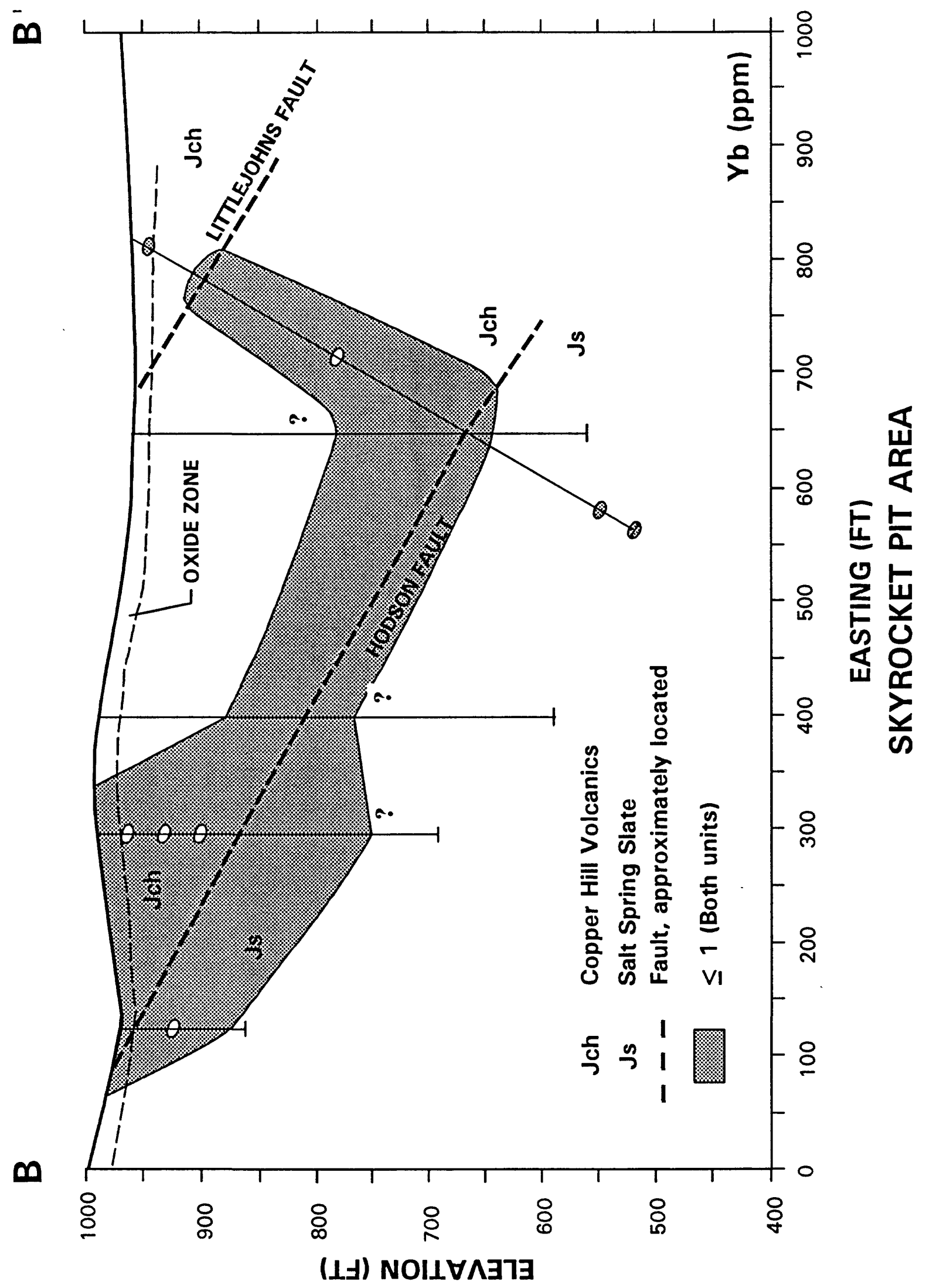




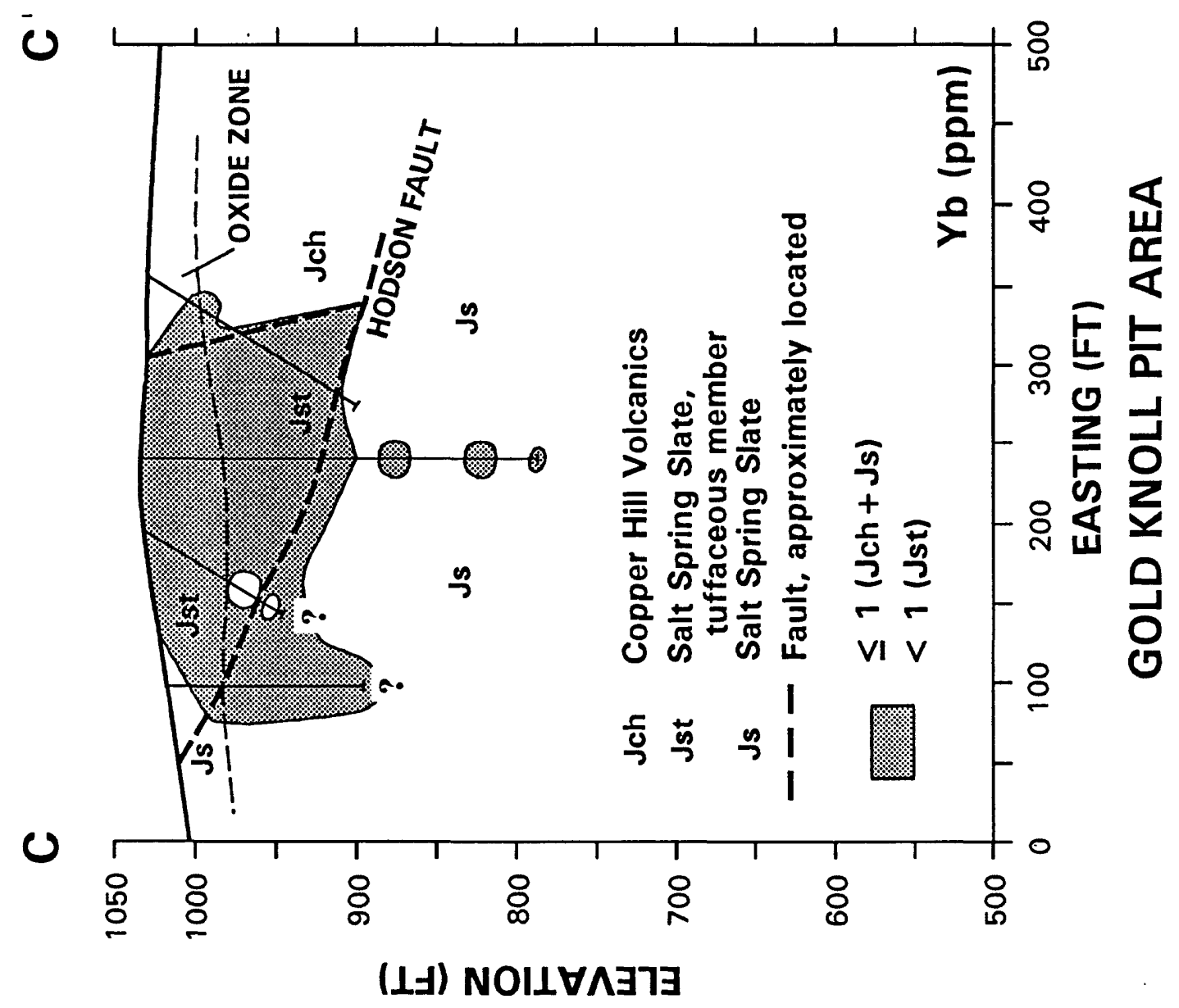




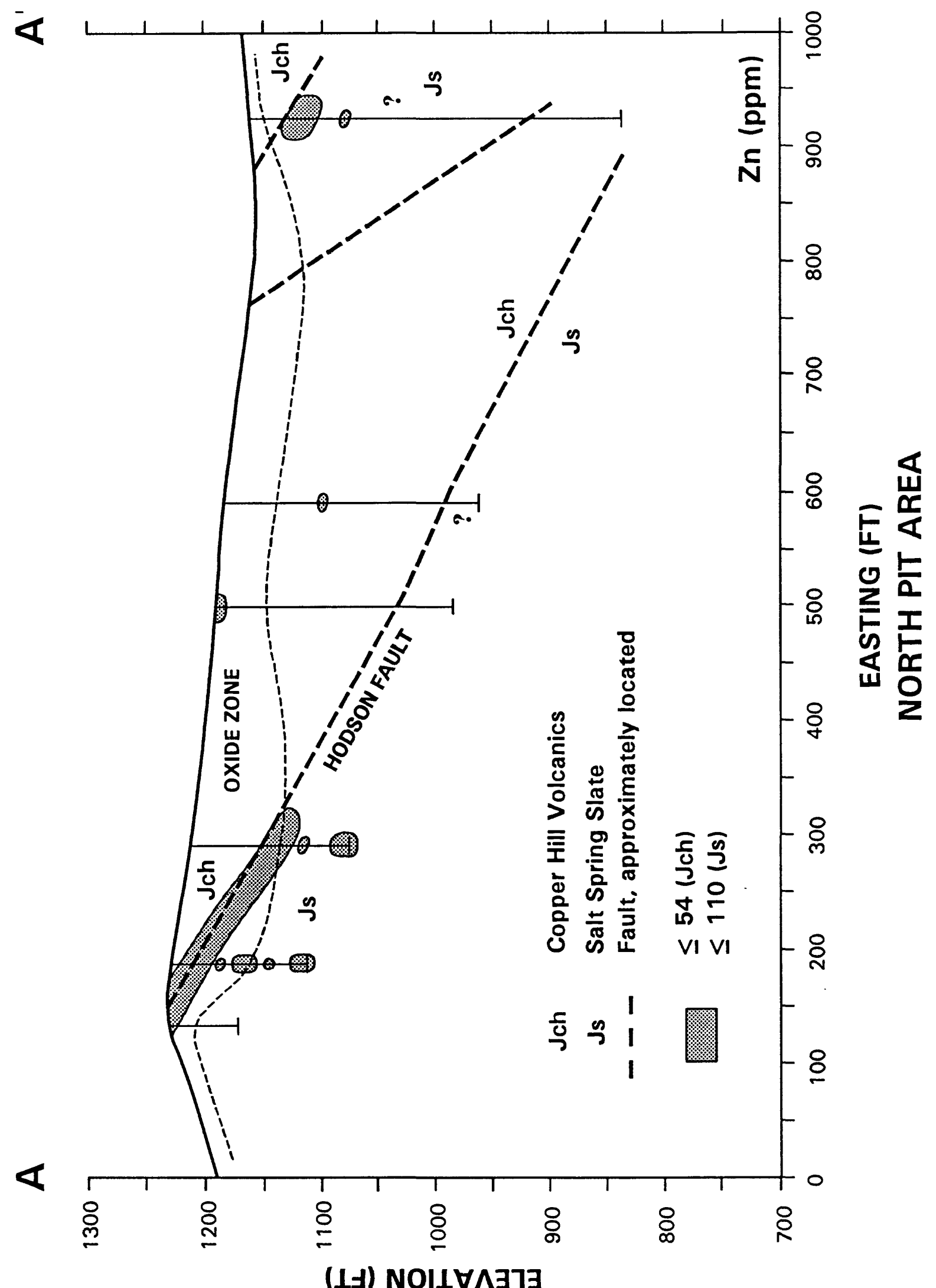




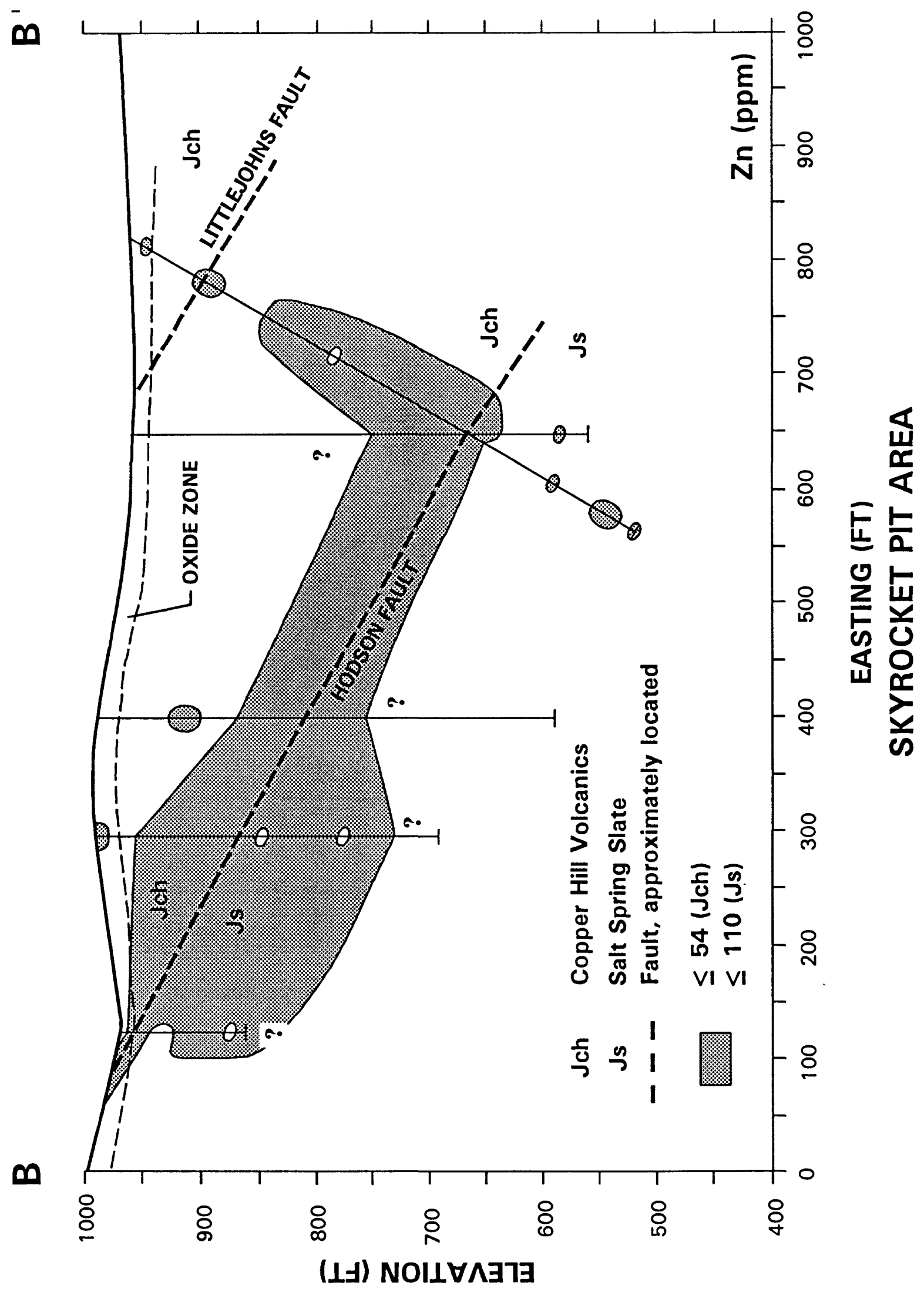




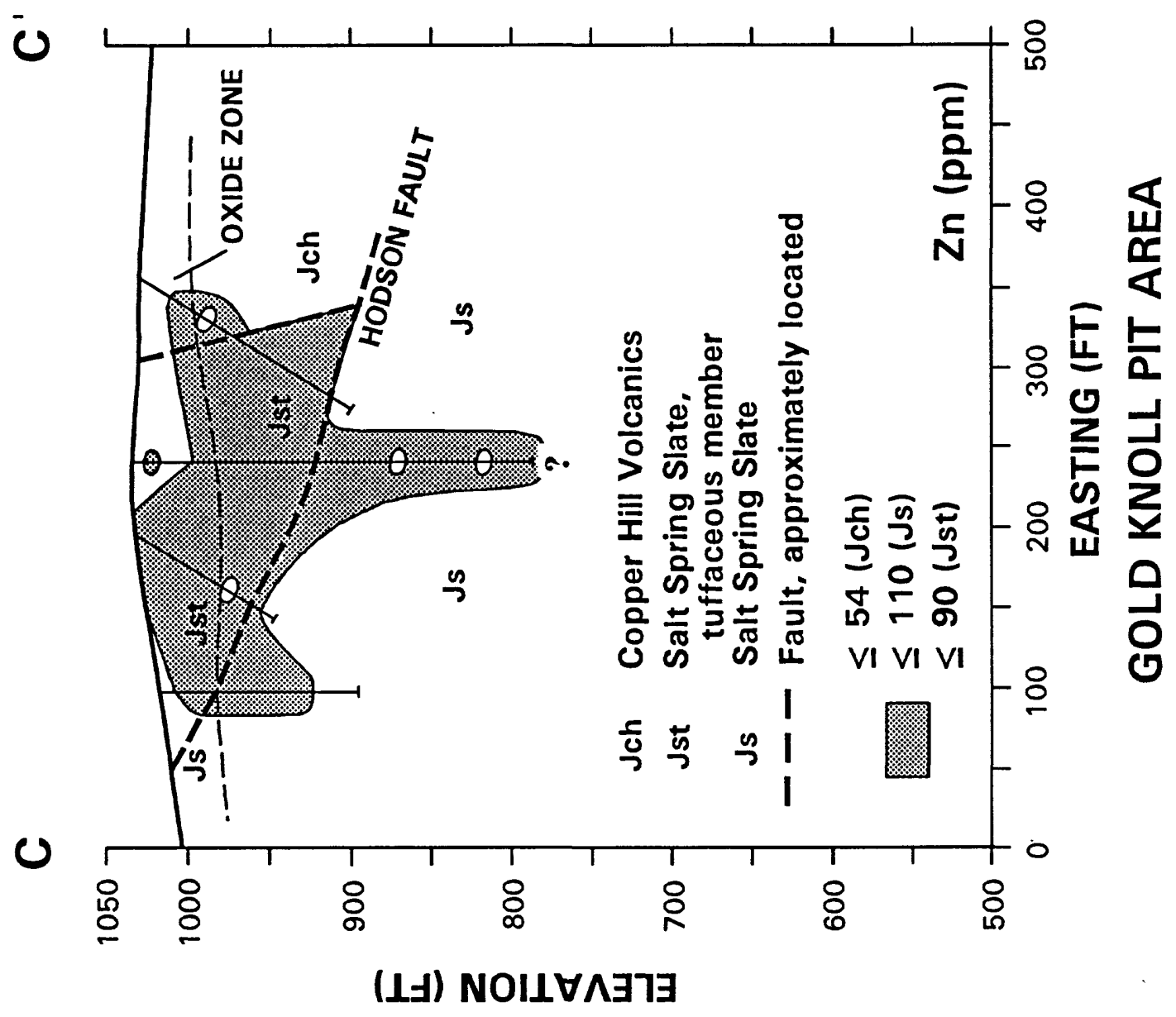




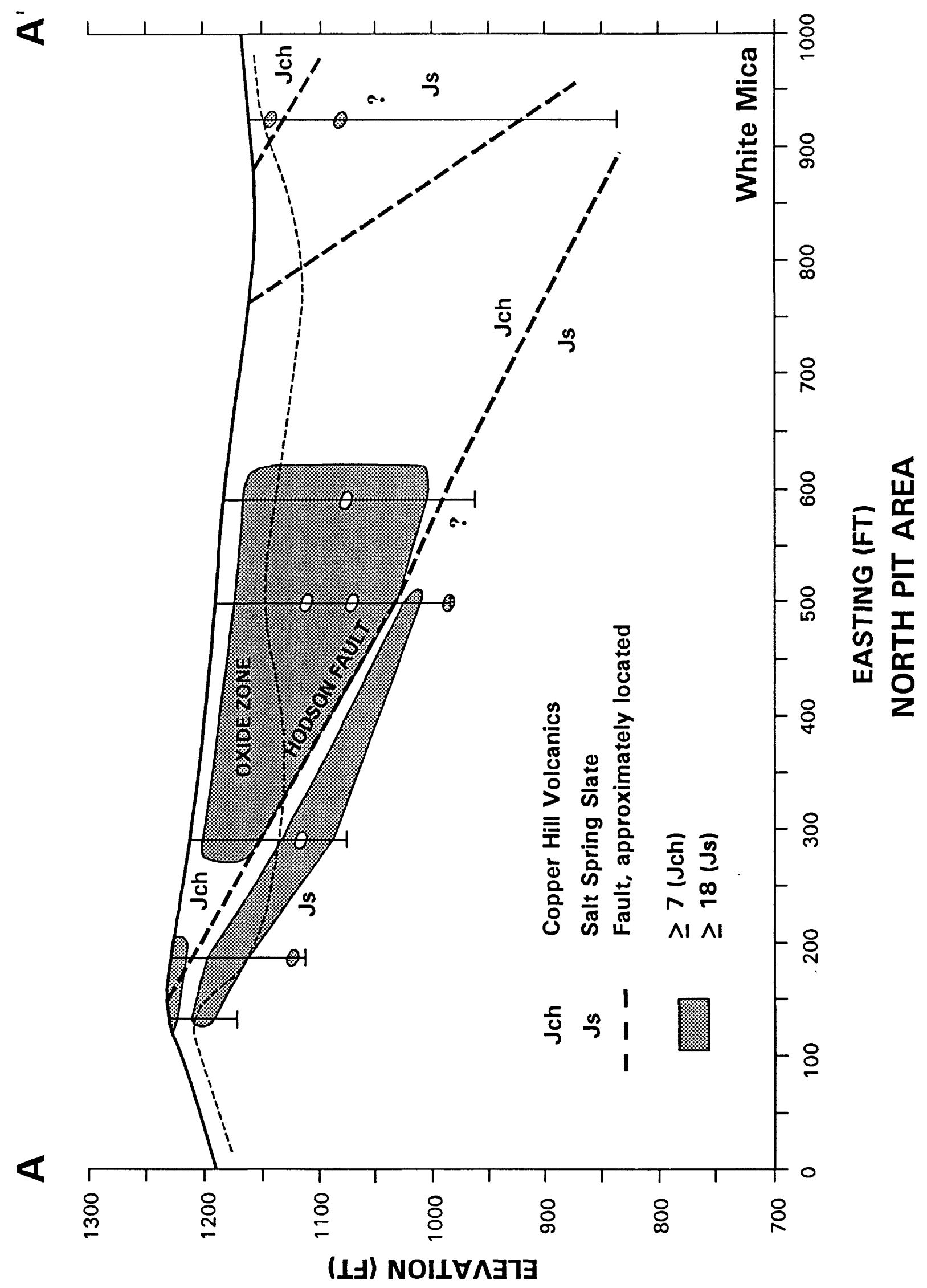




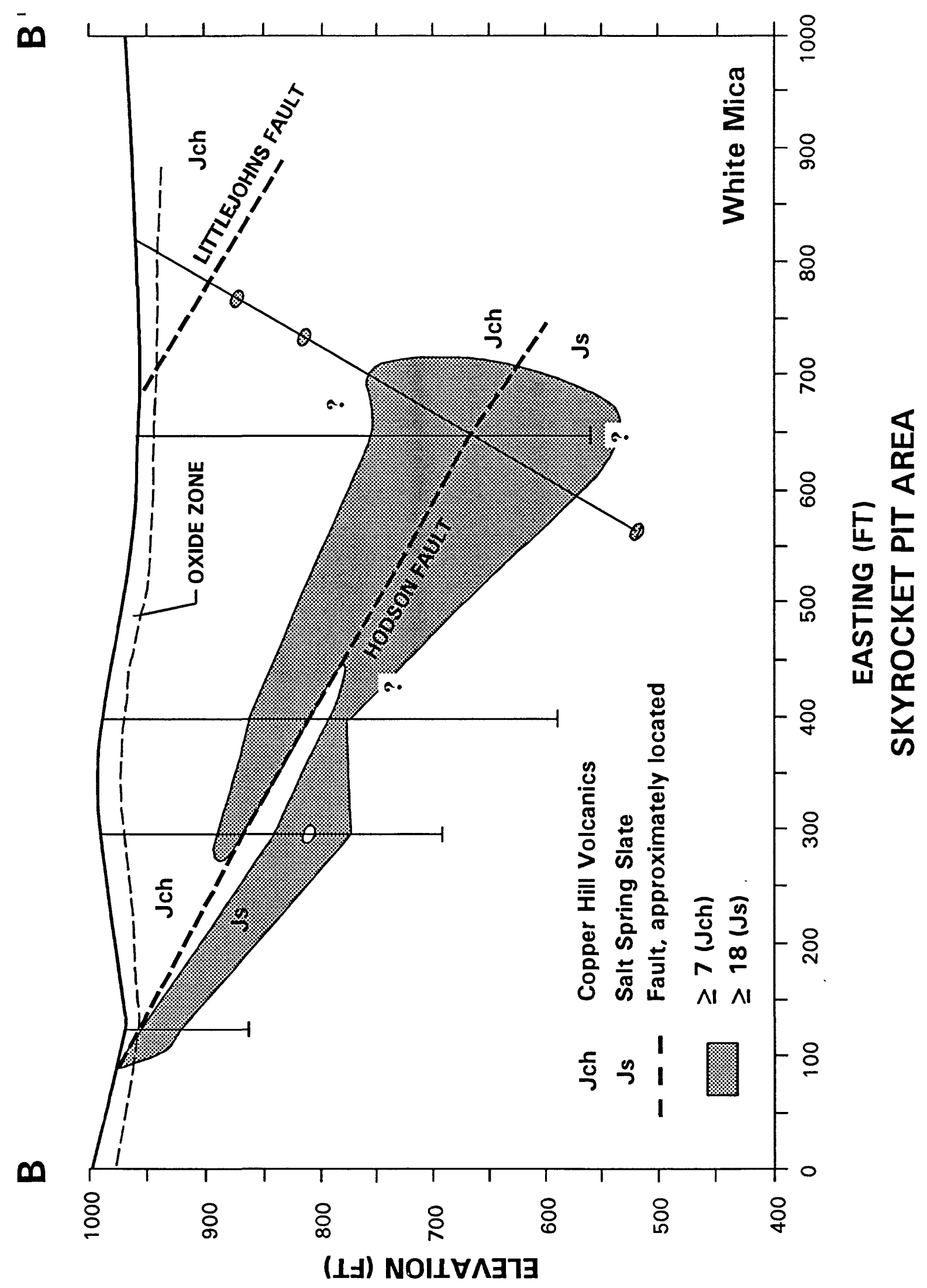




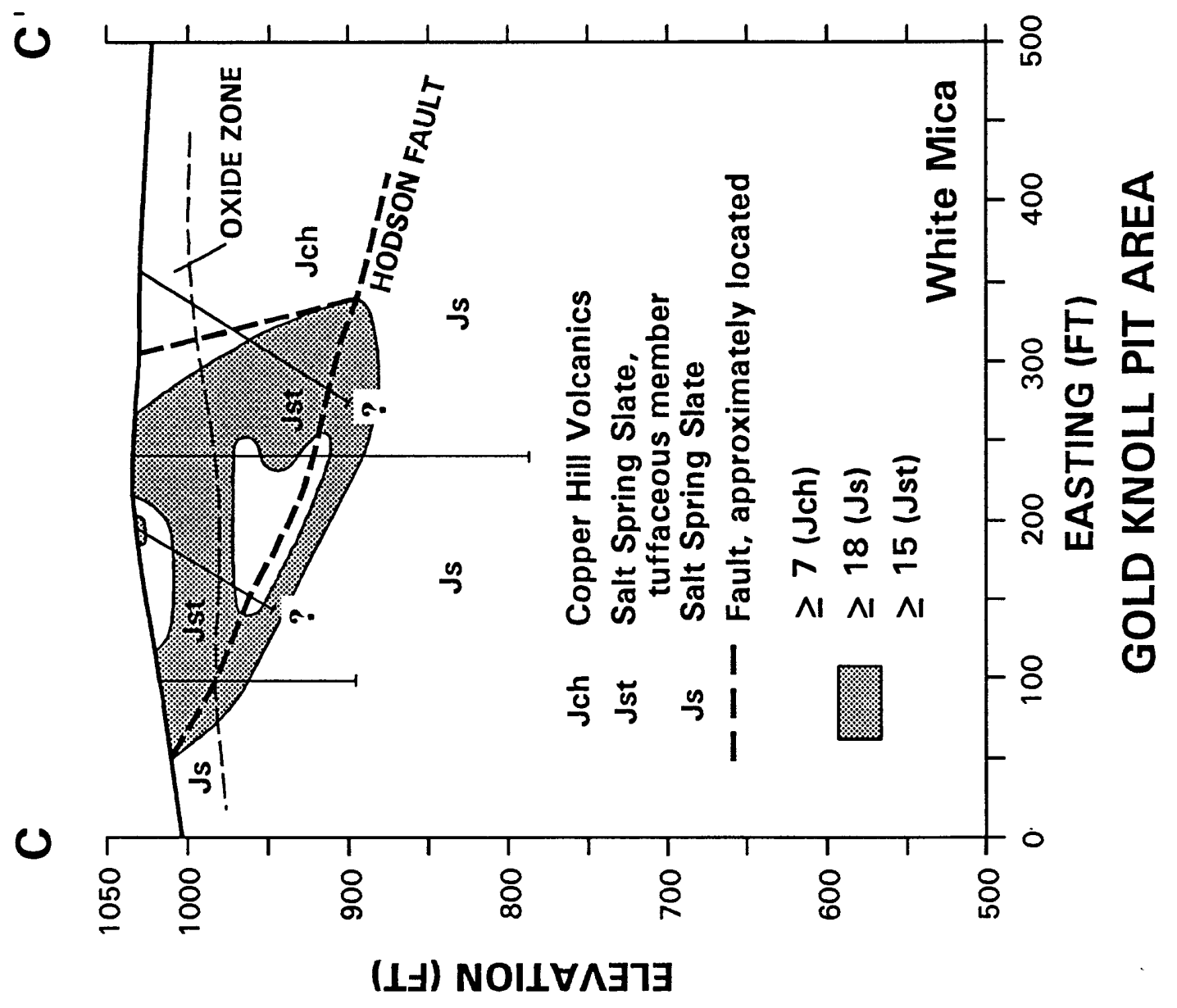




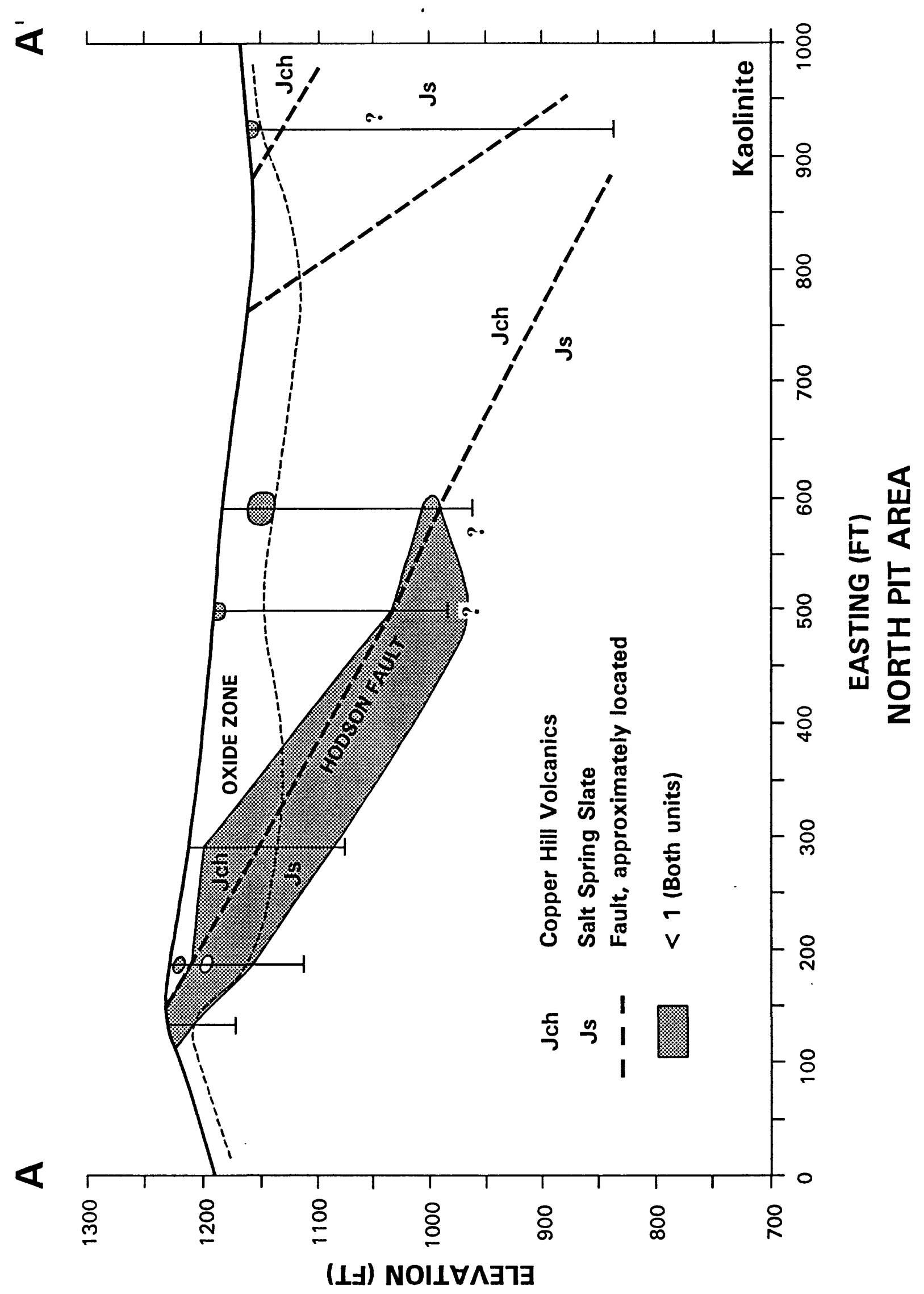




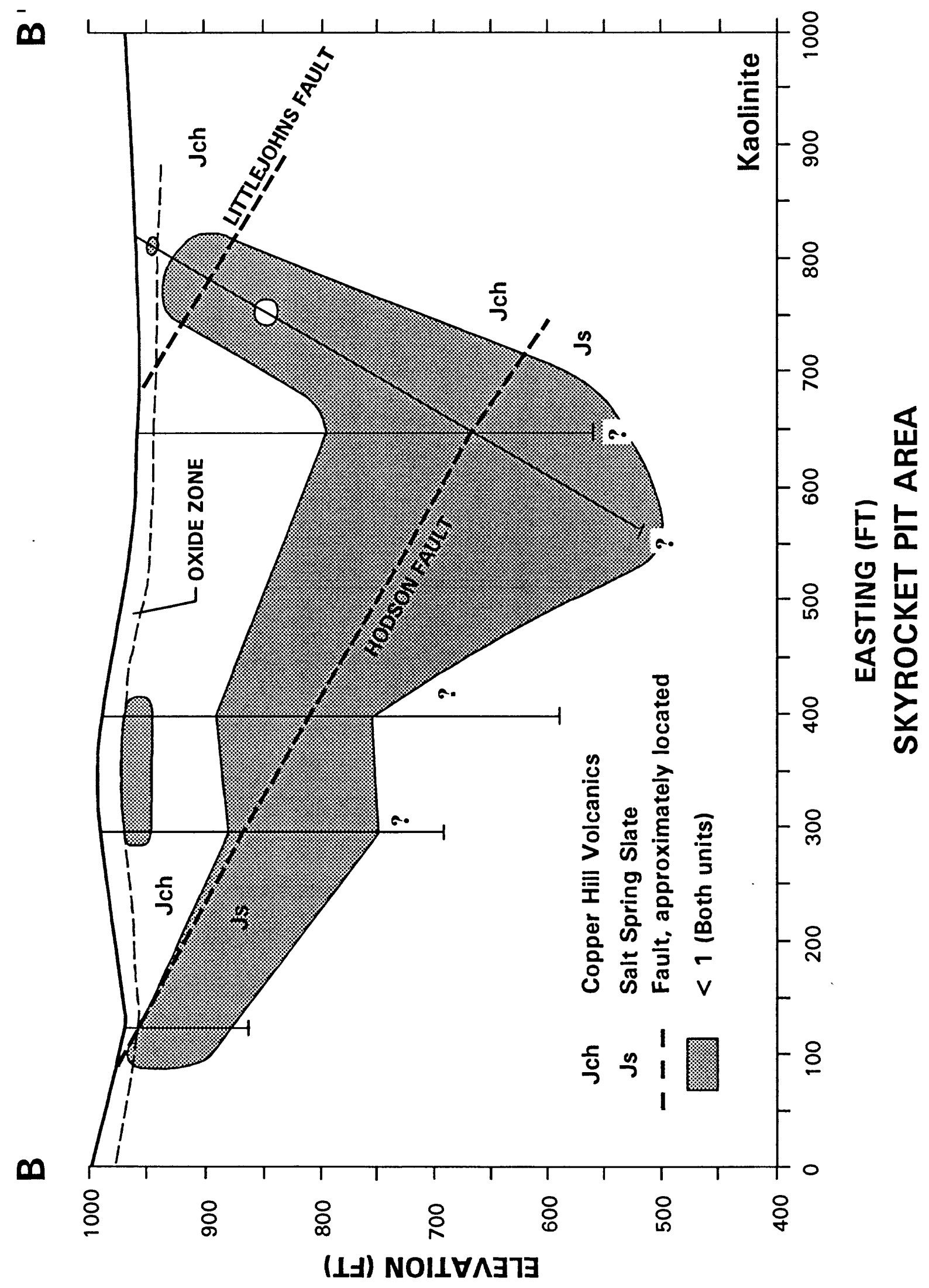




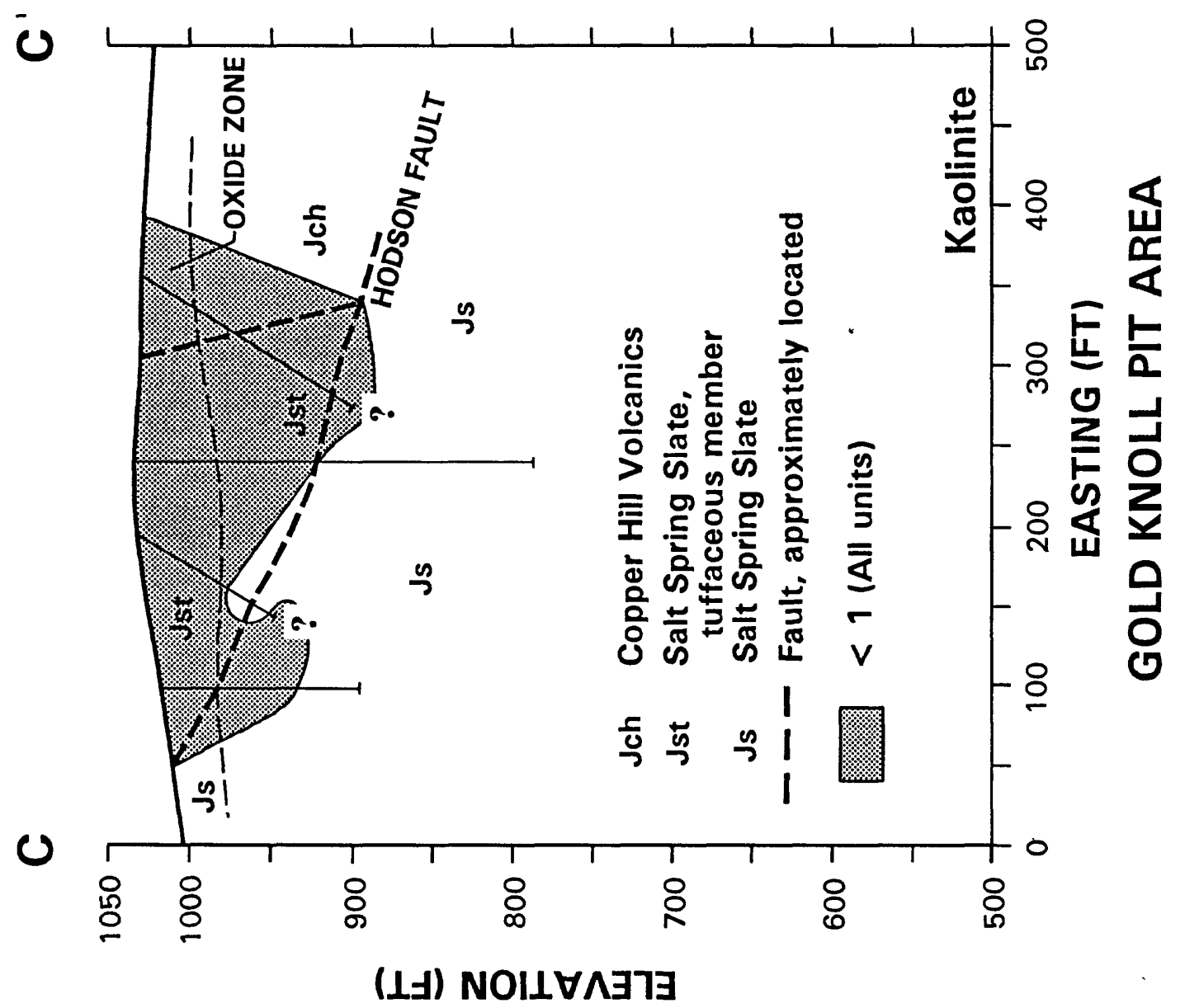




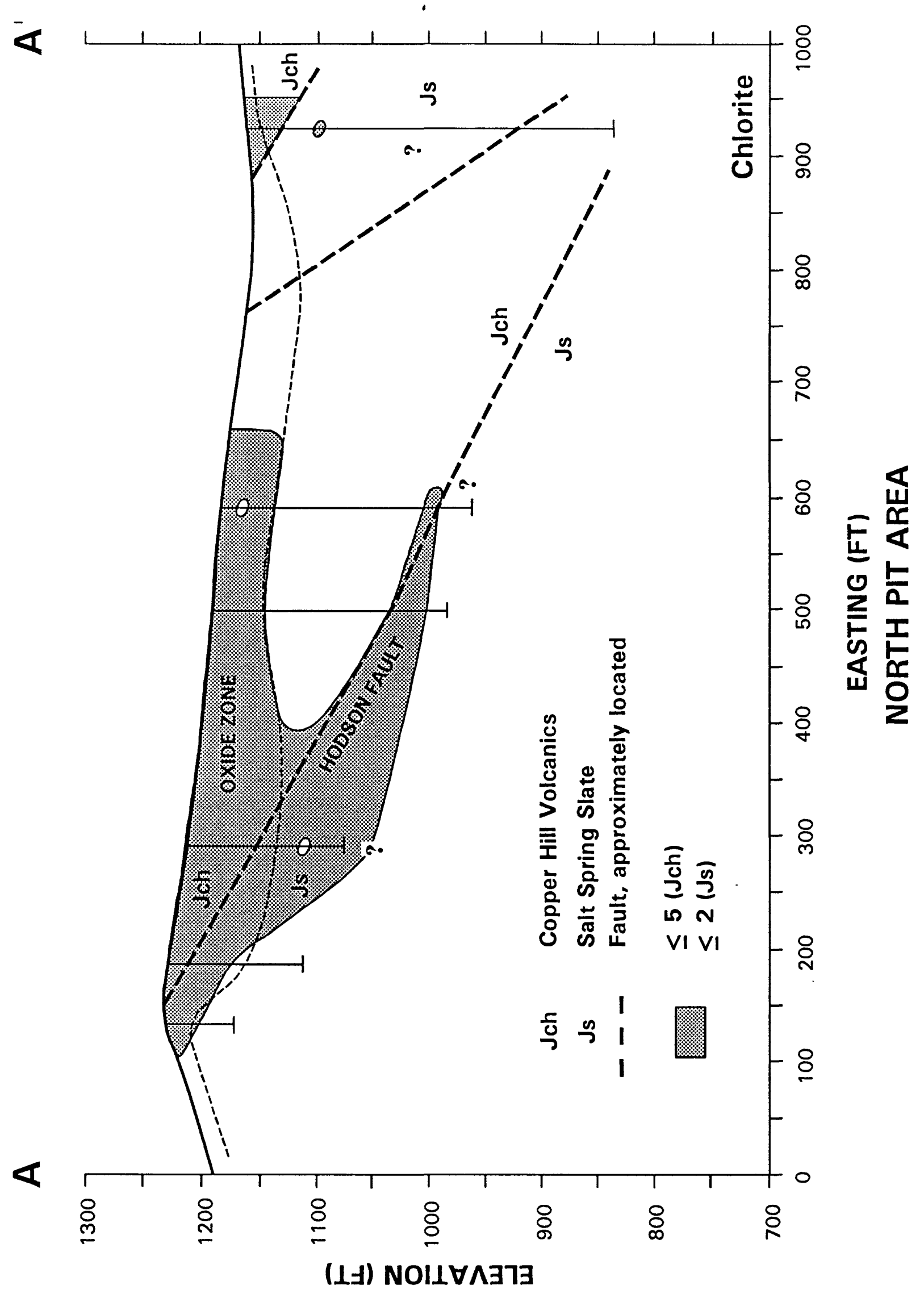




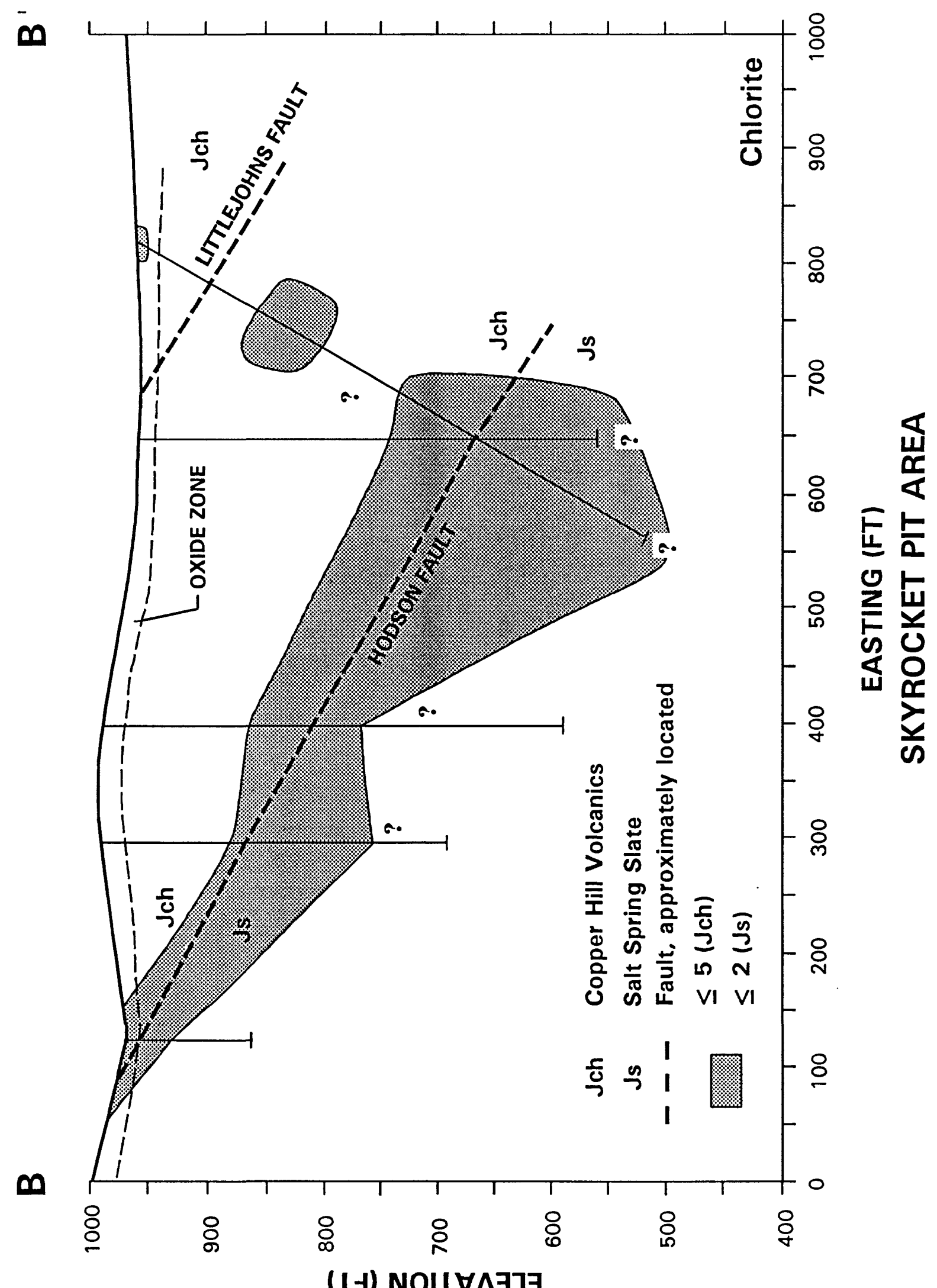




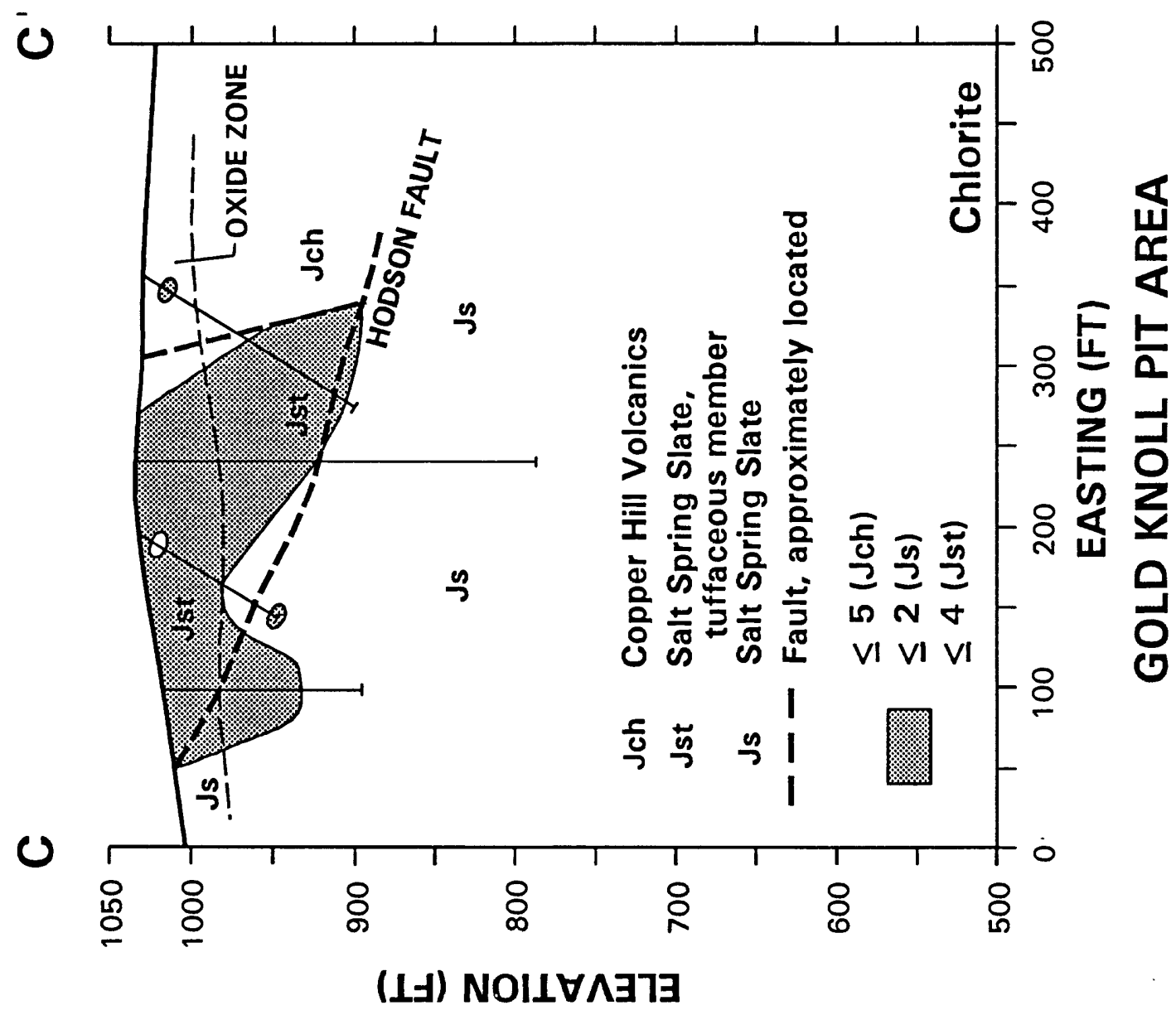




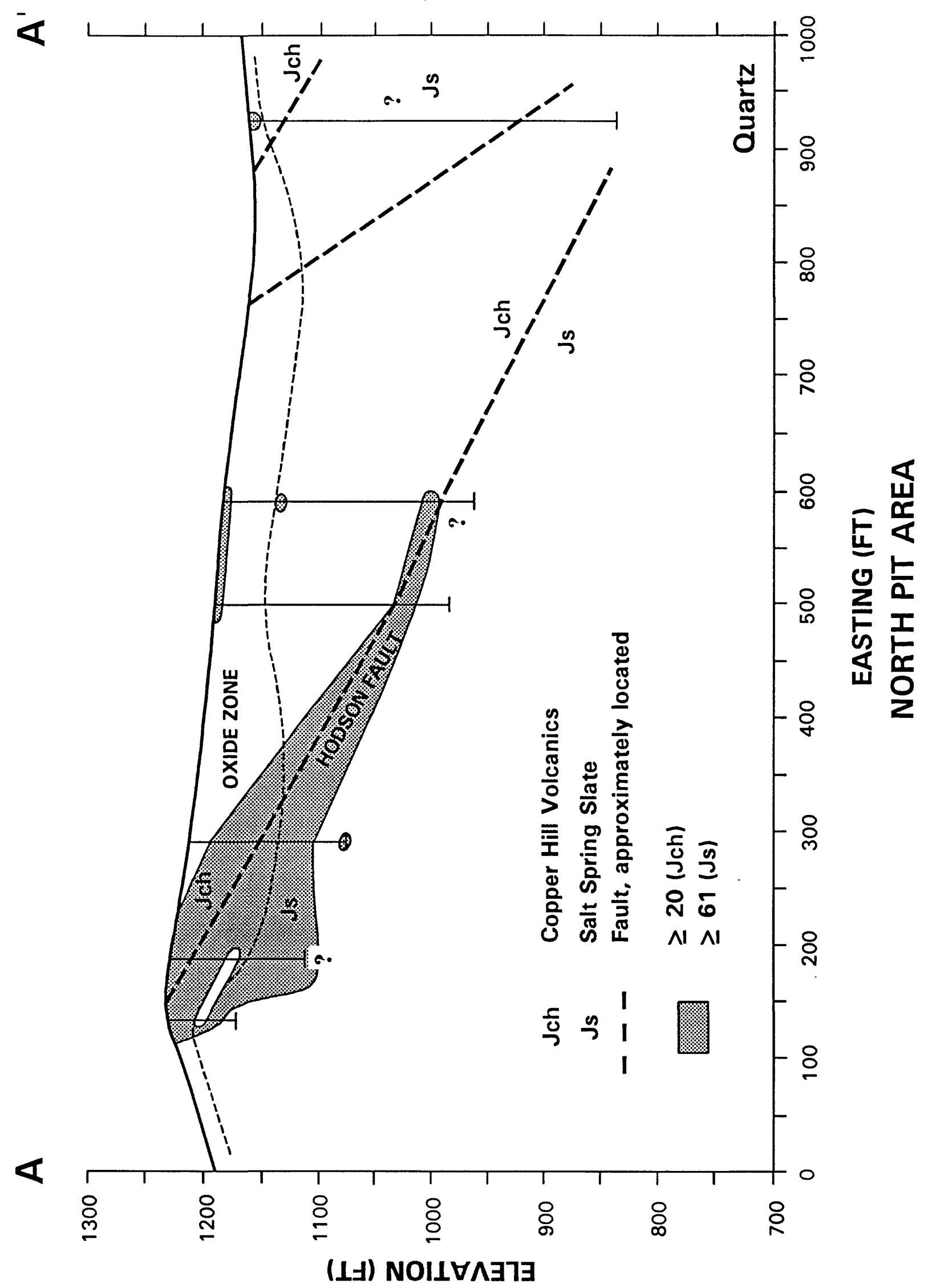




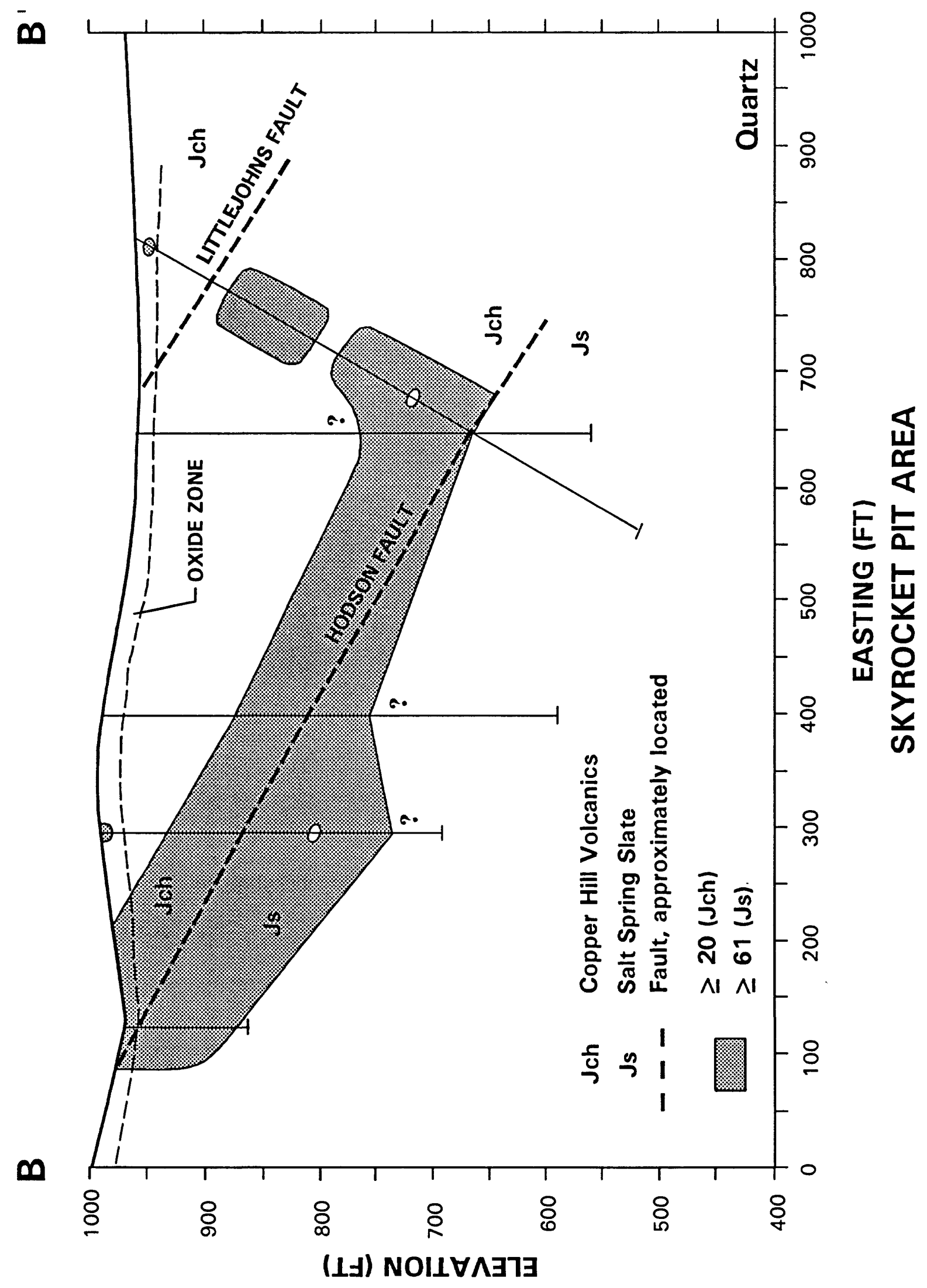




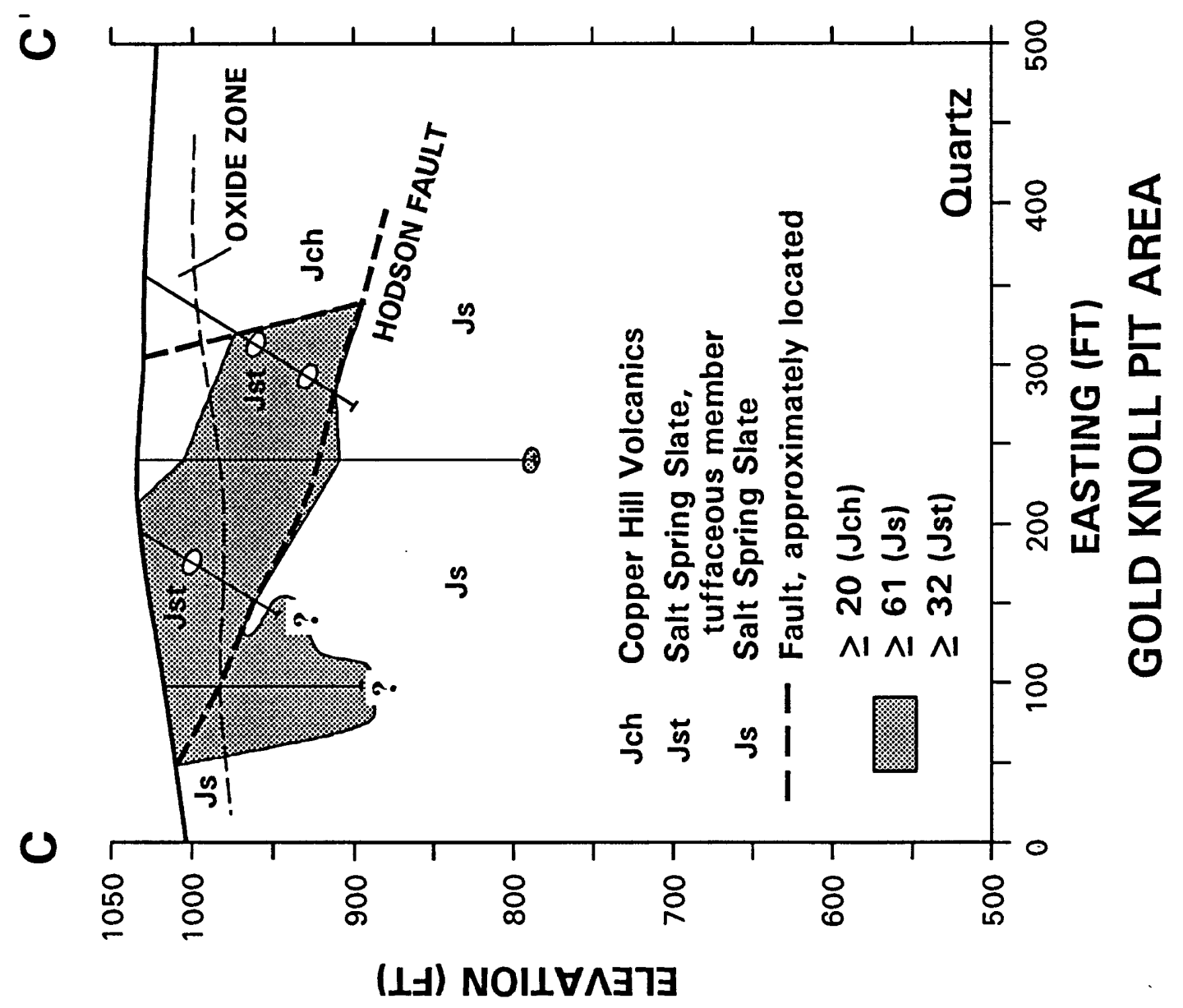




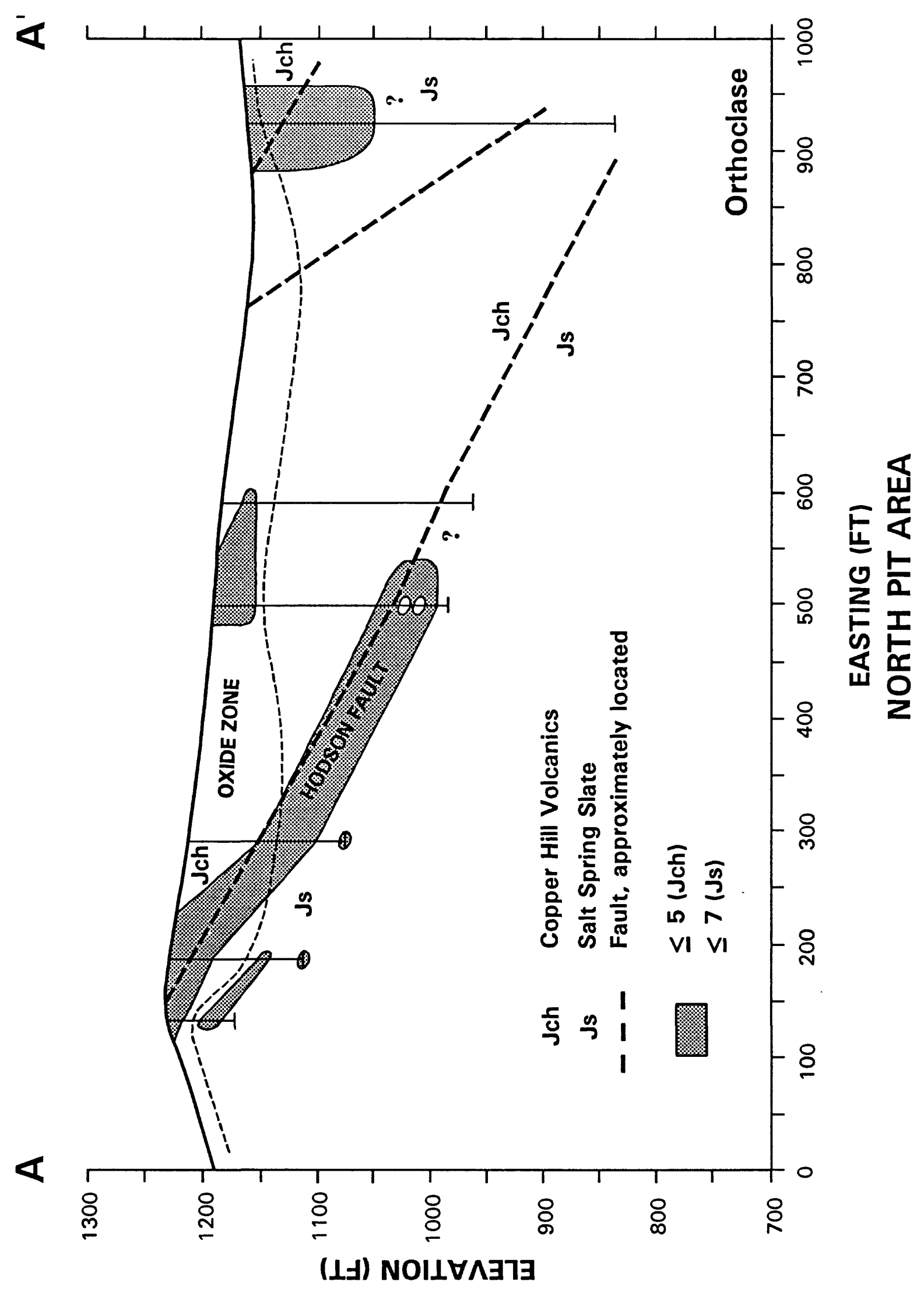




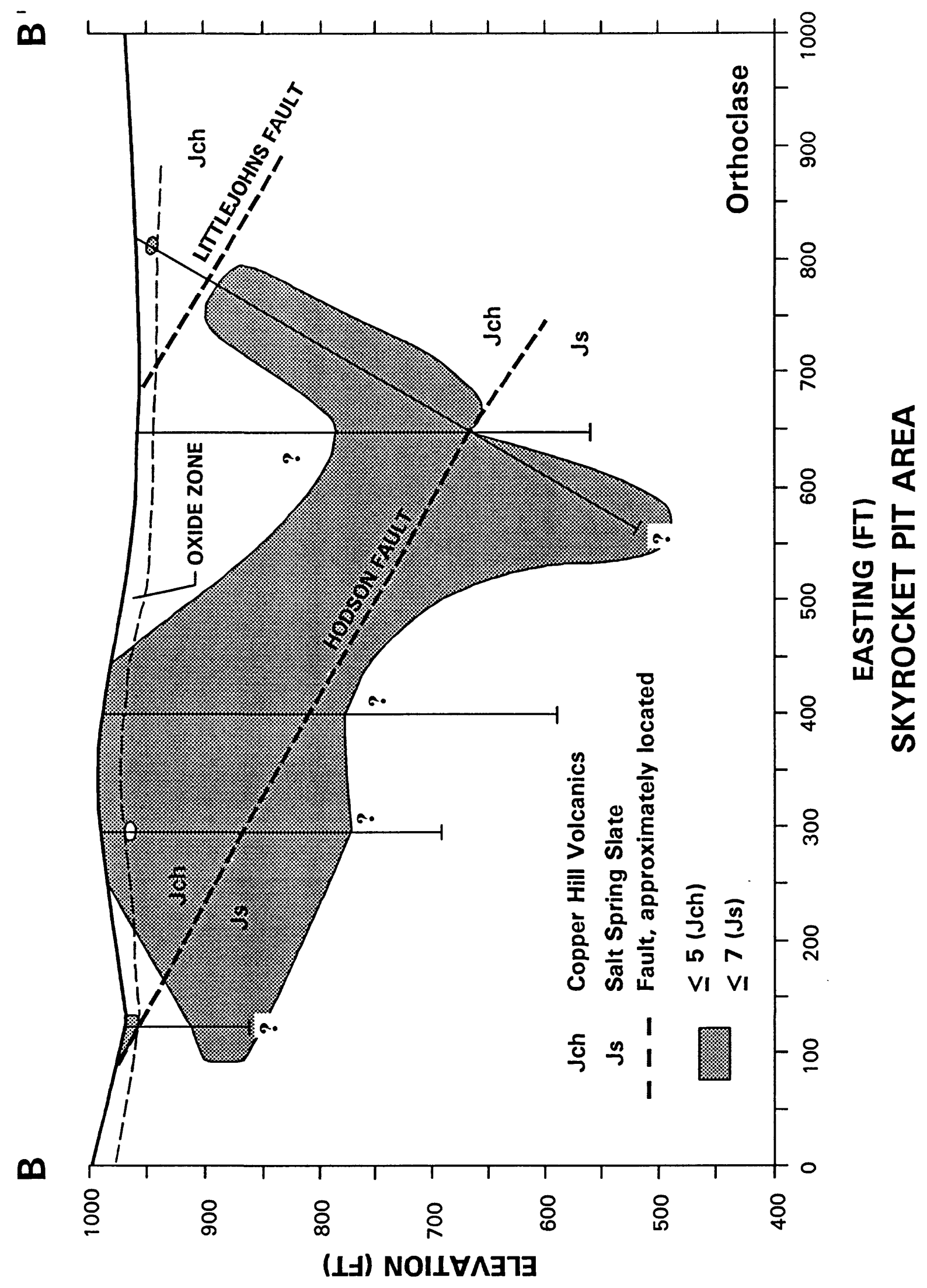




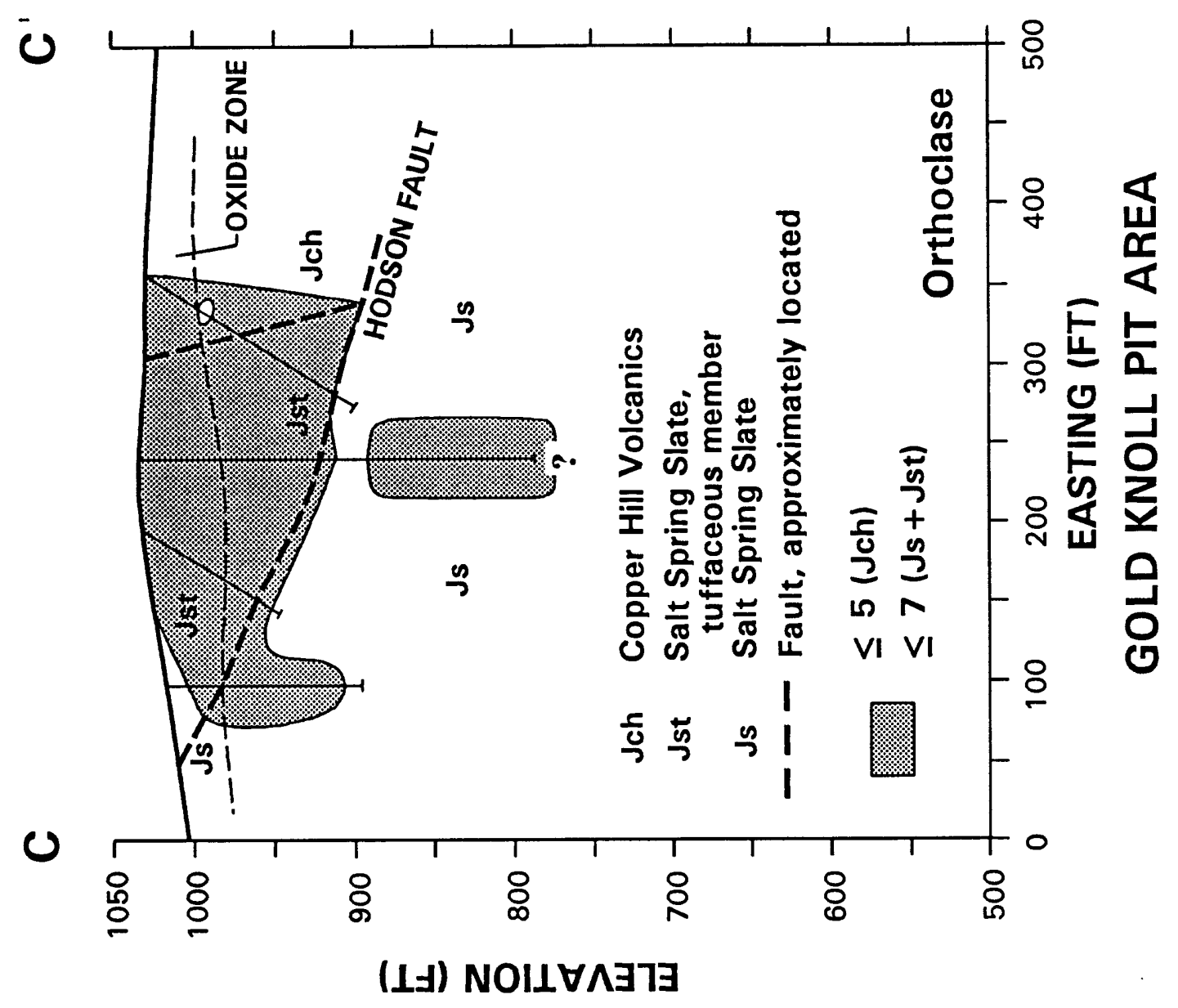




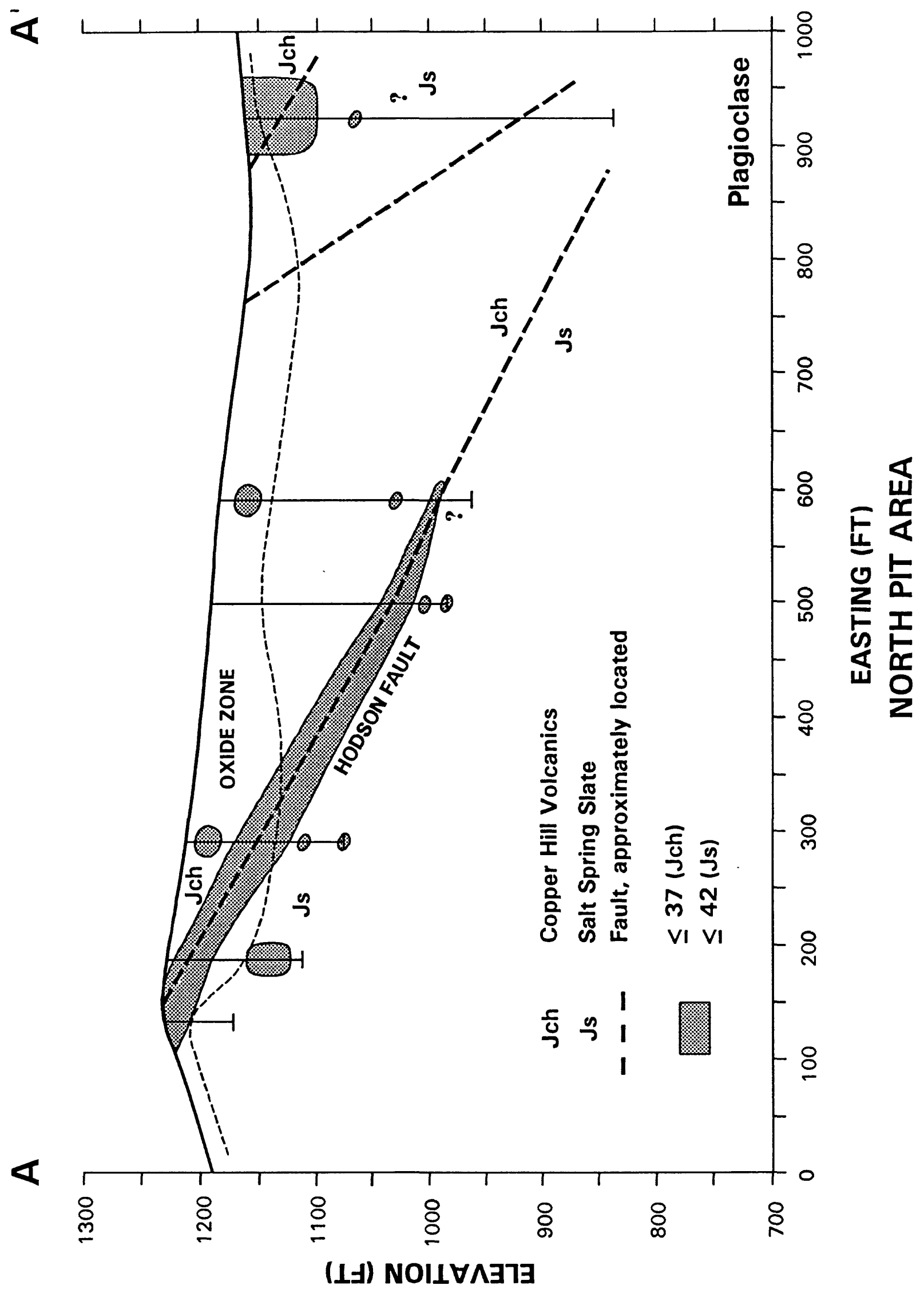




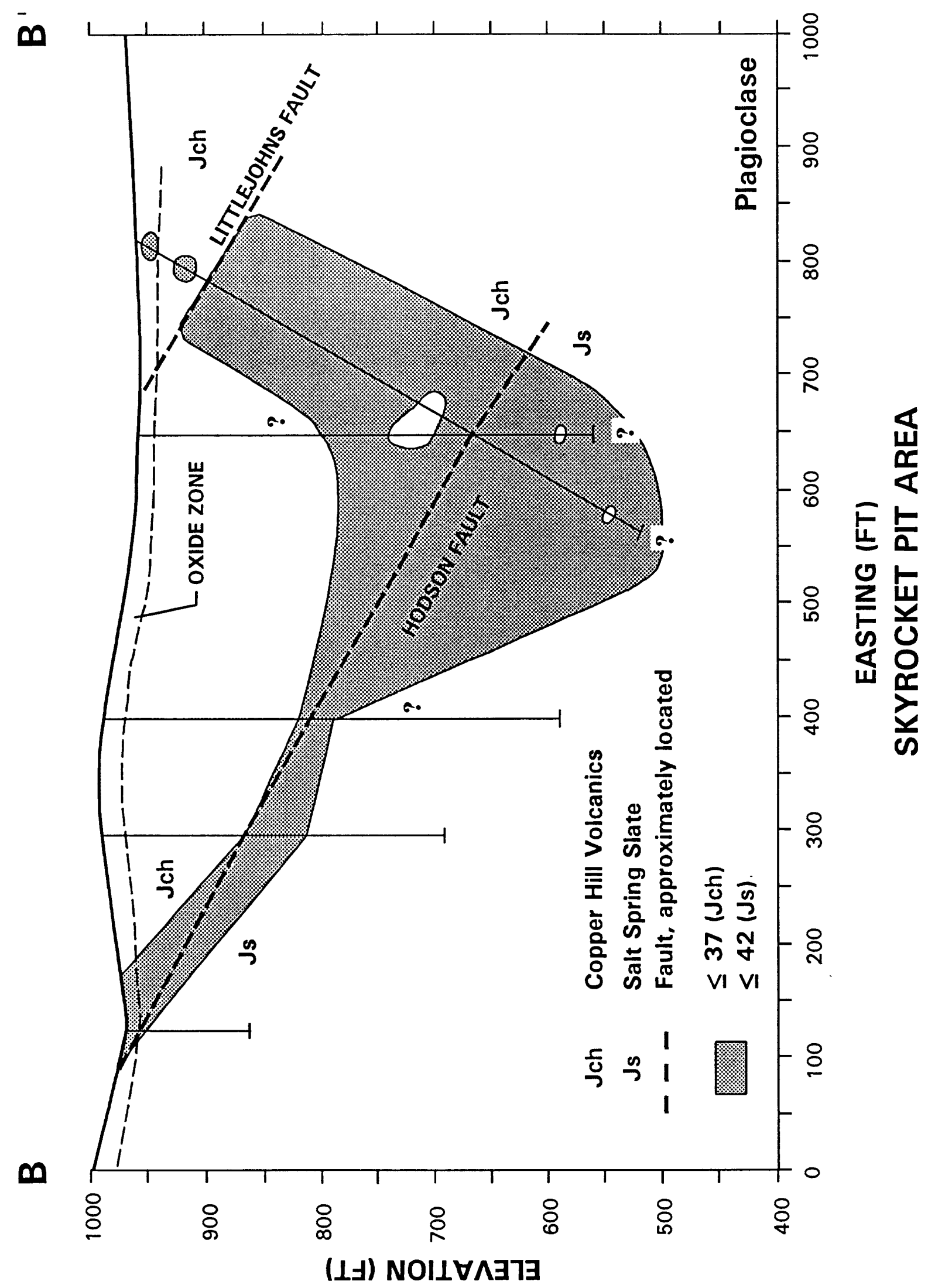




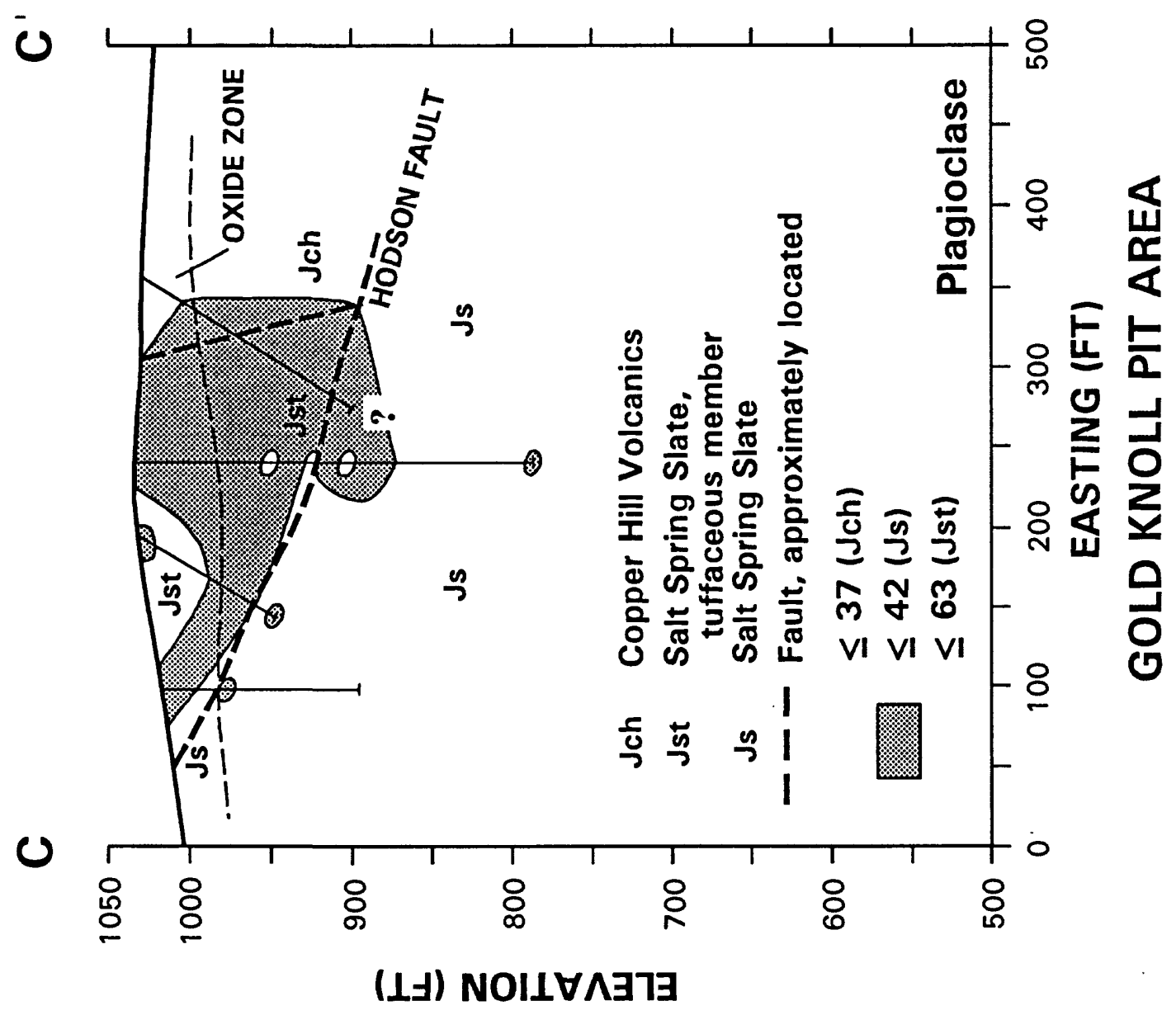




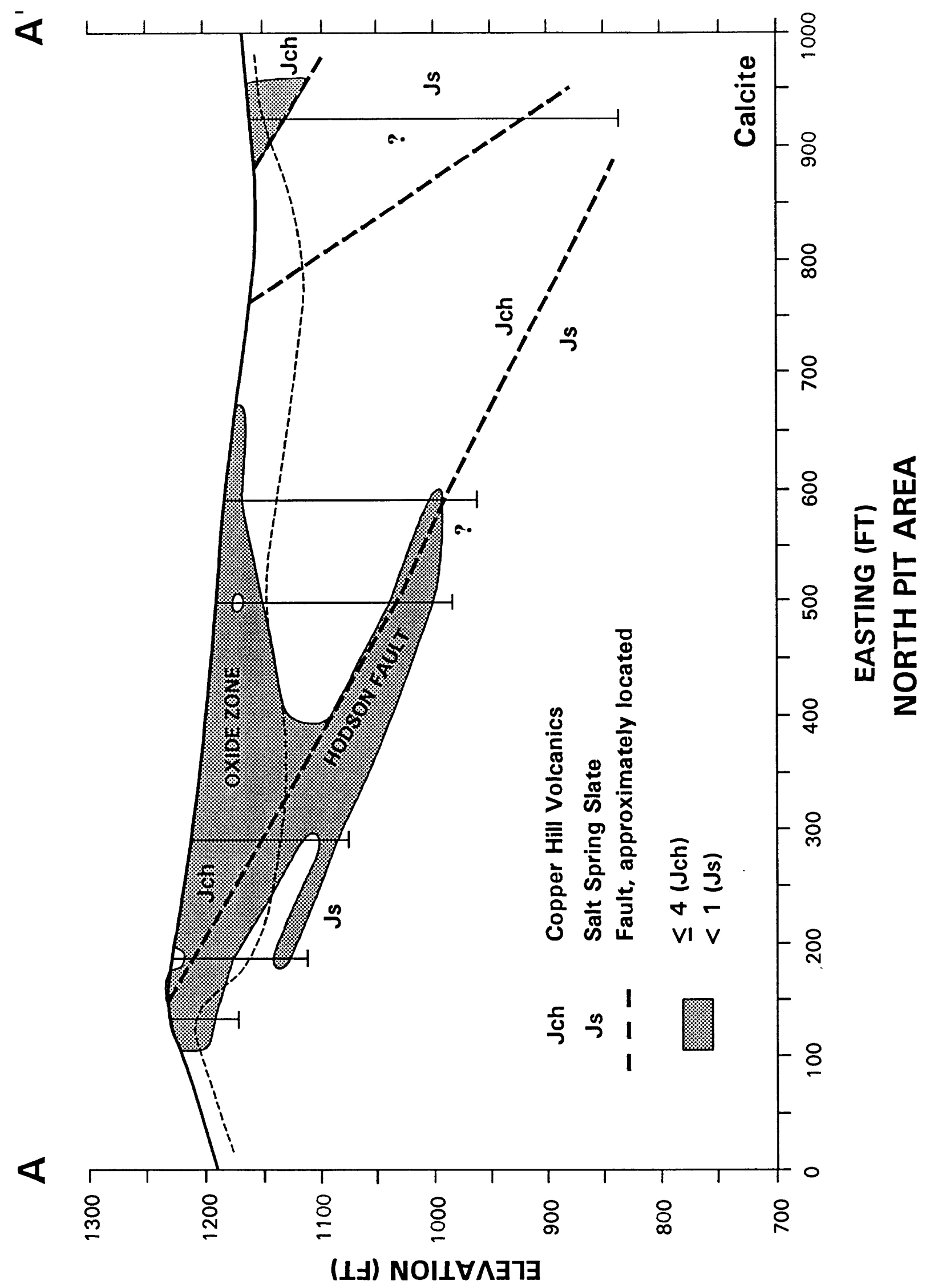




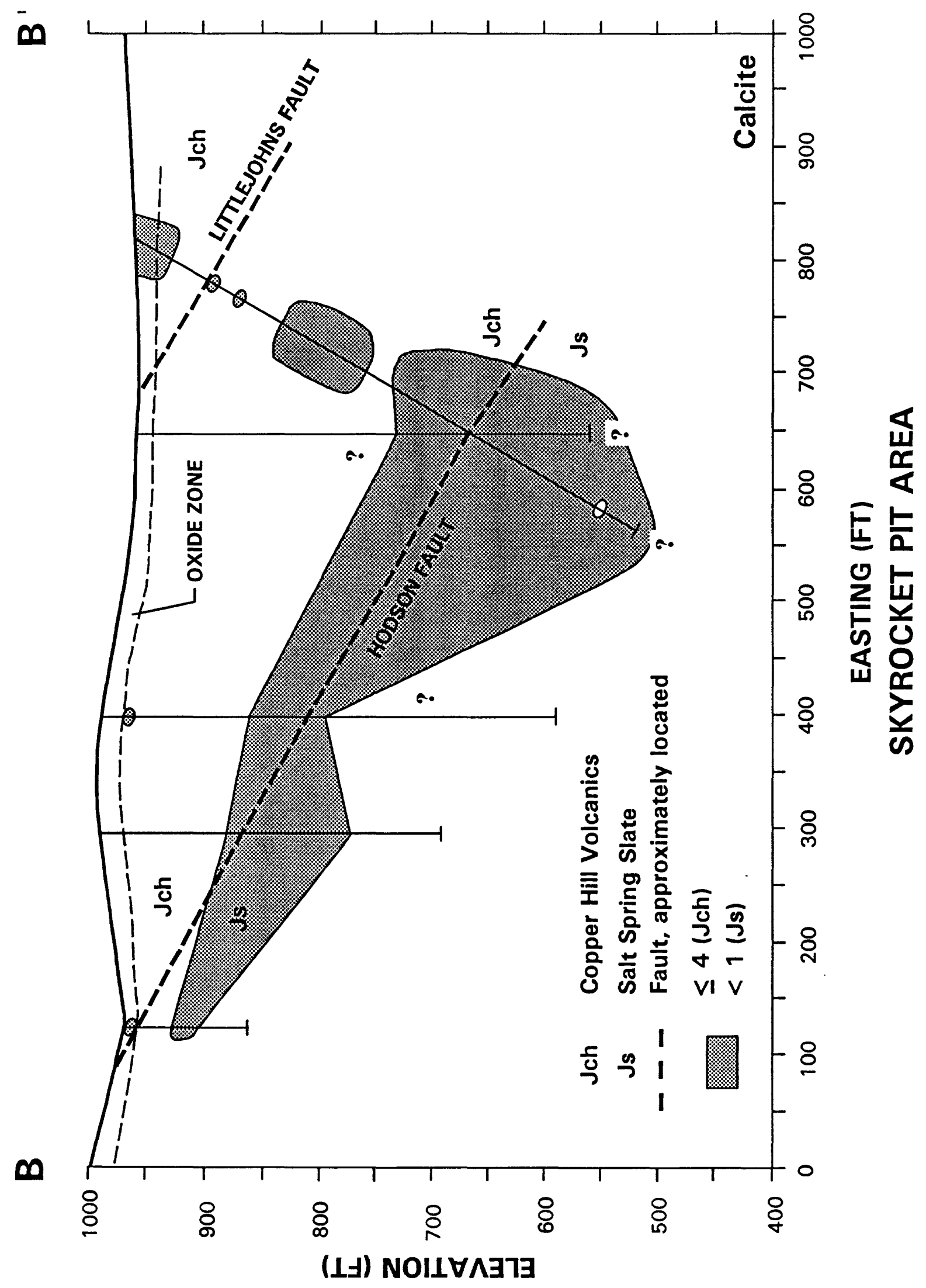




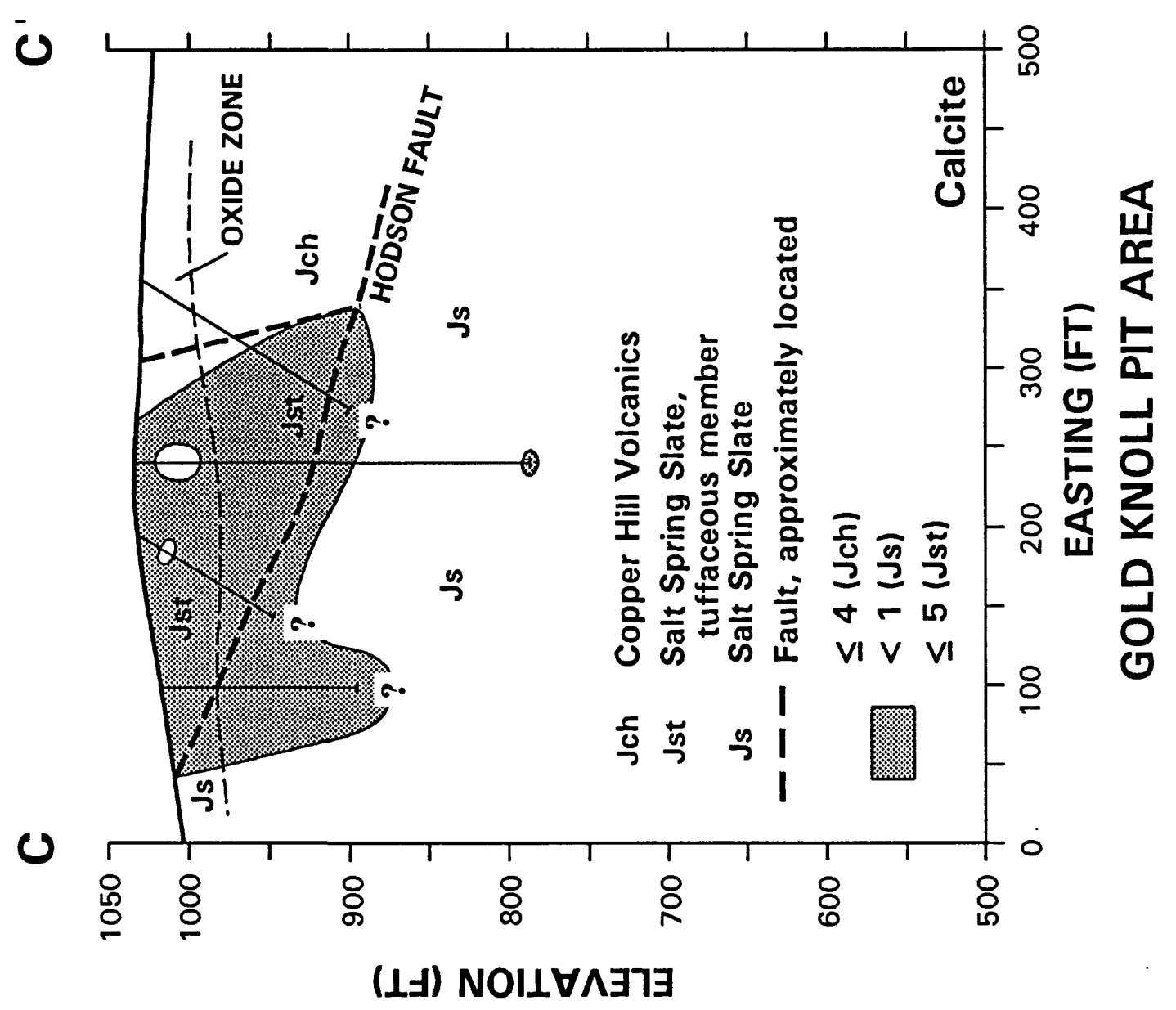




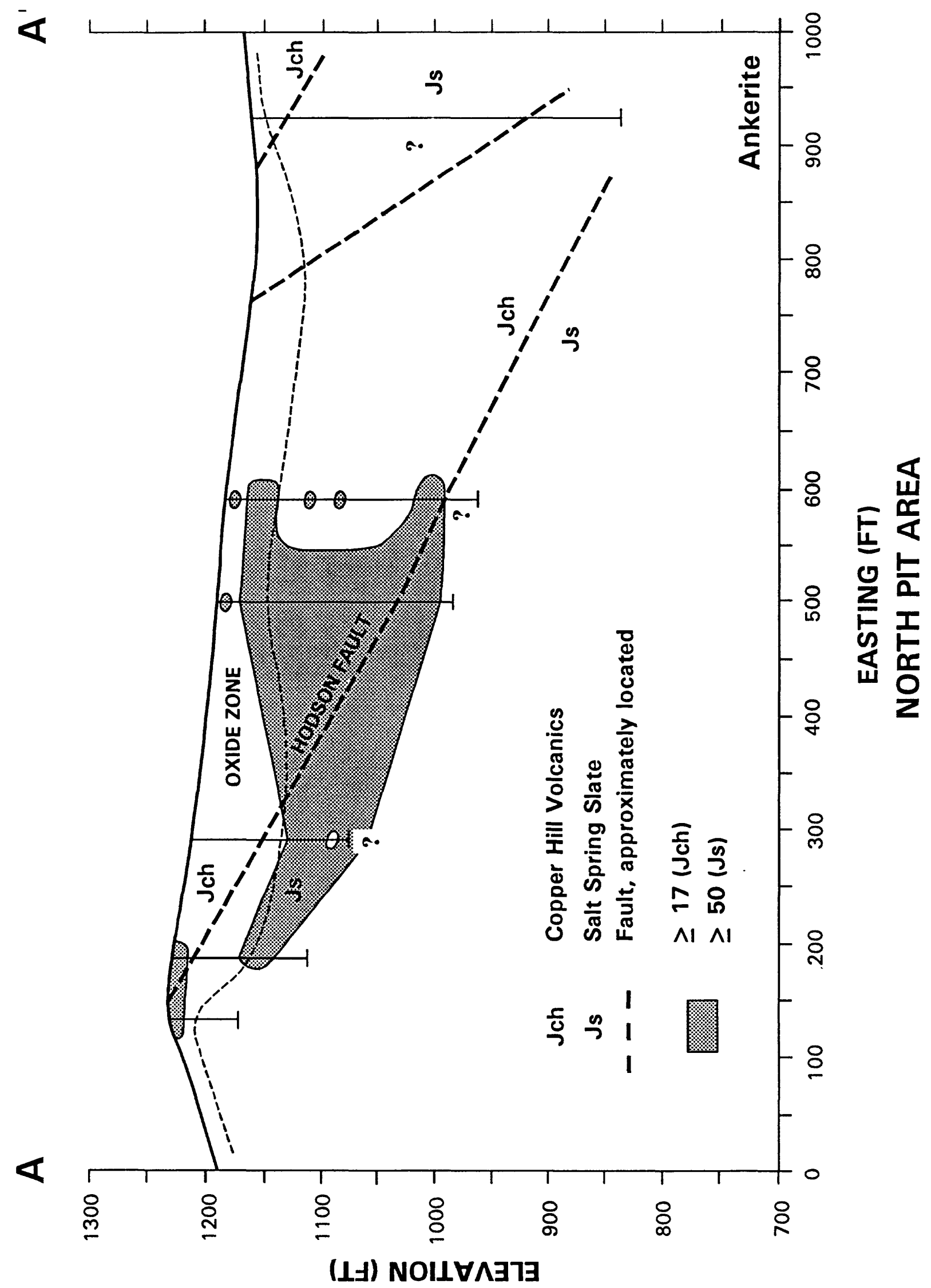




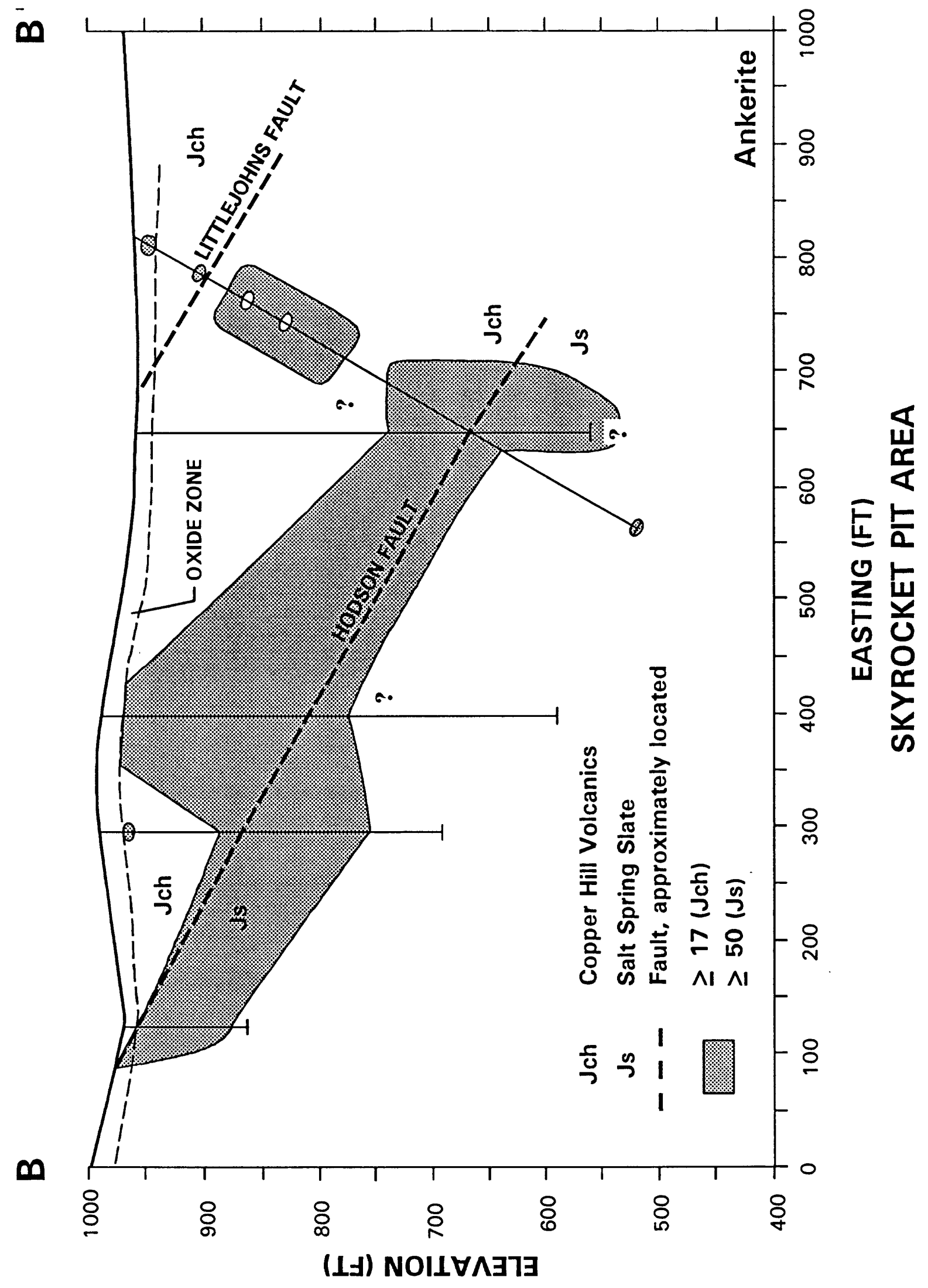




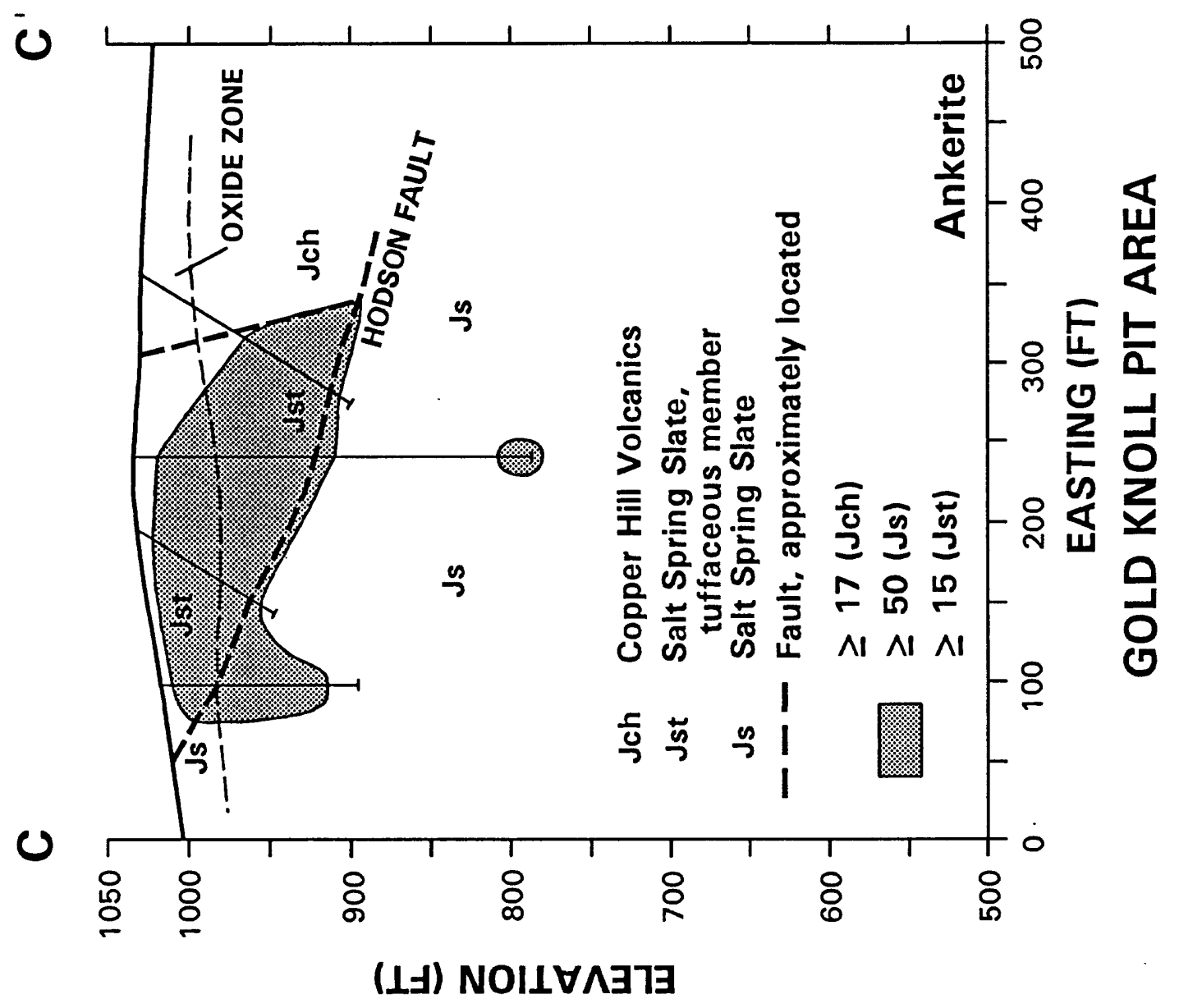




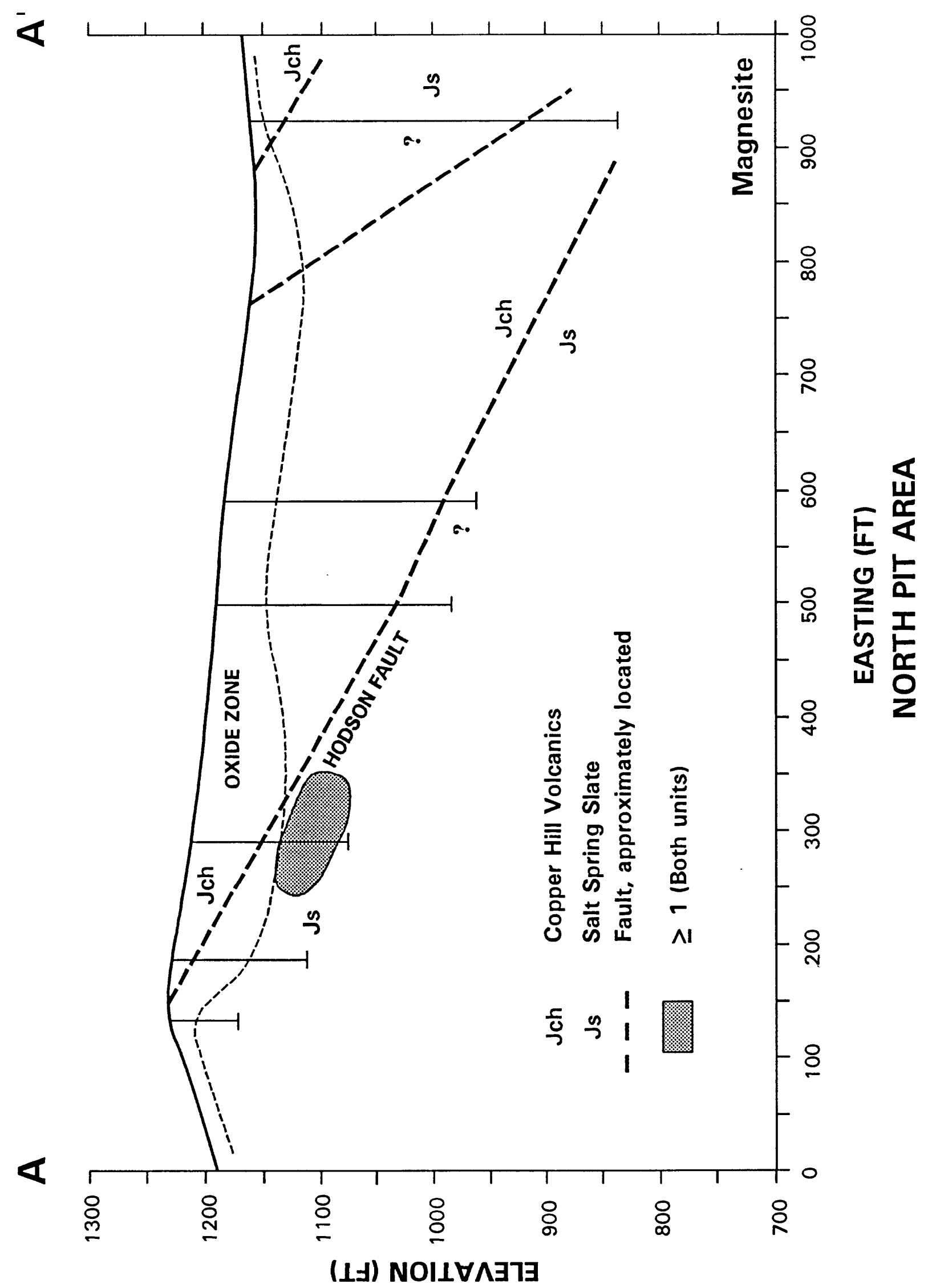




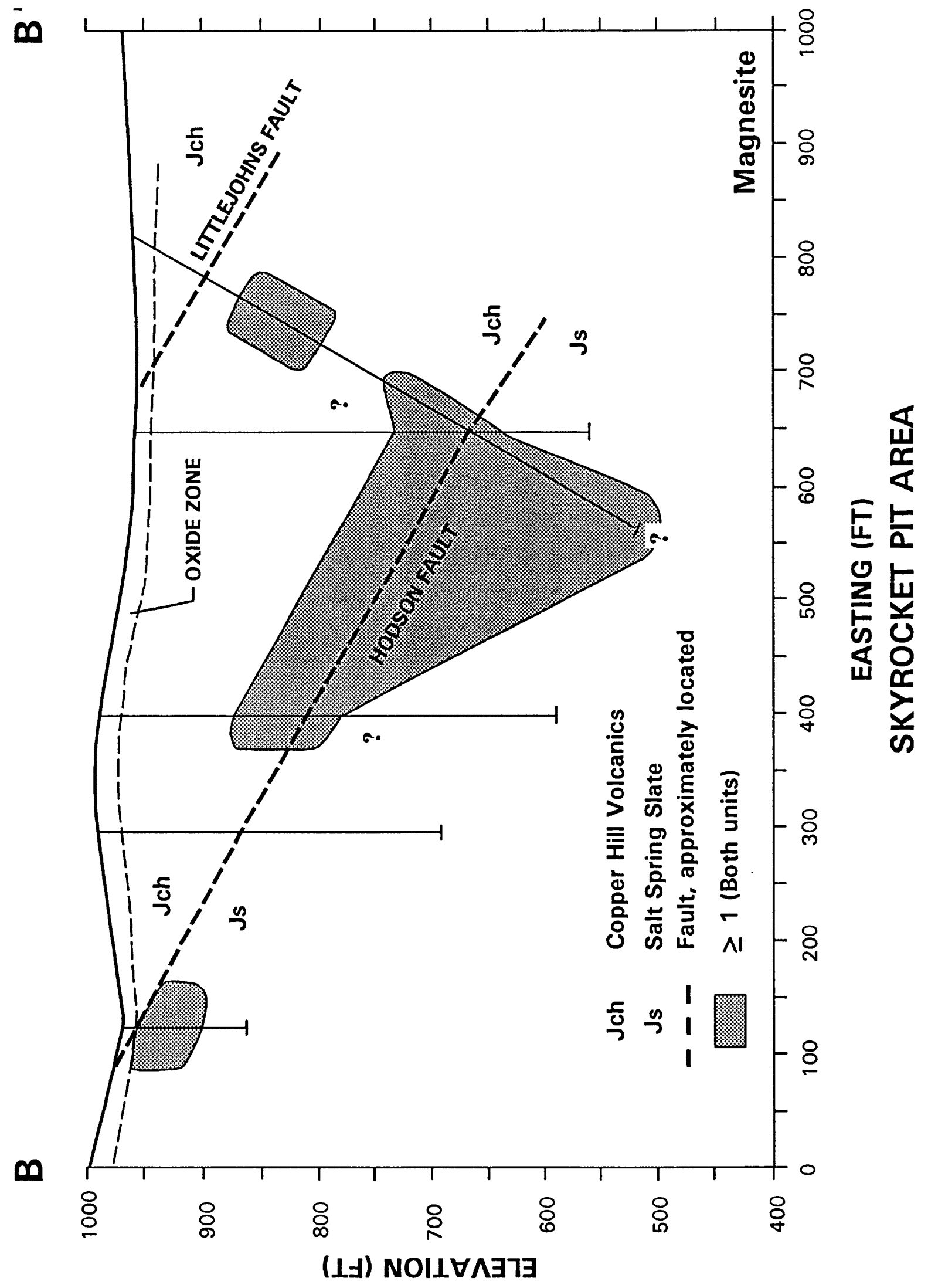




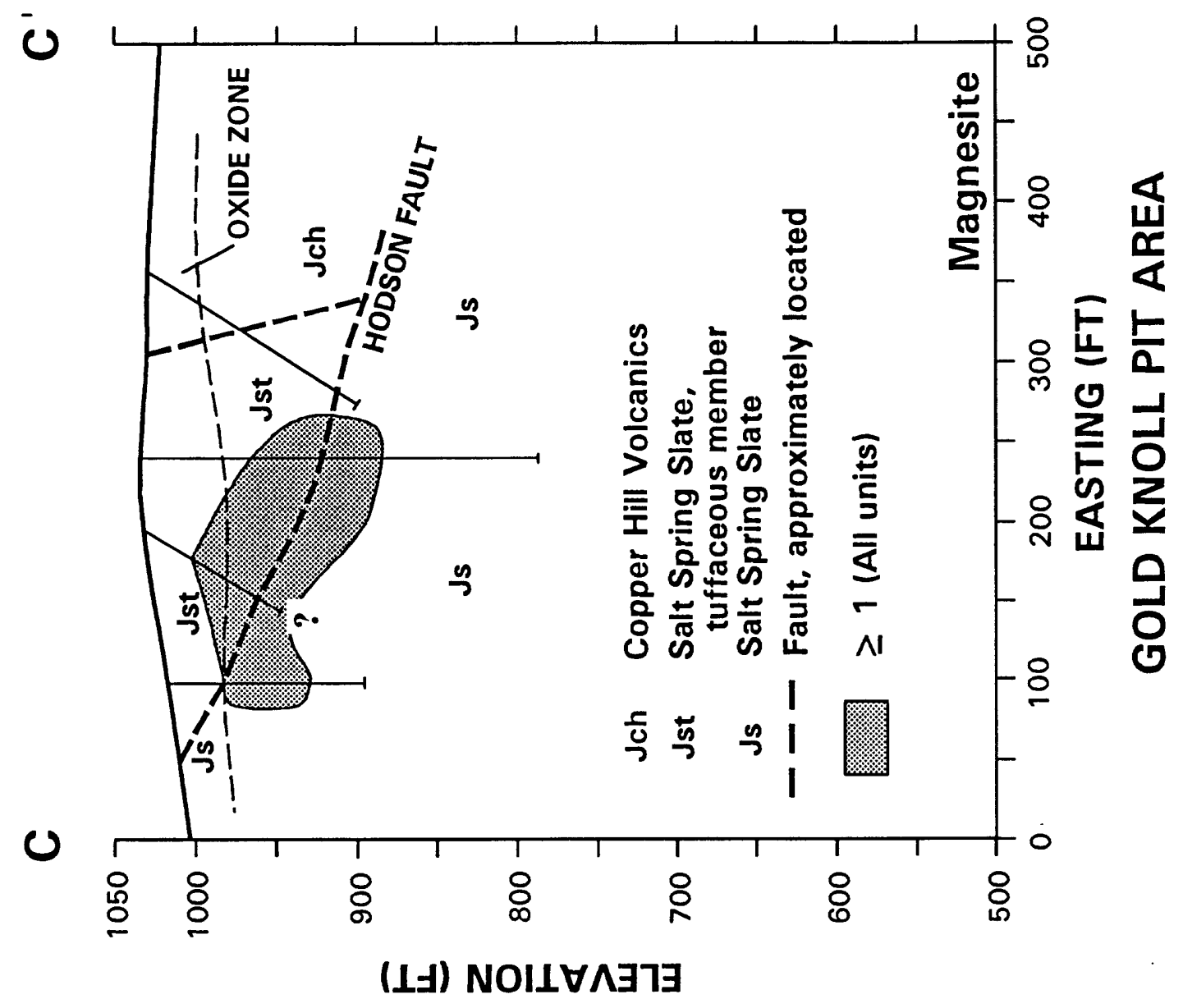




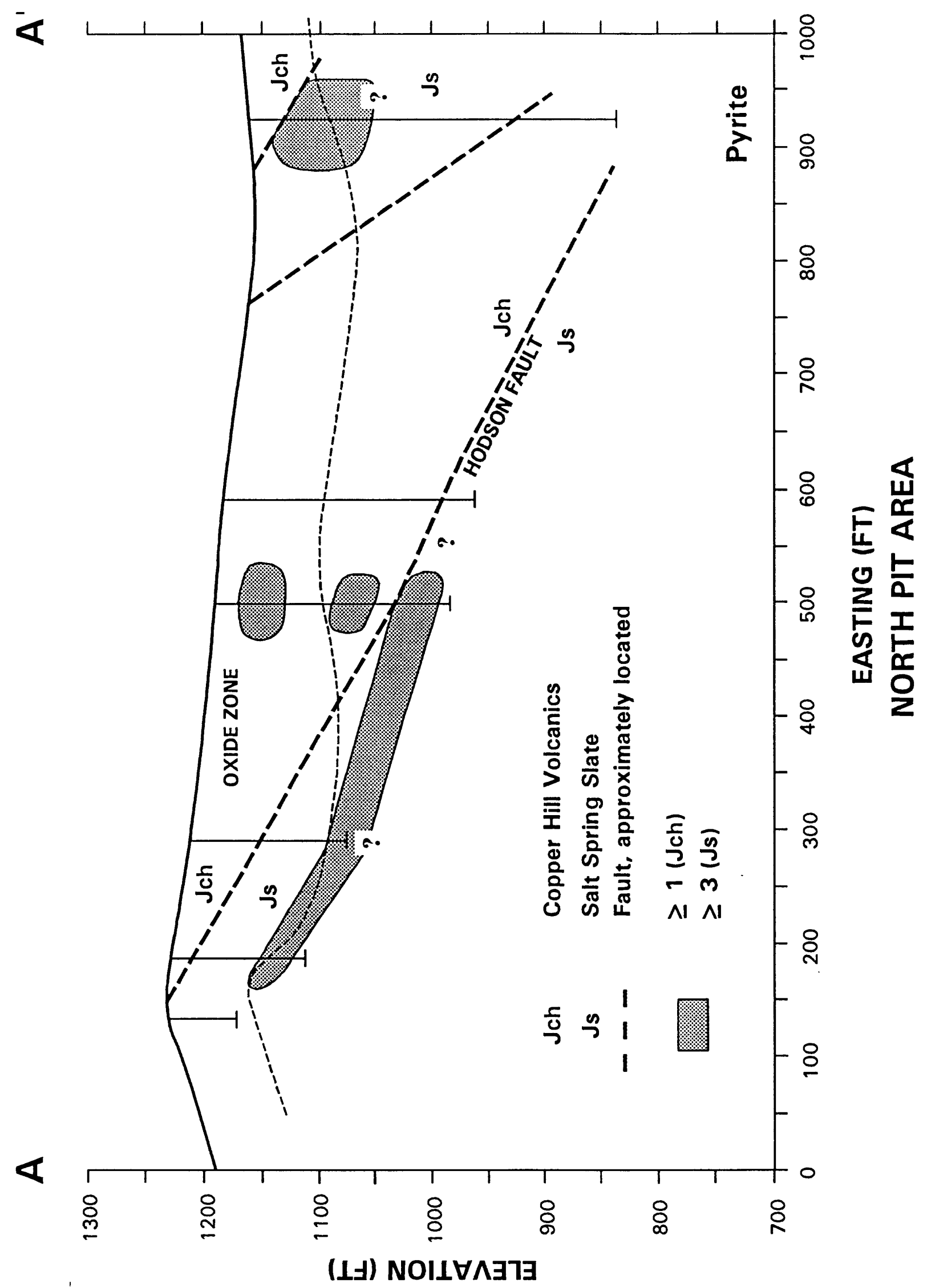




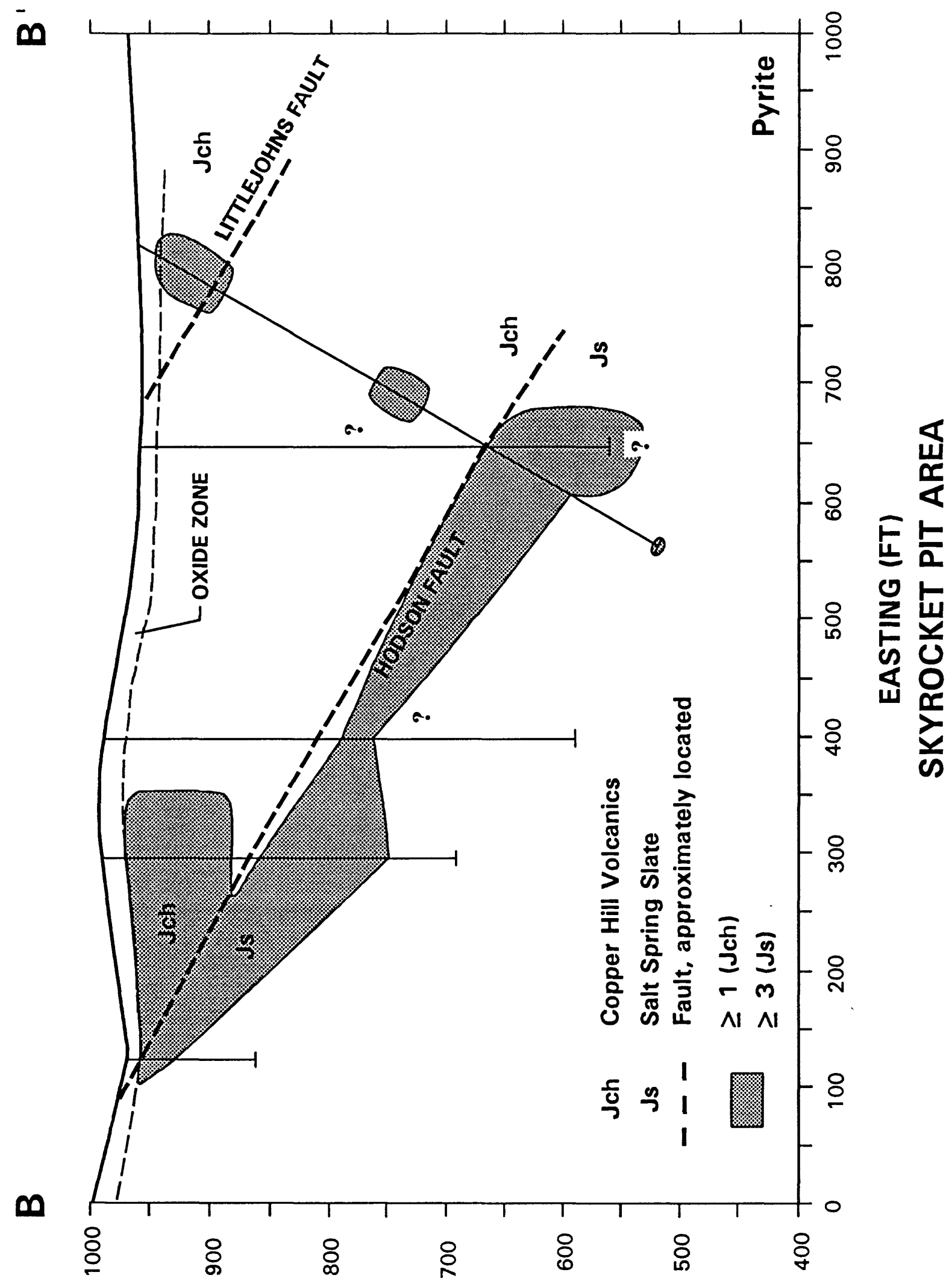

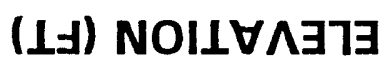




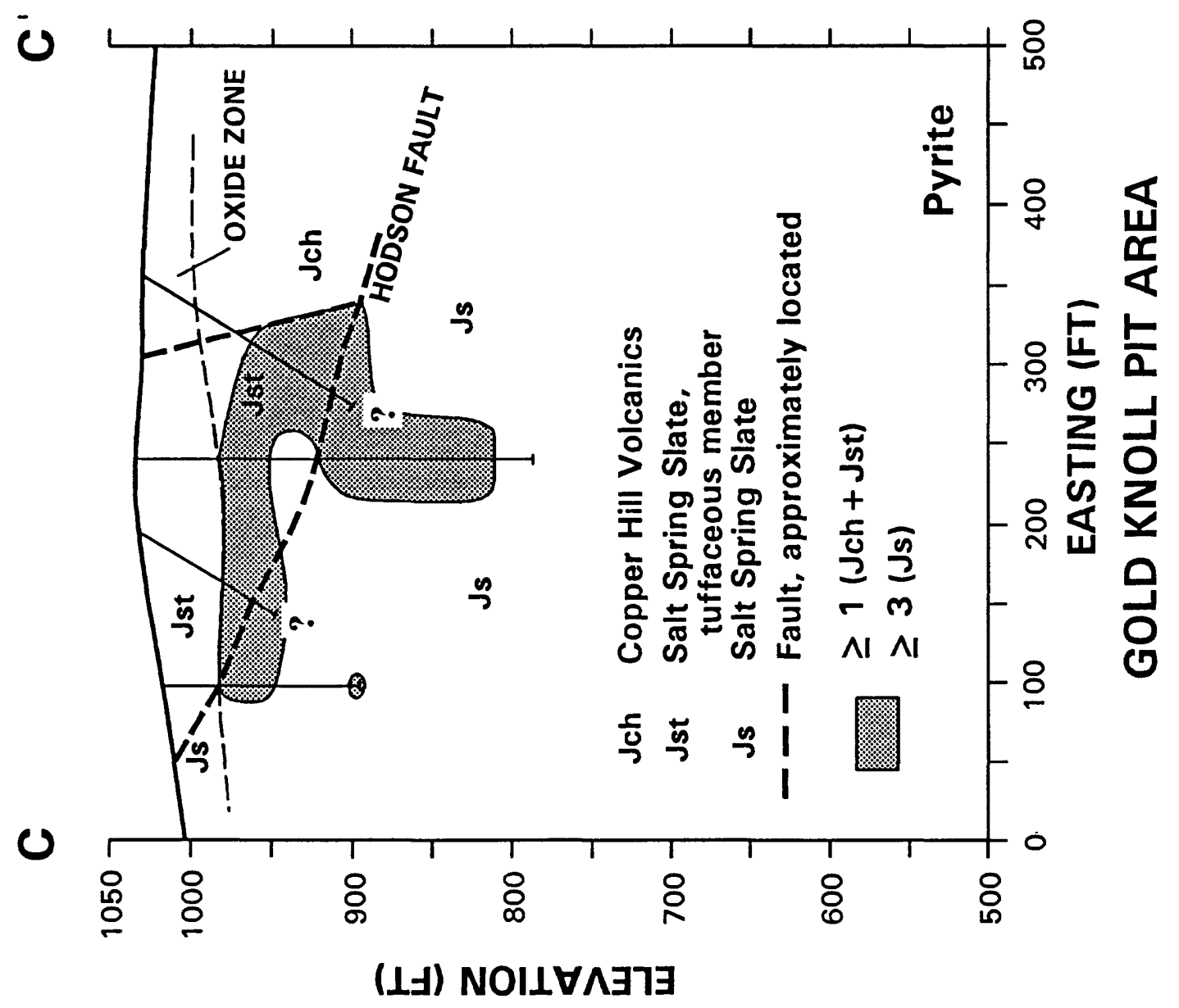




\section{DESCRIPTIONS OF APPENDICES 1 AND 2}

Appendix 1 lists the chemical analyses for 44 elements determined in 300 samples of drill core or cuttings from the Hodson district. Following is a brief description of the column headings.

Sam. ID--For each sample ID, the letters (HD or MK) are for project identification. The first two numbers identify individual drill holes and the last three numbers give the average depth of the sample, in feet, below the collar.

Latitude and Longitude--The next two columns give, in degrees, minutes and seconds the approximate latitude and longitude for the appropriate cross section on which a given drill hole is located. The hole IDs are labelled on figures 3 to 5 .

Ag ppm through zr ppm--These columns of analyses list the element symbol, whether the concentrations are in percent or parts per million (ppm), and the analytical method. Within the data set, the values may be qualified with "N", "L", or "H". The meaning of these qualifiers is given on the first page of appendix 1. The letters "icp" below an element name indicate that it was determined by total extraction using inductively coupled plasma-atomic emission spectrometry (ICP-AES); "picp" indicates partial-extraction ICP; "aa" indicates atomic absorption analysis; "grav" indicates gravimetric analysis; "comb" indicates a combustion technique; and "xrf" indicates X-ray fluorescence analysis. Details of the analytical methods are given in the Analysis of Samples section of this report.

Appendix 2 lists the estimated values for peak heights for 10 minerals in 172 samples of drill core or cuttings, as determined by X-ray diffraction. A "0" for a given mineral indicates that it was looked for but not detected for a given sample. Leaders (--) for a given sample indicate that it was not analyzed for its mineralogy. 
Appendix 1.--DATA FOR SAMPLES OF DRILL CORE OR CUTTINGS, HOOSON DISTRICT, CALIFORNIA

$[\mathrm{N}=$ not detected at lower limit of determination shown preceding letter. $\mathrm{L}=$ detected, but in a concentration less than value shown preceding letter. $H=$ not reported because of interference. See text for data on analytical methods]

Sam. ID Latitude Longitude

Ag ppm picp

Al \% As ppin

Au ppm

$\begin{array}{lllllll}\text { HD01007 } & 38 & 00 & 14 & 120 & 41 & 53 \\ \text { HD01012 } & 38 & 00 & 14 & 120 & 41 & 53 \\ \text { HD01017 } & 38 & 00 & 14 & 120 & 41 & 53 \\ \text { HD01022 } & 38 & 00 & 14 & 120 & 41 & 53 \\ \text { HD01032 } & 38 & 00 & 14 & 120 & 41 & 53\end{array}$

$\begin{array}{llr}0.073 & 9.02 & 20 \\ 0.160 & 9.02 & 70 \\ 0.130 & 9.04 & 70 \\ 0.140 & 8.24 & 70 \\ 0.220 & 9.54 & 100\end{array}$

aa

0.062
0.050
0.016
0.100
0.050

$\begin{array}{lll}0.170 & 9.04 \quad 70\end{array}$

0.028

0.190

5.27

80

0.050

0.660

9.10100

HD01047 $38 \quad 00 \quad 14$

HDO1052 $38 \quad 0014$

1204153

$\begin{array}{llll}H D 01057 \quad 38 & 00 \quad 14\end{array}$

0.620

8.94100

1.300

$2.59 \quad 120$

0.022

0.042

0.900

$\begin{array}{lll}0.370 & 1.51 \quad 40\end{array}$

2.600

3.92120

$\begin{array}{lllll}H 001067 & 38 & 00 & 14\end{array}$

$\begin{array}{llll}H 001072 & 38 & 00 & 14\end{array}$

$\begin{array}{lllll}H 001077 & 38 & 00 & 14\end{array}$

HDO1082 $38 \quad 00 \quad 14$

$\begin{array}{llll}H D 01087 & 38 & 00 & 14\end{array}$

HDO1092 $38 \quad 00 \quad 14$

HDO1097 $38 \quad 00 \quad 14$

HDO1102 $38 \quad 0014$

$\begin{array}{llll}H D 01107 & 38 & 00 & 14\end{array}$

HDO

$\begin{array}{lllll}H 001117 & 38 & 00 & 14\end{array}$

$\begin{array}{llll}H D 01122 & 38 & 00 & 14\end{array}$

$\begin{array}{lllll}H 001127 & 38 & 00 & 14\end{array}$

HDO1132 $38 \quad 00 \quad 14$

$\begin{array}{rllll}H 001137 & 38 & 00 & 14\end{array}$

HDO2OO2 $38 \quad 00 \quad 14$

HDO2O07 $38 \quad 00 \quad 14$

HDO2O12 $38 \quad 00 \quad 14$

HDO2O17 $38 \quad 00 \quad 14$

1204153

$120 \quad 4153$

$120 \quad 4153$

1204153

2.900

$1.45 \quad 40$

4.000

$2.22 \quad 140$

1.700

4.31250

0.250

0.300

0.350

0.250

0.024

2.600

$3.01 \quad 80$

1.250

$4.92 \quad 40$

0.150

0.016

0.900

$4.68 \quad 100$

1.400

5.11140

0.006

0.012

$0.002 \mathrm{~L}$

$0.002 \mathrm{~N}$

$0.002 \mathrm{~N}$

$0.002 \mathrm{~L}$

$0.002 \mathrm{~N}$

1204153

0.720

$6.46 \quad 50$

$6.42 \quad 40$

1.200

$3.56 \quad 70$

$0.610 \quad 6.74 \quad 50$

0.002

0.049

7.72

10

0.004

$\begin{array}{lllll}0.045 N & 8.91 & 10 \mathrm{~L} & 0.002\end{array}$

$\begin{array}{lllll}0.045 & 9.34 & 10 \mathrm{~L} & 0.002\end{array}$

$0.045 N 9.61$

$10 \mathrm{~L}$

0.002

$0.045 N 9.82$

$$
10
$$

$0.045 N 8.77$

$0.045 N 8.53$

$0.045 \mathrm{~N} 8.71$

$0.045 \mathrm{~N} 7.61$

$$
10 \mathrm{~L}
$$

$10 \mathrm{~L} \quad 0.002 \mathrm{~L}$

$10 \mathrm{~L} \quad 0.004$

$10 \mathrm{~L} \quad 0.002 \mathrm{~N}$

$0.045 N \quad 8.05$

$$
10 \mathrm{~L}
$$

$0.045 N 9.35$

$0.045 N \quad 8.14$

$0.450 \quad 8.01$

$0.076 \quad 8.56$

$$
10 \mathrm{~L}
$$

10

$60 \quad 0.750$

$10 \mathrm{~L}$

$0.002 \mathrm{~L}$

icp icp

Ba ppm Be ppm Bi ppm Ca \% Cd ppm Ce ppm icp icp picp icp picp icp

$\begin{array}{ll}205 & 1 \\ 464 & 2 \\ 374 & 2 \\ 390 & 2 \\ 533 & 3\end{array}$

$0.60 \mathrm{~N}$

$\begin{array}{ll}1.22 & 0.051\end{array}$

$\begin{array}{lll}0.60 \mathrm{~N} & 0.60 & 0.260\end{array}$

$0.60 \mathrm{~N}$

$0.63 \quad 0.140$

$0.60 \mathrm{~N}$

$0.37 \quad 0.120$

$0.60 \mathrm{~N}$

$0.44 \quad 0.150$

1842

$\begin{array}{lll}0.60 \mathrm{~N} & 0.74 & 0.160\end{array}$

$178 \quad 2$

$\begin{array}{lll}0.60 \mathrm{~N} & 0.28 & 0.390\end{array}$

$\begin{array}{lll}0.60 \mathrm{~N} & 0.46 & 0.860\end{array}$

2982

$0.60 \mathrm{~N}$

$0.47 \quad 0.660$

$\begin{array}{llllll}115 & 1 \mathrm{~L} & 0.60 \mathrm{~N} & 0.06 & 0.240\end{array}$

48
50
51
39
47

51

29

48

44

13

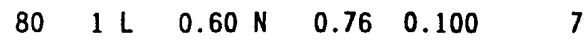

$\begin{array}{llllll}161 & 2 & 0.60 \mathrm{~N} & 0.29 & 0.210\end{array}$

$\begin{array}{llllll}66 & 1 L & 0.60 N & 0.05 & 0.068\end{array}$

$1351 \mathrm{~L}$

$0.60 \mathrm{~N}$

$0.70 \quad 0.180$

$344 \quad 1$

$0.60 \mathrm{~N}$

$2.27 \quad 0.320$

$159 \quad 11$

$\begin{array}{lll}0.60 N \quad 9.40 & 0.210\end{array}$

$3521 \mathrm{~L}$

$0.60 \mathrm{~N} \quad 3.45 \quad 0.300$

$357 \quad 1$

$\begin{array}{lll}0.60 \mathrm{~N} & 3.22 & 0.420\end{array}$

1651

$0.60 \mathrm{~N} \quad 5.510 .052$

$0.60 \mathrm{~N} \quad 2.41 \quad 0.470$

4462

$527 \quad 2$

$\begin{array}{lll}0.60 N \quad 2.33 & 0.470\end{array}$

$0.60 \mathrm{~N} \quad 2.20 \quad 0.490$

$0.60 \mathrm{~N} \quad 1.69 \quad 0.580$

$\begin{array}{lll}0.60 \mathrm{~N} & 2.92 \quad 0.550\end{array}$

$\begin{array}{lll}0.60 \mathrm{~N} & 2.71 & 0.190\end{array}$

$248 \quad 1$

6012

$\begin{array}{lll}0.60 \mathrm{~N} & 1.94 & 0.200\end{array}$

$0.60 \mathrm{~N} \quad 4.62 \quad 0.110$

$0.60 \mathrm{~N} \quad 5.70 \quad 0.060$

$\begin{array}{lll}0.60 \mathrm{~N} & 2.67 & 0.110\end{array}$

$0.60 \mathrm{~N} \quad 5.80 \quad 0.100$

$171 \quad 1$

$\begin{array}{lll}0.60 N & 7.60 & 0.093\end{array}$

$0.60 \mathrm{~N} \quad 10.10 \quad 0.160$

$0.60 \mathrm{~N} \quad 11.20 \quad 0.130$

$\begin{array}{lll}0.60 \mathrm{~N} & 8.95 & 0.086\end{array}$

$0.60 N \quad 12.20 \quad 0.150$

911

$0.60 \mathrm{~N} \quad 12.50 \quad 0.150$

$\begin{array}{lll}0.60 \mathrm{~N} & 6.13 & 0.067\end{array}$

$\begin{array}{lll}0.60 \mathrm{~N} & 9.32 & 0.091\end{array}$

$\begin{array}{lll}0.60 \mathrm{~N} & 6.76 & 0.100\end{array}$

$\begin{array}{llll}0.60 \mathrm{~N} & 8.56 & 0.150\end{array}$

1441

$\begin{array}{lll}0.60 N & 8.57 & 0.099\end{array}$

$0.045 N 8.62$

$10 \mathrm{~L} \quad 0.002 \mathrm{~N} \quad 148 \quad 1$

$0.60 \mathrm{~N} \quad 7.90 \quad 0.130$

$\begin{array}{lll}0.60 N \quad 5.47 & 0.064\end{array}$

$0.045 N \quad 8.85$

$10 \mathrm{~L} \quad 0.002 \mathrm{~L}$

$176 \quad 1$

$0.60 \mathrm{~N}$

$2.61 \quad 0.370$

$7.100 \quad 2.02$

140

1. 150

$1571 \mathrm{~L}$

$0.60 \mathrm{~N}$

$3.29 \quad 0.420$
$4 \mathrm{~L}$

11

22

6

25

21

20

23

27

17

23

39

44

53

49

51

44

49

45

42

44

54

55

42

49 $\begin{array}{lll}1.600 & 4.61 \quad 170\end{array}$

0.100

3551

$\begin{array}{lllllll}H D 02157 & 38 & 00 & 14 & 120 & 41 & 53\end{array}$ 
Appendix 1.---continued

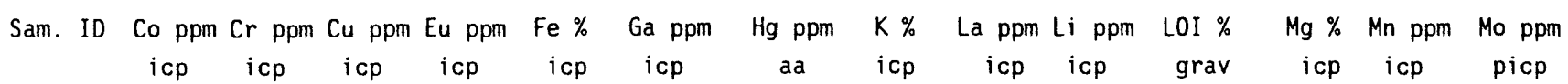

\begin{tabular}{|c|c|c|c|c|c|c|c|c|c|c|c|c|c|c|}
\hline HD01007 & 67 & 57 & 45 & 2 & 7.47 & 19 & $0.02 \mathrm{~N}$ & 0.77 & 22 & 76 & 9.11 & 1.90 & 545 & 0.37 \\
\hline HD01012 & 51 & 50 & 50 & 2 & 7.70 & 23 & $0.02 \mathrm{~N}$ & 2.64 & 25 & 42 & 7.04 & 1.03 & 3030 & 2.00 \\
\hline HD01017 & 31 & 58 & 52 & $2 \mathrm{~L}$ & 7.60 & 21 & $0.02 \mathrm{~N}$ & 2.54 & 26 & 45 & 7.28 & 1.26 & 1140 & 1.20 \\
\hline HDO1022 & 26 & 54 & 55 & $2 \mathrm{~L}$ & 6.62 & 19 & 0.02 & 2.65 & 19 & 37 & 6.60 & 1.14 & 779 & 0.93 \\
\hline HD01032 & 34 & 59 & 58 & $2 \mathrm{~L}$ & 8.12 & 22 & 0.04 & 3.21 & 23 & 34 & 6.49 & 0.92 & 1950 & 1.80 \\
\hline HD01037 & 36 & 64 & 44 & $2 \mathrm{~L}$ & 7.51 & 21 & 0.02 & 1.43 & 24 & 47 & 7.55 & 1.33 & 690 & 1.00 \\
\hline HDO1042 & 29 & 44 & 30 & $2 \mathrm{~L}$ & 6.50 & 12 & 0.04 & 1.71 & 14 & 13 & 3.58 & 0.36 & 477 & 0.94 \\
\hline HDO1047 & 59 & 70 & 52 & 2 & 7.27 & 20 & 0.04 & 2.45 & 23 & 28 & 7.23 & 1.12 & 1050 & 0.73 \\
\hline HDO1052 & 60 & 89 & 44 & 2 & 7.56 & 20 & 0.04 & 2.21 & 22 & 29 & 7.47 & 1.15 & 810 & 0.84 \\
\hline HDO1057 & 16 & 21 & 21 & $2 \mathrm{~L}$ & 3.43 & 6 & 0.06 & 0.85 & 6 & 3 & 1.69 & 0.12 & 205 & 0.53 \\
\hline HDO1062 & 6 & 7 & 7 & $2 \mathrm{~L}$ & 1.05 & 4 & 0.04 & 0.54 & 3 & 2 & 2.02 & 0.30 & 241 & 0.25 \\
\hline HDO1067 & 11 & 61 & 41 & $2 \mathrm{~L}$ & 4.21 & 9 & 0.14 & 1.39 & 10 & 3 & 2.81 & 0.27 & 186 & 0.64 \\
\hline HDO1072 & 3 & 57 & 11 & $2 \mathrm{~L}$ & 1.07 & $4 \mathrm{~L}$ & 0.24 & 0.40 & $2 \mathrm{~L}$ & $2 \mathrm{~L}$ & 0.79 & 0.06 & 28 & 0.31 \\
\hline HDO1077 & 11 & 48 & 32 & $2 \mathrm{~L}$ & 2.18 & 6 & 0.18 & 0.74 & 4 & 7 & 2.64 & 0.43 & 136 & 0.49 \\
\hline HDO1082 & 15 & 64 & 43 & $2 \mathrm{~L}$ & 4.87 & 10 & 0.34 & 1.45 & 12 & 11 & 7.19 & 1.52 & 656 & 0.86 \\
\hline HDO1087 & 14 & 62 & 44 & $2 \mathrm{~L}$ & 4.71 & 9 & 0.44 & 1.13 & 3 & 3 & 19.40 & 3.88 & 1110 & 0.16 \\
\hline HDO1092 & 11 & 71 & 33 & $2 \mathrm{~L}$ & 4.40 & 11 & 0.20 & 1.26 & 6 & 11 & 10.30 & 1.90 & 794 & 0.57 \\
\hline HDO1097 & 13 & 63 & 44 & $2 \mathrm{~L}$ & 4.70 & 10 & 0.16 & 1.42 & 12 & 13 & 10.30 & 2.04 & 764 & 0.73 \\
\hline HDO1102 & 32 & 260 & 12 & $2 \mathrm{~L}$ & 5.24 & 11 & 0.06 & 1.41 & 4 & 20 & 21.20 & 6.93 & 1220 & 0.13 \\
\hline HDO1107 & 16 & 111 & 56 & $2 \mathrm{~L}$ & 5.21 & 13 & 0.14 & 1.86 & 13 & 5 & 11.00 & 2.19 & 669 & 0.98 \\
\hline HDO1112 & 24 & 93 & 60 & $2 \mathrm{~L}$ & 5.10 & 15 & 0.18 & 2.11 & 11 & 4 & 9.45 & 1.81 & 554 & 1.10 \\
\hline HD01117 & 15 & 91 & 56 & $2 \mathrm{~L}$ & 5.00 & 14 & 0.14 & 1.98 & 10 & 4 & 10.20 & 1.84 & 736 & 1.00 \\
\hline HDO1122 & 14 & 80 & 52 & $2 \mathrm{~L}$ & 4.79 & 14 & 0.14 & 1.82 & 11 & 3 & 9.09 & 1.75 & 450 & 1.20 \\
\hline HDO1127 & 12 & 69 & 55 & $2 \mathrm{~L}$ & 4.62 & 14 & 0.14 & 1.72 & 14 & 6 & 10.20 & 1.81 & 523 & 1.10 \\
\hline HDO1132 & 8 & 46 & 19 & $2 \mathrm{~L}$ & 2.54 & 9 & 0.20 & 0.86 & 9 & 24 & 6.12 & 1.10 & 444 & 0.89 \\
\hline HDO1137 & 19 & 91 & 54 & $2 \mathrm{~L}$ & 4.63 & 15 & 0.16 & 1.62 & 11 & 40 & 6.13 & 1.55 & 1120 & 1.20 \\
\hline HDO2002 & 15 & 27 & 32 & 2 & 4.64 & 17 & 0.02 & 0.37 & 22 & 21 & 5.27 & 0.89 & 458 & 0.12 \\
\hline HD02007 & 25 & 54 & 56 & 2 & 6.75 & 19 & 0.04 & 1.44 & 25 & 40 & 5.66 & 1.74 & 739 & 0.13 \\
\hline HDO2O12 & 26 & 61 & 48 & 2 & 7.21 & 21 & $0.02 \mathrm{~N}$ & 2.28 & 28 & 51 & 5.61 & 1.72 & 939 & 0.19 \\
\hline HD02017 & 28 & 51 & 49 & 2 & 6.52 & 22 & 0.02 & 1.30 & 26 & 43 & 4.41 & 1.71 & 881 & 0.13 \\
\hline HD02022 & 27 & 45 & 38 & 2 & 5.93 & 22 & 0.16 & 2.01 & 28 & 28 & 5.60 & 1.43 & 954 & 0.11 \\
\hline HDO2O32 & 21 & 50 & 47 & 2 & 5.20 & 21 & 0.02 & 1.05 & 24 & 24 & 8.47 & 1.35 & 1270 & 0.15 \\
\hline HD02042 & 24 & 34 & 50 & 2 & 5.28 & 20 & $0.02 \mathrm{~N}$ & 1.22 & 28 & 22 & 9.75 & 1.35 & 1270 & 0.17 \\
\hline HDO2052 & 24 & 36 & 52 & 2 & 5.64 & 20 & 0.02 & 1.20 & 25 & 25 & 7.54 & 1.40 & 1190 & 0.15 \\
\hline HDO2062 & 21 & 27 & 43 & 2 & 4.70 & 17 & 0.06 & 0.54 & 24 & 20 & 11.30 & 1.23 & 1480 & 0.41 \\
\hline HD02072 & 22 & 24 & 49 & 2 & 4.89 & 19 & 0.04 & 0.88 & 26 & 20 & 11.30 & 1.27 & 1480 & 0.17 \\
\hline HD02082 & 32 & 27 & 61 & 3 & 6.86 & 21 & 0.02 & 2.13 & 28 & 34 & 4.49 & 1.89 & 744 & 0.12 \\
\hline HD02092 & 24 & 11 & 40 & 3 & 6.19 & 20 & $0.02 \mathrm{~N}$ & 1.35 & 31 & 31 & 7.83 & 1.67 & 966 & 0.09 \\
\hline HD02102 & 28 & 33 & 55 & $2 \mathrm{~L}$ & 6.19 & 19 & 0.08 & 2.27 & 23 & 36 & 9.79 & 1.89 & 824 & 0.26 \\
\hline HDO2112 & 24 & 49 & 50 & 2 & 5.80 & 20 & 0.02 & 0.77 & 26 & 29 & 6.99 & 1.80 & 988 & 0.18 \\
\hline HD02122 & 33 & 161 & 66 & 2 & 5.93 & 20 & $0.02 \mathrm{~N}$ & 0.77 & 26 & 29 & 6.25 & 2.52 & 1130 & 0.19 \\
\hline HD02132 & 30 & 54 & 57 & 2 & 5.95 & 21 & 0.04 & 0.90 & 26 & 24 & 5.60 & 1.88 & 999 & 0.18 \\
\hline HDO2142 & 27 & 54 & 60 & 2 & 6.63 & 20 & 0.08 & 2.68 & 27 & 36 & 7.98 & 2.11 & 637 & 0.15 \\
\hline HDO2152 & 7 & 33 & 32 & $2 \mathrm{~L}$ & 2.43 & 4 & 0.74 & 0.52 & 4 & 11 & 4.94 & 1.01 & 436 & 0.74 \\
\hline HD02157 & 13 & 66 & 49 & $2 \mathrm{~L}$ & 4.79 & 10 & 0.32 & 1.48 & 8 & 7 & 8.53 & 1.76 & 736 & 0.79 \\
\hline
\end{tabular}




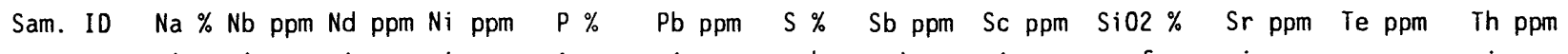
icp icp icp icp icp icp comb picp icp xrf icp aa icp

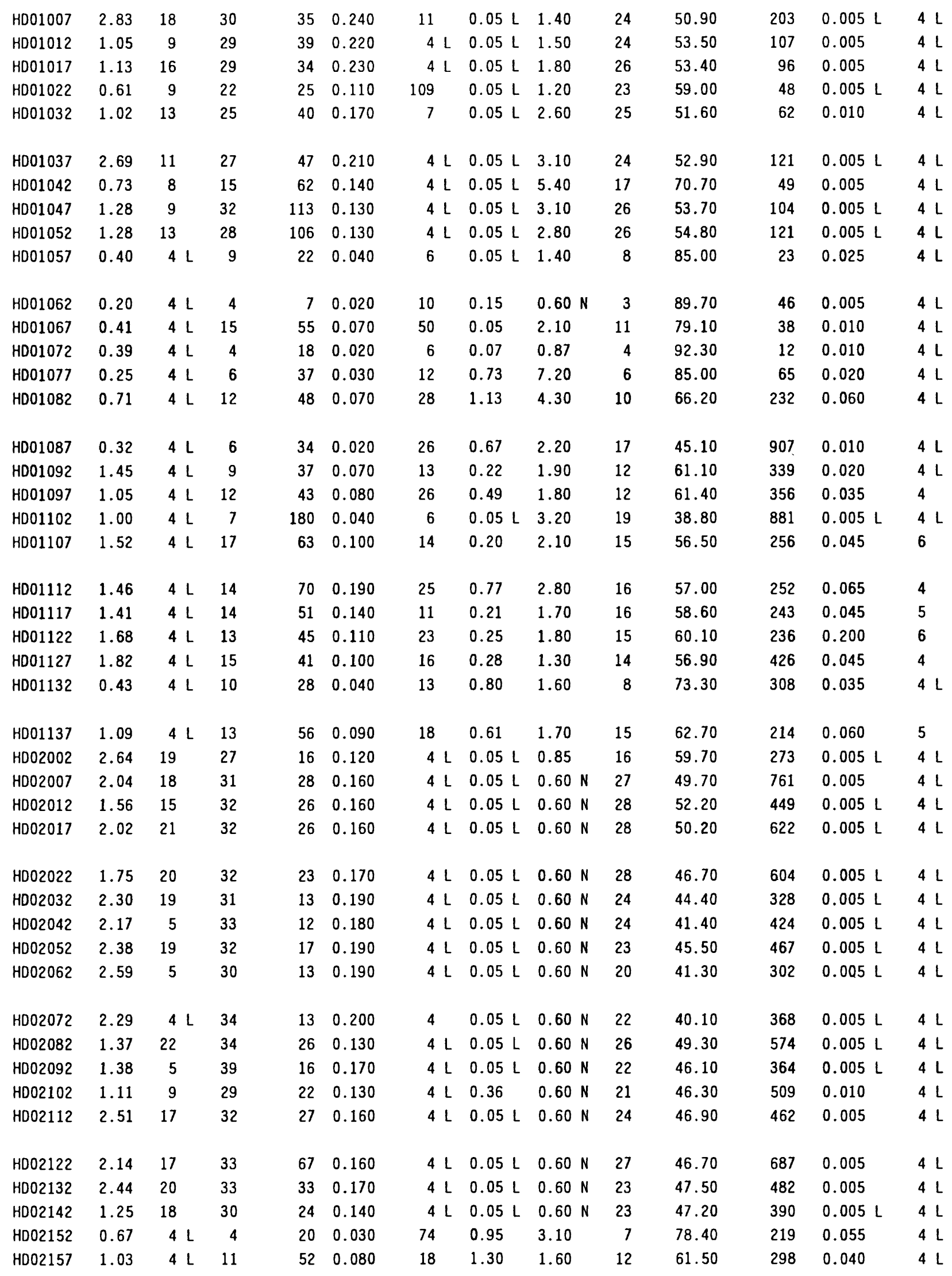


Appendix 1.--continued

\begin{tabular}{|c|c|c|c|c|c|c|c|c|}
\hline Sam. ID & $\begin{array}{l}\mathrm{Ti} \% \\
\text { icp }\end{array}$ & $\begin{array}{c}\text { Tl ppm } \\
\text { aa }\end{array}$ & $\begin{array}{c}V \text { ppm } \\
\text { icp }\end{array}$ & $\begin{array}{l}\text { W ppm } \\
\text { aa }\end{array}$ & $\begin{array}{l}Y \text { ppm } \\
\text { icp }\end{array}$ & $\begin{array}{l}\text { Yb ppm } \\
\text { icp }\end{array}$ & $\begin{array}{l}\text { Zn ppm } \\
\text { icp }\end{array}$ & Geologic unit \\
\hline HDO1007 & 1.040 & 0.10 & 304 & 4.0 & 25 & 3 & 89 & Copper Hill Volcanics \\
\hline HD01012 & 0.450 & 0.30 & 352 & 23.0 & 17 & 2 & 88 & Copper Hill Volcanics \\
\hline HDO1017 & 0.760 & 0.25 & 354 & 18.0 & 16 & 2 & 98 & Copper Hill Volcanics \\
\hline HDO1022 & 0.440 & 0.25 & 307 & 27.0 & 11 & 1 & 127 & Copper Hill Volcanics \\
\hline HDO1032 & 0.470 & 0.40 & 398 & 36.0 & 14 & 1 & 100 & Copper Hill Volcanics \\
\hline HD01037 & 0.530 & 0.10 & 333 & 19.0 & 18 & 2 & 106 & Copper Hill Volcanics \\
\hline HD01042 & 0.390 & 0.25 & 229 & 12.0 & 13 & 1 & 89 & Copper Hill Volcanics \\
\hline HD01047 & 0.520 & 0.20 & 338 & 18.0 & 28 & 2 & 288 & Copper Hill Volcanics \\
\hline HD01052 & 0.760 & 0.20 & 352 & 17.0 & 29 & 3 & 319 & Copper Hill Volcanics \\
\hline HDO1057 & 0.090 & 0.15 & 98 & 14.0 & 5 & $1 \mathrm{~L}$ & 70 & Copper Hill Volcanics \\
\hline HDO1062 & 0.050 & 0.10 & 42 & 9.0 & 3 & $1 \mathrm{~L}$ & 41 & Copper Hill Volcanics \\
\hline HD01067 & 0.090 & 0.30 & 114 & 14.0 & 23 & 1 & 92 & Copper Hill Volcanics \\
\hline HD01072 & 0.050 & 0.10 & 37 & 4.0 & 6 & $1 L$ & 26 & Copper Hill Volcanics \\
\hline HDO1077 & 0.040 & 0.15 & 56 & 5.5 & 6 & $1 \mathrm{~L}$ & 53 & Salt Spring Slate \\
\hline HDO1082 & 0.130 & 0.30 & 87 & 6.0 & 11 & $1 \mathrm{~L}$ & 114 & Salt Spring Slate \\
\hline HDO1087 & 0.040 & 0.20 & 98 & 6.0 & 9 & $1 \mathrm{~L}$ & 64 & Salt Spring Slate \\
\hline HDO1092 & 0.070 & 0.15 & 79 & 4.0 & 9 & $1 \mathrm{~L}$ & 97 & Salt Spring Slate \\
\hline HDO1097 & 0.120 & 0.25 & 87 & 4.0 & 11 & 1 & 144 & Salt Spring Slate \\
\hline HD01102 & 0.100 & 0.30 & 126 & 7.0 & 8 & $1 L$ & 30 & Salt Spring Slate \\
\hline HD01107 & 0.190 & 0.30 & 125 & 5.0 & 12 & 2 & 135 & Salt Spring Slate \\
\hline HDO1112 & 0.100 & 0.35 & 136 & 7.0 & 13 & 1 & 126 & Salt Spring Slate \\
\hline HDO1117 & 0.090 & 0.30 & 127 & 5.0 & 12 & 1 & 138 & Salt Spring Slate \\
\hline HDO1122 & 0.130 & 0.35 & 130 & 4.0 & 11 & 1 & 155 & Salt Spring Slate \\
\hline HDO1127 & 0.160 & 0.30 & 115 & 5.0 & 15 & 2 & 171 & Salt Spring Slate \\
\hline HD01132 & 0.110 & 0.20 & 75 & 7.5 & 9 & $1 \mathrm{~L}$ & 57 & Salt Spring Slate \\
\hline HDO1137 & 0.220 & 0.20 & 143 & 4.5 & 15 & 1 & 111 & Salt Spring Slate \\
\hline $\mathrm{HDO} 2002$ & 0.750 & 0.05 & 251 & 3.0 & 24 & 3 & 49 & Copper Hill Volcanics \\
\hline HDO2007 & 1.030 & 0.05 & 281 & 1.0 & 22 & 2 & 95 & Copper Hill Volcanics \\
\hline HD02012 & 0.890 & $0.05 \mathrm{~L}$ & 280 & 2.0 & 22 & 2 & 77 & Copper Hill Volcanics \\
\hline HDO2017 & 1.070 & 0.10 & 293 & 4.0 & 23 & 2 & 90 & Copper Hill Volcanics \\
\hline HDO2022 & 1.060 & 0.05 & 288 & 1.0 & 25 & 2 & 65 & Copper Hill Volcanics \\
\hline HD02032 & 0.990 & $0.05 \mathrm{~L}$ & 285 & 2.0 & 21 & 2 & 59 & Copper Hill Volcanics \\
\hline $\mathrm{HD} 02042$ & 0.990 & $0.05 \mathrm{~L}$ & 287 & 1.0 & 22 & 2 & 66 & Copper Hill Volcanics \\
\hline HD02052 & 1.010 & 0.05 & 250 & 4.0 & 22 & 2 & 122 & Copper Hill Volcanics \\
\hline HDO2062 & 0.910 & $0.05 \mathrm{~L}$ & 242 & 1.0 & 19 & 2 & 73 & Copper Hill Volcanics \\
\hline HD02072 & 0.880 & $0.05 \mathrm{~L}$ & 273 & 1.0 & 21 & 2 & 76 & Copper Hill Volcanics \\
\hline HD02082 & 1.120 & 0.05 & 261 & 1.0 & 23 & 3 & 91 & Copper Hill Volcanics \\
\hline HD02092 & 1.020 & $0.05 \mathrm{~L}$ & 227 & 1.0 & 24 & 3 & 90 & Copper Hill Volcanics \\
\hline HD02102 & 0.650 & 0.20 & 246 & 7.5 & 15 & 1 & 79 & Copper Hill Volcanics \\
\hline $\mathrm{HDO} 2112$ & 1.010 & $0.05 \mathrm{~N}$ & 295 & 1.0 & 22 & 2 & 67 & Copper Hill Volcanics \\
\hline HDO2122 & 1.010 & $0.05 \mathrm{~L}$ & 297 & 0.5 & 23 & 3 & 70 & Copper Hill Volcanics \\
\hline HD02132 & 1.030 & $0.05 \mathrm{~L}$ & 305 & 1.0 & 22 & 2 & 73 & Copper Hill Volcanics \\
\hline HD02142 & 0.890 & 0.15 & 244 & 1.0 & 17 & 2 & 82 & Copper Hill Volcanics \\
\hline HD02152 & 0.040 & 0.10 & 39 & 6.0 & 4 & $1 \mathrm{~L}$ & 156 & Salt Spring Slate \\
\hline HDO2157 & 0.070 & 0.25 & 81 & 4.5 & 9 & $1 \mathrm{~L}$ & 160 & Salt Spring Slate \\
\hline
\end{tabular}


Appendix 1.--continued

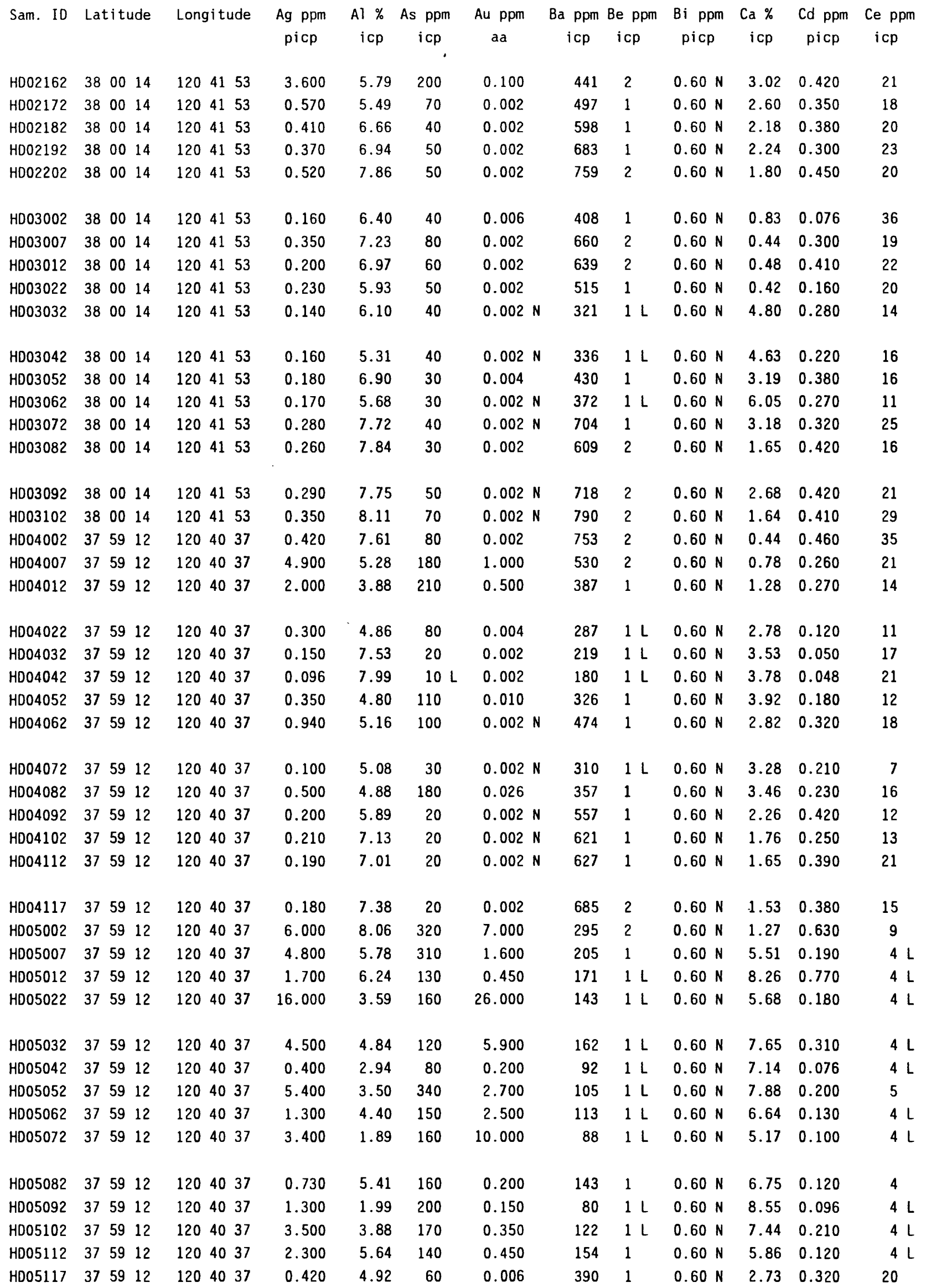


Sam. ID Co ppm Cr ppm Cu ppm Eu ppm Fe \% $\quad$ Ga ppm $\quad$ Hg ppm $\quad$ K \% $\quad$ La ppm Li ppm $\quad$ LOI $\% \quad$ Mg $\% \quad$ Mn ppm $\quad$ Mo ppm icp icp icp icp icp icp aa icp icp icp grav icp icp $p i c p$

\begin{tabular}{|c|c|c|c|c|c|c|c|c|c|c|c|c|c|c|}
\hline $\mathrm{HDO} 2162$ & 16 & 85 & 58 & $2 \mathrm{~L}$ & 4.88 & 13 & 0.40 & 1.98 & 10 & 8 & 7.82 & 1.64 & 731 & 1.00 \\
\hline HDO2172 & 14 & 83 & 44 & $2 \mathrm{~L}$ & 4.87 & 12 & 0.26 & 1.55 & 8 & 14 & 9.50 & 1.84 & 735 & 0.88 \\
\hline HD02182 & 16 & 97 & 56 & $2 \mathrm{~L}$ & 4.39 & 14 & 0.22 & 1.55 & 9 & 41 & 6.57 & 1.60 & 871 & 1.10 \\
\hline HD02192 & 19 & 99 & 59 & $2 \mathrm{~L}$ & 4.91 & 16 & 0.18 & 1.66 & 11 & 44 & 6.91 & 1.63 & 1060 & 1.20 \\
\hline HD02202 & 17 & 115 & 65 & $2 \mathrm{~L}$ & 4.97 & 18 & 0.16 & 1.84 & 9 & 52 & 6.35 & 1.66 & 639 & 1.30 \\
\hline $\mathrm{HD} 03002$ & 17 & 88 & 36 & $2 \mathrm{~L}$ & 4.66 & 16 & 0.12 & 1.25 & 18 & 40 & 5.82 & 1.24 & 677 & 0.66 \\
\hline HD03007 & 18 & 122 & 96 & $2 \mathrm{~L}$ & 4.88 & 17 & 0.24 & 2.26 & 9 & 45 & 4.31 & 1.68 & 452 & 0.99 \\
\hline HD03012 & 17 & 113 & 59 & $2 \mathrm{~L}$ & 4.63 & 17 & 0.20 & 2.15 & 10 & 46 & 4.05 & 1.66 & 410 & 0.94 \\
\hline HD03022 & 12 & 89 & 45 & $2 \mathrm{~L}$ & 4.17 & 14 & 0.22 & 1.72 & 10 & 43 & 3.47 & 1.51 & 397 & 0.50 \\
\hline HD03032 & 25 & 218 & 57 & $2 \mathrm{~L}$ & 4.43 & 13 & 0.14 & 1.10 & 8 & 64 & 7.81 & 2.66 & 1010 & 0.57 \\
\hline HD03042 & 23 & 191 & 60 & $2 \mathrm{~L}$ & 3.87 & 12 & 0.22 & 1.07 & 8 & 58 & 7.41 & 2.23 & 1070 & 0.96 \\
\hline HD03052 & 27 & 154 & 70 & $2 \mathrm{~L}$ & 4.95 & 14 & 0.16 & 1.34 & 9 & 68 & 6.60 & 2.53 & 958 & 1.00 \\
\hline HD03062 & 23 & 150 & 60 & $2 \mathrm{~L}$ & 4.18 & 12 & 0.18 & 1.17 & 7 & 59 & 8.85 & 1.98 & 1410 & 1.10 \\
\hline HD03072 & 24 & 115 & 65 & $2 \mathrm{~L}$ & 4.82 & 16 & 0.16 & 2.13 & 14 & 53 & 6.57 & 1.78 & 810 & 1.60 \\
\hline HD03082 & 28 & 127 & 64 & $2 \mathrm{~L}$ & 4.66 & 16 & 0.22 & 2.27 & 9 & 48 & 4.78 & 1.62 & 571 & 1.30 \\
\hline HD03092 & 31 & 118 & 77 & $2 \mathrm{~L}$ & 5.11 & 17 & 0.26 & 2.17 & 11 & 55 & 6.13 & 1.78 & 771 & 1.90 \\
\hline HD03102 & 38 & 128 & 80 & $2 \mathrm{~L}$ & 5.43 & 18 & 0.28 & 2.37 & 16 & 54 & 5.14 & 1.80 & 616 & 2.40 \\
\hline HD04002 & 19 & 130 & 83 & $2 \mathrm{~L}$ & 4.90 & 17 & 0.12 & 2.72 & 17 & 11 & 5.21 & 0.64 & 654 & 1.30 \\
\hline HDO4007 & 14 & 85 & 52 & $2 \mathrm{~L}$ & 4.20 & 12 & 0.20 & 1.95 & 10 & 7 & 4.19 & 0.53 & 387 & 1.20 \\
\hline HD04012 & 11 & 48 & 51 & $2 \mathrm{~L}$ & 3.77 & 9 & 0.14 & 1.50 & 8 & 4 & 4.35 & 0.67 & 315 & 1.20 \\
\hline HD04022 & 11 & 37 & 30 & $2 \mathrm{~L}$ & 2.80 & 11 & 0.04 & 1.50 & 7 & 3 & 7.08 & 1.36 & 502 & 0.38 \\
\hline HD04032 & 11 & 22 & 24 & $2 \mathrm{~L}$ & 2.72 & 15 & 0.02 & 2.05 & 10 & 4 & 9.00 & 1.56 & 458 & 0.10 \\
\hline HD04042 & 14 & 50 & 33 & $2 \mathrm{~L}$ & 3.02 & 17 & 0.04 & 1.61 & 12 & 17 & 9.54 & 1.98 & 546 & 0.10 \\
\hline HDO 4052 & 14 & 99 & 35 & $2 \mathrm{~L}$ & 3.35 & 11 & 0.04 & 1.67 & 9 & 4 & 10.30 & 2.29 & 793 & 0.23 \\
\hline HD04062 & 18 & 69 & 54 & $2 \mathrm{~L}$ & 4.52 & 12 & 0.12 & 1.84 & 9 & 4 & 9.71 & 1.98 & 857 & 1.00 \\
\hline HD04072 & 12 & 94 & 30 & $2 \mathrm{~L}$ & 3.30 & 10 & 0.12 & 0.97 & 5 & 11 & 8.29 & 1.56 & 670 & 0.57 \\
\hline HO04082 & 12 & 80 & 31 & $2 \mathrm{~L}$ & 3.26 & 10 & 0.10 & 1.27 & 9 & 4 & 8.59 & 1.66 & 579 & 0.64 \\
\hline HD04092 & 15 & 95 & 51 & $2 \mathrm{~L}$ & 3.91 & 12 & 0.08 & 1.43 & 7 & 40 & 7.02 & 1.72 & 745 & 0.88 \\
\hline HD04102 & 15 & 88 & 55 & $2 L$ & 4.39 & 15 & 0.10 & 1.66 & 7 & 48 & 6.04 & 1.68 & 709 & 1.20 \\
\hline HD04112 & 21 & 107 & 66 & $2 \mathrm{~L}$ & 4.41 & 15 & 0.16 & 1.61 & 9 & 49 & 5.55 & 1.74 & 755 & 1.20 \\
\hline HD04117 & 19 & 113 & 63 & $2 \mathrm{~L}$ & 4.46 & 16 & 0.16 & 1.77 & 8 & 52 & 5.41 & 1.73 & 686 & 1.40 \\
\hline HDO5002 & 43 & 456 & 183 & $2 \mathrm{~L}$ & 8.49 & 16 & 0.22 & 2.62 & 5 & 7 & 7.77 & 1.11 & 428 & 1.40 \\
\hline HD05007 & 25 & 139 & 87 & $2 \mathrm{~L}$ & 4.72 & 11 & 0.20 & 2.01 & 3 & 3 & 9.90 & 0.89 & 595 & 0.32 \\
\hline HD05012 & 35 & 253 & 89 & $2 \mathrm{~L}$ & 5.11 & 11 & 0.24 & 1.83 & 4 & $2 L$ & 13.80 & 1.29 & 896 & 0.95 \\
\hline HD05022 & 18 & 127 & 75 & $2 L$ & 3.37 & 7 & 0.36 & 1.35 & 2 & $2 L$ & 11.10 & 1.67 & 623 & 0.30 \\
\hline HD05032 & 25 & 186 & 80 & $2 L$ & 4.44 & 8 & 0.32 & 1.66 & 4 & 3 & 14.50 & 2.16 & 847 & 0.50 \\
\hline HD05042 & 14 & 152 & 38 & $2 \mathrm{~L}$ & 3.94 & 6 & 0.02 & 0.94 & 3 & $2 L$ & 15.20 & 3.13 & 903 & 0.13 \\
\hline HD05052 & 18 & 160 & 126 & $2 \mathrm{~L}$ & 4.87 & 8 & 0.16 & 1.23 & 4 & $2 L$ & 17.50 & 4.05 & 938 & 0.22 \\
\hline HD05062 & 20 & 78 & 76 & $2 \mathrm{~L}$ & 4.67 & 9 & 0.06 & 1.38 & 3 & $2 L$ & 15.20 & 3.44 & 920 & 0.14 \\
\hline HD05072 & 11 & 79 & 54 & $2 \mathrm{~L}$ & 3.08 & 5 & 0.08 & 0.74 & 2 & $2 L$ & 10.40 & 2.62 & 634 & 0.09 \\
\hline HD05082 & 19 & 176 & 36 & $2 \mathrm{~L}$ & 3.35 & 13 & 0.04 & 1.73 & 4 & 2 & 17.30 & 4.60 & 1170 & 0.11 \\
\hline HD05092 & 22 & 690 & 23 & $2 \mathrm{~L}$ & 3.14 & 6 & $0.02 \mathrm{~N}$ & 0.84 & 2 & $2 L$ & 21.40 & 5.79 & 1050 & 0.19 \\
\hline HD05102 & 17 & 174 & 67 & $2 \mathrm{~L}$ & 3.54 & 9 & 0.08 & 1.26 & 3 & $2 \mathrm{~L}$ & 17.10 & 4.32 & 995 & 0.13 \\
\hline HD05112 & 23 & 272 & 89 & $2 L$ & 4.37 & 11 & 0.10 & 1.82 & 4 & 2 & 18.40 & 5.23 & 1050 & 0.10 \\
\hline HD05117 & 15 & 105 & 62 & $2 \mathrm{~L}$ & 4.20 & 11 & 0.12 & 1.31 & 10 & 26 & 8.04 & 2.00 & 759 & 0.70 \\
\hline
\end{tabular}


Appendix 1.--continued

Sam. ID $\quad \mathrm{Na} \% \mathrm{Nb}$ ppm Nd ppm Ni ppm $\mathrm{P} \% \quad \mathrm{~Pb} p p m \quad \mathrm{~S} \% \quad$ Sb ppm $\quad$ Sc ppm SiO2 \% $\quad$ Sr ppm Te ppm Th ppm icp icp icp icp icp icp, comb picp icp xrf icp aa icp

\begin{tabular}{|c|c|c|c|c|c|c|c|c|c|c|c|c|c|}
\hline HDO2162 & 1.04 & $4 \mathrm{~L}$ & 13 & 60 & 0.080 & 16 & 1.75 & 2.50 & 13 & 59.10 & 294 & 0.045 & 41 \\
\hline HO02172 & 1.49 & $4 \mathrm{~L}$ & 9 & 47 & 0.090 & 11 & 0.47 & 2.20 & 13 & 60.80 & 290 & 0.035 & $4 \mathrm{~L}$ \\
\hline HD02182 & 1.34 & $4 \mathrm{~L}$ & 11 & 53 & 0.090 & 13 & 0.41 & 1.60 & 14 & 63.10 & 230 & 0.045 & 41 \\
\hline HOO2192 & 1.07 & $4 \mathrm{~L}$ & 14 & 55 & 0.110 & 16 & 0.49 & 1.50 & 16 & 61.30 & 252 & 0.055 & 41 \\
\hline HD02202 & 1.40 & $4 \mathrm{~L}$ & 13 & 66 & 0.140 & 17 & 0.42 & 1.20 & 17 & 59.60 & 188 & 0.050 & 5 \\
\hline HD03002 & 0.81 & 7 & 20 & 44 & 0.090 & 25 & $0.05 \mathrm{~L}$ & 1.00 & 12 & 68.30 & 128 & 0.075 & 4 \\
\hline HD03007 & 0.51 & $4 \mathrm{~L}$ & 9 & 75 & 0.110 & 13 & 0.30 & 2.40 & 14 & 66.70 & 58 & 0.090 & 41 \\
\hline HD03012 & 0.53 & $4 \mathrm{~L}$ & 12 & 71 & 0.100 & 9 & 0.36 & 1.80 & 14 & 67.80 & 60 & 0.120 & 6 \\
\hline HD03022 & 0.47 & $4 \mathrm{~L}$ & 9 & 60 & 0.090 & 9 & 0.14 & 1.70 & 11 & 72.00 & 58 & 0.100 & $4 \mathrm{~L}$ \\
\hline HD03032 & 1.04 & $4 \mathrm{~L}$ & 13 & 74 & 0.070 & 16 & 0.57 & 1.60 & 17 & 58.70 & 598 & 0.045 & 41 \\
\hline HD03042 & 0.76 & $4 \mathrm{~L}$ & 11 & 95 & 0.070 & 22 & 0.63 & 3.00 & 13 & 62.60 & 476 & 0.040 & 41 \\
\hline HDO3052 & 1.22 & $4 \mathrm{~L}$ & 12 & 88 & 0.100 & 13 & 0.56 & 3.10 & 16 & 60.00 & 277 & 0.040 & 5 \\
\hline HD03062 & 0.91 & $4 \mathrm{~L}$ & 12 & 78 & 0.090 & 16 & 0.47 & 2.90 & 14 & 58.10 & 465 & 0.030 & 41 \\
\hline HD03072 & 0.95 & $4 \mathrm{~L}$ & 15 & 73 & 0.140 & 22 & 0.54 & 4.30 & 17 & 58.20 & 229 & 0.060 & 7 \\
\hline HD03082 & 0.99 & $4 \mathrm{~L}$ & 10 & 77 & 0.100 & 17 & 0.70 & 3.90 & 16 & 61.80 & 152 & 0.045 & 6 \\
\hline HD03092 & 0.81 & $4 \mathrm{~L}$ & 15 & 81 & 0.210 & 28 & 0.58 & 4.20 & 16 & 59.10 & 215 & 0.065 & 6 \\
\hline HD03102 & 0.74 & $4 \mathrm{~L}$ & 18 & 86 & 0.140 & 37 & 0.84 & 4.70 & 18 & 60.00 & 139 & 0.150 & 8 \\
\hline HDO4002 & 0.49 & $4 \mathrm{~L}$ & 20 & 128 & 0.120 & 61 & $0.05 \mathrm{~L}$ & 3.50 & 18 & 65.00 & 59 & 0.060 & 7 \\
\hline HDO4007 & 0.37 & $4 \mathrm{~L}$ & 10 & 66 & 0.080 & 43 & $0.05 \mathrm{~L}$ & 3.50 & 12 & 73.50 & 74 & 0.060 & 41 \\
\hline HDO4012 & 0.28 & $4 \mathrm{~L}$ & 9 & 46 & 0.050 & 27 & $0.05 \mathrm{~L}$ & 2.70 & 9 & 76.50 & 63 & 0.060 & 4 \\
\hline HD04022 & 1.24 & $4 \mathrm{~L}$ & 8 & 25 & 0.050 & 7 & $0.05 \mathrm{~L}$ & 0.80 & 9 & 68.10 & 268 & 0.015 & 41 \\
\hline HD04032 & 2.15 & $4 \mathrm{~L}$ & 10 & 24 & 0.060 & 8 & 0.05 & 0.60 & 9 & 59.10 & 306 & $0.005 \mathrm{~L}$ & $4 \mathrm{~L}$ \\
\hline $\mathrm{HD} 04042$ & 2.46 & $4 \mathrm{~L}$ & 14 & 42 & 0.070 & 5 & 0.08 & $0.60 \mathrm{~N}$ & 11 & 56.10 & 333 & $0.005 \mathrm{~L}$ & 41 \\
\hline HD04052 & 0.71 & $4 \mathrm{~L}$ & 10 & 57 & 0.050 & 8 & 0.49 & 0.72 & 11 & 61.50 & 429 & 0.015 & $4 \mathrm{~L}$ \\
\hline HDO4062 & 0.63 & $4 \mathrm{~L}$ & 11 & 52 & 0.100 & 26 & 0.70 & 2.30 & 13 & 61.30 & 295 & 0.045 & $4 \mathrm{~L}$ \\
\hline HD04072 & 1.90 & $4 \mathrm{~L}$ & 7 & 45 & 0.060 & 11 & 0.25 & 1.70 & 11 & 64.60 & 248 & 0.015 & $4 \mathrm{~L}$ \\
\hline HD04082 & 1.42 & $4 \mathrm{~L}$ & 11 & 45 & 0.060 & 23 & 0.71 & 1.60 & 11 & 64.10 & 393 & 0.025 & 41 \\
\hline HD04092 & 1.14 & $4 \mathrm{~L}$ & 8 & 58 & 0.090 & 14 & 0.23 & 1.50 & 14 & 65.20 & 246 & 0.030 & 41 \\
\hline HD04102 & 1.49 & $4 \mathrm{~L}$ & 10 & 49 & 0.100 & 27 & 0.28 & 1.50 & 16 & 62.80 & 213 & 0.040 & 5 \\
\hline HDO4112 & 1.42 & $4 \mathrm{~L}$ & 11 & 64 & 0.110 & 18 & 0.45 & 1.90 & 16 & 63.20 & 183 & 0.045 & 4 \\
\hline HD04117 & 1.35 & $4 \mathrm{~L}$ & 10 & 66 & 0.110 & 21 & 0.45 & 1.90 & 16 & 62.60 & 167 & 0.045 & 6 \\
\hline HDO5002 & 1.03 & $4 \mathrm{~L}$ & 8 & 130 & 0.020 & 110 & $0.05 \mathrm{~L}$ & 33.00 & 42 & 54.90 & 83 & 0.500 & 41 \\
\hline HDO5007 & 0.88 & $4 \mathrm{~L}$ & 5 & 59 & 0.008 & 45 & $0.05 \mathrm{~L}$ & 11.00 & 25 & 58.70 & 91 & 0.055 & 4 \\
\hline HDO5012 & 1.60 & $4 \mathrm{~L}$ & 8 & 61 & 0.030 & 29 & $0.05 \mathrm{~L}$ & 4.40 & 37 & 48.40 & 139 & 0.050 & 4 \\
\hline HD05022 & 0.34 & $4 \mathrm{~L}$ & 5 & 35 & 0.009 & 289 & $0.05 \mathrm{~L}$ & 3.60 & 20 & 63.80 & 212 & 0.025 & 4 \\
\hline HD05032 & 0.76 & $4 \mathrm{~L}$ & 6 & 51 & 0.030 & 29 & $0.05 \mathrm{~L}$ & 2.50 & 27 & 52.50 & 257 & 0.015 & 41 \\
\hline HD05042 & 0.57 & $4 \mathrm{~L}$ & $4 \mathrm{~L}$ & 30 & 0.020 & 5 & $0.05 \mathrm{~L}$ & $0.60 \mathrm{~N}$ & 19 & 56.70 & 430 & $0.005 \mathrm{~L}$ & 41 \\
\hline HDO5052 & 0.57 & $4 \mathrm{~L}$ & 8 & 50 & 0.008 & 8 & 0.28 & 4.30 & 26 & 48.00 & 616 & 0.015 & 41 \\
\hline HD05062 & 0.97 & $4 \mathrm{~L}$ & $4 \mathrm{~L}$ & 38 & 0.040 & 6 & 0.45 & 1.20 & 25 & 50.60 & 442 & 0.010 & 41 \\
\hline HD05072 & 0.13 & $4 \mathrm{~L}$ & $4 \mathrm{~L}$ & 38 & $0.005 \mathrm{~L}$ & 14 & 0.91 & 3.20 & 13 & 67.10 & 442 & 0.020 & 4 \\
\hline HD05082 & 1.36 & $4 \mathrm{~L}$ & 7 & 80 & 0.007 & 4 & 0.33 & 1.70 & 24 & 46.00 & 565 & 0.005 & 4 \\
\hline HD05092 & 0.07 & $4 \mathrm{~L}$ & 6 & 174 & $0.005 \mathrm{~L}$ & 10 & 0.13 & 5.60 & 20 & 47.40 & 885 & 0.005 & 4 \\
\hline HD05102 & 0.85 & $4 \mathrm{~L}$ & 4 & 74 & $0.005 \mathrm{~L}$ & 6 & 0.63 & 7.50 & 22 & 49.30 & 673 & 0.005 & 4 \\
\hline HD05112 & 1.29 & $4 \mathrm{~L}$ & 7 & 116 & 0.010 & 7 & 0.29 & 3.80 & 25 & 43.30 & 506 & $0.005 \mathrm{~L}$ & 4 \\
\hline HD05117 & 0.90 & $4 \mathrm{~L}$ & 10 & 52 & 0.090 & 13 & 0.40 & 1.50 & 13 & 64.80 & 344 & 0.035 & 4 \\
\hline
\end{tabular}


Appendix 1.--continued

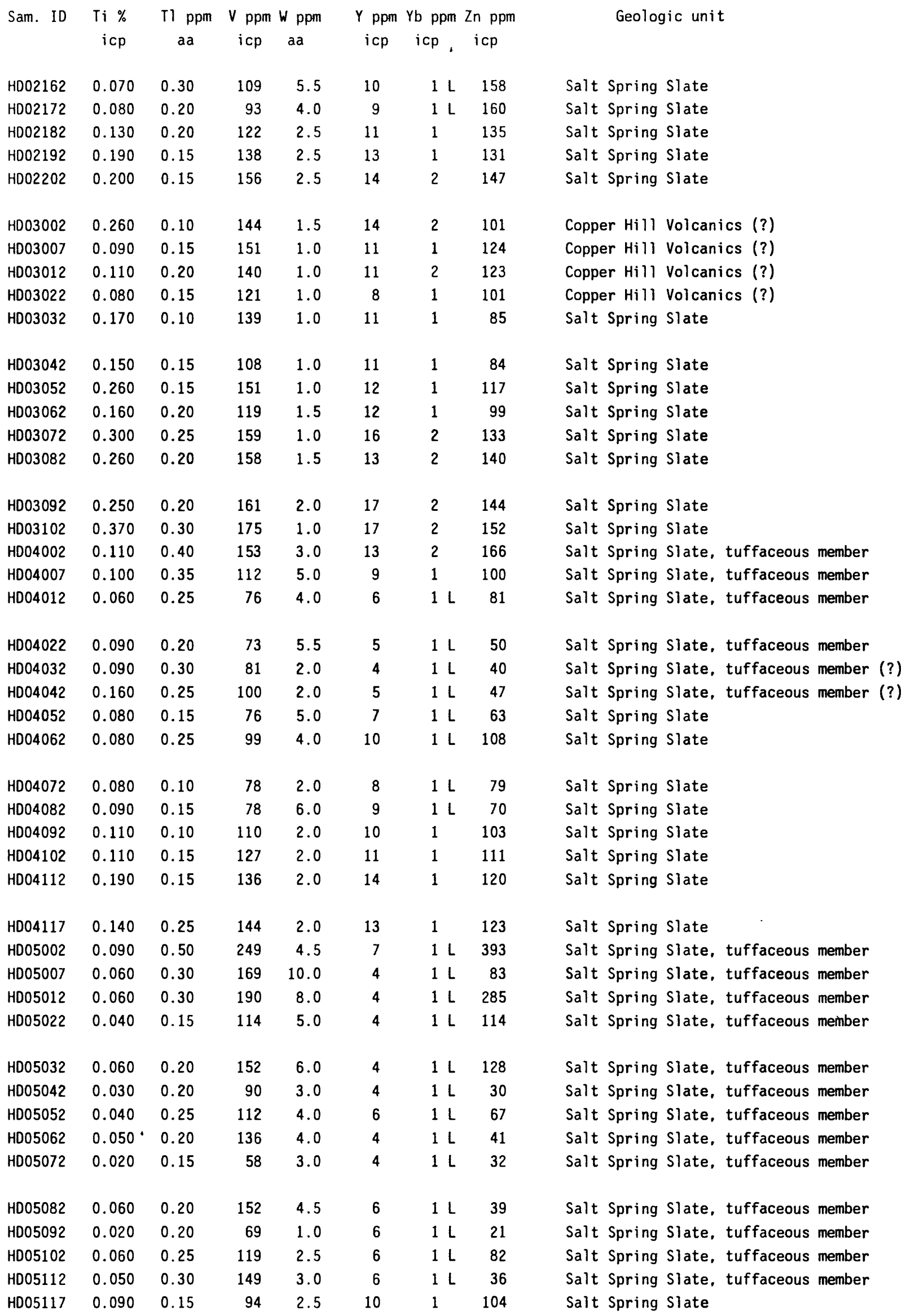


Sam. ID Latitude Longitude Ag ppm Al \% As ppm Au ppm Ba ppm Be ppm Bi ppm Ca $\% \quad$ Cd ppm Ce ppm

\begin{tabular}{|c|c|c|c|c|c|c|c|c|c|c|c|c|c|c|}
\hline & & & & & picp & $i c p$ & $i c p$ & $a a$ & $i c p$ & icp & picp & $i c p$ & picp & $i c p$ \\
\hline HD05122 & 37 & 59 & 12 & $120 \quad 40 \quad 37$ & 1.000 & 4.91 & 60 & 0.050 & 386 & 1 & $0.60 \mathrm{~N}$ & 2.74 & 0.370 & 18 \\
\hline HD05132 & 37 & 59 & 12 & $120 \quad 4037$ & 0.140 & 7.01 & 30 & $0.002 \mathrm{~N}$ & 716 & 1 & $0.60 \mathrm{~N}$ & 1.85 & 0.200 & 21 \\
\hline HD05142 & 37 & 59 & 12 & $120 \quad 40 \quad 37$ & 0.160 & 7.01 & 20 & 0.002 & 770 & 2 & $0.60 \mathrm{~N}$ & 1.74 & 0.140 & 19 \\
\hline HD05152 & 37 & 59 & 12 & $120 \quad 4037$ & 0.150 & 6.64 & 20 & $0.002 \mathrm{~L}$ & 619 & 1 & $0.60 \mathrm{~N}$ & 2.71 & 0.200 & 12 \\
\hline HD05162 & 37 & 59 & 12 & $120 \quad 40 \quad 37$ & 0.170 & 7.48 & 20 & $0.002 \mathrm{~N}$ & 733 & 2 & $0.60 \mathrm{~N}$ & 1.58 & 0.400 & 18 \\
\hline HD05172 & 37 & 59 & 12 & $120 \quad 40 \quad 37$ & 0.600 & 5.43 & $10 \mathrm{~L}$ & 0.700 & 390 & $1 L$ & $0.60 \mathrm{~N}$ & 2.41 & 0.230 & 15 \\
\hline HD05182 & 37 & 59 & 12 & $120 \quad 40 \quad 37$ & 0.150 & 6.70 & 20 & $0.002 \mathrm{~N}$ & 627 & 1 & $0.60 \mathrm{~N}$ & 2.30 & 0.290 & 12 \\
\hline HD05192 & 37 & 59 & 12 & $120 \quad 4037$ & 0.160 & 6.77 & 10 & $0.002 \mathrm{~L}$ & 740 & 1 & $0.60 \mathrm{~N}$ & 1.93 & 0.180 & 13 \\
\hline HD05202 & 37 & 59 & 12 & $\begin{array}{lll}120 & 40 & 37\end{array}$ & 0.220 & 6.72 & 30 & 0.012 & 409 & 1 & $0.60 \mathrm{~N}$ & 2.09 & 0.980 & 31 \\
\hline HDO5212 & 37 & 59 & 12 & $\begin{array}{lll}120 & 40 & 37\end{array}$ & 0.046 & 7.19 & $10 \mathrm{~L}$ & $0.002 \mathrm{~N}$ & 80 & $1 \mathrm{~L}$ & $0.60 \mathrm{~N}$ & 9.35 & 0.190 & 6 \\
\hline HDO5222 & 37 & 59 & 12 & $\begin{array}{llll}120 & 40 & 37\end{array}$ & 0.094 & 7.59 & 30 & $0.002 \mathrm{~N}$ & 108 & $1 \mathrm{~L}$ & $0.60 \mathrm{~N}$ & 6.32 & 0.140 & 7 \\
\hline HD05232 & 37 & 59 & 12 & $\begin{array}{lll}120 & 40 & 37\end{array}$ & 0.170 & 7.20 & 20 & $0.002 \mathrm{~N}$ & 699 & 1 & $0.60 \mathrm{~N}$ & 2.05 & 0.190 & 19 \\
\hline HD05242 & 37 & 59 & 12 & $\begin{array}{lll}120 & 40 & 37\end{array}$ & 0.110 & 5.20 & 40 & $0.002 \mathrm{~N}$ & 464 & 1 & $0.60 \mathrm{~N}$ & 3.46 & 0.300 & 20 \\
\hline HD06002 & 37 & 59 & 12 & $\begin{array}{llll}120 & 40 & 37\end{array}$ & 0.860 & 8.03 & 210 & 0.650 & 251 & 1 & $0.60 \mathrm{~N}$ & 0.18 & 0.055 & 11 \\
\hline HD06007 & 37 & 59 & 12 & $\begin{array}{lll}120 & 40 & 37\end{array}$ & 0.190 & 7.56 & 100 & 0.010 & 108 & $1 \mathrm{~L}$ & $0.60 \mathrm{~N}$ & 3.86 & 0.080 & 8 \\
\hline HD06012 & 37 & 59 & 12 & $\begin{array}{llll}120 & 40 & 37\end{array}$ & 0.140 & 6.07 & 150 & 0.004 & 66 & $1 \mathrm{~L}$ & $0.60 \mathrm{~N}$ & 5.55 & 0.080 & 7 \\
\hline HD06022 & 37 & 59 & 12 & $\begin{array}{llll}120 & 40 & 37\end{array}$ & 0.150 & 7.03 & 110 & 0.014 & 141 & $1 \mathrm{~L}$ & $0.60 \mathrm{~N}$ & 7.74 & 0.087 & 8 \\
\hline HD06032 & 37 & 59 & 12 & $\begin{array}{lll}120 & 40 \quad 37\end{array}$ & 0.240 & 7.70 & 40 & 0.002 & 108 & $1 \mathrm{~L}$ & $0.60 \mathrm{~N}$ & 4.50 & 0.140 & 9 \\
\hline HD06042 & 37 & 59 & 12 & $120 \quad 40 \quad 37$ & 0.340 & 5.28 & 70 & 0.500 & 210 & $1 \mathrm{~L}$ & $0.60 \mathrm{~N}$ & 4.25 & 0.260 & 12 \\
\hline HD06052 & 37 & 59 & 12 & $\begin{array}{llll}120 & 40 & 37\end{array}$ & 0.480 & 5.75 & 100 & $0.002 \mathrm{~N}$ & 419 & 1 & $0.60 \mathrm{~N}$ & 3.82 & 0.210 & 18 \\
\hline HD06062 & 37 & 59 & 12 & $\begin{array}{lll}120 & 40 & 37\end{array}$ & 0.160 & 6.93 & 30 & $0.002 \mathrm{~N}$ & 585 & 1 & $0.60 \mathrm{~N}$ & 2.48 & 0.390 & 16 \\
\hline HD06072 & 37 & 59 & 12 & $120 \quad 40 \quad 37$ & 0.150 & 6.88 & 30 & $0.002 \mathrm{~L}$ & 328 & 1 & $0.60 \mathrm{~N}$ & 2.89 & 0.210 & 14 \\
\hline HD06082 & 37 & 59 & 12 & $120 \quad 40 \quad 37$ & 0.510 & 7.12 & 30 & $0.002 \mathrm{~L}$ & 284 & $1 \mathrm{~L}$ & $0.60 \mathrm{~N}$ & 3.73 & 0.260 & 9 \\
\hline HD06092 & 37 & 59 & 12 & $\begin{array}{lll}120 & 40 & 37\end{array}$ & 0.490 & 7.71 & 70 & $0.002 \mathrm{~N}$ & 613 & 2 & $0.60 \mathrm{~N}$ & 0.63 & 0.320 & 26 \\
\hline HD06097 & 37 & 59 & 12 & $\begin{array}{lll}120 & 40 \quad 37\end{array}$ & 0.250 & 6.96 & 30 & $0.002 \mathrm{~N}$ & 716 & 2 & $0.60 \mathrm{~N}$ & 1.63 & 0.390 & 23 \\
\hline HDO 01010 & 37 & 59 & 12 & $120 \quad 40 \quad 37$ & 0.053 & 7.11 & $10 \mathrm{~L}$ & 0.004 & 82 & $1 \mathrm{~L}$ & $0.60 \mathrm{~N}$ & 4.66 & 0.053 & $4 L$ \\
\hline $\mathrm{HD} 07020$ & 37 & 59 & 12 & $\begin{array}{lll}120 & 40 & 37\end{array}$ & 0.052 & 5.43 & $10 \mathrm{~L}$ & 0.002 & 44 & $1 \mathrm{~L}$ & $0.60 \mathrm{~N}$ & 6.09 & 0.048 & $4 \mathrm{~L}$ \\
\hline HD07030 & 37 & 59 & 12 & $120 \quad 40 \quad 37$ & 0.055 & 5.67 & 10 & 0.002 & 37 & $1 \mathrm{~L}$ & $0.60 \mathrm{~N}$ & 6.44 & 0.062 & $4 L$ \\
\hline HDO 07040 & 37 & 59 & 12 & $120 \quad 40 \quad 37$ & 0.054 & 6.18 & $10 \mathrm{~L}$ & 0.002 & 39 & $1 L$ & $0.60 \mathrm{~N}$ & 4.81 & 0.037 & $4 \mathrm{~L}$ \\
\hline HD07050 & 37 & 59 & 12 & $120 \quad 40 \quad 37$ & 0.053 & 5.79 & $10 \mathrm{~L}$ & 0.004 & 25 & $1 \mathrm{~L}$ & $0.60 \mathrm{~N}$ & 5.81 & 0.084 & $4 L$ \\
\hline HD07059 & 37 & 59 & 12 & $\begin{array}{lll}120 & 40 & 37\end{array}$ & 0.088 & 5.82 & 20 & 0.004 & 32 & $1 \mathrm{~L}$ & $0.60 \mathrm{~N}$ & 5.65 & 0.066 & $4 L$ \\
\hline HD07063 & 37 & 59 & 12 & $120 \quad 40 \quad 37$ & 2.500 & 6.63 & 250 & 0.100 & 202 & 1 & $0.60 \mathrm{~N}$ & 1.49 & 0.130 & 31 \\
\hline HD07068 & 37 & 59 & 12 & $120 \quad 40 \quad 37$ & 8.200 & 7.58 & 240 & 18.000 & 160 & 1 & $0.60 \mathrm{~N}$ & 3.64 & 0.160 & 6 \\
\hline HD07080 & 37 & 59 & 12 & $120 \quad 4037$ & 4.400 & 5.56 & 150 & 0.300 & 166 & $1 \mathrm{~L}$ & $0.60 \mathrm{~N}$ & 6.16 & 0.150 & 4 \\
\hline HD07090 & 37 & 59 & 12 & $120 \quad 40 \quad 37$ & 7.500 & 6.32 & 160 & 16.000 & 116 & 1 & $0.60 \mathrm{~N}$ & 6.36 & 0.078 & $4 L$ \\
\hline HD07100 & 37 & 59 & 12 & $120 \quad 40 \quad 37$ & 4.600 & 5.11 & 40 & 4.800 & 229 & $1 \mathrm{~L}$ & $0.60 \mathrm{~N}$ & 5.45 & 0.100 & $4 \mathrm{~L}$ \\
\hline HD07110 & 37 & 59 & 12 & $\begin{array}{lll}120 & 40 & 37\end{array}$ & 2.400 & 7.21 & 100 & 0.950 & 281 & 1 & $0.60 \mathrm{~N}$ & 6.09 & 0.110 & $4 \mathrm{~L}$ \\
\hline HD07122 & 37 & 59 & 12 & $120 \quad 40 \quad 37$ & 1.400 & 7.05 & 110 & 1.100 & 294 & 1 & $0.60 \mathrm{~N}$ & 5.82 & 0.090 & $4 \mathrm{~L}$ \\
\hline HD07130 & 37 & 59 & 12 & $\begin{array}{lll}120 & 40 & 37\end{array}$ & 0.710 & 3.17 & 190 & 0.450 & 140 & $1 \mathrm{~L}$ & $0.60 \mathrm{~N}$ & 3.04 & 0.045 & $4 L$ \\
\hline HDO 140 & 37 & 59 & 12 & $\begin{array}{lll}120 & 40 & 37\end{array}$ & 1.800 & 7.66 & 260 & 0.004 & 151 & 2 & $0.60 \mathrm{~N}$ & 2.56 & 0.350 & 31 \\
\hline HD07150 & 37 & 59 & 12 & $120 \quad 4037$ & 0.230 & 9.12 & 40 & $0.002 \mathrm{~N}$ & 443 & 2 & $0.60 \mathrm{~N}$ & 0.73 & 0.190 & 38 \\
\hline HDO 08002 & 37 & 59 & 12 & $\begin{array}{lll}120 & 40 & 37\end{array}$ & 0.230 & 6.22 & 30 & 0.032 & 133 & $1 \mathrm{~L}$ & $0.60 \mathrm{~N}$ & 3.35 & 0.074 & 7 \\
\hline HDO8007 & 37 & 59 & 12 & $12040 \quad 37$ & 0.054 & 6.09 & $10 \mathrm{~L}$ & 0.002 & 75 & $1 L$ & $0.60 \mathrm{~N}$ & 5.66 & 0.046 & $4 \mathrm{~L}$ \\
\hline HD08012 & 37 & 59 & 12 & $120 \quad 40 \quad 37$ & 0.061 & 6.03 & $10 \mathrm{~L}$ & 0.002 & 69 & $1 \mathrm{~L}$ & $0.60 \mathrm{~N}$ & 6.20 & 0.053 & $4 \mathrm{~L}$ \\
\hline HD08022 & 37 & 59 & 12 & $120 \quad 4037$ & $0.045 \mathrm{~N}$ & 6.73 & $10 \mathrm{~L}$ & 0.002 & 88 & $1 \mathrm{~L}$ & $0.60 \mathrm{~N}$ & 7.01 & 0.073 & $4 \mathrm{~L}$ \\
\hline
\end{tabular}


Appendix 1.--continued

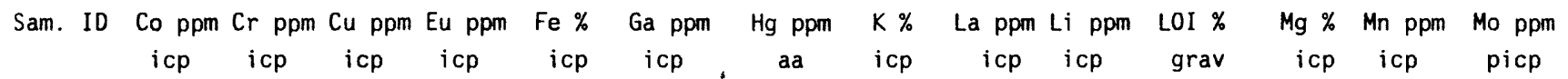

\begin{tabular}{|c|c|c|c|c|c|c|c|c|c|c|c|c|c|c|}
\hline HD05122 & 13 & 110 & 55 & $2 \mathrm{~L}$ & 4.19 & 11 & 0.12 & 1.27 & 9 & 27 & 8.12 & 2.02 & 752 & 0.87 \\
\hline HD05132 & 14 & 82 & 54 & $2 \mathrm{~L}$ & 4.67 & 16 & 0.10 & 1.90 & 11 & 25 & 6.85 & 1.56 & 533 & 0.74 \\
\hline HD05142 & 15 & 82 & 56 & $2 \mathrm{~L}$ & 4.68 & 16 & 0.08 & 2.14 & 10 & 38 & 5.47 & 1.34 & 555 & 0.83 \\
\hline HD05152 & 16 & 85 & 58 & $2 \mathrm{~L}$ & 4.23 & 14 & 0.16 & 1.77 & 7 & 40 & 5.39 & 1.34 & 787 & 0.63 \\
\hline HD05162 & 20 & 127 & 69 & $2 \mathrm{~L}$ & 4.68 & 17 & 0.10 & 1.97 & 9 & 50 & 5.27 & 1.77 & 670 & 1.40 \\
\hline HD05172 & 13 & 131 & 31 & $2 \mathrm{~L}$ & 2.96 & 12 & 0.08 & 1.00 & 8 & 38 & 4.85 & 1.40 & 604 & 0.45 \\
\hline HD05182 & 19 & 116 & 58 & $2 \mathrm{~L}$ & 4.36 & 14 & 0.10 & 1.57 & 7 & 47 & 5.39 & 1.55 & 780 & 0.84 \\
\hline HD05192 & 16 & 85 & 54 & $2 \mathrm{~L}$ & 4.32 & 15 & 0.10 & 1.88 & 8 & 44 & 5.00 & 1.40 & 740 & 0.70 \\
\hline HD05202 & 18 & 101 & 107 & $2 \mathrm{~L}$ & 4.35 & 15 & 0.24 & 1.02 & 17 & 45 & 4.37 & 1.60 & 901 & 2.20 \\
\hline HD05212 & 33 & 53 & 104 & $2 \mathrm{~L}$ & 4.76 & 12 & 0.04 & $0.05 \mathrm{~L}$ & 5 & 75 & 13.50 & 3.19 & 1350 & 0.21 \\
\hline HD05222 & 35 & 59 & 116 & $2 \mathrm{~L}$ & 5.54 & 13 & 0.04 & 0.22 & 5 & 69 & 13.10 & 3.78 & 955 & 0.21 \\
\hline HD05232 & 17 & 99 & 53 & $2 \mathrm{~L}$ & 4.84 & 16 & 0.08 & 1.76 & 10 & 47 & 5.76 & 1.60 & 800 & 0.60 \\
\hline HD05242 & 14 & 71 & 53 & $2 \mathrm{~L}$ & 4.39 & 11 & 0.08 & 1.24 & 9 & 32 & 8.37 & 1.77 & 819 & 0.72 \\
\hline HD06002 & 46 & 403 & 99 & $2 \mathrm{~L}$ & 6.06 & 15 & 0.04 & 2.04 & 5 & 11 & 6.64 & 0.67 & 643 & 0.50 \\
\hline HDO6007 & 36 & 423 & 84 & $2 \mathrm{~L}$ & 5.56 & 14 & 0.02 & 1.18 & 6 & 30 & 9.75 & 2.73 & 908 & 0.22 \\
\hline HDO6012 & 46 & 1240 & 67 & $2 \mathrm{~L}$ & 5.36 & 12 & $0.02 \mathrm{~N}$ & 0.88 & 5 & 39 & 14.20 & 4.68 & 927 & 0.13 \\
\hline HD06022 & 30 & 325 & 76 & $2 \mathrm{~L}$ & 4.59 & 12 & 0.02 & 1.85 & 6 & 6 & 14.40 & 2.03 & 823 & 0.12 \\
\hline HD06032 & 21 & 123 & 106 & $2 \mathrm{~L}$ & 4.98 & 12 & 0.02 & 1.28 & 6 & 10 & 11.60 & 2.70 & 795 & 0.10 \\
\hline HD06042 & 13 & 167 & 40 & $2 \mathrm{~L}$ & 3.62 & 10 & 0.04 & 1.55 & 7 & 4 & 10.80 & 2.49 & 734 & 2.90 \\
\hline HD06052 & 16 & 196 & 59 & $2 \mathrm{~L}$ & 4.29 & 12 & 0.06 & 2.18 & 10 & 6 & 11.30 & 2.54 & 1020 & 0.99 \\
\hline HD06062 & 24 & 227 & 73 & $2 \mathrm{~L}$ & 4.51 & 15 & 0.10 & 1.86 & 9 & 48 & 7.96 & 2.68 & 1110 & 0.85 \\
\hline HD06072 & 29 & 306 & 74 & $2 \mathrm{~L}$ & 5.02 & 13 & 0.06 & 0.94 & 9 & 91 & 9.56 & 5.13 & 1130 & 0.55 \\
\hline HD06082 & 21 & 112 & 115 & $2 \mathrm{~L}$ & 4.72 & 13 & 0.16 & 1.57 & 7 & 9 & 11.50 & 3.47 & 1010 & 1.20 \\
\hline HD06092 & 21 & 124 & 65 & $2 \mathrm{~L}$ & 4.82 & 17 & 0.18 & 2.48 & 13 & 5 & 8.41 & 1.70 & 623 & 1.60 \\
\hline HD06097 & 18 & 105 & 66 & $2 \mathrm{~L}$ & 4.67 & 15 & 0.10 & 2.39 & 12 & 19 & 8.75 & 2.08 & 922 & 1.00 \\
\hline HDO 010 & 51 & 591 & 86 & $2 \mathrm{~L}$ & 7.06 & 14 & $0.02 \mathrm{~N}$ & 0.07 & 3 & 22 & 6.86 & 5.86 & 1200 & 0.12 \\
\hline $\mathrm{HDO}=20$ & 76 & 1270 & 75 & $2 \mathrm{~L}$ & 7.42 & 11 & 0.04 & 0.18 & 3 & 32 & 6.14 & 11.10 & 1280 & $0.09 \mathrm{~N}$ \\
\hline HD07030 & 75 & 940 & 90 & $2 \mathrm{~L}$ & 7.30 & 12 & 0.04 & 0.12 & 3 & 34 & 5.53 & 10.80 & 1310 & $0.09 \mathrm{~N}$ \\
\hline HD07040 & 61 & 808 & 96 & $2 \mathrm{~L}$ & 6.90 & 11 & 0.08 & 0.07 & 3 & 29 & 4.93 & 9.08 & 1210 & $0.09 \mathrm{~N}$ \\
\hline HD07050 & 71 & 1020 & 100 & $2 \mathrm{~L}$ & 7.40 & 12 & 0.06 & $0.05 \mathrm{~L}$ & 3 & 37 & 7.31 & 10.90 & 1270 & $0.09 \mathrm{~N}$ \\
\hline HD07059 & 59 & 825 & 81 & $2 \mathrm{~L}$ & 6.81 & 11 & 0.08 & $0.05 \mathrm{~L}$ & 3 & 46 & 12.60 & 9.12 & 1090 & $0.09 \mathrm{~N}$ \\
\hline HD07063 & 43 & 666 & 61 & $2 \mathrm{~L}$ & 5.45 & 14 & 0.16 & 1.62 & 15 & 68 & 6.86 & 5.42 & 319 & 0.84 \\
\hline HD07068 & 39 & 141 & 27 & $2 \mathrm{~L}$ & 6.72 & 15 & 0.10 & 3.08 & 4 & 9 & 8.29 & 2.86 & 489 & 0.24 \\
\hline HDO7080 & 29 & 267 & 70 & $2 \mathrm{~L}$ & 4.51 & 11 & 0.10 & 2.10 & 5 & 3 & 13.30 & 4.17 & 875 & 0.16 \\
\hline HD07090 & 31 & 119 & 43 & $2 \mathrm{~L}$ & 7.03 & 13 & 0.10 & 2.65 & 3 & 3 & 13.00 & 4.44 & 896 & 0.26 \\
\hline HDOT100 & 31 & 229 & 55 & $2 \mathrm{~L}$ & 5.02 & 10 & 0.04 & 2.16 & 2 & 3 & 8.34 & 3.32 & 648 & 0.17 \\
\hline HDO7110 & 40 & 140 & 110 & $2 \mathrm{~L}$ & 5.85 & 14 & 0.08 & 2.88 & 3 & 3 & 13.50 & 4.07 & 924 & 3.60 \\
\hline HD07122 & 31 & 108 & 78 & $2 \mathrm{~L}$ & 4.62 & 15 & 2.90 & 2.70 & 4 & 3 & 14.00 & 3.82 & 843 & 1.20 \\
\hline HD07130 & 13 & 144 & 23 & $2 \mathrm{~L}$ & 2.32 & 8 & 0.04 & 1.29 & 2 & $2 \mathrm{~L}$ & 6.12 & 1.69 & 404 & 0.17 \\
\hline $\mathrm{HDO} 7140$ & 29 & 94 & 79 & $2 \mathrm{~L}$ & 6.11 & 17 & 0.08 & 2.89 & 17 & 3 & 9.94 & 2.01 & 760 & 1.40 \\
\hline HDO7150 & 29 & 132 & 81 & $2 \mathrm{~L}$ & 5.70 & 20 & 0.16 & 2.48 & 19 & 53 & 5.16 & 1.75 & 560 & 4.20 \\
\hline HD08002 & 58 & 771 & 85 & $2 \mathrm{~L}$ & 6.63 & 12 & $0.02 \mathrm{~N}$ & 0.41 & 5 & 20 & 7.74 & 4.59 & 1210 & 0.28 \\
\hline HDO8007 & 56 & 719 & 88 & $2 \mathrm{~L}$ & 6.58 & 12 & $0.02 \mathrm{~N}$ & 0.16 & 4 & 17 & 6.05 & 7.48 & 1150 & 0.17 \\
\hline HD08012 & 55 & 661 & 81 & $2 \mathrm{~L}$ & 6.56 & 12 & 0.02 & 0.18 & 4 & 16 & 5.38 & 7.60 & 1130 & 0.25 \\
\hline HDO8022 & 52 & 516 & 82 & $2 \mathrm{~L}$ & 6.90 & 14 & $0.02 \mathrm{~N}$ & 0.21 & 5 & 13 & 3.73 & 6.94 & 1260 & 0.19 \\
\hline
\end{tabular}


Appendix 1.---continued

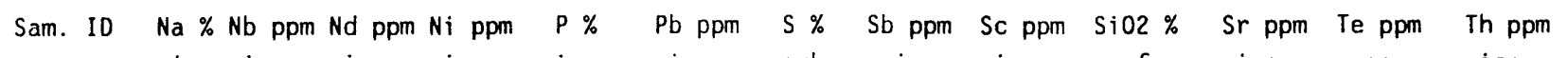

\begin{tabular}{|c|c|c|c|c|c|c|c|c|c|c|c|c|c|}
\hline & $\mathrm{icp}$ & icp & $i c p$ & $i c p$ & $\mathrm{icp}$ & $i c p$. & comb & picp & $i c p$ & $x r f$ & $i c p$ & $\mathrm{aa}$ & icp \\
\hline HD05122 & 0.92 & $4 \mathrm{~L}$ & 11 & 55 & 0.090 & 12 & 0.35 & 1.70 & 13 & 64.90 & 341 & 0.030 & 41 \\
\hline HD05132 & 1.55 & 4 & 10 & 35 & 0.080 & 17 & 0.25 & 1.10 & 14 & 62.20 & 211 & 0.040 & 7 \\
\hline HD05142 & 0.87 & 6 & 9 & 30 & 0.100 & 19 & 0.25 & 1.10 & 15 & 64.50 & 126 & 0.040 & 7 \\
\hline HO05152 & 1.09 & 4 & 10 & 36 & 0.090 & 21 & 0.56 & 1.40 & 13 & 63.90 & 236 & 0.800 & 5 \\
\hline HD05162 & 1.13 & $4 \mathrm{~L}$ & 11 & 71 & 0.110 & 19 & 0.42 & 1.30 & 16 & 62.40 & 138 & 0.045 & 5 \\
\hline HDO5172 & 1.63 & $4 \mathrm{~L}$ & 10 & 52 & 0.050 & 11 & 0.13 & 0.79 & 11 & 70.30 & 240 & 0.015 & 41 \\
\hline HD05182 & 1.34 & $4 \mathrm{~L}$ & 9 & 55 & 0.090 & 15 & 0.45 & 1.20 & 14 & 64.10 & 219 & 0.040 & 4 \\
\hline HD05192 & 0.91 & 5 & 9 & 36 & 0.090 & 18 & 0.38 & 1.30 & 14 & 65.70 & 193 & 0.035 & 6 \\
\hline HD05202 & 2.44 & 4 & 16 & 64 & 0.100 & 19 & 1.05 & 3.20 & 14 & 63.70 & 230 & 0.800 & 6 \\
\hline HD05212 & 3.74 & $4 \mathrm{~L}$ & 9 & 27 & 0.080 & 5 & 0.26 & 0.80 & 31 & 41.40 & 1120 & 0.010 & 41 \\
\hline HD05222 & 3.71 & $4 \mathrm{~L}$ & 7 & 27 & 0.060 & 5 & 0.18 & 0.98 & 34 & 43.40 & 635 & 0.005 & 41 \\
\hline HD05232 & 1.34 & 5 & 12 & 39 & 0.110 & 17 & 0.34 & 1.30 & 16 & 62.40 & 197 & 0.040 & 7 \\
\hline HD05242 & 0.94 & $4 \mathrm{~L}$ & 12 & 42 & 0.090 & 20 & 0.31 & 0.97 & 13 & 63.20 & 468 & 0.025 & 41 \\
\hline HDO6002 & 1.33 & $4 \mathrm{~L}$ & 8 & 146 & 0.030 & 8 & $0.05 \mathrm{~L}$ & 3.70 & 38 & 61.40 & 60 & 0.030 & 41 \\
\hline HD06007 & 2.48 & $4 \mathrm{~L}$ & 9 & 165 & 0.050 & 6 & $0.05 \mathrm{~L}$ & 0.99 & 36 & 52.70 & 157 & 0.005 & 41 \\
\hline HD06012 & 1.87 & $4 \mathrm{~L}$ & 8 & 476 & 0.040 & 5 & $0.05 \mathrm{~L}$ & 1.30 & 32 & 45.80 & 253 & 0.005 & 41 \\
\hline HD06022 & 2.29 & $4 \mathrm{~L}$ & 10 & 137 & 0.040 & 4 & $0.05 \mathrm{~L}$ & 1.20 & 29 & 45.20 & 207 & $0.005 \mathrm{~L}$ & 41 \\
\hline HD06032 & 3.61 & $4 \mathrm{~L}$ & 10 & 55 & 0.070 & $4 \mathrm{~L}$ & $0.05 \mathrm{~L}$ & 0.71 & 31 & 48.30 & 281 & 0.005 & 41 \\
\hline HD06042 & 1.44 & $4 \mathrm{~L}$ & 8 & 50 & 0.050 & 12 & $0.05 \mathrm{~L}$ & 1.10 & 15 & 59.20 & 384 & 0.045 & 41 \\
\hline HD06052 & 0.52 & $4 \mathrm{~L}$ & 10 & 80 & 0.070 & 18 & $0.05 \mathrm{~L}$ & 1.90 & 17 & 57.70 & 359 & 0.030 & 4 \\
\hline HD06062 & 0.92 & $4 \mathrm{~L}$ & 12 & 109 & 0.100 & 15 & 0.32 & 2.00 & 20 & 58.80 & 221 & 0.040 & 6 \\
\hline HD06072 & 1.16 & $4 \mathrm{~L}$ & 13 & 138 & 0.080 & 11 & 0.16 & 1.20 & 24 & 53.30 & 299 & 0.025 & 5 \\
\hline HD06082 & 2.62 & $4 \mathrm{~L}$ & 10 & 40 & 0.110 & 17 & 1.33 & 3.90 & 26 & 48.30 & 387 & 0.090 & 41 \\
\hline HD06092 & 1.41 & $4 \mathrm{~L}$ & 14 & 79 & 0.110 & 16 & 0.72 & 4.70 & 17 & 58.90 & 103 & 0.055 & 7 \\
\hline HD06097 & 0.73 & $4 \mathrm{~L}$ & 14 & 67 & 0.110 & 15 & 0.35 & 2.30 & 16 & 59.40 & 152 & 0.045 & 5 \\
\hline HD07010 & 2.54 & $4 \mathrm{~L}$ & 7 & 193 & 0.020 & $4 \mathrm{~L}$ & $0.05 \mathrm{~L}$ & $0.60 \mathrm{~N}$ & 36 & 50.10 & 165 & $0.005 \mathrm{~L}$ & 41 \\
\hline HD07020 & 0.81 & $4 \mathrm{~L}$ & 9 & 479 & 0.020 & 5 & $0.05 \mathrm{~L}$ & $0.60 \mathrm{~N}$ & 45 & 60.20 & 31 & $0.005 \mathrm{~L}$ & 41 \\
\hline HD07030 & 1.05 & $4 \mathrm{~L}$ & 8 & 435 & 0.020 & 7 & $0.05 \mathrm{~L}$ & $0.60 \mathrm{~N}$ & 39 & 46.40 & 38 & $0.005 \mathrm{~L}$ & 41 \\
\hline HD07040 & 2.23 & $4 \mathrm{~L}$ & 7 & 284 & 0.020 & 6 & $0.05 \mathrm{~L}$ & $0.60 \mathrm{~N}$ & 40 & 49.60 & 68 & 0.020 & 41 \\
\hline HD07050 & 1.16 & $4 \mathrm{~L}$ & 7 & 426 & 0.020 & 5 & $0.05 \mathrm{~L}$ & $0.60 \mathrm{~N}$ & 39 & 44.60 & 59 & 0.025 & 41 \\
\hline HD07059 & 0.50 & $4 \mathrm{~L}$ & 7 & 320 & 0.010 & $4 \mathrm{~L}$ & $0.05 \mathrm{~L}$ & $0.60 \mathrm{~N}$ & 37 & 43.90 & 205 & 0.010 & 41 \\
\hline HD07063 & 0.44 & $4 \mathrm{~L}$ & 17 & 245 & 0.050 & 23 & 1.66 & 3.00 & 20 & 57.30 & 63 & 0.100 & 6 \\
\hline HD07068 & 0.11 & $4 \mathrm{~L}$ & 9 & 82 & 0.030 & 38 & 5.25 & 1.70 & 31 & 54.20 & 223 & 0.200 & 41 \\
\hline HD07080 & 0.60 & $4 \mathrm{~L}$ & 10 & 95 & 0.020 & 8 & 2.40 & 25.00 & 26 & 46.70 & 491 & 0.300 & 41 \\
\hline HD07090 & 0.15 & $4 \mathrm{~L}$ & 8 & 73 & 0.008 & 14 & 4.58 & 6.60 & 34 & 37.90 & 579 & 0.400 & 41 \\
\hline HD07100 & 0.11 & $4 \mathrm{~L}$ & 5 & 73 & 0.020 & 9 & 4.44 & 10.00 & 28 & 54.70 & 371 & 0.900 & 41 \\
\hline HD07110 & 0.24 & $4 \mathrm{~L}$ & 10 & 62 & 0.007 & 9 & 2.93 & 4.30 & 36 & 39.80 & 482 & 0.750 & 41 \\
\hline HD07122 & 0.49 & $4 \mathrm{~L}$ & 8 & 48 & 0.006 & 14 & 1.85 & 2.90 & 31 & 44.50 & 520 & 0.200 & 41 \\
\hline HD07130 & 0.11 & $4 \mathrm{~L}$ & $4 \mathrm{~L}$ & 28 & $0.005 \mathrm{~L}$ & 6 & 1.20 & 0.98 & 16 & 73.20 & 282 & 0.040 & 41 \\
\hline HD07140 & 0.44 & $4 \mathrm{~L}$ & 20 & 117 & 0.130 & 29 & 2.59 & 3.50 & 17 & 51.10 & 302 & 0.100 & 7 \\
\hline HD07150 & 1.15 & $4 \mathrm{~L}$ & 22 & 70 & 0.090 & 23 & 0.86 & 2.20 & 20 & 58.70 & 81 & 0.100 & 10 \\
\hline HD08002 & 1.34 & $4 \mathrm{~L}$ & 6 & 278 & 0.020 & 19 & $0.05 \mathrm{~L}$ & 2.00 & 35 & 56.00 & 69 & 0.300 & 41 \\
\hline HD08007 & 2.01 & $4 \mathrm{~L}$ & 5 & 324 & 0.030 & 6 & $0.05 \mathrm{~L}$ & $0.60 \mathrm{~N}$ & 40 & 49.90 & 70 & 0.850 & 41 \\
\hline HD08012 & 1.88 & $4 \mathrm{~L}$ & 6 & 310 & 0.030 & 7 & $0.05 \mathrm{~L}$ & $0.60 \mathrm{~N}$ & 40 & 49.60 & 78 & $0.005 \mathrm{~L}$ & 41 \\
\hline HD08022 & 2.24 & $4 \mathrm{~L}$ & 9 & 232 & 0.040 & 7 & $0.05 \mathrm{~L}$ & $0.60 \mathrm{~N}$ & 42 & 49.00 & 92 & $0.005 \mathrm{~L}$ & 41 \\
\hline
\end{tabular}




\begin{tabular}{|c|c|c|c|c|c|c|c|c|}
\hline Sam. ID & $\begin{array}{r}\mathrm{Ti} \% \\
\text { icp }\end{array}$ & $\begin{array}{c}\text { TI ppm } \\
\text { ad }\end{array}$ & $\begin{array}{c}V_{\mathrm{icp}} \mathrm{ppm} \\
\text { che }\end{array}$ & $\begin{array}{l}\text { W ppm } \\
\text { aa }\end{array}$ & $\begin{array}{c}\text { Y ppm } \\
\text { icp }\end{array}$ & $\begin{array}{c}\text { Yb ppm } \\
\text { icp }\end{array}$ & $\begin{array}{c}\text { Zn ppm } \\
\text { icp }\end{array}$ & Geologic unit \\
\hline HD05122 & 0.130 & 0.15 & 94 & 2.0 & 10 & 1 & 96 & Salt Spring Slate \\
\hline HD05132 & 0.130 & 0.20 & 117 & 2.0 & 10 & 1 & 113 & Salt Spring Slate \\
\hline HD05142 & 0.250 & 0.15 & 123 & 1.0 & 13 & 2 & 106 & Salt Spring Slate \\
\hline HD05152 & 0.160 & 0.15 & 119 & 1.5 & 12 & 2 & 103 & Salt Spring Slate \\
\hline HD05162 & 0.200 & 0.30 & 146 & 1.5 & 14 & 2 & 146 & Salt Spring Slate \\
\hline HD05172 & 0.160 & 0.10 & 86 & 1.0 & 9 & 1 & 78 & Salt Spring Slate \\
\hline HD05182 & 0.110 & 0.15 & 126 & 1.0 & 12 & 1 & 113 & Salt Spring Slate \\
\hline HD05192 & 0.190 & 0.20 & 120 & 1.0 & 12 & 2 & 107 & Salt Spring Slate \\
\hline HD05202 & 0.190 & 0.15 & 166 & 1.5 & 13 & 2 & 191 & Salt Spring Slate \\
\hline HD05212 & 0.140 & $0.05 \mathrm{~N}$ & 211 & $0.5 \mathrm{~L}$ & 9 & $1 \mathrm{~L}$ & 42 & Salt Spring Slate \\
\hline HD05222 & 0.190 & $0.05 \mathrm{~L}$ & 237 & 1.0 & 9 & 1 & 49 & Salt Spring Slate \\
\hline HD05232 & 0.210 & 0.15 & 136 & 1.5 & 14 & 2 & 109 & Salt Spring Slate \\
\hline HD05242 & 0.060 & 0.20 & 93 & 2.5 & 11 & 1 & 111 & Salt Spring Slate \\
\hline HD06002 & 0.150 & 0.40 & 247 & 4.5 & 6 & $1 \mathrm{~L}$ & 54 & Salt Spring Slate, tuffaceous member \\
\hline HD06007 & 0.160 & 0.15 & 237 & 2.5 & 6 & $1 \mathrm{~L}$ & 51 & Salt Spring Slate, tuffaceous member \\
\hline HD06012 & 0.090 & 0.10 & 186 & 2.5 & 6 & $1 \mathrm{~L}$ & 42 & Salt Spring Slate, tuffaceous member \\
\hline HD06022 & 0.080 & 0.20 & 202 & 4.0 & 5 & $1 \mathrm{~L}$ & 42 & Salt Spring Slate, tuffaceous member \\
\hline HD06032 & 0.130 & 0.10 & 220 & 2.5 & 5 & $1 \mathrm{~L}$ & 43 & Salt Spring Slate, tuffaceous member \\
\hline HD06042 & 0.060 & 0.20 & 98 & 4.5 & 5 & $1 \mathrm{~L}$ & 62 & Salt Spring Slate, tuffaceous member \\
\hline HD06052 & 0.090 & 0.10 & 131 & 4.0 & 8 & $1 \mathrm{~L}$ & 73 & Salt Spring Slate, tuffaceous member \\
\hline HD06062 & 0.110 & 0.15 & 153 & 2.0 & 10 & 1 & 105 & Salt Spring Slate, tuffaceous member \\
\hline HD06072 & 0.150 & 0.05 & 180 & 1.5 & 9 & 1 & 71 & Salt Spring Slate, tuffaceous member \\
\hline HD06082 & 0.180 & 0.15 & 223 & 1.5 & 8 & $1 \mathrm{~L}$ & 60 & Salt Spring Slate (?) \\
\hline HD06092 & 0.210 & 0.35 & 162 & 2.5 & 12 & 2 & 133 & Salt Spring Slate (?) \\
\hline HD06097 & 0.100 & 0.25 & 140 & 2.0 & 11 & 1 & 125 & Salt Spring Slate (?) \\
\hline HD07010 & 0.270 & $0.05 \mathrm{~N}$ & 217 & 1.0 & 12 & 2 & 56 & Copper Hill Volcanics \\
\hline HD07020 & 0.300 & $0.05 \mathrm{~N}$ & 210 & 0.5 & 10 & 2 & 51 & Copper Hill Volcanics \\
\hline HD07030 & 0.260 & $0.05 \mathrm{~L}$ & 188 & 1.0 & 10 & 1 & 50 & Copper Hill Volcanics \\
\hline HD07040 & 0.260 & $0.05 \mathrm{~N}$ & 194 & 1.0 & 8 & 1 & 52 & Copper Hill Volcanics \\
\hline HD07050 & 0.240 & $0.05 \mathrm{~N}$ & 200 & 1.0 & 10 & 2 & 53 & Copper Hill Volcanics \\
\hline HD07059 & 0.190 & $0.05 \mathrm{~N}$ & 208 & 1.0 & 9 & 1 & 50 & Copper Hill Volcanics \\
\hline HD07063 & 0.090 & 0.15 & 154 & 8.0 & 9 & 1 & 83 & Salt Spring Slate, tuffaceous member \\
\hline HD07068 & 0.050 & 0.55 & 238 & 5.5 & 4 & $1 L$ & 64 & Salt Spring Slate, tuffaceous member \\
\hline HDO7080 & 0.050 & 0.35 & 173 & 6.5 & 5 & $1 L$ & 53 & Salt Spring Slate, tuffaceous member \\
\hline HD07090 & 0.040 & 0.40 & 200 & 7.5 & 5 & $1 L$ & 33 & Salt Spring slate, tuffaceous member \\
\hline HD07100 & 0.030 & 0.50 & 162 & 3.0 & 3 & $1 L$ & 24 & Salt Spring Slate, tuffaceous member \\
\hline HDO7110 & 0.050 & 0.50 & 234 & 7.0 & 5 & $1 \mathrm{~L}$ & 43 & Salt Spring Slate, tuffaceous member \\
\hline HD07122 & 0.050 & 0.45 & 199 & 9.0 & 5 & $1 L$ & 36 & Salt Spring Slate, tuffaceous member \\
\hline HD07130 & 0.030 & 0.20 & 103 & 4.5 & 3 & $1 \mathrm{~L}$ & 12 & Salt Spring slate, tuffaceous member \\
\hline HD07140 & 0.050 & 0.30 & 147 & 7.0 & 13 & 1 & 152 & Salt Spring Slate \\
\hline HD07150 & 0.180 & 0.20 & 180 & 1.5 & 13 & 2 & 129 & Salt Spring Slate \\
\hline HD08002 & 0.250 & 0.10 & 181 & 2.0 & 11 & 1 & 57 & Copper Hill Volcanics \\
\hline HD08007 & 0.290 & $0.05 \mathrm{~L}$ & 195 & 1.0 & 12 & 1 & 50 & Copper Hill Volcanics \\
\hline HD08012 & 0.290 & $0.05 \mathrm{~L}$ & 205 & 1.0 & 11 & 2 & 47 & Copper Hill Volcanics \\
\hline HD08022 & 0.340 & $0.05 \mathrm{~L}$ & 242 & 1.0 & 12 & 2 & 52 & Copper Hill Volcanics \\
\hline
\end{tabular}


Appendix 1.--continued

\begin{tabular}{|c|c|c|c|c|c|c|c|c|c|c|c|c|c|c|}
\hline Sam. ID & & titu & ude & Longitude & $\begin{array}{c}\text { Ag ppm } \\
\text { picp }\end{array}$ & $\begin{array}{r}\text { Al \% } \\
\text { icp }\end{array}$ & $\begin{array}{c}\text { As ppm } \\
\text { icp }\end{array}$ & $\begin{array}{c}\mathrm{Au} \text { ppm } \\
\mathrm{aa}\end{array}$ & $\begin{array}{c}\text { Ba ppm } \\
\text { icp }\end{array}$ & $\begin{array}{c}\text { Be ppm } \\
\text { icp }\end{array}$ & $\begin{array}{c}\text { Bi ppm } \\
\text { picp }\end{array}$ & $\begin{array}{r}\text { Ca \% } \\
\text { icp }\end{array}$ & $\begin{array}{c}\text { Cd ppm } \\
\text { picp }\end{array}$ & $\begin{array}{l}\text { Ce ppm } \\
\text { icp }\end{array}$ \\
\hline HD08032 & 37 & 59 & 12 & $\begin{array}{lll}120 & 40 & 37\end{array}$ & $0.045 \mathrm{~N}$ & 5.44 & $10 \mathrm{~L}$ & 0.002 & 34 & $1 \mathrm{~L}$ & $0.60 \mathrm{~N}$ & 6.20 & 0.032 & $4 \mathrm{~L}$ \\
\hline HD08042 & 37 & 59 & 12 & $\begin{array}{lll}120 & 40 \quad 37\end{array}$ & $0.045 \mathrm{~N}$ & 3.93 & $10 \mathrm{~L}$ & 0.004 & $7 \mathrm{~B}$ & $1 \mathrm{~L}$ & $0.60 \mathrm{~N}$ & 13.50 & 0.097 & $4 \mathrm{~L}$ \\
\hline HD08052 & 37 & 59 & 12 & $\begin{array}{lll}120 & 40 \quad 37\end{array}$ & 2.100 & 4.30 & 220 & 0.100 & 157 & $1 \mathrm{~L}$ & $0.60 \mathrm{~N}$ & 3.49 & 0.340 & 15 \\
\hline HD08062 & 37 & 59 & 12 & $\begin{array}{lll}120 & 40 & 37\end{array}$ & 3.000 & 5.81 & 70 & 0.046 & 65 & 1 & $0.60 \mathrm{~N}$ & 7.95 & 0.062 & $4 \mathrm{~L}$ \\
\hline HD08072 & 37 & 59 & 12 & $12040 \quad 37$ & 0.490 & 6.24 & 40 & 0.030 & 137 & $1 \mathrm{~L}$ & $0.60 \mathrm{~N}$ & 5.45 & 0.075 & $4 \mathrm{~L}$ \\
\hline HD08082 & 37 & 59 & 12 & $\begin{array}{lll}120 & 40 & 37\end{array}$ & 1.400 & 6.06 & 30 & 0.050 & 178 & $1 \mathrm{~L}$ & $0.60 \mathrm{~N}$ & 7.93 & 1.200 & 7 \\
\hline HD08092 & 37 & 59 & 12 & $\begin{array}{lll}120 & 40 \quad 37\end{array}$ & 7.800 & 5.65 & 120 & 0.550 & 188 & $1 \mathrm{~L}$ & $0.60 \mathrm{~N}$ & 7.40 & 0.180 & 12 \\
\hline HD08102 & 37 & 59 & 12 & $120 \quad 40 \quad 37$ & 0.830 & 1.81 & 50 & 0.250 & 88 & $1 \mathrm{~L}$ & $0.60 \mathrm{~N}$ & 2.95 & 0.036 & $4 \mathrm{~L}$ \\
\hline HD08112 & 37 & 59 & 12 & $\begin{array}{lll}120 & 40 & 37\end{array}$ & 0.990 & 5.64 & 80 & 0.010 & 172 & $1 \mathrm{~L}$ & $0.60 \mathrm{~N}$ & 4.94 & 0.096 & 5 \\
\hline HDo8122 & 37 & 59 & 12 & $\begin{array}{lll}120 & 40 & 37\end{array}$ & 0.580 & 4.20 & 130 & 0.008 & 310 & 1 & $0.60 \mathrm{~N}$ & 4.38 & 0.180 & 15 \\
\hline HD08132 & 37 & 59 & 12 & $\begin{array}{lll}120 & 40 & 37\end{array}$ & 0.250 & 7.24 & 100 & 0.002 & 525 & 1 & $0.60 \mathrm{~N}$ & 1.86 & 0.230 & 20 \\
\hline HD08137 & 37 & 59 & 12 & $\begin{array}{lll}120 & 40 & 37\end{array}$ & 0.220 & 7.08 & 50 & $0.002 \mathrm{~L}$ & 631 & 2 & $0.60 \mathrm{~N}$ & 1.53 & 0.310 & 25 \\
\hline HDO9005 & 37 & 59 & 44 & $12041 \quad 15$ & $0.045 \mathrm{~N}$ & 7.95 & 10 & 0.008 & 195 & $1 \mathrm{~L}$ & $0.60 \mathrm{~N}$ & 3.24 & 0.070 & 16 \\
\hline HD09010 & 37 & 59 & 44 & 1204115 & 0.045 & 8.03 & $10 \mathrm{~L}$ & 0.002 & 160 & $1 \mathrm{~L}$ & $0.60 \mathrm{~N}$ & 5.31 & 0.099 & $4 \mathrm{~L}$ \\
\hline HD09020 & 37 & 59 & 44 & $12041 \quad 15$ & $0.045 \mathrm{~N}$ & 6.68 & $10 \mathrm{~L}$ & $0.002 \mathrm{~L}$ & 163 & $1 \mathrm{~L}$ & $0.60 \mathrm{~N}$ & 6.05 & 0.082 & $4 \mathrm{~L}$ \\
\hline HD09030 & 37 & 59 & 44 & $12041 \quad 15$ & 0.087 & 7.78 & 10 & $0.002 \mathrm{~L}$ & 222 & $1 \mathrm{~L}$ & $0.60 \mathrm{~N}$ & 2.26 & 0.330 & 5 \\
\hline HDO9040 & 37 & 59 & 44 & 1204115 & 0.061 & 7.43 & $10 \mathrm{~L}$ & 0.002 & 259 & $1 \mathrm{~L}$ & $0.60 \mathrm{~N}$ & 6.41 & 0.066 & $4 \mathrm{~L}$ \\
\hline HD09060 & 37 & 59 & 44 & $12041 \quad 15$ & $0.045 \mathrm{~N}$ & 7.45 & $10 \mathrm{~L}$ & $0.002 \mathrm{~L}$ & 124 & $1 \mathrm{~L}$ & $0.60 \mathrm{~N}$ & 6.94 & 0.034 & $4 \mathrm{~L}$ \\
\hline HD09080 & 37 & 59 & 44 & 1204115 & $0.045 \mathrm{~N}$ & 4.04 & $10 \mathrm{~L}$ & $0.002 \mathrm{~L}$ & 20 & $1 \mathrm{~L}$ & $0.60 \mathrm{~N}$ & 4.62 & $0.030 \mathrm{~N}$ & $4 \mathrm{~L}$ \\
\hline HD09100 & 37 & 59 & 44 & $12041 \quad 15$ & 0.440 & 5.14 & 160 & $0.002 \mathrm{~L}$ & 122 & $1 \mathrm{~L}$ & $0.60 \mathrm{~N}$ & 6.51 & 0.055 & $4 \mathrm{~L}$ \\
\hline HDO9110 & 37 & 59 & 44 & $12041 \quad 15$ & 0.800 & 0.24 & 490 & 0.008 & 9 & $1 \mathrm{~L}$ & $0.60 \mathrm{~N}$ & 2.19 & $0.030 \mathrm{~N}$ & $4 \mathrm{~L}$ \\
\hline HD09120 & 37 & 59 & 44 & $12041 \quad 15$ & 0.470 & 0.26 & 320 & 0.050 & 10 & $1 \mathrm{~L}$ & $0.60 \mathrm{~N}$ & 5.80 & $0.030 \mathrm{~N}$ & $4 \mathrm{~L}$ \\
\hline HD09130 & 37 & 59 & 44 & 1204115 & 0.270 & 0.18 & 520 & 0.006 & 10 & $1 \mathrm{~L}$ & $0.60 \mathrm{~N}$ & 1.82 & $0.030 \mathrm{~N}$ & $4 \mathrm{~L}$ \\
\hline HD09140 & 37 & 59 & 44 & 1204115 & 0.270 & 0.19 & 170 & 0.002 & 7 & $1 \mathrm{~L}$ & $0.60 \mathrm{~N}$ & 2.18 & $0.030 \mathrm{~N}$ & $4 \mathrm{~L}$ \\
\hline HD09150 & 37 & 59 & 44 & $12041 \quad 15$ & 0.180 & 0.13 & 210 & $0.002 \mathrm{~L}$ & 4 & $1 L$ & $0.60 \mathrm{~N}$ & 0.71 & $0.030 \mathrm{~N}$ & $4 \mathrm{~L}$ \\
\hline HD09164 & 37 & 59 & 44 & 1204115 & 0.450 & 2.69 & 530 & $0.002 \mathrm{~L}$ & 97 & $1 \mathrm{~L}$ & $0.60 \mathrm{~N}$ & 7.19 & 0.057 & $4 \mathrm{~L}$ \\
\hline HD09170 & 37 & 59 & 44 & 1204115 & 0.370 & 2.41 & 270 & 0.200 & 86 & $1 \mathrm{~L}$ & $0.60 \mathrm{~N}$ & 3.85 & 0.035 & $4 \mathrm{~L}$ \\
\hline HDO9180 & 37 & 59 & 44 & 1204115 & 0.160 & 5.01 & 30 & 0.004 & 5 & $1 \mathrm{~L}$ & $0.60 \mathrm{~N}$ & 5.27 & 0.081 & $4 \mathrm{~L}$ \\
\hline HDo9200 & 37 & 59 & 44 & 1204115 & $0.045 \mathrm{~N}$ & 6.33 & $10 \mathrm{~L}$ & $0.002 \mathrm{~L}$ & 33 & $1 \mathrm{~L}$ & $0.60 \mathrm{~N}$ & 5.02 & 0.045 & 5 \\
\hline HDO9220 & 37 & 59 & 44 & $12041 \quad 15$ & $0.045 \mathrm{~N}$ & 5.90 & $10 \mathrm{~L}$ & $0.002 \mathrm{~N}$ & 4 & $1 L$ & $0.60 \mathrm{~N}$ & 4.52 & $0.030 \mathrm{~N}$ & $4 \mathrm{~L}$ \\
\hline HD09240 & 37 & 59 & 44 & 1204115 & $0.045 \mathrm{~N}$ & 5.07 & $10 \mathrm{~L}$ & 0.002 & 6 & $1 \mathrm{~L}$ & $0.60 \mathrm{~N}$ & 4.87 & 0.039 & $4 \mathrm{~L}$ \\
\hline$H D 09260$ & 37 & 59 & 44 & $12041 \quad 15$ & 2.200 & 4.20 & 290 & $0.002 \mathrm{~L}$ & 107 & $1 \mathrm{~L}$ & $0.60 \mathrm{~N}$ & 5.00 & 0.067 & $4 \mathrm{~L}$ \\
\hline HD09270 & 37 & 59 & 44 & 1204115 & 0.510 & 5.32 & 140 & 0.150 & 99 & $1 \mathrm{~L}$ & $0.60 \mathrm{~N}$ & 5.53 & 0.061 & 5 \\
\hline HDO9280 & 37 & 59 & 44 & $12041 \quad 15$ & 0.360 & 7.09 & 100 & 0.020 & 143 & 1 & $0.60 \mathrm{~N}$ & 4.25 & 0.050 & $4 \mathrm{~L}$ \\
\hline HD09290 & 37 & 59 & 44 & $12041 \quad 15$ & 0.150 & 5.55 & 230 & 0.002 & 131 & 2 & $0.60 \mathrm{~N}$ & 4.64 & 0.044 & $4 \mathrm{~L}$ \\
\hline HD09300 & 37 & 59 & 44 & 1204115 & 0.370 & 6.76 & 330 & 0.006 & 150 & 1 & $0.60 \mathrm{~N}$ & 3.25 & 0.035 & $4 \mathrm{~L}$ \\
\hline HD09320 & 37 & 59 & 44 & 1204115 & 1.600 & 4.92 & 290 & 0.006 & 82 & $1 \mathrm{~L}$ & $0.60 \mathrm{~N}$ & 5.36 & 0.078 & $4 \mathrm{~L}$ \\
\hline HD09330 & 37 & 59 & 44 & 1204115 & 1.100 & 3.67 & 440 & 0.002 & 121 & $1 \mathrm{~L}$ & $0.60 \mathrm{~N}$ & 5.59 & 0.072 & $4 \mathrm{~L}$ \\
\hline HD09340 & 37 & 59 & 44 & $12041 \quad 15$ & 0.960 & 3.75 & 440 & 0.100 & 114 & 1 & $0.60 \mathrm{~N}$ & 6.45 & 0.075 & $4 \mathrm{~L}$ \\
\hline HD09350 & 37 & 59 & 44 & 1204115 & 4.000 & 5.96 & 240 & 0.050 & 152 & 2 & $0.60 \mathrm{~N}$ & 2.74 & 0.330 & 31 \\
\hline HD09370 & 37 & 59 & 44 & 1204115 & 3.600 & 8.18 & 470 & 0.010 & 146 & 3 & $0.60 \mathrm{~N}$ & 1.84 & 0.350 & 37 \\
\hline HDo9390 & 37 & 59 & 44 & 1204115 & 2.000 & 8.79 & 230 & 0.002 & 797 & 3 & $0.60 \mathrm{~N}$ & 1.17 & 0.310 & 45 \\
\hline HDo9410 & 37 & 59 & 44 & 1204115 & 0.960 & 7.72 & 110 & $0.002 \mathrm{~L}$ & 680 & 2 & $0.60 \mathrm{~N}$ & 2.57 & 0.320 & 33 \\
\hline HD09430 & 37 & 59 & 44 & 1204115 & 1.800 & 8.46 & 230 & 0.002 & 725 & 3 & $0.60 \mathrm{~N}$ & 1.88 & 0.300 & 42 \\
\hline HDO9450 & 37 & 59 & 44 & $12041 \quad 15$ & 3.700 & 6.66 & 340 & 0.006 & 226 & 3 & $0.60 \mathrm{~N}$ & 2.87 & 0.210 & 35 \\
\hline
\end{tabular}


Appendix 1.--continued

Sam. ID Co ppm Cr ppm Cu ppm Eu ppm Fe \% icp icp icp icp icp
Ga ppm Hg ppm K\% La ppm Li ppm LOI \% icp aa icp icp icp grav
Mg \% Mn ppm Mo ppm icp icp picp

\begin{tabular}{|c|c|c|c|c|c|c|c|c|c|c|c|c|c|c|}
\hline HD08032 & 71 & 922 & 92 & $2 \mathrm{~L}$ & 7.21 & 12 & $0.02 \mathrm{~N}$ & $0.05 \mathrm{~L}$ & 3 & 27 & 6.01 & 11.60 & 1250 & 0.12 \\
\hline HD08042 & 40 & 605 & 52 & $2 \mathrm{~L}$ & 4.49 & 8 & $0.02 \mathrm{~N}$ & 0.07 & 3 & 24 & 18.10 & 6.55 & 1250 & $0.09 \mathrm{~N}$ \\
\hline HD08052 & 17 & 94 & 44 & $2 \mathrm{~L}$ & 4.03 & 10 & 0.30 & 1.51 & 7 & 19 & 7.66 & 2.49 & 780 & 0.79 \\
\hline HD08062 & 32 & 259 & 59 & $2 \mathrm{~L}$ & 6.16 & 11 & 0.08 & 1.73 & 3 & 5 & 12.60 & 4.50 & 698 & 0.22 \\
\hline HD08072 & 26 & 116 & 100 & $2 \mathrm{~L}$ & 5.06 & 11 & 0.02 & 1.04 & 4 & 4 & 12.10 & 3.62 & 1000 & 0.24 \\
\hline HD08082 & 32 & 259 & 121 & $2 \mathrm{~L}$ & 5.15 & 11 & 0.06 & 1.63 & 5 & 2 & 15.80 & 3.94 & 1670 & 0.35 \\
\hline HD08092 & 26 & 299 & 69 & $2 \mathrm{~L}$ & 4.67 & 11 & 0.12 & 2.15 & 6 & $2 \mathrm{~L}$ & 17.70 & 4.76 & 1170 & 0.92 \\
\hline HD08102 & 10 & 115 & 12 & $2 \mathrm{~L}$ & 1.69 & $4 \mathrm{~L}$ & $0.02 \mathrm{~N}$ & 0.68 & $2 L$ & $2 L$ & 5.80 & 1.66 & 327 & 0.10 \\
\hline HD08112 & 22 & 167 & 32 & $2 \mathrm{~L}$ & 4.10 & 11 & $0.02 \mathrm{~N}$ & 2.15 & 3 & $2 \mathrm{~L}$ & 17.70 & 5.07 & 1070 & 0.12 \\
\hline HO08122 & 15 & 121 & 30 & $2 L$ & 3.49 & 9 & 0.20 & 1.49 & 8 & 7 & 11.20 & 2.57 & 660 & 0.50 \\
\hline HD08132 & 21 & 137 & 47 & $2 \mathrm{~L}$ & 4.27 & 13 & 0.08 & 1.71 & 10 & 4 & 9.01 & 2.06 & 534 & 0.89 \\
\hline HD08137 & 18 & 109 & 63 & $2 \mathrm{~L}$ & 4.55 & 14 & 0.10 & 1.88 & 12 & 30 & 7.08 & 1.74 & 618 & 1.20 \\
\hline HD09005 & 32 & 159 & 89 & $2 \mathrm{~L}$ & 6.14 & 15 & $0.02 \mathrm{~N}$ & 0.75 & 8 & 19 & 5.00 & 2.47 & 1290 & 0.47 \\
\hline HD09010 & 37 & 309 & 95 & $2 \mathrm{~L}$ & 6.35 & 17 & 0.02 & 1.45 & 3 & 15 & 3.38 & 4.78 & 1260 & 0.12 \\
\hline HD09020 & 50 & 763 & 75 & $2 L$ & 6.18 & 17 & 0.02 & 1.33 & $2 \mathrm{~L}$ & 24 & 3.79 & 7.99 & 1220 & 0.12 \\
\hline HD09030 & 34 & 168 & 121 & $2 \mathrm{~L}$ & 7.01 & 17 & 0.08 & 2.06 & 3 & 24 & 3.65 & 4.35 & 1420 & 0.15 \\
\hline HD09040 & 36 & 276 & 132 & $2 \mathrm{~L}$ & 6.31 & 15 & 0.02 & 1.75 & 3 & 18 & 4.70 & 4.70 & 1260 & 0.48 \\
\hline HD09060 & 49 & 463 & 71 & $2 \mathrm{~L}$ & 6.33 & 14 & $0.02 \mathrm{~N}$ & 0.53 & 3 & 41 & 3.80 & 7.22 & 1300 & 0.16 \\
\hline HD09080 & 84 & 1650 & 49 & $2 \mathrm{~L}$ & 6.48 & 9 & $0.02 \mathrm{~N}$ & $0.05 \mathrm{~L}$ & $2 \mathrm{~L}$ & 75 & 7.67 & 16.90 & 1320 & 0.18 \\
\hline HD09100 & 50 & 697 & 57 & $2 \mathrm{~L}$ & 5.43 & 11 & 0.28 & 1.62 & $2 \mathrm{~L}$ & 42 & 20.70 & 8.59 & 1540 & 0.43 \\
\hline HDo9110 & 94 & 1900 & 11 & $2 \mathrm{~L}$ & 5.27 & 4 & 0.50 & $0.05 \mathrm{~L}$ & $2 \mathrm{~L}$ & 10 & 30.20 & 15.30 & 871 & $0.09 \mathrm{~N}$ \\
\hline HD09120 & 82 & 1660 & 12 & $2 L$ & 5.02 & $4 \mathrm{~L}$ & 1.30 & 0.06 & $2 \mathrm{~L}$ & 17 & 26.50 & 12.90 & 1110 & $0.09 \mathrm{~N}$ \\
\hline HD09130 & 86 & 1980 & 9 & 21 & 5.00 & $4 \mathrm{~L}$ & 0.30 & 0.06 & $2 L$ & 5 & 27.80 & 14.40 & 724 & $0.09 \mathrm{~N}$ \\
\hline H009140 & 115 & 2380 & 11 & $2 \mathrm{~L}$ & 5.69 & $4 \mathrm{~L}$ & 0.36 & $0.05 \mathrm{~L}$ & $2 \mathrm{~L}$ & 9 & 34.70 & 20.00 & 1020 & $0.09 \mathrm{~N}$ \\
\hline HD09150 & 90 & 2100 & 5 & $2 \mathrm{~L}$ & 4.30 & $4 \mathrm{~L}$ & 0.20 & $0.05 \mathrm{~L}$ & $2 L$ & 11 & 32.00 & 21.10 & 796 & $0.09 \mathrm{~N}$ \\
\hline HD09164 & 72 & 1120 & 10 & $2 \mathrm{~L}$ & 5.87 & 8 & 0.08 & 1.23 & $2 \mathrm{~L}$ & 7 & 30.70 & 11.40 & 1200 & 0.44 \\
\hline HD09170 & 40 & 726 & 34 & $2 \mathrm{~L}$ & 3.74 & 7 & 0.10 & 0.97 & 2 & 8 & 14.40 & 4.86 & 700 & 0.20 \\
\hline HD09180 & 76 & 1320 & 77 & $2 \mathrm{~L}$ & 6.81 & 12 & $0.02 \mathrm{~N}$ & $0.05 \mathrm{~L}$ & $2 L$ & 66 & 16.30 & 11.80 & 1310 & $0.09 \mathrm{~N}$ \\
\hline HD09200 & 52 & 696 & 170 & $2 \mathrm{~L}$ & 5.92 & 11 & $0.02 \mathrm{~N}$ & 0.38 & 4 & 58 & 4.04 & 9.28 & 1070 & 0.16 \\
\hline HD09220 & 80 & 1710 & 6 & $2 \mathrm{~L}$ & 7.08 & 13 & $0.02 \mathrm{~N}$ & $0.05 \mathrm{~L}$ & $2 \mathrm{~L}$ & 100 & 5.44 & 13.80 & 1200 & $0.09 \mathrm{~N}$ \\
\hline HDo9240 & 75 & 1270 & 33 & $2 \mathrm{~L}$ & 7.10 & 12 & 0.02 & $0.05 \mathrm{~L}$ & 2 & 57 & 8.44 & 11.80 & 1250 & 0.16 \\
\hline HD09260 & 59 & 875 & 113 & $2 \mathrm{~L}$ & 5.59 & 9 & 0.28 & 1.64 & 2 & 7 & 23.80 & 9.05 & 1060 & $0.09 \mathrm{~N}$ \\
\hline HD09270 & 44 & 519 & 85 & $2 \mathrm{~L}$ & 4.79 & 9 & 0.08 & 1.14 & 4 & 4 & 17.60 & 4.96 & 896 & 0.34 \\
\hline HD09280 & 31 & 377 & 87 & $2 \mathrm{~L}$ & 5.00 & 13 & 0.04 & 1.62 & 3 & 5 & 17.30 & 5.23 & 895 & 0.34 \\
\hline$H D 09290$ & 52 & 651 & 49 & $2 \mathrm{~L}$ & 7.74 & 13 & 0.04 & 1.97 & $2 \mathrm{~L}$ & 4 & 24.30 & 8.18 & 1290 & 0.13 \\
\hline HD09300 & 59 & 681 & 91 & $2 \mathrm{~L}$ & 7.27 & 12 & 0.04 & 2.11 & 3 & 5 & 21.10 & 7.41 & 1190 & 0.15 \\
\hline HD09320 & 46 & 775 & 31 & $2 \mathrm{~L}$ & 4.66 & 8 & 0.06 & 1.19 & $2 \mathrm{~L}$ & 4 & 21.00 & 7.01 & 905 & 0.20 \\
\hline H009330 & 63 & 1120 & 38 & $2 L$ & 5.54 & 10 & 0.02 & 1.44 & $2 L$ & 4 & 25.10 & 9.25 & 1060 & 0.14 \\
\hline HD09340 & 55 & 1110 & 44 & $2 \mathrm{~L}$ & 5.07 & 9 & 0.12 & 1.24 & 2 & 16 & 24.40 & 8.69 & 1080 & 0.31 \\
\hline HD09350 & 14 & 87 & 31 & $2 \mathrm{~L}$ & 4.18 & 14 & 0.48 & 2.26 & 17 & 8 & 5.96 & 1.37 & 775 & 5.30 \\
\hline HD09370 & 22 & 163 & 51 & $2 \mathrm{~L}$ & 4.75 & 19 & 0.34 & 3.42 & 20 & 3 & 8.04 & 1.31 & 399 & 1.20 \\
\hline HD09390 & 19 & 144 & 80 & $2 \mathrm{~L}$ & 4.47 & 19 & 0.18 & 3.58 & 23 & 3 & 8.76 & 1.47 & 431 & 1.80 \\
\hline HD09410 & 18 & 132 & 54 & $2 \mathrm{~L}$ & 4.73 & 17 & 0.08 & 2.96 & 17 & 4 & 10.00 & 1.79 & 763 & 1.40 \\
\hline HD09430 & 25 & 127 & 63 & $2 \mathrm{~L}$ & 5.09 & 20 & 0.12 & 2.95 & 21 & 4 & 8.65 & 1.65 & 755 & 1.00 \\
\hline HD09450 & 12 & 73 & 51 & $2 \mathrm{~L}$ & 3.69 & 16 & 0.10 & 2.76 & 18 & 4 & 6.70 & 1.24 & 516 & 1.20 \\
\hline
\end{tabular}


Appendix 1.--continued

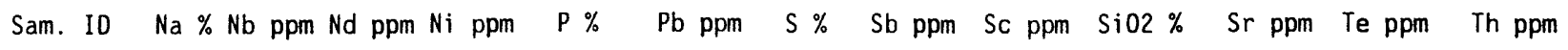
icp icp icp icp icp icp, comb picp icp xrf icp aa icp

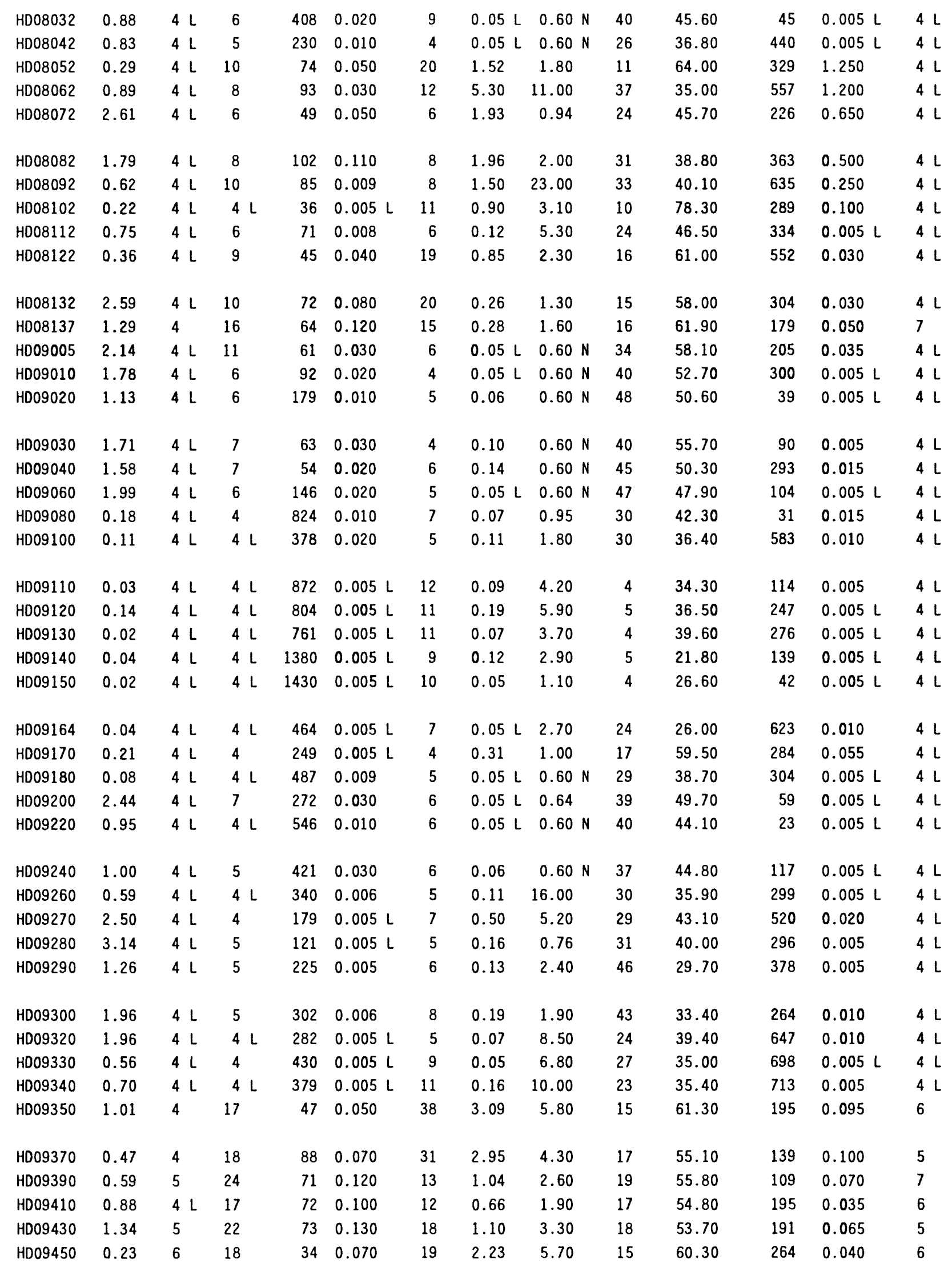




\begin{tabular}{|c|c|c|c|c|c|c|c|c|}
\hline Sam. ID & $\begin{array}{l}\mathrm{Ti} \% \\
\text { icp }\end{array}$ & $\begin{array}{c}\text { Tl ppm } \\
\text { a a }\end{array}$ & $\begin{array}{c}V \mathrm{ppm} \\
\text { icp }\end{array}$ & $\begin{array}{l}\text { W ppm } \\
\text { aa }\end{array}$ & $\begin{array}{c}Y \mathrm{ppm} \\
\text { icp }\end{array}$ & $\begin{array}{l}\text { Yb ppm } \\
\text { icp. }\end{array}$ & $\begin{array}{l}\text { Zn ppm } \\
\text { icp }\end{array}$ & Geologic unit \\
\hline HD08032 & 0.280 & $0.05 \mathrm{~L}$ & 200 & 1.0 & 10 & 1 & 50 & Copper Hill Volcanics \\
\hline HD08042 & 0.150 & 0.05 & 138 & 1.0 & 7 & $1 \mathrm{~L}$ & 30 & Copper Hill Volcanics \\
\hline HD08052 & 0.060 & 0.25 & 84 & 3.5 & 7 & $1 \mathrm{~L}$ & 120 & Salt Spring Slate, tuffaceous member \\
\hline HD08062 & 0.100 & 0.25 & 191 & 8.5 & 8 & $1 \mathrm{~L}$ & 19 & Salt Spring Slate, tuffaceous member \\
\hline HD08072 & 0.150 & 0.15 & 189 & 4.0 & 6 & 1 & 72 & Salt Spring Slate, tuffaceous member \\
\hline HD08082 & 0.110 & 0.25 & 208 & 3.5 & 9 & $1 \mathrm{~L}$ & 94 & Salt Spring Slate, tuffaceous member \\
\hline HD08092 & 0.040 & 0.35 & 185 & 6.0 & 7 & $1 \mathrm{~L}$ & 56 & Salt Spring Slate, tuffaceous member \\
\hline HD08102 & 0.020 & 0.15 & 51 & 2.5 & 2 & $1 \mathrm{~L}$ & 9 & Salt Spring Slate, tuffaceous member \\
\hline HD08112 & 0.060 & 0.35 & 165 & 5.0 & 4 & $1 \mathrm{~L}$ & 31 & Salt Spring Slate, tuffaceous member \\
\hline HD08122 & 0.060 & 0.20 & 94 & 6.0 & 8 & $1 \mathrm{~L}$ & 74 & Salt Spring Slate \\
\hline HD08132 & 0.120 & 0.25 & 121 & 4.0 & 10 & 1 & 99 & Salt Spring Slate \\
\hline HD08137 & 0.210 & 0.15 & 141 & 3.0 & 13 & 2 & 124 & Salt Spring Slate \\
\hline HD09005 & 0.370 & 0.10 & 252 & 16.0 & 18 & 2 & 68 & Copper Hill Volcanics \\
\hline HD09010 & 0.300 & 0.15 & 252 & 1.0 & 20 & 2 & 62 & Copper Hill Volcanics \\
\hline HD09020 & 0.230 & 0.20 & 209 & 1.0 & 10 & 1 & 51 & Copper Hill Volcanics \\
\hline HD09030 & 0.440 & 0.25 & 297 & 1.5 & 17 & 2 & 238 & Copper Hill Volcanics \\
\hline HD09040 & 0.330 & 0.15 & 283 & 1.0 & 14 & 2 & 57 & Copper Hill Volcanics \\
\hline HD09060 & 0.280 & 0.10 & 241 & 1.0 & 11 & 1 & 45 & Copper Hill Volcanics \\
\hline HD09080 & 0.180 & 0.05 & 151 & 1.0 & 8 & $1 \mathrm{~L}$ & 39 & Copper Hill Volcanics \\
\hline HD09100 & 0.100 & 0.30 & 145 & 3.0 & 7 & 1 & 58 & Copper Hill Volcanics \\
\hline HD09110 & $0.005 \mathrm{~L}$ & $0.05 \mathrm{~L}$ & 24 & 1.0 & $2 \mathrm{~L}$ & $1 \mathrm{~L}$ & 164 & Copper Hill Volcanics \\
\hline HD09120 & $0.005 \mathrm{~L}$ & $0.05 \mathrm{~L}$ & 20 & 2.0 & $2 \mathrm{~L}$ & $1 \mathrm{~L}$ & 71 & Copper Hill Volcanics \\
\hline HD09130 & $0.005 \mathrm{~L}$ & $0.05 \mathrm{~L}$ & 23 & 1.0 & $2 \mathrm{~L}$ & $1 \mathrm{~L}$ & 183 & Copper Hill Volcanics \\
\hline HD09140 & $0.005 \mathrm{~L}$ & $0.05 \mathrm{~L}$ & 13 & 1.0 & $2 \mathrm{~L}$ & $1 \mathrm{~L}$ & 54 & Copper Hill Volcanics \\
\hline HD09150 & $0.005 \mathrm{~L}$ & $0.05 \mathrm{~N}$ & 8 & 1.0 & $2 \mathrm{~L}$ & $1 \mathrm{~L}$ & 17 & Copper Hill Volcanics \\
\hline HD09164 & 0.020 & 0.15 & 107 & 2.0 & 5 & $1 \mathrm{~L}$ & 37 & Copper Hill Volcanics \\
\hline HD09170 & 0.030 & 0.20 & 95 & 2.0 & 3 & $1 \mathrm{~L}$ & 19 & Copper Hill Volcanics \\
\hline HD09180 & 0.030 & $0.05 \mathrm{~L}$ & 156 & 1.0 & 4 & $1 \mathrm{~L}$ & 61 & Copper Hill Volcanics \\
\hline HDO9200 & 0.380 & 0.05 & 230 & 1.0 & 14 & 2 & 16 & Copper Hill Volcanics \\
\hline HDo9220 & 0.270 & $0.05 \mathrm{~L}$ & 186 & 1.0 & 10 & 1 & 19 & Copper Hill Volcanics \\
\hline HD09240 & 0.250 & $0.05 \mathrm{~L}$ & 187 & 2.0 & 10 & 1 & 47 & Copper Hill Volcanics \\
\hline HD09260 & 0.040 & 0.30 & 136 & 2.0 & 4 & $1 \mathrm{~L}$ & 36 & Copper Hill Volcanics \\
\hline HD09270 & 0.060 & 0.15 & 148 & 7.0 & 5 & $1 \mathrm{~L}$ & 31 & Copper Hill Volcanics \\
\hline HD09280 & 0.070 & 0.25 & 188 & 6.5 & 4 & $1 \mathrm{~L}$ & 30 & Copper Hill Volcanics \\
\hline HD09290 & 0.120 & 0.35 & 213 & 6.0 & 6 & $1 \mathrm{~L}$ & 45 & Copper Hill Volcanics \\
\hline HD09300 & 0.120 & 0.35 & 201 & 6.5 & 5 & $1 \mathrm{~L}$ & 48 & Copper Hill Volcanics \\
\hline HD09320 & 0.040 & 0.25 & 126 & 3.0 & 4 & $1 \mathrm{~L}$ & 29 & Copper Hill Volcanics \\
\hline HD09330 & 0.030 & 0.30 & 147 & 2.0 & 5 & $1 \mathrm{~L}$ & 32 & Copper Hill Volcanics \\
\hline HD09340 & 0.030 & 0.25 & 132 & 2.5 & 5 & $1 \mathrm{~L}$ & 37 & Copper Hill Volcanics \\
\hline HD09350 & 0.150 & 0.35 & 199 & 13.0 & 11 & 1 & 130 & Salt Spring Slate \\
\hline HD09370 & 0.110 & 0.30 & 150 & 5.0 & 11 & 2 & 131 & Salt Spring Slate \\
\hline HD09390 & 0.160 & 0.35 & 168 & 5.0 & 14 & 2 & 118 & Salt Spring slate \\
\hline HD09410 & 0.130 & 0.35 & 147 & 5.0 & 12 & 2 & 110 & Salt Spring Slate \\
\hline HD09430 & 0.150 & 0.40 & 158 & 7.5 & 14 & 2 & 122 & Salt Spring Slate \\
\hline HD09450 & 0.200 & 0.30 & 117 & 6.0 & 13 & 2 & 102 & Salt Spring Slate \\
\hline
\end{tabular}


Appendix 1.--continued

\begin{tabular}{|c|c|c|c|c|c|c|c|c|c|c|c|c|c|}
\hline Sam. ID & Latitu & ude & Longitude & $\begin{array}{c}\mathrm{Ag} \text { ppm } \\
\text { picp }\end{array}$ & $\begin{array}{r}\text { Al } \% \\
\text { icp }\end{array}$ & $\begin{array}{c}\text { As } p p m \\
i c p\end{array}$ & $\begin{array}{c}\text { Au ppm } \\
\text { aa }\end{array}$ & $\begin{array}{c}\text { Ba ppm } \\
\text { icp }\end{array}$ & $\begin{array}{l}\text { Be ppm } \\
\text { icp }\end{array}$ & $\begin{array}{c}\text { Bi ppm } \\
\text { picp }\end{array}$ & $\begin{array}{r}\mathrm{Ca} \% \\
\mathrm{icp}\end{array}$ & $\begin{array}{c}\text { Cd ppm } \\
\text { picp }\end{array}$ & $\begin{array}{l}\text { Ce ppm } \\
\text { icp }\end{array}$ \\
\hline HD09470 & 3759 & 44 & $12041 \quad 15$ & 0.350 & 6.39 & 80 & $0.002 \mathrm{~L}$ & 488 & 1 & $0.60 \mathrm{~N}$ & 1.42 & 0.180 & 19 \\
\hline HD09490 & 3759 & 44 & $12041 \quad 15$ & 0.350 & 8.58 & 40 & 0.0021 & 1140 & 2 & $0.60 \mathrm{~N}$ & 1.12 & 0.140 & 19 \\
\hline HD09510 & 3759 & 44 & 1204115 & 1.100 & 6.17 & 230 & 0.008 & 143 & 2 & $0.60 \mathrm{~N}$ & 2.40 & 0.280 & 24 \\
\hline $\mathrm{HD} 10002$ & 3759 & 44 & 1204115 & 0.430 & 4.36 & 100 & 0.032 & 338 & $1 \mathrm{~L}$ & $0.60 \mathrm{~N}$ & 1.28 & 0.130 & 16 \\
\hline HD10007 & 3759 & 44 & 1204115 & 0.570 & 1.34 & 100 & 0.350 & 140 & $1 \mathrm{~L}$ & $0.60 \mathrm{~N}$ & 0.63 & 0.082 & 7 \\
\hline HD10012 & 3759 & 44 & $12041 \quad 15$ & 1.000 & 3.41 & 160 & 0.250 & 225 & $1 \mathrm{~L}$ & $0.60 \mathrm{~N}$ & 0.11 & 0.160 & 11 \\
\hline HD10022 & 3759 & 44 & $12041 \quad 15$ & 0.860 & 5.11 & 50 & 0.002 & 381 & 1 & $0.60 \mathrm{~N}$ & 2.72 & 0.260 & 16 \\
\hline HD10032 & 3759 & 44 & $12041 \quad 15$ & 0.440 & 6.51 & 70 & 0.002 & 644 & 2 & $0.60 \mathrm{~N}$ & 1.45 & 0.180 & 18 \\
\hline HD1 0042 & 3759 & 44 & $12041 \quad 15$ & 0.220 & 7.73 & 70 & $0.002 \mathrm{~L}$ & 786 & 2 & $0.60 \mathrm{~N}$ & 0.94 & 0.150 & 23 \\
\hline HD10052 & 3759 & 44 & $12041 \quad 15$ & 0.160 & 5.92 & 30 & $0.002 \mathrm{~L}$ & 519 & 1 & $0.60 \mathrm{~N}$ & 2.32 & 0.140 & 19 \\
\hline HD10062 & 3759 & 44 & $12041 \quad 15$ & 0.130 & 6.72 & 40 & $0.002 \mathrm{~L}$ & 625 & 1 & $0.60 \mathrm{~N}$ & 2.36 & 0.210 & 12 \\
\hline HD10072 & 3759 & 44 & $12041 \quad 15$ & 0.095 & 5.70 & 30 & 0.002 & 329 & $1 \mathrm{~L}$ & $0.60 \mathrm{~N}$ & 2.35 & 0.150 & 13 \\
\hline HD10082 & 3759 & 44 & $12041 \quad 15$ & 0.140 & 6.26 & 20 & $0.002 N$ & 399 & 1 & $0.60 \mathrm{~N}$ & 1.57 & 0.210 & 20 \\
\hline HD10092 & 3759 & 44 & 1204115 & 0.210 & 8.26 & 20 & 0.002 & 672 & 2 & $0.60 \mathrm{~N}$ & 1.08 & 0.160 & 17 \\
\hline HD10102 & 3759 & 44 & $12041 \quad 15$ & 0.190 & 6.59 & 20 & 0.002 & 590 & 1 & $0.60 \mathrm{~N}$ & 2.50 & 0.180 & 16 \\
\hline HD11002 & 3759 & 44 & 1204115 & 0.120 & 3.59 & 40 & 0.008 & 89 & $1 \mathrm{~L}$ & 0.64 & 0.32 & 0.033 & $4 \mathrm{~L}$ \\
\hline HD1 1007 & 3759 & 44 & $12041 \quad 15$ & 0.150 & 5.95 & 30 & 0.002 & 98 & $1 \mathrm{~L}$ & $0.60 \mathrm{~N}$ & 0.37 & 0.064 & 5 \\
\hline HD11012 & 3759 & 44 & 1204115 & 0.140 & 6.79 & 50 & 0.018 & 98 & $1 \mathrm{~L}$ & $0.60 \mathrm{~N}$ & 1.43 & 0.087 & 5 \\
\hline HD11022 & 3759 & 44 & $12041 \quad 15$ & 0.055 & 7.31 & 10 & $0.002 L$ & 33 & $1 \mathrm{~L}$ & 0.61 & 5.64 & 0.071 & $4 \mathrm{~L}$ \\
\hline HD11032 & 3759 & 44 & $12041 \quad 15$ & 0.080 & 7.15 & 10 & 0.002 & 36 & $1 \mathrm{~L}$ & $0.60 \mathrm{~N}$ & 5.00 & 0.047 & $4 \mathrm{~L}$ \\
\hline HD1 1042 & 3759 & 44 & 1204115 & 0.110 & 6.54 & 10 & 0.002 & 61 & $1 \mathrm{~L}$ & $0.60 \mathrm{~N}$ & 6.46 & 0.074 & $4 \mathrm{~L}$ \\
\hline HD11052 & 3759 & 44 & 1204115 & 0.093 & 5.17 & $10 \mathrm{~L}$ & 0.002 & 25 & $1 \mathrm{~L}$ & $0.60 \mathrm{~N}$ & 7.43 & 0.075 & $4 \mathrm{~L}$ \\
\hline HD11062 & 3759 & 44 & 1204115 & 0.120 & 6.51 & $10 \mathrm{~L}$ & 0.0021 & 283 & $1 \mathrm{~L}$ & $0.60 \mathrm{~N}$ & 6.34 & 0.077 & $4 \mathrm{~L}$ \\
\hline HD11072 & 3759 & 44 & 1204115 & 0.460 & 5.53 & 80 & 0.050 & 154 & $1 \mathrm{~L}$ & $0.60 \mathrm{~N}$ & 8.02 & 0.085 & $4 \mathrm{~L}$ \\
\hline HD11082 & 3759 & 44 & $12041 \quad 15$ & 0.099 & 6.08 & 20 & 0.002 & 66 & $1 \mathrm{~L}$ & $0.60 \mathrm{~N}$ & 7.13 & 0.077 & $4 \mathrm{~L}$ \\
\hline HD1 1092 & 3759 & 44 & $12041 \quad 15$ & 0.046 & 6.95 & 20 & 0.002 & 101 & $1 \mathrm{~L}$ & $0.60 \mathrm{~N}$ & 5.47 & 0.045 & $4 \mathrm{~L}$ \\
\hline HD11102 & 3759 & 44 & $12041 \quad 15$ & 0.290 & 6.82 & 30 & 0.014 & 47 & $1 \mathrm{~L}$ & $0.60 \mathrm{~N}$ & 5.36 & 0.068 & $4 \mathrm{~L}$ \\
\hline HD11112 & 3759 & 44 & $12041 \quad 15$ & 0.560 & 4.98 & 100 & 0.150 & 113 & $1 \mathrm{~L}$ & 0.61 & 6.36 & 0.071 & $4 \mathrm{~L}$ \\
\hline HD11122 & 3759 & 44 & $12041 \quad 15$ & 2.300 & 1.99 & 170 & 0.450 & 134 & $1 \mathrm{~L}$ & 0.62 & 5.83 & 0.150 & 6 \\
\hline HD11132 & 3759 & 44 & $12041 \quad 15$ & 3.700 & 5.01 & 500 & 0.008 & 123 & 1 & $0.60 \mathrm{~N}$ & 2.88 & 0.320 & 24 \\
\hline HD11142 & 3759 & 44 & $12041 \quad 15$ & 4.100 & 4.36 & 310 & 0.100 & 148 & 1 & $0.60 \mathrm{~N}$ & 3.08 & 0.240 & 17 \\
\hline HD11152 & 3759 & 44 & $12041 \quad 15$ & 6.000 & 4.51 & 330 & 0.022 & 257 & 2 & $0.60 \mathrm{~N}$ & 2.42 & 0.250 & 20 \\
\hline HD11162 & 3759 & 44 & $12041 \quad 15$ & 2.900 & 5.69 & 370 & 0.018 & 166 & 2 & 0.72 & 3.60 & 0.200 & 23 \\
\hline HD11172 & 3759 & 44 & $12041 \quad 15$ & 4.500 & 4.89 & 350 & 0.016 & 156 & 2 & $0.60 \mathrm{~N}$ & 2.57 & 0.210 & 22 \\
\hline HD11182 & 3759 & 44 & 1204115 & 5.200 & 3.92 & 310 & 0.400 & 265 & 1 & $0.60 \mathrm{~N}$ & 2.15 & 0.190 & 16 \\
\hline HO11192 & 3759 & 44 & $12041 \quad 15$ & 2.000 & 5.08 & 250 & 0.030 & 310 & 1 & $0.60 \mathrm{~N}$ & 3.62 & 0.250 & 24 \\
\hline HD11202 & 3759 & 44 & 1204115 & 0.570 & 5.86 & 80 & 0.004 & 589 & 1 & $0.60 \mathrm{~N}$ & 2.32 & 0.250 & 16 \\
\hline HD11212 & 3759 & 44 & $12041 \quad 15$ & 0.360 & 5.85 & 40 & 0.002 & 482 & 1 & $0.60 \mathrm{~N}$ & 2.60 & 0.280 & 19 \\
\hline HD11222 & 3759 & 44 & $12041 \quad 15$ & 0.600 & 5.78 & 40 & 0.020 & 528 & 1 & $0.60 \mathrm{~N}$ & 2.25 & 0.200 & 16 \\
\hline HD1 2017 & 3759 & 44 & $12041 \quad 15$ & 0.230 & 7.77 & 30 & 0.018 & 105 & $1 \mathrm{~L}$ & $0.60 \mathrm{~N}$ & 5.55 & 0.094 & 5 \\
\hline HD12022 & 3759 & 44 & $12041 \quad 15$ & 0.310 & 8.02 & 20 & 0.006 & 77 & $1 \mathrm{~L}$ & $0.60 \mathrm{~N}$ & 6.32 & 0.110 & $4 \mathrm{~L}$ \\
\hline HD12042 & 3759 & 44 & $12041 \quad 15$ & 0.056 & 7.93 & 10 & 0.002 & 194 & $1 \mathrm{~L}$ & $0.60 \mathrm{~N}$ & 6.44 & 0.120 & $4 \mathrm{~L}$ \\
\hline HD12057 & 3759 & 44 & $12041 \quad 15$ & $0.045 \mathrm{~N}$ & 7.93 & 20 & 0.004 & 157 & $1 \mathrm{~L}$ & $0.60 \mathrm{~N}$ & 6.56 & 0.067 & $4 \mathrm{~L}$ \\
\hline HD12082 & 3759 & 44 & $12041 \quad 15$ & 0.068 & 7.35 & 10 & 0.002 & 50 & $1 \mathrm{~L}$ & $0.60 \mathrm{~N}$ & 7.13 & 0.057 & $4 \mathrm{~L}$ \\
\hline HD12102 & 3759 & 44 & $12041 \quad 15$ & $0.045 \mathrm{~N}$ & 8.03 & 10 & 0.004 & 36 & $1 \mathrm{~L}$ & $0.60 \mathrm{~N}$ & 7.32 & 0.074 & $4 \mathrm{~L}$ \\
\hline
\end{tabular}


Appendix 1.--continued

Sam. ID Co ppm Cr ppm Cu ppm Eu ppm Fe \% Ga ppm Hg ppm K\% La ppm Li ppm LOI \% icp icp icp icp icp icp, aa icp icp icp grav

\begin{tabular}{|c|c|c|c|c|c|c|c|c|c|c|c|c|c|c|}
\hline & $i c p$ & $i c p$ & $i c p$ & $i c p$ & $i c p$ & $i c p$ & $\mathrm{aa}$ & $i c p$ & $i c p$ & $i c p$ & grav & $i c p$ & $i c p$ & picp \\
\hline HDO 470 & 16 & 191 & 27 & $2 \mathrm{~L}$ & 3.17 & 14 & 0.02 & 1.74 & 10 & 3 & 6.52 & 1.49 & 365 & 0.40 \\
\hline HD09490 & 15 & 104 & 59 & $2 \mathrm{~L}$ & 4.58 & 19 & 0.08 & 3.45 & 9 & 4 & 8.19 & 1.29 & 482 & 0.87 \\
\hline HD09510 & 24 & 94 & 37 & $2 \mathrm{~L}$ & 4.57 & 14 & 0.18 & 2.40 & 14 & 3 & 7.15 & 1.37 & 458 & 0.85 \\
\hline HO10002 & 18 & 204 & 41 & $2 \mathrm{~L}$ & 3.93 & 8 & 0.10 & 1.08 & 9 & 28 & 3.98 & 1.93 & 616 & 0.76 \\
\hline HD10007 & 4 & 23 & 15 & $2 \mathrm{~L}$ & 1.32 & $4 \mathrm{~L}$ & 0.04 & 0.43 & 4 & 5 & 1.39 & 0.14 & 415 & 0.38 \\
\hline HD10012 & 29 & 727 & 47 & $2 \mathrm{~L}$ & 4.12 & 8 & 0.12 & 0.69 & 6 & 92 & 3.57 & 2.98 & 793 & 0.59 \\
\hline HD1 0022 & 16 & 120 & 40 & $2 \mathrm{~L}$ & 4.34 & 11 & 0.24 & 1.51 & 8 & 14 & 8.46 & 1.95 & 735 & 0.87 \\
\hline HD10032 & 16 & 114 & 55 & $2 \mathrm{~L}$ & 4.86 & 14 & 0.22 & 2.28 & 10 & 10 & 7.83 & 1.59 & 618 & 1.30 \\
\hline HD1 0042 & 20 & 100 & 66 & $2 \mathrm{~L}$ & 5.49 & 17 & 0.22 & 2.64 & 12 & 8 & 8.15 & 1.51 & 679 & 1.30 \\
\hline HD10052 & 13 & 101 & 41 & $2 \mathrm{~L}$ & 3.82 & 13 & 0.10 & 1.53 & 11 & 30 & 6.72 & 1.49 & 710 & 0.66 \\
\hline HD10062 & 15 & 145 & 32 & $2 \mathrm{~L}$ & 3.82 & 14 & 0.12 & 1.76 & 7 & 34 & 6.80 & 1.64 & 590 & 0.86 \\
\hline HD10072 & 14 & 170 & 38 & $2 \mathrm{~L}$ & 3.25 & 12 & 0.06 & 0.87 & 7 & 33 & 5.93 & 1.64 & 566 & 0.47 \\
\hline HD10082 & 15 & 128 & 30 & $2 \mathrm{~L}$ & 3.13 & 12 & 0.06 & 0.97 & 10 & 36 & 4.82 & 1.59 & 378 & 0.60 \\
\hline HD10092 & 21 & 127 & 80 & $2 \mathrm{~L}$ & 5.63 & 18 & 0.12 & 1.78 & 8 & 62 & 5.11 & 2.07 & 450 & 2.80 \\
\hline HD10102 & 16 & 123 & 47 & $2 \mathrm{~L}$ & 4.20 & 14 & 0.08 & 1.51 & 9 & 44 & 6.11 & 1.66 & 625 & 0.71 \\
\hline HD11002 & 17 & 242 & 59 & $2 \mathrm{~L}$ & 3.38 & 6 & 0.02 & 0.56 & $2 \mathrm{~L}$ & 18 & 3.75 & 1.33 & 425 & 0.44 \\
\hline HD11007 & 29 & 282 & 78 & $2 \mathrm{~L}$ & 5.34 & 10 & 0.02 & 0.74 & 2 & 40 & 6.11 & 2.70 & 659 & 0.35 \\
\hline HD11012 & 45 & 563 & 97 & $2 \mathrm{~L}$ & 6.49 & 11 & 0.02 & 0.54 & 2 & 59 & 7.37 & 5.12 & 1000 & 0.19 \\
\hline HD11022 & 45 & 461 & 90 & $2 \mathrm{~L}$ & 6.47 & 13 & $0.02 \mathrm{~N}$ & 0.06 & 4 & 43 & 3.70 & 6.39 & 1200 & 0.16 \\
\hline HD11032 & 47 & 508 & 80 & $2 \mathrm{~L}$ & 6.25 & 12 & 0.04 & 0.12 & 3 & 45 & 4.17 & 6.08 & 1120 & 0.22 \\
\hline HD11042 & 44 & 389 & 101 & $2 \mathrm{~L}$ & 5.92 & 12 & 0.02 & 0.34 & 4 & 42 & 9.04 & 5.47 & 1180 & 0.81 \\
\hline HD11052 & 56 & 840 & 82 & $2 L$ & 6.18 & 10 & $0.02 \mathrm{~N}$ & 0.17 & 3 & 54 & 13.80 & 9.40 & 1260 & 1.10 \\
\hline HD11062 & 39 & 444 & 71 & $2 \mathrm{~L}$ & 5.72 & 13 & $0.02 \mathrm{~N}$ & 0.34 & 4 & 37 & 9.45 & 5.42 & 1260 & 0.16 \\
\hline HD11072 & 29 & 294 & 79 & $2 \mathrm{~L}$ & 5.05 & 10 & 0.04 & 1.53 & 3 & 25 & 16.70 & 4.94 & 1140 & 0.15 \\
\hline HD11082 & 39 & 471 & 75 & $2 \mathrm{~L}$ & 5.64 & 11 & 0.02 & 0.40 & 3 & 48 & 11.90 & 5.52 & 1150 & 0.18 \\
\hline HD11092 & 40 & 398 & 91 & $2 \mathrm{~L}$ & 6.29 & 13 & 0.04 & 0.14 & 3 & 40 & 4.22 & 5.40 & 1200 & 0.17 \\
\hline HD11102 & 37 & 357 & 103 & $2 \mathrm{~L}$ & 6.03 & 12 & 0.02 & 0.47 & 3 & 33 & 9.94 & 4.72 & 1130 & 0.11 \\
\hline HD11112 & 29 & 291 & 71 & $2 \mathrm{~L}$ & 5.15 & 9 & 0.04 & 1.29 & 2 & 5 & 17.60 & 4.72 & 1110 & 0.15 \\
\hline HD11122 & 9 & 81 & 27 & $2 \mathrm{~L}$ & 2.86 & 5 & 0.24 & 0.54 & 5 & 17 & 11.30 & 3.32 & 1310 & 0.56 \\
\hline HD11132 & 13 & 91 & 26 & $2 \mathrm{~L}$ & 3.52 & 13 & 0.24 & 2.07 & 13 & 3 & 5.84 & 1.49 & 556 & 0.91 \\
\hline HD11142 & 12 & 72 & 24 & $2 \mathrm{~L}$ & 3.53 & 11 & 0.44 & 1.86 & 9 & 3 & 5.84 & 1.51 & 570 & 0.90 \\
\hline HD11152 & 11 & 80 & 56 & $2 \mathrm{~L}$ & 2.72 & 11 & 0.24 & 1.89 & 11 & 3 & 5.01 & 1.23 & 503 & 0.87 \\
\hline HD11162 & 17 & 118 & 44 & $2 \mathrm{~L}$ & 3.87 & 14 & 0.14 & 2.18 & 12 & 4 & 6.76 & 1.80 & 647 & 0.96 \\
\hline HD11172 & 14 & 72 & 30 & $2 \mathrm{~L}$ & 3.56 & 12 & 0.20 & 2.03 & 12 & 3 & 5.69 & 1.32 & 543 & 0.92 \\
\hline HD11182 & 10 & 82 & 31 & $2 \mathrm{~L}$ & 2.51 & 9 & 0.24 & 1.37 & 8 & 3 & 4.14 & 1.10 & 383 & 0.50 \\
\hline HD11192 & 11 & 80 & 43 & $2 L$ & 3.27 & 12 & 0.12 & 1.79 & 13 & 2 & 8.18 & 1.77 & 717 & 0.73 \\
\hline HD11202 & 15 & 144 & 32 & $2 \mathrm{~L}$ & 3.37 & 12 & 0.14 & 1.79 & 9 & 4 & 7.97 & 1.58 & 530 & 0.81 \\
\hline HO11212 & 15 & 147 & 34 & $2 \mathrm{~L}$ & 3.41 & 12 & 0.08 & 1.20 & 12 & 22 & 6.51 & 1.74 & 646 & 0.48 \\
\hline HD11222 & 14 & 133 & 33 & $2 \mathrm{~L}$ & 3.56 & 12 & 0.08 & 1.17 & 10 & 26 & 5.55 & 1.66 & 576 & 0.65 \\
\hline HD12017 & 39 & 452 & 106 & $2 \mathrm{~L}$ & 6.21 & 14 & 0.04 & 0.40 & 5 & 35 & 5.60 & 4.50 & 1110 & 0.36 \\
\hline HD12022 & 39 & 385 & 104 & $2 L$ & 6.17 & 15 & 0.02 & 0.30 & 5 & 35 & 5.41 & 4.64 & 1130 & 0.85 \\
\hline HD12042 & 39 & 473 & 126 & $2 L$ & 6.13 & 15 & $0.02 \mathrm{~N}$ & 0.74 & 4 & 33 & 4.21 & 5.47 & 1200 & 0.33 \\
\hline HD12057 & 37 & 427 & 109 & $2 L$ & 6.03 & 15 & 0.02 & 0.59 & 4 & 33 & 4.68 & 5.18 & 1190 & 0.22 \\
\hline HD12082 & 36 & 350 & 105 & $2 L$ & 5.73 & 13 & $0.02 \mathrm{~N}$ & 0.39 & 4 & 40 & 7.06 & 4.82 & 1190 & 0.30 \\
\hline HD12102 & 38 & 336 & 132 & $2 \mathrm{~L}$ & 6.02 & 15 & $0.02 \mathrm{~N}$ & 0.14 & 4 & 40 & 5.20 & 4.87 & 1210 & 0.39 \\
\hline
\end{tabular}

$\mathrm{Mg} \%$ Mn ppm Mo ppm icp icp picp 
Appendix 1.--continued

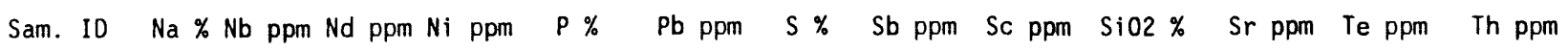
icp icp icp icp icp icp, comb picp icp xrf icp aa icp

\begin{tabular}{|c|c|c|c|c|c|c|c|c|c|c|c|c|c|}
\hline HDO9470 & 2.03 & $4 \mathrm{~L}$ & 10 & 66 & 0.060 & 6 & 0.16 & 1.00 & 13 & 65.90 & 184 & 0.015 & $4 \mathrm{~L}$ \\
\hline HD09490 & 0.78 & 6 & 10 & 36 & 0.100 & 25 & 0.26 & 1.10 & 18 & 57.90 & 107 & 0.040 & 7 \\
\hline HDo9510 & 0.61 & $4 \mathrm{~L}$ & 14 & 60 & 0.070 & 28 & 1.96 & 1.50 & 13 & 61.60 & 291 & 0.040 & 5 \\
\hline HD10002 & 0.92 & $4 \mathrm{~L}$ & 9 & 144 & 0.040 & 11 & $0.05 \mathrm{~L}$ & 1.50 & 11 & 73.50 & 115 & 0.040 & $4 \mathrm{~L}$ \\
\hline 4010007 & 0.39 & $4 \mathrm{~L}$ & 4 & 19 & 0.006 & 8 & $0.05 \mathrm{~L}$ & $0.60 \mathrm{~N}$ & 4 & 90.40 & 60 & 0.025 & $4 L$ \\
\hline HD10012 & 0.42 & $4 \mathrm{~L}$ & 7 & 247 & 0.010 & 9 & $0.05 \mathrm{~L}$ & 1.40 & 14 & 76.40 & 36 & 0.045 & $4 \mathrm{~L}$ \\
\hline HD10022 & 1.48 & $4 \mathrm{~L}$ & 11 & 64 & 0.070 & 12 & 0.72 & 2.60 & 12 & 62.50 & 311 & 0.025 & $4 \mathrm{~L}$ \\
\hline HD10032 & 1.09 & 5 & 11 & 52 & 0.090 & 18 & 0.51 & 2.60 & 15 & 61.60 & 170 & 0.035 & 7 \\
\hline HD10042 & 1.37 & 5 & 13 & 48 & 0.110 & 22 & 0.53 & 1.60 & 17 & 58.30 & 140 & 0.095 & 8 \\
\hline HD10052 & 1.36 & 5 & 10 & 42 & 0.080 & 11 & 0.18 & 0.94 & 13 & 65.70 & 254 & 0.025 & 4 \\
\hline HD10062 & 1.43 & $4 \mathrm{~L}$ & 9 & 64 & 0.080 & 7 & 0.12 & 1.20 & 15 & 63.40 & 327 & 0.030 & $4 \mathrm{~L}$ \\
\hline HD10072 & 2.27 & $4 \mathrm{~L}$ & 8 & 56 & 0.060 & 10 & 0.10 & 1.20 & 12 & 67.60 & 262 & 0.015 & $4 \mathrm{~L}$ \\
\hline HD10082 & 2.48 & 4 & 10 & 66 & 0.050 & 10 & 0.16 & 1.30 & 12 & 68.60 & 238 & 0.020 & 4 \\
\hline HD10092 & 1.79 & $4 \mathrm{~L}$ & 11 & 70 & 0.120 & 14 & 0.50 & 2.00 & 20 & 59.50 & 175 & 0.120 & 6 \\
\hline HD10102 & 1.49 & 6 & 10 & 54 & 0.080 & 9 & 0.21 & 1.30 & 16 & 63.90 & 319 & 0.020 & 4 \\
\hline HD11002 & 0.69 & $4 \mathrm{~L}$ & $4 \mathrm{~L}$ & 81 & 0.010 & 38 & $0.05 \mathrm{~L}$ & $0.60 \mathrm{~N}$ & 18 & 79.50 & 22 & 0.045 & $4 \mathrm{~L}$ \\
\hline HD11007 & 1.41 & $4 \mathrm{~L}$ & 4 & 113 & 0.020 & $4 \mathrm{~L}$ & $0.05 \mathrm{~L}$ & 0.77 & 30 & 66.00 & 43 & 0.045 & $4 \mathrm{~L}$ \\
\hline HD11012 & 1.47 & $4 \mathrm{~L}$ & 6 & 206 & 0.020 & 5 & $0.05 \mathrm{~L}$ & 0.82 & 40 & 56.50 & 42 & 0.050 & $4 \mathrm{~L}$ \\
\hline HD11022 & 2.77 & $4 \mathrm{~L}$ & 8 & 190 & 0.030 & 6 & $0.05 \mathrm{~L}$ & 1.10 & 44 & 50.30 & 53 & 0.025 & $4 \mathrm{~L}$ \\
\hline HD11032 & 2.84 & $4 \mathrm{~L}$ & 7 & 186 & 0.030 & 5 & 0.13 & 0.76 & 43 & 51.20 & 212 & 0.050 & $4 \mathrm{~L}$ \\
\hline HD11042 & 2.20 & $4 \mathrm{~L}$ & 9 & 154 & 0.030 & 5 & 0.09 & 0.82 & 40 & 47.70 & 104 & 0.035 & $4 \mathrm{~L}$ \\
\hline HD11052 & 0.08 & $4 \mathrm{~L}$ & 6 & 331 & 0.020 & 6 & $0.05 \mathrm{~L}$ & 0.69 & 36 & 40.70 & 85 & 0.015 & $4 \mathrm{~L}$ \\
\hline HD11062 & 2.19 & $4 \mathrm{~L}$ & 7 & 148 & 0.020 & 5 & $0.05 \mathrm{~L}$ & 0.77 & 37 & 47.80 & 96 & 0.005 & $4 \mathrm{~L}$ \\
\hline HD11072 & 0.83 & $4 \mathrm{~L}$ & 5 & 107 & 0.010 & $4 \mathrm{~L}$ & 0.06 & 0.72 & 30 & 42.50 & 220 & 0.015 & $4 \mathrm{~L}$ \\
\hline HDI1082 & 1.56 & $4 \mathrm{~L}$ & 8 & 150 & 0.030 & 5 & $0.05 \mathrm{~L}$ & 0.67 & 37 & 45.80 & 96 & 0.010 & $4 \mathrm{~L}$ \\
\hline HDI1092 & 3.07 & $4 \mathrm{~L}$ & 6 & 137 & 0.020 & 6 & $0.05 \mathrm{~L}$ & 1.50 & 42 & 52.00 & 106 & 0.005 & $4 \mathrm{~L}$ \\
\hline HD11102 & 2.82 & $4 . L$ & 7 & 114 & 0.020 & 4 & 0.05 & 1.10 & 39 & 48.00 & 142 & 0.005 & $4 \mathrm{~L}$ \\
\hline HD11112 & 1.92 & $4 \mathrm{~L}$ & 6 & 105 & 0.010 & $4 \mathrm{~L}$ & 0.16 & 0.72 & 31 & 43.40 & 284 & $0.005 \mathrm{~L}$ & $4 \mathrm{~L}$ \\
\hline HD11122 & 0.66 & $4 \mathrm{~L}$ & 7 & 35 & 0.020 & 14 & 1.00 & 1.50 & 8 & 62.60 & 524 & 0.015 & $4 \mathrm{~L}$ \\
\hline HD 11132 & 0.43 & $4 \mathrm{~L}$ & 14 & 53 & 0.030 & 21 & 2.60 & 5.10 & 12 & 65.10 & 246 & 0.055 & $4 \mathrm{~L}$ \\
\hline HD11142 & 0.28 & $4 \mathrm{~L}$ & 11 & 55 & 0.050 & 21 & 2.37 & 6.00 & 11 & 66.30 & 272 & 0.100 & $4 \mathrm{~L}$ \\
\hline HD11152 & 0.30 & $4 \mathrm{~L}$ & 12 & 46 & 0.040 & 18 & 1.82 & 12.00 & 11 & 69.90 & 201 & 0.100 & 4 \\
\hline HD11162 & 0.71 & $4 \mathrm{~L}$ & 15 & 61 & 0.050 & 20 & 2.25 & 3.70 & 15 & 60.00 & 349 & 0.040 & $4 \mathrm{~L}$ \\
\hline HD11172 & 0.31 & $4 \mathrm{~L}$ & 14 & 52 & 0.060 & 21 & 2.34 & 6.50 & 12 & 65.70 & 255 & 0.040 & $4 \mathrm{~L}$ \\
\hline HD11182 & 0.78 & $4 \mathrm{~L}$ & 9 & 40 & 0.030 & 20 & 1.47 & 5.00 & 9 & 74.10 & 199 & 0.025 & $4 \mathrm{~L}$ \\
\hline HD11192 & 0.89 & $4 \mathrm{~L}$ & 13 & 41 & 0.050 & 16 & 1.31 & 2.50 & 12 & 62.70 & 401 & 0.030 & $4 \mathrm{~L}$ \\
\hline HD11202 & 1.66 & $4 \mathrm{~L}$ & 10 & 54 & 0.060 & 9 & 0.24 & 1.90 & 13 & 64.10 & 280 & 0.020 & $4 \mathrm{~L}$ \\
\hline $\mathrm{HD} 11212$ & 2.05 & $4 \mathrm{~L}$ & 12 & 59 & 0.060 & 11 & 0.23 & 1.60 & 14 & 65.20 & 259 & 0.020 & $4 \mathrm{~L}$ \\
\hline HD11222 & 1.99 & $4 \mathrm{~L}$ & 11 & 56 & 0.060 & 11 & 0.36 & 1.90 & 13 & 66.30 & 225 & 0.020 & $4 \mathrm{~L}$ \\
\hline HD12017 & 2.00 & $4 \mathrm{~L}$ & 8 & 117 & 0.030 & 15 & 0.15 & $0.60 \mathrm{~N}$ & 42 & 51.50 & 63 & 0.015 & $4 \mathrm{~L}$ \\
\hline HD12022 & 1.69 & $4 \mathrm{~L}$ & 8 & 106 & 0.030 & 19 & 0.07 & 1.10 & 44 & 51.10 & 50 & 0.015 & $4 \mathrm{~L}$ \\
\hline HD12042 & 1.85 & $4 \mathrm{~L}$ & 6 & 113 & 0.020 & 8 & $0.05 \mathrm{~L}$ & $0.60 \mathrm{~N}$ & 43 & 50.00 & 80 & 0.015 & $4 \mathrm{~L}$ \\
\hline HD12057 & 1.82 & $4 \mathrm{~L}$ & 7 & 105 & 0.030 & 7 & 0.07 & 0.83 & 43 & 50.10 & 75 & 0.015 & $4 \mathrm{~L}$ \\
\hline HD12082 & 1.51 & $4 \mathrm{~L}$ & 6 & 97 & 0.030 & 7 & 0.16 & 1.40 & 41 & 50.50 & 87 & 0.010 & $4 \mathrm{~L}$ \\
\hline HD12102 & 1.86 & $4 \mathrm{~L}$ & 8 & 96 & 0.030 & 6 & $0.05 \mathrm{~L}$ & 0.78 & 41 & 49.70 & 71 & 0.010 & $4 \mathrm{~L}$ \\
\hline
\end{tabular}


Appendix 1.--continued

\begin{tabular}{|c|c|c|c|c|c|c|c|c|}
\hline Sam. ID & $\begin{array}{l}\mathrm{Ti} \% \\
\text { icp }\end{array}$ & $\begin{array}{c}\text { Tl ppm } \\
\text { aa }\end{array}$ & $\begin{array}{c}V \mathrm{ppm} \\
\text { icp }\end{array}$ & $\begin{array}{l}\text { W ppm } \\
\text { aa }\end{array}$ & $\begin{array}{c}Y \text { ppm } \\
\text { icp }\end{array}$ & $\begin{array}{l}\text { Yb ppm } \\
\text { icp. }\end{array}$ & $\begin{array}{l}\text { Zn ppm } \\
\text { icp }\end{array}$ & Geologic unit \\
\hline HDO 9470 & 0.080 & 0.20 & 105 & 2.5 & 8 & 1 & 82 & Salt Spring Slate \\
\hline HD09490 & 0.200 & 0.25 & 162 & 3.5 & 12 & 2 & 124 & Salt Spring Slate \\
\hline HD09510 & 0.100 & 0.35 & 121 & 5.0 & 10 & 1 & 108 & Salt Spring Slate \\
\hline HD10002 & 0.130 & 0.20 & 113 & 10.0 & 7 & $1 \mathrm{~L}$ & 58 & Copper Hill Volcanics \\
\hline HD10007 & 0.020 & 0.10 & 33 & 5.0 & 2 & $1 \mathrm{~L}$ & 21 & Copper Hill Volcanics \\
\hline HD10012 & 0.070 & 0.10 & 101 & 4.5 & 3 & $1 \mathrm{~L}$ & 49 & Copper Hill Volcanics \\
\hline HD10022 & 0.120 & 0.15 & 92 & 4.0 & 9 & 1 & 89 & Salt Spring Slate \\
\hline HD10032 & 0.220 & 0.25 & 126 & 4.0 & 11 & 1 & 122 & Salt Spring slate \\
\hline HD10042 & 0.200 & 0.35 & 160 & 3.5 & 12 & 2 & 148 & Salt Spring Slate \\
\hline HD10052 & 0.190 & 0.30 & 110 & 3.0 & 10 & 1 & 78 & Salt Spring Slate \\
\hline HD10062 & 0.110 & 0.30 & 126 & 3.0 & 11 & 1 & 92 & Salt Spring Slate \\
\hline HD10072 & 0.120 & 0.05 & 102 & 2.0 & 9 & 1 & 70 & Salt Spring Slate \\
\hline HD10082 & 0.200 & 0.10 & 93 & 2.0 & 9 & 1 & 76 & Salt Spring Slate \\
\hline HD10092 & 0.160 & 0.20 & 183 & 2.0 & 12 & 2 & 136 & Salt Spring Slate \\
\hline HD10102 & 0.230 & 0.15 & 133 & 1.5 & 12 & 2 & 92 & Salt Spring Slate \\
\hline HD1 1002 & 0.080 & 0.10 & 121 & 2.0 & 3 & $1 \mathrm{~L}$ & 25 & Copper Hill Volcanics \\
\hline HD11007 & 0.150 & 0.10 & 205 & 4.5 & 7 & $1 \mathrm{~L}$ & 46 & Copper Hill Volcanics \\
\hline HD11012 & 0.210 & 0.10 & 255 & 2.0 & 10 & 1 & 55 & Copper Hill Volcanics \\
\hline HD11022 & 0.310 & $0.05 \mathrm{~N}$ & 256 & 1.5 & 12 & 2 & 53 & Copper Hill Volcanics \\
\hline HD11032 & 0.290 & $0.05 \mathrm{~N}$ & 230 & 1.5 & 11 & 1 & 50 & Copper Hill Volcanics \\
\hline HD11042 & 0.290 & 0.10 & 244 & 1.5 & 11 & 1 & 47 & Copper Hill Volcanics \\
\hline HD11052 & 0.190 & 0.05 & 197 & 1.5 & 9 & 1 & 44 & Copper Hill Volcanics \\
\hline HD11062 & 0.280 & 0.10 & 229 & 1.0 & 11 & 2 & 43 & Copper Hill Volcanics \\
\hline HD11072 & 0.070 & 0.25 & 198 & 6.0 & 8 & $1 \mathrm{~L}$ & 32 & Copper Hill Volcanics \\
\hline HD11082 & 0.220 & 0.05 & 210 & 1.5 & 10 & 1 & 42 & Copper Hill Volcanics \\
\hline HD1 1092 & 0.300 & $0.05 \mathrm{~N}$ & 246 & 2.0 & 11 & 2 & 49 & Copper Hill Volcanics \\
\hline HD11102 & 0.200 & 0.10 & 230 & 3.0 & 9 & 1 & 49 & Copper Hill Volcanics \\
\hline HD11112 & 0.060 & 0.20 & 157 & 5.0 & 5 & $1 \mathrm{~L}$ & 36 & Copper Hill Volcanics \\
\hline HD11122 & 0.040 & 0.15 & 44 & 4.0 & 4 & $1 \mathrm{~L}$ & 40 & Copper Hill Volcanics \\
\hline HD11132 & 0.060 & 0.30 & 92 & 5.5 & 7 & $1 \mathrm{~L}$ & 119 & Salt Spring Slate \\
\hline HD11142 & 0.050 & 0.25 & 85 & 4.0 & 7 & $1 \mathrm{~L}$ & 66 & Salt Spring Slate \\
\hline HD11152 & 0.060 & 0.20 & 85 & 4.5 & 7 & $1 \mathrm{~L}$ & 88 & Salt Spring Slate \\
\hline HD11162 & 0.060 & 0.25 & 112 & 6.5 & 8 & 1 & 67 & Salt Spring Slate \\
\hline HD11172 & 0.060 & 0.30 & 95 & 5.0 & 8 & 1 & 74 & Salt Spring Slate \\
\hline HD11182 & 0.060 & 0.25 & 60 & 4.5 & 5 & $1 \mathrm{~L}$ & 51 & Salt Spring Slate \\
\hline HD11192 & 0.060 & 0.25 & 91 & 7.0 & 9 & 1 & 123 & Salt Spring Slate \\
\hline HD11202 & 0.090 & 0.35 & 105 & 4.0 & 8 & $1 \mathrm{~L}$ & 88 & Salt Spring Slate \\
\hline HD11212 & 0.120 & 0.20 & 109 & 3.0 & 9 & 1 & 79 & Salt Spring Slate \\
\hline HD11222 & 0.140 & 0.15 & 100 & 3.0 & 9 & 1 & 79 & Salt Spring Slate \\
\hline HD12017 & 0.310 & 0.05 & 247 & 1.5 & 14 & 2 & 64 & Copper Hill Volcanics \\
\hline HD12022 & 0.320 & $0.05 \mathrm{~N}$ & 262 & 1.5 & 15 & 2 & 60 & Copper Hill Volcanics \\
\hline HD12042 & 0.340 & 0.05 & 264 & 1.5 & 14 & 2 & 55 & Copper Hill Volcanics \\
\hline HD12057 & 0.330 & 0.05 & 261 & 1.0 & 15 & 2 & 53 & Copper Hill Volcanics \\
\hline HD12082 & 0.300 & $0.05 \mathrm{~L}$ & 246 & 1.0 & 13 & 2 & 50 & Copper Hill Volcanics \\
\hline HD12102 & 0.340 & $0.05 \mathrm{~N}$ & 256 & 1.5 & 14 & 2 & 55 & Copper Hill Volcanics \\
\hline
\end{tabular}


Sam. ID Latitude Longitude Ag ppm Al \% As ppm Au ppm Ba ppm Be ppm Bi ppm Ca $\% \quad$ Cd ppm Ce ppm

\begin{tabular}{|c|c|c|c|c|c|c|c|c|c|c|c|c|c|c|c|}
\hline HD12122 & 37 & 59 & 44 & 120 & $41 \quad 15$ & 0.410 & 6.63 & 10 & 0.008 & 94 & $1 \mathrm{~L}$ & $0.60 \mathrm{~N}$ & 6.99 & 0.084 & 4 \\
\hline HD12132 & 37 & 59 & 44 & 120 & $41 \quad 15$ & 0.550 & 6.04 & 30 & 0.012 & 125 & $1 \mathrm{~L}$ & $0.60 \mathrm{~N}$ & 5.34 & 0.065 & 4 \\
\hline HD12142 & 37 & 59 & 44 & 120 & $41 \quad 15$ & 0.320 & 5.30 & 20 & 0.008 & 83 & $1 \mathrm{~L}$ & $0.60 \mathrm{~N}$ & 6.45 & 0.079 & 4 \\
\hline HD12152 & 37 & 59 & 44 & 120 & $41 \quad 15$ & 0.180 & 5.36 & $10 \mathrm{~L}$ & 0.002 & 89 & $1 \mathrm{~L}$ & $0.60 \mathrm{~N}$ & 6.36 & 0.078 & 4 \\
\hline HD12162 & 37 & 59 & 44 & 120 & $41 \quad 15$ & 0.380 & 5.16 & 70 & 0.006 & 105 & $1 \mathrm{~L}$ & $0.60 \mathrm{~N}$ & 5.30 & 0.065 & 4 \\
\hline HD12172 & 37 & 59 & 44 & 120 & $41 \quad 15$ & 0.310 & 3.85 & 200 & 0.006 & 113 & $1 \mathrm{~L}$ & $0.60 \mathrm{~N}$ & 6.07 & 0.057 & 4 \\
\hline HD12182 & 37 & 59 & 44 & 120 & 4115 & 2.800 & 3.03 & 360 & 0.450 & 168 & $1 \mathrm{~L}$ & $0.60 \mathrm{~N}$ & 3.10 & 0.190 & 12 \\
\hline HD12192 & 37 & 59 & 44 & 120 & 4115 & 4.100 & 4.88 & 410 & 0.150 & 146 & 1 & $0.60 \mathrm{~N}$ & 2.32 & 0.160 & 14 \\
\hline HD12202 & 37 & 59 & 44 & 120 & $41 \quad 15$ & 1.500 & 5.37 & 220 & 0.010 & 300 & 1 & $0.60 \mathrm{~N}$ & 3.01 & 0.150 & 13 \\
\hline HD13002 & 37 & 59 & 44 & 120 & 4115 & $0.045 \mathrm{~N}$ & 6.87 & 20 & 0.002 & 108 & $1 \mathrm{~L}$ & $0.60 \mathrm{~N}$ & 6.27 & 0.075 & 4 \\
\hline HD13007 & 37 & 59 & 44 & 120 & 4115 & $0.045 \mathrm{~N}$ & 6.89 & 10 & $0.002 \mathrm{~L}$ & 73 & $1 \mathrm{~L}$ & $0.60 \mathrm{~N}$ & 6.17 & 0.071 & 4 \\
\hline HD13012 & 37 & 59 & 44 & 120 & 4115 & $0.045 \mathrm{~N}$ & 7.38 & 10 & $0.002 \mathrm{~L}$ & 62 & $1 \mathrm{~L}$ & $0.60 \mathrm{~N}$ & 6.84 & 0.060 & 4 \\
\hline HD13022 & 37 & 59 & 44 & 120 & 4115 & $0.045 \mathrm{~N}$ & 7.60 & 10 & 0.002 & 69 & $1 \mathrm{~L}$ & $0.60 \mathrm{~N}$ & 6.69 & 0.064 & 4 \\
\hline HD13032 & 37 & 59 & 44 & 120 & 4115 & $0.045 \mathrm{~N}$ & 7.69 & $10 \mathrm{~L}$ & 0.004 & 44 & $1 \mathrm{~L}$ & $0.60 \mathrm{~N}$ & 4.36 & 0.041 & 4 \\
\hline HD14200 & 37 & 59 & 44 & 120 & 4115 & 0.130 & 4.85 & $10 \mathrm{~L}$ & $0.002 \mathrm{~L}$ & 6 & $1 \mathrm{~L}$ & $0.60 \mathrm{~N}$ & 6.01 & 0.053 & 4 \\
\hline HD14210 & 37 & 59 & 44 & 120 & 4115 & 0.061 & 4.91 & 10 & $0.002 \mathrm{~L}$ & 46 & $1 \mathrm{~L}$ & $0.60 \mathrm{~N}$ & 5.82 & 0.070 & 4 \\
\hline HD14220 & 37 & 59 & 44 & 120 & 4115 & 0.750 & 4.17 & 390 & 0.002 & 115 & 1 & $0.60 \mathrm{~N}$ & 5.81 & 0.077 & 4 \\
\hline HD14230 & 37 & 59 & 44 & 120 & 4115 & 0.360 & 4.67 & 140 & 0.004 & 113 & $1 \mathrm{~L}$ & $0.60 \mathrm{~N}$ & 6.25 & 0.100 & 4 \\
\hline HD14240 & 37 & 59 & 44 & 120 & 4115 & 1.000 & 4.64 & 300 & 0.008 & 99 & 1 & $0.60 \mathrm{~N}$ & 6.32 & 0.100 & 4 \\
\hline HD14250 & 37 & 59 & 44 & 120 & 4115 & 0.880 & 5.58 & 240 & $0.002 \mathrm{~L}$ & 116 & $1 \mathrm{~L}$ & $0.60 \mathrm{~N}$ & 5.36 & 0.100 & 4 \\
\hline HD14260 & 37 & 59 & 44 & 120 & 4115 & 0.730 & 4.83 & 210 & 0.010 & 112 & $1 \mathrm{~L}$ & $0.60 \mathrm{~N}$ & 5.17 & 0.068 & 4 \\
\hline HD14270 & 37 & 59 & 44 & 120 & 4115 & 1.300 & 4.65 & 250 & 0.006 & 80 & $1 \mathrm{~L}$ & $0.60 \mathrm{~N}$ & 7.32 & 0.130 & 4 \\
\hline HD14280 & 37 & 59 & 44 & 120 & 4115 & 1.200 & 3.42 & 150 & 0.004 & 89 & $1 \mathrm{~L}$ & $0.60 \mathrm{~N}$ & 4.94 & 0.080 & 4 \\
\hline HD14288 & 37 & 59 & 44 & 120 & 4115 & 9.200 & 1.73 & 310 & 40.000 & 75 & $1 \mathrm{~L}$ & $0.60 \mathrm{~N}$ & 7.13 & 0.270 & 4 \\
\hline HD14300 & 37 & 59 & 44 & 120 & 4115 & 5.000 & 7.96 & 340 & 0.150 & 330 & 2 & $0.60 \mathrm{~N}$ & 3.55 & 0.250 & 26 \\
\hline HD14310 & 37 & 59 & 44 & 120 & 4115 & 5.100 & 8.71 & 800 & 0.050 & 67 & 3 & $0.60 \mathrm{~N}$ & 1.32 & 0.220 & 55 \\
\hline HD14320 & 37 & 59 & 44 & 120 & 4115 & 9.200 & 9.92 & 620 & 0.012 & 60 & 3 & $0.60 \mathrm{~N}$ & 2.55 & 0.370 & 34 \\
\hline HD14330 & 37 & 59 & 44 & 120 & 4115 & 3.100 & 8.06 & 520 & 0.002 & 113 & 3 & $0.60 \mathrm{~N}$ & 3.75 & 0.350 & 41 \\
\hline HD14340 & 37 & 59 & 44 & 120 & 4115 & 4.100 & 8.77 & 370 & 0.300 & 535 & 2 & $0.60 \mathrm{~N}$ & 5.48 & 0.570 & 22 \\
\hline HD1 4350 & 37 & 59 & 44 & 120 & 4115 & 3.100 & 8.70 & 450 & 0.004 & 152 & 3 & $0.60 \mathrm{~N}$ & 3.35 & 0.370 & 44 \\
\hline HD14360 & 37 & 59 & 44 & 120 & 4115 & 0.860 & 7.90 & 180 & $0.002 \mathrm{~L}$ & 662 & 2 & $0.60 \mathrm{~N}$ & 2.29 & 0.250 & 28 \\
\hline HD14370 & 37 & 59 & 44 & 120 & $41 \quad 15$ & 1.800 & 8.16 & 100 & $0.002 \mathrm{~N}$ & 720 & 2 & $0.60 \mathrm{~N}$ & 1.62 & 0.400 & 41 \\
\hline HD14380 & 37 & 59 & 44 & 120 & 4115 & 1.800 & 7.75 & 270 & 0.006 & 573 & 2 & $0.60 \mathrm{~N}$ & 3.70 & 0.380 & 30 \\
\hline HD14390 & 37 & 59 & 44 & 120 & $41 \quad 15$ & 4.000 & 9.80 & 540 & 0.006 & 100 & 3 & $0.60 \mathrm{~N}$ & 3.52 & 0.340 & 42 \\
\hline MK34002 & 38 & 00 & 14 & 120 & 4153 & 0.810 & 5.74 & 80 & 0.050 & 307 & 1 & $0.60 \mathrm{~N}$ & 2.93 & 0.160 & 22 \\
\hline MK34007 & 38 & 00 & 14 & 120 & 4153 & 0.840 & 1.91 & 110 & 1.250 & 84 & $1 \mathrm{~L}$ & $0.60 \mathrm{~N}$ & 0.03 & 0.140 & 8 \\
\hline MK34012 & 38 & 00 & 14 & 120 & 4153 & 1.000 & 1.52 & 60 & 1.900 & 81 & $1 \mathrm{~L}$ & $0.60 \mathrm{~N}$ & 0.10 & 0.080 & 8 \\
\hline MK34017 & 38 & 00 & 14 & 120 & 4153 & 0.650 & 0.55 & 20 & 0.300 & 31 & $1 \mathrm{~L}$ & $0.60 \mathrm{~N}$ & 0.03 & $0.030 \mathrm{~N}$ & 4 \\
\hline MK34032 & 38 & 00 & 14 & 120 & 4153 & 0.160 & 7.03 & 70 & 0.018 & 517 & 1 & $0.60 \mathrm{~N}$ & 0.23 & 0.410 & 20 \\
\hline MK34042 & 38 & 00 & 14 & 120 & 4153 & 1.400 & 5.77 & 120 & 0.100 & 457 & 1 & $0.60 \mathrm{~N}$ & 2.33 & 0.300 & 18 \\
\hline MK34052 & 38 & 00 & 14 & 120 & 4153 & 1.500 & 6.60 & 130 & 0.004 & 586 & 2 & $0.60 \mathrm{~N}$ & 1.55 & 0.310 & 27 \\
\hline MK34062 & 38 & 00 & 14 & 120 & 4153 & 0.260 & 5.35 & 50 & 0.002 & 478 & 1 & $0.60 \mathrm{~N}$ & 5.63 & 0.200 & 13 \\
\hline MK34072 & 38 & 00 & 14 & 120 & 4153 & 0.097 & 4.69 & 30 & $0.002 \mathrm{~L}$ & 312 & $1 \mathrm{~L}$ & $0.60 \mathrm{~N}$ & 3.30 & 0.260 & 15 \\
\hline MK34082 & 38 & 00 & 14 & 120 & 4153 & 0.250 & 7.36 & 40 & 0.002 & 622 & 1 & $0.60 \mathrm{~N}$ & 0.32 & 0.300 & 24 \\
\hline MK34092 & 38 & 00 & 14 & 120 & 4153 & 0.250 & 5.28 & 40 & $0.002 \mathrm{~L}$ & 479 & 1 & $0.60 \mathrm{~N}$ & 2.80 & 0.280 & 22 \\
\hline
\end{tabular}


Appendix 1.---continued

Sam. ID Co ppm Cr ppm Cu ppm Eu ppm Fe \% Ga ppm Hg ppm K\% La ppm Li ppm LOI \% icp icp icp icp icp icp, aa icp icp icp grav

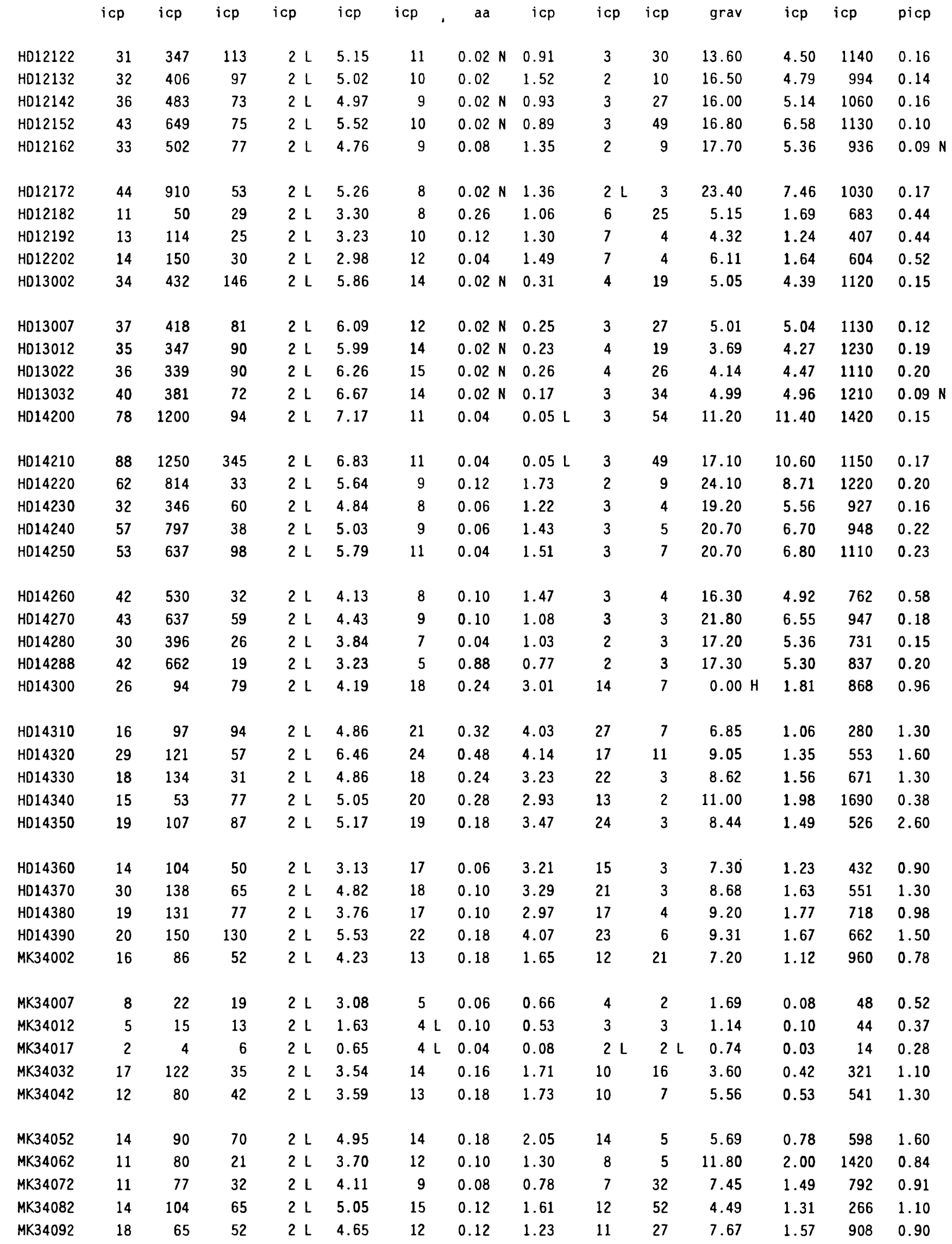

Mg \% Mn ppm Mo ppm icp icp picp 


\begin{tabular}{|c|c|c|c|c|c|c|c|c|c|c|c|c|c|}
\hline Sam. ID & $\begin{array}{r}\mathrm{Na} \% \\
\text { icp }\end{array}$ & $\begin{array}{l}\text { lb ppm } \\
\text { icp }\end{array}$ & $\begin{array}{l}\text { Nd ppm } \\
\text { icp }\end{array}$ & $\begin{array}{l}\text { Ni ppm } \\
\text { icp }\end{array}$ & $\begin{array}{l}P \% \\
i c p\end{array}$ & $\begin{array}{l}\mathrm{Pb} p p m \\
\text { icp }\end{array}$ & $\begin{array}{r}S \% \\
\text { comb }\end{array}$ & $\begin{array}{l}\text { Sb ppm } \\
\text { picp }\end{array}$ & $\begin{array}{l}\text { Sc ppm } \\
\text { icp }\end{array}$ & $\begin{array}{c}\text { Si02 \% } \\
\text { xrf }\end{array}$ & $\begin{array}{c}\text { Sr ppm } \\
\text { icp }\end{array}$ & $\begin{array}{c}\text { Te ppm } \\
\text { da }\end{array}$ & $\begin{array}{c}\text { Th ppm } \\
\text { icp }\end{array}$ \\
\hline HD12122 & 2.42 & $4 \mathrm{~L}$ & 5 & 80 & 0.050 & 6 & 0.12 & $0.60 \mathrm{~N}$ & 37 & 44.60 & 220 & 0.010 & $4 \mathrm{~L}$ \\
\hline HD12132 & 2.35 & $4 \mathrm{~L}$ & 5 & 117 & 0.020 & 6 & 0.19 & $0.60 \mathrm{~N}$ & 33 & 43.90 & 446 & 0.010 & $4 \mathrm{~L}$ \\
\hline HD12142 & 1.85 & $4 \mathrm{~L}$ & 7 & 149 & 0.050 & 9 & 0.15 & $0.60 \mathrm{~N}$ & 31 & 45.20 & 348 & 0.005 & $4 \mathrm{~L}$ \\
\hline HD12152 & 1.00 & $4 \mathrm{~L}$ & 5 & 195 & 0.050 & $4 \mathrm{~L}$ & 0.05 & $0.60 \mathrm{~N}$ & 35 & 43.10 & 216 & 0.005 & $4 \mathrm{~L}$ \\
\hline HD12162 & 1.84 & $4 \mathrm{~L}$ & 6 & 156 & 0.020 & 4 & 0.13 & 4.80 & 28 & 44.90 & 239 & $0.005 \mathrm{~L}$ & $4 \mathrm{~L}$ \\
\hline HD12172 & 0.78 & $4 \mathrm{~L}$ & $4 \mathrm{~L}$ & 284 & $0.005 \mathrm{~L}$ & 5 & 0.13 & 2.50 & 27 & 37.70 & 425 & 0.005 & $4 \mathrm{~L}$ \\
\hline HO12182 & 0.63 & $4 \mathrm{~L}$ & 6 & 29 & 0.040 & 12 & 2.14 & 1.80 & 8 & 70.20 & 261 & 0.040 & $4 \mathrm{~L}$ \\
\hline HD12192 & 1.78 & $4 \mathrm{~L}$ & 8 & 53 & 0.030 & 14 & 2.49 & 5.30 & 10 & 68.10 & 210 & 0.035 & $4 \mathrm{~L}$ \\
\hline HDI2202 & 1.76 & $4 \mathrm{~L}$ & 6 & 55 & 0.050 & 8 & 1.05 & 0.90 & 12 & 64.90 & 224 & 0.020 & $4 \mathrm{~L}$ \\
\hline HD13002 & 2.22 & $4 \mathrm{~L}$ & 7 & 133 & 0.020 & 109 & $0.05 \mathrm{~L}$ & $0.60 \mathrm{~N}$ & 35 & 54.30 & 119 & 0.020 & $4 \mathrm{~L}$ \\
\hline HD13007 & 2.01 & $4 \mathrm{~L}$ & 7 & 129 & 0.020 & 6 & $0.05 \mathrm{~L}$ & $0.60 \mathrm{~N}$ & 41 & 53.10 & 48 & 0.010 & $4 \mathrm{~L}$ \\
\hline HD13012 & 2.79 & $4 \mathrm{~L}$ & 9 & 103 & 0.020 & 6 & $0.05 \mathrm{~L}$ & $0.60 \mathrm{~N}$ & 39 & 53.00 & 112 & 0.010 & $4 \mathrm{~L}$ \\
\hline HD13022 & 2.31 & $4 \mathrm{~L}$ & 8 & 106 & 0.020 & 6 & $0.05 \mathrm{~L}$ & $0.60 \mathrm{~N}$ & 40 & 51.90 & 100 & 0.010 & $4 \mathrm{~L}$ \\
\hline HDI3032 & 3.23 & $4 \mathrm{~L}$ & 7 & 123 & 0.020 & 5 & $0.05 \mathrm{~L}$ & $0.60 \mathrm{~N}$ & 41 & 51.70 & 132 & $0.005 \mathrm{~L}$ & $4 \mathrm{~L}$ \\
\hline HO14200 & 0.39 & $4 \mathrm{~L}$ & 7 & 446 & 0.010 & $4 \mathrm{~L}$ & $0.05 \mathrm{~L}$ & 1.20 & 34 & 42.60 & 221 & 0.015 & $4 \mathrm{~L}$ \\
\hline HD14210 & 0.23 & $4 \mathrm{~L}$ & 7 & 435 & 0.010 & $4 \mathrm{~L}$ & $0.05 \mathrm{~L}$ & 1.30 & 33 & 39.10 & 371 & 0.085 & $4 \mathrm{~L}$ \\
\hline HD1422O & 0.25 & $4 \mathrm{~L}$ & 5 & 342 & $0.005 \mathrm{~L}$ & 7 & 0.09 & 7.70 & 28 & 35.90 & 313 & $0.005 \mathrm{~L}$ & $4 \mathrm{~L}$ \\
\hline HO1423O & 1.76 & $4 \mathrm{~L}$ & 7 & 129 & $0.005 \mathrm{~L}$ & $4 \mathrm{~L}$ & 0.17 & 4.80 & 29 & 43.30 & 553 & $0.005 \mathrm{~L}$ & $4 \mathrm{~L}$ \\
\hline HO14240 & 1.37 & $4 \mathrm{~L}$ & 7 & 311 & $0.005 \mathrm{~L}$ & 6 & 0.28 & 2.70 & 26 & 39.40 & 673 & $0.005 \mathrm{~L}$ & $4 \mathrm{~L}$ \\
\hline HO14250 & 1.87 & $4 \mathrm{~L}$ & 7 & 235 & 0.020 & 5 & 0.12 & 2.60 & 33 & 37.50 & 341 & 0.020 & $4 \mathrm{~L}$ \\
\hline HD14260 & 1.46 & $4 \mathrm{~L}$ & $4 \mathrm{~L}$ & 187 & $0.005 \mathrm{~L}$ & $4 \mathrm{~L}$ & 0.25 & 6.30 & 22 & 48.80 & 541 & 0.005 & $4 \mathrm{~L}$ \\
\hline HD14270 & 1.98 & $4 \mathrm{~L}$ & 6 & 230 & $0.005 \mathrm{~L}$ & 7 & 0.15 & 5.90 & 24 & 38.40 & 798 & 0.060 & $4 \mathrm{~L}$ \\
\hline HD1428O & 1.02 & $4 \mathrm{~L}$ & 6 & 158 & $0.005 \mathrm{~L}$ & $4 \mathrm{~L}$ & 0.05 & 6.60 & 19 & 52.10 & 511 & 0.005 & $4 \mathrm{~L}$ \\
\hline HD14288 & 0.14 & $4 \mathrm{~L}$ & 6 & 278 & $0.005 \mathrm{~L}$ & 162 & 0.44 & 3.90 & 17 & 54.70 & 731 & 0.065 & $4 \mathrm{~L}$ \\
\hline HD14300 & 1.26 & $4 \mathrm{~L}$ & 15 & 42 & 0.030 & 15 & 2.20 & 7.90 & 23 & $0.00 \mathrm{H}$ & 234 & 0.050 & $4 \mathrm{~L}$ \\
\hline HD1431O & 0.38 & $4 \mathrm{~L}$ & 25 & 55 & 0.020 & 31 & 3.91 & 6.80 & 17 & 57.60 & 113 & 0.025 & 8 \\
\hline HD1432O & 0.56 & $4 \mathrm{~L}$ & 22 & 89 & 0.090 & 58 & 5.58 & 11.00 & 20 & 46.20 & 179 & 0.010 & 7 \\
\hline HD1 4330 & 0.49 & $4 \mathrm{~L}$ & 22 & 75 & 0.100 & 22 & 2.88 & 4.40 & 17 & 51.40 & 282 & 0.050 & 5 \\
\hline HD1434O & 1.41 & 5 & 19 & 41 & 0.130 & 11 & 1.70 & 2.10 & 17 & 43.80 & 396 & 0.065 & $4 \mathrm{~L}$ \\
\hline HD14350 & 0.58 & $4 \mathrm{~L}$ & 23 & 73 & 0.080 & 21 & 3.02 & 4.30 & 19 & 49.90 & 287 & 0.050 & 5 \\
\hline HD14360 & 0.35 & $4 \mathrm{~L}$ & 17 & 51 & 0.090 & 9 & 0.94 & 2.20 & 17 & 46.40 & 191 & 0.040 & 6 \\
\hline HDI 4370 & 0.53 & $4 \mathrm{~L}$ & 22 & 84 & 0.120 & 14 & 0.80 & 4.10 & 18 & 57.00 & 140 & 0.090 & 7 \\
\hline HDI 4380 & 0.71 & $4 \mathrm{~L}$ & 18 & 65 & 0.070 & 12 & 1.16 & 2.20 & 16 & 54.60 & 272 & 0.040 & 6 \\
\hline HDI 4390 & 0.36 & 6 & 24 & 84 & 0.090 & 28 & 3.44 & 5.50 & 22 & 45.70 & 275 & 0.085 & 7 \\
\hline MK34002 & 1.08 & 7 & 14 & 42 & 0.110 & 16 & 0.23 & 4.30 & 14 & 64.50 & 189 & 0.050 & $4 \mathrm{~L}$ \\
\hline MK34007 & 0.09 & $4 \mathrm{~L}$ & 5 & 16 & 0.020 & 18 & $0.05 \mathrm{~L}$ & 1.70 & 7 & 87.90 & 13 & 0.020 & $4 \mathrm{~L}$ \\
\hline MK34012 & 0.15 & $4 \mathrm{~L}$ & $4 \mathrm{~L}$ & 10 & 0.020 & 29 & $0.05 \mathrm{~L}$ & 1.00 & 4 & 91.00 & 13 & 0.010 & $4 \mathrm{~L}$ \\
\hline MK34017 & 0.13 & $4 \mathrm{~L}$ & $4 \mathrm{~L}$ & 6 & 0.010 & 33 & $0.05 \mathrm{~L}$ & $0.60 \mathrm{~N}$ & $2 \mathrm{~L}$ & 95.50 & 9 & 0.005 & $4 \mathrm{~L}$ \\
\hline MK34032 & 1.79 & $4 \mathrm{~L}$ & 10 & 72 & 0.090 & 18 & $0.05 \mathrm{~L}$ & 1.70 & 13 & 70.00 & 85 & 0.045 & $4 \mathrm{~L}$ \\
\hline MK34042 & 1.39 & $4 \mathrm{~L}$ & 11 & 43 & 0.060 & 17 & $0.05 \mathrm{~L}$ & 2.10 & 12 & 68.70 & 95 & 0.050 & $4 \mathrm{~L}$ \\
\hline MK34052 & 1.37 & 7 & 15 & 50 & 0.100 & 15 & $0.05 \mathrm{~L}$ & 3.60 & 16 & 64.50 & 125 & 0.065 & 6 \\
\hline MK34062 & 1.82 & $4 \mathrm{~L}$ & 10 & 35 & 0.090 & 7 & $0.05 \mathrm{~L}$ & 1.20 & 11 & 56.40 & 329 & 0.010 & 4 \\
\hline MK34072 & 1.33 & $4 \mathrm{~L}$ & 7 & 41 & 0.100 & 16 & $0.05 \mathrm{~L}$ & 1.20 & 11 & 66.60 & 320 & 0.025 & $4 \mathrm{~L}$ \\
\hline MK34082 & 1.29 & 7 & 16 & 58 & 0.120 & 14 & 0.14 & 1.30 & 16 & 65.90 & 92 & 0.045 & 8 \\
\hline MK34092 & 1.07 & $4 \mathrm{~L}$ & 13 & 45 & 0.100 & 24 & 0.54 & 1.50 & 13 & 63.90 & 330 & 0.045 & $4 \mathrm{~L}$ \\
\hline
\end{tabular}




\begin{tabular}{|c|c|c|c|c|c|c|c|c|}
\hline Sam. IO & $\begin{array}{r}\mathrm{Ti} \% \\
\text { icp }\end{array}$ & $\begin{array}{c}\text { T1 ppm } \\
\mathbf{a a}\end{array}$ & $\begin{array}{c}\text { V ppm } \\
\text { icp }\end{array}$ & $\begin{array}{l}\text { W ppm } \\
\text { aa }\end{array}$ & $\begin{array}{l}Y \text { ppm } \\
\text { icp }\end{array}$ & $\begin{array}{l}\text { Yb ppm } \\
\text { icp. }\end{array}$ & $\begin{array}{l}\mathrm{Zn} \mathrm{ppm} \\
\text { icp }\end{array}$ & Geologic unit \\
\hline HD12122 & 0.130 & 0.10 & 202 & 3.0 & 8 & 1 & 41 & Copper Hill Volcanics \\
\hline HD12132 & 0.070 & 0.20 & 178 & 4.0 & 5 & $1 \mathrm{~L}$ & 33 & Copper Hill Volcanics \\
\hline HO12142 & 0.070 & 0.15 & 170 & 3.0 & 5 & $1 \mathrm{~L}$ & 36 & Copper Hill Volcanics \\
\hline HD12152 & 0.060 & 0.20 & 186 & 2.5 & 5 & $1 \mathrm{~L}$ & 40 & Copper Hill Volcanics \\
\hline H012162 & 0.060 & 0.20 & 163 & 4.0 & 5 & $1 \mathrm{~L}$ & 28 & Copper Hill Volcanics \\
\hline HD12172 & 0.030 & 0.30 & 145 & 5.0 & 5 & $1 \mathrm{~L}$ & 33 & Copper Hill Volcanics \\
\hline HD12182 & 0.100 & 0.15 & 59 & 12.0 & 6 & $1 \mathrm{~L}$ & 64 & Salt Spring Slate \\
\hline HD12192 & 0.070 & 0.20 & 77 & 6.0 & 6 & 1 & 58 & Salt Spring Slate \\
\hline HO12202 & 0.080 & 0.25 & 89 & 6.0 & 7 & $1 \mathrm{~L}$ & 66 & Salt Spring Slate \\
\hline HD13002 & 0.280 & $0.05 \mathrm{~N}$ & 231 & 1.0 & 11 & 2 & 41 & Copper Hill Volcanics \\
\hline HD13007 & 0.300 & $0.05 \mathrm{~N}$ & 248 & 1.0 & 11 & 2 & 48 & Copper Hill Volcanics \\
\hline HD13012 & 0.310 & $0.05 \mathrm{~N}$ & 246 & 1.0 & 12 & 1 & 47 & Copper Hill Volcanics \\
\hline HD13022 & 0.310 & $0.05 \mathrm{~N}$ & 271 & 1.0 & 13 & 2 & 52 & Copper Hill Volcanics \\
\hline HD13032 & 0.310 & $0.05 \mathrm{~N}$ & 261 & 1.0 & 13 & 2 & 58 & Copper Hill Volcanics \\
\hline HD14200 & 0.200 & $0.05 \mathrm{~L}$ & 176 & 1.0 & 9 & 1 & 34 & Copper Hill Volcanics \\
\hline $\mathrm{HO1} 4210$ & 0.020 & $0.05 \mathrm{~N}$ & 167 & 1.0 & 6 & $1 \mathrm{~L}$ & 23 & Copper Hill Volcanics \\
\hline HD14220 & 0.040 & 0.30 & 140 & 2.0 & 4 & $1 \mathrm{~L}$ & 37 & Copper Hill Volcanics \\
\hline HO14230 & 0.030 & 0.15 & 135 & 4.0 & 5 & $1 \mathrm{~L}$ & 26 & Copper Hill Volcanics \\
\hline $\mathrm{HO} 14240$ & 0.030 & 0.25 & 142 & 3.5 & 5 & $1 \mathrm{~L}$ & 28 & Copper Hill Volcanics \\
\hline HD14250 & 0.040 & 0.20 & 188 & 3.0 & 5 & $1 \mathrm{~L}$ & 39 & Copper Hill Volcanics \\
\hline HD1 4260 & 0.070 & 0.25 & 138 & 6.0 & 4 & $1 \mathrm{~L}$ & 21 & Copper Hill Volcanics \\
\hline HD14270 & 0.020 & 0.15 & 120 & 2.5 & 5 & $1 \mathrm{~L}$ & 29 & Copper Hill Volcanics \\
\hline HD14280 & 0.030 & 0.15 & 108 & 2.0 & 4 & $1 \mathrm{~L}$ & 21 & Copper Hill Volcanics \\
\hline HD14288 & 0.010 & 0.15 & 73 & 1.0 & 4 & $1 \mathrm{~L}$ & 90 & Copper Hill Volcanics \\
\hline HD14300 & 0.100 & 0.30 & 213 & 16.0 & 7 & 1 & 71 & Salt Spring Slate \\
\hline HD1 4310 & 0.090 & 0.55 & 187 & 5.0 & 9 & 2 & 98 & Salt Spring Slate \\
\hline HD14320 & 0.070 & 0.40 & 179 & 9.0 & 12 & 2 & 168 & Salt Spring Slate \\
\hline HD14330 & 0.160 & 0.35 & 149 & 7.0 & 13 & 2 & 119 & Salt Spring Slate \\
\hline HD14340 & 0.230 & 0.25 & 153 & 17.0 & 15 & 2 & 227 & Salt Spring Slate \\
\hline HD14350 & 0.090 & 0.35 & 163 & 6.0 & 14 & 2 & 132 & Salt Spring Slate \\
\hline HDI 4360 & 0.090 & 0.30 & 153 & 8.0 & 11 & 2 & 90 & Salt Spring Slate \\
\hline HD14370 & 0.130 & 0.45 & 165 & 5.0 & 12 & 2 & 135 & Salt Spring Slate \\
\hline HD14380 & 0.100 & 0.25 & 135 & 9.0 & 11 & 2 & 147 & Salt Spring Slate \\
\hline HD14390 & 0.260 & 0.55 & 200 & 4.0 & 15 & 3 & 136 & Salt Spring Slate \\
\hline MK34002 & 0.270 & 0.20 & 125 & 7.0 & 12 & 1 & 71 & Copper Hill Volcanics \\
\hline MK34007 & 0.060 & 0.10 & 73 & 11.0 & 5 & $1 \mathrm{~L}$ & 45 & Copper Hill Volcanics \\
\hline MK34012 & 0.090 & 0.10 & 52 & 7.0 & 3 & $1 \mathrm{~L}$ & 25 & Copper Hill Volcanics \\
\hline MK34017 & 0.010 & $0.05 \mathrm{~N}$ & 11 & 1.0 & $2 \mathrm{~L}$ & $1 \mathrm{~L}$ & 22 & Salt Spring Slate \\
\hline MK34032 & 0.130 & 0.30 & 109 & 3.0 & 11 & 1 & 122 & Salt Spring Slate \\
\hline MK34042 & 0.140 & 0.35 & 91 & 3.0 & 10 & 1 & 96 & Salt Spring Slate \\
\hline MK34052 & 0.270 & 0.20 & 133 & 4.0 & 13 & 2 & 126 & Salt Spring Slate \\
\hline MK34062 & 0.130 & 0.25 & 80 & 2.0 & 10 & 1 & 88 & Salt Spring Slate \\
\hline MK34072 & 0.140 & 0.05 & 90 & 1.0 & 12 & 1 & 97 & Salt Spring Slate \\
\hline MK34082 & 0.290 & 0.05 & 157 & 3.0 & 16 & 2 & 125 & Salt Spring Slate \\
\hline MK34092 & 0.170 & 0.20 & 114 & 2.5 & 14 & 2 & 106 & Salt Spring Slate \\
\hline
\end{tabular}


Appendix 1.--continued

\begin{tabular}{|c|c|c|c|c|c|c|c|c|c|c|c|c|}
\hline Sam. ID & Latitude & Longitude & $\begin{array}{l}\text { Ag ppm } \\
\text { picp }\end{array}$ & $\begin{array}{l}\text { Al \% } \\
\text { icp }\end{array}$ & $\begin{array}{c}\text { As } p p m \\
\text { icp }\end{array}$ & $\begin{array}{c}\text { Au ppm } \\
\text { ad }\end{array}$ & $\begin{array}{c}\text { Ba ppm } \\
\text { icp }\end{array}$ & $\begin{array}{l}\text { Be ppm } \\
\text { icp }\end{array}$ & $\begin{array}{c}\text { Bi ppm } \\
\text { picp }\end{array}$ & $\begin{array}{l}\text { Ca \% } \\
\text { icp }\end{array}$ & $\begin{array}{c}\text { Cd ppm } \\
\text { picp }\end{array}$ & $\begin{array}{l}\text { Ce ppm } \\
\text { icp }\end{array}$ \\
\hline MK34102 & $\begin{array}{lll}38 & 00 & 14\end{array}$ & 1204153 & 0.260 & 6.39 & 40 & $0.002 \mathrm{~N}$ & 598 & 1 & $0.60 \mathrm{~N}$ & 1.98 & 0.270 & 18 \\
\hline MK34112 & $\begin{array}{lll}38 & 00 & 14\end{array}$ & 1204153 & 0.120 & 6.48 & 20 & $0.002 \mathrm{~N}$ & 565 & 1 & $0.60 \mathrm{~N}$ & 1.85 & 0.320 & 15 \\
\hline MK34117 & $\begin{array}{lll}38 & 00 & 14\end{array}$ & 1204153 & 0.110 & 6.07 & 20 & $0.002 \mathrm{~N}$ & 438 & $1 \mathrm{~L}$ & $0.60 \mathrm{~N}$ & 3.51 & 0.310 & 13 \\
\hline MK35002 & $\begin{array}{lll}38 & 00 & 14\end{array}$ & 1204153 & 1.400 & 4.55 & 130 & 0.550 & 201 & 1 & $0.60 \mathrm{~N}$ & 3.46 & 0.130 & 19 \\
\hline MK35007 & $\begin{array}{llll}38 & 00 & 14\end{array}$ & 1204153 & 1.700 & 4.71 & 150 & 0.550 & 342 & 2 & $0.60 \mathrm{~N}$ & 0.80 & 0.140 & 20 \\
\hline MK35012 & $\begin{array}{lll}38 & 00 & 14\end{array}$ & 1204153 & 0.460 & 5.69 & 100 & 0.100 & 430 & 2 & $0.60 \mathrm{~N}$ & 0.06 & 0.140 & 21 \\
\hline MK35022 & $\begin{array}{lll}38 & 00 & 14\end{array}$ & 1204153 & 0.120 & 8.49 & 20 & $0.002 \mathrm{~L}$ & 776 & 2 & $0.60 \mathrm{~N}$ & 0.28 & 0.440 & 18 \\
\hline MK35032 & $\begin{array}{lll}38 & 00 & 14\end{array}$ & 1204153 & 0.120 & 7.20 & 20 & $0.002 \mathrm{~N}$ & 579 & 1 & $0.60 \mathrm{~N}$ & 0.28 & 0.430 & 19 \\
\hline MK35042 & $\begin{array}{lll}38 & 00 & 14\end{array}$ & 1204153 & 0.220 & 7.21 & 30 & $0.002 \mathrm{~L}$ & 594 & 1 & $0.7 B$ & 0.40 & 0.300 & 24 \\
\hline MK35052 & $\begin{array}{lll}38 & 00 & 14\end{array}$ & 1204153 & 0.120 & 7.13 & 20 & $0.002 \mathrm{~L}$ & 545 & 1 & $0.60 \mathrm{~N}$ & 1.04 & 0.190 & 22 \\
\hline MK35057 & $\begin{array}{lll}38 & 00 & 14\end{array}$ & 1204153 & 0.100 & 7.48 & 20 & $0.002 \mathrm{~N}$ & 591 & 1 & $0.60 \mathrm{~N}$ & 0.96 & 0.190 & 22 \\
\hline MK62002 & $\begin{array}{lll}38 & 00 & 14\end{array}$ & 1204153 & 0.360 & 8.01 & 40 & 0.100 & 383 & 1 & $0.60 \mathrm{~N}$ & 1.90 & 0.130 & 33 \\
\hline MK62007 & $\begin{array}{lll}38 & 00 & 14\end{array}$ & 1204153 & 0.047 & 8.99 & $10 \mathrm{~L}$ & 0.008 & 149 & 2 & $0.60 \mathrm{~N}$ & 5.02 & 0.130 & 45 \\
\hline MK62012 & $\begin{array}{lll}38 & 00 & 14\end{array}$ & 1204153 & 0.055 & 7.87 & $10 \mathrm{~L}$ & 0.004 & 149 & 1 & $0.60 \mathrm{~N}$ & 9.35 & 0.130 & 39 \\
\hline MK62022 & $\begin{array}{lll}38 & 00 & 14\end{array}$ & 1204153 & 0.260 & 8.06 & 30 & 0.006 & 260 & 2 & $0.60 \mathrm{~N}$ & 5.98 & 0.190 & 29 \\
\hline MK62032 & $\begin{array}{lll}38 & 00 & 14\end{array}$ & 1204153 & 1.200 & 7.70 & 220 & 1.950 & 285 & 2 & $0.60 \mathrm{~N}$ & 4.13 & 0.130 & 32 \\
\hline MK62042 & $\begin{array}{lll}38 & 00 & 14\end{array}$ & 1204153 & 0.710 & 8.31 & 40 & 0.650 & 288 & 2 & $0.60 \mathrm{~N}$ & 8.13 & 0.150 & 30 \\
\hline MK62052 & $\begin{array}{lll}38 & 00 & 14\end{array}$ & 1204153 & $0.045 \mathrm{~N}$ & 8.39 & $10 \mathrm{~L}$ & $0.002 \mathrm{~L}$ & 160 & 1 & $0.60 \mathrm{~N}$ & 5.76 & 0.079 & 53 \\
\hline MK62062 & $\begin{array}{lll}38 & 00 & 14\end{array}$ & 1204153 & 0.060 & 8.56 & $10 \mathrm{~L}$ & 0.004 & 167 & 1 & $0.60 \mathrm{~N}$ & 7.06 & 0.085 & 50 \\
\hline MK62072 & $\begin{array}{lll}38 & 00 & 14\end{array}$ & 1204153 & 0.049 & 7.18 & $10 \mathrm{~L}$ & $0.002 \mathrm{~N}$ & 183 & 1 & $0.60 \mathrm{~N}$ & 12.40 & 0.140 & 40 \\
\hline MK62082 & $\begin{array}{lll}38 & 00 & 14\end{array}$ & 1204153 & $0.045 \mathrm{~N}$ & 7.88 & $10 \mathrm{~L}$ & $0.002 \mathrm{~L}$ & 124 & 1 & $0.60 \mathrm{~N}$ & 11.80 & 0.130 & 41 \\
\hline MK62092 & $\begin{array}{lll}38 & 00 & 14\end{array}$ & 1204153 & $0.045 \mathrm{~N}$ & 8.26 & $10 \mathrm{~L}$ & $0.002 \mathrm{~L}$ & 175 & 1 & $0.60 \mathrm{~N}$ & 9.69 & 0.069 & 43 \\
\hline MK62102 & $\begin{array}{lll}38 & 00 & 14\end{array}$ & 1204153 & $0.045 \mathrm{~N}$ & 8.22 & $10 \mathrm{~L}$ & 0.200 & 141 & 1 & $0.60 \mathrm{~N}$ & 9.98 & 0.120 & 41 \\
\hline MK62112 & $\begin{array}{lll}38 & 00 & 14\end{array}$ & 1204153 & $0.045 \mathrm{~N}$ & 8.19 & $10 \mathrm{~L}$ & 0.090 & 210 & 1 & $0.60 \mathrm{~N}$ & 10.00 & 0.075 & 43 \\
\hline MK62122 & $\begin{array}{lll}38 & 00 & 14\end{array}$ & 1204153 & 0.130 & 8.88 & 10 & $0.002 \mathrm{~L}$ & 302 & 1 & $0.60 \mathrm{~N}$ & 6.51 & 0.062 & 37 \\
\hline MK62132 & $\begin{array}{lll}38 & 00 & 14\end{array}$ & 1204153 & $0.045 \mathrm{~N}$ & 8.69 & $10 \mathrm{~L}$ & 0.005 & 167 & 1 & $0.60 \mathrm{~N}$ & 7.73 & 0.072 & 44 \\
\hline MK62142 & $\begin{array}{lll}38 & 00 & 14\end{array}$ & 1204153 & $0.045 \mathrm{~N}$ & 8.44 & $10 \mathrm{~L}$ & 0.004 & 183 & 1 & $0.60 \mathrm{~N}$ & 7.33 & 0.094 & 47 \\
\hline MK62152 & $\begin{array}{lll}38 & 00 & 14\end{array}$ & 1204153 & $0.045 \mathrm{~N}$ & 8.98 & $10 \mathrm{~L}$ & $0.002 \mathrm{~L}$ & 187 & 1 & $0.60 \mathrm{~N}$ & 5.37 & $0.030 \mathrm{~N}$ & 48 \\
\hline MK62162 & $\begin{array}{lll}38 & 00 & 14\end{array}$ & 1204153 & $0.045 \mathrm{~N}$ & 9.05 & $10 \mathrm{~L}$ & 0.002 & 173 & 1 & $0.60 \mathrm{~N}$ & 7.31 & 0.047 & 49 \\
\hline MK62172 & $\begin{array}{lll}38 & 00 & 14\end{array}$ & 1204153 & 1.500 & 7.62 & 170 & 2.000 & 299 & 2 & $0.60 \mathrm{~N}$ & 5.92 & 0.130 & 29 \\
\hline
\end{tabular}


Appendix 1.--continued

\begin{tabular}{|c|c|c|c|c|c|c|c|c|c|c|c|c|c|c|}
\hline Sam. ID & $\begin{array}{c}\text { Co ppm } \\
\text { icp }\end{array}$ & $\begin{array}{l}\mathrm{Cr} p \mathrm{ppm} \\
\text { icp }\end{array}$ & $\begin{array}{l}\text { Cu ppm } \\
\text { icp }\end{array}$ & $\begin{array}{l}\text { Eu ppm } \\
\text { icp }\end{array}$ & $\begin{array}{r}\mathrm{Fe} \% \\
\text { icp }\end{array}$ & $\begin{array}{c}\text { Ga ppm } \\
\text { icp }\end{array}$ & $\begin{array}{c}\mathrm{Hg} \mathrm{ppm} \\
\text { ad }\end{array}$ & $\begin{array}{l}K \% \\
\text { icp }\end{array}$ & $\begin{array}{c}\text { La ppm } \\
\text { icp }\end{array}$ & $\begin{array}{l}\text { Li ppm } \\
\text { icp }\end{array}$ & $\begin{array}{l}\text { LOI \% } \\
\text { grav }\end{array}$ & $\begin{array}{l}M g \% \\
\text { icp }\end{array}$ & $\begin{array}{l}\text { Mn ppm } \\
\text { icp }\end{array}$ & $\begin{array}{l}\text { Mo ppm } \\
\text { picp }\end{array}$ \\
\hline MK34102 & 23 & 85 & 64 & $2 \mathrm{~L}$ & 4.94 & 14 & 0.20 & 1.43 & 8 & 41 & 5.85 & 1.58 & 956 & 1.10 \\
\hline MK34112 & 17 & 102 & 37 & $2 \mathrm{~L}$ & 4.71 & 13 & 0.10 & 1.33 & 7 & 43 & 5.61 & 1.63 & 592 & 0.93 \\
\hline MK34117 & 14 & 88 & 35 & $2 \mathrm{~L}$ & 4.13 & 14 & 0.08 & 1.12 & 8 & 43 & 7.00 & 1.46 & 863 & 0.74 \\
\hline MK35002 & 12 & 61 & 41 & $2 \mathrm{~L}$ & 3.81 & 12 & 0.22 & 1.67 & 10 & 4 & 7.37 & 1.13 & 621 & 0.79 \\
\hline MK35007 & 8 & 92 & 57 & $2 \mathrm{~L}$ & 4.48 & 11 & 0.54 & 1.42 & 9 & 14 & 4.70 & 0.46 & 278 & 1.40 \\
\hline MK35012 & 41 & 94 & 76 & $2 \mathrm{~L}$ & 5.73 & 12 & 0.28 & 1.37 & 9 & 26 & 3.99 & 0.48 & 433 & 1.30 \\
\hline MK35022 & 20 & 124 & 63 & $2 \mathrm{~L}$ & 5.35 & 18 & 0.10 & 1.91 & 7 & 57 & 4.39 & 1.51 & 473 & 1.50 \\
\hline MK35032 & 17 & 107 & 62 & $2 \mathrm{~L}$ & 5.71 & 15 & 0.10 & 1.42 & 8 & 56 & 3.75 & 1.47 & 591 & 2.20 \\
\hline MK35042 & 14 & 108 & 70 & $2 \mathrm{~L}$ & 5.36 & 15 & 0.18 & 1.47 & 10 & 55 & 3.64 & 1.48 & 299 & 1.90 \\
\hline MK35052 & 11 & 137 & 52 & $2 \mathrm{~L}$ & 4.91 & 14 & 0.10 & 1.34 & 11 & 58 & 4.05 & 1.60 & 366 & 0.84 \\
\hline MK35057 & 12 & 125 & 57 & $2 \mathrm{~L}$ & 4.90 & 16 & 0.12 & 1.49 & 11 & 57 & 4.24 & 1.59 & 373 & 0.88 \\
\hline MK62002 & 19 & 89 & 69 & $2 \mathrm{~L}$ & 5.50 & 17 & 0.16 & 1.20 & 16 & 35 & 6.58 & 1.20 & 521 & 0.87 \\
\hline MK62007 & 23 & 104 & 58 & 2 & 6.22 & 20 & 0.06 & 0.46 & 26 & 36 & 6.75 & 1.40 & 1010 & 0.27 \\
\hline MK62012 & 21 & 92 & 50 & $2 \mathrm{~L}$ & 5.28 & 17 & 0.04 & 0.96 & 23 & 35 & 11.20 & 1.55 & 1140 & 0.36 \\
\hline MK62022 & 27 & 122 & 58 & $2 \mathrm{~L}$ & 6.86 & 18 & 0.08 & 2.95 & 16 & 14 & 10.40 & 0.60 & 1650 & 1.10 \\
\hline MK62032 & 24 & 79 & 60 & $2 \mathrm{~L}$ & 7.02 & 21 & 0.48 & 3.02 & 17 & 7 & 9.38 & 1.05 & 1140 & 0.99 \\
\hline MK62042 & 24 & 68 & 26 & $2 \mathrm{~L}$ & 6.26 & 21 & 0.16 & 3.21 & 17 & 6 & 15.80 & 1.72 & 1130 & 0.75 \\
\hline MK62052 & 25 & 41 & 55 & 2 & 6.44 & 19 & 0.04 & 1.24 & 30 & 41 & 6.34 & 1.59 & 700 & 0.23 \\
\hline MK62062 & 26 & 59 & 63 & 2 & 6.63 & 20 & 0.02 & 1.16 & 28 & 36 & 7.04 & 1.73 & 796 & 0.21 \\
\hline MK62072 & 22 & 58 & 61 & $2 L$ & 5.96 & 18 & 0.04 & 1.25 & 23 & 25 & 12.00 & 1.61 & 1040 & 0.24 \\
\hline MK62082 & 23 & 74 & 53 & $2 \mathrm{~L}$ & 5.64 & 19 & 0.02 & 0.78 & 24 & 25 & 10.60 & 1.72 & 1210 & 0.22 \\
\hline MK62092 & 22 & 72 & 53 & 2 & 5.92 & 19 & 0.02 & 1.27 & 23 & 26 & 8.06 & 1.80 & 1050 & 0.18 \\
\hline MK62102 & 26 & 78 & 58 & 2 & 6.08 & 20 & 0.02 & 0.87 & 23 & 27 & 8.23 & 1.90 & 1000 & 0.28 \\
\hline MK62112 & 22 & 85 & 66 & 2 & 6.15 & 20 & 0.02 & 1.58 & 26 & 28 & 8.95 & 1.81 & 925 & 0.38 \\
\hline MK62122 & 27 & 116 & 64 & $2 \mathrm{~L}$ & 6.65 & 19 & 0.02 & 2.63 & 21 & 32 & 7.46 & 2.17 & 761 & 0.23 \\
\hline MK62132 & 25 & 111 & 59 & 2 & 6.17 & 19 & 0.02 & 1.16 & 25 & 30 & 6.55 & 2.02 & 802 & 0.37 \\
\hline MK62142 & 24 & 110 & 59 & 2 & 6.93 & 19 & 0.04 & 1.30 & 25 & 34 & 5.95 & 2.09 & 609 & 0.31 \\
\hline MK62152 & 23 & 59 & 42 & 2 & 7.76 & 21 & 0.04 & 1.48 & 24 & 43 & 4.24 & 2.12 & 546 & 0.20 \\
\hline MK62162 & 26 & 53 & 53 & 2 & 6.88 & 21 & 0.02 & 1.25 & 28 & 33 & 5.45 & 1.83 & 701 & 0.18 \\
\hline MK62172 & 28 & 21 & 53 & $2 \mathrm{~L}$ & 5.94 & 18 & 0.44 & 3.29 & 16 & 4 & 12.80 & 1.98 & 884 & 0.24 \\
\hline
\end{tabular}


Appendix 1.--continued

\begin{tabular}{|c|c|c|c|c|c|c|c|c|c|c|c|c|c|}
\hline Sam. ID & $\begin{array}{l}\mathrm{Na} \% \\
\mathrm{icp}\end{array}$ & $\begin{array}{l}\text { Nb ppm } \\
\text { icp }\end{array}$ & $\begin{array}{l}\text { Nd ppm } \\
\text { icp }\end{array}$ & $\begin{array}{l}\text { Ni ppm } \\
\text { icp }\end{array}$ & $\begin{array}{l}P \% \\
\text { icp }\end{array}$ & $\begin{array}{c}\mathrm{Pb} \mathrm{ppm} \\
\mathrm{icp}\end{array}$ & $\begin{array}{l}\text { S \% } \\
\text { comb }\end{array}$ & $\begin{array}{c}\text { Sb ppm } \\
\text { picp }\end{array}$ & $\begin{array}{c}\text { Sc ppm } \\
\text { icp }\end{array}$ & $\begin{array}{l}\text { Si02 } \% \\
\text { xrf }\end{array}$ & $\begin{array}{l}\text { Sr ppm } \\
\text { icp }\end{array}$ & $\begin{array}{c}\text { Te ppm } \\
\text { aa }\end{array}$ & $\begin{array}{c}\text { Th ppm } \\
\text { icp }\end{array}$ \\
\hline MK34102 & 1.14 & 4 & 11 & 64 & 0.080 & 30 & 0.70 & 2.40 & 14 & 63.80 & 184 & 0.095 & $4 \mathrm{~L}$ \\
\hline MK34112 & 1.45 & $4 L$ & 10 & 58 & 0.100 & 13 & 0.38 & 1.00 & 14 & 64.50 & 228 & 0.075 & $4 \mathrm{~L}$ \\
\hline MK34117 & 1.52 & $4 \mathrm{~L}$ & 10 & 43 & 0.090 & 12 & 0.20 & 1.10 & 13 & 63.40 & 363 & 0.065 & $4 \mathrm{~L}$ \\
\hline MK35002 & 0.69 & 6 & 11 & 21 & 0.100 & 19 & 0.57 & 3.70 & 12 & 66.20 & 183 & 0.045 & $4 \mathrm{~L}$ \\
\hline MK35007 & 0.46 & 4 & 9 & 34 & 0.070 & 98 & 0.12 & 4.00 & 12 & 74.10 & 93 & 0.050 & 5 \\
\hline MK35012 & 1.01 & $4 \mathrm{~L}$ & 13 & 135 & 0.070 & 20 & $0.05 \mathrm{~L}$ & 2.00 & 13 & 71.30 & 54 & 0.040 & $4 \mathrm{~L}$ \\
\hline MK35022 & 1.35 & 5 & 14 & 76 & 0.130 & 20 & $0.05 \mathrm{~L}$ & 1.50 & 19 & 62.30 & 96 & 0.100 & 7 \\
\hline MK35032 & 1.35 & $4 \mathrm{~L}$ & 13 & 69 & 0.110 & 20 & $0.05 \mathrm{~L}$ & 1.70 & 15 & 66.40 & 84 & 0.020 & 5 \\
\hline MK35042 & 1.38 & 5 & 13 & 63 & 0.110 & 22 & $0.05 \mathrm{~L}$ & 2.20 & 14 & 66.70 & 85 & 0.040 & 5 \\
\hline MK35052 & 1.43 & 4 & 15 & 62 & 0.120 & 13 & $0.05 \mathrm{~L}$ & 1.10 & 14 & 65.90 & 101 & 0.070 & 6 \\
\hline MK35057 & 1.47 & 6 & 15 & 59 & 0.100 & 12 & $0.05 \mathrm{~L}$ & 0.99 & 15 & 64.90 & 104 & 0.065 & 6 \\
\hline MK62002 & 1.55 & 7 & 20 & 40 & 0.100 & 28 & 0.06 & 2.00 & 19 & 60.30 & 182 & 0.030 & $4 \mathrm{~L}$ \\
\hline MK62007 & 2.41 & $4 \mathrm{~L}$ & 31 & 28 & 0.160 & 8 & $0.05 \mathrm{~L}$ & $0.60 \mathrm{~N}$ & 26 & 51.60 & 330 & $0.005 \mathrm{~L}$ & $4 \mathrm{~L}$ \\
\hline MK62012 & 2.39 & 15 & 29 & 22 & 0.180 & $4 \mathrm{~L}$ & $0.05 \mathrm{~L}$ & $0.60 \mathrm{~N}$ & 22 & 43.90 & 339 & 0.030 & $4 \mathrm{~L}$ \\
\hline MK62022 & 0.64 & $4 \mathrm{~L}$ & 20 & 28 & 0.190 & $4 \mathrm{~L}$ & 0.05 & $0.60 \mathrm{~N}$ & 23 & 48.10 & 82 & 0.010 & $4 \mathrm{~L}$ \\
\hline MK62032 & 0.41 & $4 \mathrm{~L}$ & 20 & 29 & 0.140 & $4 \mathrm{~L}$ & 0.41 & $0.60 \mathrm{~N}$ & 21 & 50.70 & 166 & 0.015 & $4 \mathrm{~L}$ \\
\hline MK62042 & 0.89 & $4 \mathrm{~L}$ & 21 & 24 & 0.190 & $4 \mathrm{~L}$ & 0.29 & $0.60 \mathrm{~N}$ & 21 & 37.20 & 290 & $0.005 \mathrm{~L}$ & $4 \mathrm{~L}$ \\
\hline MK62052 & 2.35 & $4 \mathrm{~L}$ & 34 & 27 & 0.140 & $4 \mathrm{~L}$ & $0.05 \mathrm{~L}$ & $0.60 \mathrm{~N}$ & 23 & 50.70 & 414 & $0.005 \mathrm{~L}$ & $4 \mathrm{~L}$ \\
\hline MK62062 & 2.24 & 4 & 33 & 30 & 0.170 & $4 \mathrm{~L}$ & $0.05 \mathrm{~L}$ & $0.60 \mathrm{~N}$ & 24 & 47.70 & 367 & $0.005 \mathrm{~N}$ & $4 \mathrm{~L}$ \\
\hline MK62072 & 1.38 & 4 & 29 & 27 & 0.150 & $4 \mathrm{~L}$ & $0.05 \mathrm{~L}$ & $0.60 \mathrm{~N}$ & 22 & 40.40 & 386 & $0.005 \mathrm{~L}$ & $4 \mathrm{~L}$ \\
\hline MK62082 & 2.02 & $4 L$ & 31 & 24 & 0.160 & $4 \mathrm{~L}$ & $0.05 \mathrm{~L}$ & $0.60 \mathrm{~N}$ & 23 & 40.90 & 324 & 0.100 & $4 \mathrm{~L}$ \\
\hline MK62092 & 2.01 & $4 \mathrm{~L}$ & 30 & 22 & 0.150 & $4 \mathrm{~L}$ & $0.05 \mathrm{~L}$ & $0.60 \mathrm{~N}$ & 24 & 44.20 & 455 & $0.005 \mathrm{~N}$ & $4 \mathrm{~L}$ \\
\hline MK62102 & 2.18 & $4 \mathrm{~L}$ & 28 & 34 & 0.140 & $4 \mathrm{~L}$ & $0.05 \mathrm{~L}$ & $0.60 \mathrm{~N}$ & 25 & 44.10 & 479 & $0.005 \mathrm{~L}$ & $4 \mathrm{~L}$ \\
\hline MK62112 & 1.73 & 6 & 28 & 24 & 0.130 & $4 \mathrm{~L}$ & $0.05 \mathrm{~L}$ & $0.60 \mathrm{~N}$ & 25 & 43.10 & 601 & $0.005 \mathrm{~L}$ & $4 \mathrm{~L}$ \\
\hline MK62122 & 1.20 & 12 & 26 & 30 & 0.120 & $4 \mathrm{~L}$ & 0.06 & $0.60 \mathrm{~N}$ & 29 & 46.40 & 391 & $0.005 \mathrm{~N}$ & $4 \mathrm{~L}$ \\
\hline MK62132 & 2.38 & $4 \mathrm{~L}$ & 29 & 29 & 0.120 & $4 \mathrm{~L}$ & $0.05 \mathrm{~L}$ & $0.60 \mathrm{~N}$ & 28 & 47.00 & 498 & $0.005 \mathrm{~N}$ & $4 \mathrm{~L}$ \\
\hline MK62142 & 1.46 & 5 & 29 & 39 & 0.120 & $4 \mathrm{~L}$ & $0.05 \mathrm{~L}$ & $0.60 \mathrm{~N}$ & 26 & 48.60 & 558 & $0.005 \mathrm{~N}$ & $4 \mathrm{~L}$ \\
\hline MK62152 & 1.61 & 18 & 28 & 28 & 0.090 & $4 \mathrm{~L}$ & $0.05 \mathrm{~L}$ & $0.60 \mathrm{~N}$ & 27 & 50.50 & 697 & $0.005 \mathrm{~L}$ & $4 \mathrm{~L}$ \\
\hline MK62162 & 2.06 & 12 & 33 & 28 & 0.150 & $4 \mathrm{~L}$ & $0.05 \mathrm{~L}$ & $0.60 \mathrm{~N}$ & 26 & 47.70 & 755 & $0.005 \mathrm{~L}$ & $4 \mathrm{~L}$ \\
\hline MK62172 & 0.59 & $4 \mathrm{~L}$ & 19 & 19 & 0.130 & $4 \mathrm{~L}$ & 0.78 & $0.60 \mathrm{~N}$ & 19 & 44.10 & 254 & 0.010 & $4 \mathrm{~L}$ \\
\hline
\end{tabular}




\begin{tabular}{|c|c|c|c|c|c|c|c|c|}
\hline Sam. ID & $\begin{array}{r}\mathrm{Ti} \% \\
\text { icp }\end{array}$ & $\begin{array}{c}\text { Tl ppm } \\
\text { aa }\end{array}$ & $\begin{array}{l}V \text { ppm } \\
\text { icp }\end{array}$ & $\begin{array}{l}\text { W ppm } \\
\text { aa }\end{array}$ & $\begin{array}{l}\text { Y ppm } \\
\text { icp }\end{array}$ & $\begin{array}{l}\text { Yb ppm } \\
\text { icp }\end{array}$ & $\begin{array}{l}\text { Zn ppm } \\
\text { icp }\end{array}$ & Geologic unit \\
\hline MK34102 & 0.150 & 0.15 & 136 & 1.0 & 12 & 1 & 122 & Salt Spring Slate \\
\hline MK34112 & 0.150 & 0.15 & 119 & 2.0 & 11 & 1 & 112 & Salt Spring Slate \\
\hline MK34117 & 0.160 & 0.10 & 106 & 1.5 & 12 & 2 & 98 & Salt Spring Slate \\
\hline MK35002 & 0.290 & 0.20 & 140 & 15.0 & 9 & $1 \mathrm{~L}$ & 53 & Salt Spring Slate \\
\hline MK35007 & 0.170 & 0.20 & 110 & 6.0 & 9 & 1 & 119 & Salt Spring Slate \\
\hline MK35012 & 0.170 & 0.20 & 113 & 2.0 & 24 & 2 & 250 & Salt Spring Slate \\
\hline MK35022 & 0.170 & 0.25 & 179 & 1.0 & 13 & 2 & 145 & Salt Spring Slate \\
\hline MK35032 & 0.180 & 0.20 & 144 & 1.5 & 12 & 2 & 146 & Salt Spring Slate \\
\hline MK35042 & 0.190 & 0.10 & 148 & 1.0 & 14 & 2 & 137 & Salt Spring Slate \\
\hline MK35052 & 0.220 & 0.10 & 138 & 1.5 & 14 & 2 & 127 & Salt Spring Slate \\
\hline MK35057 & 0.280 & 0.10 & 150 & 1.5 & 14 & 2 & 132 & Salt Spring Slate \\
\hline MK62002 & 0.460 & 0.15 & 194 & 3.0 & 18 & 2 & 90 & Copper Hill Volcanics \\
\hline MK62007 & 0.970 & $0.05 \mathrm{~N}$ & 295 & 1.0 & 26 & 3 & 68 & Copper Hill Volcanics \\
\hline MK62012 & 0.870 & 0.05 & 263 & $0.5 \mathrm{~N}$ & 20 & 2 & 62 & Copper Hill Volcanics \\
\hline MK62022 & 0.300 & 0.35 & 253 & 6.0 & 15 & 1 & 76 & Copper Hill Volcanics \\
\hline MK62032 & 0.310 & 0.35 & 224 & 18.0 & 13 & 1 & 85 & Copper Hill Volcanics \\
\hline MK62042 & 0.250 & 0.35 & 260 & 14.0 & 16 & 2 & 74 & Copper Hill Volcanics \\
\hline MK62052 & 0.730 & 0.05 & 294 & 1.0 & 22 & 2 & 71 & Copper Hill Volcanics \\
\hline MK62062 & 0.930 & $0.05 \mathrm{~N}$ & 315 & 1.0 & 23 & 2 & 70 & Copper Hill Volcanics \\
\hline MK62072 & 0.790 & $0.05 \mathrm{~N}$ & 336 & 1.0 & 20 & 2 & 54 & Copper Hill Volcanics \\
\hline MK62082 & 0.810 & $0.05 \mathrm{~N}$ & 288 & $0.5 \mathrm{~L}$ & 19 & 2 & 57 & Copper Hill Volcanics \\
\hline MK62092 & 0.880 & $0.05 \mathrm{~N}$ & 243 & $0.5 \mathrm{~L}$ & 19 & 2 & 57 & Copper Hill Volcanics \\
\hline MK62102 & 0.880 & $0.05 \mathrm{~N}$ & 302 & $0.5 \mathrm{~L}$ & 19 & 2 & 58 & Copper Hill Volcanics \\
\hline MK62112 & 0.900 & $0.05 \mathrm{~N}$ & 232 & 0.5 & 22 & 2 & 57 & Copper Hill Volcanics \\
\hline MK62122 & 0.880 & 0.10 & 242 & 5.0 & 19 & 2 & 63 & Copper Hill Volcanics \\
\hline MK62132 & 0.860 & $0.05 \mathrm{~N}$ & 246 & 0.5 & 21 & 2 & 59 & Copper Hill Volcanics \\
\hline MK62142 & 0.890 & $0.05 \mathrm{~N}$ & 183 & $0.5 \mathrm{~L}$ & 20 & 2 & 58 & Copper Hill Volcanics \\
\hline MK62152 & 0.970 & 0.05 & 199 & 1.0 & 19 & 2 & 68 & Copper Hill Volcanics \\
\hline MK62162 & 0.960 & $0.05 \mathrm{~N}$ & 245 & 1.0 & 24 & 2 & 67 & Copper Hill Volcanics \\
\hline MK62172 & 0.200 & 0.35 & 212 & 7.5 & 11 & $1 \mathrm{~L}$ & 70 & Copper Hill Volcanics \\
\hline
\end{tabular}


Appendix 2.--MINERALOGICAL DATA FOR SAMPLES OF DRILL CORE OR CUTTINGS, HODSON DISTRICT, CALIFORNIA ["0"=looked for but no meaningful value determined. "---" indicates no analysis.

Numbers $>100$ are estimated by extrapolation]

Sam. ID White Kaolinite Chlorite Quartz Orthoclase, Plagioclase Calcite Ankerite Magnesite Pyrite mica

\begin{tabular}{|c|c|c|c|c|c|c|c|c|c|c|}
\hline HDO10D7 & 4 & 3 & 0 & 13 & 12 & 73 & 0 & 0 & 0 & 0 \\
\hline HDO1012 & 22 & 0 & 0 & 20 & 13 & 30 & 0 & 0 & 0 & 0 \\
\hline HD01017 & 25 & 0 & 0 & 23 & 13 & 33 & 0 & 0 & 0 & 0 \\
\hline HD01022 & -- & -- & --- & --- & -- & -- & --- & -- & -- & -- \\
\hline HD01032 & 26 & 0 & 0 & 30 & 12 & 45 & 0 & 0 & 0 & 0 \\
\hline HDO1037 & --- & --- & --- & --- & --- & -- & -- & -- & -- & -- \\
\hline HDO 042 & 19 & 0 & 0 & 72 & 7 & 27 & 0 & 0 & 0 & 0 \\
\hline HDO1047 & --- & --- & -- & -- & --- & --- & -- & -- & $\cdots$ & --- \\
\hline HD01052 & 23 & 0 & 0 & 26 & 7 & 37 & 0 & 0 & 0 & 0 \\
\hline HD01057 & 16 & 0 & 0 & 100 & 7 & 22 & 0 & 0 & 0 & 1 \\
\hline HD01062 & 10 & 0 & 0 & 100 & 6 & 10 & 0 & 25 & 0 & 1 \\
\hline HD01067 & -- & -- & -- & -- & -- & --- & $-\cdots$ & --- & --- & --- \\
\hline HDO 072 & 10 & 0 & 0 & 110 & 0 & 21 & 0 & 0 & 0 & 0 \\
\hline HD01077 & --- & --- & --- & -- & --- & --- & --- & --- & --- & --- \\
\hline HD01082 & 21 & 0 & 0 & 74 & 6 & 27 & 0 & 50 & 26 & 2 \\
\hline HD01087 & --- & --- & --- & -- & --- & --- & --- & --- & -- & --- \\
\hline HD01092 & 14 & 0 & 0 & 71 & 6 & 48 & 4 & 73 & 31 & 0 \\
\hline HD01097 & --- & --- & --- & --- & --- & --- & --- & -- & --- & --- \\
\hline HD01102 & 19 & 0 & 7 & 29 & 0 & 30 & 0 & 100 & 67 & 0 \\
\hline HD01107 & --- & --- & --- & --- & --- & --- & --- & --- & --- & --- \\
\hline HDO 1112 & 25 & 0 & 0 & 47 & 9 & 53 & 0 & 48 & 38 & 6 \\
\hline HD01117 & --- & --- & --- & --- & --- & --- & --- & --- & --- & --- \\
\hline HD01122 & 30 & 0 & 0 & 55 & 10 & 63 & 0 & 50 & 52 & 3 \\
\hline HD01127 & --- & -- & --- & $\cdots$ & --- & --- & --- & -- & -- & --- \\
\hline HD01132 & 10 & 4 & 0 & 86 & 0 & 17 & 7 & 54 & 0 & 6 \\
\hline HD01137 & --- & $-\cdots$ & --- & -- & --- & --- & --- & -- & -- & --- \\
\hline HDO2002 & 2 & 0 & 5 & 33 & 0 & 85 & 4 & 40 & 0 & 0 \\
\hline HD02007 & 8 & 5 & 3 & 11 & 0 & 54 & 22 & 15 & 0 & 0 \\
\hline HD02012 & --- & --- & --- & --- & -- & --- & --- & --- & --- & --- \\
\hline HD02017 & 9 & 5 & 4 & 7 & 0 & 54 & 3 & 22 & 0 & 4 \\
\hline HD02022 & --- & -- & --- & --- & --- & --- & --- & -- & -- & --- \\
\hline HD02032 & 7 & 5 & 5 & 6 & 10 & 57 & 73 & 23 & 0 & 3 \\
\hline HD02042 & --- & $\cdots$ & --- & $-\cdots$ & -- & --- & -- & $-\cdots$ & --- & -- \\
\hline HD02052 & 8 & 10 & 8 & 9 & 11 & 69 & 60 & 17 & 0 & 3 \\
\hline HD02062 & -- & -- & --- & -- & $\cdots$ & --- & $-\cdots$ & -- & -- & -- \\
\hline HDO2072 & 5 & 5 & 7 & 6 & 10 & 70 & 100 & 20 & 0 & 0 \\
\hline HD02082 & --- & --- & --- & -- & --- & --- & -- & -- & $-\cdots$ & -- \\
\hline HD02092 & 9 & 15 & 11 & 14 & 9 & 37 & 67 & 17 & 0 & 0 \\
\hline HD02102 & --- & -- & --- & --- & -- & --- & -- & -- & -- & -- \\
\hline HD02112 & 5 & 5 & 10 & 9 & 10 & 63 & 54 & 18 & 0 & 3 \\
\hline HDO2122 & --- & -- & --- & -- & --- & --- & --- & -- & -- & -- \\
\hline HD02132 & 6 & 5 & 12 & 10 & 10 & 67 & 41 & 22 & 0 & 4 \\
\hline HD02142 & 23 & 10 & 13 & 14 & 0 & 36 & 52 & 10 & 0 & 0 \\
\hline HD02152 & 7 & 0 & 0 & 100 & 6 & 27 & 0 & 68 & 0 & 6 \\
\hline HDO2157 & 23 & 0 & 0 & 73 & 8 & 44 & 0 & 72 & 0 & 6 \\
\hline
\end{tabular}


Sam. ID Mica Kaolinite Chlorite Quartz Orthoclase Plagioclase Calcite Ankerite Magnesite Pyrite

\begin{tabular}{|c|c|c|c|c|c|c|c|c|c|c|}
\hline HD02162 & 22 & 0 & 0 & 60 & 6 & 42 & 0 & 72 & 0 & 10 \\
\hline HDO2172 & 19 & 0 & 1 & 56 & 8 & 53 & 0 & 54 & 0 & 4 \\
\hline HDO2182 & 16 & 0 & 12 & 56 & 7 & 45 & 4 & 47 & 0 & 3 \\
\hline HDO2192 & --- & --- & -- & --- & -- & --- & -- & $\cdots$ & $\cdots$ & --- \\
\hline HD02202 & 18 & 0 & 15 & 44 & 9 & 41 & 5 & 30 & 0 & 1 \\
\hline HD03002 & 7 & 0 & 4 & 33 & 0 & 29 & 0 & 0 & 0 & 0 \\
\hline HD03007 & 14 & 5 & 12 & 11 & 0 & 19 & 0 & 0 & 0 & 0 \\
\hline HD03012 & --- & --- & --- & --- & --- & --- & --- & --- & --- & --- \\
\hline HD03022 & --- & -- & --- & --- & --- & --- & $-\cdots$ & -- & --- & --- \\
\hline HD03032 & 8 & 10 & 18 & 6 & 0 & 36 & 79 & 0 & 0 & 4 \\
\hline HDO3042 & 7 & 10 & 15 & 9 & 0 & 24 & 71 & 0 & 0 & 3 \\
\hline HD03052 & --- & --- & --- & --- & --- & --- & --- & -- & --- & --- \\
\hline HD03062 & --- & --- & --- & --- & --- & --- & --- & -.- & --- & --- \\
\hline HD03072 & 20 & 20 & 22 & 6 & 5 & 38 & 45 & 0 & 0 & 5 \\
\hline HD03082 & --- & --- & --- & --- & --- & --- & --- & --- & --- & --- \\
\hline HD03092 & --- & --- & --- & --- & --- & --- & --- & --- & --- & --- \\
\hline HDO3102 & 15 & 10 & 19 & 9 & 6 & 23 & 17 & 0 & 0 & 6 \\
\hline HDO4002 & 23 & 0 & 0 & 68 & 9 & 17 & 0 & 0 & 0 & 0 \\
\hline HDO4007 & 18 & 0 & 0 & 98 & 7 & 17 & 0 & 0 & 0 & 0 \\
\hline HD04012 & 16 & 0 & 0 & 100 & 6 & 12 & 5 & 16 & 0 & 0 \\
\hline HDO4022 & 20 & 0 & 0 & 95 & 5 & 70 & 0 & 89 & 0 & 0 \\
\hline HDO4032 & 26 & 0 & 0 & 50 & 5 & 100 & 0 & 100 & 0 & 0 \\
\hline HDO & --- & --- & --- & --- & --- & --- & --- & --- & --- & --- \\
\hline HDO4052 & 20 & 0 & 1 & 76 & 4 & 32 & 0 & 110 & 22 & 3 \\
\hline HD04062 & --- & --- & -- & --- & --- & --- & --- & -- & --- & --- \\
\hline HD04072 & 14 & 0 & 2 & 72 & 7 & 72 & 0 & 86 & 14 & 2 \\
\hline HD04082 & --- & --- & --- & --- & --- & -.. & --- & --- & --- & -.- \\
\hline HDO4092 & 12 & 5 & 10 & 71 & 5 & 43 & 0 & 59 & 0 & 2 \\
\hline HDO4102 & --- & -- & --- & --- & --- & --- & --- & --- & --- & --- \\
\hline HDO4112 & --- & --- & --- & --- & --- & --- & -.- & -. & -.- & -.- \\
\hline HDO4117 & 16 & 10 & 16 & 69 & 8 & 53 & 5 & 33 & 0 & 6 \\
\hline HDO5002 & 21 & 0 & 0 & 31 & 6 & 32 & 0 & 14 & 0 & 0 \\
\hline HDO5007 & --- & -- & --- & -- & --- & --- & --- & --- & --- & --- \\
\hline HDO5012 & 30 & 0 & 0 & 25 & 6 & 41 & 62 & 35 & 0 & 0 \\
\hline HDO5022 & --- & --- & --- & -- & --- & --- & --- & -- & $\cdots$ & --- \\
\hline HD05032 & 24 & 0 & 0 & 45 & 5 & 28 & 48 & 78 & 0 & 0 \\
\hline HD05042 & --- & --- & --- & --- & & --- & --- & --- & -.- & --- \\
\hline HD05052 & 20 & 0 & 0 & 57 & 4 & 20 & 0 & 120 & 0 & 0 \\
\hline HD05062 & 20 & 0 & 0 & 74 & 4 & 39 & 0 & 105 & 0 & 0 \\
\hline HD05072 & 11 & 0 & 0 & 93 & 4 & 95 & 0 & 110 & 0 & 4 \\
\hline HD05082 & --- & --- & -- & --- &.- & -- & -- &.- & --- & --- \\
\hline HD05092 & 14 & 0 & 0 & 60 & 3 & 4 & 0 & 115 & 20 & 0 \\
\hline HDO5102 & 16 & 0 & 0 & 47 & 4 & 29 & 0 & 125 & 15 & 0 \\
\hline HDO5112 & 27 & 0 & 0 & 34 & 5 & 46 & 0 & 110 & 47 & 0 \\
\hline HDO5117 & 17 & 3 & 8 & 72 & 6 & 30 & 0 & 56 & 16 & 3 \\
\hline
\end{tabular}


Sam. ID Mica Kaolinite Chlorite Quartz Orthoclase Plagioclase Calcite Ankerite Magnesite Pyrite

\begin{tabular}{|c|c|c|c|c|c|c|c|c|c|c|}
\hline HD05122 & --- & --- & --- & --- & -- & --- & --- & --- & --- & --- \\
\hline HD05132 & 19 & 5 & 8 & 42 & 8 & 48 & 0 & 31 & 12 & 3 \\
\hline HD05142 & --- & -- & --- & --- & --- & -- & --- & -- & -- & --- \\
\hline HD05152 & 16 & 10 & 13 & 45 & 7 & 33 & 32 & 12 & 0 & 4 \\
\hline HD05162 & --- & --- & --- & --- & --- & --- & --- & --- & --- & --- \\
\hline HD05172 & --- & -- & --- & --- & --- & --- & --- & --- & --- & $\cdots$ \\
\hline HD05182 & 15 & 15 & 17 & 50 & 6 & 46 & 21 & 11 & 0 & 4 \\
\hline HD05192 & --- & --- & --- & --- & --- & --- & --- & --- & --- & $\cdots$ \\
\hline HD05202 & 9 & 15 & 17 & 37 & 0 & 60 & 24 & 11 & 0 & 8 \\
\hline HD05212 & --- & --- & --- & --- & --- & --- & --- & --- & --- & -- \\
\hline HD05222 & 2 & 3 & 12 & 25 & 0 & 100 & 19 & 82 & 0 & 0 \\
\hline HD05232 & -- & --- & -- & --- & --- & --- & --- & --- & --- & -- \\
\hline HD05242 & 15 & 5 & 6 & 71 & 7 & 30 & 0 & 72 & 0 & 0 \\
\hline HD06002 & 22 & 0 & 2 & 54 & 7 & 58 & 0 & 0 & 0 & 0 \\
\hline HD06007 & --- & --- & --- & --- & --- & --- & -- & --- & -- & -- \\
\hline HD06012 & 11 & 0 & 13 & 32 & 3 & 68 & 14 & 100 & 0 & 0 \\
\hline HD06022 & -- & --- & --- & --- & --- & --- & --- & --- & --- & -- \\
\hline HD06032 & 18 & 0 & 3 & 18 & 5 & 100 & 0 & 100 & 8 & 0 \\
\hline HD06042 & --- & --- & --- & --- & --- & --- & --- & --- & --- & $\cdots$ \\
\hline HD06052 & 20 & 0 & 1 & 67 & 7 & 21 & 0 & 100 & 7 & 2 \\
\hline HD06062 & 16 & 5 & 18 & 72 & 6 & 31 & 0 & 71 & 5 & 3 \\
\hline HD06072 & 6 & 3 & 21 & 45 & 4 & 33 & 0 & 75 & 2 & 2 \\
\hline HD06082 & 13 & 3 & 2 & 29 & 4 & 81 & 0 & 89 & 41 & 10 \\
\hline HD06092 & --- & --- & --- & --- & --- & --- & --- & --- & --- & -- \\
\hline HD06097 & 20 & 0 & 4 & 64 & 8 & 24 & 0 & 40 & 54 & 4 \\
\hline HD07010 & 0 & 0 & 2 & 3 & 0 & 54 & 1 & 13 & 0 & 0 \\
\hline HD07020 & --- & --- & -- & --- & --- & --- & --- & -- & --- & --- \\
\hline $\mathrm{HD07030}$ & 0 & 0 & 23 & 3 & 10 & 22 & 4 & 11 & 0 & 0 \\
\hline HD07040 & --- & --- & --- & --- & --- & --- & --- & --- & --- & -- \\
\hline HD07050 & 0 & 0 & 30 & 4 & 5 & 22 & 18 & 4 & 0 & 0 \\
\hline HD07059 & 0 & 0 & 42 & 22 & 4 & 8 & 67 & 0 & 0 & 1 \\
\hline HD07063 & 10 & 0 & 12 & 41 & 4 & 17 & 12 & 0 & 0 & 7 \\
\hline HD07068 & 46 & 0 & 4 & 29 & 7 & 18 & 0 & 77 & 0 & 14 \\
\hline HDO 07080 & --- & --- & --- & --- & --- & --- & --- & --- & --- & --- \\
\hline HD07090 & 37 & 0 & 0 & 34 & 4 & 16 & 0 & 110 & 0 & 10 \\
\hline HD07100 & --- & --- & --- & --- & --- & --- & --- & --- & --- & --- \\
\hline HD07110 & 40 & 0 & 0 & 31 & 6 & 20 & 0 & 105 & 0 & 13 \\
\hline HD07122 & --- & --- & --- & --- & --- & --- & -- & --- & --- & -- \\
\hline HD07130 & 20 & 0 & 0 & 100 & 0 & 9 & 0 & 100 & 0 & 3 \\
\hline HD07140 & 33 & 0 & 0 & 47 & 9 & 21 & 0 & 53 & 0 & 12 \\
\hline HD07150 & 21 & 0 & 20 & 36 & 8 & 37 & 0 & 11 & 0 & 5 \\
\hline HD08002 & --- & -- & --- & --- & --- & -- & --- & --- & --- & -- \\
\hline HD08007 & --- & -- & --- & -- & --- & -- & --- & -- & -- & --- \\
\hline HD08012 & -- & --- & --- & --- & -- & --- & -- & --- & -- & --- \\
\hline HD08022 & --- & -- & $\cdots$ & --- & $-\cdots$ & -- & -- & --- & -- & --- \\
\hline
\end{tabular}


Sam. ID Mica Kaolinite Chlorite Quartz Orthoclase Plagioclase Calcite Ankerite Magnesite Pyrite

\begin{tabular}{|c|c|c|c|c|c|c|c|c|c|c|}
\hline HDO8032 & $\ldots$ & --- & -- & $-\cdots$ & --- & --- & -.- & -.- & $\ldots$ & -- \\
\hline HDO 04042 & --- & -- & --- & --- & --- & --- & --- & -.- & $-\cdots$ & --- \\
\hline HD08052 & --- & --- & -- & --- & --- & --- & -- &.- & $-\cdots$ & --- \\
\hline HD08062 & -.- & -- & --- & -- & --- & --- & --- & --- & -- & --- \\
\hline HD08072 & --- & $-\cdots$ & --- & --- & --- & --- & --- & -- & $-\cdots$ & --- \\
\hline HDO8082 & --- & $-\cdots$ & --- & --- & -- & --- & --- & --- & $\cdots$ & -- \\
\hline HD08092 & -- & --- & -- & --- & --- & --- & --- & -- & -- & --- \\
\hline HD08102 & --- & -- & --- & --- & --- & --- & --- & -.- &.-- & -- \\
\hline HDO8112 & -- & -- & -- & --- & -- & --- & --- & --- & --- & --- \\
\hline HD08122 & --- & $-\cdots$ & -- & -- & --- & --- & --- & --- & --- & -- \\
\hline HD08132 & -- & --- & --- & --- & --- & --- & --- & --- & --- & --- \\
\hline HD08137 & --- & --- & --- & --- & --- & --- & --- & --- & -- & -- \\
\hline HD09005 & 2 & 5 & 3 & 20 & 7 & 55 & 2 & 13 & 0 & 0 \\
\hline HD09010 & 3 & 0 & 8 & 14 & 0 & 39 & 0 & 23 & 0 & 5 \\
\hline HD09020 & 3 & 0 & 12 & 7 & 19 & 26 & 0 & 17 & 0 & 9 \\
\hline HD09030 & 5 & 5 & 15 & 18 & 13 & 37 & 0 & 5 & 0 & 3 \\
\hline HDO9040 & 3 & 0 & 9 & 12 & 22 & 36 & 25 & 15 & 0 & 10 \\
\hline HD09060 & 1 & 0 & 13 & 2 & 36 & 45 & 5 & 28 & 0 & 13 \\
\hline HDO9080 & 0 & 0 & 27 & 4 & 8 & 0 & 4 & 4 & 0 & 6 \\
\hline HD09100 & 13 & 0 & 18 & 32 & 0 & 2 & 2 & 120 & 43 & 0 \\
\hline HDog110 & 0 & 0 & 0 & 84 & 0 & 0 & 26 & 7 & 150 & 0 \\
\hline HDo9120 & 0 & 0 & 0 & 23 & 0 & 11 & 29 & 38 & 100 & 0 \\
\hline HDog130 & 0 & 1 & 0 & 103 & 0 & 0 & 8 & 37 & 130 & 0 \\
\hline HDO9140 & 0 & 0 & 7 & 29 & 0 & 0 & 26 & 8 & 160 & 0 \\
\hline HDO9150 & --- & -- & -- & -- & --- & --- & --- & --- & -- & --- \\
\hline HDo9164 & 11 & 0 & 2 & 24 & 0 & 3 & 0 & 130 & 110 & 0 \\
\hline HDO9170 & --- & $\cdots$ & -- & --- & --- & --- & --- & --- & -- & --- \\
\hline HDO9180 & 0 & 0 & 39 & 25 & 1 & 0 & 0 & 110 & 0 & 0 \\
\hline HD09200 & --- & -- & --- & -- & --- & --- & --- & --- & -- & --- \\
\hline HDO9220 & 0 & 0 & 37 & 6 & 0 & 11 & 1 & 0 & 0 & 8 \\
\hline HDo9240 & 0 & 0 & 28 & 10 & 4 & 17 & 45 & 0 & 0 & 3 \\
\hline HD09260 & 18 & 0 & 0 & 30 & 3 & 19 & 0 & 110 & 105 & 2 \\
\hline HDO9270 & --- & --- & --- & --- & --- & --- & --- & --- & --- & --- \\
\hline HDO9280 & --- & -- & --- & --- & --- & $\cdots$ & --- & --- & --- & -- \\
\hline HD09290 & 14 & 0 & 0 & 10 & 4 & 34 & 0 & 90 & 110 & 0 \\
\hline HD09300 & --- & --- & -- & --- & --- & $\cdots$ & --- & --- & --- & -- \\
\hline HDO932O & 17 & 0 & 0 & 23 & 3 & 58 & 0 & 110 & 87 & 0 \\
\hline HD09330 & 16 & 0 & 0 & 33 & 0 & 19 & 0 & 110 & 95 & 0 \\
\hline HD09340 & --- & --- & -- & --- & --- & --- & --- & --- & -- & -- \\
\hline HDO9350 & 19 & 0 & 0 & 60 & 6 & 30 & 0 & 54 & 5 & 19 \\
\hline HDO9370 & 32 & 0 & 0 & 31 & 7 & 18 & 0 & 39 & 13 & 15 \\
\hline HD09390 & --- & --- & --- & --- & --- & --- & -- & --- & -- & -- \\
\hline HD09410 & --- & --- & -- & -- & --- & --- & --- & --- & --- & --- \\
\hline HDo9430 & -- & --- & -- & -- & --- & -- & -- & --- & --- & -- \\
\hline HDo9450 & --- & -- & -- & -- & --- & -- & -- & -- & -- & $-\cdots$ \\
\hline
\end{tabular}


Sam. ID Mica Kaolinite Chlorite Quartz Orthoclase Plagioclase Calcite Ankerite Magnesite Pyrite

\begin{tabular}{|c|c|c|c|c|c|c|c|c|c|c|}
\hline HD09470 & 18 & 0 & 0 & 58 & 5 & 66 & 10 & 29 & 34 & 0 \\
\hline HD09490 & --- & -.- & --- & --- & --- & -.- & --- & -.- & --- & --- \\
\hline HD09510 & 23 & 0 & 0 & 56 & 7 & 23 & 0 & 53 & 16 & 12 \\
\hline HD10002 & 7 & 2 & 3 & 57 & 0 & 22 & 3 & 12 & 0 & 0 \\
\hline HD10007 & 5 & 0 & 0 & 105 & 0 & 16 & 8 & 2 & 0 & 0 \\
\hline HD10012 & 8 & 2 & 9 & 100 & 0 & 12 & 0 & 3 & 0 & 0 \\
\hline HD10022 & 21 & 0 & 0 & 63 & 8 & 47 & 2 & 105 & 26 & 4 \\
\hline HD10032 & --- & --- & --- & --- & --- & --- & --- & --- & --- & --- \\
\hline HD10042 & --- & --- & --- & --- & --- & --- & --- & --- & --- & --- \\
\hline HD10052 & 19 & 0 & 9 & 77 & 8 & 56 & 0 & 59 & 12 & 0 \\
\hline HD10062 & $\cdots$ & --- & --- & --- & --- & --- & --- & --- & --- & --- \\
\hline HD10072 & 12 & 0 & 10 & 69 & 0 & 82 & 3 & 55 & 0 & 0 \\
\hline HD10082 & --- & -.. & --- & --- & --- & --- & -.. & -.- & --- & --- \\
\hline HD10092 & --- & --- & --- & --- & --- & --- & --- & --- & --- & --- \\
\hline HD1D102 & 16 & 5 & 16 & 47 & 6 & 52 & 19 & 25 & 0 & 0 \\
\hline HD11002 & --- & --- & --- & --- & --- & --- & --- & --- & --- & --- \\
\hline HD11007 & --- & --- & --- & --- & --- & --- & --- & --- & --. & --- \\
\hline HD11012 & 2 & 1 & 18 & 41 & 5 & 42 & 12 & 0 & 0 & 0 \\
\hline HD11022 & 0 & 0 & 15 & 3 & 6 & 70 & 10 & 19 & 0 & 8 \\
\hline HD11032 & 0 & 0 & 19 & 6 & 0 & 92 & 11 & 12 & 0 & 6 \\
\hline HO11042 & 1 & 5 & 19 & 18 & 0 & 51 & 65 & 0 & 0 & 3 \\
\hline HD11052 & --- & --- & --- & --- & --- & --- & --- & --- & --- & --- \\
\hline HD11062 & --- & --- & --- & --- & --- & --- & --- & --- & --- & --- \\
\hline HD11072 & --- & --- & --- & --- & --- & --- & --- &.-- & --- & --- \\
\hline HD11082 & 2 & 5 & 24 & 22 & 0 & 39 & 77 & 11 & 0 & 3 \\
\hline HD11092 & --- & --- & --- & --- & --- & --- & --- & --- & --- & --- \\
\hline HD11102 & 3 & 5 & 17 & 16 & 0 & 66 & 36 & 36 & 0 & 1 \\
\hline HD11112 & 10 & 0 & 0 & 32 & 0 & 51 & 2 & 120 & 0 & 0 \\
\hline HD11122 & 4 & 0 & 1 & 92 & 0 & 34 & 0 & 110 & 0 & 4 \\
\hline HD11132 & --- & --- & --- & --- & --- & --- & --- & --- & --- & --- \\
\hline HD11142 & 21 & 0 & 0 & 77 & 6 & 14 & 0 & 71 & 0. & 14 \\
\hline HD11152 & --- & --- & --- & --- & --- & --- & --- & --- & --- & --- \\
\hline HD11162 & 17 & 0 & 0 & 56 & 4 & 29 & 0 & 77 & 0 & 11 \\
\hline HD11172 & --- & --- & --- & --- & -.- & --- & --- & --- & -.- & --- \\
\hline HD11182 & --- & --- & --- & --- & --- & --- & --- & -- & --- & --- \\
\hline HD11192 & 20 & 0 & 0 & 68 & 6 & 43 & 0 & 90 & 0 & 9 \\
\hline HD11202 & --- & --- & --- & --- & --- & --- & --- & --- & --- & --- \\
\hline HD11212 & --- & --- & --- & --- & --- & --- & --- & --- & --- & --- \\
\hline HD11222 & 11 & 0 & 7 & 61 & 4 & 64 & 2 & 47 & 0 & 3 \\
\hline HD12017 & --- & --- & -.- & --- & --- & -.- & -.- & -.- & --- & --- \\
\hline HD12022 & 2 & 0 & 12 & 14 & 0 & 45 & 3 & 31 & 0 & 0 \\
\hline HD12042 & --- & -.- & --- & --- & -- & --. & --- & --- & --- & --- \\
\hline HD12057 & 2 & 4 & 14 & 10 & 0 & 48 & 9 & 29 & 0 & 0 \\
\hline HD12082 & -.- & --- & -- & --- & --- & --- & --- & --- & --- & -.- \\
\hline HD12102 & 0 & 0 & 15 & 18 & 0 & 55 & 16 & 28 & 0 & 0 \\
\hline
\end{tabular}


Appendix 2.--cont inued

Sam. I0 Mica Kaolinite Chlorite Quartz Orthoclase Plagioclase Calcite Ankerite Magnesite Pyrite

\begin{tabular}{|c|c|c|c|c|c|c|c|c|c|c|}
\hline HD12122 & --- & -- & --- & --- & --- & --- & --- & -- & --- & --- \\
\hline HD12132 & 15 & 0 & 3 & 21 & 4 & 100 & 0 & 105 & 56 & 0 \\
\hline HD12142 & --- & --- & $-\cdots$ & --- & --- & --- & -- & --- & -- & -- \\
\hline HD12152 & --- & -- & 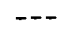 & -.- & --- & --- & -- & --- & $\ldots$ & $-\cdots$ \\
\hline HD12162 & 16 & 0 & 3 & 32 & 0 & 54 & 0 & 110 & 53 & 0 \\
\hline HD12172 & 13 & 0 & 0 & 31 & 3 & 24 & 0 & 105 & 98 & 0 \\
\hline HD12182 & 15 & 0 & 0 & 98 & 7 & 28 & 0 & 84 & 2 & 0 \\
\hline H012192 & --- & --- & -- & --- & --- & --- & --- & --- & $\cdots$ & --- \\
\hline HD12202 & 21 & 0 & 0 & 63 & 5 & 72 & 10 & 81 & 10 & 7 \\
\hline HD13002 & --- & --- & --- & $-\cdots$ & -.- & --- & -- & $-\cdots$ & --- & --- \\
\hline HD13007 & --- & -- & --- & --- & -- & --- & -- & --- & --- & --- \\
\hline HD13012 & $-\cdots$ & --- & --- & --- & --- & --- & $\cdots$ & --- & --- & --- \\
\hline HD13022 & --- & --- & --- & --- & --- & --- & --- & --- & --- & --- \\
\hline HD13032 & --- & --- & --- & --- & --- & --- & --- & --- & --- & --- \\
\hline HD14200 & 0 & 0 & 40 & 16 & 0 & 7 & 77 & 0 & 0 & 0 \\
\hline HD14210 & --- & --- & --- & --- & -.- & --- & --- & --- & --- & -- \\
\hline HD14220 & --- & --- & --- & --- & -- & -- & --- & --- & --- & --- \\
\hline HD14230 & --- & -- & --- & --- & --- & --- & --- & --- & --- & --- \\
\hline HD14240 & 14 & 0 & 1 & 32 & 0 & 39 & 0 & 110 & 73 & 0 \\
\hline HD14250 & --- & --- & --- & --- & -- & --- & --- & --- & --- & --- \\
\hline HD14260 & --- & -- & --- & --- & -- & --- & --- & --- & --- & --- \\
\hline HD1 4270 & 15 & 0 & 0 & 25 & 3 & 72 & 0 & 120 & 68 & 0 \\
\hline HD14280 & 16 & 0 & 0 & 74 & 4 & 36 & 3 & 105 & 61 & 0 \\
\hline HD14288 & --- & --- & --- & --- & $\cdots$ & --- & -- & -- & --- & --- \\
\hline HD14300 & 38 & 0 & 0 & 37 & 11 & 42 & 0 & 75 & 8 & 10 \\
\hline HD14310 & --- & --- & --- & --- & --- & --- & --- & -- & --- & --- \\
\hline HD1432O & --- & --- & --- & --- & --- & --- & -.- & --- & --- & --- \\
\hline HD14330 & --- & --- & --- & -- & $\cdots$ & $-\cdot$ & --- & --- & --- & --- \\
\hline HD14340 & 33 & 0 & 0 & 21 & 12 & 55 & 0 & 100 & 0 & 12 \\
\hline HD14350 & -- & -- & --- & -.. & -- & -- & --- & -.. & --- & --- \\
\hline HD14360 & --- & --- & --- & --- & --- & --- & --- & --- & -- & --- \\
\hline HD14370 & $\cdots$ & --- & --- & --- & --- & --- & -.- & --- & --- & --- \\
\hline HD14380 & 36 & 0 & 0 & 45 & 9 & 27 & 0 & 89 & 0 & 8 \\
\hline HD14390 & --- & --- & -.- & --- & --- & --- & --- & --- & -.. & --- \\
\hline MK34002 & 13 & 2 & 3 & 73 & 5 & 49 & 14 & 33 & 0 & 0 \\
\hline MK34007 & 7 & 0 & 0 & 105 & 5 & 4 & 0 & 0 & 0 & 0 \\
\hline MK34012 & 12 & 0 & 0 & 110 & 6 & 9 & 0 & 0 & 0 & 0 \\
\hline MK34017 & 2 & 0 & 0 & 110 & 0 & 4 & 0 & 0 & 0 & 0 \\
\hline MK34032 & 21 & 1 & 2 & 72 & 10 & 76 & 0 & 0 & 0 & 0 \\
\hline MK34042 & 23 & 0 & 0 & 73 & 8 & 55 & 27 & 12 & 0 & 0 \\
\hline MK34052 & 27 & 0 & 0 & 59 & 9 & 46 & 6 & 19 & 0 & 1 \\
\hline MK34062 & --- & --- & --- & --- & --- & --- & --- & --- & --- & --- \\
\hline MK34072 & 11 & 5 & 12 & 75 & 7 & 42 & 10 & 50 & 0 & 0 \\
\hline MK34082 & --- & -.- & --- & --- & -.. & -- & -.. & $\cdots$ &.- & --- \\
\hline MK34092 & 16 & 10 & 12 & 72 & 8 & 31 & 0 & 73 & 0 & 6 \\
\hline
\end{tabular}


Sam. ID Mica Kaolinite Chlorite Quartz Orthoclase Plagioclase Calcite Ankerite Magnesite Pyrite

\begin{tabular}{|c|c|c|c|c|c|c|c|c|c|c|}
\hline MK34102 & 21 & 25 & 24 & 69 & 8 & 38 & 9 & 44 & 0 & 5 \\
\hline MK34112 & --- & $\cdots$ & -- & $\cdots$ & $\cdots$ & -- & $\cdots$ & $\cdots$ & $\cdots$ & --- \\
\hline MK34117 & 13 & 10 & 15 & 62 & 5 & 54 & 42 & 23 & 0 & 0 \\
\hline MK35002 & 19 & 0 & 0 & 90 & 7 & 31 & 0 & 73 & 0 & 0 \\
\hline MK35007 & 12 & 0 & 0 & 83 & 7 & 17 & 0 & 13 & 0 & 0 \\
\hline MK35012 & 14 & 4 & 1 & 87 & 8 & 34 & 0 & 6 & 0 & 0 \\
\hline MK35022 & 27 & 15 & 22 & 42 & 10 & 46 & 0 & 7 & 0 & 0 \\
\hline MK35032 & 18 & 20 & 22 & 65 & 6 & 46 & 0 & 8 & 0 & 0 \\
\hline MK35042 & 16 & 10 & 20 & 70 & 7 & 45 & 5 & 8 & 0 & 0 \\
\hline MK35052 & -- & $\cdots$ & -- & --- & --- & --- & --- & --- & -- & -- \\
\hline MK35057 & 16 & 10 & 19 & 56 & 8 & 49 & 12 & 8 & 0 & 0 \\
\hline MK62002 & 11 & 5 & 3 & 40 & 9 & 52 & 2 & 16 & 0 & 0 \\
\hline MK62007 & 0 & 2 & 0 & 13 & 14 & 58 & 2 & 23 & 0 & 0 \\
\hline MK62012 & 5 & 5 & 6 & 12 & 10 & 58 & 91 & 8 & 0 & 0 \\
\hline MK62022 & 29 & 0 & 1 & 26 & 5 & 23 & 73 & 0 & 0 & 0 \\
\hline MK62032 & 46 & 0 & 0 & 37 & 10 & 24 & 14 & 48 & 0 & 0 \\
\hline MK62042 & 40 & 0 & 0 & 13 & 10 & 39 & 25 & 95 & 0 & 0 \\
\hline MK62052 & 9 & 15 & 11 & 20 & 12 & 68 & 47 & 11 & 0 & 0 \\
\hline MK62062 & -- & --- & -- & -- & --- & --- & --- & -- & --- & --- \\
\hline MK62072 & 10 & 15 & 11 & 12 & 7 & 36 & 100 & 18 & 0 & 0 \\
\hline MK62082 & --- & --- & -- & --- & --- & --- & --- & --- & --- & --- \\
\hline MK62092 & 10 & 15 & 12 & 10 & 10 & 55 & 75 & 14 & 0 & 0 \\
\hline MK62102 & 6 & 15 & 13 & 9 & 9 & 74 & 68 & 17 & 0 & 0 \\
\hline MK62112 & 9 & 10 & 10 & 8 & 8 & 47 & 73 & 12 & 0 & 0 \\
\hline MK62122 & 14 & 10 & 11 & 14 & 8 & 33 & 46 & 14 & 0 & 0 \\
\hline MK62132 & --- & --- & --- & --- & --- & --- & --- & -- & -- & --- \\
\hline MK62142 & 8 & 10 & 12 & 15 & 8 & 40 & 33 & 17 & 0 & 0 \\
\hline MK62152 & --- & $\cdots$ & $\cdots$ & -- & $\cdots$ & --- & -- & $-\cdots$ & -- & -- \\
\hline MK62162 & 8 & 10 & 13 & 12 & 10 & 54 & 30 & 20 & 0 & 0 \\
\hline MK62172 & 33 & 0 & 0 & 26 & 9 & 26 & 4 & 100 & 0 & 0 \\
\hline
\end{tabular}

